Andrews University

Digital Commons @ Andrews University

\title{
Toward a Biblical Theology of God's Presence in Christian Theology: A Study of How Difference Interpretations of the Divine Presence affect liturgy
}

Karl Tsatalbasidis

Andrews University, tsatalba@andrews.edu

Follow this and additional works at: https://digitalcommons.andrews.edu/dissertations

Part of the Religious Thought, Theology and Philosophy of Religion Commons

\section{Recommended Citation}

Tsatalbasidis, Karl, "Toward a Biblical Theology of God's Presence in Christian Theology: A Study of How Difference Interpretations of the Divine Presence affect liturgy" (2019). Dissertations. 1685.

https://digitalcommons.andrews.edu/dissertations/1685

https://dx.doi.org/10.32597/dissertations/1685

This Dissertation is brought to you for free and open access by the Graduate Research at Digital Commons @ Andrews University. It has been accepted for inclusion in Dissertations by an authorized administrator of Digital Commons@ Andrews University. For more information, please contact repository@andrews.edu. 


\section{ABSTRACT \\ TOWARD A BIBLICAL THEOLOGY OF GOD'S PRESENCE IN CHRISTIAN THEOLOGY: A STUDY OF HOW DIFFERENT INTERPRETATIONS OF THE DIVINE PRESENCE AFFECT LITURGY}

by

Karl Tsatalbasidis

Adviser: Fernando Canale 


\section{ABSTRACT OF GRADUATE RESEARCH}

Dissertation

Andrews University

Seventh-day Adventist Theological Seminary

\section{Title: TOWARD A BIBLICAL THEOLOGY OF GOD'S PRESENCE IN CHRISTIAN THEOLOGY: A STUDY OF HOW DIFFERENT INTERPRETATIONS OF THE DIVINE PRESENCE AFFECT LITURGY}

Name of Researcher: Karl Tsatalbasidis

Name and degree of faculty chair: Fernando Canale, Ph.D.

Date Completed: June 2019

\section{Problem}

In spite of the universal agreement on the importance of the divine presence as the central aspect of liturgy, there are three conflicting ways in which the presence of God relates to liturgy. They broadly correspond to the main liturgical traditions: Sacramental (Roman Catholic), Kerygmatic (Protestant) and Charismatic (Pentecostal and Interdenominational). In our current situation, how does this universal agreement about the presence of God as the central aspect of liturgy relate to the conflicting means by which congregations assess his presence? 


\section{Purpose}

The purpose of this study was (1) to describe how the three diverging views relate the presence of God to liturgy, (2) to ascertain the cause/s of this divergence by focusing on the divine presence as the central component, and (3) to overcome this divergence by examining the possibility of developing a theology of the divine presence on the basis of Scripture.

\section{Methodology}

The methodology in this study included an historical overview of the nature and extent of liturgical conflict in Christianity, a phenomenological method that discovered all of the parts of liturgy, a model method that grouped all the parts of liturgy around the divine presence, a hermeneutical method that revealed the macro hermeneutical presuppositions that each model interprets, and an exegetical and systematic method of the selected OT and NT Scriptures.

\section{Findings}

The most significant finding revealed by the historical overview was that Protestants and Charismatics who employ the terms real presence and musical transubstantiation to describe the divine presence in preaching and music have never challenged the interpretation of the divine presence via transubstantiation championed by the Catholic Church. This has led to contradictory views of the divine presence, the rest of the liturgical components, and the ecumenical search for unity. As a result, this study concluded that there are two main causes of liturgical pluralism and disunity in Christian liturgy. The first is the intentional use of timeless Being via the transubstantiation 
hypothesis by the Sacramental model. The second is the failure of the Kerygmatic and Charismatic models to deconstruct the transubstantiation hypothesis, and to apply the Sola Scriptura principle to the divine presence, the rest of the liturgical components, and to the ecumenical search for unity.

Since the previous models failed to apply the Sola Scriptura principle to all of the liturgical components, the aim of the Biblical Sanctuary model was to employ a phenomenological exegesis to the selected OT and NT passages in which the liturgical components are found. This exegetical and systematic method allowed the data in each passage to unfold its meaning by rendering groundless the hermeneutical role of timeless Being. Furthermore, employing a phenomenological exegesis led to the discovery of God's infinite analogical temporal Being as the framework for interpreting the divine presence. This discovery allowed the heavenly sanctuary to function as the macro hermeneutical presupposition that grounds the temporal relationship between the divine presence, the rest of the liturgical components, their complex interrelationships, and the biblical search for unity. Hence, by employing the exegetical and systematic methods that are grounded in the Sola Scriptura principle, the Biblical Sanctuary model reveals that it is possible to build a theology of the divine presence within the context of the search for unity. 
Andrews University

Seventh-day Adventist Theological Seminary

\title{
TOWARD A BIBLICAL THEOLOGY OF GOD'S PRESENCE IN CHRISTIAN THEOLOGY: A STUDY OF HOW DIFFERENT INTERPRETATIONS OF THE DIVINE PRESENCE AFFECT LITURGY
}

\author{
A Dissertation \\ Presented in Partial Fulfillment \\ of the Requirements for the Degree \\ Doctor of Philosophy
}

by

Karl Tsatalbasidis

June 2019 
(C) Copyright by Karl Tsatalbasidis 2019

All Rights Reserved 


\title{
TOWARD A BIBLICAL THEOLOGY OF GOD'S PRESENCE IN CHRISTIAN THEOLOGY: A STUDY OF HOW DIFFERENT INTERPRETATIONS OF THE DIVINE PRESENCE AFFECT LITURGY
}

\author{
A dissertation \\ presented in partial fulfillment \\ of the requirements for the degree \\ Doctor of Philosophy
}

by

Karl Tsatalbasidis

APPROVAL BY THE COMMITTEE:

Faculty Advisor

Fernando L. Canale

Emeritus Professor of Theology and Philosophy

Roy Gane

Professor of Hebrew and Ancient Near Eastern

Languages

Félix Cortez

Associate Professor of New Testament

David Williams

Assistant Professor of Worship and Sacred Music

Timothy O'Malley

Academic Director, Notre Dame Center for Liturgy
Director of Ph.D./Th.D. Program

Thomas Shepherd

Dean SDA Theological Seminary

Jiří Moskala 


\section{TABLE OF CONTENTS}

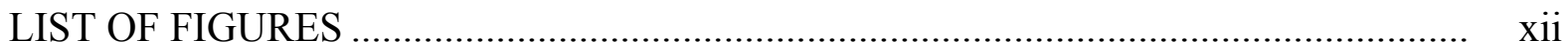

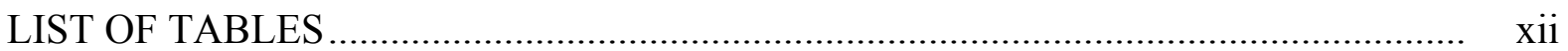

LIST OF ABBREVIATIONS......................................................................... xiii

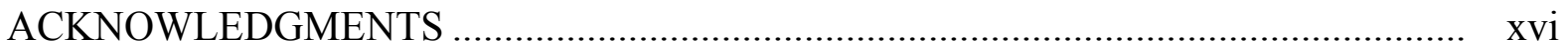

Chapter

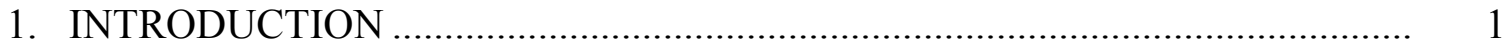

Background to the Problem ............................................................................. 1

Problem ...........................................................................................

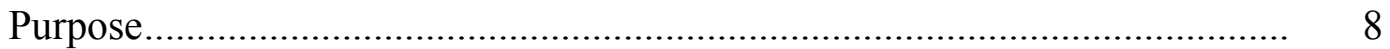

Significance of This Study ........................................................................ 8

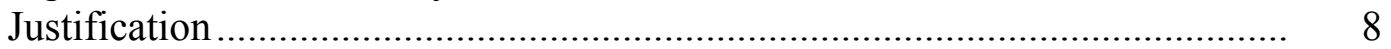

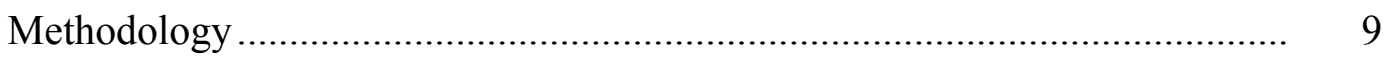

Outline of Study .................................................................................... 15

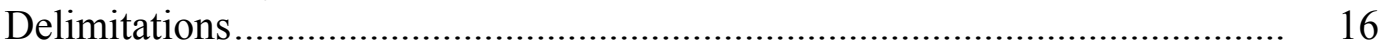

2. HISTORY OF CHRISTIAN LITURGY …...................................................... 18

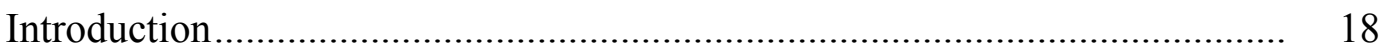

The Focus of Liturgy .................................................................................. 19

Architecture and the Focus of Liturgy ………………………………...... 23

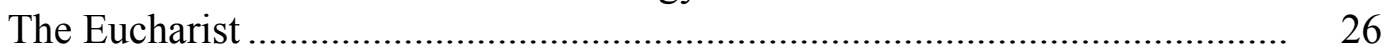

Preaching the Word........................................................................................ 38

Aim and Purpose of Preaching ............................................................. $\quad 39$

Methods of Preaching ........................................................................... 44

Qualifications for Preaching ............................................................... 47

Frequency and Length of Preaching ....................................................... 48

Worship, Preaching and Use of Language................................................ 49

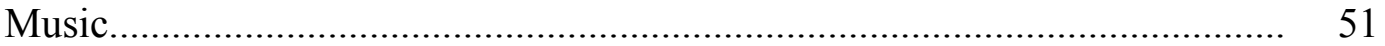

The Use of Instruments ...................................................................... 52

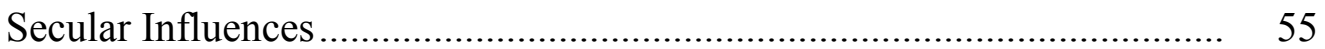

Musical Style ................................................................................ 57

Congregational and Participatory Versus Professional and Passive.......... $\quad 60$

The Purpose of Music ............................................................................ 62 
Conclusion

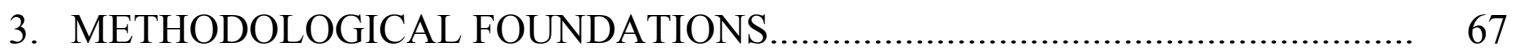

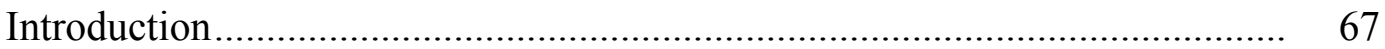

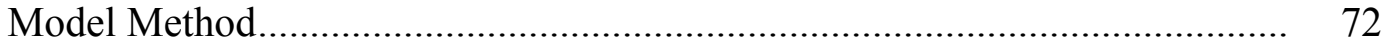

Models and Liturgy ……………………………………………….... 74

Phenomenological Method .................................................................... $\quad 80$

Description of Liturgy and Worship in Scripture ....................................... 81

Scholarly Description of Liturgy and Worship......................................... 84

Scholarly Observations About the Divine Presence .............................. 84

Scholarly Observations About Humans Performing Liturgical Actions ............................................................................... 85

Scholarly Oberservations About Sacred Places and Liturgical Activity ………................................................................... 86

Scholarly Observations About Worship Activity ................................ 87

Hermeneutical Method .......................................................................... 89

The Conditions of Method and the Components of Liturgy ....................... $\quad 90$

Ontology and the Conditions ................................................................... 93

Summary and Conclusion .......................................................................... 99

4. MODELS MEDIATING THE PRESENCE OF GOD IN LITURGY ................... 101

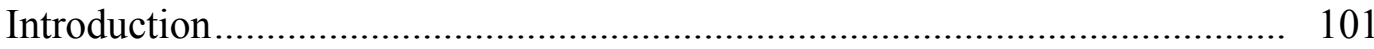

Sacramental Model ............................................................................ 102

Divine Presence ......................................................................... 102

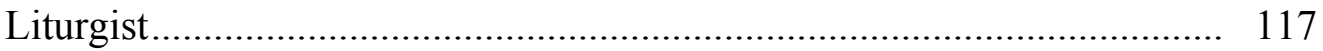

Liturgical Setting and Actions ………….............................................. 120

Encounter ................................................................................... 134

Response to the Encounter.................................................................... 139

Ecumenical Search for Unity ............................................................ 144

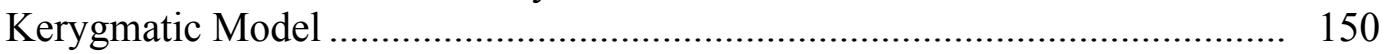

Divine Presence ......................................................................... 150

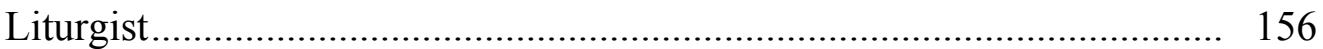

Liturgical Setting and Actions ……………………............................ 159

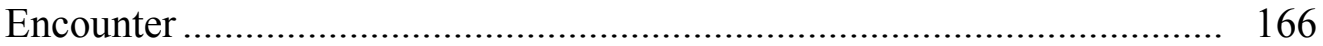

Response to the Encounter............................................................. 169

Ecumenical Serach for Unity ............................................................ 171

The Charismatic Model.......................................................................... 180

Divine Presence …………………............................................. 180

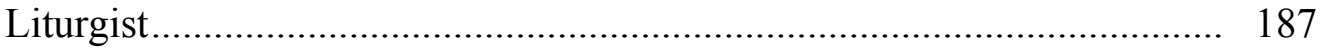

Liturgical Setting and Actions ............................................................ 191

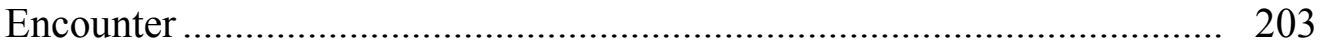

Response to the Encounter.................................................................. 208

Ecumenical Search for Unity ............................................................... 213 


\section{BIBLICAL SANCTUARY MODEL: SURVEY OF OLD TESTAMENT}

DATA

Introduction

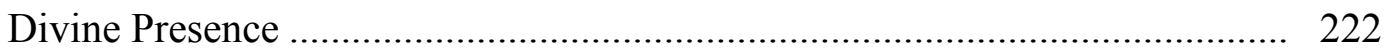

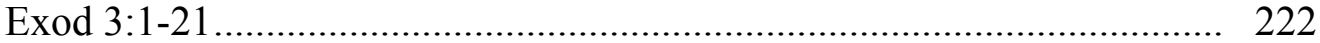

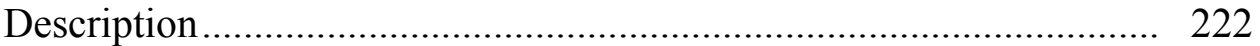

Analysis............................................................................. 223

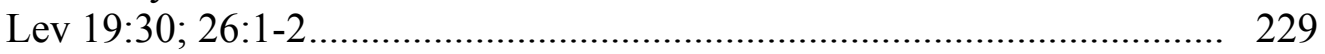

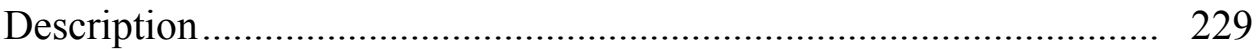

Analysis................................................................................ 231

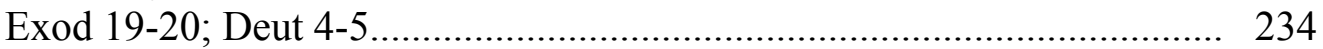

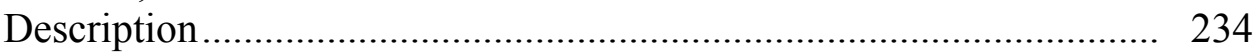

Analysis............................................................................... 236

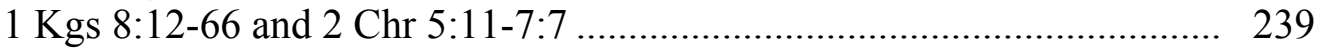

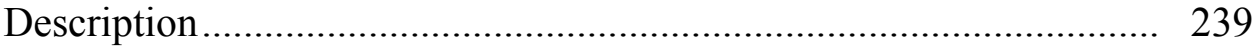

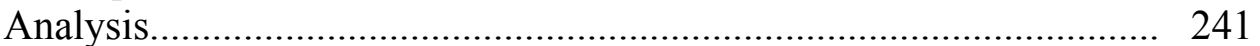

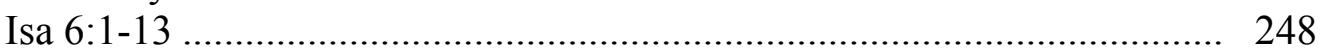

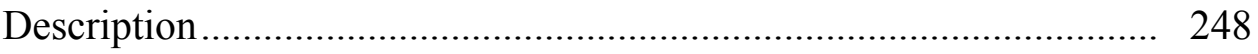

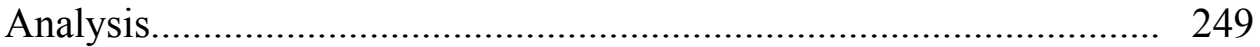

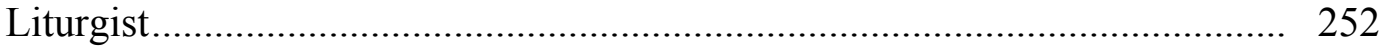

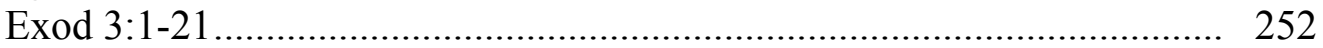

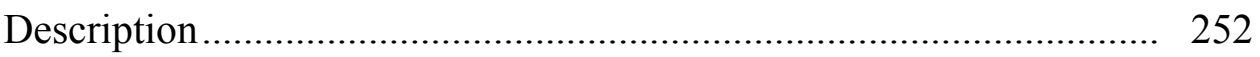

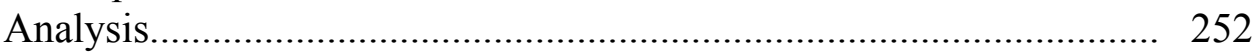

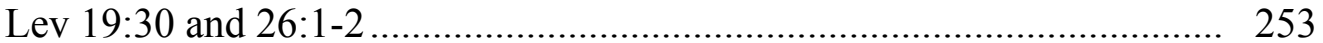

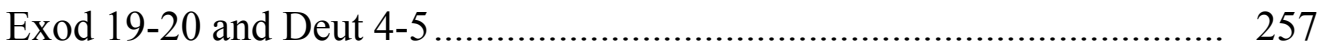

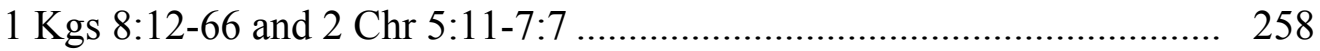

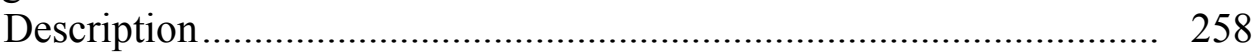

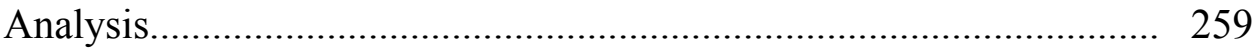

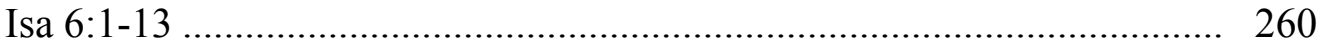

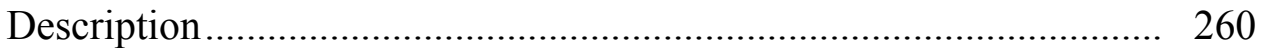

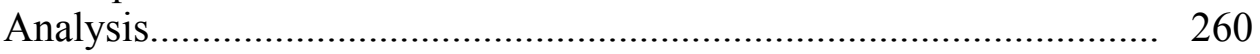

Liturgical Setting and Actions .................................................................... 261

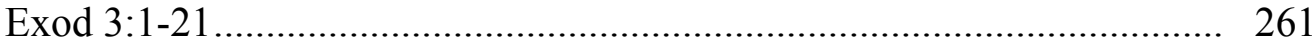

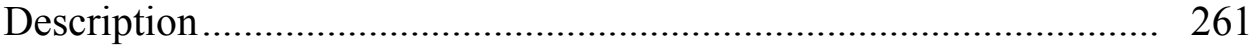

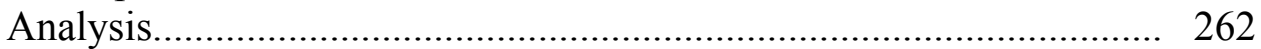

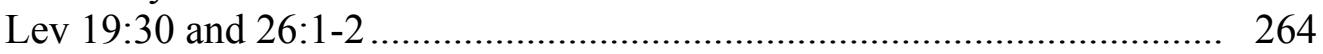

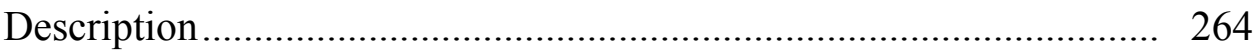

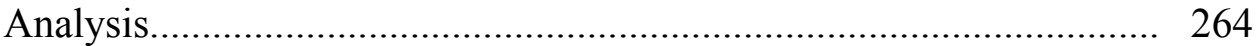

Exod 19-20 and Deut 4-5 ............................................................. 266

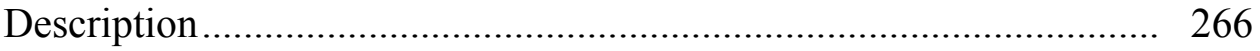

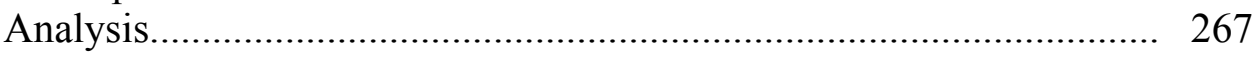

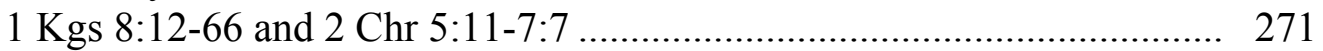

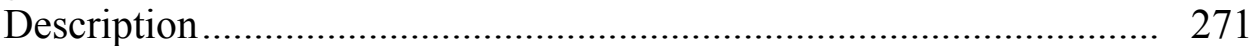

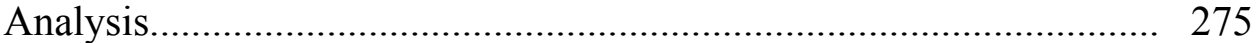

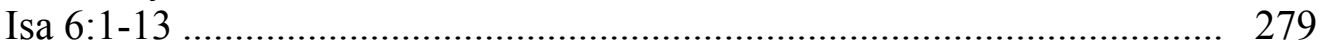




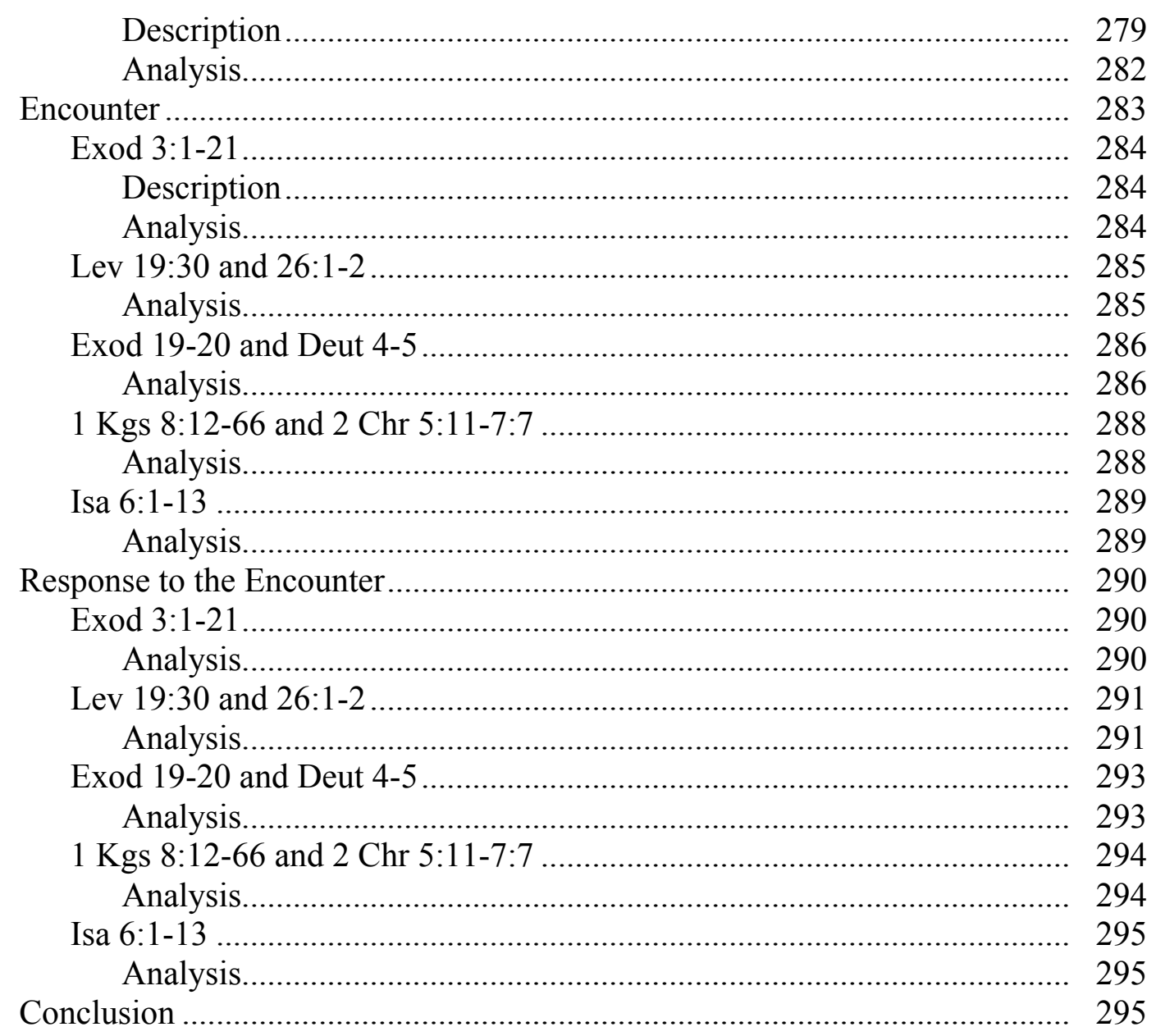

\section{BIBLICAL SANCTUARY MODEL: SURVEY OF NEW TESTAMENT} DATA

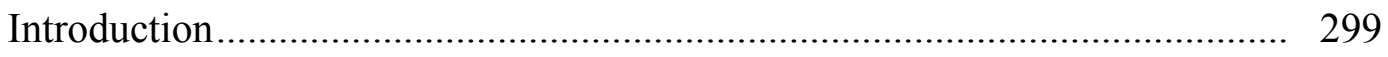

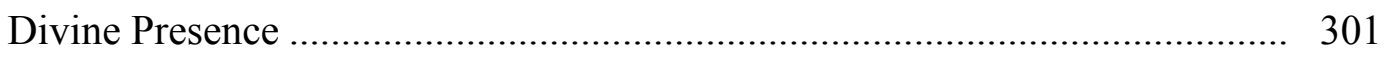

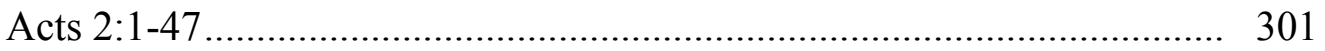

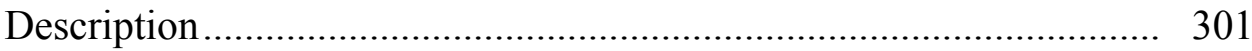

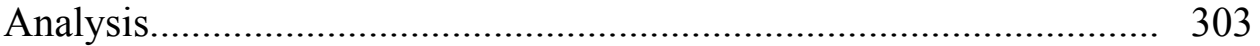

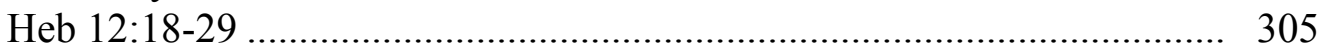

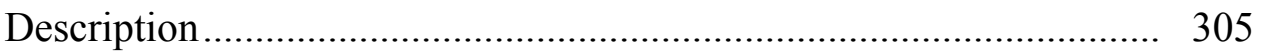

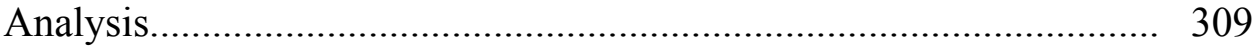

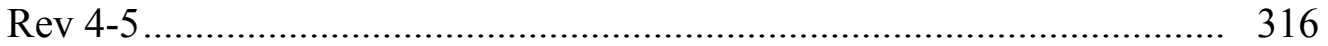

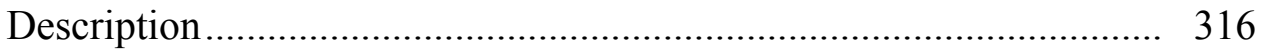

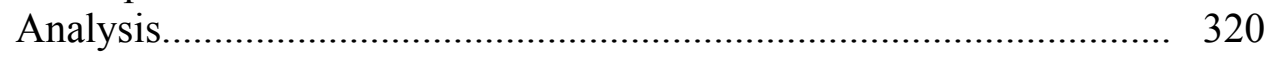

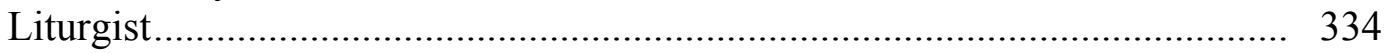

Luke 4:16-30; Acts 2:1-47; 13:13-52 ……………........................... 334

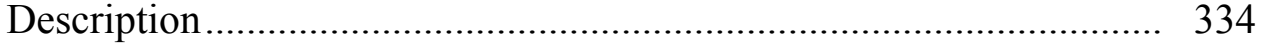

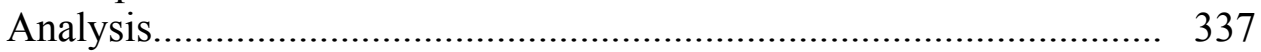

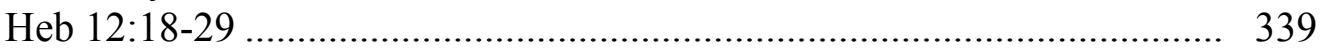




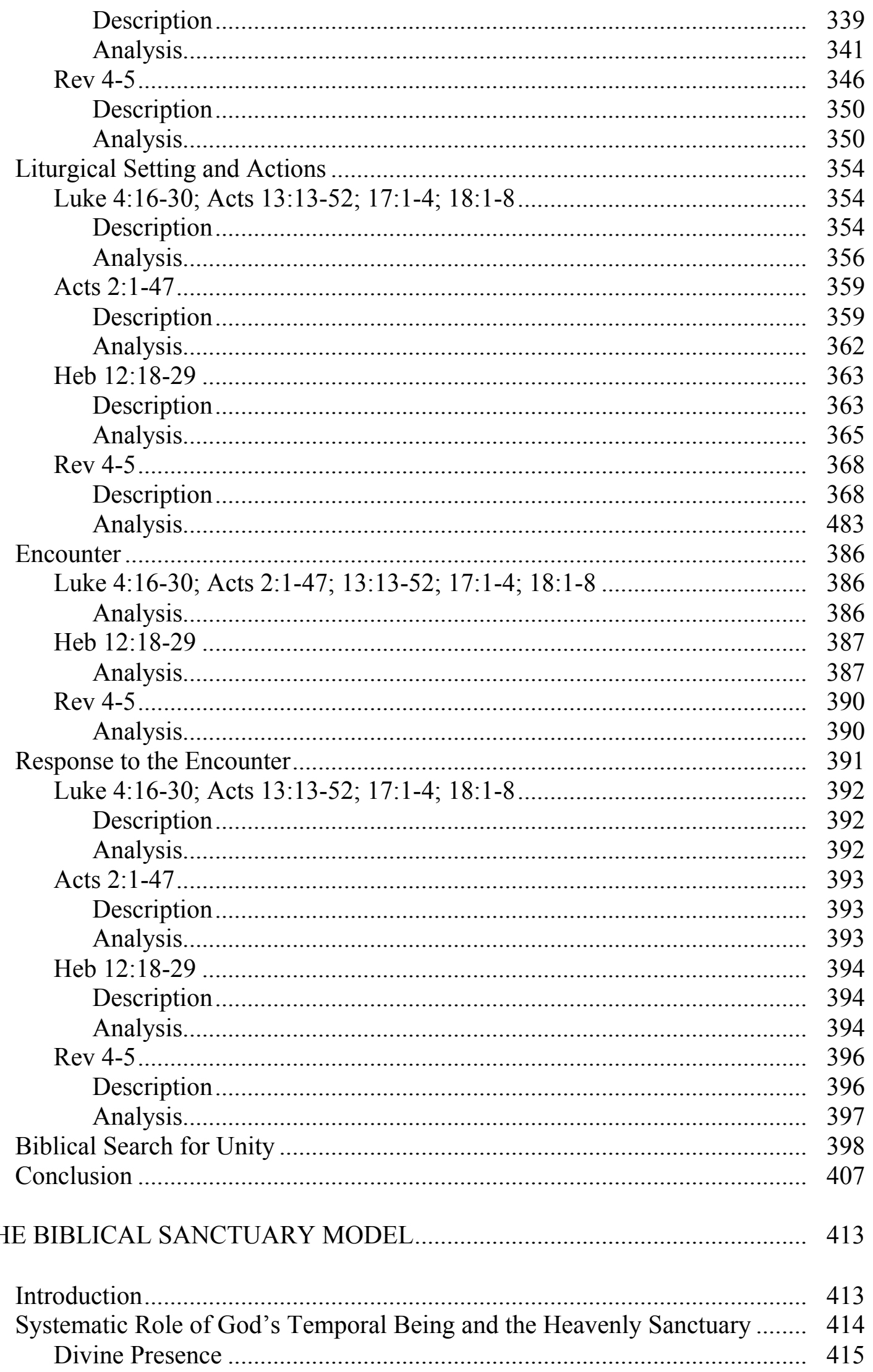


The I AM and the Divine Presence as Trinity ..................................... 416

Sola Scriptura, the Sanctuary, and the Divine Presence as Trinity ...... 416

The Sanctuary and the Function of the Trinity in Liturgy ................... 417

The Sanctuary Distinguishes the Divine Presence from the Word....... 418

The Sanctuary Interprets Transcendence and Immanence.................... 418

The Sanctuary Interprets Divine Presence and Omnipresence ............. 419

The Sanctuary Interprets Christ's Divinity .......................................... 419

The Sanctuary Interprets Christ's Humanity ……………………........ 420

The Santuary Interprets Relationship between Christ's Divinity

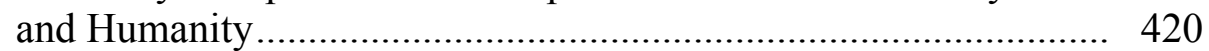

Abandoning the Sanctuary: Implications for the Divine Presence ....... 421

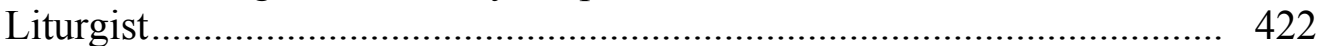

The Sanctuary and the Divine, Angelic, and Human Liturgists ........... 423

The Sanctuary and God's Word as Basis for Liturgical Authority....... 424

The Sanctuary, Mediation, and Issues Over Liturgical Authority ........ 425

Abandoning the Sanctuary: Implications for Mediation and

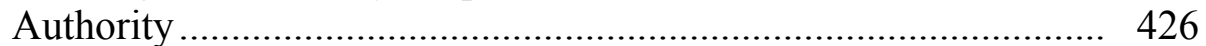

Liturgical Setting and Actions ............................................................... 428

The Sanctuary and Speech as Central Liturgical Action ..................... 429

The Sabbath and Speech as Central Liturgical Action ......................... 429

The Sanctuary and the Universal Meaning of Speech......................... 430

The Heavenly Sancutary and Earthly Places of Worship .................... 431

Abandoning the Sanctuary: Implications for Speech............................ 432

Encounter ...................................................................................... 433

Hermeneutical Role of the Heavenly Sanctuary in the Encounter ....... 433

The Covenant Interprets the Nature of the Encounter .......................... 434

The Heavenly Sanctuary and the Goal of the Encounter..................... 435

Abandoning the Sanctuary: Implications for the Encounter.................. 436

Response to the Encounter..................................................................... 437

Sanctuary Grounds Relationship between Divine Presence and

Response ........................................................................ 437

Sanctuary Grounds Relationship between Human Nature and

Varied Response .................................................................... 437

Sanctuary Grounds Relationship between Speech and the

Response .............................................................................. 438

Sanctuary Grounds Relationship between Encounter and Response.... 439

Heavenly Sanctuary as a Model for Earthly Responses to the

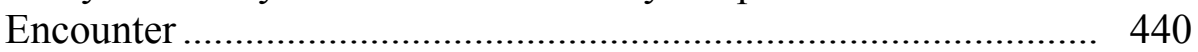

Abandoning the Sanctuary: Implications for the Response .................. 440

Biblical Search for Unity ..................................................................... 441

Sanctuary and Trinity: Unity in Originating and Revealing the

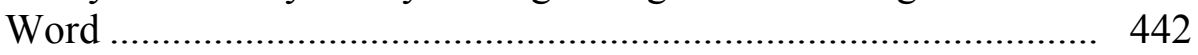

Sanctuary and Liturgists: Unity in Ministering the Word .................... 443

Sanctuary and Sabbath: Unity of Place and Time in Ministering the Word. 
Sanctuary and Covenant: Unity in Cognitive/Spiritual Encounter with the Word

Sanctuary and Worshippers: Ground for a Unified Response to the Word.

Abandoning the Sanctuary: Implications for the Biblical Search for Unity

Pantheism and Conflicting Views of the Divine Presence 446 Pantheism and Conflicting Views of the Liturgist's Ministry ........ Pantheism and Altars that Mediate Conflicting Content ..... 448 Pantheism and No Divine Revelation in Encounter and Lack of Unity in Response.

Description of the Models

Sacramental Model 452

Kerygmatic Model 452

Charismatic Model 454

Biblical Sanctuary Model 456

Comparing and Analyzing the Models: Hermeneutical Role of Being .

Divine Presence 459 462 462

Sacramental, Kerygmatic, and Charismatic Models. 463

Transubstantiation's Dominant Role in Interpreting the Divine Presence 463

Conflicting Sacraments, Mediation, and the Divine Presence. 464

Conflicting Interpretations of the Divine Presence. 465

Conflicting Focus of Liturgy 466

Conflicting Christology 466

Conflicting Pneumatology . 467

Hermeneutical Effects on the Trinity...... 468

Conflicting View of the Word of God, Scripture, and Tradition.... 468

Biblical Sanctuary Model 469

Temporal Being's Dominant Role in Interpreting the Divine Presence 470

Focus on the Trinity..... 470

The Trinity, Transcendence, and Immanence ................................. 471

The Trinity Presence and Omnipresence ....................................... 471 Divine Presence Only Revealed by God's Word........................... 473

Liturgist

Sacremental, Kerygmatic, and Charismatic Models........................... 474

Conflicting Cause of Liturgy ....................................................... 474

Conflicting Views Regarding Authority ...................................... 476

Conflicting View of Mediation................................................... 478

Biblical Sanctuary Model .............................................................. 479

Nature of the Liturgist and Ministry of the Word in OT and NT ... 479

Liturgist is Efficient Cause .......................................................... 480

Authority of Liturgist Based on Scripture .................................... 481

Mediation Based on Nature of Liturgist ...................................... 482

Liturgical Setting and Actions ................................................................ 483 
Sacramental, Kerygmatic, and Charismatic Models ............................ 483

Conflicting Liturgical Centers …………..................................... 483

Conflicting Architectural Styles .................................................. 486

Conflicting Relationship between Divine Presence and Other

Liturgical Actions .................................................................. 487

Biblical Sanctuary Model .............................................................. 489

Sabbath and the Centrality of Speech ............................................ 489

Sanctuary and Centrality of Speech.............................................. 491

Sanctuary, the Holy Spirit and the Centrality of Speech ............... 493

Sanctuary and Architecture........................................................... 494

Encounter

497

Sacramental, Kerygmatic, and Charismatic Models ............................ 497

Conflicting Views Over the Place of the Encounter...................... 497

Conflicting Means Employed in Receiving the Encounter............. 497

Conflicting Views of the Divine Person Received in the

Encounter .................................................................... 498

Conflicting Views of the Nature of the Encounter ........................ 498

Interpretive Dissonance .......................................................... 498

Biblical Sanctuary Model ............................................................... 499

Sanctuary and the Nature of the Encounter .................................. 499

Sanctuary, Covenant, and the Place of the Encounter ................... 500

Sanctuary, Covenant, and the Encounter with God's Word Not

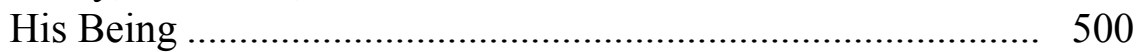

Response to the Encounter................................................................... 500

Sacramental, Kerygmatic, and Charismatic Models ............................ 501

Passive Response ................................................................. 502

Conflicting Active Responses that are Passive........................... 502

Biblical Sanctuary Model .............................................................. 504

Active and Varied Responses .................................................. 504

Active Responses and Integrated View of Human Nature ............. 505

Responses as Universal Moral Judgment ..................................... 506

Biblical Search for Unity .................................................................... 506

Sacramental, Kerygmatic, and Charismatic Models............................ 506

Unity as Uniformity ............................................................... 507

Unity in Essentials and Diversity in Non-Essentials:

Sacramental Model ........................................................... 508

Unity in Essentials and Diversity in Non-Essentials:

Kerygmatic Model ............................................................ 509

Unity in Essentials and Diversity in Non-Essentials:

Charismatic Model........................................................ 510

Disunity and Confusion .............................................................. 511

Biblical Sanctuary Model .............................................................. 512

Heavenly Sanctuary as Ground for Establishing Unity ................. 512

Heavenly Sanctuary Unites Heaven and Earth .............................. 512

Heavenly Sanctuary Integrates Divine Presence with All Created Realities 


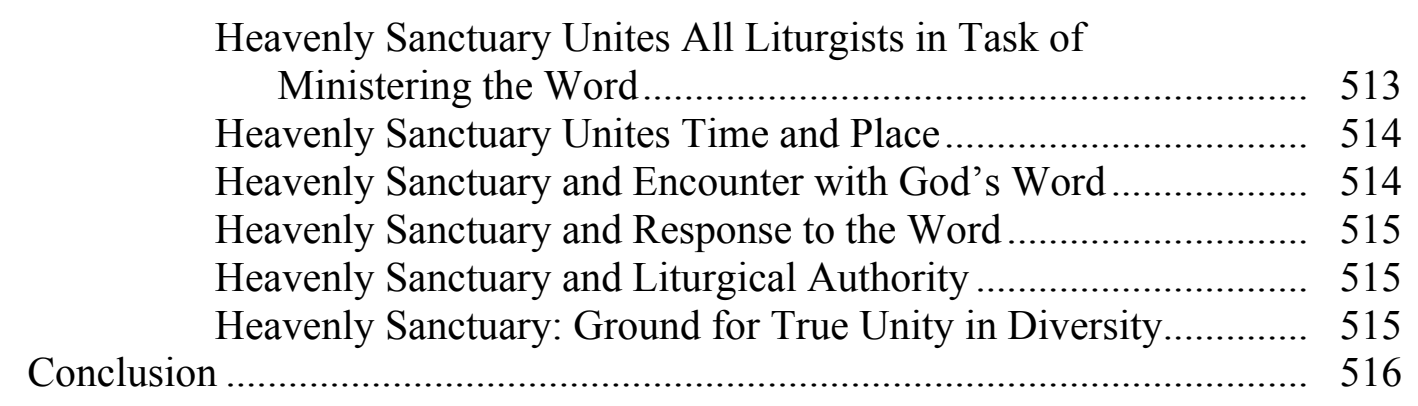

8. SUMMARY, CONCLUSIONS, AND RECOMMENDATIONS ....................... 519

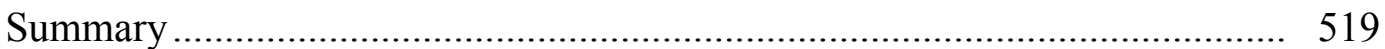

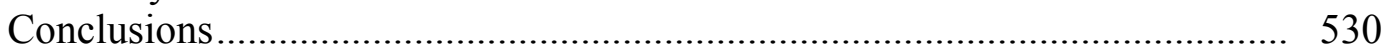

Recommendations for Further Research....................................................... 534

Appendix

A. Music in the Biblical Sanctuary Model................................................................. 537

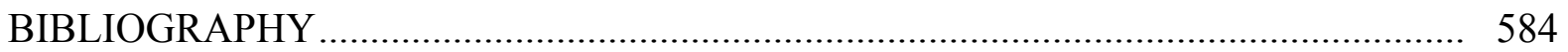

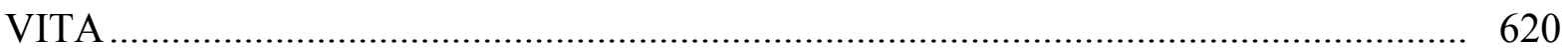




\section{LIST OF FIGURES}

1. Liturgy as a Complex Phenomenon ........................................................................ 68

2. Divine Presence as Fundamental Notion of Liturgy ...................................................... 69

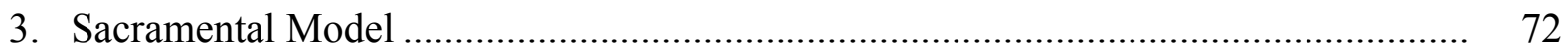

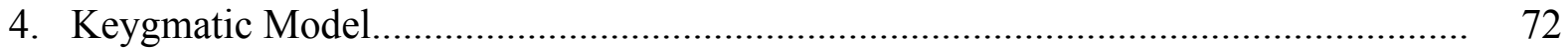

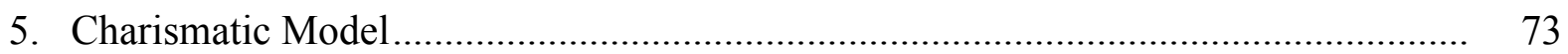

\section{LIST OF TABLES}

1. Thematic Parrallels between Rev 4-5 and Rev 14 _................................................ 381

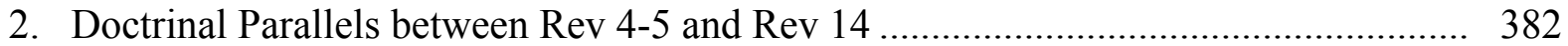

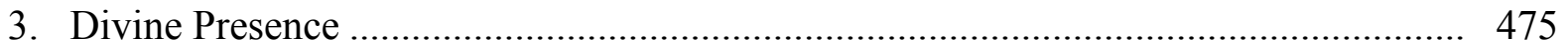

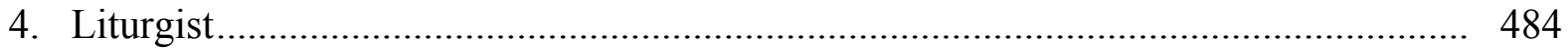

5. Liturgical Setting and Actions …………………................................................ 495

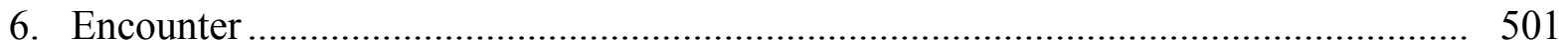

7. Response to Encounter.......................................................................................... 507

8. Ecumenical Search for Unity ………………................................................... 517 


\section{LIST OF ABBREVIATIONS}

\begin{tabular}{|c|c|}
\hline $\mathrm{AB}$ & Anchor Bible \\
\hline AUSS & Andrews University Seminary Studies \\
\hline AYB & The Anchor Yale Bible \\
\hline BDAG & $\begin{array}{l}\text { Bauer, W., F. W. Danker, W. F. Arndt, and F. W. Gingrich. Greek- } \\
\text { English Lexicon of the New Testament and Other Early Christian } \\
\text { Literature. 3rd ed. Chicago, } 2000\end{array}$ \\
\hline BECNT & Baker Exegetical Commentary on the New Testament \\
\hline$B S a c$ & Bibliotheca Sacra \\
\hline $\mathrm{CBC}$ & The Cambridge Bible Commentary \\
\hline CCSOT & Communicator's Commentary Series: Old Testament \\
\hline$D V$ & Vatican II, Dei Verbum \\
\hline HALOT & The Hebrew and Aramaic Lexicon of the Old Testament \\
\hline Hermeneia & Hermeneia - A Critical and Historical Commentary on the Bible \\
\hline HCOT & Historical Commentary on the Old Testament \\
\hline ICC & International Critical Commentary \\
\hline$I C R$ & John Calvin, Institutes of the Christian Religion \\
\hline ITC & International Theological Commentary \\
\hline KJV & King James Version \\
\hline LCC & The Library of Christian Classics \\
\hline$L G$ & Vatican II, Lumen Gentium \\
\hline
\end{tabular}




\begin{tabular}{|c|c|}
\hline LGBT & Lesbian, Gay, Bisexual, and Transgender \\
\hline LXX & Septuagint \\
\hline$L W$ & Martin Luther, Luther's Works \\
\hline NET & Net English Translation \\
\hline NIB & The New Interpreter's Bible \\
\hline NIBC & New International Biblical Commentary \\
\hline NICNT & New International Commentary on the New Testament \\
\hline NIGTC & New International Greek Testament Commentary \\
\hline NIV & New International Version \\
\hline NKJV & New King James Version \\
\hline$N P N F$ & Nicene and Post-Nicene Fathers \\
\hline NSBT & New Studies in Biblical Theology \\
\hline NT & New Testament \\
\hline OT & Old Testament \\
\hline OTL & Old Testament Library \\
\hline PNTC & The Pillar New Testament Commentary \\
\hline SBLDS & Society of Biblical Literature Dissertation Series \\
\hline$S C$ & Vatican II, Sacrosanctum Concilium \\
\hline$S D A B C$ & Seventh-day Adventist Bible Commentary \\
\hline$S T$ & Thomas Aquinas, Summa Theologiae \\
\hline$T D N T$ & $\begin{array}{l}\text { Theological Dictionary of the New Testament. Edited by G. Kittel } \\
\text { and G. Friedrich. Translated by G.W. Bromiley. } 10 \text { vols. Grand } \\
\text { Rapids, MI 1964-1976 }\end{array}$ \\
\hline TOTC & Tyndale Old Testament Commentary \\
\hline
\end{tabular}


TynBul

$U R$

WBC
Tyndale Bulletin

Vatican II Document, Unitatis Redintegratio

Word Biblical Commentary 


\section{ACKNOWLEDGEMENTS}

This study on the subject of liturgy and worship was not just an academic exercise for me. It has proven to be one of the most rewarding intellectual and spiritual experiences for which I hope to be eternally grateful, despite the long and arduous effort required to produce such a work including the financial and personal costs involved in undertaking it.

Yet, I did not accomplish this on my own. I wish to thank my parents for coming from Greence to this part of the world and giving me the opportunity to take advantage of the education offered here. I want to thank my wife Lily May, the best musician I know, for working long and countless hours to financially support our family during the long years it took to see this project through. I also want to thank my children, Sofia and Dino, for their patience and understanding. I pray that they will rise to whatever challenges the Lord lays on their path.

As for my committee, my most profound gratitude goes to Dr. Fernando Canale who has introduced me to the amazing hermeneutical tools involved in constructing this project. I want to thank him for inviting me to be a visitor to the Adventist Sola Scriptura Research Group. The presentations and discussions that took place played a key role in shaping my thoughts concerning the Biblical Sanctuary Model. His commitment to excellence and to the Sola Scriptura principle have been an inspiration. Thank you, Dr. Roy Gane, for your very valuable contributions. Your painstaking observations have greatly improved the quality of this work. Thank you, Dr. Félix Cortez, for providentially being guided to be a part of this project. Your expertise in the book of Hebrews has greatly contributed to my insights into 
this project. I want to thank Dr. David Williams for his contributions and insights during the defense of this dissertation. Lastly, I want to thank Dr. Timothy O’Malley, the external examiner from Notre Dame, for his probing questions and observations.

I would also like to thank those who contributed financially to the scholarship fund that I have benefitted from, and to Ouachita Hills College for their financial assistance and for the privilege of teaching there for 8 years.

Finally, even though my prayers for greater musical ability and proficiency were never answered or realized over the almost 30 years after I accepted the Lord Jesus Christ and the Seventh-day Adventist message, I am nevertheless grateful that this dissertation provides evidence that the Lord has begun to answer my prayers for greater wisdom and knowledge concerning the complex issues surrounding liturgy, and for the possibility of constructing an understanding of liturgy on the basis of the Sola Scriptura principle. So, I want to thank God the only One worthy of worship for miraculously sustaining me through this process, for not answering my prayers, for answering my prayers, and for the privilege of one day soon being among the combined worshippers of heaven and earth who sing the following words: "Blessing and honor and glory and power be to Him who sits on the throne, and to the Lamb, forever and ever!" (Rev 5:13). 


\section{CHAPTER 1}

\section{INTRODUCTION}

\section{Background to the Problem}

No one can doubt that Christianity has been, and is continuing to face a major crisis regarding the nature, scope, purpose and focus of liturgy. ${ }^{1}$ This liturgical crisis has been taking place within an ecumenical context where Christians have been focusing on liturgy as a means of achieving full visible unity. ${ }^{2}$ The momentum for the use of liturgy as a major tool for ecumenism came around the time of the Second Vatican Council. ${ }^{3}$

${ }^{1} \Lambda \varepsilon \iota \tau o v \rho \gamma i ́ \alpha$ or liturgy refers to a public or formal service pertaining to ritual and cultic services, see Bauer, W., F.W. Danker,, W. F. Arndt, and F. W. Gingrich. GreekEnglish Lexicon of the New Testament and Other Early Christian Literature. 3rd ed. Chicago, 2000 (BDAG), s.v. " $\Lambda \varepsilon ı \tau o v \rho \gamma i$ í." Worship, on the other hand, focusses on the internal attitude and action of the worshiper, see BDAG, s.v. " $\pi \rho \circ \sigma \kappa v v \varepsilon \varepsilon \omega . "$ In addition, the titles to various books have given expression to the liturgical crisis, see Marva J. Dawn and Daniel Taylor, How Shall We Worship? Biblical Guidelines for the Worship Wars (Wheaton, IL: Tyndale House, 2003); Thomas G. Long, Beyond the Worship Wars: Building Vital and Faithful Worship (Bethesda, MD: Alban Institute, 2001); Ronald P. Byars, The Future of Protestant Worship: Beyond the Worship Wars (Louisville, KY: John Knox Press, 2002); Elmer L. Towns, Putting an End to Worship Wars (Nashville, TN: Broadman \& Holman, 1997); John Ylvisaker, What Song Shall We Sing? Healing the Worship Wars with Fusion (Minneapolis, MN: Augsburg Fortress, 2005); Terry W. York, America's Worship Wars (Peabody, MA: Hendrickson, 2003).

${ }^{2}$ Romey P. Marshall and Michael J. Taylor, Liturgy and Christian Unity (Englewood Cliffs, NJ: Prentice-Hall, 1965); James F. Puglisi, ed., Liturgical Renewal as a Way to

${ }^{2}$ Romey P. Marshall and Michael J. Taylor, Liturgy and Christian Unity (Englewood Cliffs, NJ: Prentice-Hall, 1965); James F. Puglisi, ed., Liturgical Renewal as a Way to Christian Unity (Collegeville, MN: Liturgical Press, 2005); Geoffrey Wainwright, Worship with One Accord: Where Liturgy and Ecumenism Embrace (New York: Oxford University Press, 1997).

${ }^{3}$ The ecumenical aims of Vatican II led to the collaboration between Catholic and non-Catholic scholars, which ultimately resulted in "the founding of Societas Liturgica, an 
However, in spite of these sincere efforts, some are expressing doubts about the possibility of employing liturgy as the means of bringing unity to the churches. ${ }^{4}$

A brief overview of Roman Catholic, Protestant, Charismatic and Emerging Church liturgies will help to illustrate the liturgical crisis within Christianity. For centuries, Roman Catholic liturgy has been uniform and predictable, relying on set rubrics and ceremonies. Of the seven sacraments, "the Mass" is considered the first and the greatest. ${ }^{5}$ The Eucharist has been and is the main rite in Roman Catholic liturgy. The central position the altar occupies in Roman Catholic churches underlies its centrality. In the past, Roman Catholic liturgy has been uniform. However, as of late there have been considerable changes which have occurred in the following areas, (1) the use of the vernacular, (2) changes in music and art, (3) the priest facing the people at mass, and (4) a greater emphasis on reading the Scriptures during worship. ${ }^{6}$

In contrast to the emphasis on the Eucharist, Protestant worship during the Reformation has traditionally upheld the centrality of the Scriptures as the focus of

international, ecumenical organization of liturgy scholars, begun in 1962 by Wiebe Vos of the Netherlands." Rita Ferrone, Liturgy: Sacrosanctum Concilium, ed. Christopher M. Bellitto, Rediscovering Vatican II (New York: Paulist Press, 2007), 57.

${ }^{4}$ David R. Holeton, "Ecumenical Liturgical Consensus: A Bumpy Road to Christian Unity Presidential Address," Studia Liturgica 38 (2008): 13-16.

${ }^{5}$ Cyprian Vagaggini, Theological Dimensions of the Liturgy: A General Treatise on the Theology of the Liturgy, 4th Italian ed. (Collegeville, MN: Liturgical Press, 1976), 158.

${ }^{6}$ Ferrone, Liturgy: Sacrosanctum Concilium, 60. Vatican II, Sacrosanctum Concilium (SC) Art. 51. For instance, within the area of church music there have been significant changes that range from the monophonic sounds of Gregorian chant to the complex polyphony of Palestrina in the sixteenth century, see James F. White, Roman Catholic Worship: Trent to Today, 2nd ed. (Collegeville, MN: The Liturgical Press, 2003), 20. However the most important changes occurred as a result of the Second Vatican Council, which strongly encouraged indigenous musical forms to be used in the liturgy, see $S C$ Art. 119. 
liturgy. ${ }^{7}$ However, after Vatican II, Protestant liturgy moved closer to Roman Catholic liturgy by celebrating the Lord's Supper more frequently. Conversely, Catholic liturgy has moved closer to Protestant liturgy by putting more emphasis on the Scriptures. ${ }^{8}$ Generally, Protestant liturgy has departed from Roman Catholic liturgy in the following ways, (1) its focus, (2) architecture, and (3) music. ${ }^{9}$ However, when it comes to baptism, there are both similarities and differences. ${ }^{10}$

For centuries, the focus of Christian liturgy has been primarily upon the Eucharist or the Word. However the advent of the Charismatic movement in the mid-twentieth century brought significant change. ${ }^{11}$ The Charismatic movement and its worship switched the focus of liturgy to worship bands, replacing the altar and the pulpit by occupying the central focus of the worshippers. Furthermore, in Charismatic worship the

${ }^{7}$ James F. White, Protestant Worship: Traditions in Transition (Louisville, KY: John Knox Press, 1989), 41, 42, 47, 60.

${ }^{8}$ Ibid., 34. Yet, not all Protestants agree about the centrality of the Scriptures as the focus of liturgy. For instance, Wolfhart Pannenberg believes that the Eucharist should occupy the central aspect of worship, instead of the Scriptures. See Wolfhart Pannenberg, Christian Spirituality (Philadelphia: Westminster Press, 1983), 40.

${ }^{9}$ Protestant liturgy gives more time to the preaching of the Word. Historically, having the pulpit in the center instead of the altar applies to the Reformed, Puritan and Methodist churches. See James F. White, Protestant Worship and Church Architecture: Theological and Historical Considerations (New York: Oxford University Press, 1964), 81, $82,85,89,94,106$. Also the architecture in many Protestant churches is much simpler and more modest than the grand cathedrals and basilicas of Catholicism. Musically, congregational singing and not chant represents the core of Protestant church music. See Charles L. Etherington, Protestant Worship Music: Its History and Practice (New York: Holt, Rinehart and Winston, 1962), 261-265.

${ }^{10}$ While the magisterial Reformers upheld infant baptism, which harmonized with Roman Catholic practice, the Anabaptists believed it to be unscriptural and thus eventually began to practice adult baptism by immersion. See White, Protestant Worship: Traditions in Transition, 82.

${ }^{11}$ Pentecostalism began with Charles F. Parham and James Seymour in the early part of the twentieth century before it grew into the Charismatic movement in 1959. See Stanley M. Burgess, ed. Pentecostal and Charismatic Timeline, Revised and Expanded ed., The New International Dictionary of Pentecostal and Charismatic Movements (Grand Rapids, MI: Zondervan, 2002), 1232-1234. 
majority of the time is actually devoted to music. ${ }^{12}$

Last is the Emerging Church, which sprang up around the 1990's, and mostly among Evangelicals. ${ }^{13}$ Preaching the Scriptures does not occupy the central position in its liturgy, although the reading of the sacred text is involved. Its alternative approaches to liturgy combine the sacramental practices of the early and medieval church with liturgical expressions grounded in "twenty-first-century Western culture."14 This blending between early, medieval and twenty first century Western culture includes icons, the Eucharist, contemplative prayer, mystical spiritual practices, casual dress, casual atmosphere, lots of art, images, and all varieties of music; all of which emphasize sensory experience. ${ }^{15}$

This brief and incomplete outline indicates that liturgical practices have experienced considerable changes during the past two thousand-year history of Christianity with very substantial changes occurring in the late twentieth century. ${ }^{16}$ Yet at

${ }^{12}$ Daneil E. Albrecht, Rites in the Spirit: A Ritual Approach to Pentecostal/Charismatic Spirituality (Sheffield, England: Sheffield Academic Press, 1999), 160.

${ }^{13}$ John Jovan Markovic, "The Emerging Church: A Call to Action and Authenticity (Part 1 of 2)," Ministry Magazine, March 2010, 11. Although the public began to believe that the "emerging" began in the 1990's, Markovic has come across sources that date the movement as far back as the 1970's.

${ }^{14}$ Eddy Gibbs and Ryan K. Bolger, Emerging Churches (Grand Rapids, MI: Baker Academic, 2005), 29.

${ }^{15}$ Markovic, "The Emerging Church: A Call to Action and Authenticity (Part 1 of 2)," 20. Its liturgy consists of

casual dress, physical rearrangement of seats and the pulpit in order to create a more casual and relaxed atmosphere, candlelight, visual arts, icons, all types of music, the eucharist, medieval centering or contemplating prayers, moments of silence, various forms of meditation (including Eastern forms of meditation) and mystical practices, prayer labyrinths, designated places for personal meditation, silence and prayer, and so forth-all of which have the purpose of making worship EPIC — experiential, participatory, image-driven, and connected.

${ }^{16}$ Liturgical scholar James F. White has stated, "In the quarter century after the Constitution on the Sacred Liturgy (1963), far more changes happened than in the previous four centuries." White, Protestant Worship: Traditions in Transition, 33. See also George 
the same time there has been general agreement among Christians about the primary role of the Scriptures, which constitute the main source of the gospel message in the liturgy. ${ }^{17}$ Nevertheless, the liturgically diverse practices that have occurred in the late twentieth century have tended to complicate the already bumpy road to Christian unity.

In spite of their diverse and even divergent practices in Christian liturgy, Christians almost entirely agree that the real purpose of liturgy is to enter into, celebrate or experience the presence of God. This agreement about the importance of the presence of God in liturgy is evident among Roman Catholics, ${ }^{18}$ various Protestants, ${ }^{19}$

Barna, "Worship in the Third Millennium," in Experience God in Worship (Loveland, CO: Group Publishing, 2000), 18-19.

${ }^{17}$ Eduard Schillebeeckx, The Real Achievement of Vatican II, trans. H.J.J. Vaughan (New York: Herder and Herder, 1967), 40-41. See also, Bradley Truman Noel, Pentecostal and Postmodern Hermeneutics: Comparisons and Contemporary Impact (Eugene, OR: Wipf \& Stock, 2010), 141-145; Robert E. Webber, The Younger Evangelicals: Facing the Challenges of the New World (Grand Rapids, MI: Baker Books, 2002), 192.

${ }^{18}$ For Roman Catholicism, see Gary A. Anderson, "To See Where God Dwells: The Tabernacle, the Temple, and the Origins of the Mystical Tradition," in Temple and Contemplation: God's Presence in the Cosmos, Church, and Human Heart, ed. Scott W. Hahn, Letter and Spirit (Steubenville, OH: St. Paul Center for Biblical Theology, 2008), 1345; SC Art. 7; Edward J. Kilmartin, "Christ's Presence in the Liturgy," in Bread from Heaven, ed. Paul J. Bernier (New York: Paulist Press, 1977), 102-113; Davd. N. Power, Unsearchable Riches: The Symbolic Nature of Liturgy (New York: Pueblo, 1984), 72; Scott Hahn, The Lamb's Supper: The Mass as Heaven on Earth (New York: Doubleday, 1999), 115-116; Vagaggini, Theological Dimensions of the Liturgy, 254-255; Michael J. Skelley, The Liturgy of the World: Karl Rahner's Theology of Worship (Collegeville, MN: The Liturgical Press, 1991), 43, 44, 52, 58; Karl Rahner, Faith and Ministry, Theological Investigations, vol. XIX (New York: Crossroad, 1983), 143.

${ }^{19}$ For Protestants, see Don E. Saliers, Worship as Theology: Foretaste of Glory Divine (Nashville, TN: Abingdon Press, 1994), 23, 132; Barry Liesch, People in the Presence of God: Models and Directions for Worship (Grand Rapids, MI: Ministry Resources Library, 1988), xviii, 21-23; Pannenberg, Christian Spirituality, 40; Donald G. Bloesch, The Church: Sacraments, Worship, Ministry, Mission (Downer's Grove, IL: InterVarsity Press, 1997), 137; Donald G. Bloesch, Holy Scripture: Revelation, Inspiration \& Interpretation (Downer's Grove, IL: InterVarsity Press, 2006), 120; John Killinger, "Holydays and Holidays," in Mastering Worship (Portland, OR: Christianity Today, 1990), 135; Paul Anderson, "Balancing Form and Freedom," in Changing Lives through Preaching And Worship: 30 Strategies for Powerful Communication, ed. Marshall Shelley (Nashville, TN: Moorings, 1995), 196; Marva J. Dawn, Reaching out without Dumbing Down: A Theology of Worship for the Turn-of-the-Century Culture (Grand Rapids, MI: Eerdman's, 
Pentecostals, ${ }^{20}$ and adherents of the Emerging Church. ${ }^{21}$ In fact, according to William

Dyrness, "the fact of God's presence in worship is the universal premise of worship."22

Lester Ruth points out that when the questions of time, energy, prominent space

and expensive furnishings are answered, most worship services are "organized around

one of three categories: music, Word/preaching, or table (meaning the Lord's Supper).,"23

He further indicates that these three categories are not merely organizing principles. He

states, "one of these three categories is usually the normal means by which a

congregation assesses God's presence in worship or believes that God is made present in

1995), 94, 192, 247; Ted Peters, "Worship Wars," Dialog 33 (Summer 1994): 167; Robert E. Webber, ed. The Renewal of Sunday Worship, in The Complete Library of Christian Worship (Nashville, TN: Star Song Pub., 1993), 100, 387-388; J.-J. von Allmen, Worship: It's

Theology and Practice (New York: Oxford University Press, 1965), 27.

${ }^{20}$ For Pentecostals see, Constance M. Cherry, "Merging Tradition and Innovation in the Life of the Church: Moving from Style to Encountering God in Worship," in The Conviction of Things Not Seen: Worship and Ministry in the 21st Centurgy, ed. Todd E. Johnson (Grand Rapids, MI: Brazos Press, 2002), 25; James White states that Pentecostal worship manifests the "action and presence of the Holy Spirit," White, Protestant Worship: Traditions in Transition, 200; Lester Ruth, "A Rose by Any Other Name: Attempts at Classifying North American Protestant Worship," in The Conviction of Things Not Seen: Worship and Ministry in the 21st Centurgy, ed. Todd E. Johnson (Grand Rapids, MI: Brazos Press, 2002), 41; Albrecht, Rites in the Spirit, 160; Donald E. Miller and Tetsunao Yamamori, Global Pentecostalism: The New Face of Christian Social Engagement (Los Angeles: University of California Press, 2007), 137-138; Kilian McDonnell, Presence, Power, Praise: Documents on the Charismatic Renewal, 3 vols. (Collegeville, MN: The Liturgical Press, 1980), 1:574-575; Daniel E. Albrecht, "Pentecostal Spirituality: Looking through the Lens of Ritual," Pneuma 14, no. 2 (Fall 1992): 111.

${ }^{21}$ For the Emerging Church, see Sally Morgenthaler, Worship Evangelism: Inviting Unbelievers into the Presence of God (Grand Rapids, MI: Zondervan, 1995), 23, 24, 65-67, 97-102; John D. Witvliet, "At Play in the Lord's House: Why Worship Matters," Books and Culture 4, no. 6 (November/December 1998): 23; Robert E. Webber, Ancient-Future Worship: Proclaiming and Enacting God's Narrative (Grand Rapids, MI: Baker Books, 2008), 133; Ray S. Anderson, An Emergent Theology for Emerging Churches (Downer's Grove, IL: InterVarsity Press, 2006), 59; Gibbs and Bolger, Emerging Churches, 81; Peter Rollins, How (Not) to Speak of God (Brewster, MA: Paraclete Press, 2006), 24; Webber, The Younger Evangelicals, 191-195; Dan Kimball, The Emerging Church: Vintage Christianity for New Generations (Grand Rapids, MI: Zondervan, 2003), 116.

${ }^{22}$ William A. Dyrness, A Primer on Christian Worship: Where We've Been, Where We Are, Where We Can Go (Grand Rapids, MI: Eerdman's, 2009), 24.

${ }^{23}$ Ruth, “A Rose by Any Other Name," 48. 
worship. ${ }^{, 24}$ Various other scholars also support the idea that music, Word/preaching, and the Eucharist/Lord's Supper constitute the major vehicles of the divine presence. ${ }^{25}$ Hence, the presence of God is directly related to liturgical activities.

Thus, there seems to be universal agreement about the presence of God as the central aspect of liturgy, yet at the same time there is disagreement about the way in which the presence of God relates to liturgy. This raises one key question: In our current situation, how does this universal agreement about the presence of God as the central aim of liturgy relate to the divergent means by which congregations assess his presence?

\section{Problem}

Even though current debates about liturgy take place within the general context of the ecumenical search for Christian unity, theologians and scholars who specialize in liturgy still identify the existence of at least three diverging interpretations of the way in which the presence of God relates to liturgy. They broadly correspond to the main liturgical traditions, Sacramental (Roman Catholic), Kerygmatic (Protestant) and Charismatic (Pentecostal and Interdenominational). This current situation in Christianity leaves us with the challenging task of sorting out whether there ought to be only one mode in which congregations assess and experience the divine presence or whether there should be two or three as delineated by the liturgical traditions.

\footnotetext{
${ }^{24}$ Ibid. See also pp. 41, 43, 51. After surveying the various styles of worship in the Protestant tradition, William Dyrness distills the wide variety of worship forms down to three: those that are music-oriented, Word- oriented or table-oriented. The key question that resulted in this contemporary typology is, "Where in the service do worshipers feel that they are closest to God? Or to put it another way, what part of the service constitutes a 'theophany' - that is, what is the particular element that communicates the presence of God?" Dyrness, A Primer on Christian Worship, 68-69.

${ }^{25}$ For more support on Eucharist, Word, and music as the main vehicles of the divine presence, see Chapter 3 of this dissertation pages 78-80.
} 


\section{Purpose}

The purpose of this study is threefold: (1) to describe how the three diverging interpretations relate the presence of God to liturgy, (2) to ascertain the cause/s for this divergence by focusing on the presence of God as the central component of the liturgical event, and (3) to seek to address this divergence by examining the possibility of developing a theology of the presence of God in Christian liturgy that is based on the Scriptures.

\section{Significance of This Study}

This study will contribute to scholarship within the field of Christian liturgy in two main ways. First, it will focus on the centrality of the presence of God as a vital key to understanding the divergences in liturgy. This study will examine how the understanding of general ontology or Being as a major presupposition affects (1) the interpretation of the divine presence assumed by the main liturgical traditions, and (2) how the interpretation of the presence of God in each tradition relates to the main components of corporate worship. Second, this study will explore an interpretation of the divine presence and its assumed ontology that is consistent with Sola Scriptura and which has implications for how the divine presence relates to liturgy.

\section{Justification}

There are two ways in which this study is unique, both of which pertain to the methodology employed in Chapter 3. First, this study employs a phenomenological description of liturgy for the purpose of discovering the broadest possible components that make up liturgy and which are interpreted in the worship wars outlined in Chapter 2. Second, this study employs Thomas Kuhn's influential work on paradigms and data as a 
framework for analyzing the two conflicting interpretations of Being as important paradigms that exercise a dominant hermeneutical influence on the data, which in this case is the divine presence and the liturgical components.

Furthermore, in this dissertation I will use the sola, tota, and prima Scriptura principles in order to ascertain the possibilities of dealing with the question of liturgical and ecumenical unity. ${ }^{26}$ Whereas all models that will be discussed in Chapter 4 of this study have different perspectives on the role of tradition, philosophy, and science as theological sources, they nevertheless all agree on the normative and foundational role of the Bible. Moreover, since all models have the Bible in common as a primary source, this study will focus on the use of Scripture alone in order to overcome the present liturgical crisis by constructing a biblical view of the divine presence that lays the groundwork for revealing the manner in which God's presence is communicated to worshippers.

\section{Methodology}

The complexity of the question of liturgy and the stated purpose of this dissertation require an interdisciplinary methodological approach that includes five methods. $^{27}$

The first method is a historical overview of liturgy. The purpose of this step is to discover and ascertain the existence of liturgical diversity in Christendom.

\footnotetext{
${ }^{26}$ Although Christian theology affirms the primary role of the Scriptures, it nevertheless relies on other sources in the theological task, see Winfield H. Bevins, "A Pentecostal Appropriation of the Wesleyan Quadrilateral," Journal of Pentecostal Theology 14, no. 2 (2006): 229-246; Vatican II, Dei Verbum (DV), Art. 10; Thomas C. Oden, The Living God, Systematic Theology Series (San Francisco: Harper and Row, 1987), 341. The sola, tota, and prima Scriptura principles restrict the issue of theological sources to the Bible.

${ }^{27}$ Fernando Canale, "Interdisciplinary Method in Theology? In Search of a Working Proposal," Neue Zeitschrift für systematische Theologie und Religionsphilosophie 43, no. 3 (2001): 366-389.
} 
The second method consists of a phenomenological description of the complex reality of liturgy that is designed to discover what exactly is being interpreted in the diverse liturgies of Christendom. Such a description is expected to reveal several indispensable components in Christian liturgy.

First is the divine presence and action as the object of worship. Scholars point out that liturgical rites and ritual actions (1) "explicitly mediate contact with the divine,"28 (2) are centered on sacred presences, ${ }^{29}$ (3) shed light on the doctrine of God, ${ }^{30}$ and (4) include objects that symbolize and embody the divine presence, which is understood as immanent in the sacred object, yet also transcendent and beyond it at the same time. ${ }^{31}$

Second is the human experience of the divine, comprising the subjects who lead and those who experience the worship event. It has been pointed out that ritual studies are too often restricted to the verbal dimension of life. In contrast, Mark Searle mentions the "Puritan preference for word to the exclusion of rite was based on an anthropology that granted priority to the individual over the community, to mind over body, and to the conscious over the unconscious.. ${ }^{, 32} \mathrm{He}$ believes that "liturgy requires the physical presence of living bodies....[It] is uniquely a matter of the body: both the individual body and the collective body." 33

\footnotetext{
${ }^{28}$ Mark Searle, "Ritual," in The Study of Liturgy, ed. Geoffrey Wainwright, Cheslyn Jones, Edward Yarnold, and Paul Bradshaw (New York: Oxford University Press, 1992), 55.

${ }^{29}$ Evan M. Zuesse, "Ritual," The Encyclopedia of Religion, ed. Mircea Eliade (New York: Macmillan, 1987), 16:405.

${ }^{30}$ Gerald A. Klingbeil, A Comparative Study of the Ritual of Ordination as Found in Leviticus 8 and Emar 369 (Lewiston, NY: Edwin Mellen Press, 1998), 6-7.

${ }^{31}$ Harold W. Turner, From Temple to Meeting House: The Phenomenology and Theology of Places of Worship (New York: Mouton Publishers, 1979), 10.

${ }^{32}$ Searle, "Ritual," 56-57.

${ }^{33}$ Ibid., 57.
} 
Third is the worship event itself, which is considered a divine/human encounter taking place in creation. The encounter or worship event contains a special message that is performed at a special time and/or place. ${ }^{34}$ In addition, the phenomenological analysis of sacred places shows that temples and meetinghouses form the center from which all other components of liturgy are understood. That is, the sacred place functions as (1) the center of human life, (2) microcosm of the cosmic realm, including cosmogony, (3) the place where humans interact with the divine by offering prayers and sacrifices, and (4) the place where the immanent/transcendent divine presence is manifested. ${ }^{35}$

The last of the indispensable components refers to the rituals or means employed during the worship event. Scholars have described these means as ordered sequences of behavior, distinguished from ordinary interaction involving both participants and the wider public. ${ }^{36}$ These rituals encompass rites and symbols that are comprised of words, actions and material elements. ${ }^{37}$

In the third method I will use what systematic theologians know as model methodology. Various theologians have employed models in the theological task by

\footnotetext{
${ }^{34}$ Jan Platvoet, "Ritual in Plural and Pluralist Societies," in Pluralism and Identity: Studies in Ritual Behaviour, ed. Jan Platvoet and Karel van der Toorn (Leiden: E.J. Brill, 1995), 41.

${ }^{35}$ Turner, From Temple to Meeting House, 10. Kavanagh further points out the relationship between Christian worship and creation. He states, "since Christian worship swims in creation as a fish swims in water, theology has no option but to accept the created world as a necessary component of every equation and conclusion it produces." Aidan Kavanagh, On Liturgical Theology (Collegeville, MN: The Liturgical Press, 1992), 4.

${ }^{36}$ Platvoet, "Ritual in Plural and Pluralist Societies," 41.

${ }^{37}$ Anscar J. Chupungco, "Introduction," in Handbook for Liturgical Studies: Fundamental Liturgy, ed. Anscar J. Chupungco (Collegeville, MN: Liturgical Press, 1997), vii; Gerald A. Klingbeil, Bridging the Gap: Ritual and Ritual Texts in the Bible, ed. Richard S. Hess, Bulletin for Biblical Research Supplements, vol. 1 (Winona Lake, IN: Eisenbrauns, 2007), 19-21.
} 
applying them to ecclesiology,${ }^{38}$ studies in revelation and inspiration, ${ }^{39}$ the relationship between science and theology ${ }^{40}$ biblical studies ${ }^{41}$ and liturgy. ${ }^{42}$ The use of models will help us to discover the most general and pervasive patterns involved in the worship wars. In this way the great variety of liturgical practices in Christendom will be reduced to three general models. The Sacramental model mediates the presence of God through the Eucharist, the Kerygmatic model mediates the divine presence through the Word, and the Charismatic model uses music as the vehicle of God's presence. ${ }^{43}$

\footnotetext{
${ }^{38}$ Avery Dulles, Models of the Church, exp. ed. (Garden City, NY: Image Books, 1987).

${ }^{39}$ Avery Dulles, Models of Revelation (Maryknoll, NY: Orbis Books, 1992); Fernando Canale, Back to Revelation-Inspiration (New York: University Press of America, 2001).

${ }^{40}$ Ian G. Barbour, Myths, Models, and Paradigms; a Comparative Study in Science
} and Religion (New York: Harper \& Row, 1974); Idem, Religion and Science: Historical and Contemporary Issues (San Francisco: HarperSanFrancisco, 1997); Hans Küng, Theology for the Third Millennium: An Ecumenical View (New York: Doubleday, 1988); Ian T. Ramsey, Models and Mystery (London: Oxford University Press, 1964).

${ }^{41}$ Gerhard F. Hasel, "Recent Models of Biblical Theology: Three Major Perspectives," Andrews University Seminary Studies 33, no. 1-2 (1995): 55-75.

${ }^{42}$ The concept of models has also been applied to liturgy. Robert Webber provides the following paradigms of history in his description of worship: (1) a pre-Constantinian era, in which liturgy was informal and intimate (2) post Constantine era in which liturgy was more public with large basilicas, (3) the medieval era with clericalized worship, (4) the Reformation where the focus was on the Word, (5) Revivalism with an emphasis on an evangelistic model of worship, (6) Pentecostal worship, and (7) postmodern worship (Robert E. Webber, Ancient-Future Faith: Rethinking Evangelicalism for a Postmodern World [Grand Rapids, MI: Baker Books, 1999], 97-99). In another work, Webber provides three broad paradigms which he refers to as "Pre-Reformation Liturgies," "Reformation Models of Worship," and "Post-Reformation Models of Worship in Robert E. Webber ed., Twenty Centuries of Christian Worship, in The Complete Library of Christian Worship [Nashville, TN: Star Song, 1994], 142-258. Lester Ruth refers to music, preaching and sacraments which have the potential for a taxonomy of worship (Ruth, "A Rose by Any Other Name," $43,48,49,51)$. Barry Liesch speaks of five models of worship: (1) pre-Sinai, (2) tabernacletemple, (3) synagogue, (4) Pauline, and (5) the book of Revelation (Liesch, People in the Presence of God, xi). For a modeling of biblical and Ancient Near Eastern rituals in liturgy, see Roy Gane, Ritual Dynamic Structure Georgias Dissertations 14, Religion 2. (Piscataway, NJ: Georgias Press, 2004).

${ }^{43}$ Liturgical scholars and theologians have also attested to the Eucharist, the Word and music as three major vehicles of the divine presence throughout history. See Bloesch, 
The fourth method is hermeneutical and will focus on developing criteria in order to test the various hypotheses of the liturgical traditions against the biblical data. The purpose of the hermeneutical method is to discover the nature and content of the presuppositions assumed in the interpretation of the presence of God. ${ }^{44}$ In addition, I will

The Church: Sacraments, Worship, Ministry, Mission, 35, 137; Dyrness, A Primer on Christian Worship, 68-69; Barry Liesch, The New Worship: Straight Talk on Music and the Church (Grand Rapids, MI: Baker Books, 1996), 53; Ruth, "A Rose by Any Other Name," 41, 43, 48, 51; Webber, Ancient-Future Worship: Proclaiming and Enacting God's Narrative, 133; Witvliet, "At Play in the Lord's House," 23. For more scholarly support on the Eucharist, Word, and music as vehicles of the divine presence, see Chapter 3, pp. 78-80 footnotes 34-37. No dissertation was found that directly addressed the specific problem and purpose of this dissertation. This conclusion was reached after investigating hundreds of dissertations by conducting a search on liturgy either in the title or in the abstract, with 173 dissertations on liturgy and ecumenism. There are, however, several dissertations that relate the presence of God to the following subjects: (1) the Old Testament, (2) the Temple/Sanctuary in Revelation, (3) divine presence in Exodus, (4) God's presence and rituals and Tabernacle, (5) Eucharist, (6) preaching, (7) human nature, and (8) the Holy Spirit, see Jerry M. Jr. Carter, “The Audible Sacrament: The Sacrament of Gardner C. Taylor's Preaching" (Ph.D. dissertation, Drew Theological School, 2007); Norah Whipple Caudill, "The Presence of God in the Exodus Narrative: Purposes, Means and Implications" (Ph.D. dissertation, Fuller Theological Seminary, September 2006); Craig Collier Christina, "Calvin's Theology of Preaching: The Activity of the Holy Spirit in the Preaching Event" (Ph.D. dissertation, The Southern Baptist Theological Seminary, May 2001); Darrel W. Cox, "Physiological Phenomena Which Occurred in Connection with Manifestations of the Presence of God: Biblical and Theological Investigations" (Ph.D. dissertation, Trinity International University, June 1997); Timothy A. Janiszewski, "Trinity and Temple: Implications of Early Christian and Second Temple Worship for Doxological Access to God in Contemporary Non-Christian Religions" (Ph.D. dissertation, Trinity International University, May 2002); Teman W. III Knight, "The Presence of God in the Old Testament" (Ph.D. dissertation, New Orleans Baptist Theological Seminary, March 1992); Matias H. Kung, "The Ritual Dimensions in the Tabernacle Worship and Their Missiological Implications" (Ph.D. dissertation, Trinity International University, May 2001); Joan Lucie Roccasalvo, "The Eucharist as Beauty: A Study in the Though of Hans Urs Von Balthasar" (Ph.D. dissertation, Drew University, May 1998).

${ }^{44}$ Various scholars have underscored the importance of articulating the hermeneutical role of method in the theological task, see Kwabena Donkor, Tradition, Method, and Contemporary Protestant Theology: An Analysis of Thomas C. Oden's Vincentian Method (Lanham, MD: University Press of America, 2003); Avery Dulles, The Craft of Theology: From Symbol to System, New Expanded ed. (New York: Crossroad, 1995); Gordon D. Kaufman, An Essay on Theological Method (Missoula, MT: Scholars Press, 1975); Bernard Lonergan, Method in Theology (New York: Crossroad, 1979); John Macquarrie, Principles of Christian Theology (New York: Charles Scribner's Sons, 1966); David Tracy, Blessed Rage for Order: The New Pluralism in Theology (San Francisco: Harper and Row, 1988). Kwabena Donkor's study of the formal structure of method reveals that it consists of three 
use hermeneutical analysis in order to compare how the role of Being as a major presupposition in each model affects the issue of unity.

The fifth method is exegetical and systematic and its purpose is to ascertain the meaning of the main passages of Scripture in which liturgy is modeled. The exegetical method this study will employ consists of a phenomenological exegesis of selected biblical passages. A phenomenological exegesis distinguishes between the micro, meso, and macro levels of the text $\mathrm{x}^{45}$ and critiques interpretations of the text at all three levels that distort it and that cannot be sustained by it. ${ }^{46}$ As a result, this method allows the text to reveal its meaning at all three levels and to correct the false assumptions of the

essential components: data (material), goal (subject matter), and presuppositions (hermeneutical principles). Fernando Canale refers to them as the material condition, the teleological condition and the hermeneutical condition, see Kwabena Donkor, Tradition, Method, and Contemporary Protestant Theology, 50, 51, 58; Fernando Canale, Creation, Evolution, and Theology (Berrien Springs, MI: Andrews University Lithotech, 2005), 109. Specifically, the material condition refers to data, and sources of information, the teleological condition refers to the purpose or aim of the overall method that is employed, and hermeneutical condition includes a priori assumptions about ontology, epistemology, and system.

${ }^{45}$ John Peckham states,

Microhermeneutical principles refer to those at the level of examination of individual texts and pericopes, macrohermeneutical principles refer to the overarching conceptual framework, and mesohermeneutical principles refer to individual doctrines in between. In theological interpretation of the biblical text, each of these levels operates and impinges upon the others. That is, one's conceptual framework (macro) sets the ontological and epistemological parameters within which doctrines (meso) are conceptualized, both of which impinge upon one's reading of the text itself (micro). Conversely, one's reading of the text itself (micro) should impinge upon one's meso and macrohermeneutical presuppositions (John C. Peckham, Canonical Theology: The Biblical Canon, Sola Scriptura, and Theological Method (Grand Rapids, MI: Eerdmans, 2016), 213).

${ }^{46}$ Fernando Canale notes that in applying a philosophical-scientific epoché "exegetes and theologians cancel out all previously inherited theories that could prove to be hindrances to the understanding of Scripture. This... allows the exegete and theologian to discover and describe the general presuppositional structure assumed by the biblical writers." Fernando Canale, Back to Revelation-Inspiration, 149. 
interpreter without at the same time exhausting the meaning of the text. ${ }^{47}$ The selected biblical passages in this study are derived from the perspective of what liturgy is that is provided by the outcome of the phenomenological method. Moreover, the selected biblical passages will be analyzed by the conditions of interpretation from Scripture that are provided by the outcome of the hermeneutical method.

The exegetical method thus generates large amounts of data on the divine presence and the liturgical components. Then this data can be systematized according to the principles revealed by the hermeneutical method in order to develop a model of the complex and integrated interrelationships that exist between the divine presence, the rest of the liturgical components and the biblical search for unity in liturgy.

\section{Outline of Study}

Chapter 1 includes a brief overview of the conflicting liturgical practices within Christianity, as well as the emphasis in Christian liturgy on the presence of God. The aim of the first Chapter is to establish the problem and purpose of this study by first introducing the background to the problem.

The aim of Chapter 2 is to give a brief overview of the liturgical conflicts throughout the centuries and across denominational lines.

The aim of Chapter 3 is to introduce several interdisciplinary methodological steps that will help in achieving the purpose of the dissertation and which will be applied

\footnotetext{
${ }^{47}$ According to Peckham,
}

With a canonical approach... one closely reads and exegetes the canonical text itself in order to inform and (where necessary) transform one's doctrines (meso) and the wider conceptual framework (macro) via an ongoing hermeneutical spiral that brings one's conceptual framework and dogmatic perspectives closer and closer to those discernible in the canonical text itself (John C. Peckham, Canonical Theology, 213). 
in the fourth, fifth, sixth, and seventh Chapters. These steps will identify the components of liturgy, the models of liturgy and the hermeneutical tools that will be used to interpret the models.

The goal of Chapter 4 is to analyze the way in which the Sacramental, Kerygmatic, and Charismatic models interpret the presence of God in Christian liturgy.

The aim of Chapter 5 is to introduce the Biblical Sanctuary model by allowing Scripture to unfold the macro hermeneutical principles that are integrally linked with an exegesis of the divine presence and the liturgical components. We will apply the exegetical methodology to a survey of Old Testament (OT) data derived from the phenomenological description of liturgy in Chapter 3.

The aim of Chapter 6 continues that of Chapter 5 by applying the exegetical methodology to a survey of New Testament (NT) data.

The goal of Chapter 7 is to first take the data generated by Chapters 5 and 6 on the divine presence and the liturgical components and construct a model of the complex and integrated interrelationships that exist between these components, their subcomponents and the biblical search for unity. The second goal of this Chapter is to compare and contrast the Sacramental, Kerygmatic, and Charismatic models with the Biblical Sanctuary model.

Lastly, Chapter 8 summarizes, provides final conclusions that address the purpose of this study, and makes recommendations for further research.

\section{Delimitations}

Christian worship is a massive subject that encompasses liturgy, and liturgy in turn involves historical, ritual, Biblical, phenomenological, theological and philosophical 
elements. This dissertation will further narrow the scope of liturgy by focusing on the interpretation of the divine presence in Christian liturgy, the mode or modes in which the divine presence is revealed, and the nature of its relationship to the components of liturgy. Hence this dissertation is not intended to be a history of the liturgy, neither is its purpose to provide an exhaustive description or analysis of all the liturgical rites associated with each model. Similarly, the philosophical and theological landscape is also great and thus no attempt is made to cover all of the main theological contours that surround the models.

Even though this is an interdisciplinary study, it will primarily be a philosophical/theological analysis. It will restrict liturgical expressions to the analysis provided by the structure of method and to the broad lines proper of model methodology. In addition, since exegesis is involved, this study will not employ the higher critical forms of redaction, form or source criticism, but will instead employ a phenomenological exegesis. 


\section{CHAPTER 2}

\section{HISTORY OF CHRISTIAN LITURGY}

\section{Introduction}

This Chapter involves a history of Christian liturgy for the purpose of assessing the nature and extent of liturgical conflict across denominational lines and throughout history. However, an exhaustive examination of all of the conflicting practices throughout Christian history would go well beyond the limits of this dissertation. Moreover, that kind of exhaustive examination is unnecessary in achieving the purpose of this Chapter, which is to demonstrate the nature and extent of liturgical conflict in Christendom. Therefore, I will achieve the purpose of this Chapter by delimiting the examination of liturgical practices to the following: the focus of liturgy, the Eucharist, preaching the Word, and music. ${ }^{1}$ These liturgical actions, which are by no means exhaustive, form the building blocks that liturgical scholars use when writing about the history of liturgy. ${ }^{2}$ Thus, in order to shed light on the nature and extent of liturgical conflict, as well as how this conflict relates with the presence of God, I will seek to evaluate these liturgical actions across denominational lines and throughout history.

\footnotetext{
${ }^{1}$ The reason for this delimitation centers on the liturgical practices (the Eucharist, preaching the Word, and music) that are closely associated with the focus of liturgy. This is found in pages 19-26 of this dissertation.

${ }^{2}$ See James F. White, A Brief History of Christian Worship (Nashville, TN: Abingdon Press, 1993); Oscar Hardman, A History of Christian Worship (Nashville, TN: Cokesbury Press, 1937); Richard M. Spielmann, History of Christian Worship (New York: Seabury Press, 1966).
} 
According to liturgical scholar James F. White, far more changes happened in the quarter century after the Constitution on the Sacred Liturgy (1963) — a Vatican II document - than in the previous four centuries. ${ }^{3}$ These changes were so turbulent that recent books refer to them as "worship wars."4 The vast array of publications, of which I have only provided a small sample, provide substantial details that speak to the need of conducting an examination regarding the most significant characteristics in this liturgical conflict. Hence, the purpose of undertaking an investigation of the history of liturgy in this Chapter is to ascertain the nature and extent of the liturgical conflict in Christendom.

\section{The Focus of Liturgy}

Part of the conflict revolves around the focus of liturgy. Worship services are organized around one of three categories: music, Word/preaching or the Lord's Supper. Also, "one of these three categories is usually the normal means by which a congregation assesses God's presence in worship or believes that God is made present in worship." In this section, I will first address the conflict surrounding the focus of liturgy before I undertake a broad survey of what liturgical practices reveal about liturgical diversity and conflict in Christendom.

For centuries, the central focus of liturgy was the Eucharist: It was also the chief

${ }^{3}$ James F. White, Protestant Worship: Traditions in Transition, 33. See also George Barna, "Worship in the Third Millennium," 18-19. The debates over inculturation have provided the context for the globalization of Christian worship, which has added to the increased changes in worship practices, Martin D. Stringer, A Sociological History of Christian Worship (Cambridge: Cambridge University Press, 2005), 210.

${ }^{4}$ Byars, The Future of Protestant Worship; Dawn and Taylor, How Shall We Worship? Biblical Guidelines for the Worship Wars; Thomas G. Long, Beyond the Worship Wars; Elmer L. Towns, Putting an End to Worship Wars; John Ylvisaker, What Song Shall We Sing.

${ }^{5}$ Ruth, "A Rose by Any Other Name," 48. See also pages 41, 43, and 51; William A. Dyrness, A Primer on Christian Worship, 68-69. 
means whereby congregations experience the presence of God. Moreover, the Eucharist still continues to be central for the Roman Catholic, Eastern Orthodox, and Anglican churches. ${ }^{6}$ However, the sixteenth century Protestant Reformers shifted the focus of liturgy from the centrality of the Eucharist to the centrality of preaching the Word. ${ }^{7}$ As a matter of fact, Lutheran, Reformed, Evangelical, Puritan, and English Free Churches still agree that the central focus in liturgy is the preaching of the Word. ${ }^{8}$ This focus continues

${ }^{6}$ Horton Davies, Crisis and Creativity, 1965-Present, vol. 6 of Worship and Theology in England (Grand Rapids, MI: Eerdman's, 1996), 40; Baptism, Eucharist and Ministry (Geneva: World Council of Churches, 1982), I.1 p.8; J.D. Crichton, "A Theology of Worship," in The Study of Liturgy, ed. Geoffrey Wainwright, Cheslyn Jones, Edward Yarnold, Paul Bradshaw (New York: Oxford University Press, 1992), 13; D.H. Hislop, Our Heritage in Public Worship (Edinburgh: T \& T Clark, 1935), 226; Marshall and Taylor, Liturgy and Christian Unity, 118; Paul F. Palmer, Sacraments and Worship: Liturgy and Doctrinal Development of Baptism, Confirmation, and the Eucharist (Westminster, MD: Newman Press, 1955), ix, xviii; Keith F. Pecklers, Worship: A Primer in Christian Ritual (Collegeville, MN: Liturgical Press, 2003), 22; William H. Willimon, Word, Water, Wine and Bread (Valley Forge, PA: Judson Press, 1980), 45; Kenneth G. Phifer, A Protestant Case for Liturgical Renewal (Philadelphia: The Westminster Press, 1965), 48; Hardman, A History of Christian Worship, 28; Arthur M. Allchin, "The Liturgical Movement and Christian Unity," in Liturgical Renewal in the Christian Churches, ed. Michael J. Taylor (Baltimore, MD: Helicon, 1967), 24. The following point out the close relationship between the Eucharist and the presence of God, Oscar Cullmann, Early Christian Worship (London: Student Christian Movement Press, 1953), 19; Bernard J. Cooke, The Distancing of God: The Ambiguity of Symbol in History and Theology (Minneapolis, MN: Fortress Press, 1990), 287; Davies, From Andrewes to Baxter and Fox, vol.2 of Worship and Theology in England (Grand Rapids, MI: Eerdman's, 1996), 17; Hislop, Our Heritage in Public Worship, 226.

${ }^{7}$ Bernhard Lang, Sacred Games: A History of Christian Worship (New Haven, CT: Yale University Press, 1997), 172; Pannenberg, Christian Spirituality, 39; Christopher A. Hall, Worshiping with the Church Fathers (Downer's Grove, IL: IVP Academic, 2009), 30; Davies, From Cranmer to Hooker, vol.1 of Worship and Theology in England (Grand Rapids, MI: Eerdman's, 1996), 76; Marshall and Taylor, Liturgy and Christian Unity, 31.

${ }^{8}$ For Lutherans and Luther, see Frank C. Senn, Christian Liturgy: Catholic and Evangelical (Minneapolis, MN: Fortress Press, 1997), 366; Susan J. White, "Christian Worship since the Reformation," in The Making of Jewish and Christian Worship, ed. Paul F. Bradshaw and Lawrence A. Hoffman (South Bend, IN: University of Notre Dame Press, 1991), 185, 186; Carol M. Norén, "The Word of God in Worship: Preaching in Relationship to Liturgy," in The Study of Liturgy, ed. Cheslyn Jones et al. (New York: Oxford University Press, 1992), 45. For Reformed, see Senn, Christian Liturgy, 366; Hall, Worshiping with the Church Fathers, 30; D. G. Hart, Recovering Mother Kirk: The Case for Liturgy in the Reformed Tradition (Grand Rapids, MI: Baker Academic, 2003), 73. For Puritans, see Davies, From Cranmer to Hooker, 294; idem., From Watts and Wesley to Maurice, vol. 3 of 
in spite of the fact that many Protestants after the 1960's sought to restore the Eucharist and baptism as central aspects of worship. ${ }^{9}$ Moreover, since Vatican II, some Protestants, as a result of their study of the early church, are beginning to conclude that they should place the Eucharist at the center of liturgical worship. ${ }^{10}$ After briefly looking at the Lord's Supper in the New Testament, Phifer, who is a Protestant theologian, claims that the Eucharist is the most distinctive aspect of Christian worship. ${ }^{11}$ Two prominent Protestant theologians who disagree about the focus of liturgy are Wolfhart Pannenberg and Donald Bloesch. Pannenberg believes that the center of the church's life should not be the sermon but rather the Eucharist. ${ }^{12}$ Bloesch on the other hand believes that the proclamation of the Word is central and should not be subordinated to the Eucharist. ${ }^{13}$

The Roman Catholic view prior to Vatican II was that "the sermon is accidental to

Worship and Theology in England, (Grand Rapids, MI: Eerdman's, 1996), 31; Phifer, $A$ Protestant Case for Liturgical Renewal, 94. For English Free Churches (Baptist, Congregational, Presbyterian, and Methodist), see Davies, Crisis and Creativity, 40. For Puritans, the presence of God came through the audible word, idem., From Cranmer to Hooker, 64; idem., From Andrewes to Baxter and Fox, 523. For Calvin and the relation between the presence of God and preaching, see Thomas J. Davis, This Is My Body: The Presence of Christ in Reformation Thought (Grand Rapids, MI: Baker Academic, 2008), 110, 111, 115. For Luther see Vilmos Vajta, Luther on Worship, trans., U.S. Leopold (Philadelphia: Muhlenberg Press, 1958), 87-88. For the Reformation and the presence of God through preaching, see Bloesch, The Church: Sacraments, Worship, Ministry, Mission, 104; Webber, Ancient-Future Worship: Proclaiming and Enacting God's Narrative, 133.

${ }^{9}$ White, "Christian Worship since the Reformation," 200; Norén, "The Word of God in Worship," 45; James F. White, Introduction to Christian Worship, Third Revised and Expanded ed. (Nashville, TN: Abingdon Press, 2000), 151.

${ }^{10}$ Marshall and Taylor, Liturgy and Christian Unity, 32; Spielmann, History of Christian Worship, 7. Other Protestants also give support to the idea of the centrality of the Eucharist in liturgy, Wolfhart Pannenberg, Christian Spirituality, 42; Davies, Crisis and Creativity, 42. In addition to the study of the early church, Protestants who are placing a greater emphasis on the Lord's Supper have been profoundly influenced by the liturgical movement which culminated in Vatican II. See Marshall and Taylor, Liturgy and Christian Unity, 38; Allchin, "The Liturgical Movement and Christian Unity,", 24.

${ }^{11}$ Phifer, A Protestant Case for Liturgical Renewal, 25.

${ }^{12}$ Pannenberg, Christian Spirituality, 40.

${ }^{13}$ Bloesch, The Church: Sacraments, Worship, Ministry, Mission, 143-146. 
the mass. ${ }^{, 14}$ Therefore, prior to Vatican II, Protestants largely agreed that the focus of liturgy was on preaching the Word, whereas for Catholics the focus was on the Eucharist. Nevertheless, as a result of the liturgical movement in Protestantism and Vatican II in Catholicism, some Protestants started to place a greater emphasis on the Eucharist and Catholics placed a greater emphasis on the Word. The result was that both "Word and Table" began to constitute the focus of liturgy for Catholics and Protestants instead of the either/or approach that both had assumed before. ${ }^{15}$ However, given the dual emphasis on "Word and Table," there is still a conflict over whether the liturgy of the Word can stand on its own or whether it must always be viewed "as an integral part of the Eucharist."16

With the advent of Pentecostalism (early twentieth century) and the Charismatic movement, (mid twentieth century) the focus of liturgy shifted yet again. Bradley Noel points out that although the centrality of the Scriptures comprises the classic format of Evangelical services, Charismatic worship considers "the worship band and worship song

\footnotetext{
${ }^{14}$ Norén, "The Word of God in Worship," 36. This largely represents the Catholic view prior to Vatican II which also harmonizes with how little the Scriptures were valued for private study and personal spirituality. See Ronald D. Witherup, Scripture: Dei Verbum, ed. Christopher M. Bellitto, Rediscovering Vatican II (New York: Paulist Press, 2006), 6-7.

${ }^{15}$ Max Thurian, "The Present Aims of the Liturgical Movement," Studia Liturgica 3 (1964): 111; Norén, "The Word of God in Worship," 36, 39; Davies, Crisis and Creativity, vii; White, A Brief History of Christian Worship, 157-158; Willimon, Word, Water, Wine and Bread, 125; Geoffrey Wainwright, "Recent Eucharistic Revision," in The Study of Liturgy, ed. Cheslyn Jones et al. (New York: Oxford University Press, 1992), 331; William Johnson Everett, The Politics of Worship: Reforming the Language and Symbols of Liturgy (Cleveland, OH: United Church Press, 1999), 11. Various scholars have pointed out that the focus of liturgy in early Christianity was also that of "Word and Table," Cullmann, Early Christian Worship, 14, 30; Marianne Micks, The Future Present: The Phenomenon of Christian Worship (New York: Seabury Press, 1970), 130-131; Marshall and Taylor, Liturgy and Christian Unity, 105.

${ }^{16}$ Cullman maintains that the service of the Word "was only and always an integral part of the Eucharist from the beginning of Christian Worship," while Gregory Dix believes that "the liturgy of the word existed both as the first half of "word and table' and as an entity in itself," Norén, "The Word of God in Worship," 43. See also, White, Introduction to Christian Worship, 151.
} 
display" as "more central." 17 The reason, as Noel states, is that this is the most likely time when the worshipper can encounter the God of Scripture. ${ }^{18}$ This shift in the focus of liturgy from the centrality of the Eucharist and the Word to the centrality of music has not gone unnoticed by various liturgical scholars and theologians. ${ }^{19}$

\section{Architecture and the Focus of Liturgy}

These differences in the focus of liturgy naturally lead to divergent architectural expressions, that reveal whether the Word, the Eucharist, or music is truly central in Christian liturgy. In early Christianity, believers met in private homes in order to celebrate the Eucharist, which some scholars closely associated with a sacred meal at a table. ${ }^{20}$ Yet, according to Jungman at the end of the first century, the church grew to become too large and thus the tables disappeared, except the one at which the bishop presided. Furthermore, Jungman notes that the table, which now became the focal point, was referred to as the altar. ${ }^{21}$ From an architectural point of view, the altar in Roman

\footnotetext{
${ }^{17}$ Noel, Pentecostal and Postmodern Hermeneutics, 118.
}

${ }^{18}$ Ibid.; Robert E. Webber, ed. The Renewal of Sunday Worship, 82. Charismatic worship is strongly associated with the music driven Jesus movement of the 1960's, Christian rock, and the praise and worship style of the early 1980's, Ruth, "A Rose by Any Other Name," 24-25.

${ }^{19}$ Bloesch, The Church: Sacraments, Worship, Ministry, Mission, 35, 137; Dyrness, A Primer on Christian Worship, 68-69; Liesch, The New Worship, 53; Ruth, "A Rose by Any Other Name," 41, 43, 48, 51; Robert E. Webber, Ancient-Future Time: Forming Spirituality through the Christian Year (Grand Rapids, MI: Baker Books, 2004), 133; Witvliet, "At Play in the Lord's House: Why Worship Matters," 23.

${ }^{20}$ Cullmann, Early Christian Worship, 19; Peter G. Cobb, "The Architectural Setting of the Liturgy," in The Study of Liturgy, ed. Cheslyn Jones et al. (New York: Oxford University Press, 1992), 529; K.W. Noakes, "From New Testament Times until St Cyprian," in The Study of Liturgy, ed. Cheslyn Jones et al. (New York: Oxford University Press, 1992), 119; Hardman, A History of Christian Worship, 29.

${ }^{21}$ Jungmann states that participants no longer reclined or sat at supper, instead they stood and worshipped before God. By the second century the terms "breaking of bread" and "the Lord's meal" were discarded, Josef A. Jungmann, The Early Liturgy to the Time of 
Catholic churches has occupied the central place for centuries. ${ }^{22}$ However, with the advent of the Reformation, the pulpit replaced the altar as the central piece of furniture in the Protestant church. ${ }^{23}$

In his comparison between Anglican versus Puritan liturgy, Horton Davies draws some important architectural insights that revolve around whether the Eucharist is a means of grace (Anglican high view) or whether it is a memorial (Puritan low view). For instance, in the Anglican high view (1) the altar is central and dominating, ${ }^{24}(2)$ there is greater splendor in the decoration and fittings of the church, making the altar the throne of the presence of Christ, the dwelling place of the king, (3) the Eucharist is frequently celebrated with pomp and circumstance, and (4) one approaches the sacrament with deep obeisance, in crossings, kneelings and prostrations. In the Puritan low view, (1) the pulpit is central, (2) the communion service is conducted in a plain meeting house, and the communion table is simply adorned with a white cloth, (3) communion takes place quarterly, and (4) the gestures are standing or sitting about a table. ${ }^{25}$

In Pentecostal and Charismatic liturgy, the focus of liturgy is the worship band, symbolized by the drum kit, instead of the altar in Catholicism or the pulpit in

Gregory the Great (South Bend, IN: University of Notre Dame Press, 1966), 38. By the fourth century Christianity became the state religion, and the architectural setting of the Eucharist shifted from the home to a higher order, which was public in character and "resplendent in material and spacious in layout." Cobb, "The Architectural Setting of the Liturgy," 529.

${ }^{22}$ Robert E. Webber, ed. Music and the Arts in Christian Worship, vol. 4 of The Complete Library of Christian Worship (Nashville, TN: Star Song Pub., 1993), 598; Hart, Recovering Mother Kirk, 73; Dyrness, A Primer on Christian Worship, 22.

${ }^{23}$ Hart, Recovering Mother Kirk, 73; Phifer, A Protestant Case for Liturgical Renewal, 94; Micks, The Future Present, 130; Norén, "The Word of God in Worship," 45.

${ }^{24}$ Davies, The Ecumenical Century, 1900-1965 vol. 5 of Worship and Theology in England (Grand Rapdis, MI: Eerdman's, 1996), 310.

${ }^{25}$ Idem., From Andrewes to Baxter and Fox, 286-287. 
Protestantism. ${ }^{26}$ The purpose of the music is "to create space where people can experience the joy of being in God's presence, ${ }^{, 27}$ which underscores the architectural centrality of worship bands in Charismatic worship. ${ }^{28}$ Therefore, in this brief overview on the focus of liturgy, it is important to recognize that congregations experience the presence of God through the close association of (1) the altar and Eucharist in Catholicism, (2) the pulpit and preaching in Protestantism, and (3) worship bands and music in the Charismatic movement.

My aim thus far has been to describe the conflicting issues concerning the focus of liturgy before moving on to an analysis of what specific practices reveal liturgical diversity. Liturgical practice in Christendom includes, but is not limited to such features as the Eucharist, the preaching of the Word, baptism, prayer, Christian time which refers to services planned around the daily, weekly and yearly cycles, church music, pastoral rites such as marriage and Christian burial, leadership, architecture, and the use of language. ${ }^{29}$ The purpose of the following sections is to briefly examine what some of

${ }^{26}$ Noel, Pentecostal and Postmodern Hermeneutics, 118.

${ }^{27}$ Miller and Yamamori, Global Pentecostalism, 131, 137-138. On p. 203 they state "music actually mediates the sacred."

${ }^{28}$ Albrecht, Rites in the Spirit, 130; Margaret M. Poloma, The Assemblies of God at the Crossroads: Charisma and Institutional Dilemmas (Knoxville, TN: University of Tennesse Press, 1989), 226; Christian Worship Worldwide: Expanding Horizons, Deepening Practices, ed. E. Farhadian Charles (Grand Rapids, MI: Eerdman's, 2007), 115-116. Dyrness, A Primer on Christian Worship, 64. Webber, ed. Twenty Centuries of Christian Worship, 121-125.

${ }^{29}$ White, A Brief History of Christian Worship. These elements of the liturgy are discussed at length in White's book. See also, Lang, Sacred Games, vii-viii; John F. Baldovin, "Christian Worship to the Eve of the Reformation," in The Making of Jewish and Christian Worship, ed. Paul F. Bradshaw and Lawrence A. Hoffman (South Bend, IN: University of Notre Dame Press, 1991), 156-183. On the issue of language in worship, see John Fenwick and Bryan Spinks, Worship in Transition: The Liturgical Movement in the Twentieth Century (New York: Continuum, 1995), 147-156; Daniel B. Stevick, Languague in Worship: Reflections on a Crisis (New York: Seabury Press, 1970), 1-53. 
these practices reveal about liturgical diversity in Christendom.

\section{The Eucharist}

While Eucharistic rites among Catholics and Protestants after Vatican II have become similar, ${ }^{30}$ a brief enumeration of Eucharistic practices uncovers vast differences ${ }^{31}$ that have resulted in controversy. For instance, should the Eucharist be celebrated with bread and wine or with local and ethnic food $?^{32}$ Kabasele-Lumbala, an African Roman Catholic, insists that the Eucharist in Africa should be celebrated with local food and drink since it is a land that does not have wheat or vineyards. His argument is based on the fact that bread and wine is connected to Greek categories of thinking, and that all symbols are culturally conditioned. ${ }^{33}$

In addition, there is also controversy over the following areas: (1) whether the

\footnotetext{
${ }^{30}$ White, A Brief History of Christian Worship, 158. See also White, "Christian Worship since the Reformation," 200; Norén, "The Word of God in Worship," 36-38; Davies, Crisis and Creativity, vii.

${ }^{31}$ White, Introduction to Christian Worship, 229.

${ }^{32}$ Fenwick and Spinks, Worship in Transition, 161; Baptism, Eucharist and Ministry, Eucharist III.28, 14; Wainwright, Worship with One Accord: Where Liturgy and Ecumenism Embrace, 78. Historically, the ordination Eucharist of The Apostolic Tradition contains references to the offering and giving thanks over oil, cheese, and olives. In the paschal Eucharist, milk and honey, water and wine are given after the bishop has broken the bread. See White, Introduction to Christian Worship, 240. During the fourth and fifth centuries, "in some churches in the West, after receiving the Eucharistic bread and wine, the neophytes also received a drink of milk and honey." Noakes, "From New Testament Times until St Cyprian," 122-123; E.J. Yarnold, "The Fourth and Fifth Centuries," in The Study of Liturgy, ed. Cheslyn Jones et al. (New York: Oxford University Press, 1992), 141. Ascetic groups in the first to third centuries substituted water for wine, Baldovin, "Christian Worship to the Eve of the Reformation,"160.

${ }^{33}$ François Kabasele Lumbala, Celebrating Jesus Christ in Africa: Liturgy and Inculturation, (Maryknoll, NY: Orbis Books, 1998), 50, 53-56. See also Lucien Richard, Daniel J. Harrington, and John W. O'Malley, Vatican II the Unfinished Agenda: A Look to the Future (New York: Paulist Press, 1987), 11.
} 
wine used should be alcoholic or non-alcoholic, ${ }^{34}$ and whether the cup was reserved for the priest only or whether the laity could also partake of the cup, ${ }^{35}$ (2) whether the bread should be leavened or unleavened, ${ }^{36}$ (3) whether the Eucharist should be celebrated daily, weekly, or quarterly, ${ }^{37}$ (4) who has the right to preside over the Eucharist, should it be

\footnotetext{
${ }^{34}$ Both Byars and Davies have noted the controversy over the issue of wine. See Byars, The Future of Protestant Worship, 69; Davies, The Ecumenical Century, 358. Roman Catholics, Orthodox and Anglicans use fermented wine, while most Free Churches use unfermented wine. Anne Jordan, Christianity and Moral Issues (Cheltenham, United Kingdom: Stanley Thornes, 1999), 84; White, A Brief History of Christian Worship, 158.

${ }^{35}$ In the early centuries the laity partook of the cup, but during medieval times the cup was taken away from them. Willimon, Word, Water, Wine and Bread, 25, 57. The explanation given was a fear of spilling the blood of Christ. See Marshall and Taylor, Liturgy and Christian Unity, 74; White, A Brief History of Christian Worship, 90; Baldovin, "Christian Worship to the Eve of the Reformation,"175. The Reformers are credited with restoring the cup to the laity. See Hardman, A History of Christian Worship, 160-161, 188; White, "Christian Worship since the Reformation," 186. The council of Trent was not in favor of restoring the cup to the laity, White, A Brief History of Christian Worship, 121. As a matter of fact, Maureen Sullivan alleges that the restoration of the cup to the laity did not take place in Catholicism until Vatican II, Maureen Sullivan, 101 Questions and Answers on Vatican II (New York: Paulist Press, 2002), 35.

${ }^{36}$ For centuries, both east and west used ordinary local bread which was leavened. See Byars, The Future of Protestant Worship, 69; Willimon, Word, Water, Wine and Bread, 57 . By the $11^{\text {th }}$ century, the use of unleavened bread became widespread in the western church. Baldovin, "Christian Worship to the Eve of the Reformation," 175. The Orthodox Church has strictly used leavened bread. See Timothy G. McCarthy, The Catholic Tradition: Before and after Vatican II 1878-1993 (Chicago: Loyola University Press, 1994), 173; Justo González, From Augustine to the Eve of the Reformation, vol. 2 of A History of Christian Thought (Nashville, TN: Abingdon Press, 1987), 294; Hardman, A History of Christian Worship, 242. James White points out that Methodists use real bread, White, A Brief History of Christian Worship, 158.

${ }^{37}$ Wainwright, Taft, and the Baptism, Eucharist and Ministry document have acknowledged the controversy over the frequency of celebration of the Eucharist. Wainwright, Worship with One Accord: Where Liturgy and Ecumenism Embrace, 78; Robert F. Taft, Beyond East and West: Problems in Liturgical Understanding (Washington, DC: Pastoral Press, 1984), 61; Baptism, Eucharist and Ministry, Eucharist III.30-31, 15. Historically, frequency of celebration during the first century has been difficult to determine. See White, A Brief History of Christian Worship, 26; Baldovin, "Christian Worship to the Eve of the Reformation," 160. However, several confirm a weekly celebration in the second century. See Taft, Beyond East and West, 62; White, A Brief History of Christian Worship, 55; Baldovin, "Christian Worship to the Eve of the Reformation," 162; Hall, Worshiping with the Church Fathers, 29. By the third century the Eucharist was added to the Synaxis of Wednesday and Friday, then by the fourth century it was celebrated daily in the churches of the West. See Palmer, Sacraments and Worship, 39.
} 
priest and minister or lay person? ${ }^{38}$ Also is the efficacy of the sacrament dependent upon the morality of the priest? ${ }^{39}$ In other words, does it matter whether the priest/minister is unholy and immoral? (5) Should participation in the Eucharist be restricted to only those

Up to, and during the Reformation, frequency of celebration for Catholics was rare. Luther called for more frequent celebration than four times per year, which according James White is not a Protestant invention but which has been practiced by them the longest. Calvin wanted it celebrated once a week but was overruled and Zwingli celebrated it four times a year and the Anabaptists followed Zwingli. See White, A Brief History of Christian Worship, 122-123; Davies, From Cranmer to Hooker, 118. Hardman concurs that the Reformers increased the frequency. Hardman, A History of Christian Worship, 156. Anglicans also have weekly celebration. See White, A Brief History of Christian Worship, 152; White, "Christian Worship since the Reformation," 197. Lutherans had a weekly celebration but the Enlightenment brought an end in most Lutheran countries. White, Introduction to Christian Worship, 160; Byars, The Future of Protestant Worship, 67. Wesley also celebrated on a weekly basis. Marshall and Taylor, Liturgy and Christian Unity, 33; White, Introduction to Christian Worship, 246. With the twentieth century, Catholics began to celebrate communion more frequently, White, A Brief History of Christian Worship, 157 and Protestants also increased the frequency of celebration after Vatican II. Pecklers, Worship: A Primer in Christian Ritual, 3. Yet for many Protestants in the twentieth century, the Eucharist is still an occasional service. White, A Brief History of Christian Worship, 158. For Pentecostals, the celebration ranges from weekly to rarely and with no set form. White, Introduction to Christian Worship, 246.

${ }^{38}$ For those like McCarthy, it is clear that it is simply not possible to celebrate the Eucharist unless a priest is presiding over it. McCarthy, The Catholic Tradition, 225. See also Spielmann, History of Christian Worship, 59; Hall, Worshiping with the Church Fathers, 67; Hardman, A History of Christian Worship, 15. However, according to Davies, laymen in the English Free Churches "had as much right to celebrate it as a minister." Davies, The Ecumenical Century, 358-359.

${ }^{39}$ The Donatists of course believed that immoral priests needed to be rebaptized in order for the sacrament to be efficacious. However, Augustine disagreed and developed his theology of the sacraments in opposition to the Donatists. The major thrust of Augustine's argument was the ex opere operato principle. Olson elaborates on the meaning of this principle by stating,

a baptism performed by an immoral priest with no valid ordination would not be a sacrament. But a baptism performed by an immoral or heretical priest with valid ordination and in communion with the Great Church would be a true sacrament. That is the meaning of ex opere operato (Roger E. Olson, The Story of Christian Theology: Twenty Centuries of Tradition and Reform (Downer's Grove, IL: Inter Varsity Press Academic, 1999), 266).

Pope Innocent III in a profession of faith for the Waldenses states that the Eucharist is not affected adversely by sinful and unholy priests, rather it should be welcomed. Palmer, Sacraments and Worship, 89. Augustine's influence in this area had a "profound impact" on "the whole Western world's - understanding of the Church and sacraments," Hans Küng, Theology for the Third Millennium, 140-141. See also Palmer, Sacraments and Worship, 82. 
who are baptized $?^{40}$ Or only to those considered to be penitent and worthy? ${ }^{41}$ Or to those who are of sufficient age? ${ }^{42}$ Should participation be open to all, as in the English Free Churches, or closed to anyone outside a particular faith, such as in the Catholic Church? ${ }^{43}$ Moreover, (6) for centuries the Eucharist in the Catholic Church was in Latin in spite of the shift to the vernacular during the Reformation among Protestants. ${ }^{44}$ It was not until Vatican II that the Catholic Church also switched to the vernacular, ${ }^{45}$ but the Latin still controls how the Eucharistic service is translated into the vernacular, even in this post

${ }^{40}$ According to the Didache, the answer is yes. Palmer, Sacraments and Worship, 2; Senn, Christian Liturgy, 63; White, Introduction to Christian Worship, 236. Cullmann, Early Christian Worship, 19; Hall, Worshiping with the Church Fathers, 74. According to Palmer, Justin Martyr also concurs. Palmer, Sacraments and Worship, 4. Also in agreement is The Apostolic Tradition of Hippolytus. Willimon, Word, Water, Wine and Bread, 34.

${ }^{41}$ Both Calvinists and Baptists agree that the celebration of the Eucharist should be restricted to only the penitent and worthy. See White, A Brief History of Christian Worship, 123; White, "Christian Worship since the Reformation," 188-189.

${ }^{42}$ From Charlemagne to the Reformation, reverence for the Eucharistic bread and wine led to the postponement of the first communion to about the age of seven. J.D.C. Fisher and E.J. Yarnold, "The West from About Ad 300 to the Reformation," in The Study of Liturgy, ed. Cheslyn Jones et al. (New York: Oxford University Press, 1992), 151. In the 1970's the Anglican Church faced a major problem - "whether the child who approached the altar rail at the Eucharist should be sent away." They decided that the child should receive a blessing at the altar rather than simply be refused the consecrated elements, Davies, Crisis and Creativity, 10.

${ }^{43}$ Davies, The Ecumenical Century, 358-363. Pentecostals, who were barred from participating in a Catholic Eucharist ask where in Scripture is the justification for using the Lord's Table as a disciplinary tool-as in a closed table. Thus while Pentecostals are refused at the Lord's Table with Catholics, they note that at the same time Catholics whose lives do not conform to the Gospel are admitted to the Eucharist simply on the basis of their Catholic faith, Walter J. Hollenweger, Pentecostalism: Origins and Developments Worldwide (Peabody, MA: Hendrickson, 1997), 171-172.

${ }^{44}$ Hardman, A History of Christian Worship, 156; Davies, From Cranmer to Hooker, 103. However, the council of Trent did not permit this shift to the vernacular and the shift did not come until 1967, White, A Brief History of Christian Worship, 88, 121.

${ }^{45}$ Clifford Howell, "From Trent to Vatican II," in The Study of Liturgy, ed. Cheslyn Jones et al. (New York: Oxford University Press, 1992), 293; Patrick Lyons, "Liturgy and Ecumenism," in Handbook for Liturgical Studies: Introduction to the Liturgy, ed. Anscar J. Chupungco (Collegeville, MN: Liturgical Press, 1997), 90. 
Vatican II ecumenical age. This approach has been a major source of division. ${ }^{46}$

An additional point of contention revolves around the question of the purpose of

the Eucharist in liturgy and its subsequent connection to salvation. Davies points out that

the major question in what he terms as "the Eucharistic Controversy" is the mode of

Christ's presence in the sacrament. The intensity of the controversy is revealed by a

series of questions that link the mode of Christ's presence with Eucharistic practices. ${ }^{47}$

Specifically, "was the sacrament, as most Catholics and Anglicans believed, a means of

\footnotetext{
${ }^{46}$ Holeton, "Ecumenical Liturgical Consensus: A Bumpy Road to Christian Unity Presidential Address," 1-16. Johnson describes the negative impact that Liturgiam Authenticum had on the translation of liturgical texts, inferring that political power in high places in the Vatican had circumvented the ecumenical goals that Christians were working toward ever since Vatican II. Maxwell E. Johnson, "The Loss of a Common Language: The End of Ecumenical-Liturgical Convergence?," Studia Liturgica 37 (2007): 55-72.

${ }^{47}$ Note the following questions by Davies that revolved around the Eucharistic controversy.
}

What were the chief Scriptural sources for the institution and meaning of the Eucharist? Did not John 6 and I Corinthians 11 give radically different interpretations? How were the Dominical words Hoc est corpus meum ("This is my body") to be interpreted-literally or figuratively? Did "body" refer to Christ's historical body, His resurrected body, or the church as His extension or "Body?" If a literal interpretation was preferred, was "Transubstantiation" or "Consubstantiation" the better interpretation of Christ's presence, following Scripture and the Fathers? Or was it even better to affirm this as a supreme and transcendent mystery? Where is the "body" of Christ located: on the altar, in heaven, or in the hearts of the faithful? If it is on the altar, is the body "in" or "under" the bread and wine, and at what point in the Liturgy does consecration take place? Is the Eucharist a propitiatory sacrifice for the living and the dead? But if Christ's sacrifice was complete on the Cross, what need was there for repetition? Or was the Eucharist a memorial banquet? Or was it the oblation of the church with thanksgiving? What were the eschatological dimensions of the Eucharist? Is consecration effected by Christ the Word made flesh as the priest uses His words of institution, as was commonly held in the West, or was it, as in the East, effected by the agency of the re-creating Holy Spirit? Was faith essential to the reception of the Eucharist, or would a wicked man really be partaking of the body of Christ? Who were the chief exponents of the various interpretations of the modality of Christ's sacramental presence, and were their philosophical presuppositions nominalist or idealist? Was there a direct ratio between the more conservative the doctrine of the Eucharist and its more frequent reception? To be precise, did a transubstantiatory interpretation lead to more frequent reception of the Holy Communion than a Zwinglian or Memorialist interpretation of the Lord's Supper? (Davies, From Cranmer to Hooker, 77-78). 
grace, or, as many Puritans affirmed, was it mainly a mnemonic" of the Last Supper? ${ }^{48}$

This question is closely tied to the role of the divine presence in the Eucharistic celebration, which forms the basis for grace that results in salvation. Roman Catholics, Orthodox, Anglicans and Lutherans, believe in the real presence, and of these groups, all except Lutherans see the Eucharist as essential for salvation. ${ }^{49}$ However, only Roman Catholics accept transubstantiation as a viable explanation of how the real presence is manifested in the Eucharist, which requires that the authority of priests who preside over the Eucharist be grounded in apostolic succession. ${ }^{50}$ Furthermore, Roman Catholics originated the interpretation of the substance in transubstantiation on the basis of Aristotle, ${ }^{51}$ who grounds substance in Parmenides notion of Being. ${ }^{52}$ As the broadest

${ }^{48}$ Davies, From Andrewes to Baxter and Fox, 286.

${ }^{49}$ For Catholics, Aquinas stated that denying the real presence is heresy, see Thomas Aquinas, Summa Theologiae (ST) Part III, Question 75, Article 1. For Greek Orthodox affirmations of the real presence, see Elly Hélène Economou, "The Greek Orthodox Church and Her Relations with the Heterodox Churches: A Historico-Dogmatic Study on the Problem of Intercommunion" (Ph.D. dissertation, University of Strasbourg, Faculty of Protestant Theology, 1975), 271-276. For Anglicans, see Philip Schaff, The Evangelical Protestant Creeds with Translations, vol. 3 of The Creeds of Christendom with a History and Critical Notes (New York: Harper and Brothers, 1877), 505-506. For Lutherans, see Davies, From Cranmer to Hooker, 81. Except for Lutherans, all others see the Eucharist as essential for salvation. For Roman Catholics see, Aquinas, Part III Question 61, Article 1; Part III Question 73, Article 3; Part III Question 79, Article 1; Cyprian Vagaggini, Theological Dimensions of the Liturgy, 62. For Orthodox, see Economou, "The Greek Orthodox Church and Her Relations with the Heterodox Churches," 267, 315. For Anglican, see Schaff, The Evangelical Protestant Creeds with Translations, 505.

${ }^{50}$ Vatican II, Lumen Gentium (LG), 8, 20, 21, 25, 26.

${ }^{51}$ See Metaphysics, book V part 8. See also, Diogenes Allen and Eric O. Springstead, Philosophy for Understanding Theology (Louisville, KY: John Knox Press, 2007), 65-67. White points out that Aquinas used "the best of philosophical tools available, especially Aristotle," in order to describe how "this miracle...could be expressed," White, Introduction to Christian Worship, 253. For further support on the use of Aristotelian philosophy to explain the change in the emblems, see D.H. Hislop, Our Heritage in Public Worship, 233; Lang, Sacred Games, 317-319; Senn, Christian Liturgy, 250-252.

${ }^{52}$ Johannes Hirschberger, The History of Philosophy, 2 vols. (Milwaukee, WI: Bruce Publishing, 1958), 1:166-167. 
possible presupposition, ${ }^{53}$ Being has been interpreted as entirely static, non-material, and simple. $^{54}$

All others who accept the real presence, including Calvin, who took somewhat of a mediating position between the real presence on the one hand and the memorial view on the other, leave the transformation to real presence in the realm of mystery. ${ }^{55}$ Both Roman Catholics and Greek Orthodox churches accept the adoration of the Eucharist and the unbloody sacrifice of the mass. ${ }^{56}$ In contrast to this, Protestants reject the sacrifice of the mass and the adoration of the host, meaning the Eucharist. ${ }^{57}$ One major difference between Roman Catholicism and Greek Orthodoxy is the means by which the conversion of the host takes place. In the Greek Church it is the Holy Spirit who effects the change, but in the Roman Catholic Church it is Christ, the Word made flesh, who effects the change as the priest pronounces the words "This is my body." 58

${ }^{53}$ Fernando Canale, A Criticism of Theological Reason: Time and Timelessness as Primordial Presuppositions Andrews University Seminary Doctoral Dissertation Series 10 (Berrien Springs, MI: Andrews University Press, 1987), 66-74.

${ }^{54}$ Ibid., 76-85, 89-95.

${ }^{55}$ See Aquinas for the affirmation of transubstantiation, Aquinas, ST Part III Question 75, Articles $6 \& 8$. For denials of transubstantiation and affirmations of mystery regarding the change in the Eucharist, see Economou, "The Greek Orthodox Church and Her Relations with the Heterodox Churches," 274-275; Martin Luther, "The Babylonian Captivity of the Church--Part I (1520)" in Martin Luther, Luther's Works (LW), eds. J. Pelikan and H.T. Lehmann, American ed., 55 vols. (Philadelphia: Fortress Press, 19551986): 36:11-57; Schaff, The Evangelical Protestant Creeds with Translations, 505-506. For an exposition of Calvin's position, see Davies, From Cranmer to Hooker, 83-84.

${ }^{56}$ Annibale Bugnini, The Reform of the Liturgy 1948-1975, trans., Matthew J. O'Connell (Collegeville, MN: The Liturgical Press, 1990), 284; Economou, "The Greek Orthodox Church and Her Relations with the Heterodox Churches," 268.

${ }^{57}$ For a rejection of the sacrifice of the mass, see Luther, "The Babylonian Captivity of the Church--Part I (1520)" LW 36:40-57; Schaff, The Evangelical Protestant Creeds with Translations, 506. See also, Davies, From Cranmer to Hooker, 33. For Protestant rejection of the worship of the host, see ibid., 33, 104; Schaff, The Evangelical Protestant Creeds with Translations, 506.

${ }^{58}$ Davies, From Cranmer to Hooker, 33. See also, ibid., 77. 
In contrast to the views just presented, which assume the real presence of Christ's body in the Eucharist, is the view attributed to Zwingli that the Lord's Supper is a memorial. Consequently, "there is in Zwingli no distinctive Eucharistic presence of Jesus Christ" since He is in no sense "substantially present in the consecrated elements." 59 Zwingli's view brings into focus the Eucharistic crisis among Protestants who profess to accept the authority of Scripture. This crisis came to a head during the Marburg Colloquy in 1529, revealing "the depths of the yawning chasm between Lutheran and Zwinglian interpretations of the Eucharist. ${ }^{, 60}$ Over four hundred years later, Protestants are still divided about how to understand the presence of God in the Lord's Supper. ${ }^{61}$

At this point, it is important to observe the following concerning transubstantiation. While Roman Catholics, Orthodox, Lutherans and Anglicans believe that Christ is really present in the Eucharist, only Roman Catholics believe that the words "this is my body" pronounced by the priest who is ordained in accordance with apostolic succession can effect a change in which the substance of the bread is literally transformed into the substance of the divine and human Son of God. Orthodox Christians are content to leave the transformation of the Eucharistic elements to the realm of mystery, and they reject transubstantiation as an explanation for the change in the elements. ${ }^{62}$ Protestants especially reject transubstantiation as an explanation for the miraculous change of the

${ }^{59}$ Ibid., 82 (emphasis original).

${ }^{60}$ Ibid., 76.

${ }^{61}$ The Lord's Supper: Five Views, ed. Gordon T. Smith (Downer's Grove, IL: InterVarsity Press Academic, 2008); Understanding Four Views on the Lord's Supper, ed. Paul E. Engle (Grand Rapids, MI: Zondervan, 2007).

${ }^{62}$ Economou, "The Greek Orthodox Church and Her Relations with the Heterodox Churches," 274-275. 
Eucharistic elements. ${ }^{63}$ The reasons for their rejection are based on the inextricable links to the authority of the priesthood to produce these changes, ${ }^{64}$ the fact that Christ is sacrificed over and over again, ${ }^{65}$ and that the elements themselves are regarded as worthy of being adored and worshipped. ${ }^{66}$

However, this rejection of transubstantiation must be differentiated from the interpretation of the divine presence that many Christians uncritically assume on the basis of Aristotle's substance and matter philosophy in which substance is grounded in Parmenides notion of Being. Hence, when referring to transubstantiation, one must distinguish between transubstantiation as the explanation for the miraculous change of the substance of the elements that are linked with the real presence, which all but Catholics reject; and the interpretation of the real presence that has its roots in Aristotelian philosophy, which many uncritically assume.${ }^{67}$ Neither the opposition of

${ }^{63}$ John Calvin, Institutes of the Christian Religion (ICR), ed. John T McNeill, trans. Ford Lewis Battles, 2 vols. (Philadelphia: The Westminster Press, 1960), Book 4 Chapter 17 Sections 12-15, pages 1372-1379 All future quotations from $I C R$ are from this edition; Philip Schaff, History of the Christian Church, 8 vols. (Grand Rapids, MI: W.B. Eerdman \& Sons, 1910), 7:215-216.

${ }^{64}$ Norman Geisler, Systematic Theology: Church, Last Things (Minneapolis, MN: Bethany House Publishers, 2003), 172; Philip Schaff, History of the Christian Church, 8 vols. 7:605.

${ }^{65}$ Norman Geisler, Systematic Theology: Church, Last Things, 159-160.

${ }^{66}$ Ibid., 158.

${ }^{67}$ In The Babylonian Captivity of the Church, Luther clearly denied a miraculous change regarding the bread and wine. Moreover, Luther preferred the view that the divine presence is located within the substance of the bread as well as within the accidents as opposed to the Catholic view in which the divine presence is located only in the substance of the bread and wine and not in the accidents. With respect to these two positions, he states,

Therefore I permit every man to hold either of these opinions, as he chooses. My one concern at present is to remove all scruples of conscience, so that no one may fear being called a heretic if he believes that real bread and real wine are present on the altar, and that every one may feel at liberty to ponder, hold, and believe either one view or the other without endangering his salvation (See $L W 36: 30$ ). 
Lutherans and Anglicans to transubstantiation, nor the more scriptural approach of Zwingli, nor those who affirm the real presence as a mystery, has developed an alternative interpretation of the presence of God in contradistinction to the Roman Catholic view based on transubstantiation. Protestants who profess the Sola Scriptura principle are merely reacting to the interpretation of the real presence assumed by Roman Catholics instead of using biblical materials to construct a viable, biblical alternative. Hence, many Christians have assumed only one common interpretation of the divine presence.

In addition, Horton Davies correctly draws our attention to the important role of presuppositions regarding the issues surrounding the divine presence when he asks, "Who were the chief exponents of the various interpretations of the modality of Christ's sacramental presence, and were their philosophical presuppositions nominalist or idealist?" ${ }^{68}$ Davies is correct to ask about how the role of philosophical presuppositions affects the mode of the divine presence, yet does the distinction he points out between nominalist ${ }^{69}$ and idealist ${ }^{70}$ presuppositions indicate a change in the interpretation of the divine presence or does it still assume the same interpretation? This question necessitates the need for the development of hermeneutical tools of analysis so that liturgical scholars

Thus, despite railing against Aristotle and Aquinas in The Babylonian Captivity of the Church Luther only deals with the mode of the divine presence without at all deconstructing the interpretation of the divine presence.

${ }^{68}$ Davies, From Cranmer to Hooker, 77.

${ }^{69}$ Nominalism is the philosophical position that universal concepts (universals) do not exist either prior to particular objects as the template to which the individual object conforms as in Plato, or that they exist in particular objects as their form (Aristotle), William G.T. Shedd, Dogmatic Theology, ed. Alan W. Gomes, 3rd ed. (Phillipsburg, NJ: P \& R Publishing, 2003), 958.

${ }^{70}$ Idealism is of course in contrast to nominalism in footnote 69 above, and posits that universals and substances exist apart from objects (Plato) and also within objects (Aristotle) as a form of realism that has objective reality, Ibid., 471. 
can apply them to the question of the presence of God in the Eucharist. The aim of developing and applying these hermeneutical tools is to find a possible cause for the conflicting Eucharistic practices.

"The constitutional purpose of the World Council of Churches is to help the churches advance to "visible unity in one faith and in one Eucharistic fellowship." ${ }^{, 71}$ In addition, some consider the Eucharist as the "sacrament of unity" drawing together high and low parishes as well as Roman Catholics and Protestants. ${ }^{72}$ Simply stated, some consider the Eucharist to be the "greatest sacrament of Christian unity."73 However, Christopher Hall concludes, "It is sad and ironic that the sacrament of the Eucharist continues to divide Christians.... Too often the Eucharist has led to schism rather than unity." ${ }^{, 74}$ Adams concurs, yet he adds that ecclesiology becomes a cause of schism on account of the fact that it is integrally related to the Eucharist for certain churches. ${ }^{75}$ For instance, Catholic ecclesiology is grounded in apostolic succession that grants authority

${ }^{71}$ Wainwright, Worship with One Accord: Where Liturgy and Ecumenism Embrace, 177. See also, McCarthy, The Catholic Tradition, 192.

${ }^{72}$ Davies, The Ecumenical Century, 321; Marshall and Taylor, Liturgy and Christian Unity, 153.

${ }^{73}$ Marshall and Taylor, Liturgy and Christian Unity, 162, 163; White, Introduction to Christian Worship, 200.

${ }^{74}$ Hall, Worshiping with the Church Fathers, 51. See also, Wainwright, Worship with One Accord: Where Liturgy and Ecumenism Embrace, 42.

${ }^{75} \mathrm{He}$ states that the Catholic Church does not acknowledge the Eucharistic celebrations of "ecclesial communities," meaning Protestants, and that participation in these Eucharistic celebrations cannot be recommended. Thus, instead of becoming a means of unity, the Eucharist has become a source of division, Michael Adams, Vatican II on Ecumenism (Chicago: Scepter Books, 1966), 51, 57-58. Lyons points out the principle brought out by the Vatican II document Unitatis Redintegratio (UR) that "eucharistic communion is inseparably linked to full ecclesial communion and its visible expression" (UR 22). This principle, according to Lyons, "which logically applies in the case of sharing with the Eastern Churches also, here has the effect of excluding an ecclesial basis on which liturgical sharing can take place because of this lack of fullness of the means of salvation. Members of Reformation Churches are then in this context treated as individual Christians," Lyons, "Liturgy and Ecumenism," 85. 
to the priest to transform the substance of the bread and wine of the Eucharist into the substance of the human and divine Son of God. ${ }^{76}$ Hence, acceptance of this ecclesiology, ${ }^{77}$ which is problematic even for those who believe in a real presence, is a necessary condition for entering into Eucharistic fellowship. ${ }^{78}$ Moreover, the relationship between the Eucharist and unity is not entirely clear. For instance, Catholics see the Eucharist as the expression of an already existing doctrinal and ecclesiastical unity while some Protestants see it as a means to unity. ${ }^{79}$ Although Wainwright acknowledges the ecclesiastical, theological, and attitudinal obstacles to achieving full visible unity in Christendom, he still nevertheless believes that the goal is possible ${ }^{80}$ despite not having a

${ }^{76}$ ST Part III Q75, Art.2. Willimon asserts that in transubstantiation "the substance of both Christ's human nature as well as his divine nature must be present in the consecrated bread and wine," Willimon, Word, Water, Wine and Bread, 56.

${ }^{77}$ John Paul II, Ut Unum Sint: On Commitment to Ecumenism (Boston, MA: St. Paul Books and Media, 1995), Art. 97.

${ }^{78}$ All Protestants agree that the validity of their orders does "not depend upon episcopal ordination in the historic apostolic succession." Francis A. Sullivan, From Apostles to Bishops: The Development of the Episcopacy in the Early Church (New York: The Newman Press, 2001), 11.

${ }^{79}$ Catholic and Protestant Churches regard the Eucharist differently. Catholics regard the Eucharist as a sign of an already existing unity in ecclesial life, apostolic tradition, and mission. For many Protestants, the Eucharist is a sign of a growing unity and a means to its fulfillment, McCarthy, The Catholic Tradition, 199-200, 203. McCarthy points out that Vatican II has set forth two principles for intercommunion that are in conflict. "First, since Eucharist is a sign of unity, then intercommunion is not recommended on a regular basis. Second, since Eucharist is a means of grace, then intercommunion is to be encouraged (UR 8). Intercommunion is appropriate on special occasions, for example, when friendship, cooperation, and ecumenical understanding will grow." Ibid., 203-204. Also, "only in cases of "urgent necessity" may Catholics share the Eucharist with others." Ibid., 204. While Vatican II has softened the Catholic position on the relationship between the Eucharist and unity, the Greek Orthodox position of the Eucharist as the result rather than the means to unity has been completely unaffected by Vatican II and the ecumenical movement. Economou, "The Greek Orthodox Church and Her Relations with the Heterodox Churches," 321-341. 273.

${ }^{80}$ Wainwright, Worship with One Accord: Where Liturgy and Ecumenism Embrace, 
solid proposal as to how to overcome the ecclesiastical obstacles that others recognize ${ }^{81}$ and which are inextricably linked to a Eucharistic communion. ${ }^{82}$ His frustration is expressed in the following words, "Unjustifiable confessional oppositions within the body of Christ" and "our lack of reconciliation 'makes mockery' of the Eucharist." 83

\section{Preaching of the Word}

John Guice notes that certain variations even within Protestantism can lead some observers to the conclusion that the worshippers are not worshipping the same God. ${ }^{84}$ Hence the specific aim here will be to examine what the following categories reveal about conflicts that surround the preaching of the Word: namely, (1) the approach to preaching, including the aim and purpose of preaching, and methods of preaching, (2) qualifications for preaching, (3) frequency of preaching and length of sermons, and (4) the language used in preaching.

Webber notes that there are three main approaches to preaching that one can view as being divergent. The Bible as the starting point represents the first of these approaches: The second introduces creeds, catechesis, and Christian doctrines in order to teach the system of Christian faith, and the third begins with human need as the starting point of

\footnotetext{
${ }^{81}$ Sullivan, From Apostles to Bishops, 11.

${ }^{82}$ John Paul II, Ut Unum Sint: On Commitment to Ecumenism, Art. 97.

${ }^{83}$ Wainwright, Worship with One Accord: Where Liturgy and Ecumenism Embrace, 163.

${ }^{84}$ Guice points out that the differences in Protestant preaching between the "prayer book tradition" and "Free Church tradition" are extreme. He concludes, some "might be hard pressed to determine that both are worshipping the same God." John Guice, From Pentecostal to Episcopalian: The Confusing World of Protestant Worship (Indiannapolis, IN: Dog Ear, 2010), 83.
} 
preaching. ${ }^{85}$ These three different approaches encompass and have a direct impact on the aim and purpose of preaching, the methods of preaching, and the style and content of preaching.

\section{Aim and Purpose of Preaching}

What is the aim and purpose of preaching? A cursory survey taken from many denominations covering centuries reveals that the answer to the question is elusive. Perhaps the sheer number of different aims raises the issue of how to distinguish between aims that are complementary as opposed to ones that are contradictory. For instance, working within Webber's framework, what is the aim and purpose of preaching for those who accept the Bible as the starting point? There are several options: (1) the aim of making Christ present through the sermon ${ }^{86}$ as a sacrament ${ }^{87}$ that transfers the real presence of the Eucharist to the sermon and results in grace, power, and salvation, (2) a

${ }^{85}$ Webber, ed. The Renewal of Sunday Worship, 302. Webber notes that these three main approaches to preaching include their own subdivisions. The Biblical approach incorporates evangelistic, expository, liturgical, narrative, proclamatory, prophetic and textual preaching. The creedal approach includes catechetical and doctrinal preaching, and the human needs approach includes African-American, confessional, contextual, lay, lifesituational, progressive-emotive, and seeker-sensitive preaching. John Guice states, "today, preaching styles are as varied as the numerous traditions-all operating under the banner of "Christianity." Guice, From Pentecostal to Episcopalian, 83. This statement seems to imply not only difference but also conflict.

${ }^{86}$ For the close connection between preaching, the presence of Christ, and its subsequent result in salvation, see Norén, "The Word of God in Worship," 33, 38, 42; Kilmartin, "Christ's Presence in the Liturgy," 104, 108; Charles Lynvel Rice, The Embodied Word: Preaching as Art and Liturgy (Minneapolis, MN: Fortress Press, 1990), 46-47, 56; Davis, This Is My Body, 100 footnotes \#23, 102, 105, 107; Hart, Recovering Mother Kirk, 27- 29.

${ }^{87}$ For preaching as a sacrament, see Davies, The Ecumenical Century, 253; Hart, Recovering Mother Kirk, 27. 
focus on Christ and the gospel, ${ }^{88}$ (3) a doxological aim, ${ }^{89}$ and (4) a didactic and expository aim. ${ }^{90}$

The second approach, according to Webber, focuses on creeds and doctrinal systems as the starting point of preaching. In this approach, the reform of the church, the overthrow of error and the preservation of ecclesiastical institutions constitute the aim of preaching. ${ }^{91}$

Webber's third approach to preaching has a human-centered focus, which includes preaching that aims at (1) eternal life and salvation, ${ }^{92}$ (2) conversion, ${ }^{93}(3)$ coping with life's problems and finding inner peace, ${ }^{94}(4)$ healing and therapy, ${ }^{95}(5)$

${ }^{88}$ See Webber, Ancient-Future Faith, 119, 122-123. For a focus on the Gospel, see Vajta, Luther on Worship, 83; Davies, From Andrewes to Baxter and Fox, 162-163.

${ }^{89}$ See Norén, "The Word of God in Worship," 42.

${ }^{90}$ See, Lang, Sacred Games, 164, 182, 184, 196; Davies, From Andrewes to Baxter and Fox, 134; Schaff, History of the Christian Church, 8 vols. 6:671-679; Bloesch, The Church: Sacraments, Worship, Ministry, Mission, 182; William B. McClain, "The Soul of Black Worship," African Methodist Episcopal Zion Quarterly Review 93 no.3 (October 1981): 11-29; Davies, The Ecumenical Century, 230-231; Edwin Charles Dargan, From the Apostolic Fathers to the Great Reformers, A.D. 70-1572, vol. 1 A History of Preaching (New York: Hodder and Stoughton, 1905), 379-380; Haddon W. Robinson, "What Is Expository Preaching?," Bibliotheca Sacra 131 no. 521 (Ja-Mr 1974): 55-60; Davis, This Is My Body, 96, 99.

${ }^{91}$ Dargan, From the Apostolic Fathers to the Great Reformers, A.D. 70-1572, 375; Hardman, A History of Christian Worship, 165; Duncan Macpherson, "Preaching in the Roman Ecclesial Context," in The Future of Preaching, ed. Geoffrey Stevenson (London: Student Christian Movement, 2010), 28; Davies, From Andrewes to Baxter and Fox, 134.

${ }^{92}$ Davies, From Andrewes to Baxter and Fox, 152; Lang, Sacred Games, 149; James L. Hendershedt, "The Sermon: A Tool for Evangelism," Trinity Seminary Review 7 no. 2 (Fall 1985): 23-29.

${ }^{93}$ Davies, From Cranmer to Hooker, 295; White, Introduction to Christian Worship, 126; White, "Christian Worship since the Reformation," 196, 198; Hardman, A History of Christian Worship, 37; Bloesch, The Church: Sacraments, Worship, Ministry, Mission, 182.

${ }^{94}$ Webber, ed. The Renewal of Sunday Worship, 322-323; Lang, Sacred Games, 172.

${ }^{95}$ Lang, Sacred Games, 162-163, 196; Webber, Ancient-Future Worship: Proclaiming and Enacting God's Narrative, 70. 
revival, ${ }^{96}(6)$ making a decision, ${ }^{97}$ and (7) applying the ethical teachings of Jesus to social customs, economic systems, racial problems and international needs. ${ }^{98}$

Lang identifies three great preaching traditions: instructional preaching, ethical preaching, and affective preaching, with each of them pursuing a different aim. However he notes that even these are affected by an even broader overall purpose. ${ }^{99}$ Scholars who study preaching identify several aims of preaching that are in conflict. Webber notes that a shift has taken place from a didactic aim toward a focus on therapeutic or inspirational preaching along with entertaining worship. The result, he notes, has been a neglect of the study of the Biblical text. ${ }^{100}$ However, some younger evangelicals are returning from the "therapeutic to focus on the teaching of Scripture."101

By contrast, post Vatican II preaching does not necessarily focus on instruction and exhortation, since this has a detrimental effect on preaching's mystical function. In other words, according to some Roman Catholics, preaching should neither be

\footnotetext{
${ }^{96}$ Norén, "The Word of God in Worship," 47; White, A Brief History of Christian Worship, 170.

${ }^{97}$ Hendershedt, "The Sermon: A Tool for Evangelism," 23-29; Macpherson,
} "Preaching in the Roman Ecclesial Context," 28.

${ }^{98}$ Lang, Sacred Games, 190

${ }^{99}$ Lang speaks of (1) instructional sermons that impart saving knowledge, (2) sermons where the Pastor is an advisor, aiming at ethical preaching which makes their audience fit for life, and (3) the centrality of the act of faith as the adequate response to affective preaching. He summarizes by stating that preachers "may address the head, the hands, or the heart of those who listen." He also observes that some show a preference for one of these traditions while others, whose goal is a mystical union with God, blend them. Lang, Sacred Games, 197. 117.

${ }^{100}$ Webber, Ancient-Future Worship: Proclaiming and Enacting God's Narrative, 70,

${ }^{101}$ Robert E. Webber, The Younger Evangelicals, 192. Further illustrating divergence with regard to the aim of preaching, Webber states that the purpose of preaching for traditional evangelicals is didactic, for pragmatic evangelicals its therapeutic, and for the younger evangelicals, its back to Scripture, and obedience and Christian living. Ibid., 192, 202. Preaching also becomes performance when the emphasis is no longer on the Word but on the preacher. Bloesch, The Church: Sacraments, Worship, Ministry, Mission, 182. 
explanatory nor relevant but contemplative and conducive to mature prayer about the presence of God. ${ }^{102}$ Furthermore, "the regeneration of the human heart," which the sinner needs most, is often missing when preaching is reduced to instructional Bible Study. ${ }^{103}$ As a result, whenever preachers aim at impressing their congregations with learning and eloquence, they inform rather than transform them. ${ }^{104}$

Donald Bloesch observes that the aim of preaching today is no longer for the glory of God but for entertainment. ${ }^{105}$ Similarly, those who focus on life-situational sermons that bring hope and healing ignore the Bible in favor of psychology and reduce "theology to anthropology."106 In addition, the sacramental aim of preaching, which is to make Christ present in the sermon, "is short circuited" when preaching focuses on therapy, promotion, and education. ${ }^{107}$ Davis notes that the fundamental aim of preaching is to make Christ present in the sermon: "everything else flows from recognition of this experience." ${ }^{108}$ This sacramental goal of preaching in Calvin's writings is echoed by the same goal in the Lord's Supper, namely to experience the real presence. ${ }^{109}$ In addition, Luther also brings out the close relationship between the Word of God, the Eucharist and the presence of God when he asserts that Christ "has put himself into the Word, and

${ }^{102}$ Franz Jozef van Beeck, Catholic Identity after Vatican II: Three Types of Faith in the One Church (Chicago: Loyola University Press, 1985), 68.

${ }^{103}$ Bloesch, The Church: Sacraments, Worship, Ministry, Mission, 182.

${ }^{104}$ Davies, From Cranmer to Hooker, 295; idem., From Andrewes to Baxter and Fox, 162-163.

${ }^{105}$ Bloesch, The Church: Sacraments, Worship, Ministry, Mission, 179.

${ }^{106}$ Webber, ed. The Renewal of Sunday Worship, 323; Thomas G. Long, The Witness of Preaching, 2nd ed. (Louisville, KY: Westminster John Knox Press, 2005), 34-35.

${ }^{107}$ Byars, The Future of Protestant Worship, 71; Norén, "The Word of God in Worship," 42.

${ }^{108}$ Davis, This Is My Body, 102; Hart, Recovering Mother Kirk, 29.

${ }^{109}$ Davis, This Is My Body, 16. 
through the Word he puts himself into the bread also." ${ }^{110}$ Thus, the real presence is also found in the spoken Word, and by logical extension to the preached Word: It is not restricted to the Lord's Supper.

At this point, the liturgical student makes a startling discovery about Protestants, the presence of God, and preaching. Just like the Lutherans, Anglicans, and even Zwingli, who did not deconstruct but uncritically accepted the Catholic interpretation of the divine presence in the Eucharist that was grounded in Aristotle's understanding of Being via transubstantiation, Protestants who refer to preaching as sacramental and as the real presence make no attempt to distinguish their view of the divine presence from the Catholic view that is grounded in transubstantiation, despite their shift to the Scriptures as the authority and mechanism for experiencing the presence of God. Furthermore, debates between Catholics and Protestants in the past centered on the sacerdotal and sacrificial connections with transubstantiation as the explanation for the real presence, not on the interpretation of the divine presence. This uncritical and tacit acceptance of transubstantiation as the interpretation of the divine presence by Protestants has paved the way for Catholics and Protestants in this post Vatican II era to affirm the importance of the divine presence in preaching without engaging in polemical debates about how to interpret it. ${ }^{111}$ These assumptions about the content of the divine presence justify the need for the development of hermeneutical tools in the third Chapter of the present work. Moreover, I will apply these tools to the assumptions about the divine presence in the fourth Chapter.

Lastly, in contrast to the focus on sacramental preaching, Puritans believed that

\footnotetext{
${ }^{110}$ This occurs when the words, "This is my Body" are pronounced, $L W 36: 341,343$.

${ }^{111}$ See footnote 67 above.
} 
the focus of preaching should be practical. In other words, a sermon should aim at what congregations should do, and not just on what they should think, or even how they should feel. ${ }^{112}$ Evangelistic preaching conducted by revivalists and evangelicals echoes this by preaching for a decision and aiming at a response. ${ }^{113}$ Moreover, apologetic preachingwhich Davies characterizes as the most typical twentieth century kind of preachingeclipses sacramental preaching. ${ }^{114}$

\section{Methods of Preaching}

A view of the methods of preaching includes content, style, form, and planning. While the content of preaching during the first few centuries had a basis in Scripture, the main elements were "apostolic tradition, Scripture, and the personal contribution of the preacher." ${ }^{115}$ In later centuries the content of preaching included a focus on fables and legends, the elevation of the Virgin Mary and the saints, as well as emphasis on patristic and classical lore. ${ }^{116}$ The direct result of this focus is a meager use of Scripture and little theological or moral teaching. ${ }^{117}$ In contrast to this, the use of Scripture by the Reformers represents the glory of Reformation preaching. "In the hands of the reformers the Word

${ }^{112}$ Davies, From Andrewes to Baxter and Fox, 162.

${ }^{113}$ Hendershedt, "The Sermon: A Tool for Evangelism," 23-29.

${ }^{114}$ Davies, The Ecumenical Century, 230.

${ }^{115}$ Dargan, From the Apostolic Fathers to the Great Reformers, A.D. 70-1572, 38. Also, Hardman, A History of Christian Worship, 37.

${ }^{116}$ For fables and legends, see Dargan, From the Apostolic Fathers to the Great Reformers, A.D. 70-1572, 243. For Mary and the saints, see ibid., 141, 155; Hardman, $A$ History of Christian Worship, 104. For an emphasis on patristic and classical lore, see Edwin Charles Dargan, From the Close of the Reformation Period to the End of the Nineteenth Century 1572-1900, vol. 2 of A History of Preaching (New York: Hodder and Stoughton, 1912), 136.

${ }^{117}$ Dargan, From the Apostolic Fathers to the Great Reformers, A.D. 70-1572, 141, 155, 189; Hardman, A History of Christian Worship, 104. 
of God again comes into [prominence] and rules the pulpit." ${ }^{118}$ As a result of this emphasis on the Word, the Reformers concentrated on Christ and his righteousness, and justification by faith. ${ }^{119}$ While the preaching of the early and medieval churches had tended to focus on tradition that dwelt on the saints, Mary and legends, Reformation preaching focused more on Scripture as the content of preaching. However, when it comes to the contemporary context, Spiller has witnessed a decreasing use of Scripture in the content of preaching, which now incorporates all kinds of elements that actually constitute the sermon. ${ }^{120}$

Stylistically speaking, preaching began to develop toward an oratorical form in the fourth century, when greater artistry in preaching developed. Some notable representatives of homiletical artistry are John Chrysostom, Ambrose, and Augustine. ${ }^{121}$ Moreover, Dargan notes that this artistic emphasis is also part of Catholic and AfricanAmerican pulpit style. ${ }^{122}$ However, the poetic and artistic emphasis that was just mentioned is contrasted by a scholastic style of preaching that is more analytical and

${ }^{118}$ Dargan, From the Apostolic Fathers to the Great Reformers, A.D. 70-1572, 374. As a result, tales of the saints and other stories are banished. Petty fables and impossible adventures do not appear in the sermons of the Protestant Reformers. Ibid., 377.

${ }^{119}$ Ibid., 365, 388; Vajta, Luther on Worship, 78.

${ }^{120} \mathrm{For}$ instance the use of drama, interviews, discussion, audio-visuals, insertion of hymns, the use of lyrics, clips from films, sport events, soaps, adverts, phone-in discussions, the use of a dry ice machines in order to capture the meaning of what the Bible states by "a great cloud of witnesses." These can all be viewed as differing parts the sermon, and not necessarily additions to the sermon. Roger Spiller, "Preaching and Liturgy: An Anglican Perspective," in The Future of Preaching, ed. Geoffrey Stevenson (London: Student Christian Movement, 2010), 35-36.

${ }^{121}$ Dargan, From the Apostolic Fathers to the Great Reformers, A.D. 70-1572, 61-65.

${ }^{122}$ Dargan, From the Close of the Reformation Period to the End of the Nineteenth Century 1572-1900, 88; McClain, "The Soul of Black Worship," 11-29. 
logical, ${ }^{123}$ yet, at the same time, the analytical and logical style is contrasted with a third style that is characterized as emotional and down to earth. ${ }^{124}$

Another stylistic issue concerns the relationship between homilies and preaching. Sermons were elaborate, structured discourses that contained detailed analysis, while homilies were informal, structureless conversational talks that lacked logical order and did not seem to follow a previously prepared outline. ${ }^{125}$ Puritans did not believe that homilies could actually function as substitutes for preaching. Perhaps the reason is because they were read, dry, predictable and could not meet the spiritual needs of the worshipers like preaching could by penetrating to the heart. ${ }^{126}$ This difference between the homily and preaching also raises another issue: should preaching be memorized or extemporized $?^{127}$

As to the form of preaching, there are differences between narrative and discursive, evocative and rationalistic, dynamic and static, inductive and deductive, and true to the contours of biblical thought rather than to Aristotelian rhetoric or logic. ${ }^{128}$

Regarding sermon planning, there have been two basic approaches throughout Christian history: preaching through the lectionary, which is ordered by the Christian

${ }^{123}$ This is the case with thirteenth century scholasticism where there was minute analysis and logical treatment of material. See Dargan, From the Apostolic Fathers to the Great Reformers, A.D. 70-1572, 230, 261; Webber, ed. The Renewal of Sunday Worship, 298.

${ }^{124}$ Lang, Sacred Games, 177; White, A Brief History of Christian Worship, 170; Willimon, Word, Water, Wine and Bread, 102. 70.

${ }^{125}$ Dargan, From the Apostolic Fathers to the Great Reformers, A.D. 70-1572, 41, 65,

${ }^{126}$ Davies, From Andrewes to Baxter and Fox, 139; idem., From Cranmer to Hooker, 296-297.

${ }^{127}$ Dargan, From the Apostolic Fathers to the Great Reformers, A.D. 70-1572, 305. For Evangelicals and Puritans, see Davies, From Watts and Wesley to Maurice, 231.

${ }^{128}$ Webber, ed. The Renewal of Sunday Worship, 306. 
year, and preaching through a biblical book. ${ }^{129}$ During the Reformation, the Reformers mainly preached on biblical texts, sometimes going through entire books of the Bible. "This became the preferred Reformed pattern and contributed to the setting aside of the traditional Christian year. ${ }^{\prime 130}$ However, in recent times there has been a return to lectionary preaching that has forced preachers to dig as much out of the passage as they can. As a result, there has been a greater emphasis on exegetical preaching, and a lesser emphasis on topical preaching, catchy series, and even thematic unity. ${ }^{131}$

\section{Qualifications for Preaching}

The basic issues surrounding the qualifications of those who preach are (1) whether preaching is the exclusive domain of the clergy, and (2) whether women are permitted to preach. During the first two centuries lay preaching was the rule, not the exception. ${ }^{132}$ Yet, as the church began to organize, it displayed a "tendency toward increasing officialism. ${ }^{, 133}$ By the fourth century and beyond, this growing tendency to restrict preaching to the bishops and presbyters became fixed. ${ }^{134}$

Protestant lay preaching began to flourish in the seventeenth century, yet as

${ }^{129}$ Ibid., 329-330; Hughes Oliphant Old, "Preaching by the Book: Using the Lectio Continua Approach in Sermon Planning," Reformed Worship 8 (Summer 1988): 24-25.

${ }^{130}$ White, A Brief History of Christian Worship, 135.

${ }^{131}$ Ibid., 172; Rice, The Embodied Word, 62-63. Part of the rationale for the return to lectionary preaching is that it forces preachers to preach on a wider selection of scripture than most did previously, White, Introduction to Christian Worship, 77.

${ }^{132}$ John A. Broadus, Lectures on the History of Preaching (New York: A.C. Armstrong and Son, 1902), 43, 45-49.

${ }^{133}$ Dargan, From the Apostolic Fathers to the Great Reformers, A.D. 70-1572, 35.

${ }^{134}$ Ibid., 35, 67; Norén, “The Word of God in Worship," 37. With the exception of Chrysostom and Augustine, bishops were the only ones to preach sermons up until the sixth century. Spielmann, History of Christian Worship, 43. Also, during the twelfth and thirteenth centuries, Popes Innocent III and Gregory IX condemned the unauthorized preaching of laymen. Schaff, History of the Christian Church, 8 vols. 5:852. 
ministers became more educated, lay preaching seemed more and more inadequate. ${ }^{135}$ Nevertheless as the church progressed, men like Wesley made use of lay preachers. ${ }^{136}$ Furthermore, with the development of the "new Code of Canon Law" in 1983, the Roman Catholic Church has lifted "the prohibition against lay preaching."137

The other issue about qualification revolves around whether lay preaching includes women. Ziklund notes that although women have always worshipped, they have not until recently taken on the public authority of preacher and worship leader. ${ }^{138}$

\section{Frequency and Length of Preaching}

Preaching was infrequent during the late sixth century and during the late medieval period, when the focus was primarily on the mass. ${ }^{139}$ However, during the Reformation in Zurich, some preachers preached "fourteen times a week." ${ }^{140} \mathrm{In}$ Wittenberg, there were three sermons on Sunday and daily sermons throughout the week. "Luther often preached every day for a week, and on fast days two or three times.",141

${ }^{135}$ Lang, Sacred Games, 48.

${ }^{136}$ Willimon, Word, Water, Wine and Bread, 100.

${ }^{137}$ William Skudlarek, "Lay Preaching and the Liturgy," Worship 58 no. 6 (November 1984): 500-506.

${ }^{138}$ Barbara Brown Zikmund, "Women as Preachers: Adding New Dimensions to Worship," Journal of Women and Religion 3 no. 2 (Summer 1984): 12-16. The issue of women who preach has often been confused with the ordination of women as pastors. Hence, there will be liturgical conflict for those who hold that women must be ordained as pastors in order to preach. The Catholic Church has only slightly modified its stance by pointing out that women may "proclaim" the Scripture reading, with the exception of the gospels when the bishop appoints them to do so when there is a shortage of priests. Norén, "The Word of God in Worship," 37.

${ }^{139}$ Webber, Ancient-Future Worship: Proclaiming and Enacting God's Narrative, 74; Willimon, Word, Water, Wine and Bread, 48.

\footnotetext{
${ }^{140}$ White, A Brief History of Christian Worship, 118.

${ }^{141}$ Ibid., 135; Broadus, Lectures on the History of Preaching, 122.
} 
As a result of Vatican II, preaching in the Catholic Church now occurs at every Sunday Mass. $^{142}$

As we now look at the length of the sermon, we note that during the fifteenth century, sermons sometimes lasted three hours during Lent, while some discourses could last up to six hours, although some preachers would limit the time to an hour. ${ }^{143}$

Anabaptist preaching rarely lasted less than an hour, and Puritan preachers such as Hugh Peters could preach for three hours on a fast day. ${ }^{144}$ Davies notes that sermons in the first half of the twentieth century were twice as quiet and half as long as the discourses in the Victorian pulpit. ${ }^{145}$ Stevenson notes that in British churches today, homilies can last three to four minutes before the Mass, while thematic or expository sermons can range from fifty to sixty minutes. ${ }^{146}$

\section{Worship, Preaching, and Use of Language}

The use of language, whether in the pulpit or during other parts of the liturgy, can be divided into two distinct categories: (1) language as in Latin versus the vernacular, and (2) God-talk or the language we use to address God, which also includes contemporary language.

In the section on the Eucharist, I pointed out that for centuries the Eucharist in the

${ }^{142}$ White, A Brief History of Christian Worship, 157.

${ }^{143}$ Schaff, History of the Christian Church, 8 vols. 6: 676-677.

${ }^{144}$ Davies, From Cranmer to Hooker, 340; idem., From Andrewes to Baxter and Fox, 130,140 .

${ }^{145}$ Idem., The Ecumenical Century, 1900-1965, 211.

${ }^{146}$ Geoffrey Stevenson, "Introduction," in The Future of Preaching, ed. Geoffrey Stevenson (London: Student Christian Movement, 2010), 1. 
Catholic Church was pronounced in Latin. ${ }^{147}$ In addition, since preaching declined from the time of Augustine all the way to the twelfth century, ${ }^{148}$ "the larger proportion of sermons that have come down to us, not only from the twelfth century, but from the entire Middle Ages, are in Latin." ${ }^{" 149}$ For Catholics the switch to the vernacular would not occur until Vatican II. ${ }^{150}$

The issue of God-talk, which encompasses both inclusive language and contemporary language, has generated "the most vehement arguments" in recent decades. ${ }^{151}$ Susan White notes that "liturgical language came under intense scrutiny" at the same time that liturgical experimentation was taking place throughout the Christian Church. ${ }^{152}$ The question of inclusive language has a direct impact on how God is addressed. Should worshippers address God as Father, Mother, or Parent, or as our Great Ancestor, or as something else? Also, should worshippers address the Spirit as a Goddess? ${ }^{153}$ Fenwick notes, "Few areas of liturgical change in the second half of the

${ }^{147}$ Hardman, A History of Christian Worship, 156; Davies, From Cranmer to Hooker, 103. However, the council of Trent did not permit this shift to the vernacular and the shift did not come until 1967, White, A Brief History of Christian Worship, 88, 121.

${ }^{148}$ Dargan, From the Apostolic Fathers to the Great Reformers, A.D. 70-1572, 106.

${ }^{149}$ Ibid., 186; Hardman, A History of Christian Worship, 104.

${ }^{150}$ Dargan, From the Apostolic Fathers to the Great Reformers, A.D. 70-1572, 305; Howell, "From Trent to Vatican II," 293; Lyons, "Liturgy and Ecumenism," 90.

${ }^{151}$ Davies points out that inclusive language has been made an issue by women who believe that "both the patriarchal society from which the Bible documents emerge, and the masculine names of the two Persons of the Trinity in Christian theology have rendered women 'invisible." "The second acute controversy is concerned with the struggle between advocates of the retention of the seventeenth century language of both the 1662 Book of Common Prayer and of the King James Bible and the passionate advocates of contemporary language in the liturgy." Davies, Crisis and Creativity, 177, 178-192.

${ }^{152}$ White, "Christian Worship since the Reformation," 200.

${ }^{153}$ Veli-Matti Kärkkäinen, Pneumatology (Grand Rapids, MI: Baker Academic, 2002), 164-169; Fenwick and Spinks, Worship in Transition, 155; Rollins, How (Not) to 
twentieth century have produce [sic] such violent reactions as that of the language of worship. $" 154$

\section{Music}

Perhaps some of the greatest liturgical battles throughout the centuries have been fought over music. ${ }^{155}$ Currently, Miller argues, "Contemporary Christian music has become one of the most controversial issues facing the church at the close of the twentieth century." ${ }^{\prime 156}$ As a result, Etherington makes the following pertinent observation; "The official attitude of the church towards worship music has been, with rare exceptions, extreme - extremely strict or extremely lax." ${ }^{\prime 157}$

The divergence has centered on the following areas, (1) the use of instruments, (2) secular influences, (3) musical style, (4) congregational and participatory versus

Speak of God, 104; Kabasele Lumbala, Celebrating Jesus Christ in Africa, 36; Wainwright, Worship with One Accord: Where Liturgy and Ecumenism Embrace, 254.

${ }^{154}$ Fenwick and Spinks, Worship in Transition, 147.

${ }^{155}$ Michael Burgess Jr. has made the following observation about music and liturgical conflict. He states, "Battles over the proper place and kind of music for worship have been around since the Old Testament days and have embroiled the Christian church from its inception. The early church fathers argued as fiercely over this issue as any theological heresy," Webber, ed. Music and the Arts in Christian Worship, 177. Liesch puts it this way, "music is the major divisive issue," The New Worship, 177. See also, Ed Christian, Joyful Noise (Hagerstown, MD: Review and Herald, 2003), 7.

${ }^{156}$ Steve Miller, The Contemporary Christian Music Debate: Worldly Compromise or Agent of Renewal? (Wheaton, IL: Tyndale House Publishers, 1993), 1. John Witvliet points out,

Ninety-nine times out of a hundred, the worship wars of the past decades (although frankly, when hasn't there been a worship war?) are about nothing more than musicwhat music will be sung, what style will it be, who will lead it, what instruments will be used, and how loud will it be (John D. Witvliet, "Beyond Style: Rethinking the Role of Music in Worship," in The Conviction of Things Not Seen: Worship and Ministry in the 21st Centurgy, ed. Todd E. Johnston (Grand Rapids, MI: Brazos Press, 2002), 68).

${ }^{157}$ Etherington, Protestant Worship Music, 10. 
professional and passive, and (5) the purpose of music in worship. ${ }^{158}$

\section{The Use of Instruments}

According to Westermeyer, our current widespread and unquestioning acceptance of instruments in worship is actually the minority position when considering the church's whole history. ${ }^{159}$ There were two instances in the church's history when instruments were not used at all: They were the patristic era and the Calvinist Reformation. ${ }^{160}$ Etherington points out that in the post Gregorian era of the fifth century, "Ecclesiastical opposition to instrumental music bordered on the fanatical."161

The church fathers either downplayed or outright rejected the use of instruments in the church because of their association with pagan festivities. ${ }^{162}$ In Eastern Orthodox worship, the Byzantine chant is never heard with musical instruments, even to this day. Yet, Western-style music that is sung in a Baroque harmonic style has influenced Russian Orthodox liturgy. Consequently, when the new harmonic style of singing was introduced in the seventeenth century, a number of Christians within the Russian Orthodox Church

${ }^{158}$ Doukhan draws attention to secular influences, the use of instruments as well as the influence on human emotions. She observes that these "are the very same issues that still raise red flags in the church today." She also notes that congregational participation "would come under attack and be constantly challenged throughout the history of the church." Lilianne Doukhan, In Tune with God (Hagerstown, MD: Autumn House Publishing, 2009), 145, 149-150. James White notes that the relationship of music to the secular world has been a perennial problem for church music. White, Introduction to Christian Worship, 117. Barry Liesch focuses on musical style as a source of division, Liesch, The New Worship, 177.

${ }^{159}$ Paul Westermeyer, "Instruments in Christian Worship," Reformed Liturgy and Music 25 no. 3 (Summer 1991): 111.

${ }^{160}$ Webber, ed. Music and the Arts in Christian Worship, 388.

${ }^{161}$ Etherington, Protestant Worship Music, 39.

${ }^{162}$ Doukhan, In Tune with God, 153; Etherington, Protestant Worship Music, 39; White, A Brief History of Christian Worship, 37, 70; Idem., Introduction to Christian Worship, 117. 
separated themselves from the church altogether so that they could continue the old traditions. $^{163}$

In the West, plainsong or Gregorian chant, "remained monadic for a long time"164 essentially stifling innovation and creativity "for centuries to come." 165 Yet, as former pagan associations regarding instruments declined, the medieval western church could not hold back the expression of creative forces through various instruments. ${ }^{166}$ This freedom to create, carried on through the centuries, led to music that was "improper, impure, or lascivious," and which ultimately led some at the council of Trent to suggest "a total suppression of music in the services of the Church." ${ }^{167}$ What actually occurred at Trent was a rigorous reform of impure elements "with the object of restoring the purity of plain-chant." ${ }^{\prime 68}$ Several centuries later Vatican II catapulted the church into the twenty first century by no longer placing a ban on such instruments as the piano and guitar. ${ }^{169}$

${ }^{163}$ Donald Hustad, Jubilate! Music in the Evangelical Tradition (Carol Stream, IL: Hope, 1981), 41; Andrew Wilson-Dickson, The Story of Christian Music: From Gregorian Chant to Black Gospel an Illustrated Guide to All the Major Traditions of Music in Worship (Minneapolis, MN: Fortress, 1996), 152, 157.

${ }^{164}$ Etherington, Protestant Worship Music, 38; Erwin Esser Nemmers, Twenty Centuries of Catholic Church Music (Milwaukee, WI: The Bruce Publishing Company, 1949), 29; White, Introduction to Christian Worship, 127; SC, Art. 116.

${ }^{165}$ Etherington, Protestant Worship Music, 38, 39, 46.

${ }^{166}$ In the eighth century the West began to employ harps, fiddles and trumpets, Hardman, A History of Christian Worship, 91. In the early Middle Ages, instruments lost their former pagan associations and began to be introduced in Christian liturgy. "By 1300, all major churches in Western Europe owned an organ and had musicians practiced in playing it. However, it still took some time before musical instruments came to accompany and support a choir," Lang, Sacred Games, 56.

${ }^{167}$ Robert F. Rayburn, Papal Legislation on Sacred Music (Collegeville, MN: Liturgical Press, 1979), 29.

${ }^{168}$ Hardman, A History of Christian Worship, 222. See also Etherington, Protestant Worship Music, 84; Rayburn, Papal Legislation on Sacred Music, 29.

169"'Pastors allowed new music in the liturgy. Use of the piano, which had been forbidden by Pope Pius X in Tra le Sollecitudini in 1903, was now permitted. Other 
At the time of the Reformation there was a stark contrast between those who advocated the total abolition of music and those who believed that the worship service should be completely musical. ${ }^{170}$ Also, the contrast over the use of instruments between Luther on the one hand and Calvin and Zwingli on the other, could not have been greater. ${ }^{171}$ "Where Luther sought to restore to music its proper function as an aid to worship, the Calvinists threw it out almost completely."172 This conflict over the use of instruments continued with Puritan and Quaker worship, and even moved into the twentieth century with some evangelical churches, notably the Church of Christ. ${ }^{173}$

Yet, even when the churches eventually agreed concerning the use of musical instruments in liturgy, they did not necessarily approve of the use of all instruments. For instance, there have been diverging opinions about the use of certain instruments such as the organ, piano, drums, and guitar in liturgy. ${ }^{174}$ Thus, ambiguity, confusion, and

instruments such as guitars, began to be heard in church as well," Ferrone, Liturgy: Sacrosanctum Concilium, 57.

${ }^{170}$ White, Introduction to Christian Worship, 121.

${ }^{171}$ Webber, ed. Music and the Arts in Christian Worship, 222-226; White, A Brief History of Christian Worship, 137; Idem., Introduction to Christian Worship, 123.

${ }^{172}$ Etherington, Protestant Worship Music, 97-98.; Webber, ed. Music and the Arts in Christian Worship, 225-226. See also Doukhan, In Tune with God, 200-201; Spielmann, History of Christian Worship, 76.

${ }^{173}$ Webber, ed. Music and the Arts in Christian Worship, 226-227; White, Introduction to Christian Worship, 125; Hustad, Jubilate! Music in the Evangelical Tradition, 41.

${ }^{174}$ Hardman notes that in the eighth century, "the organ became increasingly popular everywhere except at Rome, where it was forbidden." Hardman, A History of Christian Worship, 91. Yet, according to James White, the organ did not make its advent in churches in the West until the tenth century. White, Introduction to Christian Worship, 117. In the thirteenth century all major churches in Europe owned an organ, and they continued to be used in English music just before and during the Reformation "until the Puritans destroyed them in the early days of the Commonwealth." Hardman, A History of Christian Worship, 182; Lang, Sacred Games, 56. Zwingli had earlier destroyed the pipe organs in 1527. See Webber, ed. Music and the Arts in Christian Worship, 225-226; White, A Brief History of Christian Worship, 137; Idem., Introduction to Christian Worship, 123. The attitude toward 
contention over the use of instruments in liturgy have reigned from the early church to the contemporary church.

\section{Secular Influences}

Closely related to the issue of instruments is that of secular influences in liturgy. More specifically, should the church disseminate the gospel by using all kinds of secular music?

In the early centuries after the death of the apostles, the church used songs that were borrowed from secular tunes as a permanent feature of early congregational music. However, the church eventually eliminated congregational songs that were based on secular tunes because this method posed a threat to the integrity of the message on account of its associations. Since the church prior to the council of Laodicea in the fourth century did not develop its own sacred tunes, eliminating secular tunes effectually took singing away from the people. ${ }^{175}$

At the beginning of the Reformation, Protestantism still preserved the dualistic interpretation of reality from Plato and Aristotle ${ }^{176}$ that resulted in minimal differences between sacred and secular music since all of life was considered as sacred. ${ }^{177}$ Consequently, the "disparity between sacred and secular music could at first hardly

the organ today among some is not much better than the Puritans. For instance, the Saddleback church in California removed organ music and used rock music after conducting a survey. Also young people today like big electronically amplified music, but not the organ, Byars, The Future of Protestant Worship, 53; Herbert E. Douglass, Truth Matters (Nampa, ID: Pacific Press, 2006), 87; Towns, Putting an End to Worship Wars, 54.

${ }^{175}$ Doukhan, In Tune with God, 156.

${ }^{176}$ Friedrich Blume, Protestant Church Music: A History (New York: W.W. Norton, 1974), 29.

${ }^{177}$ Gibbs and Bolger point out religious life prior to modernity did not make a distinction between secular and sacred. Gibbs and Bolger, Emerging Churches, 66-67, 73. 
become a problem." ${ }^{178}$ In order to avoid any contact with the secular, Calvin and Zwingli banned the use of instruments in liturgy. For similar reasons, they probably preferred psalmody rather than hymnody. ${ }^{179}$

Of all the Reformers, it was Luther who initiated and established the practice of using secular music to accompany sacred text, also known as contrafacta. ${ }^{180}$ Luther did not want the "devil to usurp all the beautiful melodies," and even his attack on "love songs and carnal pieces" was always directed at the obscene texts and not against secular song in general. ${ }^{181}$

Consequently, in the current debate about Christian contemporary worship music, some are strongly advocating that the church employ rock and its derivative styles on the same basis that led Luther to wed scriptural texts with secular tunes. ${ }^{182}$ Others however point out the following problems with that argument: (1) Luther changed the melodic and

\footnotetext{
${ }^{178}$ Friedrich Blume, Protestant Church Music, 29.

${ }^{179}$ Doukhan, In Tune with God, 200-201.
}

Whereas Martin Luther would admit any suitable text to be sung in worship unless it was unbiblical, John Calvin would allow only those texts which came from Scripture. Calvin commissioned poets to write metrical settings of the Psalms for the congregations in Strassburg and Geneva. Calvinist churches throughout Europe developed large repertories of psalmody, especially churches in England and Scotland (Webber, ed. Music and the Arts in Christian Worship, 260).

${ }^{180}$ Blume, Protestant Church Music: A History, 30; James Van Horn Melton, "Confessional Power and the Power of Confession: Concealing and Revealing the Faith in Alpine Salzburg, 1730-1734," in Cultures of Power in Europe During the Long Eighteenth Century, ed. Hamish Scott and Brendan Simms (New York: Cambridge University Press, 2007), 139.

${ }^{181}$ Luther was interested in preserving the "beautiful melodies" so that Protestant truth could be apprehended through sounds that were familiar. Blume, Protestant Church Music: A History, 30. Luther drew from all types of songs to disseminate the gospel such as sacred and folk melodies, other popular tunes, art songs, love songs, herald songs, propaganda songs, dance songs and the popular ballad, see Doukhan, In Tune with God, 162-169.

${ }^{182}$ Samuele Bacchiocchi, The Christian and Rock Music: A Study on Biblical Principles of Music (Berrien Springs, MI: Biblical Perspectives, 2000), 34, 53; Miller, The Contemporary Christian Music Debate, 113. 
rhythmic structure of the tunes he borrowed, which eliminated worldly influences, (2) he avoided drinking and dance tunes, and (3) the differences between sacred and secular music were far less obvious in Luther's day then they are today. ${ }^{183}$

\section{Musical Style}

For many centuries, Gregorian chant was the predominant style of Christian liturgy, and in spite of changes in musical style that came with the advent of polyphony and instruments, it still retains pride of place in Catholic liturgy. ${ }^{184}$ Nineteenth century Catholic services used highly dramatic music with an operatic style resulting in emotional manipulation. Yet, this was contrasted with the "austere objectivity of Gregorian chant" that could be sung by congregations, albeit in Latin. ${ }^{185}$ The most drastic changes in musical style in the Catholic Church came with Vatican II and included approval of traditional music from all over the world. As a result, some of the new church music was

\footnotetext{
${ }^{183}$ Bacchiocchi, The Christian and Rock Music, 54-56. Also, those who seek to justify the borrowing of secular tunes for church services should take the following point from Doukhan into consideration. She states,

It might come as a surprise that most of the songs based on tunes borrowed from the secular repertoire were not initially intended for use in church services. They were actually destined to be sung in homes, at work, in school, or in public places (markets, inns, taverns, etc.) (Doukhan, In Tune with God, 167).

${ }^{184}$ Theodor Klauser, A Short History of the Western Liturgy: An Account and Some Reflections, 2d ed. (New York: Oxford University Press, 1979), 156. Hardman refers to plainchant as the "Church's own characteristic music." Hardman, A History of Christian Worship, 52. According to Vatican II, Gregorian chant is specially suited to the Roman liturgy, and it should be given pride of place in liturgy, $S C$, Art. 116. During the period between Trent to Vatican II, there was rigid unification in liturgy and rubricism combined with "considerable diversity in the music which accompanies the liturgy." Webber, ed. Music and the Arts in Christian Worship, 245; White, A Brief History of Christian Worship, 146.

${ }^{185}$ White, Introduction to Christian Worship, 127.
} 
difficult to distinguish from animistic music to rock concerts in America. ${ }^{186}$

Doukhan states that the current disagreements and disputes over music in our churches can be traced back to conflicts that occurred around the nineteenth century. These conflicts resulted in the ever widening split between established churches and their emphasis on musical tradition and the evangelical churches and their emphasis on emotions and persuasion. $^{187}$

Currently, most discussions of worship styles are "largely discussions of music styles and preferences." "188 As a result, musical styles have actually formed "their own denominations. ${ }^{189}$ Musical styles are divided into traditional versus contemporary in which traditional represents organ, classical/western music, and hymn singing with the emphasis on melody and harmony, and contemporary stands for electronically amplified music with a predominance of rhythm expressed through guitars and drums. ${ }^{190}$

${ }^{186}$ Ferrone, Liturgy: Sacrosanctum Concilium, 57, 60, 78; SC, Art. 119; Stringer, A Sociological History of Christian Worship, 225; Webber, ed. Music and the Arts in Christian Worship, 248-250; Wilson-Dickson, The Story of Christian Music, 176, 179.

${ }^{187}$ Doukhan points out that there was a growing influence of popular music styles during the nineteenth century, which began to be countered by a revival and return to the great masters like Palestrina, Bach and Handel. There was also a revival of plainchant, the medieval Roman Breviary and old hymns from the Middle Ages. This reform movement was "in particular, associated with the official churches, such as the Roman Catholic Church in continental Europe and the Anglican Church in England." Its influence soon reached other denominations, Doukhan, In Tune with God, 209-210.

${ }^{188}$ York, America's Worship Wars, 13.

${ }^{189}$ Mark Moring, "Pop Goes the Worship," Christianity Today, March 2011, 24.

${ }^{190}$ Byars, The Future of Protestant Worship, 3, 53, 54, 58; Long, Beyond the Worship Wars: Building Vital and Faithful Worship, 57; White, Introduction to Christian Worship, 128. Gerrit Gustafson notes the following,

Placing greater value on the physical and emotional dimensions in worship greatly affects the musical style of charismatic worship. Most noticeable is the greater emphasis on rhythm in worship music. More than melody or harmony, rhythm corresponds to the physical side of human personality. A charismatic worship band is generally built around a rhythm section (piano or guitars, bass and drums) rather than around an organ. 
Representatives of these two styles have "sharply disagreed over which outlook was superior." ${ }^{" 191}$ Scholars point out that these battles over musical style were the direct result of the cultural revolution of the 1960's in America and Vatican II. ${ }^{192}$ However, perhaps at the root of these discussions is the conflict over whether music is merely a cultural phenomenon or whether it communicates moral absolutes ${ }^{193}$ that are grounded in reality.

Bierly makes the following conclusion, "The music-style-in-worship debate is nothing if not divisive. Those who prefer traditional hymns clash with those bringing drums and guitars into the sanctuary. People on each side of the debate believe they are defenders of the way God wants to be worshiped." ${ }^{, 194}$

The organ doesn't easily accompany hand-clapping praise music (Webber, ed. Twenty Centuries of Christian Worship, 311).

Moring also points out an "unprecedented idea," namely, how the new music has led to an "emotional distance from hymns that was not felt by generations before." Moring, "Pop Goes the Worship," 24.

${ }^{191}$ Doukhan, In Tune with God, 294.

${ }^{192}$ See, Brennan Hill, Exploring Catholic Theology: God, Jesus, Church, and Sacraments (Mystic, CT: Twenty-Third Publications, 1999), 222; Richard A. Kauffman, "Beyond the Battle for the Organ: Robert Webber Calls a Truce to the "Worship Wars"," Christianity Today 41 no 12, no. (1997): 25; Long, Beyond the Worship Wars, 4; York, America's Worship Wars, 4-6.

${ }^{193}$ Byars states that there is no such thing as a sacred rhythm or sacred style of music. There is no consecrated instrument and no sacred rhythm that forbids a certain beat. Byars, The Future of Protestant Worship, 62. Towns believes that music and musical instruments are grounded in culture and cultural expression. As a result he asks if we should Westernize the world before Christianizing it? Towns, Putting an End to Worship Wars, 38, 58. Long states that expressions of music from Bach to rock are culturally grounded. Long, Beyond the Worship Wars: Building Vital and Faithful Worship, 64. Wolfgang Stefani disagrees; he states that human creativity has been affected by the Fall. Second, he states that as the letters of the alphabet combine to produce moral content, so do the notes. Third, he points out that musical styles are embodiments of significant worldviews, including the concept of God. Wolfgang H.M. Stefani, Music and Morality, ed. Samuele Bacchiocchi, The Christian and Rock Music: A Study on Biblical Principles of Music (Berrien Springs, MI: Biblical Perspectives, 2000), 345-364. See also, Calvin M. Johansson, Discipling Music Ministry: Twenty-First Directions (Peabody, MA: Hendrickson, 1992), 25, 35.

${ }^{194}$ Steve Bierly, "Sparring over Worship," Leadership (Winter 1997): 37. William Lock concurs, 


\section{Congregational and Participatory Versus \\ Professional and Passive}

During the first four centuries of the Christian era, participatory singing became the most characteristic and fundamental trait of congregational singing. Consequently, the participatory nature of word-centered worship also included worship that was musical and which belonged to the assembly rather than to the special singers. ${ }^{195}$ However, the Council of Laodicea (363-364) brought about changes that virtually eliminated congregational singing, which would not return until the Reformation. Moreover, music was becoming so specialized that only those "trained for the purpose,"196 could actually sing it. Doukhan states that congregational singing "would come under attack and be constantly challenged throughout the history of the church."197

During the Middle Ages, the rise of high art church music, which was now the exclusive domain of the professional, went hand in hand with a deep spiritual decline of the church. ${ }^{198}$ Moreover, highly complex and professional music, such as Palestrina's

One of the major problems which emerged from the church music renewal movement of the 1960s and 1970s is the division between those churches which chose to continue singing traditional songs and those assemblies which adopted praise-and-worship-style music exclusively. Also, there are those church leaders who opted for both by scheduling two services, one traditional and one contemporary. However, this practice has been just as divisive, though confined to the local church. Congregational song, however, is for all of the people of God in united acts of worship (Webber, ed. Music and the Arts in Christian Worship, 277).

${ }^{195}$ Doukhan, In Tune with God, 148, 155-156; White, Introduction to Christian Worship, 118, 119.

${ }^{196}$ The bishops grappled with issues such as the use of instruments, non-scriptural texts and secular tunes for congregational singing. They ultimately decided to prohibit all these options and opted for a more ascetic approach to music. This prohibited the participation of the people singing in the church. Doukhan, In Tune with God, 154. See also, Etherington, Protestant Worship Music, 28, 30; White, Introduction to Christian Worship, 119.

${ }^{197}$ Doukhan, In Tune with God, 149-150.

${ }^{198}$ Ibid., 155, 204. After the tenth century the 
Missa Papae Marcelli, which was written for ten parts, replaced the old monopoly of chant in unison. Consequently, "congregational song was left to Protestants." ${ }^{, 199}$ Later in the time of Mozart (1770s), there was a contrast between very elaborate classical masses and congregational singing. In contrast, some wanted worship to be a matter of the heart and funds to be spent on the poor, yet Catholic apologists for the Baroque musical culture of the late 1700's disagreed. Instead of spending money on the poor, they wanted to adorn the throne room of God with sound in much the same way that they visually decorate it. ${ }^{200}$

One of Martin Luther's objectives for reform was the active participation of the people in public worship. His method for achieving his objective was the introduction of hymns with familiar tunes in the vernacular that "people would join in singing."201 However, two centuries after Luther, Lutherans began to be involved in a controversy similar to that which Catholics faced. The feeling was that only well-trained specialists could perform God's court music. "In this, Baroque Lutheranism agreed with Baroque Catholicism.,202

Currently, congregations do very little singing in "seeker services," which are services that are designed for those who do no regularly attend church, or not all, but who

Western Church developed elaborate choir music which greatly inhibited the congregation from taking its long-established part in the service. By the twelfth century all the choral parts of the service were sung exclusively by either the clergy or the choir....The rise of choirs and elaborate church music kept them from participating in the choral parts (Spielmann, History of Christian Worship, 53, 59).

${ }^{199}$ White, Roman Catholic Worship: Trent to Today, 20.

${ }^{200}$ Lang, Sacred Games, 57-58.

${ }^{201}$ Etherington, Protestant Worship Music, 92. Also, Doukhan, In Tune with God, 157.

${ }^{202}$ Lang, Sacred Games, 58, 60. 
are seeking answers. In seeker services professional musicians target specific age groups in order to provide "entertainment evangelism" with music that "resonates in nostalgic style to whatever age group is targeted." ${ }^{, 203}$ The result, as Moring observes, is that music that was once participatory is now passive. ${ }^{204}$

\section{The Purpose of Music}

According to Calvin Johansson, "The fundamental question concerning music ministry is: What is the purpose of church music? All other questions pale next to this one.”205 The question is important, yet the following paragraphs show the conflicting answers within the history of Christianity.

First, in the conflict between Arianism and Orthodoxy, both aimed at converting society through hymns that were used to promote and teach their theology. In actuality, they used hymns as "theological propaganda"206 and as "weapons' to engage in religious warfare." $^{207}$

Second, others believe that the characteristics that are found predominantly in classical music help to achieve the primary purpose of church music, which is to "elevate

${ }^{203}$ White, Introduction to Christian Worship, 129.

Another maxim of the culturally sensitive philosophy is that a congregation would rather listen to music sung to them than to actually sing music themselves. Inherent in these statements seems to be a conviction that the probability of God's presence and blessing in the service increases exponentially with the professional quality of the entertainment (Webber, ed. Twenty Centuries of Christian Worship, 400).

\footnotetext{
${ }^{204}$ Moring, "Pop Goes the Worship," 22.

${ }^{205}$ Johansson, Discipling Music Ministry, 12.

${ }^{206}$ White, A Brief History of Christian Worship, 71.

${ }^{207}$ Doukhan, In Tune with God, 151.
} 
[the] thoughts and respond to the transcendental aspect of religion."208

Third, some have maintained that the purpose of church music is to create a truly sacred environment that inspires religious feelings by appealing to the emotional aspect of humanity. "Music, for Wesley and the classical Pentecostal tradition, must charge the atmosphere, stir up emotions, and thus open people's hearts to God."209

Fourth, among Catholics, those who were involved in worship music from the time of the Counter Reformation to the nineteenth century, strove "to make the Sunday service "a good show" by employing "all the pomp and ornamentation of the Baroque period in Western culture." ${ }^{210}$ Related to this is the view of the professional musician who performs "for the congregation to listen to, not participate in." 211

Fifth, "Luther was the first to glimpse radical new possibilities for church music. Theologically, music could enable that full participation which belongs to the priesthood of the laity." 212

A sixth purpose of music is for gospel preaching that ultimately results in winning souls. ${ }^{213}$ Yet in this endeavor James White points out that "music was often used in a frankly manipulative way in preparing people to be receptive to gospel preaching."

Lastly, a seventh purpose for music is so that congregations can experience the

${ }^{208}$ Ibid., 292.

${ }^{209}$ Lang, Sacred Games, 185, 402. Also, Doukhan, In Tune with God, 292.

${ }^{210}$ Spielmann, History of Christian Worship, 87.

${ }^{211}$ Doukhan, In Tune with God, 293.

${ }^{212}$ White, Introduction to Christian Worship, 121. Popular Low Church music consisted of congregational singing found within Protestantism as an integral part of the services and in Catholicism it only existed outside the official liturgical rituals. Doukhan, In Tune with God, 293.

${ }^{213}$ Lang, Sacred Games, 175-176; White, Introduction to Christian Worship, 126.

${ }^{214}$ White, A Brief History of Christian Worship, 173. 
presence of God. ${ }^{215}$ John Witvliet points out the irony of worship leaders "who mock supposedly simplistic theories of sacramental realism at the Lord's Supper" while at the same time they seek out liturgical/music leaders who can "make God present through music." He concludes, "No medieval sacramental theologian could have said it more strongly. Dare we call this 'musical-transubstantiation.",216

Thus, those who refer to the divine presence in music as sacramental realism and musical transubstantiation assume the same interpretation of the divine presence as those who advocate for a real presence in the Eucharist and in preaching. In other words, the Eucharist, the preaching of the Word, and music constitute three main vehicles of the divine presence, yet this brief history has uncovered that transubstantiation is the only interpretation of the divine presence in all three modalities. Those who strongly affirm that music is the agency for experiencing God's presence do not seem to offer any alternative interpretation for the content of the divine presence. Witvliet's use of the phrase "musical-transubstantiation" only serves to strengthen this conclusion, since he does not counter or provide an alternative interpretation for the presence of God. This only justifies the need for the development of hermeneutical tools that can be used to assess the content of the interpretation of the presence of God. I will develop these tools in the next Chapter, which is Chapter 3, and then later apply them to the interpretation of the divine presence in the fourth Chapter.

\footnotetext{
${ }^{215}$ The following works attach the experience of God's presence to the music itself, Ruth, "A Rose by Any Other Name," 24, 42, 49; Bloesch, The Church: Sacraments, Worship, Ministry, Mission, 138; Ruth Ann Ashton, God's Presence through Music (South Bend, IN: Lesea, 1993). Miller states that "music actually mediates the sacred," Miller and Yamamori, Global Pentecostalism, 203; Albrecht, "Pentecostal Spirituality: Looking through the Lens of Ritual," 112; Webber, ed. The Renewal of Sunday Worship, 20.

${ }^{216}$ Witvliet, "At Play in the Lord's House: Why Worship Matters," 23.
} 


\section{Conclusion}

There are several points to consider at the end of this brief partial report on the history of liturgy. First, a study of the Eucharist, preaching, and music reveals significant conflicting liturgical practices across Christian denominations all throughout the centuries.

Second, in spite of these liturgical conflicts, Christians have placed a strong emphasis on the presence of God in liturgy. Congregations experience the presence of God in three main ways: either the through the Eucharist, preaching, or music.

Third, in John 17 Jesus prayed that His followers would be united. However, conflicting practices in the areas of the focus of liturgy — the Eucharist, preaching the Word, and music — have revealed the difficulty of answering Christ's prayer.

Fourth, the observations in this Chapter about conflicting liturgical practices and a strong emphasis on the presence of God, experienced in the three ways referred to above, are not necessarily new. It is also no surprise that Protestants reject transubstantiation as the explanation for the miraculous change in the Eucharistic emblems that lead Catholics to adore and worship them. Nevertheless, in spite of this bold rejection of the explanation for the miraculous change, there has been an implicit and uncritical acceptance of the interpretation of the divine presence that is grounded in transubstantiation. This is true despite the Protestant claim that the Scriptures comprise the standard for all doctrines. Thus, neither the challenge of Protestants to transubstantiation on the one hand, nor their emphasis of building all doctrines on the Scriptures, on the other hand, has produced a new interpretation of the divine presence in contradistinction to the Catholic position. Perhaps this is the reason why the Roman Catholic theologian Cyprian Vagaggini 
concludes that the "discovery of liturgy" by Protestants, "carries with it in germ the recognition of values which, logically developed, might lead to the discovery of Catholicism. "217 Therefore, at this point, it appears that Protestantism may have more in common with Catholicism at the level of presuppositions that have a direct impact on understanding the interpretation of the divine presence than it differs from Catholicism with its claim that Scripture is the final authority for all teaching and doctrines. After all, in order to be consistent, Protestants should logically apply this claim to the level of the presuppositions that the divine presence assumes. Yet, in order to confirm Vagaggini's conclusion, more than a historical analysis is required.

At this point we must bear in mind that the purpose of this dissertation is to focus on the presence of God as the central component of liturgy. There are several aspects of this: (1) to sketch the ideas that make up the Catholic interpretation of the divine presence, (2) to discover the cause of liturgical conflict by examining the various interpretations of the divine presence summarized in this Chapter that have also been assumed by Protestants, and (3) to seek to develop a theology of the presence of God that is based on the Scriptures. Therefore, in order to achieve the purpose of this dissertation, I must construct hermeneutical tools that are capable of analyzing the presence of God in Christian liturgy at the level of the presuppositions that it assumes. The construction and description of these hermeneutical tools are in Chapter 3. The aim of Chapter 4 is to apply these tools to Christian liturgy and the fifth, sixth, and seventh Chapters will examine the possibility of developing a theology of the presence of God that is based on the Scriptures.

\footnotetext{
${ }^{217}$ Vagaggini, Theological Dimensions of the Liturgy, 66.
} 


\section{CHAPTER 3}

\section{METHODOLOGICAL FOUNDATIONS}

\section{Introduction}

The purpose of this dissertation is to examine the possibility of developing a theology of the presence of God in Christian liturgy that is based on the Scriptures by first ascertaining the cause/s for the worship wars in Christendom. However, the pathway toward determining the potential cause/s begins in this Chapter with the introduction of a methodological framework comprised of three interdisciplinary sections.

A framework is necessary for three reasons. First, in the previous Chapter, I outlined the nature and extent of liturgical conflict in Christendom throughout the centuries. Although this was not an exhaustive survey, it reveals that classifying and grouping the conflicting liturgical practices is challenging since (1) these practices differ within Catholicism ${ }^{1}$ and Protestantism, ${ }^{2}(2)$ they can even differ within the same denomination, ${ }^{3}$ and (3) theologians can have diametrically opposed opinions about

${ }^{1}$ For the use of the cup in the Eucharist, see this dissertation page 27 footnote 35; for use of leavened and unleavened bread, see page 27, footnote 36 ; for Latin versus the vernacular, see pages 29-30.

${ }^{2}$ For preaching, see this dissertation pages 38-49; for music, see pages 51-64; for frequency of the Lord's Supper, see page 27 footnote 37.

${ }^{3}$ Luther used familiar tunes in the vernacular so that all could join in singing, but two centuries later Lutherans felt that only well-trained specialists could perform God's court music (see pages 61-62 of this dissertation). 
liturgical practices. ${ }^{4}$ These considerations make it difficult to group liturgical conflicts according to denominations and theologians.

Consequently, the pathway toward determining any potential cause in the worship wars begins with the first of three interdisciplinary methods. In order to organize and group the vast amounts of liturgical data by taking into account the difficulties previously mentioned, and searching for alternative solutions I will use the model method. A model is a description of a kind of complex phenomenon occurring in the material, historical, or spiritual realm. ${ }^{5}$ In Figure 1, that complex phenomenon is the liturgical event.

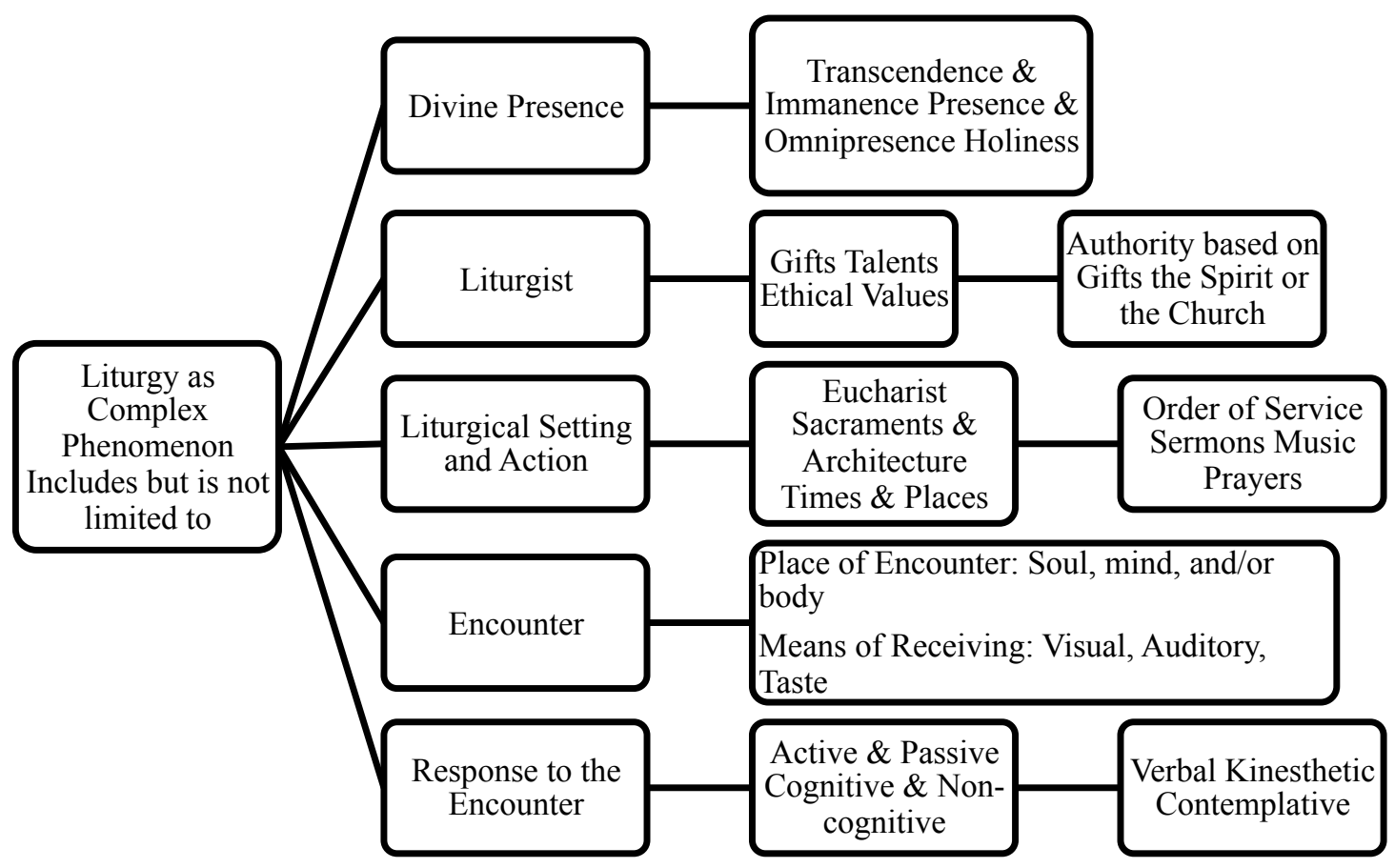

Figure 1. Liturgy as a complex phenomenon.

${ }^{4}$ Bloesch and Pannenberg differ over the focus of liturgy (see pages 21 of this dissertation). Calvin and Zwingli differed over how often to celebrate the Lord's Supper (see page 27 note 37 of this study).

${ }^{5}$ Barbour, Myths, Models, and Paradigms, 30, 31, 34, 51; Ramsey, Models and Mystery, 5, 6, 11, 14. 
Models also simplify complex realities by singling out "fundamental notions." In this study, I will simplify and classify the liturgical conflicts by organizing them around their approaches to the concept of the presence of God as the fundamental concept of liturgy as noted in Figure 2.

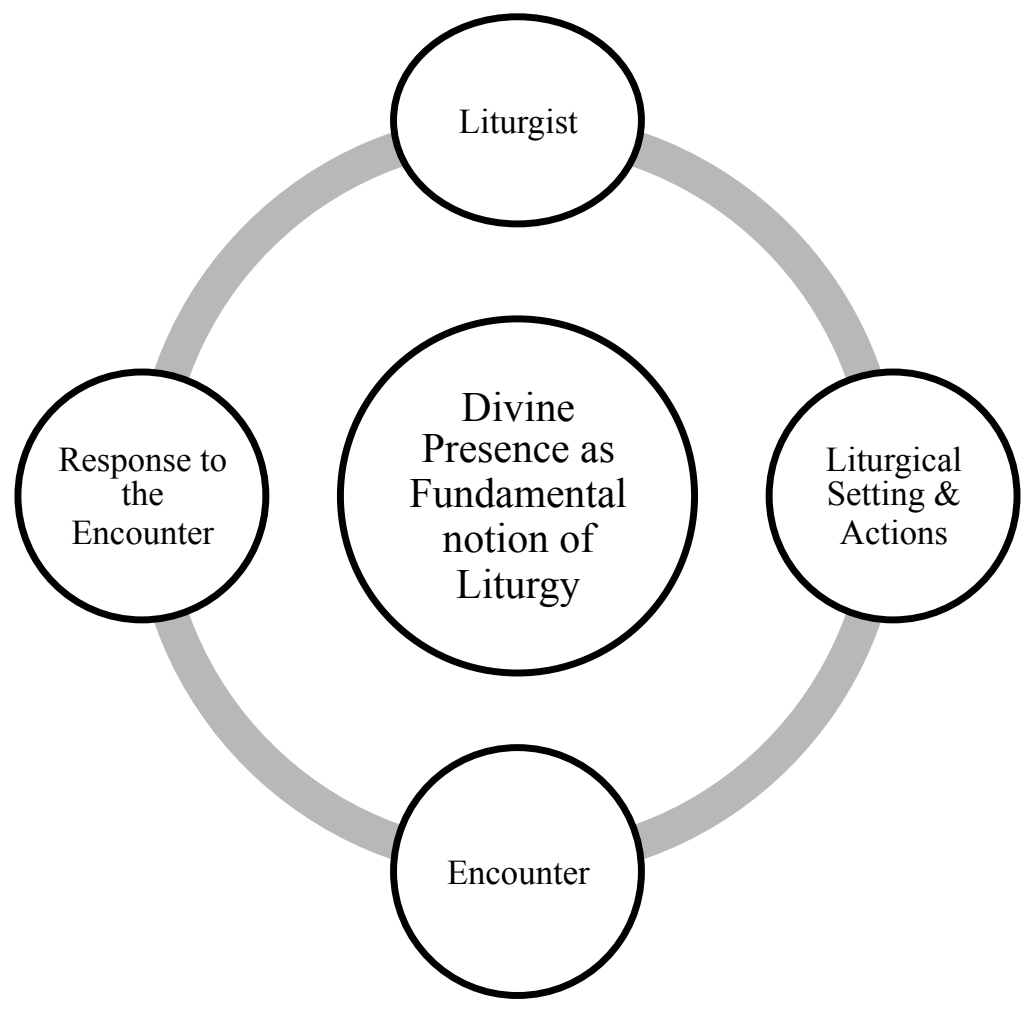

Figure 2. Divine presence as fundamental concept of liturgy.

Secondly, I will first explain why a phenomenological method is required before defining what it is and what it entails in this study. Models describe complex phenomena like the divine presence in liturgy. However, their descriptions include interpretations and hypotheses regarding two related aspects of any phenomenon under study.

First, models scale down complex realities by describing all of the constitutive

${ }^{6}$ Ian Ramsey, Models and Mystery, 12. 
parts that are involved in order for that reality to function. ${ }^{7}$ With reference to liturgy, a description scales down the complex reality of liturgy (Figure 1) to its basic component parts (Figure 2), each of which includes many sub parts (Figure 1). One must include all the basic parts as preconditions for liturgy to take place (Figure 2). The scaling down process involves interpretation. However, interpretation at this point only involves the question of whether all the parts are properly accounted for in the description.

Second, and more importantly, models generate interpretations and hypotheses ${ }^{8}$ concerning the basic component parts of liturgy, which means that a model's description of the divine presence also involves an interpretation of the divine presence. Consequently, a phenomenological method involves a proper description of all the constitutive parts of liturgy as the precondition for liturgy to function while at the same time this method brackets out and keeps us from confusing a theological interpretation of liturgy from the reality of liturgy. ${ }^{9}$ In short, a phenomenological method provides an outline of all the parts of liturgy (Figure 2) that will facilitate analysis of the components of liturgy in each model.

Finally, in order to understand and evaluate the way in which each model interprets the presence of God (the ontological ground of all liturgy) and the liturgical components, I will employ a macro hermeneutical method. This kind of method involves

${ }^{7}$ See Barbour, Myths, Models, and Paradigms, 29; Ramsey, Models and Mystery, 5.

${ }^{8 ،}$ The 'intuitive intelligibility' of a model is no guarantee at all concerning its validity; deductions from the theory to which the model leads must be carefully tested against the data and, more often than not, the proposed model must be amended or discarded. Models are not advanced as guaranteed truths; they are used to generate plausible hypotheses to investigate. They are a source of promising theories to test." Barbour, Myths, Models, and Paradigms, 34 (emphasis original).

${ }^{9}$ Ramsey notes, "Inferences from scale model to original are intrinsically precarious and in need of supplementary validation and correction." Ramsey, Models and Mystery, 6. Hence, models are interpretations of reality and not reality itself. 
an analysis of Being as the broadest possible presupposition ${ }^{10}$ and its potential to shape the divine presence and the rest of the liturgical components involved in liturgy. Ian Barbour notes that models generate theories, and that these theories are not advanced as guaranteed truths. Rather, they must be carefully tested against the data. ${ }^{11}$

Our Chapter on the history of liturgy has revealed that Catholics, Orthodox, and Protestants describe the divine presence in the Eucharist, the preaching of the Word, and music with terms such as sacramental, the real presence, and musical transubstantiation. These common descriptions disclose that even those who profess to go by the Scriptures tacitly and uncritically accept the interpretation of the divine presence that is grounded in transubstantiation and championed by Catholicism ${ }^{12}$ without offering a biblical alternative, as Figures 3 to 5 illustrate; this is true even though they reject the sacerdotal and sacrificial aspects involved as an explanation of the change of the bread and wine.

Hence, a macro hermeneutical method is necessary in order to evaluate the transubstantiation hypothesis against the data of Scripture. I will now describe and analyze each of the three methods in the order that I employ them.

\footnotetext{
${ }^{10}$ Canale, A Criticism of Theological Reason: Time and Timelessness as Primordial Presuppositions, 66-72.

${ }^{11}$ Ian Barbour, Myths, Models, and Paradigms, 34.

${ }^{12}$ See Chapter 2 of this dissertation pages 33-35, 43-44, 64-66.
} 


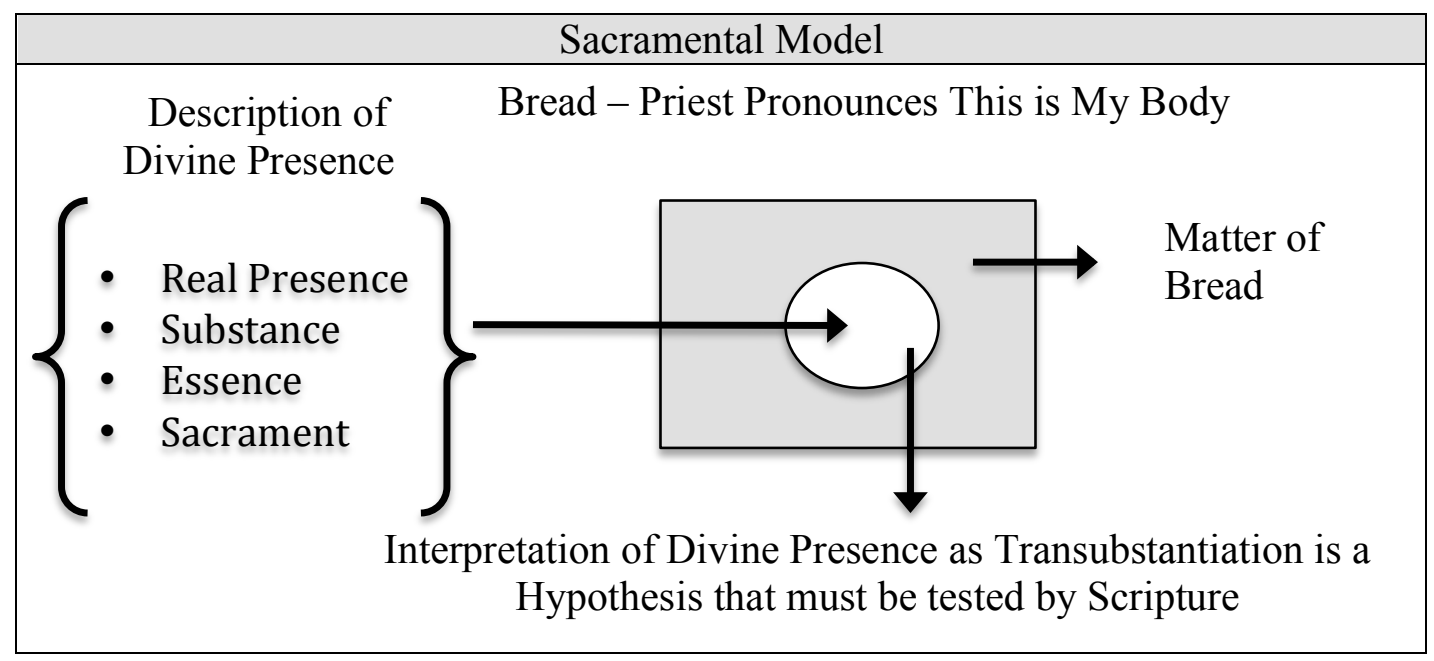

Figure 3. Sacramental model.

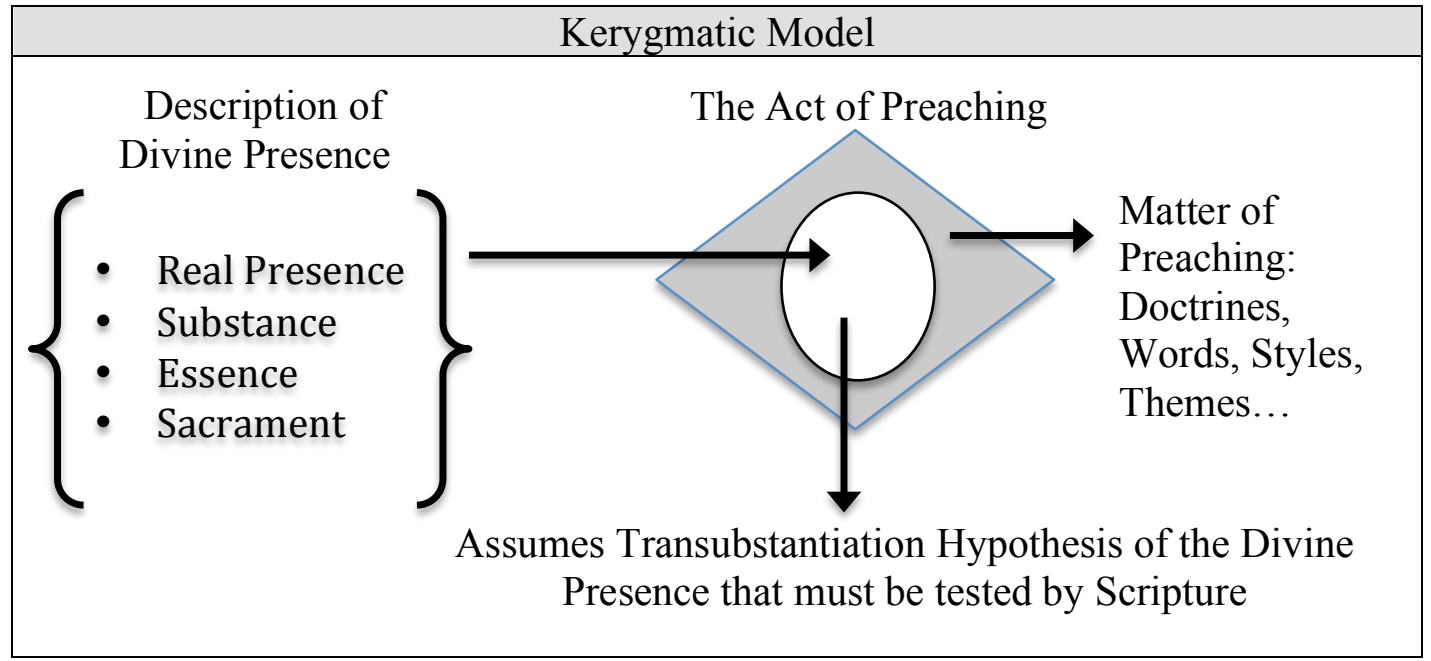

Figure 4. Kerygmatic model.

\section{Model Method}

Thomas Kuhn's widely acclaimed book The Structure of Scientific Revolutions has exercised a powerful influence in theology. ${ }^{13}$ As a result of his influence, scholars

${ }^{13}$ Kuhn's book first drew attention in the area of the history of science. Yet, it has also broken into other areas such as social science, the humanities, arts, and even theology. See Frank M. Hasel, "Scientific Revolution: An Analysis and Evaluation of Thomas Kuhn's Concept of Paradigm and Paradigm Change for Theology," Journal of the Adventist Theological Society 2, no. 2 (1991): 160. Hans Küng has made use of model methodology in the following ways: (1) He has applied models/paradigms to developments within the 


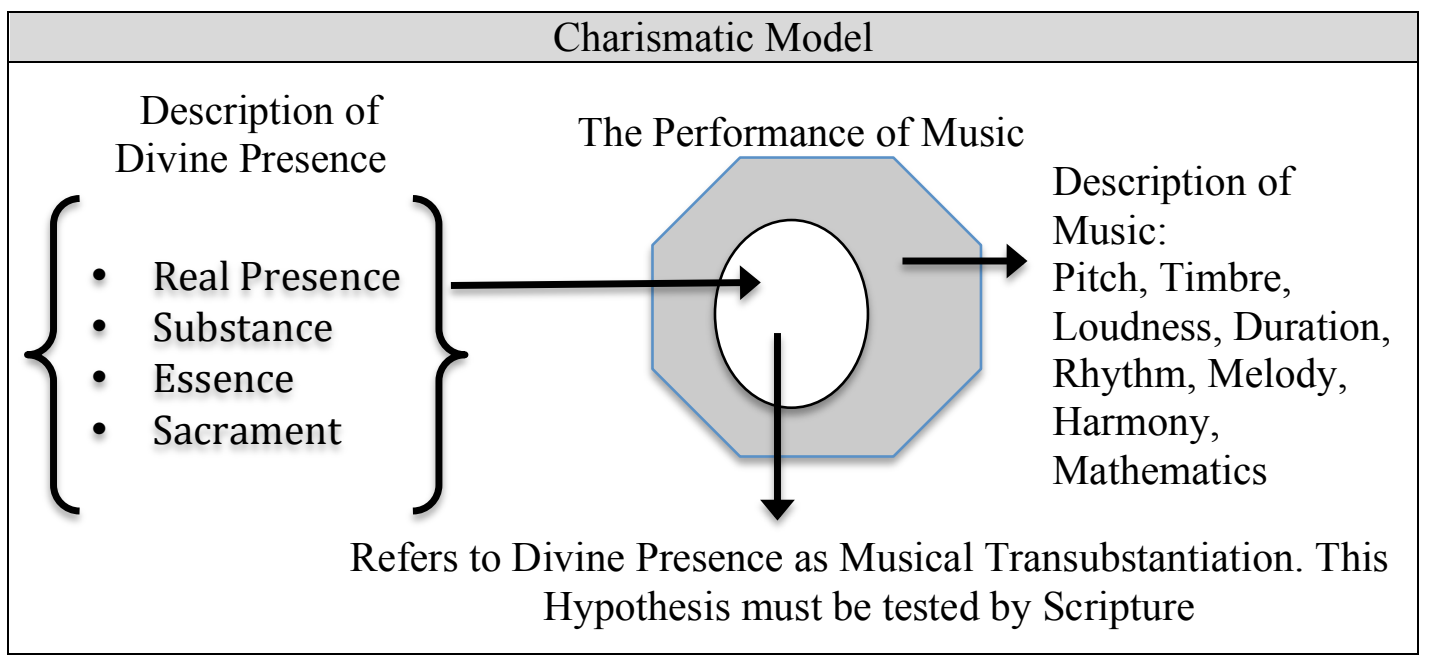

Figure 5. Charismatic Model.

have made use of models in their study of ecclesiology, ${ }^{14}$ revelation and inspiration, ${ }^{15}$ science, ${ }^{16}$ and Biblical studies. ${ }^{17}$ Before we look at how liturgical scholars employ the use of models, I would like to point out at least three reasons why scholars make use of models that we can apply to the study of liturgy.

First, models are useful for sifting through large amounts of material, which is exactly what we find when we undertake an examination of liturgy. ${ }^{18}$

Catholic Church. See Küng, Theology for the Third Millennium, 182, 183-188; (2) He has applied models/paradigms to the whole of Christianity. Ibid., 128; (3) He has used the insights gained from the sciences to classify different paradigms that refer to different schools of theological thought. Ibid., 134.

${ }^{14}$ Dulles, Models of the Church, exp. ed. (Garden City, NY: Image Books, 1987).

${ }^{15}$ Canale, Back to Revelation-Inspiration; Avery Dulles, Models of Revelation.

${ }^{16}$ Barbour, Myths, Models, and Paradigms; Idem, Religion and Science: Historical and Contemporary Issues. See also Ramsey, Models and Mystery.

${ }^{17}$ Gerhard F. Hasel, "Recent Models of Biblical Theology: Three Major Perspectives," 55-75.

${ }^{18}$ Dulles, Models of Revelation, xvii. For instance, Frank Senn mentions thirty-two headings contained in his bibliography, each of which includes many reference materials. See Senn, Christian Liturgy, 707-727. Similarly, Robert Webber's massive six-volume series on worship contains headings that include large amounts of bibliographic information. See Robert E. Webber, The Complete Library of Christian Worship. 7 vols. (Nashville, TN: 
Second, from all the vast amounts of material, models help to identify questions needing attention and clarification. ${ }^{19}$ In this study, I shall formulate questions that directly relate with the issue of the presence of God in liturgy. ${ }^{20}$

Third, models simplify and differentiate complex realities. ${ }^{21}$ As a result, this study will simplify and differentiate between the complexities involved in liturgy by seeking to identify the kinds of activities that different religious traditions use to represent the divine presence. ${ }^{22}$ Let us now examine how various scholars have employed the use of models in liturgy.

\section{Models and Liturgy}

In this section I will examine the use of models by several scholars before I outline how I will use model methodology in this study. Webber uses models in order to

Star Song, 1993-1994). These vast bibiographic sources contain historical, Biblical, phenomenological, theological, and philosophical elements that are related to the study of liturgy.

${ }^{19}$ In Models of Revelation, Avery Dulles identifies questions such as, What is revelation? and How are church pronouncements on revelation related to revelation itself? See, Dulles, Models of Revelation, xvii-xviii.

${ }^{20}$ For instance, (1) How do the Eucharist, preaching, and music relate the presence of God to the various aspects of liturgy? (2) How does focusing on the interpretation of the presence of God provide an explanation for the worship wars? And (3) Is it possible to develop a theology of the presence of God in Christian liturgy that is based on the Scriptures?

${ }^{21}$ Dulles, Models of Revelation, 30. Dulles compares a model to a tailor's dummy, which represents a person of average stature and assists in the manufacture of clothing. This is much more manageable than constructing scores of individualized dummies.

${ }^{22}$ The presence of God can be associated with many different kinds of rituals. As a result, it would be very cumbersome to analyze how worshippers experience the divine presence by undertaking an examination of every ritual that mediates the presence of God. Instead, based on model methodology, I have chosen to simplify and differentiate between how the presence of God relates to three main ritual actions: the Eucharist, preaching, and music. See pages $74-80$ of this dissertation. 
illustrate how various periods of the history of the Christian church affect liturgy. ${ }^{23}$

Webber created the criterion for his description and classification of models from a linear historical approach. Since models are grouped around questions that need attention, the implied question here is, what factors affected liturgy throughout world history?

Using a different approach, Lester Ruth and Bernhard Lang use ritual actions as the criterion for their concept of liturgical models. ${ }^{24}$ As a consequence, the ritual actions function as models around which they organize liturgy. The question here is, What are the major liturgical actions that are assumed in liturgy?

Lastly, Barry Liesch organizes liturgy around five different Biblical liturgical eras that function as the criteria for liturgical models. ${ }^{25}$ The question in Liesch's approach is, what are they key factors that are found throughout the various biblical liturgical eras, and how did they affect liturgy?

In my opinion, the approaches to liturgical models just described fall short for the purposes of this study because they do not adequately take into account the central role of

${ }^{23}$ For example, (1) in the pre-Constantinian era liturgy was informal and intimate; (2) in the post-Constantine era liturgy was more public with large basilicas; (3) in the medieval era worship was clericalized; (4) during the Reformation the focus was on the Word; (5) in the evangelistic model of worship the emphasis was on revival; (6) Pentecostal worship focused on the role of the Spirit; and (7) postmodern worship focuses on culture. See Webber, Ancient-Future Faith, 97-99. Using a similar approach to what was just covered, Webber employs the Reformation as the criterion for the description and classification of three broad models: "Pre-Reformation Liturgies," "Reformation Models of Worship," and "Post-Reformation Models of Worship." See Webber, ed. Twenty Centuries of Christian Worship, 142-258.

${ }^{24}$ Lester Ruth refers to music, preaching and sacraments, which have the potential for a taxonomy of worship. See Ruth, "A Rose by Any Other Name," 43, 48, 49, 51. Using a similar approach, Lang has organized liturgy around six models, or sacred games as he refers to them, (1) praise, (2) prayer, (3) sermon, (4) sacrifice, (5) sacrament, and (6) spiritual ecstasy. See Bernhard Lang, Sacred Games.

${ }^{25}$ The five models of liturgy include: (1) pre-Sinai, (2) tabernacle-temple, (3) synagogue, (4) Pauline, and (5) the book of Revelation, Liesch, People in the Presence of God: Models and Directions for Worship, xi. 
the divine presence as "the universal premise of worship." ${ }^{, 26}$ Catholics, Protestants, Pentecostals, and adherents of the Emerging Church affirm that the purpose of liturgy is to enter into, celebrate, and experience the presence of God in liturgy. ${ }^{27}$ The Emerging Church represents a movement that sprang up around the 1990's among Evangelicals that combines the sacramental elements of the early church with twenty-first century musical and artistic features. ${ }^{28}$ This study will use the divine presence as the central criterion in developing models for investigation of Christian liturgy.

Our focus on the presence of God as the central criterion requires that we (1) explain the distinction between worship and liturgy as it relates to models and the presence of God, (2) clarify how the concept of mediation relates to the divine presence, and (3) explain the criteria that we will use in this work to identify models of liturgy that revolve around the presence of God.

Since the presence of God is linked to worship as well as liturgy, the following distinction will help to focus the models and the components on liturgy rather than worship. Whereas worship refers to the internal attitude and action of the worshipper, which can take place in a private way and in a corporate setting, liturgy refers to a public service with objective forms and rituals external to human consciousness, and which are used by human beings in their ceremonies. ${ }^{29}$

Let us now consider how divine presence relates to liturgy. In clarifying this issue, we must keep in mind that our interpretations of God's presence need to take into

\footnotetext{
${ }^{26}$ Dyrness, A Primer on Christian Worship, 24.

${ }^{27}$ See Chapter 1 of this dissertation, pages 5-6, footnotes 18-21.

${ }^{28}$ In this dissertation, see Chapter 1 page 4 , and Chapter 4 pages 180-187.

${ }^{29}$ Fernando Canale, "Principles of Worship and Liturgy," Journal of the Adventist Theological Society 20/1-2, no. 1 (2009): 92.
} 
consideration the context in which we study it. Among possible contexts in which we can study God's presence are: (1) the presence of God/Christ in liturgy, (2) Christ's presence and role as Mediator in the work of salvation, and (3) omnipresence as a divine attribute.

This dissertation focuses on a mediated encounter ${ }^{30}$ with the divine presence that comprises the vast majority of encounters with God in liturgy, and which mainly occurs through the Eucharist, preaching, and music. However, we also note that Pentecostals and Quakers also speak of an unmediated encounter with God in liturgy. ${ }^{31}$ Although mediation of the presence of God is involved in liturgy as well as in Christ's role as mediator in the work of salvation, we will only examine elements of Christ's role as mediator if it has a direct bearing on mediation of the divine presence in liturgy. Similarly, although theologians disagree about how to interpret God's omnipresence, ${ }^{32}$

${ }^{30}$ Catholics and the Reformers speak of a mediated encounter in liturgy in which the presence of Christ, and not the presence of God as He is in Himself, is mediated through the sacraments and the Word. For Catholics, Vagaggini points out that "any worship rendered by the Church to God is always in Christ, that is, in union with Christ through Christ as the Head of the Church." Vagaggini, Theological Dimensions of the Liturgy, 24. For Luther, Christ's "presence is neither visible nor unmediated. The end has not come. But while we wait for Christ's return, he meets us in the means of grace. This advent is invisible and indirect, requiring faith on the part of man." Vajta, Luther on Worship, 127. Smith points out that the Reformers emphasized "the material conditions of worship" such as Word and Sacrament, affirming that "worship is a mediated encounter with the triune God, who condescends to meet us in the stuff of which we are made." James K.A. Smith, Desiring the Kingdom: Worship, Worldview, and Cultural Formation (Grand Rapids, MI: Baker Academic, 2009), 151.

${ }^{31}$ Pentecostals and Quakers speak of an unmediated encounter with God in liturgy. For Quakers, see Peter Collins and Pink Dandelion, "Wrapped Attention: Revelation and Concealment in Nonconformism," in Materialising Religion: Expression, Performance and Ritual, ed. Elisabeth Arweck and William J.F. Keenan (Burlington, VT: Ashgate Publishing, 2006), 51; Gay Pilgrim, "Taming Anarchy: Quaker Alternate Ordering and 'Otherness'," in The Creation of Quaker Theory: Insider Perspectives, ed. Pink Dandelion (Burlington, VT: Ashgate Publishing, 2004), 206-207. For Pentecostals, see Lang, Sacred Games, 409; Noel, Pentecostal and Postmodern Hermeneutics, 125-127.

${ }^{32}$ Pannenberg makes no distinction between God's power and His essence, while Strong makes a distinction between His power and His essence. See Marcio Costa, "The 
we will only examine interpretations of omnipresence that have a direct bearing on how we interpret the divine presence in liturgy.

Keeping in mind that models single out fundamental notions and that they simplify and classify complex phenomena, I will now outline three main factors that point to the existence of three models that are organized around the mediation of God's presence in liturgy as the fundamental notion of liturgy.

First, there are four reasons for why the Eucharist, preaching the word, and music constitute the three main vehicles of the divine presence. The first is that various scholars have specifically named the Eucharist, preaching, and music as vehicles of the divine presence. ${ }^{33}$ Second, others have noted the primary role that each vehicle plays in liturgy. ${ }^{34}$ Third, some scholars focus on the word and sacrament as the main vehicles of Christian liturgy that have occurred throughout many centuries and across many denominations, ${ }^{35}$ while others point to music as a major vehicle of God's presence. ${ }^{36}$ The

Omnipresence of God in the Views of Strong and Pannenberg Compared to a Biblical Analysis," Hermenêutica vol. 8 (2008): 85-109.

${ }^{33}$ Bloesch, The Church: Sacraments, Worship, Ministry, Mission, 35, 137; Dyrness, A Primer on Christian Worship, 68-69; Liesch, The New Worship, 53; Ruth, "A Rose by Any Other Name," 41, 43, 48, 51; Webber, Ancient-Future Worship: Proclaiming and Enacting God's Narrative, 133; Witvliet, "At Play in the Lord's House: Why Worship Matters," 23; Lorraine Brugh, "The Trinitarian Journey: Music as Gift and Sounded Word," Currents in Theology and Mission 35, no.3 (June 2008): 189; Noel, Pentecostal and Postmodern Hermeneutics, 118.

${ }^{34}$ David L. Bartlett, "Worship," in New and Enlarged Handbook of Christian Theology, ed. Donald W. Musser and Joseph L. Price (Nashville, TN: Abingdon Press, 2003), 543; Lorraine Brugh, "The Trinitarian Journey: Music as Gift and Sounded Word," Currents in Theology and Mission 35 no.3 (June 2008): 189; Marva J. Dawn, Reaching out without Dumbing Down, 170-174, 206-209, 262-265; Michael S. Horton, In the Face of God (Dallas, TX: Word Publishing, 1996); Noel, Pentecostal and Postmodern Hermeneutics, 118; Senn, Christian Liturgy, 53-266, 687-688; Spielmann, History of Christian Worship, 23.

${ }^{35}$ Max Thurian, "The Present Aims of the Liturgical Movement," 111; Norén, "The Word of God in Worship," 36, 39; Davies, Crisis and Creativity, vii; White, A Brief History of Christian Worship, 157, 158; Willimon, Word, Water, Wine and Bread, 125; Wainwright, 
fourth reason for why the celebration of the Eucharist, preaching, and music constitute the three main vehicles of the divine presence is that they function as the most representative liturgical actions ${ }^{37}$ through which congregations experience the divine presence. Since one purpose of a model is to simplify the material that theologians must analyze, there is no need to make the task unnecessarily complicated by constructing other models simply because other liturgical actions also function as vehicles of the divine presence.

The second main factor that points to the Eucharist, preaching, and music as the three main models that are organized around the mediation of God's presence in liturgy is architecture. For instance, the central position in any structure speaks to its importance. In

"Recent Eucharistic Revision," 331; Everett, The Politics of Worship, 11. Various scholars have pointed out that the focus of liturgy in early Christianity was also that of "Word and Table," Cullmann, Early Christian Worship, 14, 30; Micks, The Future Present, 130, 131; Marshall and Taylor, Liturgy and Christian Unity, 105.

${ }^{36}$ Noel, Pentecostal and Postmodern Hermeneutics, 118; Webber, ed. The Renewal of Sunday Worship, 82. Charismatic worship is strongly associated with the music driven Jesus movement of the 1960's, Christian rock, and the praise and worship style of the early 1980's, Ruth, “A Rose by Any Other Name,” 24-25.

${ }^{37}$ While Vatican II acknowledges the presence of Christ in the priest, the sacraments, His Word, prayer, in song and in the assembled saints, it specifically points out that Christ is present "especially under the Eucharistic species" See $S C$, Art. 7. Edward Kilmartin points out "the Eucharistic celebration as the most intensive form of his presence." Kilmartin, "Christ's Presence in the Liturgy," 103-104. Kilmartin reached this conclusion after summarizing the many different ways that Christ is present in liturgy found in the encyclicals Mediator Dei and Mysterium Fidei, along with the Original Schema of the Constitution on the Liturgy and the Constitution on the Sacred Liturgy. These include His presence in the priest, sacraments, gathered community, Scripture reading, preaching of His Word, works of mercy, and exercise of ecclesial authority. The Eucharist can also represent drama in the Sacramental model. See Anscar J. Chupungco, "History of the Roman Liturgy until the Fifteenth Century," in Handbook for Liturgical Studies: Fundamental Liturgy, ed. Anscar J. Chupungco (Collegeville, MN: Liturgical Press, 1997), 145-147. See also, Cooke, The Distancing of God, 200; Dyrness, A Primer on Christian Worship, 20; O.B. Hardison, Christian Rite and Christian Drama in the Middle Ages: Essay in the Origin and Early History of Modern Drama (Baltimore, MD: Johns Hopkins Press, 1965); Power, Unsearchable Riches, 52. Drama can also be represented by the sermon in the Kerygmatic model. James O. Chatham, Enacting the Word: Using Drama in Preaching (Louisville, KY: Westminster John Knox Press, 2002), 2-3. 
the Sacramental model the Eucharist is celebrated on the altar located in a central position. In the Kerygmatic model, the Word is preached from the pulpit, which is also central; and in the Charismatic model the worship bands occupy the central position. ${ }^{38}$

With reference to the third main factor, when one considers time, energy, and furnishings as indicators of priority, then most services are organized around preaching, the Eucharist, or music. ${ }^{39}$

Now that we have described the model methodology that this study will follow, we need to develop criteria by which the models will be compared, analyzed, and evaluated. This brings us to the phenomenological description of liturgy.

\section{Phenomenological Method}

The phenomenological method I am employing consists of two important principles. The first is to discover the constitutive parts of the liturgical event or reality, and the second is to keep in mind the crucial difference between a description of the constitutive parts of liturgy and the interpretation of those parts that have produced the liturgical conflicts we outlined in Chapter 2. To discover the constitutive parts of the liturgical event we need to apply the phenomenological method to the Scriptures and to scholarly writings on liturgy. ${ }^{40}$ These liturgical components are the conditions of the possibility of any liturgy. This enumeration and brief description of the components of liturgy will provide the necessary framework to organize and describe each model.

\footnotetext{
${ }^{38}$ See Chapter 2 of this dissertation pages 23-26.

${ }^{39}$ Lester Ruth, "A Rose by Any Other Name," 41, 43, 48, 51.

${ }^{40}$ The following theologians-a Catholic, a Charismatic, and an Evangelical-affirm the role of the Scriptures as a source for liturgy. Schillebeeckx, The Real Achievement of Vatican II, 40-41. See also, Noel, Pentecostal and Postmodern Hermeneutics, 141-145; Robert E. Webber, The Younger Evangelicals, 192.
} 


\section{Description of Liturgy and Worship in Scripture}

There are several reasons for employing Scripture for the phenomenological description of liturgy. First, Scripture records liturgical events that are available for analysis. Second scholars recognize Scripture as a source that contains these liturgical events. ${ }^{41}$ Third, the Greek words for liturgy in the Septuagint (LXX) are associated with the various aspects of temple liturgy. ${ }^{42}$

Accordingly, my purpose in the phenomenological description of liturgy in Scripture is only to discover the various parts of liturgy that Scripture unfolds without using Scripture or any other source for that matter to interpret the parts of liturgy. This is what a phenomenological method actually entails. Moreover, this is a necessary prerequisite for the hermeneutical method that I will then set up and apply to the parts of liturgy that the phenomenological description has uncovered.

A brief examination of the Scriptural data shows that the presence of God is linked to the liturgy in the Old Testament sanctuary. In Exod 25:8, 9, Scripture affirms that the purpose of the sanctuary is that God's presence might dwell among His people. In the context of the temple, the divine name and the divine presence are interchangeable. ${ }^{43}$ Furthermore, God chose the sanctuary/temple as the place of liturgical

${ }^{41}$ See footnote 40 above.

${ }^{42}$ For the numerous uses of $\lambda \varepsilon \varepsilon \tau o v \rho \gamma \varepsilon \dot{c} \omega$ and $\lambda \varepsilon ı \tau o v \rho \gamma i \alpha$ in the LXX in relation to the many aspects of liturgical service, see Theological Dictionary of the New Testament (TDNT), s.v. $\lambda \varepsilon \imath \tau o v \rho \gamma \varepsilon \dot{\varepsilon} \omega$ and $\lambda \varepsilon \imath \tau o v \rho \gamma i$ in in the LXX.

${ }^{43}$ The following texts indicate that the temple was built for the name of the Lord (1 Chr 22:7, 8, 10, 19; 28:3; 29:16; 2 Chr 2:1, 4; 6:5, 7-10, 34, 38; 20:8). In addition, $2 \mathrm{Chr}$ 20:8, 9 indicates that God's name is interchangeable with His presence. The text states:

And they dwell in it, and have built You a sanctuary in it for Your name, saying, 'If disaster comes upon us - sword, judgment, pestilence, or famine-we will stand before this temple and in Your presence (for Your name is in this temple), and cry out to You in our affliction, and You will hear and save.' 
celebration, ${ }^{44}$ and he also appointed Aaronic priests as the liturgists. ${ }^{45}$

While liturgical events in Scripture begin with the Pentateuch, I will draw upon texts concerning the sanctuary/temple in Chronicles since the liturgical activities connected with it are more fully developed and more numerous. As a result, a broader representation of liturgical components has the potential to produce a more accurate phenomenological description of liturgy.

The liturgy of the sanctuary included actions that were performed by Levitical priests. Some of these actions were (1) song, ${ }^{46}(2)$ prayer, $^{47}(3)$ sacrificial functions $(2$ Chr 29:20-24), (4) teaching (2 Chr 30:22), and (5) declaring God's goodness and his wonderful works (1 Chr 16:7-36; 25:1-3; 2 Chr 20:14-19). ${ }^{48}$ Moreover, the presence of God was connected not only with these actions but also with other ritual actions, such as instrumental musical performance and the Levitical choir (2 Chr 5:12-14). ${ }^{49}$

Kleinig confirms this connection between God's name and His presence. He states, "Through his name the LORD was therefore accessible to his people and present with them at his temple. Since God's name was in the temple, the people who invoked him there stood in his presence (2 Chr 20:8-9).” John W. Kleinig, The Lord's Song: The Basis, Function and Significance of Choral Music in Chronicles, Journal for the Study of the Old Testament Supplemental Series 156 (Sheffield, United Kingdom: JSOT Press, 1993), 64-65.

${ }^{44}$ See Deut $12: 5,11,14,18,21,26 ; 16: 2,6,7,11,15,16 ; 2$ Chr 7:12, 16. The implication is that the Israelites were not at liberty to choose their own place to celebrate liturgy.

${ }^{45}$ See 1 Chr 15:16; 16:4. The implication is that the Levites were not self-appointed.

${ }^{46}$ See 1 Chr 16:4, 8-10. The words were generated from King David and Asaph (2 Chr 29:30). The songs were accompanied with musical instruments (1 Chr 15:16, 19, 28; 16:4, 5), and there were also songs that served a prophetic function (1 Chr 25:1-3).

${ }^{47}$ At the Temple, Solomon and Jehoshaphat offered prayer, (2 Chr 5:2-7:3; 20:5-12).

${ }^{48}$ Kleinig notes, "Through the proclamation of his name in word and song, the LORD presented himself to his people at Jerusalem," Kleinig, The Lord's Song, 146. Kleinig also refers to these liturgical actions as "components." Ibid., 64.

${ }^{49}$ The trumpets "together with the music of the full Levitical choir, their fanfare announced the entrance [sic] the LORD into the temple at its dedication (2 Chr 5:12-14)." Ibid., 81 , see also 84 and 89 . 
A number of these liturgical activities took place at set times: (1) each morning and evening as the burnt offering was presented, (2) the weekly Sabbaths, (3) the new moon days, and (4) during the three great festivals: Passover, Pentecost, and the Feast of Tabernacles (1 Chr 23:30, 31; $2 \mathrm{Chr} 2: 4 ; 8: 13$ and 31:3). ${ }^{50}$

Israelite worshippers responded to their encounter with the presence of the Lord by (1) bowing their knees with their faces to the ground ( $2 \mathrm{Chr} 7: 3 ; 20: 18)$; (2) offering praise and thanksgiving to God (2 Chr 7:3; 20:19); offering sacrifices, thank offerings, and burnt offerings (2 Chr 29:31); and (3) rejoicing (2 Chr 29:36; 30:25, 26).

From this brief description we can identify five broad and indispensable components involved in Sanctuary liturgy: ${ }^{51}$ (1) God's presence, (2) the liturgists (the Levites), (3) the liturgical setting that includes the place of liturgy and the time/s in which liturgy occurs as well as the liturgical actions performed by the liturgists, (4) encounter with the divine presence, (5) and response to the encounter with the divine presence.

In sum, the divine presence, the liturgists, and the liturgical setting and actions constitute the necessary components to achieve the goal of experiencing a worship encounter with $\mathrm{God}^{52}$ that ultimately results in some kind of response to the encounter.

${ }^{50}$ Ibid., 75, see also pages 74-77. On p. 77 Kleinig points out that "the performance of sacred song was quite deliberately synchronized with the holy times set for the presentation of the public burnt offering at the temple."

${ }^{51}$ For more on the components of Israelite ritual, see Gerald Klingbeil, Bridging the Gap: Ritual and Ritual Texts in the Bible (Winona Lake, IN: Eisenbrauns, 2007).

${ }^{52}$ Hislop speaks of the objective aspect of God's presence: The objective aspect of the presence of other lives for worship is a social act; the objective aspect of the means through which the worship is offered, including both visible and audible means; and the experience of the interaction that takes place. Hislop, Our Heritage in Public Worship, 5. These major components can also be extrapolated from Chupungco. He mentions the presence of Christ in all aspects of the liturgy: the Church, which includes those officiating and those experiencing the liturgy; rituals such as signs, symbols, music, and art; and the encounter between the faithful and God. Anscar J. Chupungco, "Introduction," 4-9. 
These five components (1) make up what scholars interpret in the liturgical conflicts, and (2) they form the framework that we will use to analyze and compare the models. Also, the distinction between liturgy and worship enables us to distinguish between the objective aspects of liturgy that are realities that exist outside of human beings and the subjective experience of the objective aspects (worship).

\section{Scholarly Description of Liturgy and Worship}

In our brief phenomenological description of liturgy above, I employed Scriptural data for two reasons: (1) because they are recognized as primary source material for Christian liturgy, and (2) because many liturgical services are recorded therein. Yet, since Scripture does not specifically enumerate the liturgical components, one may question whether my version of the components is accurate. This plausible concern necessitates an examination of scholarly observations of liturgy in order to verify whether my choice of components is actually sustainable. As we conduct a phenomenological description of liturgy and worship from scholarly observations of liturgy,${ }^{53}$ we will suspend our interpretations of the components we are describing.

\section{Scholarly Observations About The Divine Presence}

Scholars note that the divine presence is of fundamental importance in liturgy ${ }^{54}$

\footnotetext{
${ }^{53}$ The major difference between my phenomenological description of liturgy from Scripture and the scholars' description of liturgy involves scope and sources. My phenomenological description of liturgy is restricted to the Scriptures, yet many scholars incorporated other sources of liturgy that included religions other than Christianity.

${ }^{54}$ The following statement by Paquier underscores how vital the divine presence is for liturgy. He states: "Only in God's presence is there truly divine worship. Worship is possible only when the divine presence, given by grace and received by faith, is recognized and grasped in its reality and power," Richard Paquier, Dynamics of Worship: Foundations and Uses of Liturgy (Philadelphia: Fortress Press, 1967), 9. Cooke points out: "Openness to
} 
since it grounds all other liturgical components and ritual actions ${ }^{55}$ that are inextricably

linked with it. ${ }^{56}$ Hence, due to its grounding role, we will pay close attention to the

interpretation of the divine presence in each model within the context of the liturgical

conflicts. We now move to our next component.

\section{Scholarly Observations About Humans \\ Performing Liturgical Actions}

In addition to the divine presence, Mark Searle notes that liturgy requires the

divine presence in sacrament is the essence of worship." He also states that Christian sacramentality is rooted in the divine presence, and without it, "the sensible dimensions of liturgical symbol are lifeless shell." Cooke, The Distancing of God, 348. According to Chauvet's understanding of the Constitution on the Sacred Liturgy of Vatican II, "liturgical celebrations must communicate God's presence." Louis Marie Chauvet and François Kabasele Lumbala, Liturgy and the Body (London: Student Christian Movement Press, 1995), 105. Dyrness points out: "The fact of God's presence in worship is the universal premise of worship," Dyrness, A Primer on Christian Worship, 24. This fundamental importance has already been observed by Catholics, Protestants, Charismatics, and Emergents. See Chapter 1 pages 5-6 footnotes 18-21.

${ }^{55}$ Jean Daniélou points out that the divine presence confers upon the whole cosmos a sacramental value resulting in a whole cosmic liturgy. See Jean Daniélou, "The Sign of the Temple: A Meditation," in Temple and Contemplation: God's Presence in the Cosmos, Church, and Human Heart, ed. Scott W. Hahn (Steubenville, OH: St. Paul Center for Biblical Theology, 2008), 255. Brant Pitre notes that the divine presence is foundational to the Temple as well as all aspects of liturgy performed there. See Brant Pitre, "Jesus, the New Temple, and the New Priesthood," in Temple and Contemplation: God's Presence in the Cosmos, Church, and Human Heart, ed. Scott W. Hahn (Steubenville, OH: St. Paul Center for Biblical Theology, 2008), 49, 50, 52. The divine presence also gives efficacy to art and music. According to the Constitution on the Sacred Liturgy, Christ is always present in liturgical celebrations, in the Mass, in the person of His minister, under the Eucharistic emblems of the bread and wine, in the sacraments, in His word, and when the church prays and sings $S C$, Art.7. "The arts have always had a crucial role to play in evoking the presence of the holy, functioning as 'windows on eternity," Jonny Baker and Doug Gay, Alternative Worship: Resources from and for the Emerging Church (Grand Rapids, MI: Baker Books, 2003), 145.

${ }^{56}$ For instance, ritual actions (1) "explicitly mediate contact with the divine"Searle, "Ritual," 55; (2) "are centered on cosmic structures and/or sacred presences"-see Zuesse, "Ritual," in The Encyclopedia of Religion, ed. Mircea Eliade, 16:405; and (3) shed light on the doctrine of God-see Klingbeil, A Comparative Study of the Ritual of Ordination as Found in Leviticus 8 and Emar 369, 6, 7. 
physical presence of human beings whose purpose is to perform liturgical rites, ${ }^{57}$ actions, ${ }^{58}$ and ceremonies ${ }^{59}$ that incorporate words, actions, and material elements. ${ }^{60} \mathrm{We}$ now move to the subject of the physical location of liturgy.

\section{Scholarly Observations About Sacred Places and Liturgical Activity}

A phenomenological description of liturgy reveals two important factors that are related to sacred places. First, sacred places such as temples and meetinghouses provide the physical context in which the divine-human encounter occurs. Second, as the divine presence manifests itself in specific areas within the temple or meetinghouse where liturgists perform ritual actions, this close proximity between the divine presence, the ritual actions, and the exact place in the temple can give us some indication regarding the interpretation of the components of liturgy. ${ }^{61}$

${ }^{57} \mathrm{~A}$ broad description of the word rite distinguishes two basic types in all religions. The first appears as "rites in which a properly divine action is present so that the faithful may take part in it." The second signifies "ordinary actions of human life which have been, as it were, brought within the sacral sphere," Louis Bouyer, Rite and Man: Natural Sacredness and Christian Liturgy (South Bend, IN: University of Notre Dame Press, 1963), 67.

${ }^{58}$ Searle, "Ritual," 55, 56. Platvoet describes ritual as "that ordered sequence of stylized social behavior that may be distinguished from ordinary interaction by its alerting qualities which enable it to focus the attention of its audiences-its congregations as well as the wider public_onto itself." Platvoet, "Ritual in Plural and Pluralist Societies," 41.

${ }^{59}$ Pecklers, Worship: A Primer in Christian Ritual, 1.

${ }^{60}$ Chupungco, "Introduction," vii.

${ }^{61}$ As Bouyer points out, "The sacredness of a given place, therefore, first comes from the special presence of the sacred recognized in it." Sacred places also include mountains, domes, the steeples of our churches with the rising thrust of their arches, Gothic architecture, the Jewish temple, synagogues, and basilicas. See Bouyer, Rite and Man, 151, $152,160,161,166,167$. Sacred places function as (1) the center of man's life, corresponding to the humans involved in liturgy; (2) microcosms of the cosmic realm, including cosmogony, corresponding to ritual adapted from creation; (3) the place where humans interact (encounter) with the divine by offering prayers and sacrifices; and (4) the 


\section{Scholarly Observations About Worship Activity}

In addition to the divine presence and the liturgists who perform ritual actions in sacred meetinghouses, scholars note that worship involves four main items. First, worship involves an encounter between God and the worshippers. ${ }^{62}$

Second, scholars note that the body ${ }^{63}$ and soul ${ }^{64}$ of the worshipper functions as the place where the divine presence is mediated. ${ }^{65}$

Third, the use of sight, touch, taste, and hearing functions as the "means through which the eternal message of God's Being and the sense of His Presence are mediated to the soul." 66

Fourth, worship also involves a response to the encounter. ${ }^{67}$

place where the immanent/transcendent divine presence is manifested. See Turner, From Temple to Meeting House, 10.

${ }^{62}$ Cherry asks, "What kind of worship helps people encounter God? This question will lead us away from preferences and toward the true goal of worship. Worship is first and foremost an encounter with the living God through Jesus Christ." Cherry, "Merging Tradition and Innovation in the Life of the Church," 29, 32. See also, Robert E. Webber, "Worship and Spirituality," Reformed Liturgy and Music 20, no. 2 (Spring 1986): 67-71.

${ }^{63}$ Mitchell points out that the body is "the place where God's presence and power continue." Nathan D. Mitchell, "New Directions in Ritual Research," in Foundations in Ritual Studies: A Reader for Students of Christian Worship, ed. Paul Bradshaw and John Melloh (Grand Rapids, MI: Baker Academic, 2007), 117. See also François Kabasele Lumbala, Celebrating Jesus Christ in Africa, 2.

${ }^{64}$ The presence of God at the center of the soul is the "place" where God, "in the night of the divine darkness . . . engenders the Son, proffers the Word from all eternity;" likewise it is in the "darkness of the soul" in the "silence of the night that the Word is engendered in the soul." Daniélou, "The Sign of the Temple: A Meditation," 282.

${ }^{65}$ Hislop states that the "sense of the divine presence is mediated to man." Hislop, Our Heritage in Public Worship, 142.

${ }^{66}$ Ibid., 9.

${ }^{67}$ This can be a very passive response, such as merely requiring the congregation to show up for the encounter, see Willimon, Word, Water, Wine and Bread, 54 and Byars, The Future of Protestant Worship, 66. Or it can be a very active response expressed by bodies swaying, hands clapping, and dancing. See Albrecht, "Pentecostal Spirituality: Looking through the Lens of Ritual," 113-114; Miller and Yamamori, Global Pentecostalism, 138. 
Consequently, worship includes (1) the divine presence that worshippers believe to be present, (2) liturgists, (3) the liturgical setting and actions, (4) the encounter between the divine presence and the congregation, and (5) the response to the encounter.

At this point, we can draw five inferences from my brief phenomenological description of liturgy and worship taken from Scripture and scholarship. First, there is a correspondence between my biblical analysis and that of the scholars in terms of description of the components of liturgy. ${ }^{68}$ Second, the five broad indispensible components we just spoke of above comprise the framework by which I will describe, analyze, and evaluate each model. Third, we can express the relationship between liturgy and worship as follows: Liturgy is the cause that facilitates worship, and worship is the result or consequence of liturgy. Also, liturgy is the objective and necessary condition for worship, and worship is the subjective experience of liturgy. Fourth, the foundational realities that make liturgy and worship possible include the divine presence, human beings, and cosmology, since it encompasses all ritual actions, times, and places. The fifth inference points to the need for developing a macro hermeneutical tool of analysis so that we can determine how the divine presence relates with the other four indispensable components of liturgy. ${ }^{69}$ We now turn to the hermeneutical tool of analysis as the final interdisciplinary method in this Chapter.

\footnotetext{
${ }^{68} \mathrm{My}$ description from Scripture and the description of the scholars include five broad indispensable components: (1) the divine presence; (2) human beings; (3) performing liturgical actions in certain places and times; (4) a worship encounter that occurs between the divine presence, those who perform the rituals, and the congregation; and (5) the response to the encounter.

${ }^{69}$ For instance, is the divine presence causally related to the other four liturgical components or is there a dichotomy between the divine presence and the other components?
} 


\section{Hermeneutical Method}

We will first establish why we need a macro hermeneutical tool of analysis before we outline what our purpose is for this section and how we will achieve it. There are two reasons for why we need to develop a macro hermeneutical tool of analysis.

First, models interpret the realities they seek to analyze and understand ${ }^{70}$ which means that they cannot prove the truth of what they suggest. ${ }^{71}$ Accordingly, since models generate only hypothetical theories about the presence of God and the components of liturgy, we need to test these hypotheses by theological criteria that belong to "fundamental theology." 72 The task of fundamental theology is to identify and interpret the broadest hermeneutical presuppositions, including God, humans, the world and their interrelationships that comprise the a priori conditions for Christian liturgy. ${ }^{73}$

Second, since all present theological models that revolve around the Eucharist, preaching, and music assume the transubstantiation hypothesis ${ }^{74}$ for the divine presence,

${ }^{70}$ Ian G. Barbour, Myths, Models and Paradigms, 7, 51, 66, 68.

${ }^{71}$ Dulles, Models of Revelation, 32.

${ }^{72}$ Ibid.

${ }^{73}$ For a discussion on what fundamental theology entails, see Fernando Canale, "From Vision to System: Finishing the Task of Adventist Theology Part III Sanctuary and Hermeneutics," Journal of the Adventist Theological Society 17 no.2 (2006): 5-7.

${ }^{74}$ See Chapter 2 of this dissertation, pages 33-35, 43-44, 64-66. See also, White, Introduction to Christian Worship, 191, 255. Concerning transubstantiation and the real presence in medieval theology, Frank Senn notes: "The doctrine of the real presence, articulated by the dogma of transubstantiation, had an impact on the understanding of the Eucharistic sacrifice" Senn, Christian Liturgy, 252. Also, "We have seen that the medieval church explained the real presence of Christ in the sacrament of the altar in terms of transubstantiation. Luther was slow in giving up this doctrine." Ibid., 307. Lutherans, for instance, reject transubstantiation but like the Catholics they believe in a real presence in the emblems. Moreover, preaching is referred to as sacramental and so is music, which is also referred to as musical-transubstantiation. However, those who affirm the real presence in the Lord's Supper, and those who describe preaching and music as sacramental make no effort to make any distinction between the Catholic interpretation of the divine presence and what they refer to as the real presence. A rejection of transubstantiation as the explanation for the 
we must therefore develop a macro hermeneutical tool in order to analyze this presupposition. $^{75}$

The purpose of this section is therefore to develop criteria to evaluate the Eucharistic, Kerygmatic, Charismatic, and Biblical models of liturgy. In order to achieve this purpose I will explore two areas: (1) the precise relationship between the conditions of method that refer to all of method's activities and the components of liturgy, and (2) the hermeneutical impact of the philosophical notion of Being on the conditions of method and the components of liturgy.

\section{The Conditions of Method and the Components of Liturgy}

The goal of this section is to describe and analyze the conditions of method by linking and comparing them together with the components of liturgy. ${ }^{76}$ In order to achieve this goal, however, we first need to explain what the conditions of method are and how and why we are linking them with the components of liturgy.

Aristotle refers to the conditions of method as four causes, ${ }^{77}$ namely, the efficient,

change in the emblems should not be confused with a change in the interpretation of the divine presence. This calls for the development of an instrument that can evaluate how presuppositions shape the meaning of the divine presence in the Lord's Supper, preaching, and music.

${ }^{75}$ The transubstantiation hypothesis does not include the Biblical Sanctuary modelonly the Sacramental, Kerygmatic, and Charismatic models. Transubstantiation points to the important role that presuppositions play in our understanding of the divine presence. However, although transubstantiation plays the leading role in interpreting the divine presence, we should not confuse interpretation with meaning itself. In other words, in order for us to evaluate the truthfulness of any claim about the meaning of the divine presence, we must develop suitable criteria so that we can test the claim.

${ }^{76}$ In Chapters 4 to 7 we will apply the conditions of method to the components of liturgy that are contained in each model.

${ }^{77}$ We note here that others have employed Aristotle's causes for various purposes. See Justus Buchler, The Concept of Method (New York: Columbia University Press, 1961), $110,137,138$. Canale has employed these causes in order to explain the nature of the activity performed by the theologian that is involved in the theological task. Canale, 
material, formal, and final causes. ${ }^{78}$ These causes are actually interrelated, yet for the purpose of analysis we will deal separately with each of them. ${ }^{79}$ Moreover, for the purpose of this study, we will make a distinction between a cause and a condition within the overall framework of the conditions of method. ${ }^{80}$ Consequently, in this dissertation I will refer to the conditions of method as the efficient cause, the material condition, the hermeneutical condition, and the teleological condition. ${ }^{81}$

Now we can illustrate how the conditions of method are linked with the components of liturgy. First, Aristotle's observation reveals that method is an activity, ${ }^{82}$ and our phenomenological description of liturgy reveals that liturgy is an activity.

Second, as an activity, method is impossible without conditions. Also, liturgy as

"Interdisciplinary Method in Theology? In Search of a Working Proposal," 374. For the use of Aristotle's causes in liturgy, see Cyprian Vagaggini, Theological Dimensions of the Liturgy, 73, 74.

${ }^{78}$ Aristotle associates the material cause with the bronze of a statue (Metaphysics, 1013a26-7; Physics, 194b24). The efficient cause refers to the person who is producing the changes that must also include the tools used (Metaphysics 1013a31-2; Physics 194b31-2). The formal cause refers to the form or pattern that the movement follows (Metaphysics 1013a26; Physics 194b27). The final cause refers to the purpose for which the thing is made (Physics, 194b33; Metaphysics, 1013a32-3).

${ }^{79}$ Justus Buchler, The Concept of Method, 103, 123. "It is beyond question that a method without any material to work on will accomplish nothing at all, while material simply as material, unrelated to any method, will be nothing but a chaotic, meaningless agglomerate." Andres Nygren, Meaning and Method: Prolegomena to a Scientific Philosophy of Religion and a Scientific Theology (Philadelphia: Fortress Press, 1972), 3.

${ }^{80}$ This distinction is best illustrated by Aristotle's observation about the construction of a statue where the cause of the statue is the craftsman and the conditions of the statue are the materials used (like bronze), the pattern for the statue (such as a human being), and the purpose for the statue (to sell as a piece of art). Here it is important to recall that the conditions of the statue are not the cause of the statue. The cause of the statue is the craftsman. Yet, the craftsman could not create a statue without the necessary conditions.

${ }^{81}$ Canale points out that one need not subscribe to Aristotle's implicit ontology when analyzing his four causes of movement. Canale, "Interdisciplinary Method in Theology? In Search of a Working Proposal," 372.

${ }^{82}$ Method is a path used in order to reach a certain goal whose most distinctive characteristic is action. Ibid., 371. See also Lonergan, Method in Theology, 4. 
an activity is impossible without the five components.

Third, since the conditions of method are comparable with the components of liturgy, we can evaluate each liturgical component with the appropriate conditions of method.

We are now in a better position to link the conditions of method with the components of liturgy by drawing on Aristotle's example of a statue. First, the divine presence is closely linked with the material condition. ${ }^{83}$ This corresponds to the material that is used to construct the statue.

Second, the liturgists are linked with the efficient cause. Moreover, just as the craftsman is the cause of the statue, so the liturgists are the cause of liturgy.

Third, the liturgical actions are linked with the hermeneutical condition. Yet, the hermeneutical condition assumes the efficient cause and the material condition. ${ }^{84}$

Fourth, the encounter is linked with the teleological condition. However, the teleological condition assumes the previous conditions. ${ }^{85}$

${ }^{83}$ In science the material condition is the object of study, while in liturgy God is the object of worship. In the construction of the statue, the bronze (material) is the object that is formed, while in liturgy the divine presence is the object of liturgy.

${ }^{84}$ In the construction of the statue, the bronze (material) is shaped by the pattern in the mind of the craftsman. In liturgy, the liturgical actions that are inextricably linked with the divine presence (material condition) are shaped/interpreted by the presuppositions of the liturgist. Hence, it is no more possible to have liturgy without presuppositions than it is to have a statue that is without a specific shape.

${ }^{85}$ The purpose of the statue is to sell it as a piece of art. The purpose of liturgy is for the worshippers to encounter and experience the divine presence. As we compare the sale of a piece of art to the worshippers whose purpose is to experience the divine presence, we note the following observations. The sale of the statue directly depends on the conditions that precede the sale, notably the material, the craftsman, and the pattern. Yet, the previous conditions that are assumed in the sale of the statue also determine, to some extent, the value that prospective buyers place on it. Similarly, an encounter with the divine presence in worship depends on the divine presence, the liturgists, and the liturgical actions. As a result, the nature of the encounter largely determines how the worshippers will respond to the encounter. 
Fifth, the response to the encounter is linked with all the conditions of method. ${ }^{86}$ We will now examine the hermeneutical impact of the philosophical notion of Being on the conditions of method and the components of liturgy.

\section{Ontology and the Conditions}

I will first outline the reasons for why this Chapter requires this section on ontology and the conditions of method. Then I will demonstrate how the general concept of Being (ontology) is related to the conditions of method that I will use to evaluate the liturgical components.

This section on ontology and the conditions of method is essential in helping me to achieve two things that are connected with the purpose of this dissertation. First, this section will help me to precisely determine the cause/s of liturgical conflict by examining how the Greek philosophical concept of Being hermeneutically shapes the five liturgical components in the three models in Chapter 4. Second, this section will help me to discover the way in which the Biblical concept of Being hermeneutically shapes the liturgical components in Chapters 5 and 6.

At this point we need to briefly define and describe what the concept of Being actually entails before we examine how Being is related to the conditions of method. Philosophers make the following observations about Being: (1) Being is a nonentity,

\footnotetext{
${ }^{86}$ As we compare the price that one is willing to pay for the statue with the response of the worshipper, we note the following observations. The amount that one will pay for the statue is determined by its value. Yet, the value of the statue is directly determined by: (1) the kind of material used, (2) the reputation of the craftsman as an artisan, (3) the uniqueness or difficulty of the pattern, and (4) the purpose for which it was created. Consequently, one cannot sell a statue without all the necessary conditions just mentioned. In the case of liturgy, the response to the encounter is determined by: (1) the divine presence, (2) the liturgists who enact the rituals, (3) the specific shape of each ritual, and (4) the specific nature of the encounter. Consequently, worshippers cannot respond to an encounter without all the necessary conditions just mentioned.
} 
meaning that it is not a "thing" but that it coappears with all entities; (2) Being furnishes the ground for meaning, coherence, and unity for all entities; (3) Being is the ultimate presupposition of all entities, meaning that there is nothing beyond it; ${ }^{87}$ and (4) there are only two interpretations of Being: either Being is timeless or Being is temporal. ${ }^{88}$

As we apply these observations about Being to the liturgical components, we will employ Thomas Kuhn's insights on paradigms and data in the following manner: We will equate paradigms with Being, and data with the liturgical components.

First, Kuhn points out that data cannot exist apart from paradigms. ${ }^{89}$ Since Being provides the ground for the meaning, coherence and unity of all entities, it qualifies as the paradigm through which the liturgical components, which in this present study represent the data, are interpreted. Since Being is a nonentity that coappears with all entities, we can conclude that Being coappears with the liturgical components. However, Being is neither synonymous with the divine presence, nor with the other four liturgical components. $^{90}$

${ }^{87}$ See, Canale, A Criticism of Theological Reason: Time and Timelessness as Primordial Presuppositions, 66-72.

${ }^{88}$ Ibid., 84, note 4.

Heidegger's revolution in the interpretation of being purported to overthrow two millennia of philosophical thought. From Parmenides and Plato on, eternal or atemporal being has been considered as more 'real' than temporal being. According to this tradition, only what is eternal can be an object of real knowledge. . . As Heidegger says in the second half of section 5, temporality (Zeitlichkeit) is the horizon of understanding being, because temporality is the most fundamental ontological structure of Dasein, and because Dasein has understanding of being (Herman Philipse, Heidegger's Philosophy of Being: A Critical Interpretation (Princeton, NJ: Princeton University Press, 1998), 148).

89"'Philosophers of science have repeatedly demonstrated that more than one theoretical construction can always be placed upon a given collection of data." Thomas Kuhn, The Structure of Scientific Revolutions, 3rd ed. (Chicago: University of Chicago Press, 1966), 76. See also page 7 of the same book by Kuhn.

${ }^{90}$ Yet, we hasten to point out that paradigms are not data. In calculating planetary motion, the Earth and the sun function as paradigms, but the motion of the planets functions 
Second, Kuhn states that it is not possible to understand and interpret data apart from paradigms. ${ }^{91}$ Thus, as paradigms interpret data, so Being hermeneutically interprets the liturgical components, regardless of whether Being is timeless or temporal. Moreover, since Being is the ultimate primordial presupposition, we must make sure that we do not neglect it in our search for the cause of liturgical conflict, or in our exegesis of the Biblical materials. $^{92}$

Third, Kuhn reveals that when new paradigms are discovered, they are diametrically opposed to and completely incompatible with the old paradigms they just replaced. ${ }^{93}$ Accordingly, timeless Being is completely incompatible with and opposed to temporal Being. In the task of interpreting the liturgical components, one must choose between timeless Being and temporal Being. ${ }^{94}$ Moreover, even though theologians claim

as the data. Hence paradigms and data are not synonymous with each other, but at the same time they cannot exist apart from each other in the task of calculating planetary motion.

${ }^{91}$ Kuhn, The Structure of Scientific Revolutions, 68, 69.

${ }^{92}$ It is important to note that the neither the historical critical method, nor the historical grammatical method are designed to take into consideration the role of Being. As a result, both of these methods end up assuming the hermeneutical role of Being instead of accounting for how it operates. See Fernando Canale, "From Vision to System: Finishing the Task of Adventist Biblical and Systematic Theologies-Part II," Journal of the Adventist Theological Society 16/1-2 (2005): 1-29.

${ }^{93}$ The scientific revolutions of Copernicus, Newton, Lavoisier, and Einstein display what all scientific revolutions are about. Each of them necessitated the community's rejection of one time-honored scientific theory in favor of another incompatible with it. . . Scientific revolutions are 'non-cumulative developmental episodes in which an older paradigm is replaced in whole or in part by an incompatible new one,' (Kuhn, The Structure of Scientific Revolutions, 6, 92).

The Ptolemaic paradigm did not morph into the Copernican paradigm by the accumulation of adjustments to itself (see ibid., 7). As Brand states, "Putting the sun in the middle of the universe is one option, and putting the earth in the middle is another. One can't make a compromise between them; we must choose one or the other." Brand, Faith, Reason, and Earth History, (Berrien Springs, MI: Andrews University Press, 1997), 52.

${ }^{94}$ William Lane Craig points out that it is not possible to combine timelessness and temporality in order to affirm God's transcendence and immanence. He states that "temporality and timelessness are contradictories: An entity must exist one way or the other 
that the divine presence is timeless, ${ }^{95}$ temporal, ${ }^{96}$ or timeless and temporal, ${ }^{97}$ one should

and cannot exist both ways at once." William Lane Craig, Time and Eternity: Exploring God's Relationship to Time (Wheaton, IL: Crossway Books, 2001), 15.

${ }^{95}$ According to Erickson, God is timeless. Erickson also criticizes process theologians who admit that there are aspects of reality that do not change, yet they do not articulate the meaning of these unchangeable aspects. He questions, "If there are principles of reality that do not change, may not something of the nature of God be similarly timeless and absolute?" Erickson, Christian Theology $2^{\text {nd }}$ ed (Grand Rapids, MI: Baker Book House, 1998), 300, 306. Barth says:

God exists in His act. God is His own decision. God lives from and by Himself. God is. The first and basic general definition of this statement has now been given. Whatever else we may have to say must always correspond to this first definition.

For Barth, God's timeless and immutable will decides the contents of nature and history, and even of His own being. Karl Barth, Church Dogmatics, 13 vols. (Edinburgh: T \& T Clark, 1957), 2/1:272. See also, Wayne Grudem, Systematic Theology, (Grand Rapids, MI: Zondervan, 1994), 169-172. "Eternality means nontemporality or timelessness;" Norman Geisler, Systematic Theology: God: Creation, (Minneapolis, MN: Bethany House, 2003), 94; Robert Reymond, A New Systematic Theology of the Christian Faith (Nashville, TN: Thomas Nelson, 1998), 178. "Classical theism has been the position of Western Christian orthodoxy-from Augustine, Aquinas, Scotus, Luther, Calvin, and their followers to the present. It is undeniable that although the Bible is its source and standard, traditional Christian theology has been shaped significantly by the legacy of Platonic philosophy." John W. Cooper, Panentheism-The Other God of the Philosophers: From Plato to the Present, (Grand Rapids, MI: Baker Academic, 2006), 32. "The Fathers of the church have been virtually unanimous in their declaration that God is a timeless Being. This is evident in their writings as well as their creeds." Geisler, God: Creation, 96.

${ }^{96}$ Fernando Canale has also brought into sharp focus theology's dependence upon timelessness in the formulation of reason. Canale, A Criticism of Theological Reason: Time and Timelessness as Primordial Presuppositions; cf. Norman Gulley, Systematic Theology: God as Trinity, (Berrien Springs, MI: Andrews University Press, 2011). Others who have also criticized the idea of God as timeless include Nelson Pike, God and Timelessness (New York: Schocken Books, 1970); and Reymond, A New Systematic Theology of the Christian Faith, 172-178. The debate concerning whether God is timeless or temporal continues in such works as Gregory E. Ganssle, ed. God and Time: Four Views (Downer's Grove, IL: InterVarsity Press, 2001).

${ }^{97}$ Classical panentheism has two major features: emanation and dialectics. Emanation refers to the world that has been timelessly generated by the transcendent One. In dialectical theology, being and nonbeing, infinity and finitude, immanence and transcendence, contingency and necessity, freedom and determination "must be included in God but not be identical with God, who also remains the transcendent One." Cooper, Panentheism-The Other God of the Philosophers, 63. In modern or dynamic panentheism, dialectic is projected "into the very heart of God himself, as the form of his own eternal self-generation, not just the generation of the world." Ibid., 63, 116. Hence, the following philosophers and theologians view God as timeless and historical. According to John Cooper, process theologian Charles Hartshorne "claims to modify rather than repudiate classical theology" by referring to process theology as "neo-classical theism." Ibid., 181. Cooper's analysis of 
neither confuse nor fuse together "the God principle with the Being principle.",98

Fourth, Kuhn observed that anomalous data are symptomatic of a paradigm that is in crisis and in need of being replaced by a new one. ${ }^{99}$ Consequently, we should view the

Schelling and Hegel affirms that "God, though eternal in essence, develops in existence by involving himself in the world and the world in himself." Ibid., 118. In Teilhard de Chardin's cosmic evolution to the Omega point, "His aim is to combine the transcendent God of classical orthodoxy with the God immanent in cosmic evolution," a "conjunction ... . between the old God of the Above and the God of the Ahead." Ibid., 157. "The world consists of individuals, but the totality of individuals as a physical or spatial whole is God's body, the Soul of which is God." Charles Hartshorne, Omniopotence and Other Theological Mistakes (Albany: State University of New York Press, 1984), 94. According to Cooper's analysis of Hartshorne, modern panentheism "recognizes God's dipolar nature and locates the world in one part of God." Cooper, Panentheism-The Other God of the Philosophers, 184. Kalistos Ware points out the distinction among the Greek Fathers between

God's transcendent essence (ousia) and of his immanent energies or operations (energeiai). In his essence God is infinitely transcendent, utterly beyond all created being, beyond all understanding and all participation from the human side. But in his energies-which are nothing else than God himself in action-God is inexhaustibly immanent, maintaining all things in being, animating them, making each of them a sacrament of his dynamic presence. So we may interpret in terms of essence and energies the saying invoked by Charles Williams and quoted earlier: 'This also is Thou [= the energies]; neither is this Thou [= the essence].' While present in created things, these energies are not themselves created but uncreated and eternal.

Ware points out that this "essence-energies distinction goes back at least as far as Philo of Alexandria," Kalistos Ware, "God Immanent yet Transcendent: The Divine Energies According to Saint Gregory Palamas," in In Whom We Live and Move and Have Our Being: Panentheistic Reflections on God's Presence in a Scientific World, ed. Philip Clayton and Arthur Peacocke (Grand Rapids, MI: Eerdmans, 2004), 160.

${ }^{98}$ Canale states:

We should avoid confusing or fusing the God principle with the Being principle. In his later writings Heidegger calls the concept of Being to play the role that is usually played by the concept of God or the concept of the One. This usage not only replaces the God principle but also involves panentheism. For this reason, we should avoid mixing the God principle (the One) with the Being principle (the universal notion of Being) as Heidegger seems to do so. On the contrary, we should understand the formal definition of the Being principle as playing a role in the epistemological realm (Fernando Canale, "Philosophical Foundations and the Biblical Sanctuary," Andrews University Seminary Studies (AUSS) 36, no. 2 (Autumn 1998): 185).

${ }^{99}$ Kuhn notes that by the sixteenth century, an increasing number of Europe's best astronomers were recognizing that the Ptolemaic "astronomical paradigm was failing in application to its own traditional problems. That recognition was the prerequisite to Copernicus' rejection of the Ptolemaic paradigm and his search for a new one." Kuhn, The Structure of Scientific Revolutions, 68, 69. The same could be said about how the oxygen theory of combustion replaced the phlogiston theory. Ibid., 70, 71. Kuhn notes that in the 
worship wars as a call to critically analyze and evaluate the interpretation of Being that the Sacramental, Kerygmatic, and Charismatic models assume.

Fifth, Kuhn points out that holding on to failing paradigms prevents scientists from seeing that anomalous data can function as the prelude to the discovery of new paradigms, ${ }^{100}$ and thus further breakthroughs. The worship wars uncovered in Chapter 2 of this dissertation point to the possibility of a failing paradigm that hermeneutically shapes the liturgical components of the Sacramental, Kerygmatic, and Charismatic models. As a result, this failing paradigm may be preventing theologians and exegetes from using what these three models view as anomalous data to develop a new paradigm from which to interpret the liturgical components. ${ }^{101}$

Thus, the purpose of the Biblical Sanctuary model is to employ Scripture to discover the new paradigm from which the theologian and exegete can construct a Biblical view of the divine presence and the liturgical components.

cases of oxygen and X-rays, the perception of anomaly within a paradigm "played an essential role in preparing the way for the perception of novelty. But, again in both cases, the perception that something had gone wrong was only the prelude to discovery." Ibid., 53, 56.

${ }^{100}$ Kuhn illustrated this by referring to the discovery of X-rays, which ultimately led to $20^{\text {th }}$-century physics. Within the old paradigm, X-rays that comprise the data would not have been correctly interpreted. They constituted an anomaly that violated "the paradigm induced expectations that govern normal science." It is only when new paradigms are explored that the data can be correctly interpreted and scientific advancement can be made. Kuhn, The Structure of Scientific Revolutions, 53, 60, 61.

${ }^{101 ،}$ “By paying attention to the type of thinking used by Bible writers we have been led to discover how Scripture presents hermeneutical presuppositions, which tradition forgetfully bypassed for nearly two millennia," Canale, Back to Revelation-Inspiration, 162. In other words, in our quest to develop a Scriptural theology of the divine presence, the uncritical assumption of timeless Being can render certain doctrines in Scripture that are closely associated with the divine presence to be regarded as anomalous. Accordingly, these doctrines would be interpreted through the lenses of timeless Being. The result is that these doctrines would be considered as inconsequential and unnecessary when it comes to the development of a Scriptural theology of the divine presence. 


\section{Summary and Conclusion}

In this Chapter we outlined the multidisciplinary methodological framework required to properly analyze and evaluate the history of conflicts in liturgy. This multidisciplinary methodology includes (1) a model method, (2) a phenomenological method and, (3) a macro hermeneutical method.

Our purpose for developing a model methodology was to simplify and differentiate all of the vast amounts of information associated with liturgy by seeking ritual actions that mediate the divine presence. Our study revealed that the divine presence is mediated through three main models: the Sacramental model, the Kerygmatic model, and the Charismatic model.

Our purpose for developing a phenomenological method was to identify the broadest possible categories involved in the practice of liturgy. We accomplished this by conducting a phenomenological description of liturgy from Scripture and from scholars. We concluded that liturgy involves five indispensable components: the divine presence, liturgists, liturgical actions, the encounter between the divine presence and the congregation, and the response to the encounter. These five components make up what scholars interpret in the worship wars, and they form the criteria that we will use to analyze and compare the models.

Lastly, we developed a hermeneutical tool of analysis in order to develop criteria that we can use to evaluate how each model interprets the liturgical components. The conditions of method constitute the criteria that we will use to evaluate the liturgical components. These conditions include the efficient cause, the material condition, the hermeneutical condition and the teleological condition. The criteria also include the 
hermeneutical role of Being. In Chapter 4 we will examine the role of Being that the Sacramental, Kerygmatic, and Charismatic models assume as the potential cause of liturgical conflict. In Chapters 5, 6, and 7 we will explore the Biblical concept of Being and its role in the development of a Biblical interpretation of the liturgical components.

We will now proceed to analyze and evaluate the models by applying the hermeneutical tool of analysis to the five liturgical components that are contained in each model. 


\section{CHAPTER 4}

\section{MODELS MEDIATING THE PRESENCE \\ OF GOD IN LITURGY}

\section{Introduction}

In our brief study of the history of liturgy in Chapter 2, we uncovered significant conflict in various liturgical practices throughout the centuries and across denominational lines.

However, in spite of the liturgical conflict, all Christians agree on the central importance of the presence of God in liturgy, even though congregations experience the presence of God through the Eucharist (Sacramental Model), preaching (Kerygmatic Model), or music (Charismatic Model). These three models have helped us to reduce the complex phenomena in liturgical practice by concentrating on how each model relates to the divine presence.

The purpose of this Chapter is to work toward understanding the cause of liturgical conflict in Christendom. In order to achieve this purpose I will describe and analyze the five liturgical components ${ }^{1}$ contained in each model. Next, I will evaluate the liturgical components of each model by applying the conditions of method to each of the

${ }^{1}$ The five indispensable components that make up liturgy drawn from the phenomenological method include (1) the divine presence, (2) the liturgists, (3) liturgicali actions, (4) the encounter, and (5) the response to the encounter. The first three of these components make up the objective liturgical forms and the last two describe the subjective experience of the objective forms. 
components as needed, which primarily includes Being's hermeneutical role in shaping the liturgical components. Finally, I will apply the hermeneutical tool of analysis to each model's quest for the ecumenical search for unity.

\section{Sacramental Model}

\section{Divine Presence}

In the Sacramental model, the Eucharist is inextricably linked with the divine presence. ${ }^{2}$ Moreover, it is comprised of four elements: the first Eucharistic element is fermented wine; ${ }^{3}$ the second is either unleavened bread or leavened bread; ${ }^{4}$ the third element consists of the Scriptural words "This is my body," spoken by the presider; 5 and the fourth is Christ's body, which includes his divine and human natures, and which replaces the substance of the bread and wine after the prayer of consecration. ${ }^{6}$

In our analysis, I will be predominantly applying the material condition to the

${ }^{2}$ The following point out the close relationship between the Eucharist and the presence of God, Oscar Cullmann, Early Christian Worship, 19; Bernard J. Cooke, The Distancing of God, 287; Davies, From Andrewes to Baxter and Fox, 17; Hislop, Our Heritage in Public Worship, 226.

${ }^{3}$ See this dissertation page 27 footnote 34 .

${ }^{4}$ See this dissertation page 27 footnote 36 .

${ }^{5}$ Liturgical scholars refer to this third element as the prayer of consecration. See, Dyrness, A Primer on Christian Worship, 22; Byars, The Future of Protestant Worship, 66; Spielmann, History of Christian Worship, 59; White, A Brief History of Christian Worship, 88. Dyrness notes that the space, objects and action of the ancient liturgy "centered on the central event of the consecration of the host." He also points out that the prayer of consecration must also be seen "as central to the course of Christian worship," Dyrness, $A$ Primer on Christian Worship, 22, 25-27.

${ }^{6} S T$ Part III Q75, Art.2. Willimon asserts that in transubstantiation "the substance of both Christ's human nature as well as his divine nature must be present in the consecrated bread and wine," Willimon, Word, Water, Wine and Bread, 56. 
divine presence. ${ }^{7}$ Furthermore, my analysis of the divine presence will take into consideration the shift from static timeless Being (classical theism) ${ }^{8}$ to dynamic timeless Being (panentheism) $)^{9}$ that occurred as a result of Vatican II. ${ }^{10}$ I will use static timeless Being as the hermeneutical tool to analyze the divine presence prior to Vatican II, and I will use dynamic timeless Being as the tool to analyze the divine presence after Vatican II. The four main elements of the divine presence I will analyze and evaluate, are: (1) the terms used to describe the divine presence in the Eucharist, (2) the Eucharistic emblems themselves, (3) the divine/human natures of Jesus, and (4) the Scriptural words spoken by the presider.

Let's first begin with the terms scholars use to describe the divine presence in the

${ }^{7}$ In the hermeneutical tool of analysis in the previous Chapter, we noted that the divine presence is closely linked with the material condition, see page 92 of this dissertation. As a representative of the Sacramental model, Vagaggini concurs with the close relationship between the divine presence and the material condition when he refers to God "as ultimate object of worship," Vagaggini, Theological Dimensions of the Liturgy, 73.

${ }^{8}$ See pages 104-105 of this dissertation for an explanation of static timeless Being.

${ }^{9}$ See Chapter 3 pages 95-97 footnotes 97 and 98 for an explanation of dynamic timeless Being through an analysis of panentheism.

${ }^{10}$ Pierre Teilhard de Chardin's theology has been described as panentheistic, see Cooper, Panentheism the Other God of the Philosophers, 155-164; Stanley J. Grenz and Roger E. Olson, 20th Century Theology: God \& the World in a Transitional Age (Downers Grove, Il: InterVarsity Press, 1992), 142, 163-164. Various scholars confirm that Teilhard de Chardin's writings exercised a dominant influence on Vatican II. See McCarthy, The Catholic Tradition, 57-58. David Lane points out that the modernist concepts of progress, dynamic evolution and universalism that are found in the Vatican II documents, especially the "Pastoral Constitution on the Church in the Modern World," are directly traceable to Chardin. Robert Faricay SJ, who teaches at the Gregorian University in Rome states that Chardin's influence on the Council was a dominant one. See David Lane, The Phenomenon of Teilhard: Prophet for a New Age (Macon, GA: Mercer University Press, 1996), 87-88. See also, Rama P. Coomaraswamy, The Destruction of Christian Tradition (Bloomington, IN: World Wisdom, 2006), 137, 165, 366, 436; Cooper, Panentheism the Other God of the Philosophers, 148; Ormond Rush, Still Interpreting Vatican II: Some Hermeneutical Principles (New York: Paulist Press, 2004), 10-11. 
Eucharist. The Sacramental model uses terms such as the real presence, ${ }^{11}$ and substance and essence, ${ }^{12}$ in order to describe the presence of God in the Eucharist. However, the use of the term transubstantiation clearly points to timeless Being as the interpretation ${ }^{13}$ of the divine presence. We will now outline how static timeless Being provides the hermeneutical foundation for interpreting transubstantiation, the real presence, substance, and essence.

First, the Eucharistic emblems consist of a substance and accidents. ${ }^{14}$ Second, Aquinas uses the term "transubstantiation" to articulate the change in the substance of the bread and wine to the substance of Christ's body and blood. ${ }^{15}$ Third, scholars point to the fact that Aquinas used Aristotelian philosophy as the hermeneutical tool to explain the miraculous change in the emblems. ${ }^{16}$ Fourth, Aquinas equates the terms substance and

${ }^{11}$ See page 31 footnote 49 of this dissertation.

${ }^{12}$ The following liturgical scholars describe the divine presence in the Eucharist by using the terms "substance" and "essence," Augustin Cardinal S.J. Bea, The Way to Unity after the Council (New York: Herder and Herder, 1967), 151; Jean Daniélou, "The Sign of the Temple: A Meditation," 257; Davies, From Cranmer to Hooker, 80; Hislop, Our Heritage in Public Worship, 142; Lang, Sacred Games, 315-327; Vagaggini, Theological Dimensions of the Liturgy, 609.

${ }^{13}$ At this point, we must not confuse the mode in which God is present in the Eucharist with the interpretation of God's presence in the Eucharist. As we shall see, the terms real presence, substance and essence are interpreted from Aristotle's second substance, which lies at the basis and foundation of transubstantiation.

${ }^{14}$ Substance refers to the inner immaterial reality of the bread and wine that is only perceived by reason. Accidents refer to what is perceivable by the senses, meaning the bread and wine. Only the substance changed, not the accidents, see White, Introduction to Christian Worship, 253; Willimon, Word, Water, Wine and Bread, 56.

${ }^{15}$ In $S T$ Part III Q.75 Article 4.

${ }^{16}$ White points out that Aquinas used "the best of philosophical tools available, especially Aristotle," in order to describe how "this miracle...could be expressed." White, Introduction to Christian Worship, 253. For further support on the use of Aristotelian philosophy to explain the change in the emblems, see Hislop, Our Heritage in Public Worship, 233; Lang, Sacred Games, 317-319; Senn, Christian Liturgy, 250-252. 
essence with God himself and with His existence. ${ }^{17}$ Fifth, Aristotle distinguishes between primary and secondary substances. Primary substance is similar to the accidents in the Eucharist, and secondary substance corresponds to what something is substantially or essentially. ${ }^{18}$ This means that the presence of God is equated with secondary substance. Sixth, in Aristotle's philosophy secondary substance is the counterpart of the Platonic Idea. ${ }^{19}$ Seventh, the Platonic Idea is understood on the basis of Parmenides' notion of static timeless Being. ${ }^{20}$

\footnotetext{
${ }^{17}$ This is clearly articulated by Aquinas, $S T$ Part III, Question 75, Article 2. In $S T$ Part I, Question 8, Article 3 God is described as substance. In ST Part I, Question 3, Article 3 God is the same as His essence. In ST Part I, Question 3, Article 4 Aquinas reaches back to Aristotle's use of potency and act to articulate God's essence and existence. Aquinas points out that God's essence is His existence, since there's no potentiality in God. In other words, God is pure actuality with no potentiality. This means that God is understood on the basis of static timeless Being.

${ }^{18}$ See Metaphysics, book V part 8. See also, Allen and Springstead, Philosophy for Understanding Theology, 65-67.

${ }^{19}$ Hirschberger states,
}

The Idea in the World. With this we are again confronted with the Platonic eidos as a metaphysical principle. Form plays the same role in the philosophy of Aristotle as it had in Plato: it determines the quiddity (essence) both in the logical and ontological order; it is being in its proper sense; it guides action and is consequently the reason for phenomena, entirely apart from the fact that in his works the form is called eidos and occasionally also the paradeigma. In addition the Aristotelian forms are as eternal as the Platonic ideas. But to Aristotle the form is, as must be emphasized again and again, immanent to the body. The world is no longer in the idea, but the idea is now in the world (Hirschberger, The History of Philosophy, vol. 1:166-167).

${ }^{20}$ Plato reveals the relationship between eternity and time by stating,

Now the nature of the ideal being was everlasting, but to bestow this attribute in its fullness upon a creature was impossible. Wherefore he resolved to have a moving image of eternity, and when he set in order the heaven, he made this image eternal but moving according to number, while eternity itself rests in unity; and this image we call time. For there were no days and nights and months and years before the heaven was created, but when he constructed the heaven he created them also. They are all parts of time, and the past and future are created species of time, which we unconsciously but wrongly transfer to the eternal essence; for we say that he "was," he "is," he "will be," but the truth is that "is" alone is properly attributed to him, and that "was" and "will be" only to be spoken of becoming in time, for they are motions, but that which is immovably the same cannot become older or younger by time, nor ever did or has become, or hereafter will be, older or younger, nor is subject at all to any of those states which affect moving and sensible 
Let's now take a look at the Eucharistic emblems themselves. Some post Vatican II theologians such as Kabasele-Lumbala argue that the Eucharist should be celebrated with local food and drink ${ }^{21}$ instead of being limited to bread and wine. He claims that the material elements of the Eucharist are culturally conditioned, ${ }^{22}$ and since the divine presence pervades the entire universe, ${ }^{23}$ it makes little sense to deny the use of local food and drink as vehicles for the divine presence. Nevertheless, there are several explanations for why the Catholic Church maintains that "the essential signs of the Eucharist... are unleavened wheat bread and grape wine. ${ }^{.24}$ First, Aquinas states that bread and wine are

things and of which generation is the cause. These are the forms of time, which imitates eternity and revolves according to a law of number (Plato, Timaeus, 37-38).

Stumpf states, "Plato took the basic ideas of Parmenides regarding the unchangeability of being and on the basis of this developed his distinction between the intelligible world and the visible world. Plato also derived from Parmenides's unchangeable being his objective and permanent Idea." Stumpf, Socrates to Sartre: A History of Philosophy (New York: McGraw Hill, 1966), 19, 60-61. See also Julian Marias, History of Philosophy, trans., Stanley Appelbaum and Clarence C. Strowbridge (New York: Dover Publications, 1967), 44, 48; Bertrand Russell, A History of Western Philosophy (New York: Simon and Schuster, 1945), 119-120.

${ }^{21}$ Catechism of the Catholic Church, Revised ed. (London: Burns and Oates, 1999); François Kabasele Lumbala, Celebrating Jesus Christ in Africa, 19, 51.

${ }^{22}$ Ibid., 54. Kabasele-Lumbala assumes an ontological distinction between the timeless substance and the accidents. Parmenides notes that there is a "gap" or chorismos between the sensible world and the world of Truth and Reason. Consequently, there is no causal relationship between timeless Truth on the one hand and history and the material world on the other hand. See Fernando Canale, A Criticism of Theological Reason: Time and Timelessness as Primordial Presuppositions, 84 note 1.

${ }^{23}$ Kabasele-Lumbala asserts that the human being functions as a microcosm of the universe in which we find immanence and transcendence instead of dichotomy. Consequently, humans already are part of the "sacred." He states that the sacred breaks into space and time thereby allowing "transcendence, the supernatural, the timeless to break into the tangible present." Kabasele Lumbala, Celebrating Jesus Christ in Africa, 3. Teilhard de Chardin's view is that transubstantiation extends to the whole universe, which becomes Christ's body, Pierre Teilhard de Chardin, Hymn of the Universe (New York: Harper and Row, 1965), 6.

${ }^{24}$ United States Catholic Catechism for Adults, (Washington, DC: United States Conference of Catholic Bishops, 2006), 229. 
the proper matter of this sacrament. ${ }^{25}$ Second, the Catholic Church considers bread and wine as unchangeable primary symbols that are different than secondary symbols like dress and gestures, and which change according to time and place. ${ }^{26}$ Hence, the timeless view of the substance of the bread and wine does not appear to be the basis for retaining bread and wine. Instead, the justification for retaining bread and wine as the proper matter is based on Christ's choice as primary unchangeable symbols during the last supper, which should not be confused with secondary changeable symbols.

At this point, we will examine the Incarnation since it hermeneutically shapes how we interpret the divine presence in the Eucharist. ${ }^{27}$ We will specifically analyze how static timeless Being shapes the early church's view of the Incarnation up to the council of Chalcedon, and the ubiquity of the divine presence in relation to the Incarnation and the Eucharist. We will then analyze how dynamic timeless Being shapes twentieth century interpretations of the Incarnation.

Let's first begin our analysis with Christ's divinity in the early centuries before we move to his humanity. In the classic debate between Arius and Athanasius over the

${ }^{25}$ ST Part III, Question 74, Art. 1, see also Art. 3, 5. Aquinas does not allow for local food and drink, even though bread and wine are not found in many places.

${ }^{26}$ Fenwick and Spinks, Worship in Transition, 161. It is also different than the timeless form in Aristotle's form and matter philosophy. Accordingly there is the timeless form plus matter. Yet, matter is either a primary unchangeable symbol such as the bread and the wine, or it is a changeable secondary symbol like dress or gestures.

${ }^{27}$ The Sacramental model views the Eucharist "as virtually the extension of the Incarnation," Davies, From Andrewes to Baxter and Fox, 286-287. Hislop affirms that "the Eucharist is the assertion of God's presence with man which is the fruit of the Incarnation; and the morning worship which represents the Eucharist ought to be such that it mirrors the Incarnation, the presence of God with the human soul," Hislop, Our Heritage in Public Worship, 259. "Gregory of Nyssa develops the implications of the incarnation to enrich the church's understanding of the Eucharist," Hall, Worshiping with the Church Fathers, 55. See also Hardman, A History of Christian Worship, 62; Senn, Christian Liturgy, 30-49; Vagaggini, Theological Dimensions of the Liturgy, 48, 160, 300-308. 
divinity of Christ, Plato's timeless interpretation of eternity ${ }^{28}$ shaped the divine attributes of immutability and impassibility. ${ }^{29}$ Consequently, neither the pre-Incarnate Christ nor the Incarnate Christ is able to affect or be affected by those who exist in time and space. ${ }^{30}$ Moreover, Christ's immutable and impassible divine nature was the cause for why His human nature did not have "its own center of consciousness and will distinct from the Son of God's." ${ }^{\text {"31 }}$ Immutability also led to the conclusion that it was metaphysically

${ }^{28}$ In Timaeus, Plato noted that time is the moving image of eternity, thus revealing a qualitative difference between them. For instance, eternity is the absence of change and motion, and time is the measure of all created things. This lays the groundwork for interpreting immutability as the absence of motion or change. It is this concept of immutability that makes the Incarnation "a conundrum for classical theism." In addition, "In classical theism, the incarnation is difficult to reconcile with the eternity and immutability of God because the eternal Son takes a human nature in time." Cooper, Panentheism the Other God of the Philosophers, 16, 124.

${ }^{29}$ Olson's analysis reveals the hermeneutical role of timeless Being. He states,

In the deep background of the clash between Arius and Alexander over the nature of the Logos lay Greek philosophy. It is something both had in common even if they interpreted and applied it differently. Both sides of the conflict simply assumed that divinity is ontologically perfect in such a way that any change at all is impossible for it and improper to attribute to it. Thus God, being divine and therefore absolutely perfect, cannot experience change because to change is always to change either for the better or for the worse, and in either case God would not be God if he could change. Absolute static perfection-including apatheia, or impassibility (passionlessness) - is the nature of God according to Greek thought, and nearly all Christian theologians came to agree with this (Olson, The Story of Christian Theology, 143).

Moreover, John B. Cobb, Jr., David Ray Griffin, Millard Erickson, and James L. Garret, Jr., are among some of the theologians who "believe that the immutable and impassible classical views of God derive from Greek thinking." Gulley, Systematic Theology: God as Trinity, 226, notes 50-52.

${ }^{30}$ Olson points out, "The Son of God was himself in no way limited or diminished or hindered or caused to change or suffer through the incarnation," Olson, The Story of Christian Theology, 170-171.

${ }^{31}$ Ibid., 205-206. Marias points out that "matter is always determined by form, and form is always found determining matter:" actually form "confers being." Marias, History of Philosophy, 70. It would be metaphysically impossible for matter to exist without being determined by timeless form. Similarly, static timeless Being's interpretation of Christ's divinity, determines His human nature in such a way that Christ's human nature is passive. 
impossible for Jesus to $\sin .{ }^{32}$ Hence, Jesus possessed a passive human nature that was philosophically determined by static timeless Being's interpretation of immutability and impassibility.

Next, we will examine how the hermeneutical role of static timeless Being leads the adherents of the Sacramental model to conclude that the divine presence is ubiquitous. ${ }^{33}$ First, the static timeless interpretation of eternity and immutability logically leads to the deduction that it is philosophically impossible for Jesus' omnipresence to be subject to any change, even during the Incarnation. ${ }^{34}$ Second, the communicatio idiomatum $^{35}$ (communication of properties/attributes) has its basis in the timeless

\footnotetext{
${ }^{32}$ Ibid., 207. Moreover, regarding the possibility of Jesus sinning, Erickson states we must

distinguish between the epistemic possibility of sin and, more broadly, the logical or metaphysical possibility. On such grounds, it was really possible for Jesus to decide to sin, but the divine nature precluded his actually doing so. As long as his divine nature did not preclude his thinking that he could perform the sin, there was genuine temptation. This does not minimize the value of his resisting. He chose not to sin, thus never encountering the fact that he could not have sinned (Millard J. Erickson, The Word Became Flesh, 1st paperback ed. (Grand Rapids, MI: Baker Books, 2000), 562).
}

Donald Macleod is even stronger, he states that although the first Adam had "the freedom and power to do what was good, he had it mutably. He could fall from it (Westminster Confession, IX.II). With regard to the Last Adam, however, we must take higher ground. He was not able to sin." Donald Macleod, The Person of Christ, ed. Gerald Bray (Downer's Grove, IL: InterVarsity Press, 1998), 229.

${ }^{33}$ Horton Davies asks, "Where is the "body" of Christ located: on the altar, in heaven, or in the hearts of the faithful?" Davies, From Cranmer to Hooker, 77. This issue is directly related to whether there is a real presence in the Eucharist, or whether the Eucharist is a memorial banquet.

${ }^{34}$ Norman Gulley points out the views of some theologians who indicate that the idea of God's immutability lies at the basis for how the "Son of God retained His omnipresence during His incarnational life, so that although united to the Son of Man within the human body, He was concurrently omnipresent throughout the universe." Norman R. Gulley, Systematic Theology: Creation, Christ, Salvation (Berrien Springs, MI: Andrews University Press, 2012), 531.

${ }^{35}$ According to the Reformed position, the communication of attributes between Christ's divine and human natures can be predicated of Christ as a person, which means that Christ can be described as eternal as well as being born. Yet, according to the Reformed 
interpretation of immutability. ${ }^{36}$ Third, church fathers such as Origen, ${ }^{37}$ Athanasius, ${ }^{38}$ and Augustine, ${ }^{39}$ taught that the Incarnation does not detract from Christ being omnipresent: a conclusion that has its basis in the communicatio idiomatum. Hence, the static timeless interpretation of the Incarnation logically leads to a ubiquitous real presence that is also found in the Eucharistic emblems.

We now move to an analysis of Christ's divinity and humanity in the twentieth century and beyond. The justification for this further analysis is based on the view that twentieth century Christology begins with the integrity of Jesus' humanity before it seeks to make a bridge to His divinity. ${ }^{40}$ Since it is contradictory to speak of uniting a genuine

position, it would be incorrect to predicate the attributes of one nature to the other by stating that Christ's human nature is omnipresent. In contrast to this, the Lutherans argue that in view of the union of the divine and human natures, "Christ's human nature is exalted with the attribute of omnipresence (also called ubiquity)." Shedd, Dogmatic Theology, 952-953.

${ }^{36}$ Becker notes that the communicatio idiomatum is consistent with the wider Catholic tradition, which does not "involve any change to the divine nature" including the "traditional divine attributes of immutability, omnipotence, and omniscience," which we are also applying to omnipresence. Matthew L. Becker, The Self-Giving God and Salvation History: The Trinitarian Theology of Johannes Von Hofmann (New York: T \& T Clark International, 2004), 174-176.

${ }^{37}$ Ante-Nicene Fathers 4:377-378.

${ }^{38}$ Nicene and Post-Nicene Fathers (NPNF), Second Series, 4:45. Gary Anderson notes Athanasius' use of communicatio idiomatum in order to explain the relationship between the divine and human natures of Christ. Gary A. Anderson, "To See Where God Dwells," 38.

\footnotetext{
${ }^{39}$ Augustine states,
}

By this means - by the difference between His divinity and His humiliation- $-\mathrm{He}$ remained in heaven as Son of God, and as Son of man walked on earth; whilst, by that unity of His person which made His two natures one Christ, He both walked as Son of God on earth, and at the same time as the very Son of man remained in heaven (NPNF, First Series, 5:39).

See also Leo the Great, The Tome of St. Leo, NPNF, Second Series, 14:256.

${ }^{40}$ For instance, "How can the true humanity of Jesus, which is finite and subject to the temporal process of development, be reconciled with the divine Word (Logos), which had been understood to be infinite, eternal, and immutable?" Becker, The Self-Giving God and Salvation History, 176. Moreover, Welch notes that on account of biblical criticism, the quest for the historical Jesus and other factors, 
free humanity to timeless divinity under classical theism, we will trace the hermeneutical role of dynamic timeless Being in twentieth century Christology. ${ }^{41}$

Karl Rahner's ${ }^{42}$ synthesis between the church's tradition and the world in which the church exists, ${ }^{43}$ and his famous axiom known as Rahner's Rule provide the context for interpreting his position on the Incarnation as the "highest instance of the actualization of the essence of human reality." 44 Skelley points out that for Rahner, the Incarnation constitutes the "highpoint and fulfillment of liturgy." 45 Rahner's starting point begins with the question of what it means to be human. ${ }^{46}$ From there he proceeds to build the bridge to Christ's divinity, in which he asserts that the mystery of the Incarnation consists of the fact that divinity experiences change without overthrowing or

the humanity of Jesus has become the pivot of reconstruction. The question could no longer be, as it had been for so long: Given the fullness of deity in Christ, how can the genuineness of the humanity be maintained? Now it is rather: Given the integrity of the human existence, how is it possible to speak of the presence of the divine? (Claude Welch, ed. God and Incarnation in Mid-Nineteenth Century German Theology (New York: Oxford University Press, 1965), 7-8).

${ }^{41}$ Abandoning the classical theistic view of Christ's humanity that was based on static timeless Being should not be confused with abandoning timeless Being. As we will discover, static timeless Being was replaced by dynamic timeless Being as the framework for understanding the new view of Christ's humanity.

${ }^{42} \mathrm{Karl}$ Rahner is widely recognized as one of the most influential voices of Vatican II. See van Beeck, Catholic Identity after Vatican II, 8; Christopher Butler, The Theology of Vatican II: The Sarum Lectures 1966 (London: Darton, Longman and Todd, 1966), 16; Stephen Duffy, "Catholicism's Search for a New Self-Understanding," in Vatican II: Open Questions and New Horizons, ed. Gerald M. Fagin (Wilmington, DE: Michael Glazier, 1984), 9-10.

${ }^{43}$ Vatican II is acknowledged as an unfinished "synthesis," van Beeck, Catholic Identity after Vatican II, 4, 9. Joseph Ratzinger also uses the word "synthesis" to describe the merging together of Scholasticism and higher criticism in Dei Verbum. See Witherup, Scripture: Dei Verbum, 54-55.

${ }^{44}$ Karl Rahner, Foundations of Christian Faith: An Introduction to the Idea of Christianity (New York: Crossroad, 1982), 218 (emphasis original).

${ }^{45}$ Skelley, The Liturgy of the World: Karl Rahner's Theology of Worship, 116.

${ }^{46}$ Karl Rahner, Foundations of Christian Faith, 215-219; Skelley, The Liturgy of the World, 118 . Hence, he begins in the same place where twentieth century Christology begins, which is with an active, free human nature that is opposed to the Alexandrian view. 
contradicting God's immutability which remains entirely distinct from His humanity. ${ }^{47}$

Rahner attempts to solve the conundrum of joining together a genuine free humanity with timeless divinity by the application of Rahner's Rule. ${ }^{48}$ This means that the timeless divine nature of Christ actualizes itself in history ${ }^{49}$ as the human Jesus through the evolutionary process. ${ }^{50}$ This means that the natural history of the world as it progresses toward the future is in actuality the unfolding history of God who started the evolutionary process from within creation and then manifests himself as divine as evolutionary history

\footnotetext{
${ }^{47}$ Rahner criticizes those who support traditional Christology's assertion that limits change in the incarnation to the human nature of Jesus, instead of realizing that the divine Logos also experienced change while still remaining eternal and immutable. He boldly states, "God can become something. He who is not subject to change in himself can himself be subject to change in something else." Rahner, Foundations of Christian Faith, 220 (emphasis original). Rahner attempts to resolve the painful contradiction, not by rejecting Timeless Being, but by appealing to faith. He states,
}

We may not regard this process by which one changes in something else as a contradiction to God's immutability, nor allow this changing in something else to be reduced to asserting a change of something else. Here ontology has to be adapted to the message of faith and not be the schoolmaster to this message (Ibid., 221).

Thus for Rahner, "The mystery of the Incarnation must be in God himself, and precisely in the fact that, although he is immutable in and of himself, he himself can become something in another," Ibid.

${ }^{48}$ Rahner's Rule states that 'the 'economic' Trinity is the 'immanent' Trinity and the 'immanent' Trinity is the 'economic' Trinity," Karl Rahner, The Trinity, trans., Joseph Donceel (New York: Herder and Herder, 1970), 21-22. The attempt here is to avoid the traditional tendency to divide the immanent Trinity-interpreted from the timeless paradigm - from the economic Trinity - found in Scripture and history - and to assert that "the economic activity of the three persons in human history for our salvation must be recognized as the real presence of the immanent Trinity," Stanley J. Grenz and Roger E. Olson, 20th Century Theology, 250.

${ }^{49}$ John Cooper's analysis of Rahner's Rule "implies what Hegel taught- that it is essential for the immanent Trinity to actualize itself in history as the economic Trinity." Cooper, Panentheism-The Other God of the Philosophers, 225. The fact that Jesus has his own center of will and consciousness is based on Rahner's Rule. This axiom points out that the divinity of Christ actualized itself in history through the evolutionary process when it became incarnated with his humanity.

${ }^{50}$ Karl Rahner, Foundations of Christian Faith, 178-203. Cooper points out that "the existence of the cosmos, humanity, and the incarnation are natural and inevitable for God, and they participate in God." Cooper, Panentheism the Other God of the Philosophers, 226. 
progresses from simple to complex. Thus, "dynamic panentheism" Being hermeneutically shapes twentieth century Christology. ${ }^{52}$

At this time, we will focus our attention on the Scriptural words "This is My Body" spoken by the presider. The intricate relationship between "word" and "table,, 53 compels us to analyze the Scriptures as a medium of the divine presence. ${ }^{54}$ We will now trace how timeless Being interprets the meaning of the words "This is My Body" by looking at Augustine, Aquinas, and the Vatican II document Dei Verbum.

In Augustine's theology of the Word, he points out that words that are uttered by

${ }^{51}$ Cooper, Panentheism the Other God of the Philosophers, 226. Grenz and Olson conclude that a panentheistic interdependence of God and creation lurks in the background of Rahner's attempt at solving the dilemma between transcendence and immanence inherent in the Incarnation. Moreover, "Rahner's theology begins to look more like the ghost of Hegel." Grenz and Olson, Twentieth Century Theology, 254. See also Cooper, Panentheism the Other God of the Philosophers, 225 note 59 where he points out that "Moltmann, Pannenberg, and others take Rahner's Rule in this strong sense."

${ }^{52}$ In dynamic panentheism, Christ's divine nature, which is immutable and changeable, is linked with a humanity that has its own center of will and consciousness.

${ }^{53}$ See page 22 footnotes 15 and 16 of this dissertation for the word/table relationship.

${ }^{54}$ The following statement in Dei Verbum expresses the intimate connection between Word and table.

The Church has always venerated the divine Scriptures just as she venerates the body of the Lord, since, especially in the sacred liturgy, she unceasingly receives and offers to the faithful the bread of life from the table both of God's word and of Christ's body ( $D V$, Art. 21).

Moreover, Roman Catholic theologian Edward Schillebeeckx referred to Dei Verbum as one of the council's "crown jewels." He stated:

Whereas altar-and-chalice was formerly, as it were, the symbolism of Catholicism and, obviously, of the counter-Reformation, the Bible is now also taken as a symbol of the Catholic Church alongside the chalice. This dogmatic constitution officially spells an end to Catholicism's "counter-Reformation" attitude (Schillebeeckx, The Real Achievement of Vatican II, 39, 40-41).

The Constitution on the Sacred Liturgy and Dei Verbum make it clear that "there is an intimate and crucial connection between Word and sacrament in the Catholic tradition." Furthermore, it has been observed that "the biblical and liturgical movements together gave a significant push to the issues that eventually coalesced in Dei Verbum," Witherup, Scripture: Dei Verbum, 13-14. 
Christ "in time" are the results of obedience to and cooperation with God's "eternal word sounding in silence." ${ }^{, 55}$ Moreover, Aquinas points out that "in the sacraments the words are as the form, and the sensible things are as the matter." ${ }^{, 56}$ Furthermore, "in all things composed of matter and form, the determining principle is on the part of the form.. ${ }^{, 57}$ Thus, the statements of Augustine and Aquinas lead to the following two conclusions: (1) the eternal timeless word is the cause of the historical words of Scripture, and (2) Scripture is made up of timeless truths that are contained in historical writings.

As we now move to a brief analysis of Dei Verbum (God's Word), which is the dogmatic constitution on divine revelation at Vatican II, we will trace the role of dynamic timeless Being in its production. First of all, the aim of Dei Verbum was to synthesize ${ }^{58}$ scholasticism ${ }^{59}$ with higher criticism ${ }^{60}$ without sacrificing the ground - timeless Being-

${ }^{55}$ Albert C. Outler, ed. Augustine: Confessions and Enchiridion The Library of Christian Classics (LCC) Vol VII, (Philadelphia: The Westminster Press, 1955), Book Eleven, Chapter 6:8, p. 249. Augustine makes it clear that God's Word is uttered timelessly, meaning that there is no succession of things spoken in time for if there were there would neither be true eternity, nor true immortality, Ibid., Book Eleven, Chapter 7:9, p. 250.

${ }^{56}$ ST Part III, Question 60, Art. 7

${ }^{57}$ Ibid. See this Chapter page 108 footnote 31 where form determines and confers being on matter.

${ }^{58}$ Ratzinger asserts,

The text [Dei Verbum]... reveals traces of its difficult history; it is the result of many compromises. But the fundamental compromise which pervades it is more than a compromise, it is a synthesis of great importance. The text combines fidelity to Church tradition with an affirmation of critical scholarship, thus opening up anew the path that faith may follow into the world of today (Witherup, Scripture: Dei Verbum, 54-55).

${ }^{59}$ In 1879 Pope Leo XIII issued Aeterni Patris which was a treatise on the restoration of Christian philosophy. In that encyclical Thomism, which is almost synonymous with Neo-scholasticism, was not only considered "the cornerstone of Catholic theology," but it was also considered to be "the only approach to be used in all theological schools at the time, thereby eliminating any new thinking from the modern world." Sullivan, The Road to Vatican II: Key Changes in Theology, 43. It seemed that Neo-scholasticism was also the main approach to theology among the magisterium. Ibid., 17. In 1950, this approach was further strengthened by Pope Pius XII who issued Humani Generis (Of the Human Race). This encyclical rejected the new theology which espoused the use of higher criticism and it 
that Catholic theology requires for its existence. ${ }^{61}$ The architects of Vatican II could only accomplish this synthesis by replacing static timeless Being with dynamic timeless Being, and then by integrating higher criticism with dynamic panentheism. ${ }^{62}$

We will now look at how dynamic timeless Being directly shapes and interprets the following three brief statements contained in Dei Verbum. First, "Sacred tradition and Sacred Scripture form one sacred deposit of the word of God." ${ }^{, 63}$ Moreover, Pope John Paul II clarifies the relationship between the two by stating that sacred tradition is

also "required Catholic scholars to return to the orthodoxy provided by Scholasticism." Ibid. In addition Pius XII "claimed that Thomistic theology was to be the official theology of the church." Ibid., 44.

${ }^{60}$ During the Enlightenment period, scientific and biblical studies began to flourish among Protestants, yet "for the most part the [Catholic] church ignored, purposefully avoided, or sternly warned against these developments," Witherup, Scripture: Dei Verbum, 7.

${ }^{61}$ G. C. Berkouwer, The Second Vatican Council and the New Catholicism (Grand Rapids, MI: Eerdmans, 1965), 132. "Spadafora felt that everything the Church held precious was at stake in form-criticism. He was particularly fearful of the new approach to the founding of the papacy in Matthew 16." Ibid., 131. The following example of the application of higher criticism to New Testament studies touches upon the very foundation of Roman Catholicism which is based upon the promise that Christ made to Peter in Matt 16. The application of higher criticism makes a dichotomy between the Christ of history and the Christ of faith thereby casting serious doubt about the historicity of the promise made to Peter. This new exegetical approach proposes that the founding of the papacy is "a creation of the primitive Church's imagination, or at least of its a posteriori interpretation." Hence, Berkouwer points out whether the methods of form criticism and "the attempt to understand the literary genre of the Gospels touches on the very foundation of certain essential elements in Roman Catholic doctrine. Does kerugmatized history leave intact the objective historical facts on which parts of Catholic doctrine is based?" See ibid., 128, 131.

${ }^{62}$ Ernst Troeltsch had an enormous impact on higher critical scholarship. Yet, his understanding of higher criticism included a view of God within history that he inherited from Schleiermacher, Hegel, and Schelling. See Cooper, Panentheism the Other God of the Philosophers, 127-128; Bloesch, The Church: Sacraments, Worship, Ministry, Mission, 240244. Accordingly, like Hegel, Troeltsch believed in an Absolute Spirit that realized itself through the historical process, Bloesch: The Church: Sacraments, Worship, Ministry, Mission, 241. Thus, the use of higher criticism by the Sacramental model is in harmony with timeless Being, which means that the Sacramental model's theology of the Word consists of the timeless and the historical.

$$
{ }^{63} \mathrm{DV} \text {, Art. } 10 \text {. }
$$


"indispensable to the interpretation of the Word of God." ${ }^{64}$ Dei Verbum alleges that there is a unity between Scripture and Tradition, and that both comprise the Word of God as one source of authority whereas in the past they were considered as two separate sources. ${ }^{65}$ This is similar to the dichotomy that once existed in the Sacramental model between the classical transcendent God and immanent creation. However, under the framework of Dynamic Timeless Being, the classical God is now transcendent and immanent. Similarly, although Tradition and Scripture now form one sacred deposit, the interpretive role of Tradition functions as the timeless interpreter of temporal Scripture. ${ }^{66}$ Second, the Scriptures are "without error," ${ }^{, 67}$ yet at the same time "accretions and changes in the transmission of the text" allow for errors. ${ }^{68}$ Third, Dei Verbum leaves open the notion that the Scriptures do not err on teachings necessary for salvation, ${ }^{69}$ yet they may

${ }^{64}$ John Paul, Ut Unum Sint: On Commitment to Ecumenism, Art. 79.

${ }^{65}$ In panentheism there is unity as well as difference. The distinction between the timeless aspect of the divine presence and the temporal aspect corresponds to the distinction between sacred tradition and Scripture. There is no longer a radical distinction between the Word of God and sacred tradition, as there was during the Reformation. Scripture and tradition are now considered to be two manifestations of the Word of God. This corresponds to the fact that in dynamic timeless Being the divine presence is both timeless and temporal, yet nevertheless both are part of the one divine presence.

${ }^{66}$ Panentheism still contains the ontological distinction between the timeless and the temporal. Consequently, timelessness is the cause of temporality. Since tradition is still indispensable to the interpretation of the Word of God, we can see here that it corresponds to the timeless aspect of the divine presence while Scripture corresponds to the historical aspect.

${ }^{67} \mathrm{DV}$, Art.11. Since panentheism adheres to the distinction between the timeless and temporal, "without error" refers to the timeless aspect of the divine presence.

${ }^{68}$ Witherup, Scripture: Dei Verbum, 55; cf DV, Art. 20. The temporal aspect of the divine presence involves God coming to an awareness of Himself in human beings through the historical process. Consequently, errors in the text are the natural byproduct of this evolution.

${ }^{69}$ The cause of salvation comes from the timeless part of the divine presence. 
err regarding questions of history and science. ${ }^{70}$ These dichotomies reveal the

undercurrent of dynamic timeless Being. Thus, dynamic timeless Being integrates higher criticism with scholasticism, which forms the basis for interpreting Scripture as the divine presence in the Sacramental model.

\section{Liturgist}

A description and analysis of the liturgist includes three main areas. The first is the cause of liturgy. The second is the relationship between liturgists and worshippers, and the third is concerned with the legitimacy and authority of the liturgists in the Sacramental model.

According to the Sacramental model, Christ is the efficient cause of liturgy and the liturgists constitute the instrumental cause. ${ }^{71}$ Accordingly, Christ determines ${ }^{72}$ the

${ }^{70 ،}$ The books of Scripture must be acknowledged as teaching solidly, faithfully and without error that truth which God wanted put into sacred writings for the sake of salvation," $D V$, Art. 11. History and science involve the temporal aspects of the divine presence in which change and becoming are a part of the ongoing process. This naturally leads to errors in the area of history and science.

${ }^{71} S T$ Part III Q62 Art.1, 5.

The principal supersensible efficient cause of the worship which the Church renders to God is Christ Himself, because the Church's worship is nothing but the worship which Christ renders to God through the Church, making the Church participate in His worship. Hence the Church's spiritual dispositions are an instrument which Christ uses and a participation in Christ's dispositions (Vagaggini, Theological Dimensions of the Liturgy, 71).

God is also the "ultimate object of worship." Ibid., 73. See also, Palmer, Sacraments and Worship, 92; Power, Unsearchable Riches, 183.

${ }^{72}$ Aquinas declares that the only condition required for grace is a human being that is composed of form and matter. Furthermore, God timelessly moves even the free will of man in the reception of grace in the sacraments. He states,

if we speak of grace as it signifies a help from God to move us to good, no preparation is required on man's part, that, as it were, anticipates the Divine help, but rather, every preparation in man must be by the help of God moving the soul to good. And thus even the good movement of the free-will, whereby anyone is prepared for receiving the gift of grace is an act of the free-will, moved by God....Hence it is said that man's will is 
actions of the liturgists. In the Eucharistic liturgy, Aquinas declares that Christ is the efficient cause of the words, "This is My Body," that are spoken in eternity but echoed in time by the presider. ${ }^{73}$ As a result, the words spoken constitute the timeless form while bread and wine constitute the proper matter of the Eucharist. ${ }^{74}$

With regard to the differences between clergy and laity, the Catechism of the Catholic Church asserts that those who are ordained to ministry through apostolic succession during the sacrament of holy orders are permanently marked ${ }^{75}$ in their timeless soul. ${ }^{76}$ Moreover, it is this ontological distinction that qualifies them to mediate

prepared by God, and that man's steps are guided by God (ST $1^{\text {st }}$ part of $2^{\text {nd }}$ part Q112 Art.2).

${ }^{73}$ This means that those words are thus spoken timelessly, yet echoed in time through the priest who pronounces them. See, ST Part III Q60 Art.7. Aquinas also applies Aristotle's form and matter philosophy to baptism. He notes that the form and principal cause of baptism derives from the Trinity with the words "in the name of the Father, and the Son, and the Holy Ghost." Moreover, the instrumental cause comes through the minister who confers the sacrament outwardly, and is designated by the words, "I baptize thee." ST Part III Q66 Art.5. Water is the proper matter for baptism. ST Part III Q66 Art.3.

${ }^{74}$ ST Part III Q74 Art.1, see also Art.3, 5.

${ }^{75}$ The Catechism asserts,

The Sacrament of Holy Orders...confers an indelible spiritual character and cannot be repeated or conferred temporarily. It is true that someone validly ordained can, for grave reasons, be discharged from the obligations and functions linked to ordination, or can be forbidden to exercise them; but he cannot become a layman again in the strict sense, because the character imprinted by ordination is for ever. The vocation and mission received on the day of his ordination mark him permanently, (Catechism of the Catholic Church, 355 emphasis original).

${ }^{76}$ According to Hislop,

The celebration of the Holy Eucharist makes use of the eye and of touch and of taste as well as of the ear, as the means through which the eternal message of God's Being and the sense of His Presence are mediated to the soul (Hislop, Our Heritage in Public Worship, 9).

"The external sign of the sacrament points to the grace that is in the soul." Cooke, The Distancing of God, 162. "Indeed, by sacramental use man confers on visible things their supreme dignity, not merely as signs and symbols, but as effective means of grace in the soul," Jean Daniélou, "The Sign of the Temple: A Meditation," 257. 
sacred tradition to the congregation. ${ }^{77}$ Because the soul is the place where all the

sacraments are received, timeless Being, which lies at the basis of the immortality of the soul $^{78}$ is the cause of the ontological distinction between liturgists and laity.

Lastly, the legitimacy and the authority of the liturgist in the Sacramental model is grounded upon the following points: (1) Christ first granted authority to Peter, and then through apostolic succession to all of Peter's successors, ${ }^{79}$ (2) bishops enjoy the prerogative of infallibility as they maintain unity with Peter's successor, ${ }^{80}$ (3) the

${ }^{77}$ Aiden Nichols notes that liturgy unfolds and interprets tradition. Moreover, "Tradition is never accessible in itself, in its pure form, but only comes to us via some kind of concrete mediation," which is what we find in liturgy. Aidan Nichols, The Shape of Catholic Theology (Edinburgh: T \& T Clark, 1991), 183, 181. Moreover, just as knowledge of metaphysics justifies why the philosopher should govern the state so the knowledge of sacred tradition entitles liturgists to interpret divine things that are mediated in liturgy. See John Procopé, "Greek and Roman Political Theory," in The Cambridge History of Medieval Political Thought C. 350-1450, ed. J.H. Burns (New York: Cambridge University Press, 1988), 22.

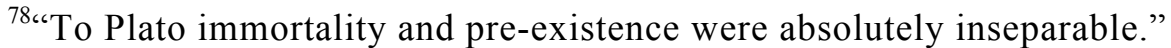
Furthermore, Froom states that one of Plato's main arguments for the immortality of the soul is a postulate of the Platonic doctrine of Ideas. Leroy Edwin Froom, The Conditionalist Faith of Our Fathers, 2 vols. (Washington, DC: Review and Herald, 1966), 1:562, 563. "His [Plato's] proofs of the immortality of the soul are based on the soul's uncomplicated form, its immateriality and its analogy to the eternal Ideas and to truth which is known through the soul," Marias, History of Philosophy, 54. Moreover, in the Sacramental model, there is widespread but not total support for universal innate immortality among ante-Nicene and post-Nicene church fathers as well as the Greek and Latin church fathers. The Ante-Nicene Fathers include Athenagoras of Athens, Tertullian of Carthage, Clement of Alexandriawho switched his position from a Conditionalist, Origen of Alexandria, Cyprian of Carthage, Froom, The Conditionalist Faith of Our Fathers, 1:758, 929-968. Post-Nicene Fathers include Eusebius of Caesarea, Basil of Caesarea, Gregory of Nyssa, Ambrose of Milan, Chrysostom of Constantinople, and Augustine of Hippo. Ibid., 1:759, 969-1028, 1070-1079. However, in contrast to universal innate immortality, all of the Apostolic Fathers appear to be Conditionalists. Ibid., 1:758-802. Furthermore, among the Ante-NPNF, Justin Martyr and Athanasius of Alexandria appear to be predominantly Conditionalist: also Theophilus of Antioch, and Irenaeus of Lyons. Ibid., 1:758-759, 803-833, 840-848, 873-901, 1053-1069. See also, Thomas W. Toews, "Biblical Sources in the Development of the Concept of the Soul in the Writings of the Fathers of the Early Christian Church, 100-325 C.E. " (Ph.D. Dissertation, Andrews University, 2011).

$$
\begin{aligned}
& { }^{79} L G, 8,20,21 . \\
& { }^{80} L G, 25 .
\end{aligned}
$$


successors of Peter and the apostles receive the sacrament of holy orders at their

ordination, which confers upon them the grace of the Holy Spirit, ${ }^{81}$ (4) only a bishop who is marked with the fullness of the sacrament of Orders can cause the Eucharist "to be offered. ${ }^{\prime 82}$ As a result, for Catholics, the timeless soul grounds episcopal ordination and apostolic succession. This logically leads to the deduction that not just any presider has authority to preside over the Eucharist ${ }^{83}$ since all liturgical functions are grounded in the bishop who exercises ultimate authority over liturgy. ${ }^{84}$

\section{Liturgical Setting and Actions}

Vatican II constitutes a major turning point in the Sacramental model.

Accordingly, I will describe and analyze ${ }^{85}$ the relevant liturgical actions revolving around

${ }^{81} L G, 21$.

${ }^{82} L G, 26$. This does not preclude priests from presiding over the Eucharist. However, the authority of any individual priest must be exercised in harmony with the bishops who maintain their unity with Peter's successor. See $L G, 25$.

${ }^{83} L G, 20,26$. See also, Berkouwer, The Second Vatican Council and the New Catholicism, 57; Hans Küng, Infallible? An Enquiry, trans., Edward Quinn (Garden City, NY: Doubleday, 1971), 31-68; Sullivan, From Apostles to Bishops, 10-11.

${ }^{84}$ Cyprian points out that no one can set up a new altar or a new priesthood without destroying the unity God, Christ and the church are founded upon through the authority granted to Peter and to his successors, the bishops. Cited in Sullivan, From Apostles to Bishops, 196. See also, Hans Von Campenhousen, Ecclesiastical Authority and Spiritual Power in the Church of the First Three Centuries, trans., J.A. Baker (Stanford, CA: Stanford University Press, 1969), 270, 281. Moreover, this iron grip over liturgy by the bishops intensified at of the Council of Trent in the sixteenth century. As a result of that council, "Rome was accorded unprecedented liturgical control" in such a way that "the whole world was to be inculturated into the Roman ways of doing the liturgy," White, Roman Catholic Worship: Trent to Today, 6, 9-10. Moreover, Vatican II states, "Regulation of the sacred liturgy depends solely on the authority of the Church, that is, on the Apostolic See and, as laws may determine, on the bishop," SC, Art. 22.

${ }^{85}$ As we begin our analysis of the ritual actions we must keep in mind the following two observations: (1) a human statue is the result of applying the pattern that is in the mind of the craftsman (hermeneutical condition) to the bronze (material condition), and (2) in a similar way, ritual actions are the result of applying the presuppositions that liturgists assume (hermeneutical condition) to the divine presence (material condition). Since ritual 
the Eucharist that occur before and after this significant council; these liturgical actions

consist of liturgical space, time, frequency, and liturgical characteristics. ${ }^{86}$

Liturgical space refers to the architectural setting in which the Eucharistic

celebration takes place. Around the time of Constantine in the fourth century, the

Eucharistic setting eventually moved toward basilicas and other grand structures: This

has resulted in Eucharistic celebrations that are more splendid and solemn than those in

the past. ${ }^{87}$ Static timeless Being hermeneutically determines the central location of the

actions include the areas of space, time, frequency, and liturgical characteristics, then the hermeneutical condition, through timeless Being, interprets those ritual actions.

${ }^{86} \mathrm{~A}$ Eucharistic celebration would not be possible if any one of these four broad areas is missing.

${ }^{87}$ John F. Baldovin, "Christian Worship to the Eve of the Reformation," 165; Anscar J. Chupungco, "History of the Liturgy until the Fourth Century," in Handbook for Liturgical Studies: Fundamental Liturgy, ed. Anscar J. Chupungco (Collegeville, MN: Liturgical Press, 1997), 108. During the first century the Lord's Supper took place in the setting of a community meal. John F. Baldovin, "Christian Worship to the Eve of the Reformation," 159, 165; Cullmann, Early Christian Worship, 14, 16; Senn, Christian Liturgy, 61; Spielmann, History of Christian Worship, 19. The location during the first century was mostly in homes. Hardman, A History of Christian Worship, 17; Noakes, "From New Testament Times until St Cyprian," 119. The first century Eucharist was a "public affair" rather than "the private devotion of a series of individuals." See R.J. Halliburton, "The Patristic Theology of the Eucharist," in The Study of Liturgy, ed. Cheslyn Jones et al. (New York: Oxford University Press, 1992), 246. Yet, as the second and third centuries approached, perhaps one of the greatest changes "in the history of the Mass, was the abandonment of the meal as the setting for the Mass." According to Jungmann, "This change had occurred already by the end of the first century." Jungmann, The Early Liturgy to the Time of Gregory the Great, 37-38. See also, Spielmann, History of Christian Worship, 21. Jungmann points out two main factors for abandoning the communal meal: (1) "the gradual enrichment of the prayer of thanksgiving and, at the same time," (2) "the continual growth of the convert communities which became too large for a domestic table-gathering." Jungmann, The Early Liturgy to the Time of Gregory the Great, 37-38. Others place the change at around the mid-second century, see Baldovin, "Christian Worship to the Eve of the Reformation,"160; Cullmann, Early Christian Worship, 30-31; Hardman, A History of Christian Worship, 31; K.W. Noakes, "From the Apostolic Fathers to Irenaeus," in The Study of Liturgy, ed. Cheslyn Jones et al. (New York: Oxford University Press, 1992), 211. Klauser and James White state that the meal died out in the fourth century. See Klauser, A Short History of the Western Liturgy, 8; White, A Brief History of Christian Worship, 26. 
altar in the basilica ${ }^{88}$ on the basis that the transubstantiated host in the Sacramental Model is an essence or a substance. ${ }^{89}$ This logically leads to the prayer of consecration as the central liturgical event. ${ }^{90}$ Consequently, static timeless Being interprets the divine presence in the host and also justifies the central location of the altar.

We will now briefly examine the notion of liturgical time as it relates to the Eucharist. Throughout the entire history of the Sacramental model, there has been an indissoluble link between the Resurrection of Christ and the celebration of the Eucharist on Sunday. ${ }^{91}$ Moreover, Justin Martyr's early influence in establishing and maintaining this link has been very strong. ${ }^{92}$

${ }^{88}$ See pages $24-25$ of this dissetation. This also includes the very costly material from which the altar is made.

${ }^{89}$ See page 104 footnote 12 of this Chapter for those who describe the divine presence in the Eucharist as a substance or essence. For the connection to static timeless Being, see pages 104-105 of this Chapter.

${ }^{90}$ See page 102 footnote 5 of this Chapter. It is during the prayer of consecration that the second substance of the emblems is transubstantiated.

${ }^{91}$ Referring to the first few centuries, Cobb points out, "We do not know of a Sunday on which the Eucharist was not celebrated. Attendance at the weekly assembly was regarded as obligatory even in times of persecution." Peter G. Cobb, "The History of the Christian Year," ed. Cheslyn Jones et al., in The Study of Liturgy (New York: Oxford University Press, 1992), 457. Vatican II states, "By a tradition handed down from the apostles which took its origin from the very day of Christ's resurrection, the Church celebrates the paschal mystery every eighth day; with good reason this, then, bears the name of the Lord's day or Sunday." $S C$, Art. 106. For further support for the strong connections between Sunday and the Eucharist, see the following: "Ever since the early church, Sunday has been the day par excellence for the celebration of the Eucharist," Louis Van Tongeren, "Liturgical Renewal Never Ends," in Vatican II and Its Legacy, ed. M and L. Kenis Lamberigts, eds. (LeuvenDudley, MA: Leuven University Press, 2002), 372. Klauser states, "It is expressly stated that Sunday is the day for celebrating the eucharist." Klauser, A Short History of the Western Liturgy, 15. Taft refers to Sunday as the "day of the Eucharist," Taft, Beyond East and West, 32. For other examples, see The Didache XIV; R. J. Bauckham, "Sabbath and Sunday in the Post-Apostolic Church," in From Sabbath to Lord's Day: A Biblical, Historical and Theological Investigation, ed. D.A. Carson (Grand Rapids, MI: Zondervan, 1982), 261.

${ }^{92}$ For those who have relied on Chapter 67 of Justin Martyr's First Apology in order to bolster the connection between the Eucharist and Sunday, see Baldovin, "Christian Worship to the Eve of the Reformation," 160; Chupungco, "History of the Roman Liturgy until the Fifteenth Century," 131; Cobb, "The History of the Christian Year," 456-457; Hall, 
We will now examine the relationship between timeless Being and Sunday by analyzing Pope John Paul II encyclical Dies Domini. There are at least two statements in the encyclical that illustrate how Sunday reveals "time's deeper meaning." 93 First, Sunday as the "image of eternity" 94 affirms Plato's unqualified distinction between the timeless interpretation of eternity, and time as its moving image. ${ }^{95}$ Second, "Sunday...becomes the soul of the other days," $" 96$ which means that as the Day of Days (Dies Dierum) Sunday points to the timeless interpretation of time or history. Hence, Plato and Aristotle's philosophy hermeneutically shapes the meaning of Sunday as a symbol for the image of eternity, and as the foundation for the weekly cycle.

There have been several changes regarding the frequency with which this model celebrates the Eucharist over the centuries, ${ }^{97}$ yet frequency of celebration does not seem

Worshiping with the Church Fathers, 27-29; Norén, "The Word of God in Worship," 41; Palmer, Sacraments and Worship, 39-40; Senn, Christian Liturgy, 86-87.

${ }^{93}$ John Paul II, Dies Domini, 0.2; V.75.

${ }^{94}$ Ibid., II.25-26. Actually, the subheading reads, "The eighth day: image of eternity."

${ }^{95}$ Plato, Timaeus, 37.

${ }^{96}$ John Paul II, Dies Domini, Conclusion, 83. Sunday is also "the foundation and kernel of the whole liturgical year." SC, Art 106. Using the Aristotelian categories of form and matter, and potency and act, Aquinas identifies the soul as the "form of the body." $\mathrm{He}$ states,

But inasmuch as the soul is the form of the body, it has not an existence apart from the existence of the body, but by its own existence is united to the body immediately. This is the case with every form which, if considered as an act, is very distant from matter, which is a being only in potentiality (ST Part I Q76 Art.7).

Thus, since "act" is ontologically and epistemologically prior to "potency," and "form" confers being to "matter," then the relationship between Sunday, and the other days is ordered and determined by the timeless paradigm. Stated differently, just as the meaning of time is understood and determined by timeless eternity, so the days of the week, and history itself are ordered around Sunday.

${ }^{97}$ Historically, the frequency of celebration during the first century has been difficult to determine. However, several confirm a weekly celebration in the second century. See White, A Brief History of Christian Worship, 26; Baldovin, "Christian Worship to the Eve of 
to have a causal connection to timeless Being. This same holds true for the shape of the Eucharist. $^{98}$

We will now proceed to describe and analyze the following liturgical characteristics: the prayers offered, medieval rubrics, liturgical language and the influence of Vatican II. The doctrine of transubstantiation directly shapes the ritual aspects of prayer in the following ways: (1) during the fourth century, the emphasis

the Reformation," 160, 162; Taft, Beyond East and West, 62; White, A Brief History of Christian Worship, 55; Hall, Worshiping with the Church Fathers, 29. By the third century the churches added the Eucharistic celebration to the gatherings that took place on Wednesday and Friday, yet by the fourth century the churches of the West celebrated it daily. Palmer, Sacraments and Worship, 39. Later during the Reformation, Catholics very seldom celebrated the Eucharist. In contrast, the Anglicans held to a weekly celebration. See White, A Brief History of Christian Worship, 122-123; Davies, From Cranmer to Hooker, 118, 122-123; White, "Christian Worship since the Reformation," 197. It's only as a result of Vatican II that the Catholic Church began to strongly encourage the laity to celebrate the Eucharist on a weekly basis, $S C, 41-42,52,56,106$. See also, White, A Brief History of Christian Worship, 157.

${ }^{98}$ James White notes that since the shape of the Eucharist is "hard to determine" in the first century, we should guard against the temptation to "read back into the New Testament period the practices in the following centuries." See White, Introduction to Christian Worship, 235-236. According to Willimon,

Most scholars believe that, at the very beginning of the church, Christians celebrated a full common meal (the agape?) with prayers of blessing (eucharistia-Greek for "thanksgiving") patterned after the Jewish table blessings and prayed before and after the meal. The pattern was thus much the same as the sacred meals in Judaism: (1) taking bread, (2) thanking God, (3) breaking bread, (4) giving the bread, (5) taking the wine after the meal, (6) thanking God, and (7) giving the wine.

Later on, Willimon asserts that the seven-action Eucharist was reduced to a four-action shape, Willimon, Word, Water, Wine and Bread, 23-25. Gregory Dix also points to an initial "seven-action scheme" found in the New Testament, which has been modified to a fouraction shape that constitutes "the absolutely invariable nucleus of every Eucharistic rite known to us throughout antiquity." Gregory Dix, The Shape of the Liturgy (New York: Continuum, 2005), 48. Although other rites would be added, Spielmann points out that this Eucharistic shape would remain until the present day, Spielmann, History of Christian Worship, 31; Noakes, "From the Apostolic Fathers to Irenaeus," 212. The move to the basilicas in the fourth century did not alter the basic character and shape of the service that was established before the fourth century; instead it lengthened it and made it more elaborate. See Spielmann, History of Christian Worship, 40. 
changed from the prayer of thanksgiving to the prayer of consecration, ${ }^{99}$ which became the central event in liturgy, ${ }^{100}$ and (2) around the time of the thirteenth century, liturgists considered the prayer of consecration to be so holy that that "the congregation should not even hear it; therefore the celebrant began to whisper the prayer." ${ }^{, 101}$ Moreover, the immortality of the soul, ${ }^{102}$ which stems from timeless Being, constitutes the reason for why the content of the prayers includes intercessions for the dead, and the refreshment and rescuing of souls in purgatory. ${ }^{103}$

The next area under liturgical characteristics includes medieval rubrics. Between the twelfth and thirteenth centuries, priests began to elevate both the Host and the

${ }^{99}$ The underlying reason for this new emphasis was an increased concern with the question of when the change occurred from bread and wine to the body and blood of Christ. Spielmann, History of Christian Worship, 44. The change from the prayer of thanksgiving to the prayer of consecration in the fourth century eventually led to the doctrine of transubstantiation as the theological explanation for what actually takes place during the prayer of consecration. Senn, Christian Liturgy, 251-252. Hence timeless Being, working through transubstantiation, became the cause and explanation for the change in emphasis from the prayer of thanksgiving to the ritual prayer aspects that emphasized when the change from bread and wine to the body and blood of Christ takes place.

${ }^{100}$ See page 102 footnote 5 of this Chapter. If the Aristotelian Form is ontologically prior to matter, and if timeless Form confers being on matter, then it follows that Form is essential. Hence, if liturgy has a central event, it is then logical to have that which is essential as the central event. Since the prayer of consecration, during which the substance of the bread and wine is changed into the substance of the body and blood of Jesus, is linked with essence, it naturally follows that this prayer is the central event in liturgy.

${ }^{101}$ Spielmann, History of Christian Worship, 59; Byars, The Future of Protestant Worship, 66; White, A Brief History of Christian Worship, 88. In this case holiness, expressed by the low auditory volume of the priest, is the effect, and timeless Being in the transubstantiated host is the cause.

${ }^{102}$ Both Froom and Marias note that the immortality of the soul is the postulate of the Platonic Idea. See page 119 footnote 78 of this dissertation. Accordingly, timeless Being is not only the direct cause of the immortality of the soul, but, also of the medieval concept of purgatory, the content of the prayers for the dead, and the intercessory role of Mary and the saints. See Samuele Bacchiocchi, Immortality or Resurrection? A Biblical Study on Human Nature and Destiny (Berrien Springs, MI: Biblical Perspectives, 2001), 23; Froom, The Conditionalist Faith of Our Fathers, 2:39-48.

${ }^{103}$ Baldovin, "Christian Worship to the Eve of the Reformation,"169; Davies, From Andrewes to Baxter and Fox, 291. 
Chalice. ${ }^{104}$ Also, in order to accentuate the solemnity and holiness of the Eucharistic celebration, the priest would now "come around the altar table and preside at the service with his back to the people. Now, the action at the altar was so holy that it should not be too visible." ${ }^{105}$ This resulted in a "disinclination to receive the chalice which became common in the twelfth century for fear of spilling the blood of Christ." ${ }^{106}$ Thus, transubstantiation, in spite of being formulated after the elevation of the host and chalice, became the cause for (1) the elevation of the host and chalice, which leads to the worship and adoration of the host, ${ }^{107}$ (2) the disinclination to receive the chalice for fear of spilling the divine presence, and (3) the solemnity and holiness of the occasion during which the priest had his back to the people while conducting the Eucharist at the altar. ${ }^{108}$

We now come to liturgical language. Liturgy did not make a complete transition to Latin until the papacy of Damasus I (384), yet the "Roman Church had already adopted it around the year 250 as its official language. From then on until the reform of

${ }^{104}$ Dyrness, A Primer on Christian Worship, 20; Spielmann, History of Christian Worship, 59. Marshall introduces the Elevation of the Host slightly earlier in the twelfth century. He also adds that the elevation of the chalice came sometime after that. Marshall and Taylor, Liturgy and Christian Unity, 114. See also D.M. Hope, "The Medieval Western Rites," in The Study of Liturgy, ed. Cheslyn Jones et al. (New York: Oxford University Press, 1992), 276.

${ }^{105}$ Spielmann, History of Christian Worship, 47; White, A Brief History of Christian Worship, 88.

${ }^{106}$ White, A Brief History of Christian Worship, 90; Willimon, Word, Water, Wine and Bread, 57.

${ }^{107}$ Aquinas points out that after the prayer of consecration, the substance of the bread and the wine is no longer there, since it has been changed into the substance of the Christ's body. He asserts that if the substance of the bread and wine were still there, then they "could not be adored with the adoration of latria," ST Part III Q75, Art.2. Regarding the "worship of the host," Phifer plainly states, "the elements of the Sacrament were to be adored because they were the body of God. Thus God became localized, and magical powers were ascribed to the consecrated element outside of the Eucharistic service itself." Phifer, A Protestant Case for Liturgical Renewal, 50.

${ }^{108}$ Hence, the reasons for why the priest had his back to the people are the same as when he spoke in a low audible voice, see also page 125 of this dissertation. 
Vatican II, Latin would be stubbornly retained as the language of the Roman Liturgy.",109 Consequently, static timeless Being undergirds the analysis of Horton Davies that Latin's mystery, transcendence and otherness come "at the cost of human nescience."

Moreover, Latin is regarded as constituting the near perfect earthly duplication of a timeless language that would cease to communicate transcendence if it were abandoned. $^{111}$

In spite of a restricted use of the mother tongue ${ }^{112}$ in certain situations at Vatican II, the vernacular is entirely based on a formal word for word translation from the Latin ${ }^{113}$

${ }^{109}$ Chupungco, "History of the Roman Liturgy until the Fifteenth Century," 132-133. About 250 Latin came to the fore in Rome. "And ever since Latin has been not only the language of church government, but for the entire West also the language of worship, the ecclesiastical language as such." Jungmann, The Early Liturgy to the Time of Gregory the Great, 206.

${ }^{110}$ Davies, From Andrewes to Baxter and Fox, 485. Referring to Latin, Hislop also notes that "the mystery of the unseen is reflected in the foreignness of the sounds." Hislop, Our Heritage in Public Worship, 138. We must also keep in mind that timeless Being provides the interpretation for transcendence in the Sacramental model. Christos Yannaras, On the Absence and Unknowability of God: Heidegger and the Areopagite, ed. Andrew Louth, trans., Haralambos Ventis (New York: T \& T Clark, 2005), 62-63.

${ }^{111}$ Centuries after becoming the official language, Latin remained the unchangeable condition for ordaining Chinese priests in the seventeenth century. The church was so unwilling to let go of Latin that the Chinese rites controversy of the seventeenth century "came with the injunction from Rome that Chinese priests might be ordained provided they could read Latin ...even if they did not understand it." J.D. Crichton, The Church's Worship: Considerations on the Liturgical Constitution of the Second Vatican Council (New York: Sheed and Ward, 1964), 122 (emphasis original).

${ }^{112}$ According to Keith Pecklers, professor of liturgy at the Pontifical Gregorian University in Rome, the burning issue at Vatican II was the vernacular. Keith F. Pecklers, Dynamic Equivalence: The Living Language of Christian Worship (Collegeville, MN: Liturgical Press, 2003), 172.

${ }^{113}$ Liturgiam Authenticam: Fifth Instruction on Vernacular Translation of the Roman Liturgy, ed. Congregation for Divine Worship and the Discipline of the Sacraments (Washington, DC: United States Conference of Catholic Bishops, 2001), Art. 5, 19, 33, 47, 60. See also, Ferrone, Liturgy: Sacrosanctum Concilium, 73. 
that requires the approval of the Holy See. ${ }^{114}$ The synthesis ${ }^{115}$ between the Latin text and the translation into the vernacular can best be explained from synthesis between God and the world that is inherent in dynamic timeless Being. For instance, the framers of the text in the mother tongue considered Latin as a theological, sacred language that communicates timeless truths. ${ }^{116}$ Consequently, all translations were based on a formal translation from the Latin so that "the theological realities of ecclesial communion and unity"117 are preserved. Hence, in this synthesis Latin symbolizes the timeless aspect of panentheism that orders and shapes the translation into the vernacular. However, this

${ }^{114} S C$, Articles 36.1-36.4. Moreover, the use of the Latin language is to be preserved in the Latin rites, Ibid.

${ }^{115}$ Dynamic timeless Being attempts to synthesize two aspects of reality that were ontologically distinct: it synthesizes static Being with historical becoming. In doing this, it provides the Sacramental model with the interpretive framework that joins together Latin with the vernacular. In the past Latin and the mother tongue remained distinct, but as we shall see Latin orders and shapes the vernacular in much the same way that timeless Being shapes becoming. See pages 95-97 footnotes 97 and 98 for an explanation of dynamic timeless Being through an analysis of panentheism. See also this Chapter pages 110-117.

${ }^{116}$ The Scriptures express truths that "transcend the limits of time and space," Liturgiam Authenticam: Fifth Instruction on Vernacular Translation of the Roman Liturgy, Art. 19. Truths that transcend time and space have always been interpreted from timeless Being in the Sacramental model. The framers of Liturgiam Authenticum refer to the translation of the Latin into the vernacular as a "sacral vernacular" Art. 47. Latin is considered to be a theological and liturgical language. See Hope, "The Medieval Western Rites," 276. There are those who "ascribe a certain Latin liturgical fundamentalist attitude... to the framers of Liturgiam Authenticum." Johnson, "The Loss of a Common Language: The End of Ecumenical-Liturgical Convergence?," 71. Although the introduction of native languages "has facilitated communication," the translation of the new liturgy has been "identified with rational intelligibility." It has also been described as "strongly rationalistic, intellectualistic and didactic," Luis Maldonado, "The Church's Liturgy: Present and Future," in Toward Vatican III: The Work That Nees to Be Done, ed. David Tracy, Hans Küng, and Johannes Baptist Metz (New York: Seabury Press, 1978), 222. This supports the notion that these translations are ordered after the timeless interpretation of "rationalistic, intellectualistic, and didactic."

${ }^{117}$ In the translation, all the rubrics, titles, arrangements of the texts, the notes in the text, and the capitalization found in the Latin must be reproduced as much as possible from the Latin. See Liturgiam Authenticam: Fifth Instruction on Vernacular Translation of the Roman Liturgy, Art. 5 emphasis supplied. See, ibid., 33, 69. See also, Ferrone, Liturgy: Sacrosanctum Concilium, 73. 
approach produced problems far beyond a "stilted and archaic" translation that was

"difficult both to speak and to understand:" 118 it led to the end of ecumenical dialogue concerning the philosophy of translating texts.

In addition to the use of the vernacular, changes introduced by Vatican II were also characterized by liturgical inculturation, which McCarthy defines as "the attempt to integrate significant and acceptable cultural values and symbols within liturgical expression, ${ }^{, 119}$ specifically indigenous music, dance, art and architecture that accompany the Eucharist. ${ }^{120}$ Liturgical inculturation includes (1) the musical and artistic expressions of all the cultures of the world into "schools and...sacred services," $" 121$ and (2) the

\footnotetext{
${ }^{118}$ Ferrone, Liturgy: Sacrosanctum Concilium, 75. This departure from a dynamic equivalent philosophy of translation to a formal equivalent translation had a disastrous effect on the ecumenical work on common texts. Horace T. Allen Jr., who is the founding co-chair of the English Language Liturgical Consultation in his report to the Centro Pro Unione in Rome, stated that as a result of these changes from Liturgiam Authenticam regarding the philosophy of translation, "the entire liturgical and ecumenical conversations are gone. Finished. Done." Johnson, "The Loss of a Common Language: The End of EcumenicalLiturgical Convergence?," 65.

${ }^{119}$ McCarthy, The Catholic Tradition, 222.

${ }^{120}$ The archbishop of Abuja, Nigeria has noted that the Eucharist is receiving the best of our cultures. He has also pointed out the differences in the Eucharistic celebrations of Africans versus those of Europeans. The Eucharistic celebrations of Europeans include their glorious architecture and fabulous paintings. The Eucharistic celebrations of Africans include their songs and lyrics, their drumming and bodily movements. See Ferrone, Liturgy: Sacrosanctum Concilium, 101-104.

${ }^{121}$ Vatican II asserts,

In certain parts of the world, especially mission lands, there are peoples who have their own musical traditions, and these play a great part in their religious and social life. For this reason due importance is to be attached to their music, and a suitable place is to be given to it, not only in forming their attitude toward religion, but also in adapting worship to their native genius, as indicated in Art. 39 and 40. Therefore, when missionaries are being given training in music, every effort should be made to see that they become competent in promoting the traditional music of these peoples, both in schools and in sacred services, as far as may be practicable (SC, Art. 119).
} 
proliferation of all kinds of different masses: children's, folk, traditional, organ, clown, youth, and charismatic to name a few. ${ }^{122}$

Our analysis of inculturation will be limited to music for two reasons. The first is that music has experienced major changes since Vatican II. ${ }^{123}$ The second is that the switch to dynamic timeless Being at Vatican II also forms the theological foundation for the Emerging Church in the Charismatic model. We will first begin by noting how static timeless Being shapes Gregorian chant ${ }^{124}$ and complex Catholic baroque music, and then we will note how dynamic timeless Being shapes post-Vatican II music.

Pope Pius X in his Motu Proprio on sacred music states that Gregorian chant is the "supreme model for sacred music." 25 Accordingly, the monophonic, unaccompanied qualities of the chant constitute the near perfect earthly duplication of timeless heavenly Forms ${ }^{126}$ such as (1) holiness, sanctity, goodness of form, universality, ${ }^{127}$ and (2)

\footnotetext{
${ }^{122}$ Ferrone, Liturgy: Sacrosanctum Concilium, 60.
}

${ }^{123}$ Ibid., 57, 60, 100-104.

${ }^{124}$ Gregorian chant is unaccompanied, monophonic and without strict meter. As a matter of fact, the rhythm of Gregorian chant is one aspect along with Gregorian modes that separates the chant from modern music. The rise and growth of polyphony was the most important factor in the chant's eventual disuse. See Nemmers, Twenty Centuries of Catholic Music, 38, 59, 76,

${ }^{125}$ Motu Proprio of Pope St. Piux X on Sacred Music, (November 22, 1903), Art. 23. The Motu Proprio has been hailed "as the "magna carta" of the liturgical movement." Keith F. Pecklers, "History of the Roman Liturgy from the Sixteenth until the Twentieth Centuries," in Handbook for Liturgical Studies: Fundamental Liturgy, ed. Anscar J. Chupungco (Collegeville, MN: Liturgical Press, 1997), 168.

${ }^{126}$ Blackwell notes that Augustine is the "most prominent representative of Christian Pythagoreanism," whose "great discovery was that number underlies musical pitch." Of course, the primary characteristic of number is timeless eternity and universality. Thus, "the Pythagorean conception of music's arithmetic...[functions] as a portal into the transcendent." Albert Blackwell, The Sacred in Music (Louisville, KY: John Knox Press, 1999), 44, 50. Augustine concluded that "music was a miniature representation" of the timeless Platonic Forms, "a copy of the universal pattern." Julius Portnoy, The Philosopher and Music: A Historical Outline (New York: The Humanities Press, 1954), 67. Moreover, Portnoy's assessment of the relationship between Gregorian chant, highly promoted by Pius 
goodness, truth and beauty. ${ }^{128}$ Moreover, based on the Neo-platonic great chain of Being, Anthony Ruff ranks Gregorian chant as highest on the metaphysical scale in terms of qualities that make music sacred. ${ }^{129}$ These links with static timeless Being constitutes one reason for why the chant remained unchanged for centuries, ${ }^{130}$ and why it is still considered as the highest form of church music even in this post Vatican II era. ${ }^{131}$

We will now note two connections between static timeless Being and complex Catholic polyphonic music that consisted of rich harmony. First, just as timeless realities shape earthly ones, so the chant exercised a considerable influence on the works of

$\mathrm{X}$, and Platonic philosophy is summed up in this way: "In the Catholic Church, Plato's aesthetics of music prevails to this very day. The Motu Proprio of Pope Pius X on Sacred Music (1903) bears this out." Ibid., 191.

${ }^{127}$ Motu Proprio of Pope St. Piux X on Sacred Music, Art. 2-3.

Therefore, it is fully legitimate to lay down the following rule: In its movement, inspiration, and mood, the more closely a church composition approaches the Gregorian form, the more sacred and liturgical it becomes. The more out of harmony it is with that supreme model, the less worthy it is of the temple (Ibid. Art.3).

${ }^{128}$ Peter Jeffery, "Chant East and West: Toward a Renewal of the Tradition," in Music and the Experience of God, ed. Mary Collins, David Power, and Mellonee Burnim (Edinburgh: T \& T Clark, 1989), 27.

${ }^{129}$ Anthony Ruff, Sacred Music and Liturgical Reform: Treasures and Transformations (Chicago: HillenbrandBooks, 2007), 281. Based on the Neo-platonic great chain of being, Ruff states,

Gregorian chant, is as sacred as music can be. All other music genres fall short of sacrality to the extent that they depart from the Platonic ideal of chant. Classical polyphony of the Roman school is quite high on the metaphysical scale because it agrees well with Gregorian chant. Modern (choral) music is lower on the scale-it is similar to classical polyphony, but it tends to become profane and is thus ontologically further removed.

Lower still is organ music and wind instruments. "The metaphysical scale goes down no further; bands may only play outside [the] church building." Ibid.

${ }^{130} \mathrm{Nemmers}$ points out that the chant begins with the fifth or sixth century and runs to the sixteenth century, yet the period of maximum development is considered to be in the eleventh and twelfth century. Nemmers, Twenty Centuries of Catholic Music, 29.

131،"The Church acknowledges Gregorian chant as specially suited to the Roman liturgy: therefore, other things being equal, it should be given pride of place in liturgical services." SC, Art. 116. 
Palestrina and his contemporaries. ${ }^{132}$ Second, the transubstantiated presence of Christ the King in the Eucharist becomes the justification for "adorning the throne room of God with sound just as it had with splendid visual decoration."

Now we will take note of how the hermeneutical role of dynamic timeless Being shapes music in the post-Vatican II era. First, there is an ontological distinction between the Eucharist and musical expression: ${ }^{134}$ In this structure the Eucharist is timeless, unchangeable and theological ${ }^{135}$ and the music is changeable and cultural. ${ }^{136}$ This ontological distinction between the timeless and the temporal is evident in Sacrosanctum

132“"Haller argues that the works of Palestrina and contemporaries invariably reflect the spirit of the chant in their melodic and rhythmic aspects." James Garratt, Palestrina and the German Romantic Imagination (New York: Cambridge University Press, 2004), 162. Portnoy states, "Classic Polyphony agrees admirably with Gregorian Chant, ... and hence it has been found worthy of a place side by side with Gregorian Chant, in the more solemn functions of the Church," Portnoy, The Philosopher and Music, 191. Others however state that Palestrina, although an expert in polyphony, knew very little about the ancient melodies of the chant. Thus, in the attempt to adorn the chant with complex polyphony, ignorance regarding the ancient melodies of the chant ended up disfiguring it. White, Roman Catholic Worship: Trent to Today, 41-42. See also footnote 129 above on the connection between classical polyphony and chant.

${ }^{133}$ White, Roman Catholic Worship: Trent to Today, 43. James White notes that Palestrina's Missa Papae Marcelli was written for ten parts, Ibid., 20. See also, Lang, Sacred Games, 57-58.

${ }^{134}$ The justification for the changes at Vatican II is based on the ontological distinction between the timeless Forms on the one hand, and changes in matter and history on the other. Hence, changes in matter and history have no causal effect on the timeless Forms. This conclusion is based on Parmenides' notion that there is a "gap" or chorismos between the sensible world and the world of Truth and Reason, Canale, A Criticism of Theological Reason: Time and Timelessness as Primordial Presuppositions, 84 note 1.

${ }^{135}$ As a result of Vatican II, many Catholics now believe that dogma is changeable since it participates in the law of historical change, Berkouwer, The Second Vatican Council and the New Catholicism, 57, 58, 85. This is true, yet since the divine presence is timeless and temporal, the timeless aspect and the proper matter of the bread and wine still applies to the Eucharist, while the temporal aspect applies to changes in musical expression via the cultures of the world.

${ }^{136}$ Bugnini's justification for inculturation during Vatican II comes from the ontological distinction between the "invisible, unchanging, and everlasting... [and, the] human, visible, and changeable"; the former is of divine institution and the latter represents the actions of the church, which extend through time and cover the entire world. Bugnini, The Reform of the Liturgy 1948-1975, 43-44. 
Concilium, ${ }^{137}$ in post-Vatican II Eucharistic celebrations, ${ }^{138}$ and it is also found among

Protestants who have uncritically accepted the sacramental interpretation of the Eucharist and preaching. ${ }^{139}$

Second, according to dynamic timeless Being, the divine presence now permeates the entire $\operatorname{cosmos}^{140}$ and not just the transubstantiated host. ${ }^{141}$ Though not all sacramental

${ }^{137}$ In $S C$ articles $37-40$ and 119 , this Vatican II document makes an essential distinction between the substantial unity of the Roman rite and legitimate variations and adaptations to different people groups in mission lands that include variations in sacred music performed in sacred services.

${ }^{138}$ Here, the Eucharist is combined with drumming, dancing, and rock concerts. See page 58 footnote 186 in this dissertation.

${ }^{139}$ Frank Senn equates cultural studies with non-theological fields such as the humanities, architecture and the arts. He then distinguishes these from theological fields that are then grounded in sacramental worship. Senn, Christian Liturgy, xiv. John Witvliet also makes a dichotomy between scientific analysis and "theological analysis." The former represents psychology, sociology and history, while the later includes the "transcendent dimension." He also notes that dualism has profound implications for sacramental theology and liturgy. John D. Witvliet, "For Our Own Purposes: The Appropriation of the Social Sciences in Liturgical Studies," in Foundations in Ritual Studies: A Reader for Students of Christian Worship, ed. Paul Bradshaw and John Melloh(Grand Rapids, MI: Baker Publishing, 2007), 29. Also, Kauffman notes that transcendence is expressed by the content and structure of worship, namely that Word and Table are non-negotiable. Yet, style, which Kauffman largely associates with music, "varies according to cultural context.... Style is really what all the fuss has been about in worship, and much of that has been about the music we use." Richard A. Kauffman, "Beyond the Battle for the Organ: Robert Webber Calls a Truce to the "Worship Wars"," 25-26.

${ }^{140}$ Vatican II has left behind the static timeless view of God as expressed by Augustine and Aquinas. See Gaudiem et Spes, Art. 5. Pierre Teilhard de Chardin's panentheistic worldview continues to enshrine timeless Being within the evolutionary development of the world that culminates into the Omega. Chardin notes "If by its very nature it [Omega] did not escape from the time and space which it gathers together, it would not be Omega." Also, "autonomy, actuality, irreversibility, and thus finally transcendence are the four attributes of Omega," Pierre Teilhard de Pierre Teilhard de Chardin, The Phenomenon of Man (New York: Harper and Row, 1959), 270. Thus, timeless Being is enshrined within the evolutionary process. With reference to Chardin's cosmic evolution to the Omega point, Cooper states: "his aim is to combine the transcendent God of classical orthodoxy with the God immanent in cosmic evolution," a "conjunction...between the old God of the Above and the God of the Ahead." Cooper, Panentheism-The Other God of the Philosophers, 157.

${ }^{141}$ Brierley points out that in panentheism, the sacraments are no longer restricted to the liturgical activities of the church because the "whole cosmos, for panentheism, is 
traditions agree with this view of the divine presence, this interpretation nevertheless legitimizes the music of all cultures for sacred services. ${ }^{142}$ Third, in the panentheistic structure, God is made up of an intermingling between the timeless and the temporal as opposed to just being timeless in classical theism. This appears to provide the basis for blending together the timeless (chant and organ music) and the cultural aspects of music (piano, drums and guitars) in blended worship. ${ }^{143}$ We will now begin our analysis of the encounter that takes place between the divine presence and the worshippers.

\section{Encounter}

The goal of liturgy is to produce an encounter or union between the divine

sacramental, for it is something under, in, and through which God comes." Thus, "everything has the potential to become a full vehicle of the divine." Michael Brierley, "Naming a Quiet Revolution: The Panentheistic Turn in Modern Theology," in In Whom We Live and Move and Have Our Being: Panentheistic Reflections on God's Presence in a Scientific World, ed. Philip Clayton and Arthur Peacocke (Grand Rapids, MI: Eerdman's, 2004), 8.

${ }^{142} S C$, Art. 37-40, 119 declares that the music of all cultures is permissible for sacred services. SC, Art. 7 states that Christ is present, not only in the Eucharist and the sacraments, but also in His Church, in the person of His minister, in His Word when it is spoken, He is present when the church prays and sings, and in the assembled worshippers. Consequently, since the scope of the divine presence has been expanded to all things, including music, then the panentheistic structure of reality from Teilhard de Chardin provides the theological rationale behind the major changes in music at Vatican II. Teilhard de Chardin's view is that transubstantiation extends to the whole universe, which becomes Christ's body, Pierre Teihard de Chardin, Hymn of the Universe, 6.

${ }^{143}$ Jeffery notes that although the question of "musical universals" divided sacred and pastoral musicians, the post Vatican II approach to achieving "true universality" does not come through "enforced uniformity" nor "shallow broad-mindedness." Instead "true universality" will come when "the whole and each of the parts are strengthened by the common sharing." Jeffery, "Chant East and West: Toward a Renewal of the Tradition," 28. Thus, the solution is neither the chant (enforced uniformity), nor the contemporary music of all cultures (shallow broad-mindedness), but rather the blending between the two, which is but the mere expression of the dialectical structure of panentheism. Also, Thomas Long captures blended worship in its expression of the panentheistic structure of reality. He states "If traditional worship is word-driven and punctuated by organ music, and contemporary worship is music-driven with pianos, drums, and guitars, then blended worship has both," Long, Beyond the Worship Wars, 12. 
presence and human worshippers. ${ }^{144}$ A description of the encounter includes three main areas: The first is the place where worshippers receive grace and/or the divine presence, the second is the means that worshippers employ in order to experience the divine presence/grace, and the third is a depiction of the actual content that worshippers receive as a result of the encounter.

In the Sacramental model, the place where worshippers experience the divine presence, grace, forgiveness and salvation "during" the divine-human encounter is the timeless immaterial soul. ${ }^{145}$ The means that worshippers employ to appropriate grace and the divine presence during the encounter are visual, auditory and gustatory, meaning that which pertains to the sense of tasting. ${ }^{146}$ However, of the three, the visual is the most

\footnotetext{
${ }^{144}$ Support for worship as an encounter or union is found in the following works. Hall states, "The Eucharist, is all about Christ and Christ's willingness to enter into union with all those who believe in Him," Hall, Worshiping with the Church Fathers, 62. Vagaggini declares,

We must understand that the sign is the bridge over which our encounter is made with the invisible reality and this reality is made present to us, even if that encounter and that presence are always very imperfect because the sign can never contain and transmit all the wealth of the invisible reality which is expressed in it (Vagaggini, Theological Dimensions of the Liturgy, 39).

${ }^{145}$ Hislop states,

The celebration of the Holy Eucharist makes use of the eye and of touch and of taste as well as of the ear, as the means through which the eternal message of God's Being and the sense of His Presence are mediated to the soul (Hislop, Our Heritage in Public Worship, 9).

"The external sign of the sacrament points to the grace that is in the soul." Cooke, The Distancing of God, 162. "Indeed, by sacramental use man confers on visible things their supreme dignity, not merely as signs and symbols, but as effective means of grace in the soul." Daniélou, "The Sign of the Temple: A Meditation," 257.

${ }^{146}$ Hislop points out,

The celebration of the Holy Eucharist makes use of the eye and of touch and of taste as well as of the ear, as the means through which the eternal message of God's Being and the sense of His Presence are mediated to the soul (Hislop, Our Heritage in Public Worship, 9).
} 
important and prominent way in which worshippers receive the divine presence. ${ }^{147}$ With

reference to the auditory means, the vast majority of worshippers throughout the

centuries either did not hear ${ }^{148}$ what was taking place during the Eucharist, or they did not comprehend Latin as the liturgical language. ${ }^{149}$ Regarding the gustatory means, a very high percentage of worshippers partook of the Eucharistic emblems during the first three centuries. ${ }^{150}$ However, when the chalice was withdrawn from the people around the twelfth century, ${ }^{151}$ their participation and reception of the emblems greatly diminished. ${ }^{152}$

${ }^{147}$ James White points out that Congregational "participation came to be understood largely in visual terms," described as "looking at the elevation... the painting of the last judgment... saints painted on walls and glazed into windows...sculptured images in wood and stone everywhere...the whole building was a textbook of saints of the past and warnings of the future." White, A Brief History of Christian Worship, 88. Dyrness concurs, stating that the "centrality of sight" lies at the basis of the celebration. He notes, "People needed to see the host, and they would push and shove to get a better view, calling out, "Lift it higher." Simply the sight of the raised host at this critical moment, it was believed conveyed special powers." Dyrness, A Primer on Christian Worship, 20 (emphasis original). "Around the same time communion in the chalice was withdrawn from the faithful, perhaps out of an exaggerated fear of spilling the precious blood, with the result that the eucharist became a visual experience whose pinnacle was seeing the consecrated host," Baldovin, "Christian Worship to the Eve of the Reformation," 175. See also White, A Brief History of Christian Worship, 88.

${ }^{148}$ Priests whispered the prayer of consecration because it was considered to be so holy that none should hear it. See Byars, The Future of Protestant Worship, 66; Spielmann, History of Christian Worship, 59; White, A Brief History of Christian Worship, 88.

${ }^{149}$ “'The central event of Christian worship, the eucharist, thus became an event celebrated in a foreign tongue, with less and less participation - at most masses the priest alone received communion and the people were silent." Baldovin, "Christian Worship to the Eve of the Reformation," 175 .

${ }^{150}$ R.J. Halliburton, "The Patristic Theology of the Eucharist," 246. The setting of the Lord's Supper was also that of a communal meal, see Baldovin, "Christian Worship to the Eve of the Reformation," 159; Cullmann, Early Christian Worship, 14, 16; Senn, Christian Liturgy, 61; Spielmann, History of Christian Worship, 19. The location of this communal meal was mostly in homes. See Hardman, A History of Christian Worship, 17; Noakes, "From New Testament Times until St Cyprian," 119.

${ }^{151}$ See note 147 above for the reference to the Chalice being withdrawn. Hardman points out that "the people's part in Eucharistic worship shrank to small dimensions, and throughout the Church there was a continued declension from the early practice of frequent Communion," Hardman, A History of Christian Worship, 79.

${ }^{152}$ Willimon states, 
There was instead a switch from participation and reception to adoration. ${ }^{153}$ Thus, in calling for greater participation, Vatican II acknowledges the great lack of it in the past. ${ }^{154}$ Moreover, the content that worshippers receive from the visual, auditory and gustatory means in the encounter includes forgiveness, grace, power, cleansing and salvation $^{155}$ on the one hand, and ideas about God, beauty, goodness and truth on the other hand. ${ }^{156}$

In our analysis of the encounter we will note the influence of timeless Being on the interpretation of the divine presence and on human nature. For instance, the nature of the encounter that takes place in the timeless soul is an instantaneous non-historical ${ }^{157}$ encounter where God acts as the efficient cause that results in Him moving the free will

Within the Mass, the elevation of the host by the priest, accompanied by the ringing of a bell, became the main focus of popular devotion. The performing of the Mass was viewed as the way to produce the real presence of Christ so that Christ's people might adore him rather than commune with him. (Willimon, Word, Water, Wine and Bread, 58).

${ }^{153}$ The move from participation to adoration was solidified at Trent and carried on to the twentieth century. Pecklers, "History of the Roman Liturgy from the Sixteenth until the Twentieth Centuries," 154.

${ }^{154}$ See $S C$, art 14, 19, 48 .

${ }^{155}$ Scott Hahn, "Temple, Sign, and Sacrament: Towards a New Perspective on the Gospel of John," in Temple and Contemplation: God's Presence in the Cosmos, Church, and Human Heart, ed. Scott W. Hahn (Steubenville, OH: St. Paul Center for Biblical Theology, 2008), 139.

${ }^{156}$ Anderson, "To See Where God Dwells," 44; Jeffery, "Chant East and West: Toward a Renewal of the Tradition," 27.

${ }^{157}$ Aquinas states,

The entire justification of the ungodly consists as to its origin in the infusion of grace. For it is by grace that free-will is moved and sin is remitted. Now the infusion of grace takes place in an instant and without succession.... Now to will and not to will- the movements of the free-will - are not successive, but instantaneous. Hence justification of the ungodly must not be successive ( $S T 1^{\text {st }}$ part of $2^{\text {nd }}$ part Q113 Art.7).

Thus, instant means in a timeless instant, which is non-historical. 
of the worshipper to accept the gift of grace. ${ }^{158}$ In the Sacramental Model, Aristotle's timeless second substance, ${ }^{159}$ which is actually the essence and substance of the sacrament and not the matter, provides the interpretation of the divine presence. The result is that the visual, auditory and gustatory means are conditions that merely act as historical and material conveyors through which worshippers receive the presence of God. Consequently, in spite of the fact that this model allows for a cognitive encounter, the content that worshippers receive is stripped of any material or historical meaning.

158،GGod's motion to justice does not take place without a movement of the free-will; but He so infuses the gift of justifying grace that at the same time He moves the free-will to accept the gift of grace." Furthermore,

Infants are not capable of the movement of their free-will; hence it is by the mere infusion of their souls that God moves them to justice. Now this cannot be brought about without a sacrament; because as original sin, from which they are justified, does not come to them from their own will, but by carnal regeneration, so also is grace given them by Christ through spiritual regeneration. And the same holds true with madmen and idiots that have never had the use of their free-will $\left(S T 1^{\text {st }}\right.$ part of $2^{\text {nd }}$ part Q113 Art.3).

${ }^{159}$ Aristotle distinguishes between primary and secondary substances, the latter referring to what something is essentially, Metaphysics, book V part 8. Primary substances include individuals, such as a particular person, a particular cabbage and a particular horse. Furthermore, primary substances have qualities such as colors, which are said to be present in primary substances: meaning that they cannot exist apart from them. Thus, when we say it is a man or it is a horse, primary substances tell us the kind of thing "it" is: it is a "man," it is a "horse." "Secondary substances tell us what a substance is essentially; the other predicates tells us what it is accidentally," Allen and Springstead, Philosophy for Understanding Theology, 65-67. As Marias points out, in addition to primary substances, there are also universals, genera or species such as man or tree which are the "counterpart of the Platonic Ideas" and which Aristotle refers to as "secondary substances....Universals are substances, but abstract substances, abstract ingredients of each individual thing, and for this reason they are called secondary substances," Marias, History of Philosophy, 70, 71.

Moreover,

The Idea in the World. With this we are again confronted with the Platonic eidos as a metaphysical principle. Form plays the same role in the philosophy of Aristotle as it had in Plato: it determines the quiddity (essence) both in the logical and ontological order; it is being in its proper sense; it guides action and is consequently the reason for phenomena, entirely apart from the fact that in his works the form is called eidos and occasionally also the paradeigma. In addition the Aristotelian forms are as eternal as the Platonic ideas. But to Aristotle the form is, as must be emphasized again and again, immanent to the body. The world is no longer in the idea, but the idea is now in the world (Hirschberger, The History of Philosophy, vol. 1:166-167). 
First, as the bread and wine is taken into the worshipper's body, it functions as the material conveyor in which grace is infused into the soul. Second, as the priest elevates the host, worshippers experience a predominantly visual encounter that was once accompanied by a liturgical language that few understood chiefly producing a noncognitive encounter.

\section{Response to the Encounter}

The goal of liturgy is not merely an encounter, but rather, an encounter that leads to some kind of a response. In the Sacramental model, the worshippers' response to the encounter is predominantly passive. Prior to Vatican II, the main active response involved worshippers who contemplate God or moral virtues that include goodness, truth and beauty. ${ }^{160}$ In addition, post Vatican II worshippers respond to the encounter in two major ways: The first is that they have a greater understanding of the encounter as a result of the use of the mother tongue. Second, worshippers respond by the performance of liturgical dance, and by singing and playing the music of their culture. ${ }^{161}$

Our analysis of these active responses reveals that static timeless Being hermeneutically shapes how the divine presence is embedded within the objects that worshippers contemplate. For instance, in the Eucharist the timeless substance is

\footnotetext{
${ }^{160}$ Kabasele-Lumbala asserts that the body/soul dichotomy in classical theism "inspired a piety that tended exclusively toward contemplation and toward the kind of prayer that ignored the body or sought liberation from it," Kabasele Lumbala, Celebrating Jesus Christ in Africa, 25. Vagaginni notes, "the sensible world's whole reason for existence lies in its function of being shadow and image designed to lead us to the participative contemplation of the invisible heavenly realities." Vagaggini, Theological Dimensions of the Liturgy, 601. Also, Aquinas states that contemplation is an activity of the soul whose primary object is God and moral virtues. $S T 2^{\text {nd }}$ part of $2^{\text {nd }}$ part Q180 Art.3, 4.

${ }^{161}$ See Ferrone, Liturgy: Sacrosanctum Concilium, 101-104; J.G. Davies, Liturgical Dance: An Historical, Theological and Practical Handbook (London: Student Christian Movement Press, 1984), 149; Kabasele Lumbala, Celebrating Jesus Christ in Africa, 25.
} 
embedded within the bread and the wine. Worshippers respond to the encounter by contemplating it, which occurs when the worshipper abstracts the divine presence from the matter of the bread and the wine, which can be done by beholding it when the host is elevated. Similarly, Anderson alleges that the Temple is made up of a timeless substance that is embedded within the furniture of the Israelite Temple itself. Yet, the only article of furniture that worshippers actually saw was the altar in the courtyard outside. As worshippers approached the Temple, they would abstract the divine presence by gazing upon it. ${ }^{162}$ Homilies also consisted of a timeless substance embedded within the spoken words that listeners would abstract from the historical and narrative aspects of the homily. ${ }^{163}$ With regard to the contemplation of music, in clear Platonic fashion, the Scholia enchiriadis posits that "music is entirely formed and fashioned after the image of numbers. $" 164$ In other words, numbers make up the timeless and eternal substance that corresponds to the Platonic view of eternity, and the sounds of music actually express these numbers, which is equivalent to the image of the eternal and timeless numbers. For instance, with strings the sound of the octave can be expressed as 1:2, meaning that the

\footnotetext{
${ }^{162}$ Regarding the ancient Israelites who would come to the major festivals three times each year, Anderson notes that they were "allowed to contemplate the invisible God in the visible form of his domestic furniture. For, as he argues, it is through this furniture that "his unimaginable presence is shown," Anderson, "To See Where God Dwells," 44. Moreover, the following question assumes the timeless interpretation of the Temple; "If God is not fused with the very furniture of this building how could viewing it fulfill the mandate for the pilgrim?" Ibid., 42. In this question, the Sacramental model merely extends Aristotle's interpretation of the timeless second substance of the Eucharist to the Temple itself.

${ }^{163}$ See page 113-114 of this Chapter for the description of how timeless Being provides the foundation for the contents of Scripture that include timeless truths wrapped in historically and culturally conditioned clothing.

${ }^{164}$ Quoted in Blackwell, The Sacred in Music, 50. The Scholia enchiriadis is a ninth or tenth century document that embraces the liberal arts as a means of coming to know God. "Pythagoras's great discovery was that number underlies musical pitch," Ibid., 53.
} 
lower note vibrates half as rapidly as the upper note. Moreover, according to Donald

Walhout, Augustine hypothesized that numbers that underlie musical pitch have an

existence that is "not limited to that temporal product but have a timeless status as objects of rational discourse." ${ }^{165}$ As a result, the soul is led to contemplate that which is eternal and immutable, ${ }^{166}$ and which will "bring the soul in the end to a contemplation of...God."167

Static timeless Being also lies at the basis of Aristotle's active intellect, ${ }^{168}$ which is the timeless soul's mechanism by which worshippers respond to the encounter by abstracting $^{169}$ the divine presence from the physical world. In this kind of contemplation, the active intellect pierces through the bread and wine of the Eucharist and arrives at the

\footnotetext{
${ }^{165}$ Quoted in Blackwell, The Sacred in Music, 84.

${ }^{166}$ Eternity and immutability in music is best illustrated through numbers. Augustine states,
}

Seven and three are ten, not only now, but forever. There has never been a time when seven and three were not ten, nor will there ever be a time when they are not ten. Therefore, I have said that the truth of number is incorruptible and common to all who think (quoted in Blackwell, The Sacred in Music, 44).

${ }^{167}$ Walhout writes about Augustine's reflections on music in the following statement:

We might note some ways in which Augustine himself thought the soul was brought toward God by music. Music can, through its abstract core of numbers, bring the soul to contemplate the eternal, and this leads to God, since eternity is a central attribute distinguishing God from mortal things. Again, musical numbers exhibit beauty and order in their arrangement, and beauty and order are of divine origin. So music brings the soul toward God through the beauty and order of its elements. Again, the very notion of music being immaterial in a central dimension of its being will bring the soul in the end to a contemplation of the most pre-eminent of immaterial things, God (quoted in Blackwell, The Sacred in Music, 84).

${ }^{168}$ In her analysis of Being in Aristotle, Catriona Hanley points out that the active intellect apprehends non-sensible ousia or God as the emergence of the first principle of first philosophy, Catriona Hanley, Being and God in Aristotle and Heidegger (Lanham, MD: Rowman \& Littlefield, 2000), 25.

${ }^{169}$ For a thorough description and analysis of how abstraction functions in Aristotle, see Canale, A Criticism of Theological Reason: Time and Timelessness as Primordial Presuppositions, 93-95, 98-100. 
divine presence; a similar process occurs as worshippers extricate the timeless cognitive truths in sermons from the culturally conditioned contexts from which they are heard. ${ }^{170}$ With regard to music, the active intellect differentiates and abstracts the sensible sounds of music in time from the timeless mathematical basis upon which those sounds are believed to be built. ${ }^{171}$ Since the architects of Vatican II now state that the divine presence is ubiquitous, worshippers are now able to respond with the entire body, ${ }^{172}$ as well as with the soul. As a result, some now view liturgical dance as the appropriate response to the Eucharistic celebration. ${ }^{173}$

Thus far, we have briefly covered the active responses in the Sacramental model. However, as we take in the long centuries through which the Sacramental model has been in existence, we note that the worshippers in this model predominantly respond to the encounter in a very passive way. There are three major ways in which the hermeneutical role of static timeless Being leads directly to a passive response. First, by means of ex

${ }^{170}$ On page 113-114 of this Chapter, we previously noted that Scripture is made up of timeless truths that are contained in historical writings. As a result, contemplation means that the worshipper abstracts the timeless truth from its historically conditioned context.

${ }^{171}$ Blackwell, The Sacred in Music, 48. "In the tradition of Christian Pythagoreanism, contemplation, and in particular contemplation of music, is experienced as a sacramental medium" that is accomplished through the activities of the soul. Ibid., 45. Early Christian figures such as Augustine and John Scotus Erigena believed that "contemplation of music serves as a portal into sacramental experience of divine harmony and glory." Ibid., 51.

Pythagorean contemplation of music...involves a sense of trust in cosmic order, basic trust that the world is grounded in and permeated by rational pattern and principle. In the language of Christian theology, contemplation of the given and enduring logic of music contributes to trust in the second person of the Trinity, God's logos, the foundational logic of the world (Ibid., 85-86).

${ }^{172}$ Brierley, "Naming a Quiet Revolution: The Panentheistic Turn in Modern Theology," 8-9.

${ }^{173}$ J.G. Davies, Liturgical Dance, 149; Kabasele Lumbala, Celebrating Jesus Christ in Africa, 25. 
opere operato ${ }^{174}$ Christ, as the efficient cause of liturgy, infuses power and grace into the soul. Consequently, Christ determines the passive and active responses, which are merely instrumental causes. ${ }^{175}$ An instrumental cause cannot thus act in and of itself; it must be acted upon first by the efficient cause just as the sculptor employs a chisel in a work of art. Second, the ritual actions of this model that have been hermeneutically shaped by timeless Being only produce passive responses. For instance, even though worshippers were present at the Eucharist, the following rituals directly produced a non-response: the whispered prayer of consecration that was not heard, the priest's performance at the altar with his back to the people that was not seen, the disinclination to receive the chalice for fear of spilling Christ's blood, and the use of Latin, a language that few understood. For some, this begs the question as to the purpose of attending the Eucharist. ${ }^{176}$ Third, a passive response precludes the exercise of faith by a free action of the will, confession,

${ }^{174}$ The meaning of this Latin phrase assumes that Christ is the efficient cause of liturgy while the priest is the instrumental cause. Olson notes,

a baptism performed by an immoral priest with no valid ordination would not be a sacrament. But a baptism performed by an immoral or heretical priest with valid ordination and in communion with the Great Church would be a true sacrament. That is the meaning of ex opere operato (Olson, The Story of Christian Theology, 266).

This renders the exercise of faith to be unnecessary, see Millard J. Erickson, Christian Theology, 1019, 1100, 1102.

${ }^{175}$ Aquinas declares that the only condition required for grace is a human being that is composed of form and matter. Furthermore, God timelessly moves even the free will of man in the reception of grace in the sacraments. He states,

if we speak of grace as it signifies a help from God to move us to good, no preparation is required on man's part, that, as it were, anticipates the Divine help, but rather, every preparation in man must be by the help of God moving the soul to good. And thus even the good movement of the free-will, whereby anyone is prepared for receiving the gift of grace is an act of the free-will, moved by God....Hence it is said that man's will is prepared by God, and that man's steps are guided by God (ST $1^{\text {st }}$ part of $2^{\text {nd }}$ part Q112 Art.2).

${ }^{176}$ See Willimon, Word, Water, Wine and Bread, 54. See also, Byars, The Future of Protestant Worship, 66. 
repentance, a cognitive understanding, ${ }^{177}$ and human decision-making. ${ }^{178}$ The only requirement for receiving and responding to the divine presence is that worshippers are present during the Eucharist. We will now apply the appropriate conditions of method to the Sacramental model's quest for the ecumenical search for unity.

\section{Ecumenical Search for Unity}

Although the adherents of the Sacramental model refer to the Eucharist as the "sacrament of unity," Christians lead some to conclude, "too often the Eucharist has led to schism rather than unity." ${ }^{180}$ I will first trace how timeless Being directly shapes the pre and post-Vatican II interpretations of unity. Then I will analyze the hermeneutical effects of those

${ }^{177}$ Aquinas states, "Confession of sins should not be required of those who are going to be baptized." ST Part III Q68 Art.6.

Secondly, something is required of necessity for Baptism, because without it the baptismal character cannot be imprinted And thus right faith is not necessary in the one baptized any more than in the one who baptizes: provided the other conditions are fulfilled which are essential to the sacrament. For the sacrament is not perfected by the righteousness of the minister or of the recipient of Baptism, but by the power of God (ST Part III Q68 Art.8).

Thus faith is not necessary for baptism. Also, baptism can be administered to those who lack the use of reason, referring to those who are "madmen and imbeciles." ST Part III Q68 Art.12.

${ }^{178} \mathrm{Bloesch}$ notes that baptismal regeneration as espoused by Catholics, Orthodox and some Lutherans and Anglicans, brings about a regeneration of the soul that takes place "outside and prior to human decision." Bloesch, The Church: Sacraments, Worship, Ministry, Mission, 156.

${ }^{179}$ Wainwright, Worship with One Accord: Where Liturgy and Ecumenism Embrace, 177. See also, McCarthy, The Catholic Tradition, 192; Davies, The Ecumenical Century, 321; Marshall and Taylor, Liturgy and Christian Unity, 153.

${ }^{180}$ Hall, Worshiping with the Church Fathers, 51. Wainwright points out that the responses of the churches to the document Baptism, Eucharist and Ministry reveal that "in a century of ecumenism, ... the old polemical distinction between Protestantism and Catholicism as respectively the "church of the word" and the "church of the sacrament" has not been overcome. Wainwright, Worship with One Accord: Where Liturgy and Ecumenism Embrace, 42. 
interpretations of unity on this model's unconditional acceptance of the Eucharist as the essential ingredient of unity on the one hand and toleration toward nonessentials on the other.

Our analysis begins by first noting that the unchanging nature of liturgy prior to Vatican II is based on the interpretation of unity as uniformity, ${ }^{181}$ which has its foundation in Plato's two worlds theory in which history and the material world constitute the near perfect duplication of the timeless Forms. ${ }^{182}$ As a result, the Roman rite, ${ }^{183}$ the Tridentine rite, ${ }^{184}$ the use of Latin ${ }^{185}$ and Gregorian chant are believed to

${ }^{181}$ Between Trent and Vatican II there was "liturgical uniformity both in theology and practice. Pecklers, "History of the Roman Liturgy from the Sixteenth until the Twentieth Centuries,"158. "For four centuries the liturgy has retained a rigidity that made it impossible to adapt it to different cultures and national traditions." Crichton, The Church's Worship, 122. There was a "centuries-old, cast-iron uniformity." Klauser, A Short History of the Western Liturgy, 58. See also, Robert A. Burns, Roman Catholicism after Vatican II (Washington, DC: Georgetown University Press, 2001), 86; Cooke, The Distancing of God, 181; Hardman, A History of Christian Worship, 56, 93, 215.

${ }^{182}$ David Power points out that in the pre-Vatican II era, "time and history are represented by images that conform to the spatial and the unchangeable," and "certain elements are felt to defy change and allow for a certain transcultural uniformity." Power, Unsearchable Riches, 79. Frank Senn quotes Jungmann who states that the whole period after Trent was characterized as "unyielding uniformity" and "timelessness." Senn, Christian Liturgy, 485. In Platonism, the things in the world are almost perfect duplicates of the eternal Forms, and "the highest principle of all being the Form of the Good, or One." Allen and Springstead, Philosophy for Understanding Theology, 5.

183، The Roman worship at least tries to fashion a rite which will unite men of all races and of every temper. Her method is the uniformity that seeks to create a unity through common associations with the same rite and ceremonial," Hislop, Our Heritage in Public Worship, 140, 141. Furthermore, "For centuries the church has seen to it that the Roman Service was celebrated everywhere in complete uniformity, also by the people of the nonwestern cultures to whom Christianity was introduced," Tongeren, "Liturgical Renewal Never Ends," 380.

${ }^{184}$ Susan and James White provide evidence for the uniformity that surrounded the Tridentine rite. See Susan J. White, "Christian Worship since the Reformation," 189, 190; James F. White, Roman Catholic Worship: Trent to Today, 9-10.

${ }^{185}$ The following sources connect the unchanging nature of Latin to uniformity and transcendence, Hislop, Our Heritage in Public Worship, 138; Davies, From Andrewes to Baxter and Fox, 485. Also, the church was so unwilling to let go of Latin that the Chinese rites controversy of the seventeenth century "came with the injunction from Rome that 
represent the near perfect duplication of the eternal and timeless Forms. ${ }^{186}$

Just prior to Vatican II, ecumenism became the main motivational force behind

the Sacramental model's transition from a western European medieval context to a

worldwide context. ${ }^{187}$ This transition would also require a change from the pre-Vatican II

understanding of unity as uniformity ${ }^{188}$ to unity as unity in essentials and

diversity/pluralism in non-essentials. ${ }^{189}$ The post Vatican II interpretation of unity has its

Chinese priests might be ordained provided they could read Latin...even if they did not understand it." Crichton, The Church's Worship, 122 (emphasis original).

${ }^{186}$ Ambrose is credited for "approaching uniformity in church music by establishing the first of the church modes which were to provide the basis for plainsong." "Extension of the church modes and important developments in the art of plainsong are attributed to Gregory I (called "the Great"), Pope from 590 to 604)." Etherington, Protestant Worship Music, 28, 30. See also pages 130-132 for evidence of how the Chant is connected to Platonic duplication.

187، The restoration of full unity among all Christians is one of the principal aims of the Second Vatican Council." Kevin McNamara, "Catholic Principles on Ecumenism," in Vatican II on Ecumenism, ed. Michael Adams (Chicago: Scepter Books, 1966), 19. For further evidence of the ecumenical aim of Vatican II, see Ferrone, Liturgy: Sacrosanctum Concilium, 19; Sullivan, 101 Questions and Answers on Vatican II, 37-38. For evidence of worldwide aims of Vatican II, see van Beeck, Catholic Identity after Vatican II, 3; Burns, Roman Catholicism After Vatican II, 83.

${ }^{188}$ Joseph Ratzinger and Edward Schillebeeckx note the problems that uniformity produced, and both welcome the diversity that the cultures of the world bring to Christianity, Joseph Ratzinger, Theological Highlights of Vatican II (Mahwah, NJ: Paulist Press, 2009), 98, 112, 113; Schillebeeckx, The Real Achievement of Vatican II, 28.

189،"The church has no desire to impose a rigid uniformity, not even in the Liturgy," $S C$, Art. 37. Tongeren notes that the Constitution on the Sacred Liturgy wishes to put "strict uniformity from the past aside, on the condition that the unity as regards the essentials is preserved (SC 37 and 38)." Tongeren, "Liturgical Renewal Never Ends," 380. "There is no doubt that the Second Vatican Council has turned away from Roman uniformity to liturgical diversity." George A. Lindbeck, ed., Dialogue on the Way (Minneapolis, MN: Augsburg, 1965), 123. For further evidence of "unity in essentials" see Walter M. Abbott, ed. Decree on Ecumenism: Unitatis Redintegratio, Documents on Vatican II (New York: Herder and Herder, 1966), Art. 4; Berkouwer, The Second Vatican Council and the New Catholicism, 19. Also, Vatican II "spoke of the incarnation (inculturation) of the Church in diverse cultures, and with it legitimate pluriformity, not as a threat to unity but as an enrichment of Church life, a true expression of unity in diversity." Burns, Roman Catholicism After Vatican II, 86. For further evidence of "unity in diversity" see, Edward Foley and others, $A$ Commentary on the General Instruction of the Roman Missal: Developed under the Auspices of the Catholic Academy of Liturgy and Cosponsored by the Federation of Diocesan Liturgical Commissions (Collegeville, MN: Liturgical Press, 2007), 31; Frederick R. 
basis in the ontological distinction between the timeless and the temporal found in Aristotelianism, ${ }^{190}$ Neoplatonism, ${ }^{191}$ and panentheism. ${ }^{192}$ Consequently, timeless Being produces two hermeneutical effects that form the basis for this model's quest to achieve unity in Christendom. The first is the unconditional acceptance of the essentials that constitute the prerequisites for Christians to celebrate the Eucharist together, ${ }^{193}$ and the second is toleration toward the nonessentials.

Let's begin by outlining the essentials. The first essential pertains to transubstantiation as the basis for defining the real presence in the Eucharist. ${ }^{194}$ This

McManus, Sacramental Liturgy (New York: Herder and Herder, 1967), 56; Paul D. Murray, "Roman Catholic Theology after Vatican II," in The Modern Theologians: An Introduction to Christian Theology since 1918, ed. David F. Ford and Rachel Muers (Malden, MA: Blackwell, 2005), 280.

${ }^{190}$ In Aristotelian philosophy the analysis of a human being illustrates the ontological distinction between the timeless and temporal. For instance human beings are defined by the timeless essence or substance in them and not by accidental qualities like age, size, color, and vocation, see Marias, History of Philosophy, 67-71.

${ }^{191}$ In Neoplatonism, the One, through the process of emanation generates the Intellect, which in turn generates the Soul, and which finally generates the physical world. "Reality is a vertical hierarchy, a "Great chain of Being," with the most perfect and infinite on top and the least perfect and most limited (pure matter) at the bottom." (This is Cooper's analysis of Plotinus, whom he considers to be Neoplatonism's seminal thinker). Cooper, Panentheism-The Other God of the Philosophers, 41, 39. In this scenario, the One is in all things while at the same time remaining ontologically distinct from them. Ibid., 43. Also, although the One is embedded in the physical world, the world only contains the One in its most limited form since it is at the bottom of the great chain of Being. The implication for the relationship between the One and the Many, and for unity in Neoplatonism is that the One constitutes what is meaningful and thus essential, while the physical world would be considered as nonessential since it is at the bottom of the great chain of being.

${ }^{192}$ In dynamic or modern panentheism, dialectic is projected within the very heart of the One, ibid., 63, 116. Thus, the One and the Many are both composed of immutability on the one hand and historical flux and change on the other. The implication for unity is similar to Neoplatonism and Aristotelianism, namely that the timeless aspect of the One, is essential while the temporal aspect of the One which is ontologically compatible with the Many, is diverse.

${ }^{193}$ John Paull II, Ut Unam Sint, Art. 77-79.

${ }^{194}$ See pages $104-105$ of this dissertation for the timeless interpretation of the Eucharist. See also, John Paull II, Ut Unam Sint, Art. 79 for the real presence in the Eucharist as the prerequisite to unity. 
view, however, causes conflict with those who adhere to the real presence but reject transubstantiation, ${ }^{195}$ and with those who believe that the Lord's Supper is a memorial. ${ }^{196}$

The second essential is the hermeneutical role of Tradition in interpreting Scripture. ${ }^{197}$

This approach is in conflict with Protestants who adhere to the sufficiency of Scripture. ${ }^{198}$ Third is the infallible teaching authority of the Pope ${ }^{199}$ and the magisterium, ${ }^{200}$ both of

\footnotetext{
${ }^{195}$ According to Pope John Paul II's encyclical, Ut Unum Sint, the word "transubstantiation" does not appear there in his discussion of the real presence. See Art. 79. However, according to the 1999 Catechism of the Catholic Church, transubstantiation still remains the only way in which the Catholic Church understands and articulates the Real Presence. Thus, Luther and "many of the Reformers [who] preserved the essence of ex opere operato in thinking of the sacraments as acts of God," and who adhered to the Real Presence, still reject transubstantiation. See page 32 footnote 55; White, Introduction to Christian Worship, 191, 255. However, Protestants merely reject transubstantiation as the explanation for the way in which the divine presence manifests itself in the Eucharist. This is not the same as rejecting the interpretation of Aristotle's second substance.

${ }^{196}$ Although Zwingli is credited with this view, the conflict between those who believe that the Lord's Supper is a memorial and those who believe in the Real Presence still continues today among Protestants who continue to oppose both transubstantiation on the one hand and other Protestants who adhere to the Real Presence on the other. See The Lord's Supper: Five Views, ed. Gordon T. Smith (Downer's Grove, IL: IVP Academic, 2008); Understanding Four Views on the Lord's Supper, ed. Paul E. Engle (Grand Rapids, MI: Zondervan, 2007).

${ }^{197}$ Pope John Paul II points out that "Sacred Tradition [is] indispensable to the interpretation of the Word of God." Ut Unam Sint, Art. 79. For the role of timeless Being in Tradition as an indispensable tool for interpreting Scripture, see this pages 113-117 of this dissertation.

${ }^{198}$ For a few examples of Protestants who adhere to the sufficiency of Scripture, see Bloesch, The Church: Sacraments, Worship, Ministry, Mission, 289-290; Norman Geisler, Systematic Theology: Church, Last Things, 91.

${ }^{199}$ Pope John Paul states,

The Catholic Church, both in her praxis and in her solemn documents, holds that the communion of the particular Churches with the Church of Rome, and of their Bishops with the Bishop of Rome, is - in God's plan-an essential requisite of full and visible communion. Indeed full communion, of which the Eucharist is the highest sacramental manifestation, needs to be visibly expressed in a ministry in which all the Bishops recognize that they are united in Christ and all the faithful find confirmation for their faith (John Paul II, Ut Unum Sint: On Commitment to Ecumenism Art. 97).

${ }^{200}$ John Paul II, Ut Unum Sint: On Commitment to Ecumenism, Art. 79.
} 
which have their basis in holy orders, apostolic succession and infallibility. ${ }^{201}$ In contrast to this, all Protestants agree that the validity of their orders does "not depend upon episcopal ordination in the historic apostolic succession."202

The second hermeneutical effect of this model's quest to achieve unity in Christendom is toleration toward nonessentials. The theological rationale for this is based on the deduction that essentials are timeless, theological and thus unchangeable, while nonessentials are non-theological, and can change according to culture; ${ }^{203}$ and changes in the nonessentials have no causal effect on the essentials. Vatican II has played a major role in switching from unity as uniformity to unity as unity in essentials and pluralism in nonessentials. ${ }^{204}$ As a result, the Sacramental model considers music, ${ }^{205}$ architecture, ${ }^{206}$ $\operatorname{art}^{207}$ and the mode of baptism ${ }^{208}$ as nonessential. However, the switch to unity in

${ }^{201}$ See Ibid., Art. 79. For the role of timeless Being in holy orders, ordination, apostolic succession and infallibility, see pages 117-120 of this dissertation.

${ }^{202}$ Sullivan, From Apostles to Bishops, 11.

${ }^{203}$ See pages $132-133$ of this dissertation to see how timeless Being hermeneutically shapes what is essential versus what is nonessential.

204،"The church has no desire to impose a rigid uniformity, not even in the Liturgy," $S C$, Art. 37. Tongeren notes that the Constitution on the Sacred Liturgy wishes to put "strict uniformity from the past aside, on the condition that the unity as regards the essentials is preserved (SC 37 and 38)," Tongeren, "Liturgical Renewal Never Ends," 380. For further evidence, see page 146 footnote 189 of this dissertation.

${ }^{205}$ See pages 131-134 of this dissertation to illustrate how timeless Being leads to the conclusion that music is merely a cultural phenomenon.

${ }^{206}$ See this dissertation page 129 note 120 and page 133 note 139 for the link between architecture and culture based on the hermeneutical role of timeless Being.

${ }^{207}$ See page 129 of this dissertation for the link between art and culture as influenced by timeless Being.

${ }^{208}$ Using Aristotle's matter and form philosophy, Aquinas points out that although "water is essential to baptism," to insist that "washing be done this or that way, is accidental to Baptism. And consequently such diversity does not destroy the oneness of Baptism." ST Part III Q66 Art.7, see also Art.3 and 5. Elsewhere he states, "washing with water is of itself required for Baptism, being essential to the sacrament: whereas the mode of washing is accidental to the sacrament." ST Part 3, Q66, Art 8. Also, the ecumenical solution to all the 
diversity has not solved the problems in Christendom over baptism ${ }^{209}$ and over the worship wars concerning music that seem to have intensified after Vatican II. ${ }^{210}$

\section{Kerygmatic Model}

\section{Divine Presence}

In the Kerygmatic model, preaching not only constitutes the central act of liturgy, it is also indissolubly linked with the divine presence. ${ }^{211}$ The Kerygmatic model encompasses only those Protestants churches that espouse the preaching of the Scriptures as the central focus of liturgy. ${ }^{212}$ Thus, this model excludes Anglicans and other Protestants who do not exclusively adhere to preaching as central in liturgy. ${ }^{213}$ The divine presence in this model is interconnected with (1) preaching the Scriptures (2) the

conflicting modes of baptism is to make all baptismal practices accidental to the One baptism. See Baptism, Eucharist and Ministry, Faith and Order Paper No. 111 (Geneva: World Council of Churches, 1982), baptism, art. 15. For the conflicting modes of baptism, see Paul E. Engle, ed. Understanding Four Views on Baptism (Grand Rapids, MI: Zondervan, 2007); White, A Brief History of Christian Worship, 151; David F. Wright, ed. Baptism: Three Views (Downer's Grove, IL: InterVarsity Press, 2009), 11-12.

${ }^{209}$ For instance, the battles between infant and adult baptism continue. See White, $A$ Brief History of Christian Worship, 113; Fenwick and Spinks, Worship in Transition, 136. During his career Karl Barth has changed his allegiance from infant to believers' baptism, Wright, Baptism: Three Views, 12. Also, "some Roman Catholic theologians have questioned this practice." White, A Brief History of Christian Worship, 147. Also, various churches continue to practice conflicting modes such as sprinkling, pouring and immersion, see Fenwick and Spinks, Worship in Transition, 144.

${ }^{210}$ See page 19 footnotes 3 and 4 of this dissertation.

${ }^{211}$ See page 39 footnote 86 of this dissertation.

${ }^{212}$ See pages 20-21 of this dissertation for Lutherans, Reformed, Evangelical, Puritan, English Free Churches, and post 1960's Protestantism.

${ }^{213}$ Examples of Protestants who do not adhere to preaching as central include, Oscar Cullmann who states that both Word and Table constitute the central focus, Cullmann, Early Christian Worship, 14, 30; Wolfhart Pannenberg, Christian Spirituality, 40; Phifer, A Protestant Case for Liturgical Renewal, 25. 
Scriptures and the Incarnation ${ }^{214}$ and (3) the "Word...in the sacrament." ${ }^{215}$ Our analysis will begin by noting how static timeless Being connects Augustine and Luther.

Augustine placed an ontological dichotomy between the eternal word that operates in silence and the temporal preaching of the word that sounds in time. ${ }^{216}$ Augustine's analysis of Scripture forms the basis for Luther's understanding of the real

${ }^{214}$ James White points out that "the whole story of the incarnation is that of God entering history in the person of a man. And that incarnation continues every time the preacher goes into the pulpit and his words become the vehicle of God's Eternal Word. The sermon becomes a means by which God's saving power is made contemporary to every hearer." White, Protestant Worship and Church Architecture, 36. Davies point out the strong connections between the incarnation, Eucharist, and the presence of Christ manifested through the "audible" rather than "the visible World." Davies, From Andrewes to Baxter and Fox, 523. Notice that no attempt is made to distinguish or to create a different interpretation of the visible sacrament from the Puritan audible sacrament. Senn points out, "It was this incarnational understanding of the word of God for which Luther contended in his controversy over the real presence with Zwingli and the Swiss Reformers." Senn, Christian Liturgy, 307.

${ }^{215}$ For Luther's position in the relationship between Word and sacrament, see footnotes 216-221 below. In addition, after his analysis of Luther and Calvin, Jerry Carter states, "to some extent then, preaching and sacrament are one and the same experience, whereby God is assiduously working to change the human condition," Carter, "The Audible Sacrament: The Sacrament of Gardner C. Taylor's Preaching," 31. James White concurs: "There is an underlying unity between the Word made present in preaching and the Word visible in the sacrament." White, Protestant Worship and Church Architecture, 49. White also points out that the "Word preached and the Word visible are the same." Thus, it may be "necessary for some time to stress the unity of sermon and sacrament in many denominations." Ibid., 158, 159. Moreover, James White also notes the links between the pulpit and its relation to the altar-table. He states, "The pulpit will be related to the altartable to stress the unity of the Word preached and the Word made visible in the sacrament and neither liturgical center will compete too vigorously with the other for visual attention." Ibid., 176. Jerry Carter also notes that R.E.C. Browne, Karl Barth, and Charles Rice state that there is an implicit relationship between Word and Sacrament. Yet, Paul Scott Wilson, Dietrich Bonhoeffer, and Ronald Ward go a step further by "explicitly speaking of the sacramental nature of preaching." Carter, "The Audible Sacrament: The Sacrament of Gardner C. Taylor's Preaching," 44.

${ }^{216}$ Augustine: Confessions and Enchiridion LCC Vol VII, Book 11, Chapter VI.8, p. 249. Augustine notes that God does not speak in a historical sequence but rather He speaks simultaneously and forever. Otherwise, Augustine notes, "We should have time and change and not a true eternity, nor a true immortality." Ibid., Book 11, Chapter VII.9. p. 250. This ontological dichotomy leads to the deduction that the Scriptures consist of a timeless aspect and a historical aspect. 
presence in sacraments ${ }^{217}$ such as baptism ${ }^{218}$ and the Lord's Supper, ${ }^{219}$ and also in the

Lord's Prayer and the Ten Commandments. ${ }^{220}$ Christ's real presence is also closely

${ }^{217}$ In Luther's Sermons on the Catechism in 1528 where he speaks on baptism, he reminds his critics about the relationship between the Word and baptism by grounding his argument on Augustine's Lectures or Tractates on the Gospel According to St. John. In that lecture, Augustine concludes, "The Word comes to the element, and it becomes a sacrament," See $L W$ 51:187. Vajta also points out that

Luther based the real presence on the Word. It is the promise of Christ by which he offers his gifts under bread and wine, for the Word alone has the power of granting heavenly gifts in earthly forms. In this connection Luther referred to Augustine's Accedat verbum ad elementum et fit sacramentum (When the word accedes to the element, it becomes a sacrament). There can be no sacrament apart from the Word (Vajta, Luther on Worship, 100).

No attempt is made in Luther's Sermons on the Catechism concerning baptism to deconstruct Augustine's philosophical interpretation of the Word that stems from timeless Being, see footnote 216 above.

${ }^{218}$ In Sermons on the Catechism on baptism, Luther states,

baptism is a living saving water on account of the Word of God which is in it. The Word of God, however, is greater than heaven and earth, sun, moon, and all angels. Don't look at the water, and see that it is wet, but rather that it has with it the Word of God. It is a holy, living, heavenly, blessed water because of the Word and command of God, which is holy (See $L W 51: 183$ ).

He states, "Take the Word away and it is the same water with which the maid waters the cow; but with the Word, it is a living, holy, divine, water." $L W$ 51:184. "Therefore baptism is water with the Word of God, and this is the essence and whole substance of baptism." See $L W 51: 185$. Thus, in describing the water as holy and divine, no effort is made by Luther to disentangle his interpretation of the divine presence from timeless Being.

${ }^{219}$ In Sermons on the Catechism on the Lord's Supper, Luther writes,

As baptism is water and God's word conjoined, so it is here. Here the bread is not the kind of bread the baker bakes, nor is the wine the kind the vintner sells; for he does not give you God's Word with it. But the minister binds God's Words to the bread and the Word is bound to the bread and likewise to the wine, for it is said, "The Word comes to the element, and it becomes a sacrament." In all his lifetime Augustine never said anything better ( $L W 51: 189$ ).

There is no attempt here by Luther to extricate his interpretation of the divine presence in the bread and wine from that of Augustine.

${ }^{220}$ In Sermons on the Catechism on the Lord's Supper, Luther systematically interconnects his theology of the Word to the Lords' Supper, baptism, the Lord's Prayer and the Ten Commandments. He states, "You must deal with this sacrament [Lord's Supper] in the same way that you heard with regard to baptism, namely, that the chief point is God's Word and command, just as in the Lord's Prayer, the Creed, and the Ten Commandments." In the following paragraph, Luther again asserts, "In the sacraments, the Ten Commandments, and the Creed, God's Word is the chief thing." See $L W$ 51:188. In spite of 
associated with preaching. ${ }^{221}$ Moreover, Luther states, "Therefore, when you hear this word "is," then do not doubt. Thus the sacrament is bread and body, wine and blood, as the words say and to which they are connected.",222

No attempt is made by Luther to deconstruct the timeless interpretation of $i$ s or Being that he inherited from Augustine. ${ }^{223}$ Thus as other scholars note, Luther's view of the real presence is hermeneutically guided by transubstantiation ${ }^{224}$ via static timeless

Luther affirming the importance of the Word, no attempt is made to distance himself from Augustine's interpretation of the divine presence that forms the basis for interpreting the nature of the divine presence and God's Word. As a result, by linking God's Words to baptism, Lord's Supper and speech, Luther's theology of the Word is interconnected with Augustine's theology of the divine presence that stems from timeless Being.

${ }^{221 ، " C h r i s t ~ n o ~ l o n g e r ~ p r e a c h e s ~ p h y s i c a l l y ~ b u t ~ i s ~ p r e s e n t ~ w i t h ~ t h e ~ W o r d ~ a n d ~ p r e a c h e s ~ t o ~}$ the spirits in their hearts." LW 30:114 (Sermons on the First Epistle of Peter, 1522). Christ is present "in baptism, the Supper, and preaching until the end of the age." $L W$ 38:29 (The Marburg Colloquy and the Marburg Articles, 1529). "Christ gives himself to us in many ways: first, in preaching; second in baptism; [third] in brotherly consolation; fourth, in the sacrament, as often as the body of Christ is eaten." $L W 38: 19$.

${ }^{222}$ Sermons on the Catechism on the Lord's Supper. See $L W$ 51:189.

${ }^{223}$ With reference to the Lord's Supper, Luther writes, "the words are not only the sound of a man who speaks them but of God who conveys [something] to the person who eats the bread," $L W 38: 41$. Augustine previously mentioned that God's eternal word operates in silence while temporal preaching is heard in time, see Augustine: Confessions and Enchiridion LCC Vol VII, Book 11, Chapter VI.8, p. 249.

${ }^{224}$ James White notes,

Perhaps the Reformation was overly dramatic for, despite the outbursts, much more the Augustinian and medieval apparatus of thinking about the sacraments was retained than discarded. Even in railing against transubstantiation, Luther was committed to thinking of the eucharist in terms of spatial presence. And many of the Reformers preserved the essence of ex opere operato in thinking of the sacraments as acts of God.

White also states, that Luther did

wrestle with the concept of presence and though rejecting the idea of transubstantiation... did insist that the bread and wine became the substance of Christ's body and blood, though still retaining the natural substances of bread and wine....Even in rebellion, Luther is captive to medieval concepts of the presence (White, Introduction to Christian Worship, 190, 255).

Concerning transubstantiation and the real presence in medieval theology, Frank Senn notes, "The doctrine of the real presence, articulated by the dogma of transubstantiation, had an impact on the understanding of the Eucharistic sacrifice," Senn, Christian Liturgy, 252. Also, "We have seen that the medieval church explained the real presence of Christ in the 
Being. ${ }^{225}$ In other words, Luther and the Catholics believed in a real spatial presence of Christ's body and blood in the sacraments. ${ }^{226}$ While Luther rejected transubstantiation as the explanation for the change that occurs in the Lord's Supper, he never challenged the Aristotelian interpretation of the substance in the real presence, nor did he develop a Scriptural interpretation of the divine presence. This begs the question as to what exactly is the difference between Luther's view of the substance of the real presence and the Catholic view.

sacrament of the altar in terms of transubstantiation. Luther was slow in giving up this doctrine.” Ibid., 307. Hence, Luther never challenged the Aristotelian interpretation of the substance in transubstantiation, although he attacked the sacerdotal and sacrificial connections.

${ }^{225}$ For evidence concerning how timeless ontology is assumed in the connection between the real presence and Scripture in Luther, see footnotes 216-221 above. Also, Davis notes, "Luther developed his notion of real presence in relation to the emphasis on the Word of promise," Davis, This Is My Body, 28 footnote 30. Regarding the real presence, Luther writes, "Christ's body is everywhere because it is at the right hand of God which is everywhere." LW 37:213 (Confessions Concerning Christ's Supper, 1528). Hence, for Luther, Christ at the right hand of God in heaven does not detract from him being in the sacrament at the same time, since the right hand of God is not "a particular place in heaven." Ibid. Moreover, "ubiquity - Luther's explanation of Christ's real presence-is the "ontological substratum" of the Word....In speaking of ubiquity as the "new structural dimension" in Luther's Eucharistic thought, Quere indicates that ubiquity causes the Word to be repositioned in Luther's Eucharistic structure, though the Word retains its function and power." Davis, This Is My Body, 42-43, footnote \#5. "The expression of power in the Eucharist, shown or signified by the real presence comprehended in the Word, is the guarantee that God's Word is reliable." Ibid., 50. To Luther, "The word is as much a means of grace as the sacraments." Senn, Christian Liturgy, 306. Moreover, "It is noteworthy that this passage about the real presence of Christ in the preaching of the word is found in a treatise in which Luther was defending the real presence of Christ in the sacrament." Ibid., 306, also 310. In connecting his view with that of Augustine, Luther is grounding his position on the basis of timeless ontology. For the role of static timeless Being in the real presence and ubiquity, see this dissertation pages 109-110. For evidence concerning how timeless ontology is assumed in the connection between the real presence and Scripture in Calvin, see the following: "Rather than regarding the Supper as something that supplements the more central ministry of the Word, Calvin taught that the elements of baptism and the Lord's Supper were visible forms of the Word." Hart, Recovering Mother Kirk, 27. Also, "The sacraments, like preaching, are the vehicle of Christ's self-communication, of the real presence." Ibid.

${ }^{226}$ However, in The Babylonian Captivity of the Church, Luther extended the scope of the divine presence to the accidents as well as to the substance while the Catholic view asserts that the divine presence is limited to the substance of the bread and wine, see $L W$ $36: 31-35$. 
Protestant theologians who declare that preaching is a sacrament, ${ }^{227}$ are assuming that the divine presence is static and timeless. ${ }^{228}$ As a sacrament, preaching is primarily a means of grace and power, as well as the vehicle to make Christ present; it is not about specific knowledge of God provided by Scripture, or about therapy, promotion or education. ${ }^{229}$

The Kerygmatic model does not produce an understanding of the Incarnation that differs from the Sacramental model. For instance, Horton Davies points out that it is inconsistent for Cranmer to affirm a substantial unity between Christ and human nature in the Incarnation, "while denying it in the Eucharist." ${ }^{230}$ The justification behind Davies' perceptive observation is that static timeless Being shapes the issue of Christ's presence in such a way that there can be no change with respect to omnipresence, even after the Incarnation. To do so, would produce a contradiction since by definition the timeless view of omnipresence is immutable. As a result, the substance of Christ is present in the Incarnation and in the Eucharist, which works well within the framework of static timeless Being. ${ }^{231}$

${ }^{227}$ Karl Barth points out that preaching becomes a third sacrament in Reformation theology, quoted in Bloesch, The Church: Sacraments, Worship, Ministry, Mission, 180. Horton Davies declares that preaching is a sacramental communication of the gift of the Gospel mediated by the Holy Spirit, Davies, The Ecumenical Century, 253. Moreover, according to Hart, "The Sacraments, like preaching, are the vehicle of Christ's selfcommunication of the real presence," Hart, Recovering Mother Kirk, 27.

${ }^{228}$ Horton Davies perceptively notes that Zwingli failed to "define a presence of Christ in the Sacrament any different from its modality in the preaching of the word." Davies, From Cranmer to Hooker, 103.

${ }^{229}$ See pages $39-40$ of this dissertation.

${ }^{230}$ Davies, From Cranmer to Hooker, 118.

${ }^{231}$ See this dissertation pages 108-110 for our analysis of how static timeless Being lays the groundwork for the communicatio idiomatum and ubiquity in the Sacramental model. 
Furthermore, the principles of the Enlightenment do not alter the interpretation of the divine presence. Kant's radical epistemology declared that knowledge is restricted to the world of space and time, which means that we cannot know anything outside of space and time or in the timeless realm. ${ }^{232}$ Since grace and power belong to the timeless substance of the sacrament, this reduced preaching from a means of grace to a testimony of grace. ${ }^{233}$ When preaching is a means of grace, it assumes that the cognitive content is interpreted on the basis static timeless Being. When preaching is a testimony to grace, Kant's epistemology precludes any cognitive content in preaching. The reason is that cognitive content is timeless, yet worshippers can only know what is in space and time. Thus, there is no cognitive communication in preaching. However, in both cases there is no change in the interpretation of the divine presence. Consequently, the emphasis that the Kerygmatic model places on preaching the Scriptures has not produced an interpretation of the divine presence that differs from that of transubstantiation.

\section{Liturgist}

The Protestant liturgists in the Kerygmatic model all agree that the "validity of their orders and ministry does not depend on episcopal ordination in the historic apostolic

${ }^{232}$ Kant's radical epistemology, which still assumed the uncritical acceptance of timeless Being, reduced what the human subject could know to the world of time and space, see Marias, History of Philosophy, 287. Yet, at the same time Kant did not deny or overthrow the existence of entities like God that were interpreted on the basis of timeless Being; he only declared that they were unknowable. See Immanuel Kant, Critique of Pure Reason, trans., J.M.D. Meiklejohn (London: Henry G. Bohn, 1855), 36.

${ }^{233}$ Bloesch, The Church: Sacraments, Worship, Ministry, Mission, 113-114. Bultmann assumes Kant's structure, which reduces the act of preaching to a "speech event" that is stripped of any cognitive content. See Fernando Canale, A Criticism of Theological Reason: Time and Timelessness as Primordial Presuppositions, 265-266 
succession. ${ }^{, 234}$ For the Magisterial Reformers, the discovery of the priesthood of all believers led to the following three implications for the liturgist: (1) Christ has abolished the need for an earthly Levitical system whose authority comes from dynastic succession, ${ }^{235}$ and he has also abolished the need for the Sacramental Model's view of apostolic succession (2) God's Word alone authorizes and legitimizes all that the liturgists in the Kerygmatic model perform ${ }^{236}$ and (3) there is no longer any ontological difference between priests, pastors and laity. ${ }^{237}$ However, merely being part of the priesthood of all believers does not entitle one to perform the principal task of the liturgist ${ }^{238}$ which is to preach the Word and administer the sacraments. ${ }^{239}$ In this model, the Lord chooses ministers in order to guard and equip His church. ${ }^{240}$ These men were later set aside and ordained for this task by the entire church and not just one individual

${ }^{234}$ Sullivan, From Apostles to Bishops, 11.

${ }^{235}$ Calvin points out

When the priesthood is transferred, there is a necessarily a transference of the law as well [Heb 7:12]. All priestly offices have been transferred to Christ and are fulfilled and completed in him. The whole right and honor of the priesthood has therefore been transferred to him (See $I C R$, Book 3 Chapter 4.4, p. 627).

${ }^{236}$ Ibid., Book 4 Chapter 9.2, pages 1166-1167.

${ }^{237}$ Ibid., Book 2 Chapter 7.1; Book 4 Chapter 19.28, p. 1476. Abolishing the ontological distinction between clergy and laity seemed to be symbolized by the adoption of the black Geneva gown in Protestant clergy, which more closely approached the common dress of the general populace than the sacred vestments worn by Catholic clergy, see Webber, ed. Music and the Arts in Christian Worship, Part 3, Section 316.

${ }^{238}$ As far as baptism is concerned, Lutherans and all other Reformed churches rejected the practice of baptism by lay persons, see Hatchett, Sanctifying Life, Time, and Space, 100; Willimon, Word, Water, Wine and Bread, 66.

${ }^{239}$ Calvin, Book 4 Chapter 3.6, pages 1058-1059.

${ }^{240}$ Calvin, Book 4 Chapter 3.2, p. 1055. These include apostles, prophets, evangelists, pastors and teachers. 
or a smaller group of individuals like the elders. ${ }^{241}$

Our analysis comprises how the liturgist in the Kerygmatic model relates to the issue of the efficient cause of liturgy, and the nature of the liturgist's authority. In spite of the discovery of the priesthood of all believers and of the claim that God's Word alone authorizes and legitimizes the liturgist and the ritual actions he performs, Luther's uncritical assumption of static timeless Being hermeneutically shaped his understanding of justification by faith through monergism ${ }^{242}$ and the bondage of the will. ${ }^{243}$ Consequently, God and not the liturgist, continues to be the efficient cause of the actions that the liturgist performs. This means that God moves the will and actions of the liturgist despite the appearance to the contrary since the liturgist is merely an instrument in God's hands. $^{244}$

${ }^{241}$ Ibid., Book 4 Chapter 3.15, pages 1065-1066; Luther, On the Councils and the Church--Part III (1539) in $L W$ 41:148-157.

${ }^{242}$ Roger Olson points out that Luther's understanding of justification by faith assumes monergism, which logically makes the recipient of justification totally passive thus making it entirely a work of God. Olson, The Story of Christian Theology, 426, 455, 466.

243،"God foreknows nothing contingently, but that he foresees and purposes and does all things by his immutable, eternal, and infallible will." Thus,

everything we do, everything that happens, even if it seems to us to happen mutably and contingently, happens in fact nonetheless necessarily and immutably, if you have regard to the will of God. For the will of God is effectual and cannot be hindered, since it is the power of the divine nature itself ( $L W 33: 37-38)$.

Hence, Luther's view on the bondage of the will is the logical consequence of the timeless interpretation of predestination, see John Peckham, "An Investigation of Luther's View of the Bondage of the Will with Implications for Soteriology and Theodicy," Journal of the Adventist Theological Society 18, no. 2 (Autumn 2007): 274-304. James White notes that Luther is "concerned that sacrifice too easily becomes a form of righteousness based on human activity rather than on God's. Ultimately, worship depends entirely on God's activity, not that of human beings," White, Protestant Worship: Traditions in Transition, 39.

${ }^{244}$ Luther taught that the church is a spiritual assembly where the Word is preached, "otherwise it is not the true church," LW 51:305. Sermon in Castle Pleissenburg, 1539. See also Justo González, From the Protestant Reformation to the Twentieth Century, vol. 3 of $A$ History of Christian Thought (Nashville, TN: Abingdon Press, 1987), 63. Moreover, "Each German State was free to devise its own system of pastorates," Hardman, A History of 
Calvin asserts that God not only willed the church into existence by his election, ${ }^{245} \mathrm{He}$ is also "present in his institution" 246 and claims that God's word is the authority behind all the functions that the liturgists perform. ${ }^{247}$ However, since God's will is grounded in timeless eternity, his description of the minister as a tool that the workman (God) uses to do his work logically leads to the conclusion that Christ must then be the efficient cause of liturgy, and also of the authority that liturgists exercise. ${ }^{248}$ Thus, in spite of the brief turn to the Scriptures, Luther and Calvin still ground the authority of the liturgist in the timeless view of the divine presence and human nature. This leads to the conclusion that the liturgical actions that liturgists perform are not caused by the liturgists' own will; they are instead caused by Christ who is the efficient cause of liturgy and of the liturgist's authority.

\section{Liturgical Setting and Actions}

The ritual actions that are linked with preaching the Scriptures that we will describe and analyze include four main areas: liturgical space, liturgical time, frequency and length. With regard to liturgical space in the Kerygmatic model, James White points

Christian Worship, 147. In the Free churches, it was the local congregations and the minister that decided the worship of the local church. This also gives the appearance of the church as the efficient cause of liturgy, Spielmann, History of Christian Worship, 83.

${ }^{245}$ Calvin, ICR Book 4 Chapter 1.3, p. 1015.

${ }^{246}$ Ibid., Book 4 Chapter 1.5, p. 1017; Book 4 Chapter 3.1, p. 1053.

${ }^{247}$ Ibid., Book 4 Chapter 9.2, pages 1166-1167.

${ }^{248}$ For instance, Calvin speaks of "the order by which the Lord willed his church to be governed." He points out that although Christ is not visibly present among us, He "uses the ministry of men to declare openly His will to us...just as a workman uses a tool to do his work," Ibid., Book 4 Chapter 3.1, p. 1053. Moreover, Calvin also asserts that Adam and Eve have fallen by the will of God. See Ibid., Book 3 Chapter 21.5, 7, pages 926, 930; Chapter 23.4, p. 951. Finally, in comparing the ministry of men as a tool in Christ's hand, it is also clear that the liturgists in Calvin's system constitute the instrumental cause of liturgy, while Christ constitutes the efficient cause. 
out that the pulpit is the liturgical center from which Bible lessons are read and the Word is preached. ${ }^{249}$ In fact, everything in the building was "subordinate to the pulpit [which]...formed the dominant architectural focus." ${ }^{250}$ As a result, pulpits were huge ${ }^{251}$ and the focus of attention. ${ }^{252}$ One of the characteristic features of the meeting houses in the Kerygmatic model includes galleries and balconies that serve the purpose of bringing the people as close to the pulpit as possible so they could hear the preaching of the Word. ${ }^{253}$ As a result, "Reformed churches mostly did without organs, choirs, and other instrumentalists but the galleries were still built to accommodate those who came to church to hear sermons." ${ }^{254}$ Lastly, the meetinghouses in the Kerygmatic model are

\footnotetext{
${ }^{249}$ White, Protestant Worship and Church Architecture, 37. In Puritan worship, "the entire service was led from the pulpit except during the sacraments." Ibid., 106.

${ }^{250}$ Ibid., 106. Even during days of persecution, the pulpit provided the only church facility available for French Protestants who fled from one hiding place to another so that they could hear God's Word. Ibid., 35.

${ }^{251}$ For instance, Puritan liturgical centers included pulpits that were as much as twelve feet tall, Ibid., 82, 106. Some meetinghouses had two and three decker pulpits. Early Methodist chapel, opened in 1778 , contains what used to be a three-decker pulpit now shorn of the top five feet of its former fifteen-foot height, see ibid., 115. Puritans had two and three decker pulpits in their meetinghouses. See Davies, From Andrewes to Baxter and Fox, 62. Moreover, "the presence of galleries accounts, in part, for the excessive height of the pulpit." Ibid., 65.

${ }^{252}$ Some of the pulpits of the eighteenth century "were of the wineglass variety [and] were perched upon four or more legs. Occasionally two curving staircases swept up from either side," White, Protestant Worship and Church Architecture, 106. In contrast to this were the nineteenth century pulpits that replaced them, which were described as desk pulpits. Ibid. "Many great revivalist preachers preferred a small desk-like pulpit big enough to hold only their notes. But they relished a large platform on which to make sorties in all directions as they pleaded for conversions." Ibid., 124.

${ }^{253}$ Galleries were "one of the most common characteristics of Puritan meetinghouses." Ibid., 107. The dominant themes in Lutheran church buildings were visibility and audibility. See White, A Brief History of Christian Worship, 139. Congregations gathered about the pulpit "on the main floor and in an encircling gallery." White, Protestant Worship and Church Architecture, 106.

${ }^{254}$ Senn, Christian Liturgy, 531. Since the altar-table was not the principal liturgical need, it could be brought out only when needed, which was about four times/year, by placing it in or at the head of an aisle, ibid.
} 
plain, "elegant in their simplicity...clean, well-lighted...[and without] traditional symbols., 255

The rediscovery of the Scriptures led directly to the centrality of the pulpit, the huge size of the pulpit, galleries for the purpose of hearing the Word preached, and the simplicity of Kerygmatic meetinghouses. Although these architectural changes do not appear to have any connection to static timeless Being, the Kerygmatic model has not advanced a Biblical understanding of the architectural setting that is directly shaped by a biblical view of the divine presence or of divine or heavenly realities. This neglect has eventually led to confusion regarding what the Kerygmatic model claims is centralwhich is preaching — and what its liturgy and architecture actually communicate about what is central. ${ }^{256}$ For instance, as a result of Kant's epistemology ${ }^{257}$ there is emphasis among some Protestants that the Eucharist should be the center of the church's liturgy and not the sermon. ${ }^{258}$ There is also the post-Vatican II emphasis on Word and Table ${ }^{259}$

${ }^{255}$ White, Protestant Worship and Church Architecture, 107. See also, Davies, From Andrewes to Baxter and Fox, 7, 25. Anabaptists had modest structures, focusing chiefly on an extended pulpit that might accommodate several preachers. White, A Brief History of Christian Worship, 139. "The same characteristics are reflected in their [Baptists and Quakers] simple meeting-houses, which are as unsacerdotal and unecclesiastical as it is possible to be." Davies, From Andrewes to Baxter and Fox, 496.

${ }^{256}$ In spite of this growing demand for art, the English Free Churches of the Kerygmatic model have not been supportive of this on account that "their worship until very recently was auditory rather than visual, emphasizing the importance of preaching, and depreciating the sacraments. This has changed in recent decades, but the tradition of four hundred years is not easily overcome." Davies, Crisis and Creativity, 231.

${ }^{257}$ See this dissertation page 156 footnote 232 .

${ }^{258}$ This is Pannenberg's position, Christian Spirituality, 40. However, if Kant's epistemology precludes any cognitive communication between a timeless God and the worshipper, then it begs the question as to how the real presence can be found in the Eucharist. James White notes that it was the Enlightenment principles that brought an end to the weekly celebration of the Eucharist in most Lutheran countries. White, Introduction to Christian Worship, 160. See also, Byars, The Future of Protestant Worship, 67.

${ }^{259}$ Pecklers, Worship: A Primer in Christian Ritual, 3. 
among adherents of the Kerygmatic model that is combined with a growing demand for Christian art in the last half of the twentieth century. ${ }^{260}$ This continued emphasis on the sacramental and the visual, combined with the neglect to break free from the interpretive shackles of timeless Being is leading churches that were once connected with the Kerygmatic model to move toward the Sacramental model.

We will now proceed to our description and analysis of the preaching of justification by faith and its relationship to liturgical time and the adiaphora in the Kerygmatic model. The adiaphoristic controversy ${ }^{261}$ and Luther's concept of natural law $^{262}$ that was borrowed from Aquinas ${ }^{263}$ led to the following hermeneutical effects: (1) preaching justification by faith was essential, ${ }^{264}$ which was emphasized by the length of

${ }^{260}$ Davies, Crisis and Creativity, 213, 218, 227.

${ }^{261}$ In an effort to preserve the importance of justification by faith the Leipzig Interim of December 17, 1548 conceded the validity of the seven sacraments "and agreed to regard many medieval rites and ceremonies as useful adiaphora... [whose meaning signifies] a thing that makes no difference." Senn, Christian Liturgy, 325.

${ }^{262}$ Although Luther does not mention the Sabbath in the context of the adiaphora, one can easily draw the conclusion from the following statement that for the Luther, the Sabbath constitutes part of the adiapora. He asserts,

It is not necessary to observe the sabbath or Sunday because of Moses' commandment. Nature also shows and teaches that one must now and then rest a day, so that man and beast may be refreshed. This natural reason Moses also recognized in his sabbath law, for he places the Sabbath under man, as also Christ does....For where it is kept for the sake of rest alone, it is clear that he who does not need rest may break the sabbath and rest on some other day, as nature allows ( $L W 40: 98)$.

${ }^{263}$ Bauckham, "Sabbath and Sunday in the Protestant Tradition," in From Sabbath to Lord's Day: A Biblical, Historical and Theological Investigation, ed. D.A. Carson (Grand Rapids, MI: Zondervan, 1982), 313; Sigve K. Tonstad, The Lost Meaning of the Seventh Day (Berrien Springs, MI: Andrews University Press, 2009), 425. Aquinas points out that natural law is unchangeable and does not vary according to time, $S T 1^{\text {st }}$ Part of Part II Q.94 Art.5. For the connection between natural law and eternal law, see $S T 1^{\text {st }}$ Part of Part II Q91 Art.2.

${ }^{264}$ Luther's preaching was everywhere pervaded by the overarching idea of justification by faith, see Broadus, Lectures on the History of Preaching, 122. Justification by faith is the one doctrine upon which the church stands or falls, Senn, Christian Liturgy, 326. 
the sermon ${ }^{265}$ as well as by the frequency ${ }^{266}$ (2) sacraments and medieval rites were nonessential, thus one could either observe them or not observe them ${ }^{267}$ (3) the Seventhday Sabbath is a nonessential ceremonial precept ${ }^{268}$ that is regulated by positive law ${ }^{269}$ not natural law and (4) all other festivals should be abolished and only Sunday

${ }^{265}$ Anabaptist preaching rarely lasted less than an hour, Puritan preachers could preach for three hours on a fast day, and sermons in the first half of the twentieth century were twice as quiet and half as long as the discourses in the Victorian pulpit. See this dissertation page 49 .

${ }^{266} \mathrm{As}$ far as frequency is concerned, some Reformation preachers in Zurich preached fourteen times a week while in Wittenberg there were three sermons on Sunday and daily sermons throughout the week. See this dissertation page 48.

${ }^{267}$ González points out that Melanchthon's theological rationale behind accepting medieval rites and ceremonies "lay in the distinction between the essential and the nonessential - the adiaphora. In essential matters - especially the doctrine of justification by faith... one must not compromise. But compromise on the adiaphora is often required for the peace of the church." González, From the Protestant Reformation to the Twentieth Century, 120. Melanchthon alleges that these rites and ceremonies, which are neither commanded nor forbidden in Scripture, are matters that God has granted the Church to change according to its circumstances. See ibid., 3:122; Senn, Christian Liturgy, 326.

${ }^{268}$ For Aquinas, setting aside time to rest is in accordance with natural law and is moral just like the other commandments. However, at the same time the command to keep the Sabbath is a ceremonial precept since it specifies a particular time, $S T 2^{\text {nd }}$ Part of Part II Q122 Art.4. Luther states, "For where [the Sabbath law] is kept for the sake of rest alone, it is clear that he who does not need rest may break the Sabbath and rest on some other day, as nature allows." $L W$ 40:98. Hence, Luther's assertion that the Sabbath commandment has "both moral and ceremonial aspects-God's command to rest being moral, and the specific day being ceremonial," is indebted to Aquinas. See Kenneth A. Strand, "Sabbath and Sunday in the Reformation Era," in The Sabbath in Scripture and History, ed. Kenneth A. Strand (Hagerstown, MD: Review and Herald, 1982), 216.

${ }^{269}$ Aquinas points out that offering sacrifice belongs generically to natural law but the determination of the various kinds of sacrifices belongs to positive law, which can be determined by man, ST $1^{\text {st }}$ part of Part II Q99 Art.3. Consequently, based on this reasoning, it is not stretching the argument to apply positive law to the Sabbath. Moreover, Aquinas also indicates that fasting is a precept of the natural law "while the fixing of the time and manner of fasting as becoming and profitable to the Christian people, is a matter of precept of positive law established by ecclesiastical authority: the latter is the Church fast, the former is the fast prescribed by nature," $S T 2^{\text {nd }}$ part of Part II Q 147 Art.3. Moreover, the Catechism of the Council of Trent also reinforces the idea that the Sabbath commandment does not belong the moral law but to the ceremonial law because it is not a principle of natural law, The Cathechism of the Council of Trent, 1st American ed. (Baltimore, MD: J. Murphy, 1829), 264. See also Tonstad, The Lost Meaning of the Seventh Day, 425. 
observance should be maintained, ${ }^{270}$ yet Sunday should be stripped of Sabbatarian restrictions that had become attached to it. ${ }^{271}$

The philosophy of Parmenides, Plato and Aristotle creates an ontological dichotomy between eternity and time, and between form and matter. It is this dichotomy that hermeneutically shapes how justification by faith relates with the adiaphora and liturgical time. For instance, since the preaching of justification by faith ${ }^{272}$ is linked with the divine presence it is analogous to the Platonic Idea or to Aristotle's second substance and is thus considered to be sacramental and essential. Moreover, divine predestination functions as the eternal timeless cause of justification by faith. ${ }^{273}$ Consequently, there are several hermeneutical effects. First, the adiaphora, which includes the seventh-day Sabbath, is considered to be nonessential and thus has no causal effect on justification by faith and the divine presence. ${ }^{274}$ Second, the dichotomy between time and eternity

${ }^{270}$ Strand, "Sabbath and Sunday in the Reformation Era," 216. Zwingli and Calvin also agreed about the practicality of Sunday observance without enforcing the kinds of Sabbatarian restrictions held by Catholics. Ibid., 217, 220.

${ }^{271}$ Ibid., 216.

${ }^{272}$ Although contemporary Protestant leaders have, for the most part, forsaken the Reformation view of justification by faith, Norman Gulley mentions the following Protestant scholars who still strongly adhere to the importance of this doctrine: He mentions J.Van Genderen and W.H. Velema, Thomas Torrence R.C. Sproul, Bruce L. McCormack, Carl E. Braaten, and D. James Kennedy, Gulley, Systematic Theology: Creation, Christ, Salvation, 798-799.

273،"The great Protestant Reformers, Martin Luther and John Calvin, causally connected the gospel, justification by faith, and the assurance of salvation to divine predestination. In other words, the divine action that causes salvation is divine predestination," Fernando Canale, Basic Elements of Christian Theology: Scripture Replacing Tradition (Berrien Springs, MI: Andrews University Lithotech, 2005), 137. See also, G.C. Berkouwer, Studies in Dogmatics: Faith and Justification (Grand Rapids, MI: Eerdmans, 1954), 141-151, 162-163; Olson, The Story of Christian Theology, 383, 421-422, 426.

${ }^{274}$ Canale makes a similar observation concerning how timeless ontological assumptions in connection with justification by faith lead evangelicals to differentiate between the necessary and unnecessary portions of Scripture. For instance, according to 
constitutes the ground for separating the moral act of resting that is predicated on natural law from the ceremonial day of rest, which is regulated by positive law. Third, other liturgical actions in this model such as the mode of baptism ${ }^{275}$ and musical style ${ }^{276}$ are also nonessential. Fourth, Anglican Reformers asserted that the ritual actions in the NT are nonessential. ${ }^{277}$ Fifth, the authority behind the ritual actions, which includes the choice and enforcement of the day on which one rests, is derived from the church or the state ${ }^{278}$ it is no longer based on the Sola Scriptura principle. ${ }^{279}$

evangelicals, Rom 3:20-28 is considered to be more directly connected to the gospel than James 2:14-26. Fernando Canale, The Cognitive Principle of Christian Theology: A Hermenuetical Study of the Revelationa and Inspiration of the Bible (Berrien Springs, MI: Andrews University Lithothec, 2005), 211-212. Moreover, the essential nature of justification by faith has also led others to regard the deluge of Genesis 6-9 as the adiaphora were regarded in Melanchthon's day. Ibid., 461-462.

${ }^{275}$ For instance, Calvin points out that although the term baptize means to immerse, and that this was the form used by the primitive church, nevertheless, "these details are of no importance." Calvin, Book 4 Chapter 15.19, p. 1320. Charles Hodge points out, "The mode of applying water as the purifying medium is unessential. The only necessary thing is to make such an application of water to the person, as shall render the act significant of the purification of the soul." Charles Hodge, Systematic Theology, 3 vols. (Grand Rapids, MI: Eerdmans, 1952), 3:526. Bloesch also believes that all forms of baptism are legitimate. Bloesch, The Church: Sacraments, Worship, Ministry, Mission, 158-159. Aquinas held the same view, see this dissertation page 148 footnote 208. Yet, others state that these views clash with the Biblical data, see Geisler, Systematic Theology: Church, Last Things, 169171; Wayne Grudem, Systematic Theology, 967-969.

${ }^{276}$ The ontological distinction between the timeless and temporal is assumed by Protestants who make distinctions between Word and Table (timeless) and musical style (temporal). See this dissertation page 133 footnote 139.

${ }^{277}$ The Anglican Reformers stated that liturgical matters found in the New Testament "are not necessarily binding on the church of all ages." See González, From the Protestant Reformation to the Twentieth Century, 187.

${ }^{278}$ The Puritan enforcement of Sunday through civil legislation is also based on the ontological dichotomy between time and eternity that previously led Aquinas to conclude that the Sabbath should be regulated by positive law. For Aquinas and positive law being ascribed to man, see this dissertation page 163 footnote 269. For the Puritans and civil legislation, see Walter B. Douglas, "The Sabbath in Puritanism," in The Sabbath in Scripture and History, ed. Kenneth A. Strand (Hagerstown, MD: Review and Herald, 1982), 229, 241.

${ }^{279}$ According to Melanchthon, the adiaphora are neither commanded nor forbidden in Scripture, thus God has granted the Church authority over them. See González, From the Protestant Reformation to the Twentieth Century, 122; Senn, Christian Liturgy, 326. This is 


\section{Encounter}

In the Kerygmatic model, the purpose of preaching is to make Christ present for the purpose of having "union with Christ." ${ }^{280}$ A description and analysis of the encounter between the divine presence and the worshipper includes the content that worshipers receive as a result of the encounter, the means employed in order to experience the divine presence, and the place where worshipers receive the divine presence.

In the encounter, the content includes God as the subject matter of contemplation, ${ }^{281}$ the heavenly mysteries, ${ }^{282}$ Christ and His righteousness, ${ }^{283}$ and the experience of justification by faith. ${ }^{284}$ Also, since sermons are preached in the native tongue, one can meditate on and understand the content of the message. The means employed for receiving the divine presence are predominantly auditory. This is underscored by the simplicity of the architecture, the centrality of the pulpit and the focus on preaching the Scriptures. However, the sight of a solid sturdy pulpit gives a sense of the divine-human encounter that is possible in preaching by suggesting an authority that

also Aquinas' position, thus showing that the Kerygmatic model assumes the same ontological structure as the Sacramental model.

${ }^{280}$ Davis, This is My Body, 105. Davis also notes:

God reveals Godself to fallen humanity...God sustains redeemed humanity through God's action and presence in the body of Christ. The body of Christ is the sine qua non of Christian life. The Christian experience is nothing more and nothing less than participation in that body. And that, for John Calvin, is how God is to be known. Scripture, Sacrament, and preaching point to that body and present it; the Holy Spirit joins the Christian to it. Calvin was never able to fully comprehend, much less explain to others, the details of the mode of union (Ibid., 107).

${ }^{281}$ Ibid.

${ }^{282}$ Calvin, Book 3 Chapter 2.34, pages 581-582.

${ }^{283}$ Dargan, From the Apostolic Fathers to the Great Reformers, A.D. 70-1572, 365, 388; Vajta, Luther on Worship, 78.

${ }^{284}$ This dissertation page 162 footnote 264 . See also page 45 . 
is far higher than the preacher's personality. ${ }^{285}$ With regard to the place of the encounter, it is clear that reason and intelligence appear to be the ultimate location where worshippers experience the divine presence. Yet, according to Calvin, reason and intelligence are the activities of the soul, thus they belong exclusively to the soul and not the body. ${ }^{286}$ Consequently, it is the timeless soul, which includes the use of reason, that ultimately receives and processes the messages that are preached. ${ }^{287}$

I will first analyze how contemplation occurs before examining the content itself. Calvin notes that the preaching of the word "cannot penetrate into our minds unless the Spirit, as the inner teacher, through his illumination makes entry for it." ${ }^{288}$ The Spirit

${ }^{285}$ White, Protestant Worship and Church Architecture, 46.

${ }^{286}$ Calvin, ICR, Book 1 Chapter 15.3, p. 188. Moreover, it is the intellect that performs the act of contemplation, which belongs to the soul, Ibid., ICR, Book 1 Chapter 15.6, p. 193.

${ }^{287}$ Calvin points out,

That the word may not beat you ears in vain and that the sacraments may not strike your eyes in vain, the Spirit shows us that in them it is God speaking to us, softening the stubbornness of our heart, and composing it to that obedience which it owes the Word of the Lord. Finally, the Spirit transmits those outward words and sacraments from our ears to our soul (Ibid., Book 4 Chapter 14.10, pages 1285-1286).

Luther states that Christ "Himself comes, is spiritually present, and speaks and preaches to the hearts of the people, just as the apostles address their words orally and physically to the ears of the people." LW 30:114 (Sermons on the First Epistle of St. Peter, 1522). According to Davis, "the Eucharist is the medicine of the soul, in Luther's mind, because it presents the healing Word of Christ." Davis, This is My Body, 31. According to Calvin, the immortal soul is not chained to the body, and neither are the powers of the soul confined to the performance of bodily functions. Calvin, ICR, Book 1 Chapter 5.5, pages 56-57. Moreover, the following functions exclusively pertain to the immortal soul: measuring, counting, ascertaining, reasoning, remembering and analyzing, ibid. Referring to the sacraments, which still assume the same presuppositional structure as preaching, Calvin asserts that the Holy Spirit penetrates the heart and procures access for the sacraments into our souls. Ibid., Book 4 Chapter 14.9, p. 1284.

${ }^{288}$ Ibid., Book 3 Chapter 2.34, p. 582. Moreover, sin has totally depraved all aspects of the soul so that supernatural grace is required in order to heal it, ibid., Book 2 Chapter 1.9 , pages 252-253. As a result man is now deprived of freedom of will and miserably enslaved, ibid., Book 2 Chapter 2, pages 255-288. Thus, any righteous act of man is really an act of God who moves the will of man by grace, ibid., Book 2 Chapter 3.7, pages 298- 
does this by ontologically enhancing the soul of the worshipper so that worshippers can contemplate timeless truths. ${ }^{289}$ This process sounds surprisingly close to that of Aquinas. ${ }^{290}$ Moreover, although worshippers employ reason and intelligence to process preaching, Calvin points out that the use of reason and intelligence are activities that belong to the timeless soul and not to the body. ${ }^{291}$ Hence, the notion of an ontologically enhanced intellect leads directly to the timeless soul as the component in human nature that ultimately receives and processes the messages that are preached. ${ }^{292}$ Since the divine presence and action are timeless, the corresponding result on the soul is that because it is totally depraved it can only be passive during the encounter. ${ }^{293}$ As a result, regardless of the actual subject matter of contemplation, the cognitive content of preaching is stripped

299. Therefore the illumination of the soul by God, and the penetration of the Word by the Spirit into our depraved soul, must happen timelessly without any cooperation on the part of the worshipper.

${ }^{289}$ When God illumines the soul it "takes on a new keenness, as it were, to contemplate the heavenly mysteries, whose splendor had previously blinded it." Ibid., Book 3 Chapter 2.34 , p. 582. In the encounter, a timeless divine presence necessitates a timeless soul capable of processing the encounter.

${ }^{290}$ Aquinas states that the prophet's intellect must be ontologically increased beyond natural reason so that the prophet may comprehend supernatural knowledge, $S T 2^{\text {nd }}$ Part of $2^{\text {nd }}$ Part Q 171 Art.2.

${ }^{291}$ Calvin, ICR, Book 1 Chapter 15.3 and 15.6, pages 188, 193.

${ }^{292}$ Ibid., Book 4 Chapter 14.9 and 10, pages 1284-1286. Davis, This is My Body, 31.

${ }^{293}$ Calvin points out,

Therefore, I make such a division between Spirit and sacraments that the power to act rests with the former, and the ministry alone is left to the latter - a ministry empty and trifling, apart from the action of the Spirit, but charged with great effect when the Spirit works within and manifests his power (Ibid., Book 4 Chapter 14.9, p. 1284).

Moreover, although seeing and hearing is naturally implanted in the eye and the ear, in contradistinction to this Christ acts in our minds "by special grace beyond the measure of nature." Ibid, p. 1285. In other words, it is impossible to understand the light of God's Word without the kind of special grace that bypasses free will. According to Calvin, this would be like trying to see without an eye. Thus, God creates the eye and the ray, and God sends the Word and creates the understanding of the worshippers without any cooperation on their part. 
of anything historical or material. This is evident in Calvin's treatment of the Sabbath where he states that it represents perpetually resting from one's works; ${ }^{294}$ and his emphasis on God as the principal object pertaining to supernatural knowledge. ${ }^{295}$

\section{Response to the Encounter}

In the Kerygmatic model, the mind has a much larger role to play than it did in the Sacramental model, not only in mentally processing the sermon but also in responding to it. ${ }^{296}$ Hence, worshipers respond to the encounter by choosing to (1) understand the preached Word, since one aim of preaching is didactic and expository (2) contemplate the divine presence (3) give praise to God and experience conversion, healing, therapy, and revival (4) exercise their will by making decisions based on the sermon, and applying the ethical teachings of Jesus and (5) overthrow error and preserve ecclesiastical institutions. $^{297}$

Our analysis of the presuppositional structure reveals that this model interprets Christ as the efficient cause of justification, ${ }^{298}$ grace, and the faith that worshippers'

${ }^{294}$ Worshippers are to meditate constantly on the spiritual rest that the Sabbath provides. In their contemplation, they are never to lose sight of the mystery of perpetual resting from their works. In clear Platonic fashion, Calvin compares the Sabbath to a shadow that disappears as a result of the Advent of Christ. Similarly to Luther, he also refers to it as the "ceremonial part of this commandment." Ibid., Book 2 Chapter 8.31, p. 397. As a result, the act of contemplation by the soul does not include the historical and material vehicles, instead it exclusively concerns itself with timeless truths.

${ }^{295}$ Davis, This is My Body, 107. For Aquinas, see $S T 2^{\text {nd }}$ Part of $2^{\text {nd }}$ Part Q 171 Art.2. Yet, both Calvin and Aquinas share the same interpretation of the divine presence and human nature as the foundational presuppositional structures for the encounter.

${ }^{296}$ Hart points out, "God initiates through his Word, and believers respond in praise, prayer, hearing the Word preached and read, and receiving the sacraments." Hart, Recovering Mother Kirk, 29.

${ }^{297}$ See this dissertation pages 39-41 for evidence for all five responses.

${ }^{298}$ Through predestination, God is the cause of justification, which took place in timeless eternity, see this dissertation page 158 footnote 243 and page 164 footnote 273 . 
exercise $^{299}$ in response to preaching. ${ }^{300}$ Accordingly, the responses of the worshippers

constitute the instrumental cause, which is identical to the Sacramental model. ${ }^{301}$ As a

result, the worshippers' exercise of faith does not arise from an autonomous and

undetermined will. If it did, then justification would be "dependent upon a human

condition." 302 Also, for Luther as well as Calvin, the faith response of the worshipper is

interpreted as an entirely passive one, even though worshippers give the appearance of

actively responding to the encounter. ${ }^{303}$

${ }^{299}$ Faith is defined in "such a way that it moves wholly from and in grace." Berkouwer, Studies in Dogmatics: Faith and Justification, 175. Here it is evident that Berkouwer is building from the same foundations as Calvin and Aquinas in his understanding of the operation of grace.

${ }^{300}$ Vajta points out that faith is entirely a work of God, which means that "God's work is the ground and cause of faith." Vajta, Luther on Worship, 24, 128. See also, Berkouwer, Studies in Dogmatics: Faith and Justification, Berkouwer, Studies in Dogmatics: Faith and Justification, 178.

${ }^{301}$ Calvin asserts that God's will operates timelessly, which hermeneutically precludes any cooperation and contribution from human beings. Calvin illustrates this by comparing God to a workman and His ministers to a tool used by the workman. See, this dissertation page 159 footnote 248. Hart seems to echo this when he states, "God initiates through his Word, and believers respond in praise, prayer, hearing the Word preached and read, and receiving the sacraments." Hart, Recovering Mother Kirk, 29. For the Sacramental model, see this dissertation page 117 footnote 72; page 143 footnotes 174 and 175 .

${ }^{302}$ Berkouwer, Studies in Dogmatics: Faith and Justification, 171. Berkouwer notes that "Correlation, is not drawn about a subjective axis consisting of a work of love or of obedience to God's commandments." Ibid., 178.

${ }^{303}$ Luther clearly contrasts two kinds of righteousness, active and passive. In clear Platonic fashion he states,

But we imagine as it were two worlds, the one heavenly and the other earthly. In these we place these two kinds of righteousness [active and passive], being separate the one far from the other. The righteousness of the law is earthly and hath to do with earthly things, and by it we do good works,

which is "earthly and active righteousness. But this righteousness is heavenly and passive: which we work not, but apprehend it by faith." Luther then asks,

Do we work nothing for the obtaining of this kind of righteousness? I answer: Nothing at all. For the nature of this righteousness is, to do nothing, to hear nothing, to know nothing whatsoever of the law or of works, but to know and to believe this only, that Christ is gone to the Father and is not now seen ( $L W 26: 8)$. 


\section{Ecumenical Search for Unity}

The purpose of this section is to first analyze the implications for the search for unity around the time of the Reformation, and then to analyze the impact of the Liturgical and Ecumenical movements on the Kerygmatic model and its attempt to unify Christendom on the basis of preaching the Scriptures. The analysis of the Reformation will examine how static timeless Being negatively impacted the search for unity by looking at the following three liturgical actions: (1) preaching justification and the nature of faith (2) the Marburg Colloquy over the Lord's Supper, and (3) the Magisterial Reformers and the Anabaptists concerning baptism. While these three areas are not the only liturgical actions in this model that have been associated with challenges, I chose justification by faith for the reason that it is directly connected to preaching the Scriptures as the main liturgical action of this model. I also chose the controversy over the Lord's Supper and baptism because both have proven to be contentious issues that are still a source of conflict in this model today. ${ }^{304}$

He goes on to state, "Thus I abandon myself from all active righteousness, both of mine own and of God's law, and embrace only that passive righteousness." $L W 26: 6$. The following is from Vajta's analysis of Luther. "Man becomes a "priest" "passively," as it were, by receiving Christ's work through Word and sacrament." Vajta, Luther on Worship, 128-129. "Luther's continuing emphasis is on the passive character of faith." Ibid., 129. "Passivity" is the mark of righteousness by faith as contrasted with the righteousness of works which is an "active" righteousness. Here the difference is between a righteousness that God gives, to be received passively by man, and one that he would infuse into man's soul as to enable him to develop faith from his own spiritual resources." Ibid. "Faith might be defined as a passive cult... because in this life it will always depend on the worship by which God imparts himself - a gift granted to the believing congregation." Ibid., 130. "God alone is active and man entirely passive." Ibid., 131. "Hearing is not a work of man to prepare himself for grace, but an entirely passive attitude." Ibid., 133. Calvin also states, "For, as regards justification, faith is something merely passive, bringing nothing of ours to the recovering of God's favor but receiving from Christ that which we lack." Calvin, ICR Book 3 Chapter 13.5, pages 768 .

${ }^{304}$ For issues over the Eucharistic presence, see this dissertation pages $30-38$. For baptism, see this dissertation page 165 footnote 275 . 
Justification by faith, predestination, monergism, and the sovereignty of grace

constitute the basis for those who propose that faith represents God's work alone. ${ }^{305}$ Such a view of salvation can only be true "if it is foreordained and eternally decreed." ${ }^{, 306}$ In clear opposition to this view, the Anabaptists and Arminius clearly rejected monergism thereby affirming the possibility of human beings to either accept or reject the grace of God. ${ }^{307}$ However, even though the Anabaptists and Arminius initially began their rejection of monergism on the basis of Scripture, their use of prevenient grace still assumes the static timeless view of God and human beings on which prevenient grace is built. ${ }^{308}$ Consequently, the assumption of static timeless Being by the Magisterial

${ }^{305}$ See footnote 300 above. In our analysis on Luther, Christ as efficient cause is identical to monergism, which is the basis of predestination and the sovereignty of grace. Olson notes that Zwingli and Calvin treat God's all-determining sovereignty and power as the first principle of Christian thought which functions as "Reformed theology's central organizing theme- the hub that holds everything together." Consequently, "If God is God...then absolutely nothing else can have any independent power or determination." Olson, The Story of Christian Theology, 402. After recounting the great faith exercised by Bible characters that resulted in salvation, Berkouwer's assumption of timeless Being leads him to conclude that interpreting "faith as a condition that comes along with salvation...would be to manipulate faith...into a work of the law. And this would touch the sovereignty of grace." Berkouwer, Studies in Dogmatics: Faith and Justification, 188. However, a phenomenological analysis of these Bible stories leads to the conclusion that faith is indeed a condition for healing and salvation.

${ }^{306}$ This means that the acceptance of salvation by sinners is not freely and actively chosen but given unconditionally and irresistibly. Olson, The Story of Christian Theology, 466.

${ }^{307}$ For Anabaptists such as Balthasar Hubmaier, Menno Simons, and Arminius, see ibid., 422, 426, 455.

${ }^{308}$ In his analysis of Hubmaier's theology, Olson notes that he was

the first Protestant thinker openly to espouse belief in free will on the basis of a work of God in Christ and through the Holy Spirit. Free will, destroyed by the Fall, is restored by Christ and by the Spirit of God working through the Word of God (Ibid., 422).

For further support, see Thomas N. Finger, A Contemporary Anabaptist Theology: Biblical, Historical, Constructive (Downer's Grove, IL: InterVarsity Press, 2004), 471, 489. Although this line of reasoning grants human beings the possibility of resisting the divine will, it still assumes the timeless view of the nature and actions of God, as well as the timeless view of grace that includes the timeless soul as location of this grace that results in free will. In his 
Reformers that resulted in monergism on the one hand, and the inability of the

Anabaptists and Arminius to deconstruct and overcome its operation by building on Scripture on the other, made it very difficult to unify over the nature of faith.

The Marburg Colloquy over the Lord's Supper also had large implications for unity. The differences between Luther's view of the Lord's Supper as the real presence, and Zwingli's view of it as a memorial, are largely based on the following points. Both used Scripture. For instance, Luther argued for a real presence on the basis of Christ's words in Matt 26:26 $6^{309}$ and Zwingli argued for a memorial on the basis of John 6:63. ${ }^{310}$ Luther's view of the real presence in the Lord's Supper assumed that the divine presence is ubiquitous while Zwingli held that Christ is in heaven. ${ }^{311}$ Luther's view that Christ's body is substantially present in the Lord's Supper does not depart from the Aristotelian

analysis of Arminius, Canale points out that Arminius' notion of God's foreknowledge is grounded in His timeless nature, and that God's will is eternal and that His decision causes all other things. This means that "God's predestination...causes what He eternally foresees in His own timeless immutable being." Canale, Basic Elements of Christian Theology: Scripture Replacing Tradition, 140. This forms the foundation for Arminius' assertion that free will is unable to begin without grace, and that grace is absolutely necessary for the inclination of the will to that which is good; also, grace operates the will. Olson, The Story of Christian Theology, 470. Thus, instead of developing a new Biblical ontology of grace, which assumes a Biblical ontology of divine and human nature, the result is that the claims of Arminius - that humans are capable of resisting the divine will and are therefore freeare clashing against the inner logic that flows from his uncritical adoption of the timeless view of God's nature and actions. These presuppositions lead to the inevitable thought that "nothing temporal can condition a timeless immutable God." Canale, Basic Elements of Christian Theology: Scripture Replacing Tradition, 140.

${ }^{309}$ LW 36:341, 343. Matt 26:26 states, "This is My Body," which forms the basis for Luther's view as the real presence.

${ }^{310}$ The reference in John 6:63 points out that the flesh profits nothing, instead the words that Jesus speaks are spirit and life. It is on this basis that Zwingli denied the real presence in the Lord's Supper. Moreover, since Christ is in heaven, He cannot also be "substantially present in the consecrated elements." See Davies, From Cranmer to Hooker, 82.

${ }^{311}$ For Luther on the ubiquity of Christ's presence, see $L W$ 37:213. Davies asks, "Where is the "body" of Christ located: on the altar, in heaven, or in the hearts of the faithful?" See Davies, From Cranmer to Hooker, 77. 
interpretation of the divine presence, ${ }^{312}$ and his view of Christ's ubiquity is also the result of static timeless Being. ${ }^{313}$ Although Zwingli opposed the doctrine of the real presence, he did not develop a Biblical ontology of the divine presence. He also failed to deconstruct the underlying timeless ontology that Luther assumed in his position. As a result, the hermeneutical role of static timeless Being has played a much larger negative role between these two Reformers and their search for unity than has been previously recognized. The crisis has brought to light the failure of this model to apply the Sola Scriptura principle to the interpretation of Being, the divine presence, and human nature, which in no small way has contributed to schism over the Lord's Supper.

Let's now examine the contention between the Magisterial Reformers and the Anabaptists on the issue of infant versus adult baptism. ${ }^{314}$ There are two theological causes for this division. We have already analyzed the first one, which is timeless Being's

${ }^{312}$ Here we must make a distinction between the mode of the divine presence and the interpretation of the divine presence.

${ }^{313}$ In fact, the disagreement between the positions of Luther and Zwingli on the "location" of the divine presence in the Eucharistic celebration is the result of differing views on the nature of Christ, specifically the Lutheran acceptance of communicatio idiomatum - the communication of attributes. See González, From the Protestant Reformation to the Twentieth Century, 129-130. See also, Olson, The Story of Christian Theology, 395. For a further analysis of the role of static timeless Being on the ubiquity of Christ's human and divine natures and the communicatio idiomatum, see this dissertation pages 108-110.

${ }^{314}$ This issue bitterly divided Protestants and even led Zwingli to persecute the Anabaptists. Willimon, Word, Water, Wine and Bread, 74. Some Anabaptists made believers' baptism a necessity for salvation while also indicating that those who still practiced infant baptism were meriting eternal damnation, Davies, From Cranmer to Hooker, 338. For Reformers supporting infant baptism see Hardman, A History of Christian Worship, 154; Senn, Christian Liturgy, 288, 369; Jeffrey A. Truscott, "The Rite of Holy Baptism in the Lutheran Book of Worship," in Baptism Today: Understanding, Practice, Ecumenical Implications, ed. Thomas F. Best (Collegeville, MN: The Liturgical Press, 2008), 45; White, "Christian Worship since the Reformation," 188. For the persecution of the Anabaptists over the question of infant baptism, see Olson, The Story of Christian Theology, 417. 
role in rendering the mode of baptism as inconsequential. ${ }^{315}$ The second cause of theological division is the connection between timeless Being, predestination and infant baptism. ${ }^{316}$ The following points illustrate how static timeless Being directly leads to infant baptism: (1) God functions as the sole cause of all of humanity's decisions ${ }^{317}$ (2) humans possess a corrupt and depraved will that is unable to choose the way of salvation without God's grace and power, ${ }^{318}$ (3) human beings participate in the sin of Adam, ${ }^{319}$

\footnotetext{
${ }^{315}$ See this dissertation page 149 footnote 208 for Catholics and page 165 footnote 275 for Protestants.

${ }^{316}$ Monergism, predestination, and the sovereignty of grace is something that the
} Reformers share with Augustine. Olson connects predestination with monergism, which points to "God's agency as all-determining in both universal history and individual salvation," making Augustine's God "an all-determining reality." This is the master thread that guides Augustine's thoughts, giving shape to those doctrines most associated with him, Olson, The Story of Christian Theology, 255-256. Since Augustine is convinced that God cannot act in the historical sequence of past, present, and future (NPNF, First Series, The Confessions of St. Augustin 1:205), therefore, the timeless paradigm, working through Platonic philosophy is what drives Augustine's interpretation of predestination. For Aquinas' strong support of the same kind of predestination as Augustine, see $S T$ Part 1 Q23 Art.1, 2, 5, 8. Kiesler points out the connection between predestination and infant baptism. He states, "Like Augustine, Calvin had a strong interest in predestination, especially in connection with the baptism of children." Herbert Kiesler, "The Ordinances: Baptism, Foot Washing, and Lord's Supper." In Handbook of Seventh-day Adventist Theology, ed. Raoul Dederen (Hagerstown, MD: Review and Herald, 2000), 590.

${ }^{317}$ For Augustine, see Olson, The Story of Christian Theology, 274. Aquinas declares, "predestination applies to angels, just as it does to men," ST Part I Q23 Art.1. Moreover, "Predestination is not anything in the predestined; but only in the person who predestines," ST Part I Q23 Art.2. "Thus God from all eternity prepared by predestination" the salvation of "some," ST Part I Q23 Art.1-2. For the Reformers, see this dissertation page 158 footnote $243 ; 164$ footnote $273 ; 172$ footnote 305 and 308; 175 footnote 316 .

${ }^{318}$ LW 33:37-38; Aecio E. Cairus, "The Doctrine of Man," in Handbook of SeventhDay Adventist Theology, ed. Raoul Dederen (Hagerston, MD: Review and Herald, 2000), 226. This is echoed in Luther's emphasis on The Bondage of the Will, see Gulley, Systematic Theology: God as Trinity, 477-478. Blazen also links together Luther's bondage of the will and original sin as being the result of predestination, Ivan T. Blazen, "Salvation," in Handbook of Seventh-Day Adventist Theology, ed. Raoul Dederen (Hagerstown, MD: Review and Herald, 2000), 304. For Calvin, see this dissertation page 159 footnote 248; 167 footnote 287; 168 footnote 293; 170 footnote 303.

${ }^{319}$ This participation occurs in much the same way that objects in Platonic philosophy "participate" in the timeless forms. 
which results in original $\sin ^{320}$ and (4) this logically leads to infant baptism which Augustine considered as "proof of original sin." ${ }^{321}$ Hence, infant baptism is not only the remedy for the disease of original sin, it also proves its existence and is thus causally related to it as the remedy.

In contrast to infant baptism is the position of the Anabaptists who baptized consenting adults who were able to make intelligent decisions regarding their faith. However, their rejection of monergism, predestination and infant baptism did not lead

The Augustinian and Calvinistic anthropologies affirm that the act by which sin came into the world of mankind was a self-determined and guilty act and that it is justly chargeable upon every individual man equally and alike. But this requires that the posterity of Adam and Eve should, in some way or other, participate in it. Participation is the ground of merited imputation, though not of unmerited or gratuitous imputation.... The posterity could not participate in the first sin in the form of individuals, and hence they must have participated in it in the form of a race. This supposes that the race-form is prior to the individual form, that man first exists as a race or species and in this mode of existence commits a single and common sin (Shedd, Dogmatic Theology, 444 (emphasis mine)).

Erickson also uses the word "participate" to describe the same phenomenon. Erickson, Christian Theology, 923. In Aristotle's philosophy of form and matter, it is the timeless form (equivalent to the timeless Platonic Idea) that explains motion and that gives shape to matter. This means that the cause of movement in matter does not come from matter but from the timeless form embedded in matter. Similarly, Shedd borrows Aristotle's philosophy of form and matter in order to explain how humans after Adam are guilty of Adam's sin by actually participating in it through their timeless soul (equivalent to Shedd's form of the race and Aristotle's form) prior to them actually becoming individuals (this is equivalent to Shedd's individual form and Aristotle's matter).

${ }^{320}$ Stoicism's principle of matter as the basis of all reality, along with the material basis of both body and soul led to the

doctrine of the transmission of the soul and of original sin.... This doctrine, known as "traducianism," is the basis on which Tertullian affirms that, just as the soul is transmitted from parents to children, so is sin. Thus, original sin becomes an inheritance that children derive from their parents, just as they derive their body (González, From the Beginnings to the Council of Chalcedon, vol. 1 of A History of Christian Thought (Nashville, TN: Abingdon Press, 1987), 183; Stumpf, Socrates to Sartre, 123).

Accordingly, the condemnation and guilt of sin is attributed to the infant via the immortality of the soul thus logically leading to infant baptism as the solution.

${ }^{321} N P N F$, First Series, 5:xxiv (Introductory Essay), 12, 18, 30. Others have also noted how predestination logically leads to original sin as the human condition. See Erickson, Christian Theology, 927-928; Hodge, Systematic Theology, 2:715-716; Shedd, Dogmatic Theology, 530, 783-784. 
them to criticize the underlying static timeless ontology that they assumed. Neither did they develop a biblical ontology for their connection between free will and adult baptism. Developing a biblical ontology of human nature as the broader framework for understanding free will would have provided theologians and biblical scholars in this Model with Scriptural criteria that they can apply to the issues surrounding the mode of baptism. The failure of this Model to do this has contributed to the ongoing controversy over baptism. ${ }^{322}$

We now move toward an analysis of the impact of the Liturgical Movement on the Kerygmatic model, and the implications for the ecumenical search for unity. In the late nineteenth and early twentieth centuries, the Liturgical ${ }^{323}$ and Ecumenical Movements, especially the former began to greatly influence the churches of the Kerygmatic model. ${ }^{324}$ The Liturgical Movement is "an interdenominational reformation of Catholic and Protestant import," whose effect has been to increase the "ecumenicity of

\footnotetext{
${ }^{322}$ For instance, the battles between infant and adult baptism continue, see White, $A$ Brief History of Christian Worship, 113; Fenwick and Spinks, Worship in Transition, 136. During his career Karl Barth has changed his allegiance from infant to believers' baptism, Wright, Baptism: Three Views, 12. Also "some Roman Catholic theologians have questioned this practice." White, A Brief History of Christian Worship, 147. Moreover, various churches continue to practice conflicting modes such as sprinkling, pouring and immersion, see Fenwick and Spinks, Worship in Transition, 144.

${ }^{323}$ Horton Davies states,
}

The Liturgical Movement may be defined as an interconfessional renewal of Christian worship and life which sees in the self-offering of the Eternal Son of God on the Cross a Sacrifice which is both the descent of Divinity and the ascent of the Perfect Humanity, and therefore as the type and pattern of Christian worship in the Eucharist, the nexus of Christian unity, the inspiration of all human talents and labour, and the supreme means of grace (Davies, The Ecumenical Century, 13).

${ }^{324}$ Ibid. The influence of the Liturgical movement on the English Free Churches such as Presbyterian and Baptist, who traditionally emphasize the centrality of preaching, is found in ibid., 378, 380-381. See also Fenwick and Spinks, Worship in Transition, 81-92. 
Christians in a tragically divided world. ${ }^{, 325}$ The movement itself is nourished by the return to the Bible and the patristic sources, and it is alleged that it is from these sources that both the "Reformation and the liturgical movement stem." ${ }^{326}$ Moreover, "the primary concern of the Liturgical Movement [is] the restoration of the Eucharist to its central place in truly corporate worship,"327 which "has an immediate link with the question of Christian unity., 328

We will now outline the Liturgical movement's impact on the Kerygmatic model and its ability to unify Christendom on the basis of preaching. First, Horton Davies alleges that instead of unifying Christendom, preaching has "accelerated the momentum towards splintering so characteristic of the history of Protestantism. ${ }^{\not 22}$ Moreover, the cause of schism in the Kerygmatic model is not only an overemphasis on preaching, but also a depreciation of the sacraments. ${ }^{330}$ Second, this devaluation of the sacraments has

${ }^{325}$ Davies, The Ecumenical Century, 14.

${ }^{326}$ Vilmos Vajta, "Renewal of Worship: De Sacra Liturgia," in Dialogue on the Way, ed. George A. Lindbeck (Minneapolis, MN: Augsburg, 1965), 103.

${ }^{327}$ Davies, The Ecumenical Century, 14. Its other characteristics include the importance of community instead of individualism, participation, a rediscovery of the early church as a model, the rediscovery of the Bible as an essential part of the eucharist, an emphasis on the vernacular, the rediscovery of other Christian traditions, and an emphasis on proclamation and social involvement. Fenwick and Spinks, Worship in Transition, 5-11.

${ }^{328}$ Allchin, "The Liturgical Movement and Christian Unity," 26.

${ }^{329}$ Davies, The Ecumenical Century, 433. This may explain why the content of preaching has evolved from the polemical sermons of the Victorian pulpit to the ecumenical sermons of the twentieth century.

${ }^{330}$ Ibid. "The Liturgical Movement has awakened many Protestants denominations to the poverty of symbols in their worship; worship reduced to the exchange of spoken words, excluding the material and the sensory, has often produced verbose, abstract, intellectualistic, or merely notional services." Davies, Crisis and Creativity, 193. He also states that as the element of adoration disappeared or was minimized that the Christian faith became over-intellectualized as a result of preaching. Moreover, Davies points out that it was the rejection of the sacraments that led to the cult of the popular preacher as well as to the splintering of Protestantism. Davies, The Ecumenical Century, 433. Allchin describes the sixteenth century Reformation in Europe as "an upheaval rather than a movement-and 
led some adherents of the Kerygmatic model to switch to liturgy that is much more visual $^{331}$ by recovering "the sacraments as the integral component of worship on the Lord's Day, thus enhancing their typically Word-oriented worship." ${ }^{, 332}$ Third, the emphasis on the sacraments has further led the adherents of the Kerygmatic model to supplement their preaching centered liturgy with symbolism, film, drama, occasional dancing, as well as processions and banners. ${ }^{333}$ Fourth, the emphasis on the Eucharist has also produced a shift in the theological understanding of the Lord's Supper from a memorial to the real presence and the chief means of grace. Consequently, in order to achieve unity, preaching must be combined with the sacraments, especially the Lord's Supper: it cannot stand alone. ${ }^{334}$

one which, so far from being a unifying force, tended to divide and disrupt Western Christendom." Allchin, "The Liturgical Movement and Christian Unity," 28.

331، The richness of the significance of the sacraments is in their visual and dramatic character and the many meanings that they suggest to the devoted and attentive worshiper." Davies, Crisis and Creativity, 203. "There are signs in architecture (if not in art) that the Free Churches are overcoming their aesthetic iconoclasm as a result of their participation in the Ecumenical and Liturgical Movements." Davies, The Ecumenical Century, 435.

${ }^{332}$ Davies, Crisis and Creativity, 3. This emphasis is something totally new in the Free Churches. Davies notes that in the Free Churches, "the Lord's Supper is rarely an appendix to the preaching services for the pious few," which is how it was regarded by many ministers in the Free Churches earlier in the twentieth century. Davies, The Ecumenical Century, 392. Davies also notes that "Every Free Church denomination... has a comprehensive and genuinely ecumenical order for Holy Communion in its official servicebook." "Such unity with the Universal Church of Christ in the chief Sacrament would have been unthinkable, even for the most sanguine of prophets only fifty years ago [1915]. It is the greatest single achievement of the combined Liturgical and Ecumenical Movements." Ibid., 393.

${ }^{333}$ Davies, Crisis and Creativity, 4. In our analysis of the Sacramental model, we discovered that timeless ontology leads to the Word and Sacrament as essential while film, drama and occasional dancing are cultural contributions, see this dissertation pages 149-150.

${ }^{334}$ Neville Clark, a Baptist, "argues for a worship which indissolubly unites Word and Sacrament." Davies, The Ecumenical Century, 380. "The error of Protestantism...is that it has often forgotten that the Word is always incarnated or embodied in some manner," just as the sacraments are. Davies, Crisis and Creativity, 202. "The most important elements in embodied worship, the sacraments, are both symbol and ceremony." Ibid., 194. "For both Catholics and Protestants unity was discovered in the coordinate stress on Word and 
Hence, by acquiescing to the agenda of the Liturgical and Ecumenical

Movements, the Kerygmatic model has placed in jeopardy its own existence as a

liturgical model. Its chief problem has been its failure to develop a Biblical ontology of

the divine presence in preaching as the basis for unity. Instead, it has uncritically

accepted the static timeless view of the divine presence and human nature. This has

ultimately paved the way for the inclusion of the Eucharist along with preaching as a

sacrament as central for liturgy and as the basis of unity in Christendom. We will now

proceed to our description and analysis of the Charismatic model.

\section{The Charismatic Model}

\section{Divine Presence}

The Charismatic model includes (1) Pentecostalism, ${ }^{335}$ (2) the charismatic movement or charismatic renewal ${ }^{336}$ that has been heavily influenced by

Sacrament." Ibid., 212. Moreover, combining "spoken word and "visible word"...gives the complete pattern of Christian worship." Davies, The Ecumenical Century, 381.

${ }^{335}$ The traditional model is that Pentecostalism is an American phenomenon that gradually spread throughout the world. In this traditional model the Azusa Street revival that took place in Los Angeles in 1906 was the Jerusalem from which the Spirit went out to the nations. Yet, recent major studies (1987 and on) of the origins of the movement in Argentina, Chile, Ghana, Korea, the Philippines, South Africa, and South India have forced historians to make revisions to the earlier paradigms.

The picture that is now becoming clear is that of a series of local "Pentecostalisms" emerging in the first decade of the twentieth century. The 1906 revival at Azusa Street was one of them. So was the 1903 revival in Pyongyang, Korea; the 1905-7 revival at Pandita Ramabais Mukti Mission in Poona, India; the Manchurian revival of 1908: the revival in Valparaiso, Chile, in 1909; the revival that broke out in the Ivory Coast, the Gold Coast, and the Liberian Km in 1914; and other revivals in Norway, China, Venezuela, and elsewhere. Each of these revivals demonstrated Pentecostal characteristics, though there was no clear connection between them. What we can now recognize as Pentecostalism was well established in India before anyone there had heard of Charles Parham, Azusa Street, or William Seymour. (Alister E. McGrath, Christianity's Dangerous Idea: The Protestant Revolution - a History from the Sixteenth to the Twenty-First Century (New York: HarperOne, 2007), 421-422).

${ }^{336}$ Peter Hocken points out, 
Pentecostalism, ${ }^{337}$ and (3) the Emerging Church that has evolved from the charismatic renewal. ${ }^{338}$ The divine presence formerly mediated through the Eucharist and preaching now becomes inextricably linked with music itself. ${ }^{339}$ In fact, the "immediacy of the Holy

The term 'charismatic movement' was coined by H. Bredesen and J. Stone in 1963 to designate what was at first called neo-Pentecostalism, that is, the occurrence of Pentecostal-type blessing within the historic Protestant denominations. This was the general connotation of 'charismatic movement' in the mid-1960s. By the late 1960s, however, there were independent groups and ministries, often calling themselves nondenominational, that identified more with the charismatic movement than with Pentecostalism per se. These nondenominational currents, which spread in the 1970s and mushroomed in the 1980s, are now generally recognized as part of the overall charismatic movement, in which we may distinguish three major strands: (1) charismatic renewal in the historic Protestant churches (from the 1950s); (2) charismatic renewal in the Roman Catholic Church (from 1967); (3) charismatic renewal in the independent sector (from the late 1960s) (Peter Hocken, "Charismatic Movement," in The Encyclopedia of Christianity, ed. Erwin Fahlbusch and Geoffrey Bromiley (Grand Rapids, MI: Eerdmans, 1999-2003), 1:404).

${ }^{337}$ McGrath notes, "The term 'charismatic' is now used to refer to movements within the mainline churches based upon the ideas and experiences of the Pentecostal movement." McGrath, Christianity's Dangerous Idea, 419. Also, "Pentecostalism began a new phase of expansion after the Second World War, paving the way for its massive froth in the second half of the twentieth century. Even in the United States, Pentecostalism has overtaken most of the mainline denominations that dominated the American religious landscape from 18001950." Ibid., 418.

338، The freedom that the charismatic churches negotiated with the Church of England paved the way for alternative worship to be born." Sue Wallace quoted in Gibbs and Bolger, Emerging Churches, 39. For further connections between the Emerging Church and the Charismatic model, see Gibbs and Bolger, Emerging Churches, 81, 93, 119-120, 228-229; Dan Kimball, Emerging Worship: Creating Worship Gatherings for New Generations (Grand Rapids, MI: Zondervan, 2004), 180-181; Webber, The Younger Evangelicals, 191-192. For further liturgical connections between the Charismatic movement and the Emerging Church, see Fernando Canale, "The Emgerging Church--Part IV: Levels of Change," Journal of the Adventist Theological Society 23/2, no. (2012): 171172.

${ }^{339}$ Margaret M. Poloma, "The "Toronto Blessing": Charism, Institutionalization, and Revival," Journal for the Scientific Study of Religion 36, no. 2 (1997): 262. Also, for the integration between the presence of God and music, Ruth, "A Rose by Any Other Name," 24, 42, 49; Witvliet, "At Play in the Lord's House: Why Worship Matters," 23; Bloesch, The Church: Sacraments, Worship, Ministry, Mission, 138; Ruth Ann Ashton, God's Presence through Music. Miller states that "music actually mediates the sacred," Miller and Yamamori, Global Pentecostalism, 203; Albrecht, "Pentecostal Spirituality: Looking through the Lens of Ritual," 112; Webber, ed. The Renewal of Sunday Worship, 20. 
Spirit" ${ }^{340}$ refers to the charismatic description of the central role of music that occupies a lot of time in liturgy as the vehicle par excellence for the divine presence among Pentecostals, ${ }^{341}$ Charismatics ${ }^{342}$ and the Emerging Church. ${ }^{343}$

According to Mark Devine, there are two main streams under the umbrella of the Emerging Church movement. He refers to the first stream as Emerging, which is friendly to Evangelical doctrines. ${ }^{344}$ Devine refers to the second stream as Emergent, which he classifies as doctrine wary or doctrine averse. ${ }^{345}$ Both the Emerging and Emergent streams differ with the Charismatic and Pentecostal movements regarding liturgy, however, Emergents differ with the rest when it comes to their ontological foundation. For instance, whereas the music driven worship of the Pentecostal and charismatic renewal is critical of liturgical tradition, both the Emerging and Emergent streams long for an experience of God's presence through the restoration of the sacramental rituals of

${ }^{340}$ Ruth, “A Rose by Any Other Name," 49. "Among Pentecostal ritual sounds, music especially functions as an auditory icon. It embraces the Pentecostal worshippers in an analogous fashion to the manner in which icons visually surround the Eastern Orthodox faithful in their sanctuaries," Albrecht, "Pentecostal Spirituality: Looking through the Lens of Ritual," 111-112 (emphasis original).

${ }^{341}$ Lang points out that the manifestation of the Spirit was carried out by rhythmic music that included the beating of drums, dancing, and solos by various instruments, and which carried on for the better part of an hour, Lang, Sacred Games, 401.

${ }^{342}$ The Charismatic renewal is characterized by what McGrath refers to as "an explosion in "worship songs," resulting in renewal and revitalized worship in many mainline denominations, McGrath, Christianity's Dangerous Idea, 420.

${ }^{343}$ In his book on resources from and for the emerging church, Baker points out that most alternative worship music "emerged out of the mainstream of charismatic Christianity in the UK." Baker and Gay, Alternative Worship, 20, 21. See also, Gibbs and Bolger, Emerging Churches, 220. Alternative worship is comprised of musical forms that much more closely align with those in current use in society than has been the case in recent church history, Baker and Gay, Alternative Worship, 20, 21.

${ }^{344}$ Mark Devine, "The Emerging Church: One Movement-Two Streams," in Evangelicals Engaging Emergent: A Discussion of the Emergent Church Movement, eds. William D. Henard and Adam W. Greenway (Nashville, TN: B \& H Publishing Group, 2009), 7-8.

${ }^{345}$ Ibid., 9. 
the early church. ${ }^{346}$ Moreover, the Emerging stream shares the same static timeless view of the divine presence as the Pentecostal and Charismatic movement ${ }^{347}$ while the Emergent stream has switched to panentheism as its view of the divine presence. ${ }^{348}$ However, in spite of the differences between Emerging, Emergent, Charismatic, and Pentecostal, all describe the inextricable link between music and the divine presence as the real presence, ${ }^{349}$ sacramental, ${ }^{350}$ "the sacramentalization of music,"351 and "musical-

${ }^{346}$ Baker and Gay, Alternative Worship, 21, 22, 27. See also, Chris Armstrong, "The Future Lies in the Past," Christianity Today February 15, 2008, 22-29; Webber, The Younger Evangelicals, 193. This is why emergents are turning toward a more quiet worship such as candlelight prayer vespers using Taizé music instead of pop choruses, ibid.

${ }^{347}$ Gibbs and Bolger point out that the sacred/secular split of modernity continued until the 1960's and included purpose driven, seeker, and Gen-X churches that continued to accept the many dualisms of modernity, Gibbs and Bolger, Emerging Churches, 66-67, 73. For an explanation of the early church father's view on the sacredness of all of life to which the Emerging movement seeks to connect with, see Webber, Ancient-Future Worship: Proclaiming and Enacting God's Narrative, 125.

\footnotetext{
${ }^{348}$ Paul Roberts points out,
}

In Charismatic worship God is located 'outside' the physical domain. This is why charismatic worship is so focused on ecstatic experience. By contrast, alternative worship relocates God back within the physical domain, so to experience God means to encounter him in and through the created things around-symbolically, iconically, sacramentally (Paul Roberts, Alternative Worship in the Church of England (Cambridge: Grove Books, 1999), 18).

Grenz very clearly outlines the features of panentheism, including Hegel's concept of the Spirit without criticizing it, see Stanley J. Grenz, Theology for the Community of God (Nashville, TN: Broadman and Holman, 1994), 81-82.

${ }^{349}$ Blackwell, The Sacred in Music, 29.

${ }^{350}$ Witvliet points out that our strongest sacramental language is not reserved for what happens at the pulpit, font, or table but rather what comes from our drums and synthesizers. See Witvliet, "Beyond Style: Rethinking the Role of Music in Worship," 71. See also, Blackwell, The Sacred in Music, 29. For Brian McLaren, see Gibbs and Bolger, Emerging Churches, 38; Phillip Luke Sinitiere, "Catholic Evangelicals and Ancient Christianity," in Vatican II Forty Years Later, ed. William Madges (Maryknoll, NY: Orbis Books, 2006), 352-354. Clark Pinnock, Flame of Love: A Theology of the Holy Spirit (Downers Grove, IL: InterVarsity Press, 1996), 120-121.

${ }^{351}$ Witvliet, "Beyond Style: Rethinking the Role of Music in Worship," 71. 
transubstantiation." ${ }^{352}$ Consequently, the transubstantiation hypothesis lives on.

The divine presence in the Charismatic model includes the Holy Spirit who is embedded within the various styles of music that are associated with this model. Since Pentecostals and Charismatics assume that reality is divided between sacred and secular, ${ }^{353}$ they interpret the divine presence (Holy Spirit) within the music as completely timeless. ${ }^{354}$ This ends up creating a dichotomy between the Holy Spirit (sacred/timeless) and musical style (secular/temporal). This underlying structure is identical with that of the Sacramental model prior to Vatican II and with the Kerygmatic model. ${ }^{355}$

Since Emergents declare that all things are potentially sacred, the divine presence is no longer restricted to specific sacraments, such as the Lord's Supper and music.

Instead, as Teilhard de Chardin states, transubstantiation extends to the whole universe, which becomes Christ's body. ${ }^{356}$ Moreover, the divine presence is no longer strictly

${ }^{352}$ Idem., "At Play in the Lord's House: Why Worship Matters," 23.

${ }^{353}$ According to Gibbs and Bolger those who adhere to a sacred secular split include Gen-X megachurches, Gen-X/young adult services, seeker churches, purpose driven churches, the Vineyard, and Free churches who are born in modernity. Thus, simply including coffee, candles and music does not make the aforementioned churches emerging churches. Gibbs and Bolger, Emerging Churches, 45-46. Furthermore, as it pertains to its worship, the emerging church's mission is to completely dismantle the following dualisms: The natural versus the supernatural; public facts versus private values; the body versus the mind and spirit; faith versus reason; power versus love; and the list goes on. Ibid., 67.

354،"In modern conservative churches, it follows that God is experienced outside material reality."Ibid., 72-73 (emphasis original). As a result, Paul Roberts notes, “'In charismatic worship, God is located outside' the physical domain. This is why charismatic worship is so focused on ecstatic experience." Ibid., 73.

${ }^{355}$ Stephenson points out that the shapes of earlier Pentecostal theologies "hardly vary from evangelical paradigms prominent in America at the times they were writing." Christopher A. Stephenson, Types of Pentecostal Theology (New York: Oxford University Press, 2013), 26, 29. Also, "Pentecostalism represents a grassroots spiritual movement rather than a novel theological construction. It has not so much produced new theology as a new kind of spirituality and aggressive evangelism methods." Kärkkäinen, Pneumatology, 91.

\footnotetext{
${ }^{356}$ Teilhard points out,
} 
timeless as before, instead its transcendence ${ }^{357}$ is now located within immanence. ${ }^{358}$

Blackwell asserts that there is a panentheistic nature to music, which formulates the

ground for a sacramental encounter with the divine presence. ${ }^{359}$

When Christ, extending the process of his incarnation, descends into the bread in order to replace it, his action is not limited to the material morsel which his presence will, for a brief moment, volatilize: this transubstantiation is aureoled with a real though attenuated divinizing of the entire universe (Pierre Teihard de Chardin, Hymn of the Universe, 6).

There is no change here in the interpretation of transubstantiation, it is still ordered by timeless Being. Only now it is universalized within Chardin's evolutionary and panentheistic framework.

${ }^{357}$ Transcendence has always been understood on the basis of timeless Being. See, Blackwell, The Sacred in Music, 50; Cooper, Panentheism-The Other God of the Philosophers, 156 notes 38-40; Grenz and Olson, Twentieth Century Theology, 234.

${ }^{358}$ We noted previously that in Charismatic worship, God is located outside the physical domain. Yet, "alternative worship relocates God back within the physical domain, so to experience God means to encounter him in and through the created things aroundsymbolically, iconically, sacramentally." Gibbs and Bolger, Emerging Churches, 73. "In worship, emerging churches embrace both the transcendence and the immanence of God." Ibid., 170. "By immersing themselves in all forms of media, emerging churches retrieve God's immanence while maintaining a commitment to God's transcendence, thereby creating a rich and beautiful worship environment." Ibid., 74. Webber notes "creation is good and, when released to express its relation to transcendence, embodies the transcendence of God. Paradoxically perhaps, the transcendent God is immanent within the created order." Webber, The Younger Evangelicals, 198. Referring to the bread and wine, Weber points out, "The entire story is supernatural. It presupposes the paradox that the transcendent God who is above and beyond creation is yet immanent in (within) creation. As we have seen, God's otherness, his quality of being invisible, is made visible in the incarnation." Webber, Ancient-Future Worship: Proclaiming and Enacting God's Narrative, 136. Stephenson quotes Amos Yong's process ontology, where Yong points out, "As mutual love, the Spirit relates the Father to the Son and the Son to the Father, eternally in the immanent Trinity and temporally in the economic Trinity." Stephenson, Types of Pentecostal Theology, 88. Macchia's view of glossolalia in Stephenson's book is described as embodying "elements of both transcendence and human frailty....Glossolalia affirms transcendence and invites engagement with the finite historical particularities." Ibid., 62.

${ }^{359} \mathrm{He}$ notes that God's transcendent and eternal Wisdom and Word are also immanent in music, thereby referring to this as panentheism and not pantheism. Blackwell, The Sacred in Music, 32, 35. He also points out, "Edwards' panentheism, regarding the created world as a fabric of theophanies, readily embraces music as a medium of divine grace." Ibid., 37.

The importance of this theological tradition [panentheism] for our study of music's sacramental potential consists in the ease with which it speaks of manifestations of God 
Incidentally, there seem to be important theological, ${ }^{360}$ influential, ${ }^{361}$ and historical $^{362}$ links between the panentheistic and evolutionary concept of the divine

in our experiences of the world, including our experiences of music and yet preserves a sense of God's unfathomable transcendence. (Ibid.)

${ }^{360}$ Teilhard de Chardin has exercised a dominant influence on Vatican II, see this dissertation page 103 footnote 10. Interestingly, Pinnock and Webber employ Teilhard de Chardin's panentheistic evolutionary concept as a tool that bridges together the timeless transcendent aspect of the divine presence with the temporal immanent and relational aspect of the divine presence. See Pinnock, Flame of Love, 66, 74. Webber here quotes Chardin, "By virtue of Creation, and still more, of the Incarnation, nothing here below is profane for those who know how to see." Webber, Ancient-Future Worship: Proclaiming and Enacting God's Narrative, 142 (emphasis original). In Chardin's explanation, the Omega, which is outside of time and space, is bringing all things in creation to Christogenesis, The Phenomenon of Man, 297; Cooper, Panentheism-The Other God of the Philosophers, 156157; Grenz and Olson, Twentieth Century Theology, 134, 164. Emergent thought leaders have been deeply influenced by some of the most prominent theologians of Vatican II such as Karl Rahner, whose theology has been described as panentheistic. See Phyllis Tickle, Emergence Christianity: What It Is, Where It Is Going, and Why It Matters? (Grand Rapids, MI: Baker Books, 2012), P-32.

${ }^{361}$ Pentecostal theologians such as Macchia point out that there should be a greater sense of dependence on and appreciation for the Roman Catholic Church's parental role, without losing sight of the Spirit who is the source for everyone. Stephenson, Types of Pentecostal Theology, 72. Moreover, Brian McLaren and Clark Pinnock have expressed a much closer affinity to the Sacramental model's kind of liturgy than to that of the Kerygmatic model. For McLaren, see Gibbs and Bolger, Emerging Churches, 38; Sinitiere, "Catholic Evangelicals and Ancient Christianity," 352-354. After noting that created reality is richly imbued with limitless sacramental possibilities, Pinnock points out that iconoclasm has impoverished the life of many churches that have no place for "festivals, drama, processions, banners, dance, color, movement, instruments, percussion and incense." As a result, "God's presence can be hard to access," Pinnock, Flame of Love, 120-121.

${ }^{362}$ The Emerging Church's mission to tear down the sacred secular split, which leads to the sacramentilization of all reality, was in fact preceded by Ronald Wilkins book written in 1968 under the full imprimatur of the Catholic Church titled The Emerging Church, Ronald J. Wilkins, The Emerging Church: The Story of the Roman Catholic Church from Its Beginnings to the Present (Dubuque, IA: Wm. C. Brown Company Publishers, 1975). I did not have access to the 1968 edition of this book that Phyllis Tickle alludes to. She notes the possible historical links between Wilkins book published in 1968 and the Emergent movement that began in 2000. She also makes reference to two other books bearing the title Emerging Church, one written in 1970 by Word publishing and the other in 1981 by Johann Baptist Metz, a student of Karl Rahner. Phyllis Tickle, Emergence Christianity, 82, 85, 90, 99, 102. Yet, even if the creation of the Emerging Church movement cannot be directly attributed to Vatican II, there is no doubt about the fact that Vatican II and the Emergent movement share the same theological understanding of the divine presence that stems from timeless Being, embedded within the evolutionary and panentheistic framework of Teilhard de Chardin. Wilkin's book describes Teilhard de Chardin as the most popular Catholic representative of our time, and on a par with the apostle Paul, Augustine, and Aquinas. 
presence of Vatican II and the Emergent concept. Consequently, neither the Emergents, nor the recent Pentecostal theologians who replace Christ with the Holy Spirit, have produced an interpretation of the divine presence that differs from the one at Vatican II that is ordered by dynamic timeless Being. ${ }^{363}$

\section{Liturgist}

Adherents of the Charismatic model strongly hold to the priesthood of all believers ${ }^{364}$ in which all Christians "share in the ministry of Christ, including laity and women." 365 This model refers to liturgists as "worship leaders" instead of priests, pastors

Chardin's evolutionary and panentheistic philosophy forms the structure and foundation upon which Wilkins grounds the interpretation of the divine presence, as well as the emergence of the Christian church in general and the Catholic church in particular in the twentieth century. See Wilkins, The Emerging Church, 36-38, 85, 199-203.

${ }^{363}$ Stephenson rightly criticizes other schools of thought that merely assume differing modes of the presence of Christ in the Eucharist. In presenting the Holy Spirit as the divine presence in the Eucharist instead of Christ, he intends to shift the issue from that of mode to theological content (the Holy Spirit). Yet, the timeless ontology that is at the basis of a panentheistic interpretation of the divine presence is never questioned. Thus, his interpretation of the Holy Spirit as divine presence is still controlled by dynamic timeless Being. Stephenson, Types of Pentecostal Theology, 121-124.

${ }^{364}$ Albrecht, Rites in the Spirit, 137. See also, Donald G. Bloesch, The Holy Spirit: Works and Gifts (Downer's Grove, IL: InterVarsity Press, 2000), 205.

Nowhere is the idea of priesthood of all believers more practiced in the Pent/Char spirituality than in the 'ministering' to one another in the services. Believers, not clergy only, are expected to be involved in healing rites of various sorts and to engage actively in prayers for those in need, particularly those in the service (Albrecht, Rites in the Spirit, 137).

See also Gibbs and Bolger, Emerging Churches, 172, 195; Webber, The Younger Evangelicals, 120.

${ }^{365}$ Bloesch, The Holy Spirit: Works and Gifts, 205.

The question of women in ministry has not been a divisive issue in most Pentecostal churches. The Catholic charismatic theologian Edward O'Connor warns that we must also be alert to the danger of 'paraclericalism' that results in the laity usurping the prerogatives of the pastoral office (Ibid.).

In principle any Pentecostal believer may 'lead' during a given moment in the service. In these Pent/Char worship services, the charismata create a fundamental equality among the members. Anyone may prophesy or perform healing rites, regardless of gender, race, 
or ministers. ${ }^{366}$ Pentecostals adhere to a Presbyterian and/or Congregational ecclesial model. ${ }^{367}$

Liturgists in the Emerging church overcome the sacred/secular divide by (1) adopting a leadership philosophy that is dynamic and fluid rather than static ${ }^{368}$ and hierarchical ${ }^{369}(2)$ assigning liturgical responsibilities that are based on God-given gifts and passion whose purpose is to further God's kingdom, rather than granting responsibilities that are based on willingness and position ${ }^{370}$ or that adhere to fixed male and female sexual identities, ${ }^{371}$ and (3) recognizing that anyone who is able to facilitate the presence of God can lead out in worship, since "there are no longer any bad places, bad people or bad times." ${ }^{372}$

The analysis of the liturgist in the Charismatic model revolves around whether the liturgists are the cause of liturgy, and issues relating to the nature of the liturgist's

ethnicity, socio-economic statues or clerical statues. They need only to be 'led/moved' by the Spirit and recognized by the congregation as behaving authentically and appropriately....The roles of leadership do not reside with the clergy or other ritual specialists alone (Albrecht, Rites in the Spirit, 139).

${ }^{366}$ Albrecht, "Pentecostal Spirituality: Looking through the Lens of Ritual," 112. Also, Gibbs and Bolger, Emerging Churches, 164-165.

${ }^{367}$ Hollenweger, Pentecostalism, 175.

${ }^{368}$ Gibbs and Bolger, Emerging Churches, 198.

${ }^{369}$ Ibid., 164-165. Emergents also believe that a hierarchical form of leadership stifles creativity. see Ibid., 194.

${ }^{370}$ Ibid., 199-201.

${ }^{371}$ Ibid., 198-213; Webber, The Younger Evangelicals, 116; Phyllis Tickle, The Great Emergence: How Christianity is Changing and Why (Grand Rapids, MI: Baker Books 2008), 101. Tickle concludes that the homosexual issue will bring about the demise of the Sola Scriptura principle. According to the trajectory of this deduction, neither sexual orientation nor gender constitutes sufficient reason to exclude one from being a liturgist.

${ }^{372}$ Gibbs and Bolger, Emerging Churches, 67. Moreover, based on the principle that there are no more bad places, times or people, "One can worship in all kinds of dress. People don't dress up these days to go out to eat. Whatever virtues there are in the "Sunday best," it's not essential for Christian worship." Byars, The Future of Protestant Worship, 62. Byars points out that the essentials are Scripture, baptism and the Lord's Supper. Ibid., 62-63. 
authority as it relates to the performance of ritual actions. With respect to the cause of liturgy, the underlying dynamic timeless ontology borrowed from Chardin ${ }^{373}$ points to the Spirit as the efficient cause of liturgy. ${ }^{374}$ Moreover, the Church as a sacrament, which is indwelt by the Spirit, ${ }^{375}$ and the sacraments as the means of grace, ${ }^{376}$ point to the timeless interpretation of the Spirit and grace. Consequently, although there is much more freedom in Emergent liturgy, ${ }^{377}$ the liturgist is only the instrumental cause of liturgy ${ }^{378}$ while the Spirit constitutes the efficient cause. ${ }^{379}$

With respect to the nature of the authority that liturgists exercise in this model, the early Pentecostals, ${ }^{380}$ Charismatics and Emergents did not develop a biblical ontology of

${ }^{373}$ In asserting that the presence of God in transubstantiation divinizes the entire universe, Teilhard de Chardin is assuming Timeless Being, Hymn of the Universe, 6. Chardin notes that Omega escapes from "time and space" and that one of its attributes is transcendence, The Phenomenon of Man, 271. Furthermore, "The end of the world: the overthrow of equilibrium, detaching the mind, fulfilled at last, from its material matrix, so that it will henceforth rest with all its weight on God-Omega." Ibid, 288.

${ }^{374}$ Although Pinnock acknowledges that the dualistic link between Spirit and matter is not Biblical, the Spirit as efficient cause is based on the Spirit's agency in moving nature from simple to complex, from nonliving to living, from unconscious to conscious, and from animal to human. See Pinnock, Flame of Love, 70, 119.

${ }^{375}$ Pinnock, Flame of Love, 121.

${ }^{376}$ Ibid., 128, 129.

${ }^{377}$ Gibbs and Bolger, Emerging Churches, 71, 155, 172, 174; Webber, The Younger Evangelicals, 206-207, 212.

${ }^{378}$ Pinnock points out that lack of faith, fear and an unwillingness to use an unlimited amount of sacramental possibilities can quench the Spirit and prevent him from manifesting himself. This gives the impression that the worshippers are the efficient cause of liturgy. See Pinnock, Flame of Love, 120-121, 137-139. However, the Spirit is clearly the efficient cause, Ibid., 70, 119.

${ }^{379}$ Ironically, and paradoxically, the panentheistic view of the divine presence that forms the ground for the Emergent attitude toward the potential use of unlimited sacramental possibilities contains within it the timeless metaphysical principle that ultimately becomes the cause of all those possibilities. Thus, since freedom is more apparent than real, it is the Spirit that is the efficient cause and not the liturgists.

${ }^{380}$ See this dissertation page 184 footnote 355 . 
human nature ${ }^{381}$ implicit in the Scriptural theme of the priesthood of all believers. They

still assumed that human beings were composed of timeless and temporal elements. As a result, the process of making all of life holy, known as sacralization, ${ }^{382}$ is the basis that drives this model's understanding of the authority, nature, and function of the liturgist. For instance, sacralization hermeneutically leads to the following: (1) the change in titles from pastors, priests and ministers to worship leaders, (2) a dynamic rather than a static philosophy of leadership, ${ }^{383}$ (3) a decentralized approach rather than a centralized hierarchical one, and (4) the liturgical right to lead liturgy is assumed by everyone who has the Spirit's gifts and passion for ministry, irrespective of gender and sexual orientation. ${ }^{384}$ With particular respect to the last point; Emergents ground the qualifications of the liturgist on the dichotomy between the timeless soul and the temporal body. Accordingly, since maleness, femaleness and sexual orientation belong to

${ }^{381}$ The emerging church's mission to overcome body and soul dualism embraces both parts of the whole human system. See Gibbs and Bolger, Emerging Churches, 78, 88. This gives the impression that the ontological dualism between the timeless and the temporal in human nature has been dissolved. Yet, there are two reasons for why dualism in human nature still exists: (1) the church as sacrament points to the timeless soul as an essential aspect of human nature, Pinnock, Flame of Love, 121, 129; and (2) Emergents do not eliminate the distinction between timeless and temporal aspects of human nature. Instead, they expand the location where the divine presence encounters the human being to the entire body, as opposed to just mind, heart or soul. This is why liturgical actions are directed to every aspect of the person. See Webber, The Younger Evangelicals, 45, 195, 200, 206, 211.

${ }^{382}$ Whereas the modern period gave birth to secular space, sacralization is "the process of making all of life sacred" which means Emergents tear down practices that foster "secular spaces, times, or activities....Sacralization is about one thing: the destruction of the sacred/secular split of modernity," Gibbs and Bolger, Emerging Churches, 66.

${ }^{383}$ Gibbs and Bolger compare dynamic leadership to a flock of birds in which leadership among the flock is fluid rather than static, and is transferred to the right person at the right time. The hierarchy of the Sacramental model is gone; instead the structure of leadership involves groups that are leaderless in the sense that there is no appointed leader but individuals exercise the control and provide the input. Gibbs and Bolger, Emerging Churches, 164-165, 198.

${ }^{384}$ Gibbs and Bolger, Emerging Churches, 198-213; Webber, The Younger Evangelicals, 116. Phyllis Tickle, The Great Emergence, 101. 
the body and not to the soul, they have no bearing on the qualifications for the liturgist. ${ }^{385}$

\section{Liturgical Setting and Actions}

In this section I will first describe and then analyze the following liturgical actions in the Charismatic model that are associated with the divine presence: the architectural setting, liturgical time, the Eucharist, preaching, and musical practices. Let's first start with the architectural setting. There are two major principles that the Liturgical movement contributed to architecture. The first is that "the decoration and shape of a church building is reflected by what happens inside, but the outside is in one sense of little importance. ${ }^{386}$ Consequently, this led to the following hermeneutical effects: (1) churches in India and Africa can resemble Hindu temples or giant huts ${ }^{387}$ (2) traditional Pentecostal church buildings are plain as opposed to being ornately decorated ${ }^{388}$ and (3) some charismatic churches are located in industrial estates and warehouse buildings with

385،"In what is likely a first, Calvary Baptist Church in Washington, DC, has ordained Allyson Robinson, who was previously ordained as a man, to the gospel ministry." The rationale for the choice was that "God has blessed her with a talent for ministry," and "is gifted to serve in this capacity." Bob Allen, "Baptist Church Ordains Transgender Woman," The Christian Century 131 no. 16 (Aug 6, 2014): 12-13. When seeking answers to the Lesbian, Gay, Bisexal, and Transgender (LGBT) issue interpreters should incorporate the "claims of contemporary research and clinicians, personal experiences of and with LGBT people, or alternative renderings of the biblical witness." David P. Gushee, "Reconciling Evangelical Christianity with Our Sexual Minorities: Reframing the Biblical Discussion." Journal of the Society of Christian Ethics 35 no. 2 (2015): 147. Since there is an ontological dichotomy between the body and the timeless soul, the hermeneutical effect is that one's gender forms no part of mediating the divine presence. In Dynamic Timeless Being, there is still an ontological dichotomy between body and soul; however, the soul is now evolving and changing.

${ }^{386}$ Fenwick and Spinks, Worship in Transition, 162; Kabasele Lumbala, Celebrating Jesus Christ in Africa, 26. In the nineteenth century, Europeans promoted the Gothic style as the Christian style of church architecture yet the Liturgical Movement forced architects and designers to rethink this, Fenwick and Spinks, Worship in Transition, 162.

${ }^{387}$ Fenwick and Spinks, Worship in Transition, 162; Kabasele Lumbala, Celebrating Jesus Christ in Africa, 26.

${ }^{388}$ Noel, Pentecostal and Postmodern Hermeneutics, 54. 
large open spaces for celebration. ${ }^{389}$ James White notes that the appearance of the building should be based on how it functions during worship, which establishes a causal connection between what takes place on the inside and the appearance of the outside. ${ }^{390}$ However, by regarding the outside of the building as of little importance in comparison to what happens inside, the Liturgical movement seems to be violating this principle and is thus open to the criticism that there is a dichotomy between the inside and the outside of the building.

The second principle of the Liturgical movement was the design of churches that "expressed the immanence of God." ${ }^{391}$ There were four reasons for emphasizing immanence: (1) the prevailing twentieth century artistic modes have no transcendent reference $^{392}$ (2) cultural clashes and movement away from Gothic structures ${ }^{393}$ that communicate transcendence and a hierarchical view of the $\operatorname{church}^{394}$ (3) the impact of secularization and liberal theology and the downplaying of supernatural aspects of faith $^{395}$ and (4) eliminating the distinction between sacred and secular that the Emerging

${ }^{389}$ Peter Hocken, The Challenges of the Pentecostal, Charismatic and Messianic Jewish Movements (Burlington, VT: Ashgate, 2009), 36.

${ }^{390}$ White, Protestant Worship and Church Architecture, 179, 198. For the relationship that should exist between theological vision and architectural forms, see Peter Hammond, Liturgy and Architecture (New York: Columbia University Press, 1961), 1-11.

${ }^{391}$ Mark A. Torgerson, An Architecture of Immanence: Architecture for Worship and Ministry Today (Grand Rapids, MI: Eerdman's, 2007), 25.

${ }^{392}$ Davies, The Ecumenical Century, 441. Davies here refers to naturalism, expressionism, and abstractionism.

${ }^{393}$ Gothic structure is seen to be irrelevant when it comes to expressing the traditional Christian faith and its relationship to contemporary culture, especially in light of twentieth century ecumenism. See ibid.

${ }^{394}$ Cobb, "The Architectural Setting of the Liturgy," 538; Webber, The Younger Evangelicals, 191-192.

${ }^{395}$ Torgerson, An Architecture of Immanence, 1. 
and Emergents streams of the Charismatic model would eventually champion. ${ }^{396}$

The hermeneutical effects of emphasizing immanence in architecture are: (1) simplified buildings that draw attention to the people as the body of Christ instead of larger scale buildings, diminished light, and an abundance of symbolism all of which point to transcendence ${ }^{397}$ (2) a more relational seating arrangement that makes "the community more aware of the presence of Christ, the head of the church, who assembles with his people, the body of Christ"398 (3) restricting the symbols of God's presence to immanent liturgical actions such as the baptismal font, the pulpit and the Eucharistic table as symbols of God's presence rather than large cathedrals that only communicate transcendence ${ }^{399}$ and (4) a desire to blend transcendence and immanence by fusing the style of the ancient cathedral with space that is contemporary, transcendent, and immanent all at once. ${ }^{400}$ The Liturgical movement's emphasis on immanence in architecture still assumes the Platonic dichotomy. This was illustrated by symbols of God's presence that pointed to transcendence and the removal of transcendent characteristics, most notably the massive gothic cathedrals as well as the abundance of symbolism that resulted in immanence. Furthermore, Emergents combined the timeless and temporal aspects of dynamic timeless Being by fusing the transcendent characteristics of the ancient cathedral with space that is contemporary and immanent all at once.

\footnotetext{
${ }^{396}$ Ibid., 17-18, 21.

${ }^{397}$ Ibid., 4-5.

${ }^{398}$ Webber, The Younger Evangelicals, 191-192, 201.

${ }^{399}$ Ibid., 192.

${ }^{400}$ Ibid., 214.
} 
Regarding liturgical time, Pentecostals ${ }^{401}$ and Charismatics ${ }^{402}$ have accepted Sunday as a time-honored custom that has allegedly continued from the days of the disciples down to our times, yet with little reflection regarding how Sunday relates to liturgy. This means that the connections between timeless Being and Sunday that the Sacramental and Kerygmatic models assume also hermeneutically guide Pentecostals and Charismatics. Emergent principles, on the other hand, can lead one to conclude that since all times are sacred, any day is acceptable. ${ }^{403}$ Yet, the most significant reason for Sunday worship among Emergents is the high estimate they place on the Eucharist, ${ }^{404}$ which is further strengthened among Pentecostals and Charismatics that are distancing themselves from the Lord's Supper as a memorial to one that embraces the Spirit's presence. ${ }^{405}$ Moreover, among Emergent authors, only Webber has been intentional in his attempt to provide meaning and authenticity to twenty-first century worship by linking Sunday with

${ }^{401}$ The word "Sunday" is not even mentioned in Foundations of Pentecostal Theology. Also of the ten times that the word "Sabbath" is mentioned, there's only one reference in which Duffield and Van Cleave allege that the disciples changed the day on account of custom. Guy P. Duffield and Nathaniel M. Van Cleave, Foundations of Pentecostal Theology (San Dimas, CA: L.I.F.E. Bible College, 1983), 200.

${ }^{402}$ Towns, Putting an End to Worship Wars, 146. Also, A cursory glance of books that address the varying musical practices in the worship wars always assumes Sunday as the liturgical day, yet they do not attempt to provide a theological connection between liturgy and Sunday. See Byars, The Future of Protestant Worship, 5-12, 22-23, 26, 76; Long, Beyond the Worship Wars, 7-8, 56; John D. Witvliet, "The Virtue of Liturgical Discernment," in Music in Christian Worship: At the Service of the Liturgy, ed. Charlotte Kroeker (Collegeville, MN: Liturgical Press, 2005); York, America's Worship Wars, 28, 46, 53,104 . Hence, among the vast majority of churches in the latter half of the twentieth century, Sunday is the one constant in a sea of diverse musical practices.

${ }^{403}$ Gibbs and Bolger, Emerging Churches, 66-67.

${ }^{404}$ Ibid., 39 note \#14, 119, 180, 229; Janine Paden Morgan, "Emerging Eucharist: Formative Ritualizing in British Emerging Churches" (Ph.D. dissertation, Fuller Theological Seminary, 2008), 268, 273; Webber, The Younger Evangelicals, 181-182.

\footnotetext{
${ }^{405}$ Stephenson, Types of Pentecostal Theology, 121-122, 124.
} 
an experience of God's renewing presence ${ }^{406}$ through various ritual actions. ${ }^{407}$ However, in outlining these links Webber and the Emergents are following Vatican II and Dies Domini's connections between timeless Being, Sunday and the liturgical components. ${ }^{408}$

We will now briefly look at how the assumption of Timeless Being catapulted the Eucharist into prominence among the adherents of the Charismatic Model. Pentecostals originally believed the Lord's Supper to be a memorial like Zwingli, ${ }^{409}$ which they described as an ordinance and not a sacrament. ${ }^{410}$ The frequency with which Pentecostals celebrated the Eucharist ranged from weekly to rarely. ${ }^{411}$ Recent Pentecostal theologians, however, have clearly switched from the timeless static view of the divine presence of their predecessors ${ }^{412}$ to a panentheistic view. ${ }^{413}$ As a result, they have moved away from the memorial view of the Lord's Supper by alleging that it is the Spirit's real presence

${ }^{406}$ Robert E. Webber, Ancient-Future Time, 172-173.

${ }^{407} \mathrm{He}$ notes the following tangible and concrete signs of his presence: (1) "the first sign of his presence in Sunday worship is the assembled people" ibid., 172. (2) "God's presence is known in the visible, tangible sign of the minister among us," ibid., 173. (3) The Bible is a visible and tangible sign through which God is made present, ibid. (4) "God is also made present through the signs of water, of oil, and of bread and wine," ibid. See also, ibid., 29-30, 151-153, 169-171, 174-177.

${ }^{408}$ For the way in which Sunday connects with the divine presence and the other liturgical components, see Pope John Paul II Encyclical Dies Domini. Also see this dissertation pages 122-123. For Webber, see notes 406 and 407 above.

${ }^{409}$ Hollenweger, Pentecostalism, 172.

${ }^{410}$ Albrecht, Rites in the Spirit, 44; Duffield and Van Cleave, Foundations of Pentecostal Theology, 417, 435.

${ }^{411}$ White, Introduction to Christian Worship, 246.

${ }^{412}$ Stephenson notes that earlier Pentecostal Theological Method hardly varied from "evangelical paradigms prominent in America." Stephenson, Types of Pentecostal Theology, 26 , see also 29.

${ }^{413}$ One example is Amos Yong's pneumatological process ontology: “As mutual love, the Spirit relates to the Father and the Son to the Father, eternally in the immanent Trinity and temporally in the economic Trinity," quoted in Stephenson, Types of Pentecostal Theology, 88 . 
and not that of Christ in the Eucharist. ${ }^{414}$ Thus, "given the realization that the Lord's supper is far more significant than merely a time of remembering Jesus' death, Pentecostals should consider both celebrating it more frequently and in a manner that makes it more central to corporate worship." ${ }^{415}$ Emergents who share the same panenetheistic view of the divine presence as the recent Pentecostals also unsurprisingly adhere to the real presence of the Eucharist. ${ }^{416}$ Consequently, they have also granted the celebration of the Eucharist a more dominant and central role in their liturgy. ${ }^{417}$ Hence, timeless Being has played no small role in moving the Eucharist to front and center in this model.

We will now briefly examine how Timeless Being led to the sacramental and functional view of preaching, and thus to its diminishing role in the Charismatic model. The static timeless conception of the divine presence among Pentecostals provides the foundation for a sacramental/functional encounter with Scripture. Pentecostals claim that "it is possible to encounter God directly and personally through the power of the Holy Spirit. God is to be known immediately and directly, not indirectly through the study of a

${ }^{414}$ Ibid., 124.

${ }^{415}$ Ibid., 127.

${ }^{416}$ Webber notes that "the younger evangelical longs for a sense of God's presence and finds it in the celebration of the Eucharist." Webber, The Younger Evangelicals, 182.

Younger evangelicals are rediscovering that the God who is present in all creation becomes intensely present in our worship through sign and symbol... Within the assembled body the chief symbols of God's presence are expressed in the baptismal font, the pulpit, and the Eucharistic table (Ibid., 192).

417"Many emerging churches place a great emphasis on the Eucharist as the central act of worship." Gibbs and Bolger, Emerging Churches, 119; cf 229. Webber notes that "younger evangelicals are also turning toward a more frequent celebration of the Eucharist....For many younger evangelicals, the Eucharist is a high point of spiritual encounter and meaning." Webber, The Younger Evangelicals, 182. See also Janine Paden Morgan, "Emerging Eucharist: Formative Ritualizing in British Emerging Churches," 139, 144, 188, 201. 
text." ${ }^{418}$ This approach strips away from Scripture any cognitive content, which directly leads to an encounter with the worshipper that occurs outside of history and culture. ${ }^{419}$ Thus, eliminating the cognitive content of Scripture directly results in (1) the use of Scripture in a sacramental and functional way, as well as (2) the diminishing role of preaching for Pentecostals. Moreover, among Emergents, Grenz and Pinnock opt for an authority that is grounded in the way that the Spirit operates in the community of faith that is based on Scripture being a witness to revelation and not revelation itself. ${ }^{420}$ Consequently, the Spirit's panentheistic presence is revealed through an unlimited possibility $^{421}$ of liturgical actions ${ }^{422}$ instead of the iconoclasm of preaching that leads to

${ }^{418}$ McGrath, Christianity's Dangerous Idea, 431.

${ }^{419}$ See this Chapter on the encounter in which I explain how the interpretation of the content of Scripture on the basis of Kant's epistemology directly conditions the encounter.

${ }^{420}$ In positing that revelation occurs in history, Grenz follows Bloesch whom he quotes as saying that the Bible is merely the original witness to that revelation. Stanley J. Grenz and John R. Franke, Beyond Foundationalism: Shaping Theology in a Postmodern Context (Louisville, KY: John Knox Press, 2001), 69-72. Gulley also points out that for Grenz Scripture is a witness to revelation rather than revelation itself. Norman R. Gulley, Systematic Theology: Prolegomena (Berrien Springs, MI: Andrews University Press, 2003), 99-110). Pinnock states, "Revelation comes to us through what has happened in history....Revelation is dynamic, historical and personal." Accordingly,

The Bible is prime testimony to revelation and secures the knowledge of saving events, together with their interpretation. The Bible is the document of revelation, which makes Jesus accessible to those who have not known him in the flesh. The witness has been placed in a literary form so as to be reliably transmitted (Pinnock, Flame of Love, 226, 227, 228).

${ }^{421}$ Pinnock notes,

Sacraments exist simply because we are bodily creatures inhabiting a material world. There is in theory no limit to the number of them. Created reality is richly imbued with sacramental possibilities. The world reflects God's glory; therefore anything can mediate the sacred, where there are eyes to see and ears to hear. Since the Spirit pervades the universe, any event or experience can bring God to mind and mediate his presence. The sacramental principle operates, let it be noted, not only in liturgy but also in the ordinary experience that grounds it. The life of many churches needs to be enriched with more signs and symbols (Pinnock, Flame of Love, 120-121).

\footnotetext{
${ }^{422}$ Pinnock asserts,
} 
impoverishment. ${ }^{423}$ Moreover, since the divine presence is timeless and temporal, the content of preaching Scripture is reduced to mostly artistic or cultural expression ${ }^{424}$ sprinkled with a few timeless truths. ${ }^{425}$ Hence, the panentheistic view of the divine presence is clearly incompatible with the notion that Scripture is the only source of revelation and authority, or that preaching Scripture has a dominant role in this model.

As we begin to describe the various musical practices of this model, we will first begin with Pentecostal music before we describe Charismatic and Emergent music. Miller and Yamamori note that the "engine of Pentecostalism is its worship" yet "the

This means that the Spirit is denied certain tools for enrichment. We are impoverished when we have no place for festivals, drama, processions, banners, dance, color, movement, instruments, percussion and incense. There are many notes on the Spirit's keyboard which we often neglect to sound, with the result that God's presence can be hard to access (Ibid., 121).

${ }^{423}$ Pinnock laments that "iconoclasm has impoverished the life of the church and often reduced worship to a cognitive affair," Ibid. As a result, Pinnock strongly encourages the use of ritual, instead of preaching because rituals move us on the affective level, Ibid., 123.

${ }^{424}$ In describing an emergent worship service, Gibbs and Bolger note that music and the Eucharist, and not preaching constitute the main reasons for why worshippers gather. Moreover, preaching is merely "an art form rather than the transformative transfer of correct information." Gibbs and Bolger, Emerging Church, 229.

${ }^{425}$ This combining of timeless truths with merely artistic and cultural content brings us back to the Sacramental model and departs from the Pentecostal view that the entirety of Scripture is culturally conditioned. Canale notes, "we should notice the emerging church's use of Scripture fits well with classical (ancient-future) teachings. In some structural sense, classical and modern thought patterns and theologies belong together and the Emerging Church is making the most out of their experience." Fernando Canale, "The Emerging Church-Part 2: Epistemology, Theology, and Ministry," Journal of the Adventist Theological Society 22 no.2 (2011): 93. This convergence between classical and modern structures is also captured by Pinnock. He states,

Revelation is neither contentless experience (liberalism) nor timeless propositions (conservatism). It is the dynamic self-disclosure of God, who makes his goodness known in the history of salvation, in a process of disclosure culminating in Jesus Christ. Revelation is not primarily existential impact or infallible truths but divine selfrevelation that both impacts and instructs (Pinnock, Flame of Love, 226). 
heart of Pentecostalism is the music. ${ }^{, 426}$ The music of early Pentecostal churches grew out of the black heritage and consisted of the "spirituals." ${ }^{\text {"427 }}$ Yet, in spite of the varying opinions over the origin and function of the spiritual, ${ }^{428}$ "it is itself at the root of at least four musical trends today": ${ }^{429}$ (1) the different styles of jazz and blues, (2) the music in white Pentecostal churches that is rooted in black music, (3) spontaneous gospel music that is more indigenous to the local community, and (4) attempts to adapt it to European and American traditional music. ${ }^{430}$ In the Charismatic movement, one can trace the style of music from the music-driven worship of the 1960's, to the Jesus movement with its Christian rock concerts, and then to the praise and worship style of the 1980's and beyond. $^{431}$

The main musical characteristic of the aforementioned styles is a predominance of rhythm manifest through syncopation and cross-rhythms ${ }^{432}$ that worshipers experience

${ }^{426}$ Miller and Yamamori, Global Pentecostalism, 23-24.

${ }^{427}$ Hollenweger, Pentecostalism, 20.

${ }^{428}$ Yet, as Hollenweger notes, opinions vary regarding the origin and function of the Negro Spiritual, which range from a misinterpreted hymn of white Christians, an adaptation of African songs, as songs originating in the camp meetings of the white revival movement, as the products of black bards, or as a blending of American and European melodies with African rhythm, ibid., 32.

${ }^{429}$ Ibid.

${ }^{430}$ Ibid.

${ }^{431}$ Cherry, "Merging Tradition and Innovation in the Life of the Church," 25, 26. See also, Webber, Ancient-Future Worship: Proclaiming and Enacting God's Narrative, 84.

${ }^{432}$ Syncopation and cross-rhythms are described as "The regular shifting of each beat in a measured pattern by the same amount ahead of or behind its normal position in that pattern." New Grove Dictionary of Music and Musicians, 2001 s.v. syncopation cf. s.v. cross rhythm. "Syncopation usually occurs in lines in which the strong beats receive no articulation. This means that either they are silent...or that each note is articulated on a weak beat (or between two beats) and tied over to the next beat....Syncopation was the defining feature...which influenced popular music and jazz." Ibid. s.v. syncopation. However, as the New Grove Dictionary of Music and Musicians brings out, sycopation applies to the music of Bach and Beethoven, as well as to rock and its derivatives. 
through the medium of worship bands, which typically include drums, bass guitar, rhythm and lead guitars, piano and/or synthesizers. ${ }^{433}$

According to Albert Blackwell and Jeremy Begbie, there has been little theological reflection by the adherents of the Charismatic model regarding the relationship between music and theology. ${ }^{434}$ Consequently, timeless Being still constitutes the framework for understanding music as "the real presence," "sacramental," and "musical transubstantiation." "435 Since Pentecostal and Charismatic music assumes the split between the sacred and the common, we will analyze the divine presence within music with static timeless Being. The predominant characteristic ${ }^{436}$ of Pentecostal and

${ }^{433}$ Witvliet mentions conga drums and synthesizers, Witvliet, "Beyond Style: Rethinking the Role of Music in Worship," 71. Davies points out that the older Baptist worship used older forms such as the pipe organ, but that "charismatics used full orchestra containing trumpet, trombone, piano, drums, saxophone and xylophone to produce music which is both relevant and cheerful." Davies, Crisis and Creativity, 128. Also, the whole concept of a worship band typically includes the drum set, bass guitar, rhythm and lead guitar, and piano and/or synthesizers. According to Noel, the worship bands are symbolized by the drum set. Noel, Pentecostal and Postmodern Hermeneutics, 118 . On page 25 of this dissertation I mention others who point to the centrality of worship bands in charismatic worship. See also Miller and Yamamori, Global Pentecostalism, 137.

${ }^{434}$ Although I have not conducted an exhaustive search, my bibliography does not reveal any significant theological insights among those in the Charismatic model. Instead, those who describe music as "iconic" or "sacramental" are assuming the Sacramental model's presuppositional structure. Blackwell notes that the scarcity of theological reflection regarding music is not restricted to the Charismatic model, or even to Christianity itself. He points out that Jewish studies have also not searched and discussed the role of music in its relationship to theology. Blackwell, The Sacred in Music, 12. See also Jeremy Begbie, "Theology and Music," in The Modern Theologians: An Introduction to Christian Theology since 1918, ed. David F. Ford and Rachel Muers (Malden, MA: Blackwell, 2005), 719-720.

${ }^{435}$ See this dissertation pages $183-184$; Music has also been referred to as an auditory icon, see page 182 footnote 340 .

${ }^{436}$ The primary characteristics of music consist of rhythm, melody, harmony, and pitch. See Roger Scruton, The Aesthetics of Music (Oxford: Oxford University Press, 1997), 20. 
Charismatic music is the rhythms, ${ }^{437}$ which mediate the Holy Spirit. Consequently, in Aristotle's form and matter philosophy, the highly rhythmic music would constitute the matter and the Holy Spirit is the timeless form. This leads to an ontological dichotomy that destroys the causal relationship between the divine presence and music wherein the latter is free to vary according to all the varieties of culture.

An emergence worship gathering "always - always — involves music, but that music can run the gamut from electronic to Southern Gospel to superb jazz to Celtic laments to Christian rock to medieval chant and back again. Sometimes there is even a mix of it all within the confines of one grouping. ${ }^{, 438}$ Some Emergent churches describe their music as alternative worship music, which consists of rave worship "directly borrowed from the culture of the dance music in the late 1980's and early 1990's."439 Consequently, in alternative worship music, there is no effort to "baptize" the music to fit any prescribed pattern provided by the church. ${ }^{440}$ Lastly, since music is often referred to

${ }^{437}$ According to Britan, the rhythms of Pentecostal and charismatic music give evidence to the following observation: "Let the melody be as 'catchy' as you please and the harmonization as rich as possible, the force of the rhythmic element will still overshadow them both." Halbert Hains Britan, The Philosophy of Music: A Comparative Investigation into the Principles of Musical Aesthetics (New York: Longman's, Green, and Co., 1911), 69.

${ }^{438}$ Tickle, Emergence Christianity, 168. Whereas the charismatic renewal contained a critique of liturgical tradition, Emergents whole-heartedly embrace catholic and orthodox traditions such as the Taizé Community and its music, rituals, icons, chants, and prayers and responses, which they insert into a mixed-media context. See Baker and Gay, Alternative Worship, 21, 22, 27. See also, Armstrong, "The Future Lies in the Past," 22-29; Webber, The Younger Evangelicals, 193, 213. Byars notes that music that resembles the popular music of two or three decades ago, should give way to music that has come to us from the previous centuries as well as the last two centuries, see Byars, The Future of Protestant Worship, 128, 130.

${ }^{439}$ Baker and Gay, Alternative Worship, 20, 21. Moreover, the style of dance was identical to what is found in a club or at a rave, as opposed to a more churchy style of dance that was associated with the charismatic renewal.

${ }^{440}$ Gibbs and Bolger point out, 
as "the worship" "441 in the Charismatic model, and since worshippers experience the divine presence through the music, worship bands can typically play for at least thirty to forty minutes. ${ }^{442}$

The analysis of the divine presence within Emergent music assumes the panentheistic framework derived from dynamic timeless Being wherein the Holy Spirit is timeless and temporal, as well as immutable and changeable. There are two major ways in which Emergent concepts of the divine presence and music assume this framework. The first is by blending the rhythms of Pentecostals and Charismatics with chants, Taizé music, organ, and hymns: ${ }^{443}$ In the blend the unchangeable and traditional sounds of the later combine with the great variety of the music of all cultures. Blackwell illustrates the second way in which this panentheistic framework works with Emergent music. He points out that the Holy Spirit is represented by the unchanging mathematical basis that remains after the music stops, whereas the temporal and transient aspect refers to the sounds of rhythm, melody and harmony. ${ }^{444}$

Instead of profaning the church, secular music becomes holy, and therefore the rest of their lives becomes holy as well. For alternative worshipers (those connected to the alternative worship movement in the U.K.), music is Christian when they glorify God with it, not because of the lyrics or because a Christian wrote it or played it. All things can be made holy as they are given to God, whether 'secular' or not (Gibbs and Bolger, Emerging Churches, 71).

${ }^{441}$ Albrecht, Rites in the Spirit, 143. See also, pages 136-137.

${ }^{442}$ The Renascer church in São Paulo Brazil typically begins with "thirty minutes of worship music led by a first-class band." Miller and Yamamori, Global Pentecostalism, 16. Worship bands in Emergent churches play for about forty minutes. Gibbs and Bolger, Emerging Churches, 229.

${ }^{443}$ For the blending of these kinds of music, see this dissertation page 134 footnote $143 ; 199$ footnote 428 .

${ }^{444}$ Blackwell refers to the inaudible aspect of music as the Pythagorean tradition, which is indispensable to the study of music. Augustine marvels over number's eternity and universality by noting that there has never been a time when seven and three are not ten, nor will there ever be a time when they are not ten. Accordingly, since music is entirely formed 


\section{Encounter}

Davies correctly notes that "the quality of worship in every religion is determined by the worshippers' conception of the nature of their deity." ${ }^{445}$ In the Charismatic model, experiencing and encountering God through the worship service that is saturated with music is the fundamental goal of liturgy. ${ }^{446}$ The description and analysis of the encounter between the divine presence and the worshippers includes a brief sketch of the content that worshippers receive as a result of the encounter, the means that are employed in order to experience the divine presence, and the place where they receive the divine presence.

There are three things that form part of the content during the encounter. The first is that the Holy Spirit is directly associated with the content instead of Christ. ${ }^{447}$ Second, the content is cognitive in nature. For instance, as an auditory icon, ${ }^{448}$ music in and of itself discloses transcendent truth; divine harmony and glory; wisdom, knowledge, ${ }^{449}$ and

and fashioned after the image of numbers, the rhythms and notes will pass away but the numbers, "though stained by the corporeal touch of pitches and motions, remain." Thus, "the Pythagorean conception of music's arithmetic...[is] a portal into the transcendent," and the audible aspects of rhythm, melody and harmony referred to as the Incarnational tradition, are temporal and transient. See Blackwell, The Sacred in Music, 43, 44, 50.

${ }^{445}$ Davies, The Ecumenical Century, 121. Or, to state it differently, the interpretation of the material condition (the divine presence) hermeneutically shapes and determines the teleological condition (encounter and response to the encounter).

${ }^{446}$ Albrecht, "Pentecostal Spirituality: Looking through the Lens of Ritual," 114.

${ }^{447}$ Albrecht, Rites in the Spirit, 143-148. In the other models the real presence in liturgy is predominantly associated with Christ, not the Holy Spirit.

448“"Among the Pentecostal ritual sounds, music especially functions as an auditory icon. It embraces the Pentecostal worshipers in an analogous fashion to the manner in which icons visually surround the Eastern Orthodox faithful in the sanctuaries," ibid., 143.

${ }^{449}$ Blackwell, The Sacred in Music, 51, 56. 
grace ${ }^{450}$ convictions about what is true, good, or beautiful; ${ }^{451}$ and it is a vehicle for salvation. ${ }^{452}$ Third, music also has affective or non-cognitive content. Pinnock asserts that while sermons touch us on the cognitive level, rituals associated with music such as dance, clapping, raising hands, percussion, shouting, celebration, processions, banners and the like, move us on the affective level. ${ }^{453}$

In spite of asserting that the encounter is cognitive, Pentecostals and charismatics still uphold the sacred/secular split of modernity. Consequently, Kant's Copernican epistemological revolution inherent in the modernist position destroyed the possibility of a cognitive encounter by limiting what can be known to time and space. This effectively rendered impossible any cognitive content coming from a timeless God to humans during an encounter. As result, the encounter is an affective non-cognitive encounter ${ }^{454}$ that is

${ }^{450}$ Ibid., 39-41.

${ }^{451}$ Jeremy Begbie, Music in God's Purposes (Edinburgh: Handsell Press, 1989), 5.

${ }^{452}$ In the following quote,

Rock musician Tom McSloy has said bluntly: 'To get into rock you have to give in to it, let it inside, flow with it to the point where it consumes you, and all you can feel or hear or think about is the music'. Certainly, films such as Prince's Purple Rain seem to carry the implication that music can be a vehicle of salvation (ibid., 7-8).

${ }^{453}$ Pinnock, Flame of Love, 122, 123.

${ }^{454}$ Here is how Kant's assumption of timeless Being hermeneutically prohibits a cognitive encounter: (1) Aristotle's active intellect, which belongs to the worshippers, and which previously was able to penetrate cognitively to the divine presence, has lost its ground. According to Kant, reason is now a temporal activity and not an activity of the timeless active intellect as it was in Aristotle, (2) Kant points out that while God and the soul still exist, he assumes that they are timeless. Accordingly, they are unknowable, see Canale, A Criticism of Theological Reason: Time and Timelessness as Primordial Presuppositions, 96; Marias, History of Philosophy, 287; Kant, Critique of Pure Reason, 36; Immanuel Kant, Kant's Critique of Practical Reason and Other Works on the Theory of Ethics, trans., Thomas Kingsmill Abbott (London: Longmans, Green \& Co., 1788), 261-262, 282-284, (3) this logically leads to a non-cognitive encounter for Pentecostals and charismatics who assume the sacred and secular split of modernity. Hence, the worshiper, whose cognitive capabilities only reach objects in space and time, is metaphysically prohibited from receiving any cognitive information from the divine presence that worshipers encounter through the music. 
often described as a power encounter with the Holy Spirit. ${ }^{455}$ This is very similar to Schleiermacher's description of the feeling of absolute dependence where worshippers encounter the divine presence in the realm of feeling rather than reason. ${ }^{456}$ Thus, each worshipper's experience ${ }^{457}$ of the Holy Spirit, wisdom, knowledge, grace, salvation, goodness, beauty and transcendent truth includes power as energy and intensity of feeling; yet these descriptions of the encounter do not contain any divine cognitive content.

In contrast to the modern Pentecostal and charismatic notion of the Holy Spirit, which only involves timelessness; the Emergent conception of the Spirit's presence is made up of the timeless and the temporal. This affects the content and nature of the encounter in two main ways. First, according to Blackwell's research there are many including Blackwell himself who view "the Pythagorean conception of music's arithmetic as a portal into the transcendent." ${ }^{458}$ Thus, music discloses the divine presence and provides the hermeneutical ground for worshippers to process their understanding of

${ }^{455}$ Albrecht, "Pentecostal Spirituality: Looking through the Lens of Ritual," 113; Doukhan, In Tune with God, 28-32; Poloma, "The "Toronto Blessing": Charism, Institutionalization, and Revival," 260-261; Ronald Schouten, "'Rituals of Renewal' the Toronto Blessing as a Ritual Change of Contemporary Christianity," Journal of Ritual Studies 17, no. 2 (2003): 25. Pinnock states that sermons affect us cognitively while musical rituals that include percussion move us on the affective level, see Pinnock, Flame of Love, $122,123$.

${ }^{456}$ Gulley mentions that Kant's epistemology turned Protestant theology away from a propositional understanding to a non-cognitive understanding that was represented by Schleiermacher as occurring in the zone of human feeling. Gulley, Systematic Theology: Prolegomena, 29; Olson, The Story of Christian Theology, 543.

${ }^{457}$ Doukhan points out that rhythm gives us a feeling of power, Doukhan, In Tune with God, 29.

${ }^{458}$ Blackwell, The Sacred in Music, 50. Some of the others who view music as disclosing the transcendent include Augustine, The Scholia Enchiriadis-a $9^{\text {th }}$ or $10^{\text {th }}$ century commentary to a musical textbook, John Scotus or Erigena in the $9^{\text {th }}$ century, Jonathan Edwards, Ibid., 49-53. To see how numbers disclose timeless reality, see this dissertation page 141 footnotes 166, 167; 203 footnote 445 . 
the encounter as cognitive. Also, this Pythagorean conception of music's arithmetic has been confirmed by the discovery of the overtone series. ${ }^{459}$ Hence, the Holy Spirit, wisdom, knowledge, grace, salvation, goodness, beauty and transcendent truth are interpreted from the timeless aspect of music's mathematics. ${ }^{460}$ Second, the temporal aspect of the Holy Spirit includes the sonorous aspects of music, power, love, ${ }^{461}$ energy and intensity of feeling. Consequently, this temporal aspect of the Spirit is associated with a non-cognitive encounter.

The means employed to access the Holy Spirit are predominantly auditory. ${ }^{462}$ However, the encounter also includes traditional visual symbols, technical visual

${ }^{459}$ The overtone series was first described at the beginning of the $18^{\text {th }}$ century. It gives much new insight into the Pythagorean principles of consonance and dissonance, and it greatly extends our capacities for acoustical analysis. It has been described as a kind of Periodic Table, but of musical tones instead of chemical elements. Hence, like the "periodic table of chemical elements, the overtone series is a part of creation's order - given, enduring, and constant." Blackwell, The Sacred in Music, 56.

${ }^{460}$ The vibrations from strings produce regular periodic harmonic overtones that include the Pythagoreans' monochord. We can illustrate this series of tones from the tone C (two octaves below middle $\mathrm{C}$ ), although any pitch can generate an exactly equivalent series. When that low $\mathrm{C}$ is struck, the next tone that is naturally heard without being struck is $\mathrm{C}$ an octave above. On Pythagoras' monochord the octave represents a ratio of 1:2 where the octave's lower tone vibrates half as rapidly as the upper tone. After $\mathrm{C}$ comes $\mathrm{G}$, a perfect fifth, which represents a ratio of $2: 3$; then $C$ again, a perfect fourth with a ratio of $3: 4$; then E, a major third with a ratio of $4: 5$; then $\mathrm{G}$, a minor third with a ratio of $5: 6$; then $\mathrm{B}$ flat another minor third; then $\mathrm{C}$, a major whole tone with a ratio of $8: 9$; then $\mathrm{D}$ followed by $\mathrm{E}$, followed by $F$ sharp, which are major whole tones; then $G$, a minor whole tone with a ratio of 9:10; then A another major whole major whole tone; then B flat, followed by B natural, followed by $\mathrm{C}$ which are all minor whole tones. Ibid., 54, 56, 57, 59.

${ }^{461}$ The Spirit is synonymous with the power of love, and both are transcendent and timeless, yet immanent within creation. The inside of creation refers to the Spirit and to the power of love that function as the transcendent cause of creation and providence, while the outside refers to aspects of creation that are directly shaped by the power of love. Pinnock points out that "Pierre Teilhard de Chardin helped us to see that things have an outside that can be measure and an inside that cannot," Pinnock, Flame of Love, 66.

${ }^{462}$ Albrecht, Rites in the Spirit, 143. Blackwell notes that "the phenomenon of music...is potentially sacramental, and not only in explicitly religious contexts. Dwelling at music's heart is a sacramental potency, awaiting only appropriate times and places for its actualization, for manifesting the holy and for expressing our experience of the holy." Blackwell, The Sacred in Music, 28. 
symbols, ${ }^{463}$ and most importantly, the sight of fellow human beings, which represent living, active, embodied icons. ${ }^{464}$ Just as in the Sacramental model, the means employed act as mere conveyors of the Spirit to timeless reason for Emergents, and to the realm of feeling for Pentecostals and charismatics. The path to timeless reason leads to a cognitive encounter whereas the path to feeling leads to an affective non-cognitive encounter. Also the conveyors merely act as indispensable conditions that do not in any way affect the interpretation of the divine presence or the nature of the content in the encounter.

Whereas other models focused on the soul as the place of the encounter; and whereas the Pentecostal and Charismatic renewal only hinted at the body, ${ }^{465}$ Emergent church worship seeks to "overcome the modern dualisms in regard to body and soul",466 by placing due emphasis in mind, body, ${ }^{467}$ heart, and soul as the place where the

${ }^{463}$ These include musical and technical instruments, sound equipment, light control boards, monitors, screens, and projectors, all of which become ritual objects that mediate the divine presence. Albrecht, Rites in the Spirit, 144, 146. See also, Pinnock who includes festivals, drama, processions, banners, color, and movement, Pinnock, Flame of Love, 121.

${ }^{464}$ Albrecht, Rites in the Spirit, 146, 147.

465، The charismatic renewal had reintroduced dance to worship in UK churches from the late 1960's," yet

alternative worship saw a different use of dance. It was 'normal dance,' 'real dance' as opposed to churchy dance.... This was perhaps more like a non-western use of dance in worship - people were dancing in church in the same way as they would dance in a club or at a rave. This forceful introduction of dance to worship, in its 'unbaptized' and 'profane' form, brought with it a whole set of questions about physicality and the body, which had been more implicitly and dualistically raised by the charismatic renewal. These were questions in search of theological answers (Baker and Gay, Alternative Worship, 21).

${ }^{466}$ Gibbs and Bolger, Emerging Churches, 78.

${ }^{467}$ Evidence for the body as the locus of the divine presence is seen by the emphasis Emergents place on rituals such as the sign of the cross, dancing in different venues, the practice of yoga, massage, and physical or body prayers, Ibid. 
encounter occurs. ${ }^{468}$ With particular reference to music, Blackwell reveals that the locus where worshippers experience the divine presence is in the mind and body ${ }^{469}$ as well as in the soul. ${ }^{470}$ For Emergents, the soul includes the active intellect or reason, which functions in a non-historical manner by abstracting the timeless mathematical content, and the body includes all other physical and affective components.

\section{Response to the Encounter}

Our purpose in this section is to describe and analyze the worshippers' affective, kinesthetic, and contemplative responses to the encounter. Let's first look at the affective response. ${ }^{471}$ The belief that God is made present in worship "shapes the embedding of emotional expressions" $" 472$ that are revealed by worshippers who "cry for no apparent reason in worship... [other than] simply enjoying the feeling of being in God's

${ }^{468}$ Phyllis Tickle points out that regardless of the particular style of music used to transmit the divine presence, "the purpose [of worship] is inevitably the same: to ensure that body, heart, and soul come as equals into the conversation." Tickle, Emergence Christianity, 168. Gibbs and Bolger state that the Emergent church movement entirely embraces the body as well as the soul as the "place" where the divine presence is experienced, Gibbs and Bolger, Emerging Churches, 78.

${ }^{469}$ Blackwell equates incarnational theology with the audible sounds of music, which resonate "in our ears and hearts and bones and muscles." He then refers to Pythagorean theology, which pertains to "the imperceptible - or in our musical application, the inaudible." Blackwell, The Sacred in Music, 39-41.

${ }^{470} \mathrm{Blackwell}$ notes that the contemplation of music takes places through the faculties of the soul. Ibid., 45. Also, Chua points out that as music tunes the cosmos according to the Pythagorean proportions, it also "scales the human soul to the same proportions." Daniel K.L. Chua, Absolute Music: And the Construction of Meaning (Cambridge: Cambridge University Press, 1999), 15.

${ }^{471}$ Pinnock strongly encourages the use of ritual, instead of preaching because rituals move us on the affective level. His justification is that "Iconoclasm has impoverished the life of the church and often reduced worship to a cognitive affair." Pinnock, Flame of Love, 121. By iconoclasm, he means preaching.

${ }^{472}$ Schouten, "'Rituals of Renewal' the Toronto Blessing as a Ritual Change of Contemporary Christianity," 30. Schouten also points out on page 31 of the same article that all rituals must be related to "religious experience, to feelings and emotion." See also, Kärkkäinen, Pneumatology, 91. 
presence." ${ }^{473}$ However, worshippers that "respond by tongues singing usually in concert" ${ }^{\prime 474}$ provide the most characteristic affective response to the Spirit's presence in Pentecostal and Charismatic worship. Glossolalia operates on the human organs of speech effectively bypassing the mind in such a way that it does not frame the utterances but is primarily a spectator to the events. ${ }^{475}$ This enables the worshipper to experience God in a superior way than cognitive dialogue ever could. ${ }^{476}$ Hence, Pinnock defines tongues singing as "prayer without concepts, prayer at a deep, non-cognitive level.",477

The following analysis will outline the connection between static timeless Being and glossolalia as the ideal response. First, although Kant's Copernican epistemological revolution precludes a cognitive encounter, ${ }^{478}$ it nevertheless does not provide an alternative interpretation to ontology, which means that God is still timeless. ${ }^{479}$ Second, assuming this foundation, Schleiermacher replaces reason with "the feeling of absolute dependence within human self-consciousness" ${ }^{\mathrm{N} 80}$ as the point of contact between the

${ }^{473}$ Miller and Yamamori, Global Pentecostalism, 138. Consequently, "Pentecostal worship is not a matter, then, of mere cognitive assent to theological propositions. It is an experience of allowing oneself to feel the presence of God," Ibid.

${ }^{474}$ Albrecht, Rites in the Spirit, 136-137.

${ }^{475}$ See Norman R. Gulley, Christ Is Coming! (Hagerstown, MD: Review and Herald, 1998), 145-146. Gulley describes the effect that glossolalia has on the worshiper in these words: it bypasses the conscious mind. He quotes Robert Anderson who states that it's dissociated from thought and flows involuntarily.

${ }^{476}$ Keith Warrington, Pentecostal Theology: A Theology of Encounter (New York: T $\&$ T Clark, 2008), 90. Warrington points out that tongues fundamentally functions as a symbol of the presence of God, which he describes in terms of His immanence and transcendence.

${ }^{477}$ Pinnock, Flame of Love, 173.

${ }^{478}$ Canale, Back to Revelation - Inspiration, 103.

${ }^{479}$ Canale, A Criticism of Theological Reason: Time and Timelessness as Primordial Presuppositions, 97 footnote 2 .

${ }^{480}$ Canale, Back to Revelation - Inspiration, 103. 
Spirit's presence and the worshipper. Third, this lays the groundwork for rhythm as the dominant musical characteristic. ${ }^{481}$ These rhythms produce a power encounter with the Spirit that is replete with energy and intensity of feeling ${ }^{482}$ inevitably making worshippers oblivious to the voice of reason or conscience. ${ }^{483}$ Hence, even if cognitive contemplation were possible, the syncopated rhythms effectively eliminate it. Fourth, Macchia states that "glossolalia is an unclassifiable, free speech in response to an unclassifiable free God. It is the language of the imago Dei. The closer one draws to the divine presence, the more urgent and more difficult expression becomes." ${ }^{\text {"484 }}$ Thus, glossolalia is the ideal non-cognitive response to a non-cognitive encounter that assumes that Parmenides' via negativa is still operative in Kant's epistemology, ${ }^{485}$ which functions as the ground for analyzing glossolalia.

${ }^{481}$ Britan points out that no matter how "catchy" the melody is nor how rich the harmonies are, the rhythmic elements will still overshadow them both. Britan, The Philosophy of Music, 69. This observation about rhythm overpowering harmony equally applies to rock music which further emphasizes its syncopated nature.

${ }^{482}$ Carl Seashore, whom Doukhan points out is a pioneer in the scientific study of the psychology of music, states that rhythm gives us a feeling of power. Doukhan, In Tune with God, 29.

${ }^{483}$ Summarizing Carl Seashore's scientific study of the psychology of music, Doukhan points out that the effect of pronounced and sustained rhythm can lead to a progressive loss of interest in the rational or cognitive control of the situation. She cites charismatic worship as an example of how these rhythms can result in making worshippers "oblivious to the voice of reason or of the conscience." Ibid., 30.

${ }^{484}$ Stephenson, Types of Pentecostal Theology, 76; McGrath, Christianity's Dangerous Idea, 425. Pentecostal theologians refer to glossolalia as a medium through which believers encounter God's presence in the same way that they encounter His presence in baptism or the Lord's Supper. Stephenson, Types of Pentecostal Theology, 64.

485،"The basic idea Parmenides was expressing through his via negative was his primordial presupposition for the dimensionality of Being, namely timelessness." Canale, $A$ Criticism of Theological Reason: Time and Timelessness as Primordial Presuppositions, 82. Canale points out that Kant suggests a disconnection between the noumen (thing in itself) and the phainos noumen (appearance). "This severing is caused by the acceptance of the Platonic chorismos, which is the expression of Parmenides' via negativa for the understanding of the ground of Being." Ibid., 97 note 2. 
The following kinesthetic responses occur as a result of the worshippers' experience of the divine presence in the music: clapping, swaying, dancing, applause as a praise offering, raising hands, joining hands in prayer, extending hands towards those in need, bowing, kneeling, standing and sitting. ${ }^{486}$ Other bodily manifestations include falling to the floor under the power of the Spirit, walking around in a trance-like state, laughing uncontrollably, behaving as if drunk, and even imitating the noises of certain animals. ${ }^{487} \mathrm{~A}$ brief analysis of the plurality of affective and kinesthetic responses to the divine presence assumes that there is no causal connection between the non-cognitive encounter and the response. As a result, this justifies a plethora of responses that are grounded in culture and society.

With the advent of the Emerging Church we come to the contemplative response. Webber notes that as younger evangelicals pray with Celtic, Iona or Taizé songs playing in the background, they look at icons as windows to heaven and see and experience the heavenly reality of the transcendent and Holy God. ${ }^{488}$ Similarly, just as icons are windows into transcendent truth Blackwell notes that the overtone series' musical tones are comparable to a spiritual icon, which he then describes as "an object of contemplation that discloses transcendent truth." ${ }^{\$ 49}$

Our analysis of the Emergent response to the Spirit's encounter through music is

${ }^{486}$ Albrecht, "Pentecostal Spirituality: Looking through the Lens of Ritual," 113-114; Kärkkäinen, Pneumatology, 91; Miller and Yamamori, Global Pentecostalism, 138.

${ }^{487}$ Poloma, "The "Toronto Blessing": Charism, Institutionalization, and Revival," 260-261; Schouten, "'Rituals of Renewal' the Toronto Blessing as a Ritual Change of Contemporary Christianity," 25.

${ }^{488}$ Webber, The Younger Evangelicals, 213. See also, Tickle, Emergence Christianity, P-12, 170-171.

${ }^{489}$ Blackwell, The Sacred in Music, 56. 
based on Blackwell's hypothesis that the Pythagorean tradition discloses the timeless aspect of the Spirit's presence through music's integral relationship with the mathematical and acoustical laws that are grounded in the overtone series; ${ }^{490}$ while the Incarnational tradition refers to the temporal aspect of the Spirit's presence that operates through rhythm, melody, and harmony. ${ }^{491}$ "Walhout is making the essentially Pythagorean argument that music's sonorous forms in motion are moving images of eternity." ${ }^{492}$ This sets the stage for the nature of the kind of contemplation that occurs. For instance, Blackwell assumes that contemplation occurs through the timeless active intellect ${ }^{493}$ that worshippers employ to abstract the timeless and eternal mathematical principles of music from their sonorous characteristics. There are two hermeneutical consequences that arise from adopting this identical structure of human reason from the Sacramental model. The first is the possibility of moral development, which assumes that the timeless soul is scaled to the same proportions as the Pythagorean ratios that tune the heavenly bodies. This creates the possibility of moral development through a patterning of the individual psyche on the cosmos by way of the study of mathematics through

${ }^{490}$ The "Pythagorean tradition emphasizes intellectual appreciation and finds God's grace revealed through our contemplating invisible objects of our understanding and subjects of our insight, in particular, through our contemplating the mathematics of music." Blackwell, The Sacred in Music, 47. On page 84, Blackwell refers to the Pythagorean ratios that underlie music and the overtone series as foundational realities that are given and enduring. On pages $85-86$, he writes, "music thus serves as a path of human and divine meeting, a finite reality through which the divine is perceived to be disclosed and communicated. Pythagorean contemplation of music is in this sense a sacramental exercise." For further evidence between the mathematics of music of Pythagoras and the overtone series, see Ibid., 53-86.

${ }^{491}$ Ibid., 39-41, 47-48.

${ }^{492}$ Ibid., 84. This of course assumes the dichotomy between timeless eternity and time that Plato later systematized into his two worlds theory.

${ }^{493}$ Blackwell notes that the Pythagorean tradition emphasizes intellectual appreciation that is revealed through worshippers that contemplate the mathematics of music. Blackwell, The Sacred in Music, 47. 
music. ${ }^{494}$ This contemplation of music as a portal to the transcendent has been the approach of those who adhere to or have been influenced by the Sacramental Model such as Augustine, The Scholia Enchiriadis, John Scotus, and Albert Blackwell. ${ }^{495}$ When Christian worshippers assert and believe that music is synonymous with the divine presence, the groundwork is laid for this kind of contemplation of the divine through music's mathematics. This bridges the gap between the timeless mathematics and the temporal musical sounds. However, the ontological dichotomy between mathematics and music that is based on Kant's epistemology means that value judgments about the aesthetic aspects of music's sounds are not moral but rather cultural and sociological. This legitimizes all kinds of musical styles that are immune from any moral judgment since there is no causal relationship between the mathematics that are grounded in the overtone series and each culture's countless musical expressions. ${ }^{496}$

\section{Ecumenical Search for Unity}

In this section we will analyze the Charismatic model's quest for unity in Christendom. Our analysis will include two main areas. The first is how the concept of diversity within unity relates with the musical styles and responses to the divine presence

${ }^{494}$ Chua, Absolute Music, 15. See also Blackwell, The Sacred in Music, 43.

${ }^{495}$ Albert Blackwell, The Sacred in Music, 49-53.

${ }^{496}$ Blackwell notes that the experiment of atonal music has not been able to extricate itself from the overtone series. He concludes by stating that the overtone series seems to be inescapable. However, the ways in which all the musical systems of the world fall under the principles of the overtone series varies immensely. Blackwell, The Sacred in Music, 71. Elsewhere he states that "we may speak of music as a universal language in countless cultural dialects" Ibid., 72. Some examples of the different musical dialects that are built on the overtone series that Blackwell refers to include, chants (61), Near Eastern, Indian, and ancient Greece (62), Chinese (62-63), Korean (66-67), European Western harmonic music (67-68), country, pop, rock, country and western, rap (69), Persian and Indian (73), and Javanese gamelan orchestra (74). 
in this model. The second is the growing recognition of the real presence in the Lord's Supper and the implications for music as the central ritual action as the means of achieving unity in this model.

McGrath states that recent historical details ${ }^{497}$ involved in the rise of Pentecostalism reveal that "diversity within unity" was present from the origins of the movement. ${ }^{498}$ Furthermore, the theme of diversity within unity is also evident in the Charismatic movement that sprang up in the 1960 's. ${ }^{499}$ The ground for unity among Pentecostals and Charismatics is based on a non-cognitive encounter with the Spirit's timeless presence. This leads to a plurality ${ }^{500}$ of doctrinal beliefs, musical styles and responses to the encounter. For Emergents, the ground for unity is based on a cognitive encounter in which the worshipper abstracts the timeless Spirit's presence from the mathematical structure of music that is grounded in the overtone series. The temporal

${ }^{497}$ Alister McGrath notes that a common misconception regarding Pentecostalism is that it began as an American phenomenon that subsequently spread to the rest of the nations, McGrath, Christianity's Dangerous Idea, 421. Yet, major studies that began in the mid 1980's and on concerning the origins of the movement in Argentina, Chile, Ghana, Korea, the Philippines, South Africa, and South India have forced historians to make revisions to the earlier paradigms. McGrath, Christianity's Dangerous Idea, 422. The picture that is now emerging is that the Azusa street revival in 1906 was just one of a series of local Pentecostalisms that began to emerge in several nations during the first decade of the twentieth century with no clear connection between them other than they all demonstrated Pentecostal characteristics. See this dissertation page 180 footnote 335.

${ }^{498}$ McGrath, Christianity's Dangerous Idea, 423. In other words, this was not an American movement that took its brand of Pentecostalism and integrated it with other cultures. Instead the movement itself "was integral to the historical emergence of the phenomenon that we now call Pentecostalism." Ibid., 423.

${ }^{499}$ As Bloesch notes, "The charismatic movement has infiltrated Episcopal, Presbyterian, Methodist, Baptist, Disciples, United Church of Christ and Roman Catholic Churches. Even Eastern Orthodox churches have been affected." Bloesch, The Holy Spirit: Works and Gifts, 186.

${ }^{500}$ Kärkkäinen speaks of the importance of the Spirit in the work for Christian unity, while also stating that the plurality and diversity promoted by the Holy Spirit is also a condition for unity. Kärkkäinen, Pneumatology, 99. This is best understood by the ontological gap between the timeless and the temporal, which we have applied in our analysis to music and its relationship to unity. 
aspect of the Spirit's presence is associated with the audible sounds of music. This leads to a few essential theological timeless truths, a plurality of musical styles, and a plurality of responses. As a result, unity neither depends upon a uniform musical style nor a uniform response. Moreover, only the encounter itself is theological while the plurality of musical styles and responses is considered to be aesthetic and cultural.

We will now look at the growing recognition of the real presence in the Lord's Supper and the implications for music as the central ritual action for this model's quest for unity in Christendom. Originally, Pentecostals believed the Lord's Supper to be a memorial like Zwingli instead of the real presence like Luther. ${ }^{501}$ While this created irreconcilable conflict in the past, Jesuit scholar Albert Ziegler noted that Catholics today should have no problem in accepting the Lord's Supper of Zwingli and the Pentecostals. His rationale for this is that "the reformation did not start with a controversy on fundamental truths but in the realm of practical Christianity....He [thus] describes Zwingli's eucharist as ecumenical." ${ }^{502}$ In other words, since the Reformation did not address the classical system with its timeless view of God and the duality of human nature as key presuppositions, it is possible to read Zwingli ecumenically since he never addressed Catholicism's fundamental framework.

More recently, however, Pentecostal theologians have exalted the Spirit's presence in the Supper, which replaces Christ's real presence in the Supper ${ }^{503}$ but which

\footnotetext{
${ }^{501}$ Hollenweger, Pentecostalism, 172. See also, Albrecht, Rites in the Spirit, 44; Duffield and Van Cleave, Foundations of Pentecostal Theology, 417, 435.

${ }^{502}$ Hollenweger, Pentecostalism, 172 \#97. Areas of practical Christianity include "celibacy of priests, the Bible in the language of the people, changes in liturgy."

${ }^{503}$ In the Sacramental Model, static timeless Being interprets omnipresence as being immutable, even after the incarnation. As a result, Christ's presence is ubiquitous leading to the view that he is substantially present in the Eucharist. The Charismatic Model simply
} 
is still interpreted on the basis of timeless Being. This view overturns the earlier view that the Lord's Supper is a mere memorial. ${ }^{504}$ Stephenson recommends that Pentecostals should consider celebrating it more frequently and in a manner that makes it more central to corporate worship. As a result, the uncritical acceptance of timeless Being by Pentecostals is bringing them into harmony with the Sacramental model's aim, which is to make the Eucharist the center around which Christianity must unify. ${ }^{505}$ Among Emergents, Morgan believes that the Eucharist is essential because, unlike preaching and entertainment driven worship,${ }^{506}$ it holds both cognitive and affective dimensions thereby making it a "meaningful conduit for theological reflection and affective communication. ${ }^{.507}$

The clear implication for a more central celebration of the Eucharist for the Charismatic model is that music appears to be insufficient as a ritual when it comes to achieving liturgical unity. There are three possible reasons for this. The first is that although cognitive communication is possible with music, at least for Emergents in this model, there are those like Morgan who believe that music fails to meet the intellectual needs of worshippers in the same way that the Eucharist does. ${ }^{508}$ Second, as a ritual that

replaces Christ with the Holy Spirit who is now substantially present in the Eucharist. In Chapter 6 of this study, we see that the Biblical Sanctuary model interprets Christ's presence as localized in the heavenly sanctuary. Hence, when Christ sends the Holy Spirit (John $14: 15-19,26 ; 15: 26 ; 16: 7-8,13-14)$, the Spirit is not substantially present in the Eucharist; the Spirit represents Christ by interacting with us in a personal way as Christ did with his disciples.

${ }^{504}$ Stephenson, Types of Pentecostal Theology, 121-122, 124.

${ }^{505}$ Ibid., 124, 127.

${ }^{506}$ Morgan, "Emerging Eucharist: Formative Ritualizing in British Emerging Churches," 267.

$$
\begin{aligned}
& { }^{507} \text { Ibid., } 273 . \\
& { }^{508} \text { Ibid., } 273 .
\end{aligned}
$$


is connected to unity, current musical styles have a short history that does not go back centuries like the Eucharist. Third, combining the post Vatican II Eucharist with a plurality of musical styles does a better job in uniting all of the cultures by balancing the cognitive aspects of the Eucharist with the affective aspects of music. Thus, the uncritical acceptance of timeless Being ultimately leads the Charismatic model to either supplement music with the Eucharist as the key ritual for liturgical unity, or it leads this model to replace music with the Eucharist as the key ritual for achieving unity. 


\section{CHAPTER 5}

\section{BIBLICAL SANCTUARY MODEL: SURVEY \\ OF OLD TESTAMENT DATA}

\section{Introduction}

The choice of the name Biblical Sanctuary Model instead of Biblical Model or Sanctuary Model is based on three factors. First, the sanctuary is the all-important setting in which liturgy occurs in Scripture. Second, the research in Chapters 5 and 6 reveals the large hermeneutical role the sanctuary plays throughout the survey of Old and New Testament data. The third reason for the name Biblical Sanctuary Model instead of Sanctuary Model is to distinguish it from the Sacramental model's use of the sanctuary in its theology and liturgy which might be described as a Sanctuary Model; ${ }^{1}$ yet its assumption of timeless Being's hermeneutical impact on the liturgical components precludes it from being identified as a Biblical Sanctuary Model.

In the last Chapter we outlined how timeless Being dominated the interpretation of the liturgical components. This Chapter seeks to examine the possibility of developing a theology of the divine presence in Christian liturgy via a survey of OT data to ascertain Scripture's interpretation of the macro hermeneutical presuppositions. Reading the text

\footnotetext{
${ }^{1}$ Scott Hahn points out that "the Temple theme is perhaps the richest in all biblical theology," Hahn, Temple and Contemplation: God's Presence in the Cosmos, Church, and Human Heart, ed. Scott W. Hahn (Steubenville, OH: St. Paul Center for Biblical Theology, 2008), 8. For more on how the Sacramental Model's use of the sanctuary/temple assumes the timeless view of the liturgical component, see Chapter 6 of this dissertation pages 368373 , especially footnote 204 .
} 
from the hermeneutical perspective of its own macro hermeneutical presuppositions, namely from the perspective of God's temporal Being, has not been done before in Christian liturgy on account of the dominance of the assumption of God's timeless Being as already witnessed in the other models. However, just before this Chapter outlines the biblical exegetical methodology it will follow, readers who desire a theological and systematic portrayal of the Biblical Sanctuary model may wish to forego the exegetical construction involved in Chapters 5 and 6 upon which such as a portrayal is based and go directly to Chapter 7.

This Chapter will employ a phenomenological exegesis instead of a hermeneutical exegesis in the analysis of the Biblical texts. Whereas a hermeneutical exegesis refers primarily to the philological and historical dimensions of the exegetical method, ${ }^{2}$ a phenomenological exegesis consists in (1) looking for the first principles, or metaphysical framework implicit in the text as canon, ${ }^{3}$ and (2) applying a phenomenological epoché to all possible theories so that they can be suspended from interpreting the text in such a way that they distort or contradict its meaning. ${ }^{4}$ Consequently, this Chapter will not employ the historical-critical method since it assumes the hermeneutical role of the extra-

${ }^{2}$ The "hermeneutical exegesis focuses on the pericope which itself contributes to and corrects the wider metaphysical framework in an ongoing reciprocal relationship, never attempting to reduce the multivalency of the text, but seeking a wider context that preserves it." John C. Peckham, "The Analogy of Scripture Revisited: A Final Form Canonical Approach to Systematic Theology," Mid-America Journal of Theology 22 (2011): 52.

${ }^{3}$ Ibid., 51. Phenomenological exegesis works and is grounded in the text itself as it is. It does not go beyond the text to find its meaning but rather looks for meaning in the text as it appears, Fernando Canale, A Criticism of Theological Reason: Time and Timelessness as Primordial Presuppositions, 296-297.

${ }^{4}$ Peckham, "The Analogy of Scripture Revisited: A Final Form Canonical Approach to Systematic Theology," 51. The phenomenological epoché woks only when all involved theories are properly understood. Otherwise they will be ignored or applied unconsciously, Canale, A Criticism of Theological Reason: Time and Timelessness as Primordial Presuppositions, 296. 
biblical idea of dynamic timeless Being in its interpretation of the entire contents of

Scripture, which includes the liturgical components. ${ }^{5}$ Moreover, although the

grammatical-historical method has its basis in the Sola Scriptura principle of the

Reformation, ${ }^{6}$ its methodological limitations leave it open to timeless Being's

interpretation of the liturgical components. $^{7}$

In this Chapter I will apply a phenomenological exegesis to the following biblical

texts: (1) Exod 3:1-21, (2) Lev 19:30; 26:2, (3) Exod 19-20 and Deut 4-5, (4) 1 Kgs 8:12-

66 and 2 Chr 5:11-7:7, and (5) Isaiah 6:1-8. The reasons for using these texts are as

follows. First, each passage reveals important information about the presence of God.

Second, with the exception of Lev 19:30 and $26: 2,{ }^{8}$ each passage includes information

${ }^{5}$ See this dissertation pages 114-117. Also, Canale notes, "the historical critical method presupposes what is supposed to be investigated and reached at the end of the exegetical procedure....The same is true regarding the historical-grammatical...method which assumes the basic guidelines of Greek ontology and epistemology," Canale, $A$ Criticism of Theological Reason: Time and Timelessness as Primordial Presuppositions, 294 footnote 2.

${ }^{6}$ Gerhard F. Hasel, Biblical Interpretation Today (Washington, DC: Biblical Research Institute, 1985), 3-4.

${ }^{7}$ The following two sources outline some of the specific procedures of this method that leave it open to timeless Being's interpretation of the liturgical components. Richard M. Davidson, "Biblical Interpretation," in Handbook of Seventh-Day Adventist Theology, ed. Raoul Dederen (Hagerstown, MD: Review and Herald, 2000), 94-97; Reymond, A New Systematic Theology of the Christian Faith, 49-52. Also, Canale states,

the historical-grammatical method was helpful in establishing the meaning of biblical events but did not help much in the theological arena. A theological method supplemented the exegetical one in determining in what sense the actions of a timeless, non-historical spiritual God are real. In an implicit sense, then, the historicalgrammatical method was incomplete and open to correction from theological and philosophical reflections (Fernando Canale, "From Vision to System: Finishing the Task of Adventist Biblical and Systematic Theologies-Part II," Journal of the Adventist Theological Society 16, no. 1-2 (2005): 8-9).

${ }^{8}$ In Lev 19:30 and 26:2 the divine name/presence is linked with ritual actions that include the Sabbath and the sanctuary. These texts do not include an encounter or the response to the encounter. I chose them because the link between the divine name/presence 
about all of the liturgical components. These passages merely represent and do not exhaust what the OT reveals about the divine presence and the liturgical characteristics. Third, scholars in various fields of study recognize these texts as addressing either the presence of God or the liturgical components (see footnotes): (1) Exod 3:1-21, ${ }^{9}$ (2) Lev $19: 30 ; 26: 2,{ }^{10}(3)$ Exod $19-20,{ }^{11}$ and Deut $4-5,{ }^{12}$ (4) I Kings 8:12-66 ${ }^{13}$ and 2 Chr 5:11$7: 7,{ }^{14}$ and (5) Isaiah $6: 1-8 .{ }^{15}$

Here is how I will explore all the aforementioned texts in this Chapter. First, I will describe the five liturgical components in each biblical passage that comprise the liturgical phenomena. I will do this by examining what each biblical passage reveals about the divine presence. Then I will proceed to find out what each passage reveals and the sanctuary and Sabbath point to a different interpretation of Being, thus providing the ground for the encounter and response to the encounter.

${ }^{9}$ Canale, A Criticism of Theological Reason: Time and Timelessness as Primordial Presuppositions, 342-361; Charles H.H. Scobie, The Ways of Our God: An Approach to Biblical Theology (Grand Rapids, MI: Eerdmans, 2003), 119-120; Webber, ed. The Biblical Foundations of Christian Worship, 71-72.

${ }^{10}$ René Péter-Contesse and John Ellington, A Handbook on Leviticus (New York: United Bible Societies, 1990), s.v. Lev 19:30. In this handbook respect is shown to the Israelite place of worship, thus there is a connection to worship. See also, John E. Hartley, Leviticus Word Biblical Commentary (WBC) 4 (Dallas, TX: Word Books, 1992), s.v. Lev 26:2. In this commentary the presence of God and worship are connected with the Sabbath and the sanctuary. Also, the observance of the Sabbath and reverencing the sanctuary are in direct opposition to idolatry. For other reasons for why I am including these texts. See footnote 8 above.

${ }^{11}$ Daniel I. Block, ""That They May Hear": Biblical Foundations for the Oral Reading of Scripture in Worship," Journal of Spiritual Formation \& Soul Care 5 no. 1 (2012): 9-10.

${ }^{12}$ Ian Wilson, Out of the Midst of the Fire: Divine Presence in Deuteronomy Society of Biblical Literature Dissertation Series (SBLDS) 151 (Atlanta, GA: Scholar's Press, 1995), 46-104.

${ }^{13}$ Elias Brasil de Souza, "The Heavenly Sanctuary/Temple Motif in the Hebrew Bible: Function and Relationship to the Earthly Counterparts" (PhD dissertation, Andrews University, 2005), 197-222.

${ }^{14}$ Eugene H. Merrill, "A Theology of Chronicles," in A Biblical Theology of the Old Testament, ed. Roy B. Zuck (Chicago: Moody Press, 1991), 159.

${ }^{15}$ de Souza, "The Heavenly Sanctuary/Temple Motif in the Hebrew Bible," 234-245. 
about the liturgist, then the liturgical actions, the encounter, and the response to the encounter; all of which comprise the necessary steps to outlining the Biblical Sanctuary Model.

Then I will apply the phenomenological exegetical methodology to the liturgical components found in each passage to unfold the meaning found therein. I will explore how each passage makes a contribution to the overall understanding of the divine presence and each liturgical component, much like the different pieces in a mosaic contribute to the overall picture. ${ }^{16}$

\section{Divine Presence}

In the description and analysis of the divine presence I will look for what the biblical text reveals about Being and the attributes that revolve around the divine presence. I will first begin with Exod 3:1-21 because it explicitly mentions Being. ${ }^{17}$ Next, I will go to Lev $19: 30 ; 26: 1-2$ to lay the groundwork for establishing the relationship between Being, the divine presence and the liturgical components. After that, I will follow the canonical order.

\section{Exod 3:1-21}

\section{Description}

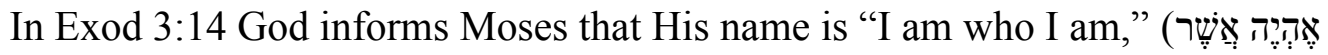

\footnotetext{
${ }^{16}$ de Souza notes that there is a structural and functional link, as well as a dynamic interaction between the earthly and heavenly sanctuaries in I Kgs 8:12-66 and Isaiah 6:1-8, see de Souza, "The Heavenly Sanctuary/Temple Motif in the Hebrew Bible," 197-222, 234245.

${ }^{17}$ Being with a capital B refers to general ontology, which is either timeless or temporal. On the other hand, being with a small $b$ refers to regional ontologies that may include God, human beings, or any part of creation. Regional ontologies, or being, can also be related to essence or substance as well.
} 
which is a direct reference to Being. ${ }^{18}$ Although the burning bush that is not consumed attracts the attention of Moses (Exod 3:2-3), God's presence is only revealed when God speaks (Exod 3:4-6). ${ }^{19}$ Hence, God reveals his Being to Moses through his Word. However, notwithstanding that God is omnipresent, the revelation of His presence in Exod 3:1-6 is restricted to that one burning bush from which Moses heard God's voice.

The words "I AM" are inextricably and causally linked with one's understanding of God's self-existence, his eternity, and his immutability. Also, since God's Being was revealed to Moses through his words, and since God's presence hallowed the place of the encounter (Exod 3:4-5), we can infer that God is invisible (Col 1:15; 1 Tim 1:17; Heb 11:27; cf. Rom 1:20) in the context of liturgy except in Rev 4-5 (cf. Rev 7:9-13) where the presence of Father and Son are visible to the worshippers in heaven. The I AM at the burning bush is also holy.

\section{Analysis}

Having now given a brief description of Being and the attributes that cluster around the divine presence, I will now begin my analysis with Being. God's name (I AM)

${ }^{18}$ See Canale $A$ Criticism of Theological Reason: Time and Timelessness as Primordial Presuppositions, 298-410 for a historical overview of how Exod 3:14 speaks of Being. Also, the Hebrew word for name šèm can also mean "essence," William H.C. Propp, Exodus 1-18: A New Translation with Introduction and Commentary Anchor Bible (AB) 2 (New York: Doubleday, 1999), 224.

${ }^{19}$ In Exod 3:16 Moses links God's appearance to the message to bring His people out of Egypt. Also in Exod 3:2,14-15 God's presence is not to be identified with the material place of his appearance (fire) but with His words. The meaning of God's Being is understood on the basis of His words. Canale, A Criticism of Theological Reason: Time and Timelessness as Primordial Presuppositions, 361. "The Being of God is "present" and at the same time "revealed" through and in His words." Ibid., 361. "God's presence and His words are essential elements of His Being. God's Being cannot be grasped as presence apart from His words." Ibid., 361 footnote 2. 
clearly points to God's Being, which is synonymous with His presence (2 Chr 20:8-9). ${ }^{20}$

Exod 3:15 reveals that God's Being is clearly temporal and not timeless. ${ }^{21}$ For instance, the text states, "the Lord (Yahweh) God of your fathers...has sent me to you.",22 This places the "I AM" in the past with Moses' fathers. In the narrative, God is currently speaking with Moses, which involves the present. Also, Exod 3:15 reads: "I am that I am" is "God's name forever (עולם) [and His] memorial to all generations," which clearly associates his name with the future. ${ }^{23}$ Hence, Exod 3:14-15 grounds the temporal interpretation of God's Being. Yet, we shall uncover more about God's Being.

\footnotetext{
${ }^{20}$ For Moses and the people, the idea of Being "was concentrated in the reality of God's presence; otherwise it would not have been revelation at all. Hence, Being is to be understood from the seminal dimension of "presence." Canale, A Criticism of Theological Reason: Time and Timelessness as Primordial Presuppositions, 345. As a result, the ground for a Biblical interpretation of the meaning of Being flows from the temporal categories of past, present and future seen in Exod 3:14-16, and not from prior Greek reflections of ontology that are assumed prior to the passage. Ibid., 346-347. God and Being are to be interpreted from the starting point of God's ontic presence. Ibid., 352.

${ }^{21}$ At this point, we should not confuse the Being principle with the God principle. The text is speaking of Being as a primordial principle, which is not the same as stating that God is temporal as panentheists do. In panentheism Being is still timeless even though God is timeless and temporal. In Exod 3:15, Being is temporal and God is temporal, see Fernando Canale, "Philosophical Foundations and the Biblical Sanctuary," 183-206.

${ }^{22}$ For the connections between the Lord, Yahweh and the tetragrammaton, see James K. Bruckner, Exodus New International Biblical Commentary (NIBC) 2 (Peabody, MA: Hendrickson, 2008), 44. Also, "From the Hebrew word translated as "I am" comes the derived form Yahweh. Yahweh, is rather consistently rendered "LORD" by the [King James Version] KJV," "This is my name," Seventh-day Adventist Bible Commentary (SDABC), $1: 511$.

${ }^{23}$ refers to eternal and eternity "but not in a philosophical sense," see The Hebrew and Aramaic Lexicon of the Old Testament (HALOT), s.v. עולם. A phenomenological exegesis brackets out the static and dynamic timeless presuppositions inherent in Greek philosophy which have distorted the meaning of עולם. Even though Aelred Cody has built his entire study of liturgy in Hebrews under timeless Being, he concurs that the biblical concept of eternity is not the Greek view of eternity. Instead

Eternity is something coexistent with time and parallel with it, God's point of view as contrasted with earthly man's point of view. The עולם of the Old Testament points backward along the line of time far beyond any definite length of time conceivable, and [עולם] points forward in the same way (Aelred Cody, The Heavenly Sanctuary and Liturgy in the Epistle to the Hebrews: The Achievement of Salvation in the Epistle's Perspective (St. Meinrad, IN: Grail Publications, 1960), 125).
} 
Since God's temporal Being constitutes the broadest possible presupposition, ${ }^{24}$ it thus provides the ground for analyzing and interpreting eternity, immutability, invisibility, and holiness; ${ }^{25}$ all of which have a direct impact on how we view his presence. Let's begin our analysis of God's attributes with eternity. Through the words "I AM" God's temporal Being lays the groundwork for interpreting his eternity as unending time. ${ }^{26}$ Hence, his presence and existence goes back prior to the creation of the universe ranging from the days of eternity ${ }^{27}$ down to the present and continuing into the unending future. ${ }^{28}$ Also, in order for the I AM to pass the law of non-contradiction, God must simultaneously exist in the entirety of space, ${ }^{29}$ and even beyond space (1 Kings 8:27). ${ }^{30}$ Additionally, the complex nature of the relationship between God's presence with time

${ }^{24}$ Fernando Canale's groundbreaking dissertation clearly set forth the issue of Being as the primordial presupposition that provides the ground for interpreting the presence of God on the basis of temporality instead of timelessness, see Canale, A Criticism of Theological Reason: Time and Timelessness as Primordial Presuppositions.

${ }^{25}$ Gulley points out that "I AM" functions as the ground for interpreting all of God's attributes. See Norman R. Gulley, Systematic Theology: God as Trinity, 68-69.

${ }^{26}$ This is in stark contrast to Plato's qualitative difference between eternity and time in Plato's Timaeus. For exegetical support for eternity as unending time, see Oscar Cullmann, Christ and Time: The Primitive Conception of Time and History (Philadelphia: Westminster Press, 1950), 53, 61, 63.

${ }^{27}$ See Micah 5:2 (מִימֶי עוֹלָם), which links with Exod 3:15 where God says this is my

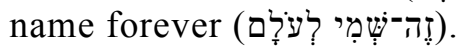

${ }^{28}$ In Exod 3:15 "I am that I am" is God's name forever and His memorial to all generations, which clearly associates His name with the future. The Hebrew word "olam" refers to eternal and eternity "but not in a philosophical sense," see HALOT, s.v. "עולם" "עe "The reference, "in a philosophical sense" obviously refers to eternity as the complete negation of succession as in past, present, future. However, a temporal eternity provides an alternative interpretation and is therefore just as philosophical as the timeless view.

${ }^{29} \mathrm{We}$ will look into this precise relationship as we continue our analysis. Gulley point out, "This means that the whole of God is present in the entirety of space." Gulley, Systematic Theology: God as Trinity, 68.

${ }^{30}$ “God is not only fully present everywhere in space, but He is also fully present beyond all space...(1 Kgs 8:27; $2 \mathrm{Chr} 2: 6)$." Ibid., 69. Yet, since the "I AM" is immutable, "beyond all space" still assumes temporal Being. Hence, linking "I AM" within immutability means that there cannot be any change in the interpretation of Being/General Ontology without involving a contradiction. 
and space better harmonizes with "I AM" as Trinity ${ }^{31}$ than does the timeless

philosophical idea of God as One, which describes God as simple and having no parts. ${ }^{32}$

Accordingly, this makes it possible for us to explore the Biblical references to God as

Trinity $^{33}$ as it relates to the divine presence without at the same denying the Scriptural

teaching that God is One. Moreover, we can infer that there is an analogical ${ }^{34}$ relationship

between creation and God. Since, analogy implies similarity, the similarity God shares

with creation is the spatio-temporal framework. ${ }^{35}$ Since Exod 3:14-15 grounds the

${ }^{31}$ In Matt 28:19, Jesus charges that His followers baptize "in the name" ( $\tau$ ò óvo $\mu \alpha$ ) of the Father, Son and Holy Spirit. Hence, the name of Father, Son and Holy Spirit is linked with Exod 3:14-15 where God instructs Moses that "I AM" is His name forever (övo $\mu \alpha$ aióviov) (LXX). God's infinite analogous temporal Being thus applies to the Trinity.

${ }^{32}$ Aquinas notes that God is simple, having no parts, see ST First Part, Question 3, Articles 1-7. The analogies of the Cappadocian fathers emphasized threeness but their abstract explanations tended to emphasize oneness. Olson, The Story of Christian Theology, 194. Canale states, "If God is simple, as perfect timeless-spaceless reality demands, we can conceive his being only as one, not three. The biblical information about the Trinity, then, becomes a problem not only because the writers grounded the Trinity in history rather than in non-historical, philosophical speculations, but also because they clearly presented God as Trinity." Fernando Canale, Basic Elements of Christian Theology: Scripture Replacing Tradition, 78. Perhaps this is why Karl Rahner states, "should the doctrine of the Trinity have to be dropped as false, the major part of religious literature could well remain virtually unchanged," Rahner, The Trinity, 10-11.

${ }^{33}$ See our description and analysis of Acts 2:1-47 and Rev 4-5 for the divine presence in Chapter 6.

${ }^{34} \mathrm{By}$ analogical, I mean that there is both similarity and dissimilarity between words and concepts when applied to God and creation. This is different than univocal and equivocal: the former implies that words or concepts apply to God and creatures in exactly the same way, and the latter means that words or concepts hold entirely different meanings when applied to God than when applied to creatures. See John C. Peckham, The Love of God: A Canonical Model (Downers' Grover, IL: InterVarsity Press, 2015), 172-173. Hence, I am employing analogy within the framework of God's temporal Being.

35“"According to biblical ontology, the analogy in the relation of God and creation is found within time." King L. She, The Use of Exodus in Hebrews (New York: Peter Lang, 2011), 84. This is implied from the I AM of Exod 3:14 which clearly points to the temporal view of eternity before creation. For other passages that point to a temporal view prior to creation, see Job 36:26; Psalm 90:2; Micah 5:2; Rev 1:4, 4:8. Nevertheless, this raises the complex issue of what time actually is, and then how it relates to God both prior to and since creation. Although a thorough investigation would go beyond the limits of this dissertation, I have concluded that time is not a container that is first defined and explained before we 
temporal interpretation of Being, God's Being is infinite and temporal, which does not mean temporary or transient. As a result, there is an analogy between God's infinite temporal time and created time. ${ }^{36}$ Yet, since analogy also implies dissimilarity, the analogical relationship also means that there is an ontological distinction between the nature and essence of God and that of creation $^{37}$ that must be interpreted from the ground of God's temporal Being. God's temporal Being is thus infinite and analogous to all created realities.

"I AM," clearly points to God's presence as immutable. ${ }^{38}$ Aside from the issue of the Incarnation, which involves a fundamental change in God's nature that we will examine later, ${ }^{39}$ we can draw two conclusions about the nature of immutability from the "I AM" of Exod 3:14-15. First, when viewed from God's infinite analogous temporal

place God into the container. Rather, time is a byproduct of reality. Accordingly, one must first understand reality, in this case God, on the basis of Scripture's revelation of his Being. Thus, within the purview of God's infinite analogous temporal Being, all realities including God temporalize themselves and are able to interact with each other. We must then adapt our understanding of time on the basis of the reality we are studying. For more on some of these issues, see Fernando Canale, The Cognitive Principle of Christian Theology, 243-275.

${ }^{36}$ This concept of analogy that has its basis in God's temporal Being derived from Exod 3:14 renders groundless the ontological dichotomy between timeless eternity and time that the three models assume in Chapter 4 of this study.

${ }^{37}$ In Aquinas' analogia entis, God is completely timeless, which means that he is pure actuality with no potentiality, or pure form with no matter. Through the Aristotelian concept of form that is traced back to the Platonic Idea, creation is made up of form and matter. Thus, for Aquinas the timeless conception of reality that God and creation share makes possible the analogy of being between God and creation. In this setting God is completely timeless whereas creation has lesser degrees of timelessness. Yet, once we replace timeless Being with God's infinite analogous temporal Being, Aquinas' analogy of being is rendered groundless.

${ }^{38}$ From the perspective of temporal Being, the immutable nature of "I AM" assumes that God has a history prior to the universe: It also assumes that God's intimate and unceasing involvement in creation (Col 1:16-17) does not violate His immutability as Heb $1: 10-12$ reveals.

${ }^{39}$ For an analysis of how God's infinite analogous temporal Being relates to the Incarnation, see our analysis of the divine presence in Acts 2:1-47, Heb 12:18-29, and Rev 4-5 in Chapter 6. 
Being, his intimate involvement and relationship with the universe within the continuum of time and space is immutable. ${ }^{40}$ Second, God is immutable in the sense that he does not progressively become aware of himself and thereby become God through the process of evolution as panentheism suggests. ${ }^{41}$ Furthermore, God's being or essential nature does not change on account of his interaction with the universe (Heb 1:10-12).

We will now briefly look at God as invisible. We noted previously that Moses did not discern the divine presence when he first looked at the burning bush. It was only God's words to Moses that revealed his presence. Consequently, equating God's Being with his words rather than with creation assumes that God is invisible.

Regarding God's holiness, the narrative in Exodus 3 reveals that God's presence at the burning bush is what made the place where Moses stood holy. However, God's holy presence was not an ontological barrier that prevented Moses from approaching him, listening to his Word and in turn speaking to him. Hence, during the encounter God mediated his holiness by accommodation so that Moses could endure the revelation of his presence. Also, Exod 3:7 reveals that God has heard the cry of the Israelites and that he knows their sorrows. Consequently, God's holiness does not make him impassible.

As a result of this brief analysis, God's infinite analogous temporal Being as revealed in Exod 3:14-15 precludes any ontological dichotomy between (1) God's Being and His presence, (2) God's Being and God's Words to Moses, and (3) God's holiness and Moses.

${ }^{40}$ The other models that we analyzed in Chapter 4 posit that God relates to the universe in a mystical and non-historical manner. That opinion involves a contradiction when viewed from the perspective of God's infinite analogous temporal Being, which violates his immutability.

${ }^{41}$ See this dissertation pages $95-97$ footnotes 97-98; also pages 114-117. 
Lev 19:30 and 26:1-2

\section{Description}

The words 'I am the Lord' in Lev 19:30 and 26:1-2 constitute the basis for the prohibition against making idols and worshiping them, as well as for the command to “keep My Sabbaths and reverence My sanctuary." In this setting, the worship of idols contrasts and counterfeits the command to keep the Sabbath and reverence the sanctuary. Consequently, idolatry on the one hand, and the sanctuary and the Sabbath on the other provide two diametrically opposed ways to interpret how the divine presence relates to the other liturgical components.

We will now briefly describe the divine presence within the context of its relationship to the Sabbath, the sanctuary, and the construction of idols. As an institution that God established at creation, the Sabbath is made up of the sum of its parts and could not exist as an institution without God, human beings and the universe. ${ }^{42}$ These broad categories roughly encompass the following liturgical components: the divine presence, liturgists, ritual actions and the worshippers. ${ }^{43}$ They also provide the building blocks for the encounter and the response to the encounter. Similarly, the sanctuary itself could not exist without the divine presence, the liturgists, ritual actions, and worshippers. ${ }^{44}$

In contrast to the Sabbath and the sanctuary, Lev 26:1 prohibits God's people

${ }^{42}$ Gen 1:1-2:4.

${ }^{43}$ See my exegesis of Luke 4:16-30; Acts $13: 13-52 ; 17: 1-4$ and 18:1-8 to see how the Sabbath includes and interprets the relationship between the divine presence and the liturgical components in Chapter 6.

${ }^{44}$ See my exegesis of $1 \mathrm{Kgs}$ 8:12-66; Isa 6:1-8; Heb 12:18-29 and Rev 4:1-5:14 to see how the sanctuary includes and interprets the divine presence and the liturgical components in Chapter 6. 
from constructing and worshipping ${ }^{45}$ idols on the basis of God's Being expressed as "I am the Lord." The worship of idols is not possible without the divine presence, and the liturgical components. For instance, the Hebrew words for idol (אָלִילִם

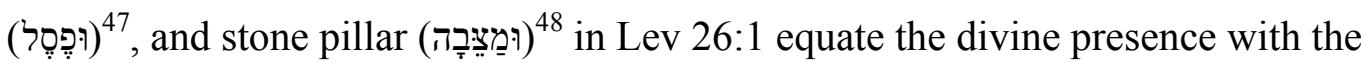
material creation. Moreover, Ancient Near Eastern peoples regarded idols as powerful living beings that allegedly partook of the divine essence and worshipped gods through their idols. ${ }^{49}$ The worship of the molded calf in Exod 32 provides an actual liturgical example of how the Israelites conflated their erroneous view of the divine presence ${ }^{50}$ with

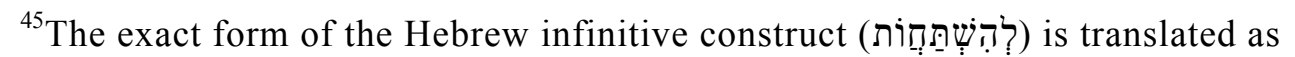
worship in the New King James Version (NKJV) in Isa 2:20; 66:23; Jer 7:2; 26:2; Ezek 46:9; Zech 14:16, 17.

${ }^{46}$ Here are the linguistic connections between idols (אלילילם) and the divine presence. First, the prohibition against turning to idols (אֶלילְם) is connected to the prohibition against making molded (מַסֵסכָָ) gods in Lev 19:4. Second, in Exod 32:8 Moses states, "They have

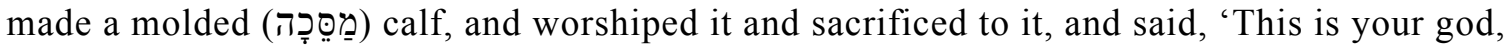
O Israel, that brought you out of the land of Egypt." Hence, idols, which include the molded calf are inextricably linked with the divine presence.

${ }^{47}$ Jacob Milgrom notes that pesel was “meant to represent Israel's God, and...was, therefore a violation of, not the first commandment of the Decalogue, but the second... [and that it] refer(s) to the use of images to worship Israel's God." Jacob Milgrom, Leviticus 2327: A New Translation with Introduction and Commentary, AB 3B (New York: Doubleday, 2001), 2280-2281. The following passages in Isaiah equate the divine presence with the carved image (ניפֶֶֶ): Isa 42:17;44:10,15, 17;45:20. The link between the divine presence and the carved image is also the basis for the prohibition against the carved image by the $2^{\text {nd }}$ Commandment (Exod 20:4).

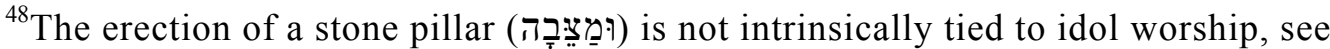
Gen 28:18, 22; 35:14, 35:20; Exod 24:4. However, In Exod 34:13-14 Moses reminds Israel that God's name is Jealous, meaning that His presence should not be confused with the material creation. This forms the reason for why Moses instructs them to break their sacred pillars.

${ }^{49}$ Roy Gane, "Leviticus" in Zondervan Illustrated Bible Backgrounds Commentary. ed. John H. Walton, (Grand Rapids, MI: Zondervan, 2009), 1:312.

50"In Exod 32:1, it is the calf (with YHWH enthroned) which "was to go before" (i.e., lead) the people." Mordechai Cogan, 1 Kings: A New Translation with Introduction and Commentary, AB 10 (New York: Doubleday, 2001), 359. The calves of Jeroboam in 1 Kings 12:28 “represented Yahweh's presence." William H.C. Propp, Exodus 19-40: A New Translation with Introduction and Commentary, AB 2A (New York: Doubleday, 2006), 577, 
the material creation. ${ }^{51}$ In Exod 32:8 Israel states, "This is your God, O Israel, that

brought you out of the land of Egypt." Therefore worshipping idols assumes an

interpretation of the divine presence as well as the nature of the relationship between it

and the liturgical components.

\section{Analysis}

We will now begin our analysis and interpretation of how the divine presence in Lev 19:30 and 26:1-2 relates to the Sabbath and sanctuary on the one hand, and idols on the other. As we proceed, we note that the "I AM" of Exod 3:14 and the "Lord" of Lev 19:30; 26:1-2 are one and the same. ${ }^{52}$ Hence, just as the "I AM" of Exod 3:14 grounds the temporal interpretation of God's Being, so also does “Lord” in Lev 19:30; 26:1-2.

581, 582; Godfrey Ashby, Exodus: Go Out and Meet God International Theological Commentary (ITC; Grand Rapids, MI: Eerdmans, 1998), 129; Bruckner, Exodus NIBC 2, 281-283. Jacob Milgrom notes, "Hence, they build a golden calf (a young bull), a visible sign of God's presence....In many respects it [the bull] was equivalent to the Ark flanked by two winged kerubim which served as YHWH's throne." Jacob Milgrom, Leviticus 23-27, AB 3B, 2284. Thus, the people's view of YHWH was linked with the material creation.

${ }^{51}$ The link between the conceptions of the divine presence, the molded calf and the carved image is the basis for why the molded calf of Exod 32:4,8 was also prohibited. First, Exod 34:17 concludes the section on the golden calf by stating, "You shall make no molded gods for yourselves," which matches the prohibition against carved images in Exod 20:4. Second, after Moses' intercession God stated that he would visit "the iniquity of the fathers upon the children and the children's children to the third and fourth generation" (Exod 34:7): a clear reference to the $2^{\text {nd }}$ Commandment which Israel violated in the worship of the golden calf. Third, after God renews the covenant with Israel in Exod 34:10 he admonishes Israel to cut down their idols and worship no other god, "for the Lord, whose name is Jealous, is a jealous God" (Exod 34:14). This is also connected with the $2^{\text {nd }}$ Commandment in Exod 20:5. Hence, the God of Israel refused to be identified with material representations, which would limit and distort human perceptions regarding him, see Roy Gane "Leviticus" 1:312. On page 287 Gane points out,

The monotheistic religion of the Israelites reflected in Leviticus, according to which the real Presence (not a mere idol) of the one all-powerful, divine Creator dwelt at his sanctuary in their midst, liberated them from the complexity and fear (especially of demons) that burdened their polytheistic neighbors.

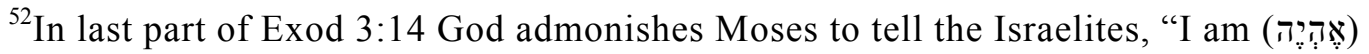
has sent me to you." In Exod 3:15 God instructs Moses to tell the Israelites, "The Lord (יהוה) God ...has sent me to you." Hence, the word Lord (יהוה) in Exod 3:15, Lev 19:30 and 26:1-2

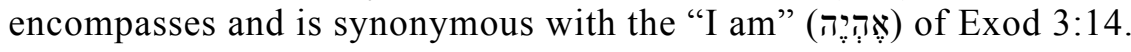


In Gen 2:3 and Exod 20:11 we find that the Lord blessed and sanctified the Sabbath day and not anything in the material creation. Consequently, the Sabbath reveals an analogica ${ }^{53}$ relationship between the Lord (Exod 20:11, cf. Exod 3:14, 15) God (Gen 2:1-3, cf Exod 3:14, 15), humans, and creation on the basis of time. The Sabbath day is thus holy because he fills it with his presence. ${ }^{54}$ The Sabbath also grounds the temporal interpretation of the relationship between the divine presence and the liturgical components. As a result, there are no longer any dichotomies between the divine presence and the liturgical components that we find in the previous three models. Furthermore, linking God's infinite analogous temporal Being with time points to his invisible holy nature in immanence ${ }^{55}$ while the distinction between Creator and creation also points to his invisible holy nature in transcendence. ${ }^{56}$ This essential distinction between God as Creator and his creation that the Sabbath points to also eliminates the timeless interpretation of the analogy of being as understood by Aquinas.

As we move to our analysis of the sanctuary, we note that God's infinite

\footnotetext{
${ }^{53}$ See Peckham, The Love of God, 172-173. Hence, I am employing analogy within the framework of God's temporal Being, which means that I reject Aquinas' interpretation of the analogia entis because analogy in his system assumes the timeless conception of Being in which there is an analogy regarding the Being of God and of creation.

${ }^{54}$ See Jiři Moskala "The Sabbath in the First Creation," Journal of the Adventist Theological Society 13 no. 1 (2002): 55-56.

${ }^{55}$ In Exod 33:20 God told Moses, "You cannot see my face; for no one shall see me, and live." John also states, "No one has seen God at any time" (John 1:18; cf. 1 Tim 6:16). However, in Rev 22:4 John states, "They shall see his face." Thus, even though he is invisible to us now, it is clear that in heaven we shall see his face. Yet, when we see his face in heaven we are still in the realm of immanence.

${ }^{56}$ In addition to immanence, the Creator/creation distinction also points to transcendence, thereby linking God's invisible nature to transcendence. While God's invisible nature in immanence will be overcome, it appears that God's invisible nature in transcendence will never be overcome. Nevertheless, God's infinite analogous temporal Being as expressed in Exod 3:14 includes immanence and transcendence.
} 
analogous temporal Being in the sanctuary ${ }^{57}$ interacts with the temporal being of humans that are involved as liturgists and worshippers as well as the temporal being of creation that encompasses the ritual actions of the sanctuary. Hence, just as the Sabbath grounds the relationship between the divine presence and the liturgical components on the basis of time, the sanctuary grounds the relationship on the basis of time and space. ${ }^{58}$ As a result, God's purpose to dwell in the sanctuary among his people (Exod 25:8) leads directly to the conclusion that there are no ontological dichotomies between the divine presence and the other components like we find in the other models. ${ }^{59}$

We will now examine how the construction of idols relates the divine presence to the liturgical components. The prohibition against worshipping idols, carved images and stone pillars in Lev 26:1 assumes that worship cannot occur without worshippers

${ }^{57}$ The passages in Deut 12:5 and $1 \mathrm{Kgs}$ 8:16 underscore the importance of placing God's name (Exod 3:14) at the specific location where the sanctuary is located, which is where he reveals his presence (2 Chr 20:8-9).

${ }^{58}$ Ian Wilson notes that instances of humans carrying out activities "before the Lord" assume a predominantly "literal (i.e. spatial) sense." Ian Wilson, Out of the Midst of the Fire: Divine Presence in Deuteronomy, SBLDS 151, 206. Jacob Milgrom states, "Reverence for the sanctuary...[indicates] that holiness has both a spatial and a temporal dimension." Jacob Milgrom, Leviticus 17-22: A New Translation with Introduction and Commentary AB 3A (New York: Doubleday, 2000), 1699. In the sanctuary God's presence is placed in geographical relationship with the liturgists, the liturgical actions and the worshippers. This is emphasized by the liturgical components that are "before the Lord." Some examples that are "before the Lord" are Aaron as high priest (Exod 28:30), the continual burnt offering by the door of the tabernacle of meeting (Exod 29:42); and incense (Exod 30:8), bread (Exod 40:22), and lamps (Exod 40:25) that are located in the holy place.

${ }^{59}$ Canale uses the term "God-building-human-beings structure" to describe how the sanctuary temporally grounds the relationship between the presence of God and all of the realities that are in turn connected to the sanctuary. See Canale, "Philosophical Foundations and the Biblical Sanctuary," 184. In this dissertation, all of the realities connected with the sanctuary comprise the divine presence, liturgist, and liturgical actions; which lay the groundwork for the encounter and the response to the encounter. King She points out that God's infinite analogous temporal Being logically leads to viewing the covenant and priesthood as inseparable from the sanctuary in a theological and philosophical way. King L. She, The Use of Exodus in Hebrews, 100. My dissertation also includes all of the liturgical components as integrated with the sanctuary by temporally grounding their relationship to the divine presence and to each other. 
interpreting the divine presence. Von Rad states that the deity became present in the image and is thus a bearer of revelation. ${ }^{60}$ Eichrodt points out that in Canaan theism is in essence a divinization of nature and that the sacred pillars were closely associated with "naturalistic conceptions of God." ${ }^{61}$ This means that we can describe the relationship between the divine presence and the idols as either pantheistic, ${ }^{62}$ panentheistic, ${ }^{63}$ or that there exists an analogy of being between the divine presence and the materials used. All of these ways of viewing the relationship between the divine presence and the liturgical components contradict God's infinite analogous temporal Being, which becomes the reason for the prohibition against constructing and worshipping idols. In contrast, God's infinite analogous temporal Being lays the groundwork for the Sabbath and the sanctuary to provide a temporal/special interpretation of the relationship between the divine presence and the liturgical components.

\section{Exod 19-20 and Deut 4-5}

\section{Description}

The passages in Exod 19-20 and Deut 4-5 refer to Being in the following two

\footnotetext{
${ }^{60}$ Gerhard Von Rad. Old Testament Theology, trans. D.M.G. Stalker, 2 vols. (New York: Harper \& Row, 1962), 1:214.

${ }^{61}$ Walter Eichrodt. The Theology of the Old Testament, trans. J.A. Baker 2 vols. (Philadelphia: Westminster Press, 1961), 1:116.

${ }^{62}$ In accepting pantheism one would then adhere to a univocal relationship between God's Being and creation, thereby making the confusing statement that his presence is synonymous with creation, which is himself. Yet, through the Sabbath and the sanctuary, Lev 26:1-2 reveals an analogical relationship between God and creation instead of a univocal one.

${ }^{63}$ Panentheism still assumes timeless Being, and it creates ontological dichotomies within God, as well as the notion that God becomes God through the evolutionary process. See this dissertation pages 95-97 footnotes 97-98; also pages 180-217. Hence, panentheism contradicts the immutability of God's infinite analogous temporal Being as revealed in Exod $3: 14$.
} 
ways. The first is through the approximately fifty times that these Chapters make reference to God's name (Lord יהוה), which is synonymous with His Being in Exod 3:1415. Second, although God is present on the mountain (Exod 19:3), he discloses his presence to Israel through his speaking of the Ten Commandments rather than through any material means (Deut 4:12, 15-19, 23, 25, 43). Moreover, it is God's name (Lord/Yahweh) in the second and third commandments (Exod 20:5, 7) that precludes worshippers from receiving his presence from creation and thereby taking it vain rather than receiving it from his words. ${ }^{64}$

The main attributes of the divine presence these Chapters disclose are God's invisible nature and holiness. We can deduce God's invisible nature from Deut 4:12, which states, "And the Lord spoke to you out of the midst of the fire. You heard the sound of the words, but saw no form; you only heard a voice. ${ }^{965}$ Moses writes about God's holiness in the following ways. First, the command for the Israelites to consecrate

\footnotetext{
${ }^{64}$ It states, "you shall not make for yourself a carved image....For (כִּ) I, the Lord your God am a jealous God." In Exod 20:5 we are admonished not to bow down and worship nature, which is based on the assumption that the divine presence is synonymous with nature. Those who do this arouse God's jealousy (Exod 20:5). Hence, equating God's presence with nature is called iniquity in Exod 20:5. Equating God's presence with nature is what the Israelites did at the golden calf. Exod 32:1 states "make us gods," thereby equating the presence of God with the golden calf. In Exod 34:7 Moses quotes Exod 20:5 about visiting the iniquity of the fathers upon the children and children's children. This visitation of God's judgment is the result of equating the presence of God with the calf. In opposition to the second commandment, the Sabbath commandment equates God's presence with the seventh-day and not with nature. In Exod 20:11 it is the Lord who blessed the Sabbath day and made it holy. It is only the presence of God that makes anything holy. In doing this God's presence is associated with time instead of nature. See Moskala, "The Sabbath in the First Creation," 55-66.

${ }^{65}$ See also Deut 4:15-19, 23, 25. In Deut 4:33 we read, "Did any people ever hear the voice of God speaking out of the midst of the fire, as you have heard, and live?" As Ian Wilson indicates, "out of the midst of the fire" indicates that God's was indeed present on Sinai but that the prohibition not to make an image of him is based on his invisibility and not on his absence. Ian Wilson, Out of the Midst of the Fire: Divine Presence in Deuteronomy SBLDS 151, 62-64.
} 
themselves is based on God revealing himself to the people as He descends upon Mount Sinai (Exod 19:10-12, 18). The word for "consecrate" (קדש) is also applied to God in Lev 11:44. Second, in Exod 19:23 the Israelites are to set bounds around the mountain and "consecrate" (קדש) it which means that they are not to touch it or break through the boundary that is set up around its perimeter (Exod 19:12, 21-24) since it is the place of God's holy presence.

\section{Analysis}

As we begin our analysis of Exod 19-20 and Deut 4-5 with Being, we note that the "I am" of Exod 3:14 is synonymous with the "Lord" of Exod 3:15. Hence, the many references to (Lord יהוה) in Exod 19-20 and Deut 4-5 must also be understood in the context of God's infinite analgous temporal Being.

In the $2^{\text {nd }}$ Commandment, "the Lord (יהוה) your God" (Exod 20:5), which is God's name (Isa 42:8) hearkens back to God's infinite analogous temporal Being in Exod 3:14. Exod 20:5 also states that God is a jealous God; and in Exod 34:14 Moses points out that God's name, meaning his essence and very being ${ }^{66}$ is Jealous. Hence, "you shall not make" (Exod 20:4) prohibits worshippers from constructing an ontology of $\operatorname{God}^{67}$ by

${ }^{66}$ Propp, Exodus 19-40 AB 2A, 615. Moshe Weinfeld notes that the objection to representing God by an image in Deut $4: 15$ is explained by the fact that the Israelites did not see any image. He further notes that this can be understood philosophically since God is beyond nature. However, instead of working on the basis of God's infinite analogous temporal Being, Weinfeld links the philosophical insights of Deut 4:15 with Aristotle's philosophy, which tries to prove that God is not corporeal. See Moshe Weinfeld, Deuteronomy 1-11: A New Translation with Introduction and Commentary AB 5 (New York: Doubleday, 1991), 292.

${ }^{67}$ In Gen 11:4 the builders of Babel said, "let us make a name for ourselves." Here the verb to make (עשה) is applied to the construction of a name (שָם) as opposed to the construction of mere material objects. Since God's name in Exod 3:14 reveals his infinite analogous temporal Being, the construction of a name can also refer to constructing an ontology of God. In the case of Babel, the builders must make bricks from what the find in 
making a "name" (Gen 11:4) as did the builders of Babel. The justification for this prohibition is that the content originates in human reason ${ }^{68}$ rather than in divine revelation via speech. ${ }^{69}$ When the being of God is thus conflated with the being of creation, it inevitably results in the kind of iniquity (Exod 20:5) that occurred at the golden calf incident of Exod 32. Moreover, although there was a thick cloud, lightning and the smoking mountain (Exod 19:11, 12, 16, 19; 20:18), these were visible signs of his invisible presence that was revealed when he spoke the Ten Commandments. ${ }^{70}$ Thus, the prohibition means that God is invisible.

The $3^{\text {rd }}$ commandment places a prohibition on those who would take God's

creation. Similarly, to make a name they must also start from creation. However, in Exod 3:14 God reveals his infinite analogous temporal Being through speech; Moses does not build an ontology of God through his analysis of the burning bush.

${ }^{68}$ Brevard Childs notes,

because God did not reveal himself in a form, but only in a voice, Israel should beware of making a graven image. Images are prohibited because they are an incorrect response to God's manner of making himself known which was by means of his word (Brevard Childs, The Book of Exodus: A Critical, Theological Commentary Old Testament Library (OTL; Philadelphia: Westminster Press, 1974), 407, cf. 406).

See also R. Alan Cole, Exodus: An Introduction and Commentary Tyndale Old Testament Commentary (TOTC; Downer's Grove, IL: InterVarsity Press, 1973), 154-156; Moshe Weinfeld, Deuteronomy 1-11 AB 5, 204.

${ }^{69}$ Peter C. Craigie reveals,

The only manner in which God could be represented was by means of language. Language, too, is a means of imagery, but it is necessary in order to articulate the knowledge and experience of God. By excluding all means other than language, God was kept free from all human attempts to impose limits on the conception of him. And even language, it may be noted, may become a form of imagery in an illegitimate sense. To construct, by theological propositions, a definition of the nature of God and then to claim adequacy for that definition, would be to construct an image as real as any wooden image (Peter C. Craigie, The Book of Deuteronomy New International Commentary on the Old Testament (Grand Rapids, MI: Eerdmans, 1976), 154).

${ }^{70}$ Although the Lord was already present on Mount Sinai, Exod 19:11 states that the Lord will come down upon Sinai and reveal His presence through speaking the Ten Commandments. See Deut 4:10. Also, "And the Lord spoke to you out of the midst of the fire. You heard the sound of the words, but saw no form; you only heard a voice" Deut 4:12. "Did any people ever hear the voice of God speaking out of the midst of fire, as you have hear, and live?" Deut 4:33. See also Deut 4:36; 5:4, 22-29. 
name $^{71}$ as revealed in Exod 3:14 ${ }^{72}$ and treat it as a worthless done (Jer 18:15; Jonah 2:9; Psalm 31:7). ${ }^{74}$ One can do this by rejecting the revelation of his presence ${ }^{75}$ that comes through his words. God states that those who do this will be judged as guilty (Exod 20:7). Furthermore, on the basis of Exod 34:5-7, God's name is also synonymous with his moral character. Hence, there is no dichotomy between God's presence and his moral character.

With regard to holiness, it is God's presence and character that makes any place holy. The verses in Exod 19 clearly show that God is not impassible, since he invites Moses in Exod 19:20 to come to the top of the mountain to speak with him; and later God invites Aaron (Exod 19:24). Yet at the same time God prohibits the people and the priests from going up into the mountain (Exod 19:12-13, 21, 24). God's infinite analogous temporal Being allows him to mediate his holiness to allow Moses and Aaron to come to the mount but not the priests or people.

${ }^{71}$ Brevard Childs notes the connection between the prohibition of the misuse of Yahweh's name, "which of course was identified with God's being itself." Brevard Childs, The Book of Exodus OTL, 412.

${ }^{72}$ God's name is directly linked to Exod 3:14 in Ian Cairns, Deuteronomy: Word and Presence ITC (Grand Rapids, MI: Eerdmans, 1992), 73.

${ }^{73}$ For the use of $20: 7$ as worthless in the context of idolatry, see Jer 18:15; Jonah 2:9; Psalm 31:7, HALOT s.v. نן

${ }^{74}$ According to HALOT s.v. name in an evil way (in a magic ritual or in an oath) Ex 20:7 Dt 5:10" constitutes a violation of the third Commandment. By this definition, the Sacramental model is in violation of this Commandment by alleging that the name of God, which constitutes his essence and being is placed within the Eucharistic emblem through the priestly ritual. This conflating of the divine presence with creation constitutes treating His great name like a worthless idol.

75" What must be understood is that the 'name' of Yahweh bespeaks God's powerful presence and purpose." General Articles on the Bible; General Articles on the Old Testament; Genesis; Exodus; Leviticus The New Interpreter's Bible (NIB) Vol. 1, 842. 
1 Kgs 8:12-66 and 2 Chr 5:11-7:7

\section{Description}

The passages in 1 Kings 8 and 2 Chr 5-7 make reference to Being in the following ways. First, following the example of Exod 3:14 ${ }^{76}$ and Deut 12:5, 11, 21 and 16:2, 6, ${ }^{77}$ God informs his people through Solomon that he will place his name/Being there in the temple at Jerusalem. ${ }^{78}$ Accordingly, as is indicated by $2 \mathrm{Chr} 20: 8-9$, "to say that God's name is present in the temple denotes his real presence" ${ }^{\text {"79; }}$ it "denotes the Lord himself." 80 The author of Chronicles "made no real distinction between building a house

\footnotetext{
${ }^{76}$ In Exod 3:14, God placed his name at the specific location of the burning bush where he revealed himself to Moses.

${ }^{77}$ Sara Japhet notes, "The phrasing of 'I have chosen this place' [2 $\mathrm{Chr} 7: 12$ ] as a statement, as well as the juxtaposition of 'choose' and 'place,' undoubtedly is connected to the common Deuteronomic formula, 'the place which the Lord will choose." The Ideology of the Book of Chronicles and Its Place in Biblical Thought (Winona Lake, IN: Eisenbrauns, 2009), 63. For additional connections to Deut 12:5, 11, 21, see Martin J. Mulder, 1 Kings Historical Commentary on the Old Testament (HCOT; Leuven, Belgium: Peeters, 1998), 406, 417. These passages in Deut 12:5, 11 and 21 stress that Israel must bring their sacrifices, tithes, and offerings to the appointed place where God chooses to place his name. In Deut 16:2 and 6, God's people must sacrifice the Passover in the place where God chooses to place his name. Hence, the revelation of God's presence in the place he chooses is foundational for the Passover, sacrifices, tithes, and offerings in these passages.

${ }^{78}$ See the following verses where God's name (שם) is mentioned in the context of the temple: I Kgs 8:16, 17, 18, 19, 20, 29, 33, 35, 41, 42, 43(2), 44, 48. God's name "denotes the Lord himself" in $1 \mathrm{Kgs}$ 5:5, see Donald J. Wiseman, 1 and 2 Kings: An Introduction and Commentary TOTC (Downer's Grove, IL: Intervarsity Press, 1993), 119; Leslie C. Allen, 1, 2 Chronicles Communicator's Commentary Series: Old Testament (CCSOT; Waco, TX: Word Books, 1986), 231.

${ }^{79}$ Gene Rice, 1 Kings: Nations Under God ITC (Grand Rapids, MI: Eerdmans, 1990), 64, also 65.
}

${ }^{80}$ See Wiseman, 1 and 2 Kings TOTC, 119 in connection with $1 \mathrm{Kgs}$ 5:5. After quoting $2 \mathrm{Chr}$ 20:9 Sara Japhet notes that

To stand before the house is to stand before God. Here we find the element missing from the body of Solomon's prayer: YHWH's presence in the Temple, which is conveyed with 'before the Lord.' The words, 'for thy name is in this house, reinforce (a) the idea that 'the name of the Lord' is fully equivalent to 'the Lord' and (b) the strong emphasis on God's presence in the Temple. The Temple does not function as a channel through which prayers pass upward to heaven, where they are heard by God; rather, prayers are 
for God and building a house for His name." ${ }^{, 1}$

Second, Solomon states, "But will God indeed dwell on the earth? Behold, heaven and the heaven of heavens cannot contain You. How much less this temple which I have built!" (I Kings 8:27). Since the revelation of God's name at the temple is assumed in this passage, God's name becomes the foundation for interpreting the way in which the divine presence relates to the (1) the temple, (2) the universe, and (3) the realm of God's transcendence that is beyond the universe. ${ }^{82}$

Third, God's name also lays the groundwork for understanding the connection between heaven and earth as God's people pray toward the earthly temple but God

said in the Temple because God hears them in the Temple. The absolute equation of God and His name is also implicit in the parallel structure of $1 \mathrm{Chr}$ 29:13: 'And now we thank thee, our God, and praise thy glorious name.' When we praise His glorious name, repeatedly utter His name in hymn and thanksgiving, we thank God; 'thee' and 'thy name' are therefore one and the same (Sara Japhet, The Ideology of the Book of Chronicles and Its Place in Biblical Thought, 54-55 (emphasis original); cf. 56).

${ }^{81}$ Sara Japhet notes the following example: In $1 \mathrm{Chr} 22: 5-11$ "the house that is to be built for the Lord must be exceedingly magnificent..." (v.5), "then he...charged [Solomon] to build a house for the Lord, the God of Israel" (v.6), "David said...'I had it in my heart to build a house for the name of the Lord my God"” (v.7), "...you shall not build a house for my name" (v.8), "...he shall build a house for my name" (v.10), “...building the house of the Lord your God" (v.11)." Sara Japhet, The Ideology of the Book of Chronicles and Its Place in Biblical Thought, 55 footnote 183. Moreover, "there is no indication in any of the relevant passages in Chronicles that God's name possessed any sort of existence distinct from the deity it named." Ibid., 56-57.

${ }^{82 ،}$ To say that God's name is present in the temple denotes his real presence but preserves the mystery of his transcendence." Rice, 1 Kings ITC, 64, also 65.

The 'name' is thus the link between the macrocosmic realm of the heavens and the microcosm of the Jerusalem Temple at the centre [sic] of the earth (the ark as the footstool of God is another means of expressing this interconnection of the two realms. 1 Chr 28.2 (William Johnstone, 1 and 2 Chronicles Journal for the Study of the Old Testament Supplemental Series 253 (Sheffield, England: Sheffield Academic Press, 1997), 344).

Hence, the flow of meaning first begins with the interpretation of God's name that provides the key to interpreting his presence in the Jerusalem Temple and the heavenly temple, and his omnipresence in the universe and beyond the universe. 
answers from the heavenly temple. ${ }^{83}$ Consequently, God is able to interact with his

people in a very intimate and dynamic way. ${ }^{84}$

Fourth, God's name is also interconnected with the Ten Commandments, which are referred to as the covenant in 1 Kings 8:21. ${ }^{85}$ God told Moses that he would meet with him and speak to him from above the mercy seat between the two cherubim which are on the ark of the testimony. ${ }^{86}$

Fifth, God's Being is also connected with the fact that he is good and merciful (2 Chr 7:3; cf 5:13).

\section{Analysis}

As we begin our analysis, we observe that the revelation of God's name at the temple $^{87}$ that is combined with the covenant temporally grounds the way in which the

${ }^{83}$ See 1 Kgs 8:29-30 where Solomon informs Israel that God's name is in the temple, yet when they pray "toward this place" then Solomon asks that God may "hear in heaven your dwelling place; and when you hear, forgive." This crucial link between God's people who prayer toward the earthly temple with God who hears from the heavenly temple is also found in $1 \mathrm{Kgs} 8: 31-32,33-34,35-36,38-39,42-43,44-45,48-49$. For God's dwelling place in heaven referring to the heavenly sanctuary, see de Souza, "The Heavenly Sanctuary/Temple Motif in the Hebrew Bible," 214-216, 220-222.

${ }^{84}$ For instance (1) God is able to hear Solomon's prayer from heaven (1 Kgs 8: 29$30,31-32,33-34,35-36,38-39,42-43,44-45,48-49)$, (2) God is asked to forgive (1 Kgs 8: $30,34,36,39,50)(3)$ to return them to the land He gave to their fathers v. 34 (4) to act and judge v. 32, 39, 43 (5) to teach them the good way in which they should walk v. 36, (6) to send rain v. 36 (7) to give to everyone according to his ways v. 39, (8) to maintain their cause v. 45, 49, 59, (9) to grant them compassion v. 50, (10) to speak and fulfill His Word v. 20, 24 and (11) to enter into and keep His covenant with His people v. 21, 23, 25.

${ }^{85}$ In the latter half of $1 \mathrm{Kgs}$ 8:20 Solomon states "I have built a temple for the name of the Lord God of Israel." He continues in the next verse stating, "And there I have made a place for the ark, in which is the covenant of the Lord which He made with our fathers, when he brought them out of the land of Egypt."

${ }^{86}$ See Exod 25:22; 30:6; Num 7:89. In Lev 16:2 God said, "I will appear in the cloud above the mercy seat."

${ }^{87}$ See the following verses where God's name (שם) is mentioned in the context of the temple: I Kgs 8:16, 17, 18, 19, 20, 29, 33, 35, 41, 42, 43(2), 44, 48. 
divine presence ${ }^{88}$ relates to the earthly and heavenly temples, the universe, and the realm of God's transcendence that is beyond the universe. ${ }^{89}$

A phenomenological exegesis of the sanctuary reveals that God is separate and distinct ${ }^{90}$ from all the articles of furniture in the sanctuary. ${ }^{91}$ With that background, we note that the Lord stated that he would "appear (ארָָה)

${ }^{88}$ The covenant is mentioned within the context of the Temple in $1 \mathrm{Kgs} 8: 9,21,23 ; 2$ Chr $5: 10 ; 6: 11,14$. The ark of the covenant is also a "specially favored phrase in Chronicles" as seen in the following texts: $1 \mathrm{Chr} 15: 25,26,28,29 ; 16: 6,37 ; 17: 1 ; 22: 19$; 28:2, 18; 2 Chr 5:2, 7. See Martin J. Selman, 2 Chronicles: A Commentary TOTC (Downer's Grove, IL: Intervarsity Press, 1994), 316. One can also find the sanctuary/covenant relationship in Exod 24:1-11; Exod 34:10-34. For the sanctuary/covenant structure in the Exodus texts, see de Souza's dissertation, "The Heavenly Sanctuary/Temple Motif in the Hebrew Bible," 154-173. See also, Heb 8-9; 12:24. The verses in Rev 4-5 clearly depict a sanctuary scene and the scroll in the right hand of Him who is seated on the throne (Rev 5:1) has been interpreted as the covenant. See Ranko Stefanovic, "The Background and Meaning of the Sealed Book of Revelation 5" (PhD dissertation, Andrews University, 1995), 305308; Alberto Treiyer, The Day of Atonement and the Heavenly Judgment from the Pentateuch to Revelation (Siloam Springs, AR: Creation Enterprises International, 1992), 553.

${ }^{89}$ The ark of the covenant of the Lord "is the supreme symbol and effective channel of the relationship between God, his people and the world." Johnstone, 1 and 2 Chronicles Journal for the Study of the Old Testament Supplemental Series 253, 335. Hence, the sanctuary/covenant gives precision to the way in which the divine presence relates to the liturgical components.

${ }^{90}$ See Canale, "Philosohical Foundations and the Biblical Sanctuary," AUSS 36 no. 2 (Autumn 1998): 183-206. Working from the perspective of timeless Being, Catholic exegetes who assume Aristotle's second substance allege that Israelite worshippers who came to the major festivals realized that God was actually infused in the very stones of the building. This recognition allegedly led the Israelites to worship at the temple. See Scott Hahn, Temple and Contemplation, 8-9 (cf. see this dissertation page 369 note 205). "In the pericope describing the installation of the desert Tabernacle, the resting of the cloud upon it was the signal that YHWH had taken up residence in the new completed Tent; cf. Exod 40:34." Cogan, 1 Kings AB 10, 281. Once we allow Scripture to reveal the temporal interpretation of Being we realize that it renders groundless the notion that God is inextricably linked with the furniture of the temple.

${ }^{91}$ See my previous exegesis of Exod 3 and Exod 19-20 and Deut 4-5 that does not equate God's presence with the physical phenomena.

${ }^{92}$ In Exod 19:9 God told Moses, "Behold, I come to you in the thick cloud, that the people may hear when I speak with you." The cloud veils the invisible presence of God on the mountain where God calls to Moses from the midst of the cloud (Exod 24:15-16). God 
seat" (Lev 16:2) that functioned as the throne of his invisible presence ${ }^{93}$ just as he appeared (נִרָאָה) to Moses (Exod 3:16) as the I AM at the burning bush. Moreover, YHWH also said that he would speak to Moses from above and between the cherubim (Exod 25:22; Num 7:89), just as he spoke to Moses at the burning bush. Since there is a strong connection between the glory ( $\delta$ ó $\xi \alpha$ ) of the Lord (LXX 1 Kings 8:11; 2 Chr 5:14) that filled the house of the Lord and the revelation of his name at the temple, ${ }^{94}$ we

also spoke to Moses from the cloud at the door of the tabernacle (Exod 33:9-10). In Exod 34:5 the Lord descended in the cloud and proclaimed his name to Moses.

${ }^{93}$ In the following texts Sara Japhet notes that the "ark serves as a further expression of divine presence," The Ideology of the Book of Chronicles and Its Place in Biblical Thought, 59. In 1 Chr 17:1-4 (parallel to 2 Sam 7:2-5) David states, "Behold, I dwell in a house of cedar, but the ark of the covenant of the Lord is under a tent (1 Chr 17:1)," to which God responds by saying, "You shall not build me a house to dwell in (1 Chr 17:4 - 2 Sam 7:5)," Ibid. For further support for the ark as an expression of the divine presence, see the connection between (1) $2 \mathrm{Chr}$ 6:2, 41 and Psalm 132:8, (2) $1 \mathrm{Chr} 28: 2,1 \mathrm{Chr}$ 17:1 and 1 Chr 22:19, Ibid, 60-61. Furthermore, in $1 \mathrm{Chr} 28: 2$ the ark is called the footstool of God, which also finds support in Num 10:35-36 and in the passages that speak of God enthroned above the cherubim (Exod 25:22, Num 7:89, 1 Sam 4:4, 2 Sam 6:2, 2 Kgs 19:15, 1 Chr 13:6, Psalm 99:1, and Isa 37:16). Japhet, however, notes that not all references to God's footstool refer to the ark, Ibid, 61. Hence, "The image of the ark, God's footstool, resting in the Temple affirms that YHWH is actually present...." Ibid, 62. Moreover, "The ark was God's portable throne on which he was invisibly present (1 Sam 4:4, 6-7)," Rice, 1 Kings ITC, 61. Also, "While it is the ark that is being brought into the temple in Ps. 24:7-10, emblem and divine presence are so completely identified that no effort is made to distinguish them," Ibid., 62. "The cherubim symbolized the royal seat on which the deity was thought to have been invisibly enthroned and the ark was viewed as the footstool," $1 \& 2$ Kings; $1 \& 2$ Chronicles; Ezra; Nehemiah; Esther; Additions to Esther; Tobit; Judith NIB Vol. 3 (Nashville, TN: Abingdon Press, 1994), 70. For further support for the ark as symbol of God's presence, see Iain W. Provan, 1 and 1 Kings NIBC 7 (Peabody, MA: Hendrickson, 1995), 75; Ralph W. Klein, 2 Chronicles: A Commentary Hermeneia - A Critical and Historical Commentary on the Bible (Hermeneia) (Philadelphia: Fortress Press, 2012), 80; Cogan, 1 Kings AB 10; Johnstone, 1 and 2 Chronicles Journal for the Study of the Old Testament Supplemental Series 253, 336.

94، Alongside the idea that God is present in the Temple through His name, Chronicles contains the parallel idea that He is present through His glory. The description of God's glory filling the Temple is transferred, with minor changes, to $2 \mathrm{Chr} 5: 11 \mathrm{a}, 13 \mathrm{~b}, 14$, and in $2 \mathrm{Chr} 7: 1-3$ the Chronicler repeats this idea in a passage of his own, added to Solomon's prayer." Sara Japhet, The Ideology of the Book of Chronicles and Its Place in Biblical Thought, 57. 
conclude that his glory represents his essence, being, presence ${ }^{95}$ and moral character

(Exod 34:5-7). This means that there is no Platonic gap between Being and appearance, ${ }^{96}$ or between Being and the glory ( $\delta$ ó $\xi \alpha)$ of the Lord (LXX 1 Kings 8:11; 2 Chr 5:14). ${ }^{97}$

Hence, God's presence in the holy of holies that is veiled by the dark cloud (1 Kings

$8: 12 ; 2$ Chr $6: 1)^{98}$ shows that he actually dwells ${ }^{99}$ in the earthly sanctuary without being

95“Most translate kābôd, "the Glory" (NAB, NEB, NRSV); but Heb kābôd is "essence, being, presence," whether used of the deity or a person." Cogan, 1 Kings AB 10, 280; cf J. Robinson, The First Book of Kings The Cambridge Bible Commentary (CBC; Cambridge: Cambridge University Press, 1972), 96. In Gen 49:6 Jacob states, "Let not my soul enter into their council; Let not my honor kābôd be united to their assembly." Thus, Jacob's honor is synonymous with his soul, or his being, presence, or essence. HALOT s.v. כָּ connects God's glory with his essence by seeing his name connected with his glory in Hebrew parallelism in Isa 42:8 and 48:11. In Psalm 102:15 (cf. Isa 59:19) we read, "So the nations shall fear the name of the Lord, And all the Kings of the earth Your glory." See also, Ezek 10:18 (cf. Ezek 9:3; 10:4, 19; 11:23) where God's glory (presence) leaves the temple.

${ }^{96}$ HALOT s.v. ראה occurs in Exod 3:2, and 16. As Canale notes, "The "appearance" of $Y H W H$ and $Y H W H$ as Being in itself (on the "ontic" level) are the same, they are the one and the same "ontic" reality," with no Platonic gap or chasm. Canale, A Criticism of Theological Reason: Time and Timelessness as Primordial Presuppositions, 358. Hence, when God tells Moses that he will "appear (אָרָה:) in the cloud above the mercy seat" (Lev 16:2) we can conclude that this appearance is the reality.

${ }^{97}$ The dichotomy between Being and $\delta$ ó $\xi \alpha$ (glory, appearance) assumes Parmenides' ontological gap that separates the eternal (timeless) God from his glory. See A Criticism of Theological Reason: Time and Timelessness as Primordial Presuppositions, 79 footnotes 1, 3; 85; 87 footnote 3. However, under God's infinite analogous temporal Being, his appearance is the reality. This means that the Hebrew and $2 \mathrm{Chr}$ 5:14 refer to God's real presence. See also Exod 16:7, 10;24:16, 17; 40:34; 2 Chr $7: 1-3$.

${ }^{98}$ God's "mystery was preserved uninfringed within the windowless Tabernacle (Exod 40:34). Within the new idiom of the Temple, Solomon has preserved that darkness in the windowless holy of holies." Johnstone, 1 and 2 Chronicles Journal for the Study of the Old Testament Supplemental Series 253, 339. In $1 \mathrm{Kgs}$ 8:10, the cloud's "amorphousness afforded a numinous quality fit for representing "the perceptible Presence... of the Deity." Cogan, 1 Kings AB 10, 280. While it is true that the high priest and even Moses were in the direct presence of God, they never saw the whole of him. However, one should not interpret amorphousness as timeless since God's infinite analogous temporal Being is invisible and thus not revealed in immanence.

${ }^{99}$ The NIB commentary points out that the view of the Temple as God's actual dwelling place constitutes a "theological misinterpretation" that the narrative in $1 \mathrm{Kgs} 8$ is allegedly trying to dispel. Moreover, the NIB commentary states that "the Temple is a concrete representation of the reality of the sovereignty of God." NIB Vol. 3, 71. Also, the 
confined there, and that he can mediate ${ }^{100}$ his holy presence and thereby accommodate himself so that he appears in the sanctuary. However, neither mediation nor accommodation involves a change in God's being.

We will now analyze Solomon's statement that the heaven of heavens cannot contain God (1 Kings 8:27). ${ }^{101}$ The verb for "contain" not only means contain, embrace, and incorporate ${ }^{102}$; it also means to hold and contain a quantity of something like a liquid. ${ }^{103}$ The implication is clear: Since "heaven cannot contain God"104 in the same way that a small container cannot hold a large amount of water, we can only deduce that God's being is at the same time within (Immanence) and outside the highest heavens, ${ }^{105}$ or the universe (Transcendence). ${ }^{106}$ Accordingly, just as the earthly sanctuary cannot

commentary makes a clear dichotomy between the deity, "who is not enthroned in the Temple per se" and the Name of God that merely represents the deity. Allegedly, "The authority of God is there, whether or not God is personally present." NIB Vol. 3, 72. See also Provan, 1 and 2 Kings NIBC 7, 77, 79; Allen, 1, 2 Chronicles CCSOT, 231. However, from the perspective of God's infinite analogous temporal Being, there is no dichotomy between God's name and his presence. Hence, God's being can actually dwell in the Jerusalem temple without compromising his omnipresence in $1 \mathrm{Kgs}$ 8:27.

${ }^{100}$ In the footnote above we noted that God employs the cloud to veil his presence in order to speak with Moses. However at other times Moses could not enter the tabernacle because the glory of the Lord filled the tabernacle (Exod 40:34-35 cf. $1 \mathrm{Kgs} 8: 10-11$ ). At mount Sinai we noted that God allowed Moses and Aaron to come up into the mount but not the priests or the people (Exod 19:24). Hence, God mediates his holy presence.

${ }^{101}$ The passages in Jer 23:23 and Psalm 139 also describe God's omnipresence. Yet, to my knowledge Solomon is the only one to state that God's presence actually transcends the universe (1 Kgs 8:27; $2 \mathrm{Chr} 2: 6 ; 6: 18)$.

${ }^{102}$ Mulder, 1 Kings HCOT, 414.

${ }^{103}$ HALOT s.v. כול In $1 \mathrm{Kgs}$ 8:64 the bronze altar could not contain or receive all of the offerings since it was too small. See also, $1 \mathrm{Kgs}$ 7:26, 28.

${ }^{104}$ Mulder, 1 Kings HCOT, 414; Rice, 1 Kings ITC, 65.

${ }^{105}$ This Hebrew superlative translated as "heaven of heavens" appears in Deut 10:14, Psalm 18:14; 2 Chr 2:5; 6:18. See Mulder, 1 Kings HCOT, 414.

${ }^{106}$ After quoting $1 \mathrm{Kgs}$ 8:27 Canale states, "God does live on earth, even in a temple, and in heaven (immanence), yet His being completely surpasses Creation (transcendence)." Fernando Canale, "Doctrine of God," in Handbook of Seventh-Day Adventist Theology, ed. Raoul Dederen (Hagerstown, MD: Review and Herald, 2000), 113. 
contain God's presence, so the heavens cannot his being since it transcends the universe. This is the way in which various theologians understand 1 Kings 8:27 although they interpret transcendence and immanence in various ways. ${ }^{107}$

Thus, in light of 1 Kings 8:27, how does the Biblical Sanctuary Model interpret the way in which God relates to the earthly temple, the entirety of heaven and beyond the universe? God's infinite analogous temporal Being allows the sanctuary to temporally ground the relationship between transcendence and immanence from the starting point of his revelation in immanence in the sanctuary. ${ }^{108}$ As a result, the following hermeneutical consequences ensue.

From the perspective of God's revelation in the sanctuary, transcendence involves a spatio-temporal context that is uncreated and that only the Trinity experience. ${ }^{109}$

${ }^{107}$ No attempt is made here to differentiate the various interpretations of transcendence among the theologians. The aim here is just to note that they understand 1 Kgs 8:27 as stating that God's being is beyond the universe. See Canale, "Doctrine of God," 112-113; Geisler, Systematic Theology: God: Creation, 518-519; Karl Barth, Church Dogmatics, 2/1: 266; Shedd, Dogmatic Theology, 277; Bloesch, Holy Scripture: Revelation, Inspiration \& Interpretation, 283, 300; Thomas C. Oden, The Living God: Systematic Theology, 59-60; Reymond, A New Systematic Theology of the Christian Faith, 169-170; Augustus Hopkins Strong, Systematic Theology, 3 vols. (Chicago: The Judson Press, 1907), 1:254, 281; Lewis Sperry Chafer, Systematic Theology, 8 vols. (Grand Rapids, MI: Kregel Publications, 1948, 1976), 1; 219; Wolfhart Pannenberg, Systematic Theology (trans. G.W. Bromily, 3 vols. Grand Rapids, MI: Eerdmans, 1991), 1:411-412.

108، Thus Scripture speaks clearly of the transcendence of God from the starting point of His immanence in the sanctuary." Canale, "Doctrine of God," 112. Classical theism first interprets transcendence from static timeless Being before proceeding to interpret God's presence in immanence in a non-historical way through the sacraments. Transcendence is thus the starting point in classical theism for understanding immanence. In panentheism the classical view of transcendence was transferred from above the universe to within an evolving universe. Here God's presence is timeless and temporal, immutable and changeable. However, timeless Being still provides the framework in which the flow of meaning still moves from transcendence to immanence.

${ }^{109}$ Gulley states,

So God's omnipresence is not only a presence everywhere in His universe but also a presence that transcends the universe. For before He created space God existed in such a way that He was able to create space. The immensity of space, like the immensity of 
Nothing else is revealed in Scripture about the nature of the transcendent reality that the Trinity experience.

Since God's infinite analogous temporal Being that is deduced by the I AM reveals that his essence is immutable, the members of the Trinity do not step outside the analogic infinite temporality revealed in Exod 3:14 when they relate among themselves in transcendence. To do so, would contradict the immutability of the temporal view of the I AM.

The spatio-temporal context that we deduce from God's infinite analogous temporal Being and the sanctuary eliminate the ontological dichotomies that exist in the previous models between transcendence and immanence, including the non-historical way ${ }^{110}$ in which God relates with the universe in those models. Hence, God is transcendent and immanent all at the same time. ${ }^{11}$

Not only does God's infinite analogous temporal Being in the context of the sanctuary eliminate the ontological dichotomies in the other models, the Biblical Sanctuary Model allows for a real presence in the earthly sanctuary as well as in the heavenly sanctuary while still preserving God's omnipresence throughout the universe and in transcendence.

eternity, causes humans to realize, to some degree, the magnitude of God's immensity and infinity (Gulley, Systematic Theology: God as Trinity, 69).

See also Barth, Church Dogmatics 2/1: 468-469 in which he states "God possesses space, His own space, and that just because of His spatiality, He is able to be the Triune, the Lord of everything else, and therefore the One in and over all things."

${ }^{110}$ In classical theism God acts "instantaneously," yet according to Augustine an instant does not have past, present or future, See Augustine: Confessions and Enchiridion LCC Vol VII, Book 11 Chapter 6:8, 7:9, pages 249, 250. Hence, in classical theism God does not act in history but within history.

${ }^{111}$ Also, the "omnipresent God is immanent as well as transcendent, and He is both at the same time." "God's immanent presence is an authentic presence of God, and so cannot be separated from His transcendence." Gulley, Systematic Theology: God as Trinity, 64. 
In addition to the issues of the divine presence, the passages in 1 Kings 8 and 2

Chr 7:3 reveal that God is good, merciful, forgiving, and one who answers prayers. ${ }^{112}$ Consequently, just as the whole of God is present in immanence and transcendence, we assert that all of God is good, merciful, and forgiving. The sanctuary thus temporally grounds the relationship between God's presence and omnipresence with God as a personal and moral being, thereby dispelling the dichotomy between a personal/moral presence and an amoral/impersonal omnipresence. ${ }^{113}$

Isa $6: 1-13$

\section{Description}

Isaiah's reference to God as YHWH (יהוה), in Isa 6:3, 5 speaks to the issue of Being, and is synonymous with ADONAI (אדן), "Lord" in Isaiah 6:1. ${ }^{114}$ Since Isaiah saw

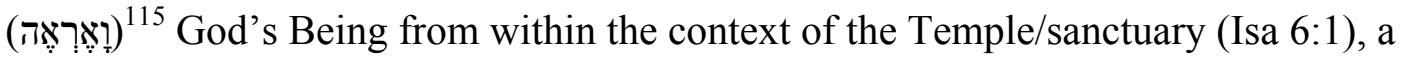
proper interpretation of God's Being in the temple is foundational for understanding how he relates to the throne where he is seated (Isa 6:1,5), the seraphim that are above the throne (Isa 6:2), the live coal, the tongs, and the altar (Isa 6:6). Moreover, God's Being is also foundational for interpreting the dynamic interaction that is taking place between

${ }^{112}$ In the following passages Solomon assumes that God is more than willing to hear and forgive the various sins that his people may commit in the future, therefore he makes his request for God to hear and forgive. See $1 \mathrm{Kgs} 8: 31-32,33-34,35-36,38-39,42-43,44-45$, 48-49.

${ }^{113}$ For Spirit as impersonal force field, see Kärkkäinen, Pneumatology, 119-120.

${ }^{114}$ See Exod 15:17, "You will bring them in and plant them in the mountain of Your inheritance, in the place, O Lord (יהוה), which You have made for Your own dwelling, the sanctuary, O Lord (אדן), which Your hands have established." Just like Isa 6:1, this is in the context of the sanctuary. For passages that contain Lord (אדן) God (יהוה) in Isaiah, see Isa $3: 15,7: 7 ; 10: 23,24 ; 22: 12,14,15 ; 25: 8 ; 28: 16,22 ; 30: 15 ; 40: 10 ; 48: 16 ; 49: 22 ; 50: 4,5$, 9; $52: 4 ; 56: 8 ; 61: 1,11 ; 65: 13,15$.

${ }^{115}$ The verb (וֹאֶרֶֶֶ) implies that the prophet had a visionary experience, see de Souza, "The Heavenly Sanctuary/Temple Motif in the Hebrew Bible," 235 footnote 3. 
those in God's temple in heaven and Isaiah on earth. For instance, the cry holy, holy, holy is the Lord of hosts (יהוה צִבְבאוֹת) that the seraphim sing in the heavenly temple (היכל) (Isa 6:3) shakes the posts of the door in the earthly temple (בית). ${ }^{117}$ Also, the seraph removes a coal from the altar in heaven ${ }^{118}$ and with it touches the mouth of Isaiah just before he tells him that his iniquity is taken away and his sin purged (Isa 6:6-7). Moreover, God inquires from the heavenly temple, "Whom shall I send...?” and Isaiah responds from earth saying, "Here am I! Send me" (Isa 6:8). ${ }^{119}$

In addition to the divine presence in the heavenly temple, holiness is the predominant attribute in this passage as evidenced by the seraphim who cry "Holy, Holy, Holy is the Lord of hosts" (Isai 6:3). The passage also points out that God is the King, the Lord of hosts (Isa 6:5), and that the earth is full of His glory (Isa 6:3).

\section{Analysis}

We will now begin our analysis of Being in Isa 6:1-8 and how it provides the foundation for interpreting what we have just described above. Since YHWH is inextricably linked with the "I am" of Exod 3:14, Isaiah assumes that God's Being is infinite, analogous, and temporal. This interpretation of Being is foundational for making

\footnotetext{
${ }^{116}$ Although scholars point out that (היכל) can refer to both earthly and heavenly temples, de Souza notes that the reference to seraphim as part of YHWH's retinue seems to enforce the view that (היכל) refers to the heavenly temple, de Souza, "The Heavenly Sanctuary/Temple Motif in the Hebrew Bible," 238-239. Moreover, a structural analysis of the pericope (Isa 6:1-8) reveals that vs. 1-3 depict a heavenly scene whereas vs. 4-5 portray the effects of the heavenly temple on its earthly counterpart, and vs. 6-8 portray the intercommunication between the heavenly temple and its earthly counterpart, Ibid., 236-237.

${ }^{117}$ de Souza points out that if (בית) is used for the temple, then in contrast to (היכל) it always refers to the temple on earth. de Souza, "The Heavenly Sanctuary/Temple Motif in the Hebrew Bible," 239.

${ }^{118}$ Ibid., 240-241.

${ }^{119}$ According to the structural analysis of Isa $6: 1-8$, vs. 6-8 portray the intercommunication between the heavenly temple and its earthly counterpart, Ibid., 236-237.
} 
possible the dynamic interaction taking place between the heavenly and earthly temples.

Moreover, the structural correspondence between the heavenly and earthly sanctuaries ${ }^{120}$ that is based on the use of the words "altar," "temple," and "tongs",121 leads to the deduction that God's revealed presence resides in both the earthly and the heavenly temples. Moreover, God's infinite analogous temporal Being lays the groundwork for how the sanctuary provides a temporal interpretation of the relationship between the divine presence and the throne upon which the Lord sits, the hosts in the phrase "Lord of hosts," the train of his robe that fills the temple, the altar, the tongs, the live coal from the altar, the seraphim that stood above the throne who cry holy, holy, holy, the voice of the Lord and the response of Isaiah. Consequently, each of the aforementioned items are distinct realities of their own not be confused with the divine presence. And yet, God accommodates himself to be able to interact with all of the complex realities that he has created without changing His being.

We pointed out earlier that divine holiness is the predominant attribute in this passage. While Strong ${ }^{122}$ and Pannenberg ${ }^{123}$ build their conceptions of holiness from timeless Being, we will draw out some principles regarding divine holiness that assume

${ }^{120}$ Ibid., 234-245.

${ }^{121}$ Ibid., 241 footnote $1 ; 245$.

${ }^{122}$ Strong's dependence upon the Platonic and Aristotelian framework in his definition of holiness is evident in his ontological dichotomy between absolute and relative holiness; and in his definition of holiness as self-affirming purity that he eternally wills and maintains. Strong, Systematic Theology, 1:247-249, 268, 273.

${ }^{123}$ Pannenberg's amoral concept of holiness as infinity, and as separateness from everything profane, assumes Kant's separation between the noumenal and phenomenal spheres. Pannenberg, Systematic Theology, 1:397-400. 
God's infinite analogous temporal Being. The first is that God does not become holy; he is holy. ${ }^{124}$

Second, since God's very nature is holy, he is separate ${ }^{125}$ from all creation. This best harmonizes with the recognition that the immanent ${ }^{126}$ divine presence in the sanctuary is at the same time transcendent. Consequently, as the transcendent One, God's holiness points to aspects of his being that are incomparable with anything in creation (Isa 40:25). However, God's holiness is neither an ontological barrier to the hosts of heaven, nor to Isaiah ${ }^{127}$ and the earthly temple. God mediates his holiness through the cultic sanctuary services so that sinners like Isaiah can experience forgiveness and hear God's voice (Isa 6:6-8).

Third, God's holiness possesses moral purity. When Isaiah saw the King he immediately recognized his moral impurity and was forgiven of his iniquity and sin (Isa

${ }^{124}$ The passage in Isa 6:3 states, "holy, holy, holy is the Lord of hosts." In Isa 43:3 we read, "For I am the Lord your God, the Holy One of Israel, your Savior." See also, Isa $43: 15 ; 47: 4 ; 48: 17$ that connect God as the Holy One.

${ }^{125}$ There simply is no analogy between the being of God and anything in creation. Holiness can refer to God's incomparable being as understood by his creative power, see Isa 40:25-26. Gerhard Hasel notes, "since the more elemental meaning of the Hebrew idea of "holy" and "holiness" is "separation," the meaning of the holiness of the seventh day as affirmed in Genesis 2:3 and Exodus 20:11 expresses that the seventh-day Sabbath is that very day that God has separated from the rest of the days." Gerhard F. Hasel, "The Sabbath in the Pentateuch," in The Sabbath in Scripture and History, ed. Kenneth A. Strand (Washington, DC: Review \& Herald, 1982), 25.

${ }^{126}$ Yet, God's immanence is not within created time and matter as in the post Vatican II Sacramental Model and the Emerging Church in the Charismatic Model, see this dissertation page 185 footnote 358. Instead God's immanence in the sanctuary refers to his historical presence as an entity among other spatio-temporal entities. Thus, when describing God's immanence, the sanctuary provides a model for how God relates to all realities in the universe by looking at how he relates to the realities associated with the sanctuary.

${ }^{127}$ Prior to the sin of Adam, God's holiness was not an ontological barrier as he interacted with him in Eden. However, as Isaiah points out in Isa 59:1-2, it is sin that separates us from God. The only barrier to God's holiness in his encounter with Isaiah in Isa 6:1-8 was the prophet's sinfulness that was the result of the sins he committed. Thus, God remedies the prophet's sinful condition by the bestowal of his grace and mercy (Isa 6:6-7); not by mediating his being to the prophet. 
6:5-7). Since his name is holy, and since his name in the context of liturgy is equal to his moral presence, we conclude that God's holiness in liturgy refers to his holy character that is revealed by his holy presence. ${ }^{128}$ Consequently, just as there is no dichotomy between God's Being and his presence, there is no dichotomy between God's presence and his holiness.

\section{Liturgist}

As we now begin our description and analysis of the liturgist, we will take into account the ways in which God's infinite analogous temporal Being and the sanctuary significantly shape Scripture's view of the liturgist. I will begin with Exod 3:1-21, then proceed to Lev 19:30; 26:1-2, and then follow the canonical order.

Exod 3:1-21

\section{Description}

In liturgy, a liturgist is one who leads the congregation by performing liturgical actions. The majority of the time those who perform liturgical actions are human. The liturgist in this passage is first introduced as the "Angel (mal'äk) of the Lord" (Exod 3:2). The choice of the Hebrew ( $m a l$ 'a $k$ ) draws our attention to the importance of a messenger

who speaks. ${ }^{129}$ As we continue to read the narrative we are informed that the Angel of the Lord is the God of Abraham, Isaac and Jacob (Exod 3:4-6), the "I AM" (Exod 3:14).

\section{Analysis}

Since, God's Being is temporal, speaking to Moses within the temporal flow of

\footnotetext{
${ }^{128}$ For God's name as holy, see Ps 111:9; Isa 57:15; Ezek 20:39; 36:20, 21, 22.

${ }^{129}$ Propp, Exodus 1-18 AB 2, 198.
} 
history is in complete harmony with his nature. Accordingly, since God himself is the liturgist who drew Moses to the burning bush and performs the liturgical action of speaking to Moses, he is the cause of liturgy. Yet, in our exegesis of the other passages in which God is not the liturgist, we note that the divine presence is the indispensible material condition of liturgy and that the liturgist is the efficient cause.

\section{Lev 19:30 and 26:1-2}

The purpose of our exegesis of Lev 19:30;26:1-2 is to sketch the hermeneutical effects of replacing timeless Being with God's infinite analogous temporal Being on the liturgist in the Biblical Sanctuary Model without entering into the details concerning the similarities and differences between liturgists in the OT and those in the NT.

First, a phenomenological reading of Lev 19:30; 26:1-2 assumes that the liturgist has autonomy to either construct idols or to observe God's Sabbaths and reverence his sanctuary. ${ }^{130}$ Hence, in the Biblical Sanctuary Model the liturgist is the cause of liturgy while the divine presence and the other components constitute the indispensible conditions of liturgy.

Second, human biblical liturgists are ontologically the same as the laity. This view is based on the sanctuary and the Sabbath as the ground of the temporal relationship between the divine presence and the liturgist. In other words, the sanctuary and the Sabbath function as the hermeneutical framework that interprets all of the components of human nature as integrated. As a result, the temporal view of the liturgist eliminates the dichotomy between body and soul where the soul is marked at ordination resulting in the

\footnotetext{
${ }^{130}$ The passage in Lev 26:1 states, "you shall not make...nor rear up...nor set up...." Instead, "you shall observe....and reverence...." This presupposes that the liturgist is capable of doing both.
} 
ontological dichotomy between liturgist and laity. ${ }^{131}$

Third, a phenomenological reading also assumes that the liturgist possesses a hermeneutical mind instead of Aristotle's active intellect ${ }^{132}$ or a Kantian modern mind. ${ }^{133}$ With a hermeneutical mind, liturgists have two options; they can either interpret the divine presence from the starting point of creation ${ }^{134}$ (idols - Lev 26:1) or from the I AM (Lord God - Lev 26:2) that only comes via revelation. ${ }^{135}$ The hermeneutical mind of the liturgist assumes that the sanctuary and the Sabbath ground the temporal relationship between the divine presence and the liturgist.

Fourth, from the temporal view of humanity we can deduce that all of the components that make up the liturgist include but are not limited to personal attitude,

${ }^{131}$ See the liturgist in the Sacramental model.

${ }^{132}$ In the Aristotelian mind assumed by Aquinas, the human subject's reasoning powers that are part of the timeless soul are elevated in order to be able to receive divine timeless truths through either revelation or illumination. This would mean that the descriptions of the liturgists and their activities in the heavenly sanctuary constitute John's culturally conditioned view of a timeless reality. See Hanley, Being and God in Aristotle and Heidegger, 25.

${ }^{133}$ In Kant's philosophy, the scope of knowledge is limited to the phenomenal world although the existence of the noumenal world is not denied. Aristotle's active intellect becomes the a priori form which then orders matter that comes from the senses. So, although knowledge is limited to the phenomena, the categories of form and matter that are necessary for knowledge to take place come from Aristotle. Form in Aristotle has its grounding in ontology, yet it is accessed by the active intellect. This ontological ground has been severed by Kant. Form in Kant is comprised of the a priori categories of space and time which order matter that comes from the senses. Knowledge here is absolute and certain yet its ground has shifted from ontology to epistemology, and from the noumenal world to the phenomenal world. Thus Aristotle is still there in Kant's epistemology that now results in objective universal knowledge of the world that is the basis for the modern scientific mind. See this dissertation page 205 footnote 455 .

${ }^{134}$ In Lev 26:1, the prohibition against developing a theology of the divine presence and worshipping it is based on the inextricable link between the divine presence and creation. Accordingly, under these circumstances, creation becomes the starting point for a theology of the divine presence, which is prohibited.

${ }^{135}$ We deduce the I AM in the text through the words Lord and God (Lev 26:1-2). God revealed himself as the I AM to Moses; the prophet did not construct this by applying his reasoning faculties to nature. Hence, the I AM, which is the divine presence only comes through revelation. 
ethical choices, beliefs, and spiritual gifts. Accordingly, these play an important role in interpreting and mediating the divine presence to the congregation via the performance of liturgical actions. ${ }^{136}$ This is because the Sabbath and the sanctuary temporally ground all of the components of the liturgist. Consequently, personal attitudes, ethical choices, beliefs, and spiritual gifts are all integrated and involved in mediating the divine presence.

Fifth, since the divine presence does not change through the evolutionary process as panentheism asserts but is immutable, biblical liturgists mediate this to the congregation by assuming that maleness and femaleness are immutable aspects of the nature of liturgists in the Biblical Sanctuary Model. For instance, Gen 1:27 states that God created Adam and Eve in his own image, and that he created them male and female. In addition to maleness and femaleness, Gen 2:7 reveals that a human being constitutes the totality of all aspects of human beings: mental, physical, social, and spiritual. The word image in Gen 1:27 suggests that Adam and Eve mediate certain aspects of the divine presence. As we further elaborate on this we note that the Sabbath functions as the immutable sign of a finished and immutable creation (Gen 2:1-3). An immutable creation intimates that maleness and femaleness constitute immutable aspects of human nature, and that a phenomenological analysis of males and females, as well as the texts pertaining to males and females can confirm this. Consequently, the Sabbath grounds the immutability of human nature with the divine presence in the following way. The

${ }^{136}$ In the Sacramental model the personal beliefs, attitudes or ethics of the liturgist played no role in mediating the divine presence to the congregation as long as the correct ritual action was performed and as long as the liturgist was ordained according to apostolic succession. This assumes a timeless view of grace as well as the body/soul dichotomy for the liturgist where the guarantee of a congregation receiving grace only depends upon the correct ritual action since the ethical decisions of the liturgist are in no way causally related to the mediation of grace he performs. 
Sabbath is the immutable sign of the immutable aspects of male and female. Moreover, as an immutable sign, the Sabbath eliminates the panentheistic view that God's being actually changes through the course of the evolutionary process. Hence, the immutable aspects of male and female mediate the immutability of God's being. Furthermore, a phenomenological exegesis of the Sabbath also eliminates timeless Being from interpreting God as timeless and the rest of creation as a combination of timeless and historical elements as Aquinas' timeless analogy of being suggests. Consequently, the Sabbath temporally grounds the relationship between God and the rest of creation.

As we further apply the principle that the Sabbath temporally grounds the relationship between God and the rest of the liturgical components to human nature we note that the liturgists' gifts, talents, attitude, and belief systems are causally related to and inextricably linked with the immutable aspects of maleness and femaleness. This is in contrast to Emergents who emphasize gifts and talents while they reject and thus dichotomize their gifts and talents from the immutable aspects of maleness and femaleness. ${ }^{137}$ Furthermore, the deduction that maleness and femaleness are subject to change is grounded on the use of timeless reason that assumes the body/soul dichotomy. ${ }^{138}$ Since maleness and femaleness are aspects of the body that are not causally

\footnotetext{
137،"In what is likely a first, Calvary Baptist Church in Washington, D.C., has ordained Allyson Robinson, who was previously ordained as a man, to the gospel ministry." The rationale for the choice was that "God has blessed her with a talent for ministry," and "is gifted to serve in this capacity." Bob Allen, "Baptist Church Ordains Transgender Woman," 12-13.

${ }^{138}$ The question is asked,

How do I know that I am a woman? I have the anatomy of a man. But just as surely as I know my anatomy, I know my soul - my spirit. And I have the soul of a woman. I did not arrive at this knowledge hastily. It comes from hours of study, prayerful meditation, and prayer. And I know I have the assurance of the Holy Spirit and the peace that passes
} 
related to the soul, Emergents assume the use of timeless reason in their deduction that the truth about human identity is ultimately based on timeless truths that are accessible only to the activity of the timeless soul. Consequently, information about maleness and femaleness that arises from sensory perception communicates nothing about human identity. They also assert that the Sola Scriptura principle (revelation) stands directly in the way of integrating LGBT liturgists into Evangelical churches. ${ }^{139}$

\section{Exod 19-20 and Deut 4-5}

Although God is the main liturgist who speaks the Ten Commandments, Moses also appears to be a liturgist whose duty is to give instructions to the people and the priests concerning the importance of properly preparing themselves for God to speak to them. ${ }^{140}$ Moreover, as temporal beings the angels also function as liturgists by their direct involvement with God speaking the Ten Commandments. ${ }^{141}$

all understanding (G.G. Bolich, Crossdressing in Context, Dress, Gender, Transgender and Religion, vol.4 (Raleigh, NC: Psyche's Press, 2008), 183).

Body/soul dichotomy goes hand in hand with the deduction that reason discards sensory perception and bases its knowledge on the timeless activity of reason.

${ }^{139}$ When seeking answers to the LGBT issue interpreters should incorporate the "claims of contemporary research and clinicians, personal experiences of and with LGBT people, or alternative renderings of the biblical witness." David P. Gushee, "Reconciling Evangelical Christianity with Our Sexual Minorities: Reframing the Biblical Discussion," 147. Timeless Being lies at the basis of the doctrine of man for conservative and progressive evangelicals. For conservative evangelicals the exclusive male-female gender is based on Platonic duplication, meaning that a male body is the duplication of a male soul. For progressives, dynamic timeless Being drives the view that our souls and bodies are in a state of change, allowing for gender identities beyond male-female heterosexual beings; and that the divine presence, working through the evolutionary process, is the cause of these changes.

${ }^{140}$ See Exod 19:10-15, 21-22, 24.

${ }^{141}$ See my exegesis of the liturgist in Heb 12:18-29 found in Chapter 6 of this dissertation page 340 footnote 120 . 


\section{Kgs 8:12-66 and 2 Chr 5:11-7:7}

\section{Description}

There were three different human liturgists at the dedication of the Temple. First, the priests and Levites brought up the ark of the Lord and the furnishings (I Kings 8:4; 2 Chr 5:5) to the Temple but then only the priests are mentioned as bringing the ark to the Most Holy Place of the sanctuary (I Kings 8:6; 2 Chr 5:7). Furthermore, the priests were the only ones authorized to sound the trumpets ( $2 \mathrm{Chr} 5: 12 ; 7: 6) .{ }^{142}$ Second, the account in Chronicles records that the Levites were the singers who were clothed in white and had stringed instruments (2 Chr 5:11-13; 7:6). The decision to appoint the Levites as the musicians ( $1 \mathrm{Chr} 15: 16 ; 16: 4 ; 23: 5)$ is "the most significant innovation of David in his organization of the choral service [which was] not done under his own authority but at the command of the Lord through Gad and Nathan (2 Chr 29:25)." ${ }^{, 143}$ The Levites nevertheless exercised a subordinate role to that of the priests. ${ }^{144}$ Third, Solomon appears to be the main liturgist in this passage where his dedicatory speech and prayer occupies the major portion of the narrative (I Kings 8:12-53), which is followed by his blessing on the assembly (I Kings 8:54-61). Solomon also takes the lead in offering a sacrifice of peace offerings (I Kings 8:62-66).

${ }^{142}$ Kleinig point this out, he states,

There was no need for David to make any new regulations for the players of the trumpets, since the priests had already been detailed for that task by Moses in Num 10:8. The only innovation for them by David was their combination with the Levitical choir in the performance of sacred song before the ark in Jerusalem (1 Chr 16:4-6)....Through the priests the trumpets were also linked ritually with the ark and the altar which, since they were most holy, were out of bounds for the Levites (Kleinig, The Lord's Song, 90).

${ }^{143}$ Ibid., 91. David traced the Levitical origins of the three heads of guilds in $1 \mathrm{Chr}$ 6:33-47, and "repeatedly referred to the musicians as Levites (1 Chr 16:4; 2 Chr 5:12; 7:6; $8: 14 ; 29: 25,30 ; 30: 21-22 ; 31: 2)$." Ibid.

${ }^{144}$ See 1 Chr 23:28, 32. 


\section{Analysis}

We will now undertake a brief analysis of the hermeneutical influence of God's infinite analogous temporal Being on the nature, role, and authority of the priests and Levites as liturgists in this narrative. As God chose (1) the place of liturgy to reveal his presence (1 Kings 8:29), (2) the time/s during which the Israelites would appear before him, and (3) the instruments involved in music (2 Chr 29:25) ${ }^{145}$; he also chose (4) Aaron and his sons ${ }^{146}$ to serve as priests until Christ himself should assume that office after his sacrifice and resurrection (Heb 5:1;8:3). Hence, the choice ${ }^{147}$ of Aaron and his sons is based on the divine reality that Christ is our high priest and that the Aaronic priesthood is patterned after the reality of Christ as high priest (Heb 9:1-7, 23-24) while the nature ${ }^{148}$ of Christ's priesthood is based on Melchizedek (Heb 7:11-16). Although Israel was called to be a kingdom of priests (Exod 19:6), the choice of Aaron's family to serve as priests could not be performed by anyone else without serious consequences. ${ }^{149}$ However, since the priests and Levites were temporal human beings their dedication ${ }^{150}$ did not make

${ }^{145}$ See the liturgical actions of the Biblical Sanctuary model where we address the place of liturgy and the time/s. See the appendix for the instruments involved.

${ }^{146}$ At Sinai, God appointed the tribe of Levi to serve Aaron and his sons in the tabernacle in place of the first-born (Num 3:6-13) as a result of their loyalty during the apostasy at the golden calf (Exod 32:26-29); He also appointed Aaron and his sons to serve as priests (Num 3:10), and he restricted the priesthood to Aaron's male descendants (Exod $28: 1 ; 40: 12-15$; Num $16: 40 ; 17 ; 18: 1-8)$.

${ }^{147}$ God's choice to have Aaron's family as priest was reiterated in a miraculous way after the incident with Korah. See Num 17:1-12.

${ }^{148} \mathrm{BDAG}, \mathrm{s.v.} \tau \alpha \dot{\xi} \xi \varsigma$.

${ }^{149}$ See Num $3: 10 ; 16: 1-41$.

${ }^{150}$ See Num 8:5-22; Exod 29; and Lev 8. Viewed from within the framework of God's infinite analogous temporal Being and temporal humanity, a dedication, ordination, or laying on of hands (Num 8:10) by the congregation should not be confused with the Sacramental model's interpretation that makes those dedicated as ontologically superior to the rest of the congregation. 
them ontologically superior to the rest of the Israelites. Since king Solomon is also a liturgist in this narrative, we could also contend that he typifies Jesus as the King of kings (Luke 1:30-33; Rev 17:14; 19:16) in a way that compliments the priests who typify Christ as high priest.

As the main liturgist who speaks in this dedication, Solomon possesses a hermeneutical mind and not a timeless active intellect and reason. ${ }^{151}$ As a result, Solomon's presuppositions concerning Being, the divine presence, human nature, and the nature of Scripture play a significant role in interpreting the very message he bears to the people. In other words, he is not simply the instrumental cause that bears timeless nonhistorical truths that bypass the interpretive process intrinsic to all historical minds. Hence, even though Solomon's address reveals a highly interpretive process capable of errors, God immediately sets the seal on his interpretation by causing fire to come down from heaven (2 $\mathrm{Chr} 7: 1)$.

\section{Isa $6: 1-13$}

\section{Description}

The liturgists in Isaiah 6:1-13 include seraphim (Isa 6:3, 6-7). However, the prominent liturgist in this passage is the Lord himself. In Isa 6:8 the Lord asks, "Whom shall I send, and who will go for Us?" After Isaiah's response, the Lord begins to specifically outline the message that Isaiah must bear to the people (Isa 6:9-13).

\section{Analysis}

A phenomenological exegesis of this passage assumes that the heavenly sanctuary

${ }^{151}$ The timeless active intellect refers to the soul's mechanism by which worshippers respond to the encounter by abstracting the divine presence from the physical world. See this dissertation, page 141 . 
provides the temporal interpretation of the relationship between heaven and earth. Accordingly, our concept of the liturgist must also include heavenly liturgists like seraphim who can directly minister to worshipers like Isaiah. That the heavenly seraph can speak to Isaiah in temporal language (Isa 6:6-7) assumes that the heavenly liturgist and the earthly worshiper share a temporal nature that makes communication and understanding possible despite the fact that there are significant differences between humans and angels, and even greater ones between humans and God.

\section{Liturgical Setting and Actions}

I will now begin to describe the liturgical setting and actions of the Biblical Sanctuary model by looking at what the texts reveal before I begin to analyze how the sanctuary grounds the temporal relationship between the divine presence and the specific liturgical actions in the Biblical passages.

\section{Exod 3:1-21}

\section{Description}

Since the Scripture does not record the specific time in which the theophany took place other than revealing that the deliverance for the Israelites had come (Exod 2:23-25), we will first begin with a description and analysis of liturgical space. The encounter between God and Moses took place at the back ${ }^{152}$ of the desert near Horeb, "the mountain of God" (Exod 3:1). There are several things we can learn about the place in which the encounter occurred from the perspective of God's infinite analogous temporal Being. First, God told Moses that the place (māqôm) where he stands is holy (qōdeš) (Exod 3:5).

\footnotetext{
${ }^{152}$ Actually the west side of the desert (RSV of Exod 3:1).
} 
The two Hebrew words "can independently connote a sanctuary.","153

Māqôm is used to designate the location of the temple where God's name, meaning his presence would dwell (1 Kings 8:29; cf. 8:30, 35), and qōdeš also refers to the sanctuary (Num 4:12;8:19) and temple (1 Kings 8:8, 10).

\section{Analysis}

Although the burning bush is not a sanctuary it contains two key components, namely the place of the encounter and holiness, both of which are the direct result of God's presence, and which are integrally connected to the sanctuary. Second, although God is omnipresent, his presence is not synonymous with creation. Accordingly, God chooses when and where to reveal his presence. Third, none of God's attributes are compromised by his choice to reveal himself to Moses at the burning bush. ${ }^{154}$ Furthermore, the fact that the bush itself was not consumed signifies that an encounter between a temporal God and a temporal bush in Exod 3:2 neither destroys nor alters the properties that make the bush what it is. ${ }^{155}$ Fourth, holiness is directly linked with the revelation of God's presence. Accordingly, the ground surrounding the bush would no longer be holy after God's presence was withdrawn.

While the burning bush is the location of his revealed presence, it is not itself the vehicle through which he reveals himself. Moses only discerned God's presence when

\footnotetext{
${ }^{153}$ Propp, Exodus 1-18 AB 2, 200. For general connections between the command to remove sandals and the sanctuary and temple, see Bruckner, Exodus NIBC 2, 40.

${ }^{154}$ This interaction with the creation in time and space has always proved to be problematic for the timeless God of the models in Chapter 4. However, God's infinite analogous temporal Being allows for an encounter in space and time, and at the same time the distinction between his being and that of the burning bush in this instance is kept clear.

${ }^{155}$ This is not the case when theologians assume that God is timeless. Often in having to explain how a timeless God interacts with humans or creation, the latter is distorted in the process. For some examples see the Sacramental Model in Chapter 4.
} 
God spoke to him (Exod 3:4). We will now from the viewpoint of God's infinite analogous temporal Being briefly analyze why speech constitutes the main liturgical ritual in the narrative. ${ }^{156}$ First and foremost, God's word, especially his introduction to Moses as the "I AM", is the only vehicle that is capable of mediating his presence. Second, as a mode of communication, the invisibility ${ }^{157}$ of God's message is the vehicle of choice that best represents his invisible presence. Third, his eternal past precedes creation thus pointing to the distinction between his being and that of creation. Consequently, the specific information contained in God's introduction to Moses as the I AM comes through revelation and cannot be inferred from the bush itself. Hence, as a vehicle of mediation, speech can communicate much more information than creation can about everything connected with the reality of God. ${ }^{158}$ Moreover, the specific information involved in delivering the Israelites can best be delivered through speech. ${ }^{159}$

${ }^{156}$ That God's message to Moses constitutes the main ritual action in the narrative is indicated by: (1) the amount of time God spends communicating to Moses His will with the regard to the children of Israel (Exod 3:4-4:17); (2) the importance of the message that includes the deliverance of an entire nation who are perishing as slaves (Exod 3:7-10); and (3) the unconventional method of deliverance that includes an aged Moses (Exod 7:7), with only his shepherd's staff (Exod 7:9; 14:16), and his brother Aaron (Exod 7:7).

${ }^{157}$ What I simply mean here is that speech is invisible, whereas art is not. There is a big difference though between speech as invisible and music, which is something we will expound upon as we deal with liturgical actions.

${ }^{158}$ As we will see, while speech can mediate the presence of God, art and music can only mediate temporal creation.

${ }^{159}$ For instance, the following is an incomplete list of information that God gives to Moses. Calling Moses name Exod 3:4; instruction to take off his shoes and the revelation that the ground is holy Exod 3:5; God introduces himself as the God of his forefathers Exod 3:6; God sees the affliction of his people and calls Moses to deliver them from the oppressor Exod 3:7-10; God assures Moses that he will be with him for he is the great I AM whose name/Being/presence goes from eternity past to eternity future Exod 3:11-15. 
Lev 19:30 and 26:1-2

\section{Description}

The passages in Lev 19:30 and 26:1-2 mention the Sabbath and the sanctuary as indicators of the time and place where liturgy occurs that I have categorized under liturgical setting and actions. Moreover, the instruction in Lev 19:30; 26:1-2 to not make idols and worship them on the one hand and then to observe the Sabbath and reverence the sanctuary on the other, directly connects the divine presence with the liturgical setting and actions. Accordingly, our purpose here is to sketch the hermeneutical effects of God's infinite analogous temporal Being on the Sabbath and the sanctuary as the liturgical setting in Lev 19:30 and 26:1-2.

\section{Analysis}

Both the Sabbath and the sanctuary ground the temporal relationship between the divine presence and the liturgical setting and actions. The liturgical setting that is linked to the Sabbath involves the time in which liturgy takes place. The liturgical setting associated with the sanctuary involves the place where liturgy occurs. ${ }^{160}$

There are several hermeneutical effects that come as direct result of this temporal ground between the divine presence and the Sabbath. First, the seventh day Sabbath actually mediates the biblical view of the divine presence by linking the day of worship

\footnotetext{
${ }^{160 \text { ' }}$ Someone has called the Sabbath a 'holy space, a sanctuary in time.' It was as holy as the Temple, which was a sanctuary in 'space.' Just as a holy place provides a space for celebrating God and praising him, so does a holy time." Ashby, Exodus ITC, 90. The reference to someone in Ashby's quote most likely refers to Abraham Heschel who stated,

Six days a week we live under the tyranny of things of space; on the Sabbath we try to become attuned to holiness in time. It is a day on which we are called upon to share in what is eternal in time, to turn from the results of creation to the mystery of creation; from the world of creation to the creation of the world (Abraham Heschel, The Sabbath: Its Meaning for Modern Man (New York: Farrar, Straus and Young, 1951), 10).
} 
directly with the manifestation of the divine presence in time. Since the biblical understanding of time is based on God's infinite analogous temporal Being, the revelation of the divine presence on the Sabbath day avoids confusing the Creator with the creation. As a result, the Sabbath interprets God's omnipresence as being ontologically distinct from nature. Second, associating the divine presence with the Sabbath also harmonizes with God as being invisible. The link between the divine presence, time and space on the Sabbath day reveals that God chooses when he reveals his presence to all worshipers regardless of where they are located on earth. Third, since God chose the Sabbath day to reveal himself, liturgists are not at liberty to choose a different day expecting that God will fill that day with his presence. Fourth, the immutability of the Sabbath as a sign of God's existence that was established at creation, observed in OT, NT and in the world to come, points to the immutability of God's nature as well as to the immutable nature of creation; these form the building blocks in the present model from which to interpret the place of the encounter and the manner in which the divine presence relates to it.

The sanctuary also mediates the biblical view of the divine presence by linking the place of worship directly with God's name. Several times Scripture points out that God will choose the specific place to put his name so that he may abide there. ${ }^{161}$ Although God is omnipresent, he can reveal himself in the place of his choice. Accordingly, his being and the being of the sanctuary are essentially distinct and should not be confused. ${ }^{162}$ A phenomenological reading of Exod 40:34-38 further emphasizes

${ }^{161}$ See Deut $12: 5,11,21 ; 16: 2,6$.

${ }^{162} \mathrm{We}$ will touch on the relationship between the earthly and heavenly sanctuary and the relation to the divine presence when we exegete the other texts. 
that God is distinct from the sanctuary when his presence moves into it. Since the place where God reveals his presence is based solely on his choice, the liturgist is not at liberty to choose a different place and still expect God to reveal himself there. Hence, God's choice of the Sabbath and the sanctuary reveal that the liturgical setting and actions are causally related to the divine presence, which means that changing them can also alter our conception of his presence. Moreover the liturgical actions are grounded in God's choice as communicated through Scripture; they are not grounded in the decisions of the church. When the priests chose to discard God's specific directions, they lost their lives (Lev 10:1-2; 16:1-2).

\section{Exod 19-20 and Deut 4-5}

\section{Description}

God speaking the Ten Commandments "out of the midst of the fire" (Deut 4:15$16,33,36 ; 5: 24,26 ; 9: 10 ; 10: 4)$ undoubtedly makes up the central liturgical action at Mt Sinai. ${ }^{163}$ This is indicated by the response of the people who marveled at the fact that they were still alive after hearing the voice of God (Deut 5:32-33); it was also indicated by the admonition to teach their children and grandchildren the importance of their encounter with the voice of God (Deut 4:9-13); and by writing the message in stone to indicate its enduring nature (Exod 31:18; cf 24:12; 32:16; Deut 4:13).

The following preparatory actions directly precede God speaking the Ten Commandments: (1) the command for the Israelites and priests to consecrate themselves

\footnotetext{
163، The fact that this narrative is cast in liturgical categories permits the narrator to... [see] this as a model meeting that serves as a paradigm for all future covenantal confrontations," NIB Vol. 1, 834.
} 
by washing their clothes, abstaining from sex, ${ }^{164}$ and being in a state of readiness (Exod $19: 10,11,14,15,21,22) ;(2)$ the command to set boundaries so that no one touches the base of the mountain (Exod 19:12,13,23); and (3) the loud trumpet call to signal when to approach the mountain (Exod 19:13, 16, 19).

As far as the time in which God spoke his law, scripture records that it was in the third month after the Israelites left Egypt that this liturgical service took place (Exod 19:1-2). Moreover, although there is no explicit indicator as to the exact day when this service took place, the commandment to "Remember the Sabbath day to keep it holy" (Exod 20:8) indicates a close relationship between the Sabbath as the day in which liturgy should occur ${ }^{165}$ and the remembrance of God's acts in history through speech as the main vehicle of remembrance. Furthermore, as the sign of the covenant (Exod 31:12-17), the Sabbath also connects the importance of placing God's words in our hearts and minds (Jer 31:31-34), which further strengthens the tie between the Sabbath and God's words.

\section{Analysis}

We will now briefly look at the correlation between God's name, remembrance and speech. Since the Sabbath is a reminder of God's acts in creation (Exod 20:8-11), one best remembers these acts by rehearsing them through speech. ${ }^{166}$ In this sense, a rehearsal of God's acts through speech on the Sabbath is inextricably linked with the words "then

${ }^{164}$ Propp, Exodus 19-40 AB 2A, 162, 163.

${ }^{165} \mathrm{We}$ have previously dealt with the liturgical setting of the Sabbath as the time in which liturgy occurs. See pages 229-234.

166، The Hebrew verb zākar means far more than the English word "remember." In the present context, the Hebrew word conveys the notion of mindful, careful observance or reenactment." Ashby, Exodus ITC, 91. 
God said" ${ }^{\prime 167}$ as the vehicle through which the world was made. This effectively ties together God's speech as the vehicle of creation and the Sabbath, which functions not only as the memorial of creation but of the necessity of God's spoken word as the efficient cause of creation. Hence, Gen 2:1-4 appropriately concludes by linking the Sabbath with God's infinite analogous temporal Being, his nature, and his spoken words. The Sabbath is also a reminder of God's acts in redemption (Deut 5:12-15). When combined with the sanctuary, God's redemptive acts go well beyond the deliverance of his people from Egypt to include other pivotal events in salvation history. ${ }^{168}$ As a result, the command to remember through speech is also grounded in Exod 3:15, which links God's infinite analogous temporal Being with a remembrance of God's name to all future generations by "remembering the mighty acts of salvation." ${ }^{\text {169 }}$ Moreover, God is holy, and the Sabbath is holy (Exod 20:8-11). Here it is important to remember that God's spoken words at the burning bush revealed to Moses God's holy presence (Exod 3:5-6); and in a liturgical context, the command to remember the Sabbath day to keep it holy (Exod 20:8) is best done by noting that God's words provide the power to create and to redeem.

As the place in which God spoke the Ten Commandments, Mt Sinai itself functionally represents the heavenly sanctuary. ${ }^{170}$ We will now examine how the Sabbath

\footnotetext{
${ }^{167}$ The phrase, "and God said" is stated nine times in the six days of creation in Gen 1. A phenomenological reading of Gen 1 assumes the temporality of God and creation.

${ }^{168} \mathrm{We}$ will describe and analyze the connections between the sanctuary and salvation history as wee look at the other biblical passages.

${ }^{169}$ Bruckner, Exodus NIBC 2, s.v. Exod 3:11-15.

${ }^{170}$ For all of the exegetical connections between mount Sinai and the heavenly sanctuary, see de Souza, "The Heavenly Sanctuary/Temple Motif in the Hebrew Bible," 154-164. Angel Rodríguez draws the following parallels between Mt Sinai and the
} 
and the sanctuary temporally ground the relationship between the divine presence and the liturgical setting and actions. In Deut 4:36 we read, "Out of heaven He let you hear His voice, that He might instruct you; on earth He showed you His great fire, and you heard His words out of the midst of the fire." Moses points out that when God speaks, his word comes from heaven as well as from the midst of the fire here on earth. ${ }^{171}$ The temporal (simultaneous) relationship between heavenly and earthly action eliminates the ontological gap that some modern interpreters assume in their distinction between noumenal and phenomenal Torah in which "noumenal Torah cannot be limited by rational categories of time and space." ${ }^{172}$ In contrast, just as Deut 4:36 declares that there

sanctuary: the fence (Exod 19:12) with the altar (Exod 24:4) parallels the court and the altar of the earthly tabernacle. The 70 elders including Aaron, Nadab, and Abihu were allowed to see God from afar (Exod 24:1, 9-11) parallels the holy place. Moses could go into the very presence of God (Exod 24:12-18), which is equivalent to the Most Holy Place See Angel Manuel Rodríguez, "Sanctuary Theology in the Book of Exodus," AUSS 24 no. 2 (1986): 132-134. See also Ronald E. Clements, Exodus CBC (Cambridge: Cambridge University Press, 1972), 117; Propp, Exodus 19-40 AB 2A, 161.

${ }^{171}$ For passages declaring that God spoke out of the midst of the fire, see Deut 4:12, $15,33,36 ; 5: 4,22,24,26,9: 10 ; 10: 4$. This scenario at Mt. Sinai is similar to God's call to Moses. The passage in Exod 3 reveals that God called unto him "out of the midst of the bush" (Exod 3:4). In Exod 3:2 it states, "the angel of the Lord appeared unto him in a flame of fire out of the midst of the bush." Hence, the divine presence is connected to the Word and not to the physical manifestations that are symbols of His presence. The passage in Deut 4:11 points out that the fire burned "to the midst of heaven" (Deut 4:11) and the following texts confirm that God's voice came from heaven: Exod 20:22; Deut 4:36; Neh 9:13. Thus, the fire burned to the midst of heaven (Deut 4:11) and Israel heard His voice from heaven, which was stated as coming out of the midst of the fire (Deut 4:33).

${ }^{172}$ Benjamin D. Sommer, "Revelation at Sinai in the Hebrew Bible and in Jewish Theology," Journal of Religion 79 no. 3, (1999): 448. One cannot fail to notice Kant's distinction between the noumenal world that assumes timeless Being, and which according to Kant cannot be known, and the phenomenal world that describes what took place at Sinai. This provides the basis for the distinction between divine content and human content in which the

divine presence in the biblical text consists not of its words but in the silent qol, the aleph of God's presence [where] the words are sign posts pointing toward a transcendence that cannot be apprehended," resulting in the "all-too-human documents we know as the Pentateuch (Ibid., 447). 
is no difference or dichotomy between the theological content of the word spoken from heaven and that which God speaks on earth, there is also no difference or dichotomy between the Lord Himself who is simultaneously "God in heaven above and on the earth beneath" (Deut 4:39). ${ }^{173}$ Since God's voice came from heaven as well as earth, his mode of manifesting his presence through speech rather than through the material creation (Exod 20:4-6; Deut 4:12-15) is his universal method of revealing his presence in heaven as well as on earth. ${ }^{174}$ Consequently, like music, speech by definition occurs in time. This means that speech is not a culturally conditioned medium of revealing God's presence that later gives way when a more visual and technological medium is accessible.

As we briefly analyze the preparatory ritual actions, we see that the holiness of God and human nature form the basis for our analysis. Moreover, the sanctuary setting grounds the temporal relationship between the holiness of God; the mental, spiritual, physical and social faculties; and the preparatory ritual actions. As a result: The holiness of God is an indispensible condition that directly results in the preparatory ritual actions we mentioned above. The temporal view of humanity reveals that the mental, spiritual, physical and social faculties are integrated and are causally related to each other. Hence, each preparatory ritual affects each faculty; it also forms an important aspect of being

Earlier in his article, Sommer summarizes Abraham Joshua Heschel and Franz Rosenzweig stating, "all Jewish tradition is a response to the act of revelation, which did not itself convey specific content." Ibid., 424. Hence, Sommer affirms an ontological gap between timeless divine content and its historical and cultural human expression in the Torah.

${ }^{173}$ Ian Wilson states,

He is God 'in heaven above' because it was from there that 'he let [them] hear his voice' (v. 36a). And he is God 'on the earth beneath' because it was on earth that 'he let [them] see his great fire, and [they] heard his words out of the midst of the fire' (v. 36b) (Ian Wilson, Out of the Midst of the Fire: Divine Presence in Deuteronomy SBLDS 151, 72).

${ }^{174}$ This meeting at Sinai is intended to be a "model meeting that serves as a paradigm for all future covenantal generations." NIB Vol. 1, 833-834, 836. 
prepared for the reception of the Ten Commandments.

\section{$1 \mathrm{Kgs} 8: 12-66$ and $2 \mathrm{Chr} 5-7$}

\section{Description}

The central liturgical action in these passages is Solomon's brief message after the completion of the temple that was followed by his dedicatory prayer (1 Kings 8:22-61; 2 Chr 6:12-42). There are two reasons why Solomon's message and dedicatory prayer constitute the central liturgical action. The first is that it contains important information regarding the divine presence, the liturgical actions and the principles regarding which the Israelites can maintain or restore their covenant relationship with God. The second is that the Lord set His seal on the content of what Solomon spoke by sending fire from heaven to consume the burnt offering and sacrifices as soon as "Solomon had made an end of praying" (2 $\mathrm{Chr} 7: 1-3) .{ }^{175}$

The sacrifices constitute another important liturgical action during the dedication of the temple. Scripture records that 22,000 bulls and 120,000 sheep were sacrificed (1 Kings 8:63; 2 Chr 7:5; cf. 1 Kings 8:6; 2 Chr 5:6) at the dedication. While these constitute private thank offerings, the Chronicler under Hezekiah's reformation in $2 \mathrm{Chr}$ 29:20-35 sets forth the presentation of the burnt offering as the center of the whole sacrificial offering. Moreover, as the burnt offering was laid upon the altar, the musicians

${ }^{175}$ The incredibly high number of bulls and sheep (22,000 bulls and 120,000 sheep I Kgs 8:63; 2 Chr 7:5; cf. I Kgs 8:6; 2 Chr 5:6) that Solomon sacrificed for the dedication of the Lord's house seems to imply that the sacrificial offerings constitute the focal point of the liturgical actions. Yet, $2 \mathrm{Chr}$ 7:1 points out that fire from the Lord came as a direct result of Solomon's prayer. Also, the glory of the Lord was manifested when the ark was brought into the temple (2 Chr 5:12-14), yet the conclusion of Solomon's prayer also includes fire from heaven in addition to glory of the Lord that filled His house (2 Chr 7:1-3). 
performed the choral service and the congregation prostrated itself (2 Chr 29:27-29). ${ }^{176}$

Directly preceding Solomon's message and prayer, there were several preparatory rituals that included (1) preparing the temple and articles of furniture including the ark of the covenant (1 Kings 7:51-8:1-4, 6-9), (2) sacrificing sheep and oxen (1 Kings 8:5), and (3) the consecration of the priests (2 Chr 5:11).

Regarding the time in which the dedication took place, scripture records that Solomon assembled all the Israelites to Jerusalem at the feast in the seventh month in order to dedicate the newly built temple (1 Kings 8:1-2). A comparison of the solemn assembly atseret held on the eighth day in $2 \mathrm{Chr}$ 7:9 with the solemn assembly atseret in Lev 23:36 indicates that the dedication of the temple took place at the time of the Festival of Booths (Tabernacles).

The temple in Jerusalem, which is the legitimate successor of the tabernacle at Gibeon, ${ }^{177}$ is the place God chose so that he could reveal himself in the sanctuary by choosing to place his name there (1 Kings $8: 16,29 ; 2 \mathrm{Chr} 6: 5-6,20)$. The temple is also the place where the liturgical actions occurred. However, the fact that Solomon asks God to hear from the heavenly sanctuary, his dwelling place in heaven, ${ }^{178}$ when his people

${ }^{176}$ See Kleinig, The Lord's Song, 103. After noting the various sacrifices associated with the temple liturgy, Kleinig notes how "all the sacrifices were interrelated with each other by their inclusion in the central rite for the presentation of the burnt offerings upon the altar." Ibid., 107.

${ }^{177}$ Kleinig notes that

The identification of the two was so complete that the temple was called 'the tabernacle of the LORD' (2 Chr 29.6) and 'the tabernacle of God's house' (1 Chr 6.33) as well as 'the tent' (1 Chr 9.19) and 'the house of the tent' (1 Chr 9.23). The inner gates of the temple were even called 'the gates of the LORD'S camp' (2 Chr 31.2; cf. $1 \mathrm{Chr} 9.19$ ) (John W. Kleinig, The Lord's Song, 69-70).

${ }^{178}$ For God's dwelling place in heaven referring to the heavenly sanctuary, see de Souza, "The Heavenly Sanctuary/Temple Motif in the Hebrew Bible," 214-216, 220-222. 
petition him at the temple in Jerusalem ${ }^{179}$ leads to several conclusions. First, scholars who assume timeless Being create a dichotomy between God's name and his presence. ${ }^{180}$ Consequently, they conclude that only God's name was there at the temple while his actual presence was conflated with heaven itself, ${ }^{181}$ since it's not possible for any literal sanctuary - earthly or heavenly — to be the abode of a timeless God. ${ }^{182}$ In contrast to this, the choice to place God's name in the Jerusalem temple and in his dwelling place in heaven reveal that God's actual presence is revealed in both the earthly and heavenly sanctuaries. ${ }^{183}$ Second, the liturgical service is ultimately oriented toward God's dwelling place in the heavenly sanctuary. ${ }^{184}$ This is more clearly brought out in 2 Chr 30:27 where "the priests, the Levites, arose and blessed the people, and their voice was heard; and

${ }^{179}$ The following passages combine the earthly and heavenly sanctuaries by placing together a human earthly petition at the Jerusalem temple with God hearing and answering from the heavenly temple, $1 \mathrm{Kgs} 8: 30,31-32$, 33-34, 35-36, 38-39, 42-43, 48-49; $2 \mathrm{Chr} 6: 21$, 22-23, 24-25, 26-27, 29-30, 32-33, 34-35.

${ }^{180}$ Following the lead of Gerhard Von Rad, Ian Wilson cites a number of scholars who create a dichotomy between YHWH and his Name, referred to as "Name Theology." For a comprehensive list see Ian Wilson, Out of the Midst of the Fire: Divine Presence in Deuteronomy SBLDS 151, 3, 4 note 21, 5 note 22, 6 note 23. Sara Japhet notes that "there is no indication in any of the relevant passages in Chronicles that God's name possessed any sort of existence distinct from the deity it named," Sara Japhet, The Ideology of the Book of Chronices and Its Place in Biblical Thought, 57.

${ }^{181}$ Ian Wilson, Out of the Midst of the Fire SBLDS 151, 4.

${ }^{182}$ For examples of how timeless Being interprets the relationship between God and spatiotemporal realities like the sanctuary, see Fernando Canale, "Philosophical Foundations and the Biblical Sanctuary," 183-206.

${ }^{183}$ For a refutation of God's name only symbolizing transcendence instead of revealing his presence, see Ian Wilson, Out of the Midst of the Fire: Divine Presence in Deuteronomy SBLDS 151, 47-81, 197, 204-206, 210; de Souza, "The Heavenly Sanctuary/Temple Motif in the Hebrew Bible," 206-211.

${ }^{184}$ For the dynamic interaction between the earthly and heavenly sanctuaries, see footnote 188 above, and de Souza, "The Heavenly Sanctuary/Temple Motif in the Hebrew Bible," 220-222. 
their prayer came up to His holy dwelling place, to heaven." ${ }^{\prime 85}$ On the basis of these first two points, the connection between God's name/Being and its revelation in the earthly and heavenly sanctuaries points to the One God as Trinity. ${ }^{186}$ Third, the earthly and heavenly sanctuaries constitute the places where God chooses to reveal his presence, which comprise the locations where liturgy occurs. Consequently, the place of liturgy in heaven is not the entirety of the universe; and the place of liturgy on earth must correspond to God's choice, referring to the Jerusalem temple and not to the entire earth via nature (1 Kings 12:28-30). ${ }^{187}$

${ }^{185}$ There are several indicators that clearly point to the heavenly sanctuary as God's holy dwelling place. First, de Souza notes that the appositional phrase "to heaven" specifies that the "dwelling place" is located in heaven. Second, YHWH's holy dwelling place should be understood as a sanctuary/temple since the term "habitation" is also applied to the Jerusalem Temple in $2 \mathrm{Chr}$ 36:15. Ibid, 477.

${ }^{186}$ The connections between God's name/Being, the close association between the heavenly and earthly places of liturgy, and the Trinity are explored in Chapter 6 in my coverage of Acts, Hebrews and Revelation.

${ }^{187}$ Those under the hermeneutical influence of timeless Being, like G.K. Beale, conflate the presence of God with nature and the universe. According to Beale, "the Old Testament tabernacle and temples were symbolically designed to point to the cosmic eschatological reality that God's tabernacling presence, formerly limited to the holy of holies, was to be extended throughout the whole earth." G.K. Beale, The Temple and the Church's Mission: A Biblical Theology of the Dwelling Place of God New Studies in Biblical Theology (NSBT; Downer's Grove, IL: Inter-Varsity Press, 2004), 25, cf. 48. Furthermore, Beale states, "on the basis of cumulative evidence, we have reached the conclusion that Ezekiel 40-48 is a figurative vision of a real heavenly temple that would descend and be established on earth in non-structural form in the latter days." Ibid, 353. Notice here that the temple is real, yet it is clearly interpreted as timeless since it is nonstructural. Elias Brasil de Souza correctly summarizes the hermeneutical effects of what I see as an allegorization or spiritualization of the presence of God and of the sanctuary on a phenomenological reading of Scripture. He states, "Beale's understanding of the heavenly sanctuary/temple as mainly a cosmic non-structural entity appears to be at odds with several biblical passages depicting the heavenly sanctuary/temple as an entity located in heaven." de Souza, "The Heavenly Sanctuary/Temple Motif in the Hebrew Bible," 18. In other words, once the sanctuary is spiritualized, so is the presence of God, and so is a phenomenological reading of Scripture. Moreover, since the sanctuary has been conflated with the divine presence throughout the cosmos, "no significant attention has been given to the correspondence and connection between the heavenly sanctuary/temple and its earthly counterpart." Ibid, 18-19. Such an approach effectively eliminates the grounding role of the 


\section{Analysis}

As the place of liturgy, the sanctuary temporally grounds the relationship between the divine presence and the liturgical setting and actions. We will now examine how the sanctuary temporally grounds and interprets the relationship between the divine presence, Solomon's dedicatory prayer and speech, the sacrifices, and the preparatory liturgical actions. Solomon's temporal words mediate and interpret the presence of God and his actions. His speech and prayer speak of God's dwelling place, ${ }^{188}$ the glory of the Lord filling the house (1 Kings 8:11), fire coming down and consuming the sacrifice (2 Chr $7: 1-3)$, his speaking, ${ }^{189}$ the fulfillment of his promises, ${ }^{190}$ and his ability to hear petitions on earth from heaven. ${ }^{191}$ Moreover, the words that the Levites sung ( 2 Chr 5:13; 7:3, 6) also mediate and interpret the presence of God. ${ }^{192}$ Evidence from 1 Chr 16:4-42 reveals that "choral music was instituted to proclaim the Lord's name and announce his presence to the congregation and the whole world at Jerusalem.",193

heavenly sanctuary in establishing a biblical view of the divine presence and the liturgical actions.

${ }^{188}$ The Lord dwells in the dark cloud - $1 \mathrm{Kgs} 8: 12$; Solomon builds a place for God to dwell forever $-1 \mathrm{Kgs} 8: 13$; God dwells in the earthly temple, as well as throughout and beyond the universe $-1 \mathrm{Kgs} 8: 27$.

${ }^{189}$ God spoke with his mouth to David stating that he would place his name in his house at Jerusalem and that David should be over Israel - $1 \mathrm{Kgs}$ 8:15-16; God says to David that Solomon will build the temple - $1 \mathrm{Kgs}$ 8:18-19.

${ }^{190}$ See, $1 \mathrm{Kgs} 8: 15-16$; $1 \mathrm{Kgs} 8: 20$; God keeps his covenant of mercy - $1 \mathrm{Kgs} 8: 23$ 25; $1 \mathrm{Kgs} \mathrm{8:56.}$

${ }^{191}$ See, 1 Kgs 8:30, 31-32, 33-34, 35-36, 38-39, 42-43, 48-49; 2 Chr 6:21, 22-23, 2425, 26-27, 29-30, 32-33, 34-35.

${ }^{192}$ The psalmist also sings of creation by attributing to God the creative power that brought the world into existence (Psalm 33:6,9). In this case, the words sung not only interpret the Being and nature of God but also the being of creation.

${ }^{193}$ Kleinig, The Lord's Song, 148. Also, "with the transferal of the ark to Jerusalem and the appointment of the singers, provision was made for the public proclamation of the Lord's name there together with the presentation of petitions for Israel.” Ibid., 148. 
I will now analyze the significance of the sacrifices from the hermeneutical perspective of the sanctuary. The revelation of God's name in the place of his choice was integrally connected with the burnt offering and other sacrifices (Deut 12:6; 16:2, 6). Similarly, God choosing to place his name at the temple (1 Kings 8:16-20, 29), and his acceptance of the burnt offering and sacrifices by fire (2 $\mathrm{Chr} 7: 1)$ signaled that God had "chosen" the temple for himself as a "house of sacrifice" (2 Chr 7:12). ${ }^{194}$ With few exceptions (Deut 14:24), the Israelites were strictly forbidden to offer their sacrifices in any other location but that of God's choice (Deut 16:5-6; 1 Kings 12:28, 32-33).

There are several hermeneutical results that arise from the link between God's presence and the temple as the location where the sacrifices were offered. First, the sanctuary temporally grounds the relationship between the divine presence and the sacrifices offered, which eliminates the sacramental interpretation of the Sacramental, Kerygmatic, and Charismatic Models. The sacrifices constitute a ritualized form of cognitive communication that closely associates the ritual enactment with God's explanation of it found in Scripture. ${ }^{195}$ Klingbeil notes, "While words are powerful and are an integral part of worship, structured actions may sometimes speak louder and more

\footnotetext{
${ }^{194}$ For the connections between the temple as a house of sacrifice and house of prayer, and for the connection between God's choice of the temple as the place of sacrifice with the Deuteronomic formula, "the place which the Lord will choose," see Sara Japhet, The Ideology of the Book of Chronices and Its Place in Biblical Thought, 62-64.

${ }^{195}$ Here are a few brief examples. The instructions for slaying the Passover lamb in Exod 12:1-11 communicated some of the following truths: God would strike all the firstborn of the land, and execute judgment on all the gods of Egypt (Exod 12:12). When God sees the blood, he will pass over his people and not destroy them (Exod 12:13, 23, 27). All of the firstborn sons shall be redeemed on the basis that God brought them out of Egypt (Exod 13:11-16). With reference to the prosperity of the wicked, the sanctuary services helped the psalmist to understand that the wicked will one day perish (Psalm 73:17).
} 
clearly to the worship participants. ${ }^{.196}$ As a result, the sacrifices do not mediate God's being; they mediate his will. The NT picks up on the terminology that is associated with the sacrifices that are fulfilled by Christ, thereby continuing this divine form of communication. ${ }^{197}$

The sanctuary also grounds the temporal relationship between the specific choice for each animal that is sacrificed, and the divine message conveyed. In other words there is a causal relationship between the animal chosen and the intended divine message that is conveyed. ${ }^{198}$ Moreover, since the sacrifices point to personages and events beyond themselves, the sanctuary also grounds the temporal relationship between the ritual

${ }^{196}$ Klingbeil, Bridging the Gap: Ritual and Ritual Texts in the Bible, 236. Klingbeil notes that ritual elements such as space, time, objects, actions, roles, and sounds can communicate profound theology; and that "highly structured ritual was a unique vehicle for remembering important theological concepts that were orally transmitted" such as the Day of Atonement ritual in Lev 16. Ibid. Hence, from God's infinite analogous temporal Being, these rituals that are especially connected with the sanctuary play a major macrohermeneutical role in systematizing and integrating the divine presence with all of the liturgical actions.

${ }^{197}$ For one example of this, see my exegesis of Heb 12:24, which points out that the blood of Christ speaks through the actions that he performs in the heavenly sanctuary in Chapter 6 pages 341-342, 363-365.

In the NT the author of the Epistle to the Hebrews quotes Exod 25:9 and applies it to the ministry and sacrifice of Jesus in a heavenly sanctuary against the backdrop of the Day of Atonement ritual. In this way the sacrificial system as prescribed in the Pentateuch is reinterpreted in the NT as a type or model of the sacrifice and ministry of Jesus. This suggests that...the sacrificial cult functioned as a model of a bigger and more relevant reality (Ibid., 236-237).

${ }^{198}$ Leslie Hardinge notes that there were six varieties of sacrificial victims that were "chosen from three animals and three birds: tame and docile oxen, sheep and goats from flocks and herds; domestic turtle-doves and pigeons, and occasionally wild sparrows (Lev $1: 2,4,10,14 ; 14: 4$, margin)." Each of these possessed "unique peculiarities" that constituted "lenses through which the worshiper focused on aspects of the nature of Jesus." Leslie Hardinge, With Jesus in His Sanctuary: A Walk Through the Tabernacle Along His Way (Harrisburg, PA: American Cassette Ministries, 1991), 368, 369. 
enactments of the sacrifices with their typological fulfillment. ${ }^{199}$

Furthermore, since the sanctuary temporally grounds the relationship between the divine presence, the sacrifices, and their meaning, to offer sacrifices in other locations as Jeroboam did (1 Kings 12:32-33; cf. Deut 16:5, 6) would risk interpreting the meaning of the sacrifice on philosophical foundations other than God's infinite analogous temporal Being in the context of the sanctuary. In such cases, the meaning of the sacrifice is derived from reason's interpretation (Lev 26:1) and not from revelation (Lev 26:2).

We will now briefly look at the preparatory liturgical actions. First, with reference to the place of worship, the earthly design of the Jerusalem temple was structurally designed to be analogous to the heavenly structures used in the heavenly sanctuary. ${ }^{200}$ Hence, the characteristics of the furniture in the earthly temple mediate and interpret our understanding of the design of the heavenly temple. Second, the characteristics of sheep when slaughtered are analogous to the silent manner in which Jesus died (Isa 53:7) thereby illustrating the analogy between sacrificial animals and Christ. Accordingly, the sacrificing of sheep and oxen mediate and interpret our view of the being and actions of God in the plan of salvation by pointing to a fundamental change in the being of Christ in the incarnation. A fundamental change in Christ's being means that his divine nature would be joined to human nature. Third, the consecration of the priests mediates and interprets human nature and the holiness of God. In 2 Chr 5:11 the priests sanctified

\footnotetext{
${ }^{199}$ For instance, 1 Cor 5:7 states, "For indeed Christ, our Passover, was sacrificed for us." Also the sprinkled blood mentioned in Exod 29:20; Num 19:14; and Lev 16:14, 15, 19 is connected to Christ's inauguration (Heb 1:3; 9:21), his mediation in the holy place (Heb 9:23-25), and the Day of Atonement service in the most holy place (Heb 9:25; 12:24).

${ }^{200}$ For an explanation of the various exegetical factors that reveal this structural and functional analogy between the earthly and heavenly sanctuaries, see de Souza, "The Heavenly Sanctuary/Temple Motif in the Hebrew Bible," 211-222.
} 


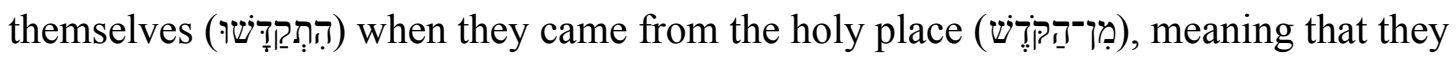
performed rituals related to purification. Hence, God and the sanctuary are holy, forming the foundation for holiness among the priests. God thus mediates his holiness so that the priests can minister in his presence and experience an encounter with him (2 Chr 5:1314). Moreover, since the ritual purification of the priests probably included ablutions, the mental act of preparation combined with ritual preparation speaks of an integrated human nature.

\section{Isa $6: 1-13$}

\section{Description}

I would like to suggest two reasons why the Lord's spoken words to Isaiah (Isaiah $6: 8-13)$ constitute the central liturgical action in this passage. First, in the vision of the Lord high and lifted up (Isa 6:1), the importance of the message God communicates to Isaiah (Isa 6:8-13) is first preceded by the greatness and holiness of the Lord himself. As a result, there is a direct and causal relationship between the exaltation of the greatness and holiness of the divine presence (Isa 6:1-3) and the resultant weight and importance of the Lord's message (Isa 6:8-13). Second, the vision of the throne (Isa 6:1-3) led Isaiah to see his true condition (Isa 6:5) and his need for forgiveness and grace (Isa 6:6-7). Only after this experience is the prophet prepared to respond to God's appeal (Isa 6:8) and then to listen and declare the Lord's message (Isa 6:9-13). Hence, each interaction between Isaiah, the Lord, and the seraphim that occurs prior to God's message to the prophet in Isaiah 6:8-13 is causally related to the ultimate goal, which is that that Isaiah hears, understands and ultimately obeys God's commission to send him to his people with an important message. 
The liturgical actions that precede God's message to Isaiah include God seated on the throne in the most holy place of the temple (Isa 6:1). ${ }^{201}$ They also include the following from the Seraphim: (1) each of them cover their face, and their feet (Isa 6:2); (2) they sing "Holy, holy, holy, is the Lord of hosts; The whole earth is full of His glory!" (Isa 6:3); (3) one of the seraphim flies to the prophet having in his hand a live coal that he had taken with the tongs from the altar and with it touches the mouth of the prophet (Isa 6:6-7); and (4) the seraph speaks to Isaiah saying, "Behold, this has touched your lips; Your iniquity is taken away, and you sin purged" (Isa 6:7).

With regard to the time in which Isaiah received this vision, commentators point out that it took place in the year that king Uzziah died, which at the same time established Isaiah in the prophetic office. This is all the information the passage reveals about liturgical time.

With reference to liturgical space, the threefold structure of Isaiah 6:1-8 reveals that the focus of the vision is the heavenly sanctuary/temple despite some evidence that points to an original Jerusalem temple setting for the vision. ${ }^{202}$ The first section is the scene in heaven (Isa 6:1-3). ${ }^{203}$ The second section portrays the effects of the heavenly

${ }^{201}$ The reference to the throne (Isa 6:1) "seems more appropriate to indicate the heavenly throne of YHWH than the ark in the Jerusalem temple." de Souza, "The Heavenly Sanctuary/Temple Motif in the Hebrew Bible," 238. Hence the contrast is between the throne in the most holy place of the earthly or of the heavenly sanctuary. Treiyer notes the following: (1) "God sits on his throne in the Most Holy Place," (2) God's glory fills both apartments as on the Day of Atonement, (3) the door separating the apartments was opened, which is confirmed by the altar next to the throne without a door separating them. Treiyer, The Day of Atonement and the Heavenly Judgment from the Pentateuch to Revelation, 305, 306. 239.

${ }^{202}$ De Souza, "The Heavenly Sanctuary/Temple Motif in the Hebrew Bible," 238,

${ }^{203}$ This includes the Lord sitting upon a lofty and exalted throne. De Souza points out that the similarity between this passage and $1 \mathrm{Kgs} 22: 19$ where virtually the same expression 
temple on the earthly temple (Isa 6:4-5). ${ }^{204}$ For instance, the Seraphs who cried one to another (Isa 6:3) and the foundations of the threshold that trembled at the voice of him who called out (Isa 6:4) reveals that "what was transpiring in the heavenly temple reverberated in the earthly counterpart as if to show the effects of the heavenly temple upon the earthly counterpart." ${ }^{, 205}$ The third section reveals the intercommunication between the heavenly temple and its earthly counterpart (Isa 6:6-8). ${ }^{206}$ The tongs utilized by the Seraph "are always in connection with the activities related to the first apartment of the temple/sanctuary." ${ }^{207}$ When combined with the work of intercession performed by the Seraph, which is associated with the altar of incense, ${ }^{208}$ it is reasonable to assume that this refers to the altar in the heavenly temple. ${ }^{209}$ Furthermore, "the mention of the "altar" of incense in the heavenly...("temple"), and the "tongs" used to remove the "burning

is used-I saw the Lord sitting on his throne-points to the heavenly throne of YHWH rather than to the ark in the Jerusalem temple. Ibid., 236-237, 238. Moreover, the reference to Seraphim and not Cherubim reinforces the view that the temple (Isa 6:1) is the heavenly temple. De Souza notes that if the scene took place in the Jerusalem temple the reference would be to the sculpted Cherubim whereas Seraphim are not mere images but actual living creatures. Ibid., 239.

${ }^{204}$ Ibid., 237. De Souza supports Knierim's statement that when used for the temple, בִּ always refers to the temple on earth. He claims an earthly setting for the context supports this where Isaiah speaks from the perspective of someone who is located in the earthly temple. Also his cry of distress reflects an earthly environment. Ibid., 239-240.

${ }^{205}$ Ibid., 244.

${ }^{206}$ Ibid., 237.

${ }^{207}$ See Exod 25:38; 37:23; Num 4:9; $1 \mathrm{Kgs}$ 7:49; 2 Chr 4:21. Interestingly, Ezek 10:2 mentions "coals of fire from between the cherubim" that should be scattered upon Jerusalem." Ibid., 241 footnote 1.

${ }^{208}$ See Lev 16:12 where the incense combines with the fire from the outer altar in an act of intercession. Treiyer notes that "the fire was taken from the outer altar, upon which the sacrifices were offered. It was placed upon the golden altar in the Holy Place, and incense was put on it." Treiyer, The Day of Atonement and the Heavenly Judgment from the Pentateuch to Revelation, 307 note 13.

209،"The altar" SDABC 4:128-129. 
coals" from it, conveys a picture of a heavenly temple structurally similar to its earthly counterpart.",210

\section{Analysis}

The structural correspondence between the heavenly and earthly sanctuaries and the dynamic interaction between all the entities therein points to the following two conclusions. First, the heavenly sanctuary constitutes the center and ground of all liturgy since the movement occurs from the heavenly and proceeds to the earthly. Consequently, earthly culture and philosophy is eliminated from grounding liturgy inasmuch as it ignores and contradicts the theological interpretations that are grounded in the heavenly temple. Second, the heavenly sanctuary temporally grounds all entities in heaven and on earth, thereby eliminating the ontological dichotomy between the heavenly and earthly realms that have plagued the other liturgical models.

At this point we will analyze how the specific liturgical actions in this passage mediate the divine presence or creation. First when God speaks to Isaiah (6:8-13), he directly reveals himself through words that in turn mediate his divine presence from the specific location of the most holy place in the heavenly temple. Accordingly, the sanctuary temporally grounds the relationship between divine cognition and language and human cognition and language. Stated differently, there is an analogical relationship between divine speech and human speech, and between divine and human knowledge. Second, the sanctuary temporally grounds the relationship between the heavenly throne and the ark in the Jerusalem temple as well as between God's presence and his specific location in the heavenly temple. Third, one of the seraphim also speaks to Isaiah after

\footnotetext{
${ }^{210}$ De Souza, "The Heavenly Sanctuary/Temple Motif in the Hebrew Bible," 245.
} 
first taking a live coal with the tongs from the altar and touching his mouth with it. The seraph interprets this by stating that this action has taken away Isaiah's iniquity and purged his sin (Isa 6:6-7). Accordingly, the sanctuary temporally grounds the relationship between angelic cognition and language and human cognition and language. Fourth, the actions and words of the seraph are associated with salvation. Accordingly, the sanctuary temporally grounds the divine presence and words spoken by the Lord and the actions and words of the seraph as necessary prerequisites that shed light on the interpretation of salvation and its goal. Fifth, the use of the tongs and the golden altar mediates creation, specifically the structure and function of the heavenly temple. As a result, the sanctuary temporally grounds the relationship between the heavenly altar and tongs with the earthly altar and tongs. The heavenly temple thus grounds the analogical relationship between all entities in heaven and all entities on earth, which also recognizes that there are some differences between them. Sixth, when the seraphim cover their faces and their feet while in the presence of God, they provide a window about the way in which all created beings should relate to a holy God in worship. These submissive liturgical acts of the seraphim are universally grounded in the heavenly temple; they are not the result of cultural earthly considerations.

We will now proceed to describe and analyze the divine-human encounter in which the worship experience takes place.

\section{Encounter}

Thus far we have described and analyzed the divine presence, the liturgist and the liturgical actions in the Biblical Sanctuary Model; all of which are external to the consciousness of the worshipper. Each passage that I will analyze in this section assumes 
God's infinite analogous temporal Being and the sanctuary that temporally grounds the relationship between the divine presence and some form of speech as the central liturgical action. Moreover, these indispensible prerequisites determine the nature of the worshippers, which then lays the groundwork for an analysis of the nature of the encounter. Hence, I will examine and analyze what each passage reveals about the nature of the worshiper and the nature of the encounter.

\section{Exod 3:1-21}

\section{Description}

God uses the burning bush as the visual means in order to attract Moses' attention. However, since God is seeking to communicate His will to Moses regarding his part in the deliverance of Israel, as well as to introduce himself as the I AM, Moses employs auditory means in order to receive and process God's presence and his message (Exod 3:4, 7-10, 14-15). Hence the nature of the content of this theophany includes important information about Being, the divine presence, the divine attributes, the liturgist, and the liturgical actions, all of which were covered previously. The theophany also includes specific content concerning the various aspects of the narrative. ${ }^{211}$

\section{Analysis}

God's infinite analogous temporal Being makes possible a phenomenological reading of the text that assumes Moses' temporal being as evidenced by the following

\footnotetext{
${ }^{211}$ The specific content includes God's Call to Moses (Exod 3:4); God's instruction about how Moses should approach Him (Exod 3:5-7); God's intimate knowledge of the pain and suffering of His people in Egypt (Exod 3:7-9); God's appeal to Moses to bring the children of Israel out of Egypt (Exod 3:10); and God patiently dealing with Moses' questions and His specific instructions regarding how He will deliver the Israelites from Egyptian slavery (Exod 3:11-4:17).
} 
points: Moses is able to hear (Exod 3:7-10), clarify (Exod 3:11, 13; 4:1, 10), react to (Exod 4:13) and ultimately trust and obey God's message after initially refusing to do so (Exod 4:18). As a result, Moses possesses an historical hermeneutical mind that is capable of exercising "free will." 212 This means that Moses encounters the divine presence through the unenhanced normal use of faculties such as hearing, cognition and language that are available to everyone. This implies that God's message is directed to the mind of Moses as the place where the encounter occurs, and that Moses is active in the encounter and not passive.

Lev 19:30 and 26:1-2

\section{Analysis}

This passage does not describe an actual liturgical occurrence. However, Lev 26:1-2 prescribes that worshippers should not respond to the encounter by bowing down to idols, carved images, sacred pillars and engraved stones. Instead, worshippers should respond by observing God's Sabbaths and reverencing His sanctuary. Accordingly, a response to the encounter assumes that an encounter has taken place. Moreover, the temporal grounding of the relationship between the divine presence and human worshippers that I conclude from the Sabbath and the sanctuary implies that there is a cognitive encounter that occurs in worship.

In contrast to this, one of the main consequences of conflating the divine presence to creation is that during the encounter the idols that are made of silver, wood, and stone

${ }^{212}$ Propp, Exodus 1-18 AB 2, 199. Also, "Yahweh does not call Moses by overpowering him, but entices him with an uncanny flame..." Ibid. 
do not speak. ${ }^{213}$ Consequently, there is no revelation or cognitive content from YHWH in such an encounter since he is not in reality the object of worship. This means that demons are the object of worship ${ }^{214}$ and that it is plausible for them to communicate content to the worshippers. An example of an encounter that contains no cognitive content from YHWH occurred at the golden calf (Exod 32). It is interesting to note that the sanctuary and the Sabbath were mentioned in the immediate context prior to the golden calf (Exod 31:1-18). However, the Israelites did not discern in these institutions the hermeneutical framework that temporally grounds the relationship between the divine presence and the worshippers as important tools to interpret the nature of the encounter.

\section{Exod 19-20 and Deut 4-5}

\section{Analysis}

I will now analyze what Exod 20 and Deut 4-5 reveal about the nature of the worshiper and the nature of the encounter. The Israelites employ auditory means in order to receive and interpret God's presence and his message. This is evidenced in Exod 20:19, which reveals that they understood God's message; it states, "You speak with us, and we will hear; but let not God speak with us, lest we die." A phenomenological reading of the text assumes that speech coming from Moses and God is a temporal phenomenon and that the message in Exod 20 is directed to the cognitive faculties of the worshipper. At this point, the commandments that begin with "Thou shalt not" assume

${ }^{213}$ On the inability for idols to speak, see Psalm 115:4-5; 135:15-17; Isa 46:7; Jer 10:15; Hab 2:18; 1 Cor 12:2. "Idols have a 'form' but do not speak. Yahweh has no 'form' but he decisively speaks. Idols are visible but dumb. Yahweh is invisible but eloquent," NIBC, s.v. Deut 4:15-20. "Any attempt to turn Yahweh into a voiceless statue effectively gags God. Idolatry therefore is fundamentally an escape from the living voice and commands of the living God." NIBC, s.v. Deut 5:8-10.

\footnotetext{
${ }^{214}$ See 1 Cor 10:20; Lev 17:7; Deut 32:16-17; Psalm 106:36-37; Gal 4:8; Rev 9:20.
} 
that human nature is not determined as it is under timeless Being. As a result, human beings can interpret the message either correctly or incorrectly by the use of their mental and spiritual faculties. The following points drawn from the $2^{\text {nd }}, 3^{\text {rd }}$, and $4^{\text {th }}$ commandments outline the temporal nature of the faculties of the worshippers. The prohibition in the $2^{\text {nd }}$ Commandment reveals that worshippers interpret the divine presence through the misuse of their ability to imagine and create (עָעֶָׁ) an interpretation of his Being and attributes. ${ }^{215}$ The prohibition in the $3{ }^{\text {rd }}$ Commandment points to the fact that humans interpret through the misuse of their ability to render a judgment in taking the name of the Lord God in vain. For instance, If we take/judge (뀨) the name of God to be in vain, then God will not judge us as guiltless. The command to "Remember the Sabbath day" only makes sense if we are prone to forget. This means that our ability to remember greatly affects how we interpret. Hence, by prohibiting the misuse of imagination, creativity, reason, judgment, and memory the Law alerts us to the fact worshippers interpret Being, the divine presence, and the message. In the NT Paul told Timothy to rightly divide or analyze the word of truth (2 Tim 2:15).

I will now point out what the Sinai passage reveals about the nature of the encounter. First, the command for the worshippers to consecrate themselves prior to the encounter by washing their clothes, abstaining from sex, and being in a state of readiness (Exod 19:10, 11, 14, 15, 21, 22) assumes that the sanctuary temporally grounds the holiness of God and the proclamation of the Law with the integrated nature of humans and the manner in which worshippers receive God's message. In other words, since the physical, mental and spiritual faculties of humans are interrelated, the command to

\footnotetext{
${ }^{215}$ In Gen 11:4 it states, "let us make (עִשֶׁi) a name for ourselves." See this Chapter pages 236-237 for the relationship between Gen 11:4 and the divine presence.
} 
consecrate themselves is causally related to the holiness of God and how worshippers receive and interpret the message of God.

Second, Deut 5:4 states that God spoke to them "face to face." This denotes a very personal rather than impersonal and non-historical encounter that is based on the covenant. $^{216}$ Furthermore, the close connection between the sanctuary and the covenant ${ }^{217}$ ensures a cognitive encounter in which worshippers receive the words of God in their minds ${ }^{218}$ instead of receiving the being of $\operatorname{God}^{219}$ during the encounter.

\section{$1 \mathrm{Kgs} 8: 12-66$ and 2 Chr 5-7}

\section{Analysis}

Since Solomon's prayer employed the normal human use of cognition and language, the message was directed to the minds of the people through auditory means.

${ }^{216}$ NIBC, sv Deut 5:4-5.

${ }^{217}$ In Deut 4:13 we read, "So He declared to you His covenant which He commanded you to perform, the Ten Commandments..." The proclamation of the Ten Commandments is also directly linked with the covenant in Deut 5:2-4. The covenant is also mentioned just before God proclaimed the Ten Commandments in Exod 19:3-8. It is also mentioned afterward in Exod 24:3-8. For more connections between the sanctuary and the covenant, see this dissertation page 242 footnote 88 .

${ }^{218}$ Referring to the Israelites, God stated, "They are right in all that they have spoken" (Deut 5:28) concerning their frightened reaction to the giving of the Law. However, God's appeal was that his words would find a lodging place in their hearts and minds; he states, "Oh that they had such a heart in them that they would fear Me and always keep all My commandments, that it might be well with them and with their children forever" (Deut $5: 29)$.

${ }^{219}$ In Deut 4:23 we read, "Take heed to yourselves, lest you forget the covenant of the Lord your God which He made with, and make for yourselves a carved image in the form of anything which the Lord your God has forbidden you." Only the words of God reveal his presence, see also Deut 4:12-19. The being of God is present on Mt Sinai, but his presence is revealed through his Words. Since the being of God cannot be seen or grasped, these verses teach that the encounter only involves the words of God and not the being of God. However, in all the previous models it is the divine presence itself or God's being that is involved in the encounter, which is really divinization. 
Since Solomon's address also contains references to the law and the covenant, ${ }^{220}$ the same observations from my analysis of the giving of the law at Sinai apply here to the temporal nature of the worshippers. The end result was that this was a cognitive encounter and that the worshippers understood the content.

Furthermore, since the sanctuary grounds the temporal relationship between the divine presence, the sacrifices offered, and the experience of the worshippers, a sacramental interpretation of the sacrifices during the encounter is discounted. Instead, the sacrifices produce a cognitive encounter based on the fact that they are a ritualized form of communication.

Isa $6: 1-13$

\section{Analysis}

Isaiah's realization of his sinful condition at the revelation of God's holiness by the seraphs (Isa 6:5); his response, "Here am I! Send me" (Isa 6:8); and his question, "Lord, how long?" (Isa 6:11) indicate that this was a cognitive encounter. Although Isa 6:1 points out that the prophet saw the Lord high and lifted up, his reaction to the divine presence occurred after the seraphim cried "Holy, holy, holy is the Lord of hosts; The whole earth is full of His glory!" (Isa 6:3). This matches the experience of Moses at the burning bush and of the Israelites at Mt Sinai. In those instances, the visual experience came first yet the realization of the presence of God came when God spoke. This same order is followed in Isa 6:1-5. Hence, while the Lord seated on his throne in the heavenly sanctuary forms the context, the cognitive encounter itself is based on the words spoken about the holiness of God by the seraphs.

\footnotetext{
${ }^{220}$ The covenant is mentioned in $1 \mathrm{Kgs} 8: 1,6,9,21,23 ; 2 \mathrm{Chr} 5: 2,7,10 ; 6: 11,14$.
} 
The heavenly sanctuary scene of this vision temporally grounds the relationship between the language and content that God and the seraphs employ in heaven, and Isaiah's ability to understand that language and content and in turn speak back to God and to the seraphs. Furthermore, the sanctuary services that reveal the greatness and holiness of God (Isa 6:1, 3) as well as the removal of sin from Isaiah (Isa 6:6-7) lay the groundwork for him as a worshipper to hear and respond to the voice of the Lord (Isa 6:8). This is an experience that the Israelites needed in order to hear the voice of the Lord like Isaiah, but many were not willing to embrace that experience which is why they would hear but not understand and see but not perceive (Isa 6:9). Thus, within a temporal framework, an unwillingness to respond to the conviction of sin and receive pardon compromises the worshipper's ability to understand and perceive God's words in a cognitive encounter.

\section{Response to the Encounter}

Each passage that I will analyze in this section assumes God's temporal divine presence, some form of speech as the central liturgical action, and a temporal cognitive encounter. Moreover, the sanctuary temporally grounds the relationship between these indispensible elements and the response to the encounter. As a result, I will examine and analyze what each passage reveals about the response to the encounter.

\section{Exod 3:1-21}

\section{Analysis}

The cognitive temporal content of God's speech lays the groundwork for Moses' active verbal and kinesthetic responses. His verbal responses involve his initial answer to God's call (Exod 3:4); questions, clarifications, greater evidence to convince the 
Israelites that he is God's deliverer, feelings of inadequacy and refusal (Exod 3:11, 13; $4: 1,10,13$ ); followed by him accepting the mission to deliver the Israelites (Exod 4:1819). His kinesthetic responses include God's request that he remove his shoes on account of God's holy presence (Exod 3:5); and Moses hiding his face, "for he was afraid to look upon God" (Exod 3:6; cf. 1 Kings 19:30). These kinesthetic responses are hermeneutically guided by God's holy and real presence in space and time as revealed to Moses through speech. In an integrated view of human nature, the physical act of removing his shoes is in some way causally related to God's intent that Moses endure his presence and comprehend his message. Moses hiding his face was also a natural response to God's holy presence that required no instruction from God. As a result, there's a causal connection between God's holiness and the kinds of kinesthetic responses that are in harmony with God's holiness.

Lev 19:30 and 26:1-2

\section{Analysis}

Although Lev 19:30 and 26:1 does not describe an actual encounter, Lev 26:1 nevertheless commands worshippers not to respond to the encounter by bowing down to idols, carved images, sacred pillars and engraved stones. The justification for this is that worshippers will erroneously conflate the divine presence with the creation. Since idols don't speak, ${ }^{221}$ worshippers do not experience a cognitive encounter with YHWH through idolatry. Moreover, the infinitive "to bow down" is used as a response (1) to God, ${ }^{222}$ (2) to silver and gold (Isa 2:20), and (3) to false gods (2 kings 5:18) or demons (1 Cor 10:20

\footnotetext{
${ }^{221}$ See this dissertation page 286 , footnote 213 .

${ }^{222}$ See 2 Chr 20:18; Isa 66:23; Jer 7:2; 26:2; Ezek 46:9; Zech 14:16, 17.
} 
Lev 17:7; Deut 32:16-17; Psalm 106:36-37; Gal 4:8; Rev 9:20). Since the encounter in

Lev 26:1 with idols contains no cognitive content from YHWH, there is in fact no causal connection between the worshippers' conception of the divine presence and their response to the divine presence.

The non-cognitive encounter at the golden calf (Exod 32) ${ }^{223}$ lays the groundwork for an entirely kinesthetic and affective response that is not causally related to the divine presence. First, the worshippers responded by offering burnt offerings and peace offerings (Exod 32:6), and by singing words to the Lord (Exod 32:18). These can constitute legitimate responses to the divine presence; however, the non-cognitive nature of the encounter creates a dichotomy between the divine presence and the response in this case. Second, worshippers shouted and danced (Exod 32:17, 19) as they responded to the war-like rhythms. ${ }^{224}$ Third, their response also included eating, drinking, and sensual lustful gratification referred to as playing (Exod 32:6) ${ }^{225}$ that they probably justified as a part of religious observance by Egyptian pagan culture. Fourth, they ran wild and were out of control (Exod 32:25), ${ }^{226}$ which perhaps best describes the lack of a causal connection between a non-cognitive encounter with the divine presence and the response to the encounter.

In contrast, God's command to observe the Sabbath and reverence the sanctuary

${ }^{223}$ See this dissertation pages 285-286.

${ }^{224}$ See this dissertation pages 551-552 footnotes 51-53 for the evidence of a predominance of rhythms.

${ }^{225}$ The word play (מחך) includes sexual gratification (Gen 26:8) as well as amusement and entertainment (Judg 16:25), see HALOT, s.v. מחך.

${ }^{226}$ See HALOT, s.v. פרע. In Pro 29:18 we read, "Where there is no revelation, the people cast off restraint (פרע); But happy is he who keeps the law." This best explains how a non-cognitive encounter (no revelation) produces a non-cognitive, kinesthetic and affective response. 
is strongly connected to various forms of speech as the central liturgical action. This produces a cognitive encounter that lays the groundwork for an active response.

Moreover, the Sabbath and the sanctuary temporally ground the relationship between the divine presence and the response of the worshippers, which ensures a causal connection.

\section{Exod 19-20 and Deut 4-5}

\section{Analysis}

The Israelites responded to God speaking the Ten Commandments in two main ways. First, their kinesthetic response included fear, trembling and standing afar off from the physical location of Mt Sinai (Exod 20:18; Deut 5:25). Moses also trembled (Heb 12:21), yet he "drew near the thick darkness where God was" (Exod 20:21). Second, their verbal responses included expressions of wonder and amazement at hearing God's voice, and the request not to have God speak to them anymore but to relay any message through Moses (Exod 20:19; Deut 5:23, 25, 27).

The content transmitted from God to the Israelites came from heaven and earth. ${ }^{227}$ Also, the sanctuary context ${ }^{228}$ temporally grounds the content that came from heaven and earth as well as the relationship between the divine presence revealed through speech and the verbal and kinesthetic responses of the worshippers at Mt Sinal. This establishes a causal relationship between the divine presence and the active responses of the worshippers.

\footnotetext{
${ }^{227}$ See this dissertation page 269 footnote 171 .

${ }^{228}$ For the connections between the sanctuary and Sinai, see this dissertation page 268 note 170 .
} 
$1 \mathrm{Kgs} 8: 12-66$ and $2 \mathrm{Chr} 5-7$

\section{Analysis}

At the end of Solomon's dedicatory prayer and blessing of the assembly, both king and people responded by sacrificing 22,000 bulls and 120,000 sheep (1 Kings 8:6263; 2 Chr 7:4-6) as thank offerings. ${ }^{229}$ The congregation also responded to the fire that came down to consume the sacrifice at the conclusion of Solomon's prayer by bowing their faces to the ground ${ }^{230}$ on the pavement, and by stating, "For He is good, For His mercy endures forever" (2 Chr 7:3). Moreover, as the priests attended to the sacrifices and the Levites praised the goodness of God with instrumental accompaniment, the narrative states that all Israel stood in response to the divine presence (2 Chr 7:4-6).

The sanctuary setting ${ }^{231}$ along with the covenant temporally grounds the relationship between the temporal content of Solomon's speech and the active responses previously mentioned. Hence, there is a direct causal relationship between the divine presence, Solomon's speech, and the active responses of the worshippers.

229“"In 2 Chr 7:4-6, the Chronicler traces the performance of choral music during the presentation of the public thank-offerings back to the institution of thanksgiving by David and the organization of the temple services by Solomon." Kleinig, The Lord's Song, 124125; cf. 126-131.

${ }^{230}$ According to Kleinig, 2 Chr 29:27-30 depicts three kinds of prostration that are the result of the close connection between the burnt offering and the choral performance. The first is a prostration of the congregation during the choral performance. The second is the prostration at the end of the performance in $2 \mathrm{Chr}$ 29:29 that alludes to $2 \mathrm{Chr} 7: 3$, and the third is final act of praise by the singers. Moreover,

The Chronicler holds that Hezekiah completed what David and Solomon had begun. In his ritual reforms he connected sacred song with the rite of prostration, so that the congregation could thereby participate in the praise of the musicians by paying homage to the one whose presence was celebrated in their song (Ibid., 121-122).

${ }^{231}$ See this dissertation pages $275-279$. 


\section{Isa $6: 1-13$}

\section{Analysis}

Isaiah first sees the Lord high and lifted upon on his throne (Isa 6:1). Yet, his response to the divine presence comes after he hears the seraphim cry, "Holy, holy, holy is the Lord of hosts; The whole earth is full of his glory" (Isa 6:3). In his response he states, "Woe is me, for I am undone! Because I am a man of unclean lips, and I dwell in the midst of a people of unclean lips; for my eyes have seen the King, the Lord of hosts" (Isa 6:5). When his sin was forgiven and cleansed, he was able to hear God's voice asking "Whom shall I send, and who will go for us?" to which he then responded, "Here am I! Send me" (Isa 6:8). When God tells him to share the message, Isaiah then responds by asking "Lord, how long?" (Isa 6:11). Thus, he is able to listen, respond, and interact with the Lord.

The sanctuary setting temporally grounds the relationship between the divine presence and the human nature of Isaiah as the worshipper. In other words, by listening and clarifying Isaiah reveals that he possesses a hermeneutical mind. The sanctuary also temporally grounds the relationship between the divine presence, the temporal content of the divine and angelic liturgists and Isaiah's verbal response. Consequently, this reveals a causal relationship between the divine presence and the response.

\section{Conclusion}

In this Chapter we have discovered that Exod 3:14-15 grounds the temporal interpretation of God's Being in the Biblical Sanctuary model. Since I AM in Exod 3:14 is God's name (Exod 3:15) and is synonymous with Lord (Yahweh) and God (Elohim) (Exod 3:15), the references to Lord and God in Lev 19:30; 26:1-2; Exod 19-20; Deut 4-5; 
1 Kings 8:12-66; 2 Chr 5-7, and Isaiah 6:1-13 also assume God's infinite analogous temporal Being. I will now briefly summarize each of the liturgical components in this survey of OT data.

With respect to the divine presence, each passage clearly reveals that God is entirely compatible with the spatio-temporal context in which all realities exist. Regarding each liturgical occurrence, God is present (Exod 3:2-3; 19:16-18) yet his presence is revealed only by his words (Exod 3:3-6; Deut 5:23-32), it is not revealed by any material object (Deut 4:12,15). When God states that he will place his name at the temple in Jerusalem (1 Kings 8:16-20,29) it indicates that he will reveal his presence in that specific location (2 Chr 20:8-9). God's presence in the sanctuary (Exod 25:22; 30:6; Num 7:89; Lev 16:2; 2 Chr 20:8-9) provides the key for the deduction that he is transcendent and immanent at the same time (1 Kings 8:27). In this context, transcendence refers to his infinite analogous temporal being beyond/outside the universe while immanence refers to his being in the context of the universe (1 Kings 8:27). God's presence is moreover what makes the location where he reveals his presence holy (Exod 3:5; 19:23), and since God is also personal (Deut 5:5) and moral (Exod 34:5-7; $2 \mathrm{Chr}$ 7:3, he can mediate his holiness so that those whom he chooses can approach his presence and interact with him (Exod 19:24; Isa 6:6-8). With the exception of Isa 6:1-13 where Isaiah sees God in vision, the divine presence remains invisible in the liturgical event since God's words constitute the agency through which he reveals his presence.

Regarding the liturgist in the Biblical Sanctuary Model, liturgists can either be divine (Exod 20:1-17), angelic (Isa 6:1-3, 6), or human (1 Kings 8:14-61). Human liturgists are free moral agents that are capable of constructing idols (Lev 26:1) or 
worshipping God (Lev 26:2). As a result, the liturgist is the cause of liturgy while the other liturgical components constitute the indispensible conditions. All of the components of the human liturgist such as the immutability of maleness and femaleness (Gen 1:27), personal attitudes, ethical choices, beliefs, and spiritual gifts are integrated (Gen 2:7) and are essential in mediating the divine presence. The human liturgist possesses a hermeneutical mind that can interpret God's presence from the starting point of creation (Lev 26:1 - idols) or from the I AM that only comes through revelation (Lev 26:2 - Lord God). In our survey of OT data, God primarily chose the family of Aaron as priests who were exclusively involved in offering sacrifices and playing the trumpets (2 Chr 5:12; 7:6). The Levites assisted the priests in their duties (Num 3:5-9), and constituted the musicians in temple music and liturgy (1 Chr 15:16; 16:4; 23:5; 2 Chr 29:25).

With respect to the liturgical setting and actions, the earthly and heavenly sanctuaries constitute the place where liturgy occurs (1 Kings 8:30-49; cf. 2 Chr 30:27; Isa $6: 1-3,4-5,6-8)$. Moreover, all liturgy, even that which occurred in the OT, ultimately assumes that the heavenly sanctuary is the place to which liturgy is oriented $(1 \mathrm{Kings}$ $8: 30,29,43,49$; Isa 6:1-8). Although liturgy occurred at various times (Deut 16:16), the seventh-day Sabbath is closely linked with the time in which liturgy should take place (Exod 20:8-11). The central liturgical action in this survey of OT data involves various forms of speech such as a message delivered (Exod 3:7-22; 20:1-17), a dedication and address (2 Chr 6:1-42), and the offering of sacrifices ( $2 \mathrm{Chr} 7: 1,12 ; 29: 27)$ that consist of a ritualized form of speech.

The Biblical Sanctuary Model assumes worshippers possess hermeneutical minds (Lev 26:1-2) that are active and not passive or determined thus ensuring that the 
encounter is a cognitive one (Exod 3:7-10, 11, 13; 4:1, 10, 13, 18; Isa 6:5, 8, 11). The place where the encounter occurs is in the mind of the worshipper (Deut 5:29). The covenant, which is always closely associated with the sanctuary, ensures that during the encounter worshippers receive the words of God and not the being of God (Jer 31:31-34). In contrast, since idols do not speak (Psalm 115:4-5; 135:15-17; Isa 46:7; Jer 10:15; Hab $2: 18 ; 1$ Cor $12: 2$ ) there is no cognitive encounter in a liturgical setting where the divine presence is conflated with the material creation as at the golden calf (Exod 32:1). In that setting the predominant rhythms (Exod 32:17) produce a non-cognitive emotional power encounter. The preparatory activities that worshippers are commanded to obey are for the purpose of purifying themselves prior to the encounter (Exod 19:10, 11, 14, 15, 21, 22). Since all the faculties of the worshipper are integrated in a cause and effect manner (Gen $1: 27 ; 2: 7)$, putting the rituals into practice assumes that there is a causal relationship with the way in which worshippers receive and interpret the divine message during the encounter. In other words, the nature and quality of the encounter is affected by whether worshippers choose to cooperate with the instructions pertaining to these preparatory rituals.

The response to the encounter involves verbal (Exod 3:4; 20:19; Deut 5:23, 25, 27), kinesthetic (Exod 3:6; 2 Chr 7:3), and affective elements (1 Chr 15:16; 2 Chr 29:30; 30:21). Moreover, the response from worshippers is always active and causally related to the specific content conveyed in the cognitive encounter whereas the non-cognitive encounter at the golden calf lays the groundwork for a response that is not causally connected to the encounter. 


\title{
CHAPTER 6
}

\section{BIBLICAL SANCTUARY MODEL: SURVEY \\ OF NEW TESTAMENT DATA}

\author{
Introduction \\ This Chapter continues our quest to examine the possibility of developing a \\ theology of the divine presence in Christian liturgy via a survey of NT data to ascertain \\ Scripture's interpretation of the macro hermeneutical presuppositions. Since the dominant \\ influence of timeless Being in the other models has mostly obscured the reading of the \\ biblical text from the perspective of its own macro hermeneutical presuppositions, there \\ is a need to employ a phenomenological exegetical methodology that allows the text to \\ reveal its content to the reader. However, just before this Chapter outlines the biblical \\ exegetical methodology it will follow, readers who desire a theological and systematic \\ portrayal of the Biblical Sanctuary model that is built upon this Chapter and the previous \\ one may wish to go directly to Chapter 7. \\ This Chapter will employ the exegetical methodology that was outlined at the \\ beginning of Chapter 5. It will apply a phenomenological exegesis that takes into \\ consideration the metaphysical framework implicit in the text as canon; and it applies a \\ phenomenological epoché to all theories not sustained by the canon. As a result, this \\ Chapter will not employ the historical critical or historical grammatical methods on
}


account of the philosophical assumptions concerning the divine presence in particular that are inherent in their methodologies. ${ }^{1}$

In this Chapter, I will apply a phenomenological exegesis to the following biblical texts: (1) Luke 4:16-30, Acts 2:1-47; 13:13-52 (cf.17:1-4; 18:1-8), (2) Heb 12:18-29, and (3) Rev 4:1-5:14. The reasons for using these texts are as follows. First, each text reveals important information about the presence of God and about all of the liturgical components without exhausting what the NT reveals about the divine presence and the liturgical characteristics. Second, scholars in various fields of study recognize these texts as addressing the presence of God and the liturgical components (see footnotes): (1) Luke 4:16-30, ${ }^{2}$ Acts $2: 1-47,{ }^{3} 13: 13-52^{4}$ (cf.17:1-4; 18:1-8), (2) Heb 12:18-29; ${ }^{5}$ and (3) Rev 4:1$5: 14 .^{6}$

Here is how I will explore all the aforementioned texts in this Chapter. First, I will describe the five liturgical components in each biblical passage that comprise the liturgical phenomena. I will do this by examining what each biblical passage reveals about the divine presence. Then I will proceed to find out what each passage reveals

${ }^{1}$ See Chapter 5 pages 218-222 for sources cited and further explanations concerning the exegetical methodology this Chapter will follow.

${ }^{2}$ Darrell L. Bock, "A Theology of Luke-Acts," in A Biblical Theology of the New Testament, ed. Roy B. Zuck (Chicago: Moody Press, 1994), 126-127; Scobie, The Ways of Our God, 582.

${ }^{3}$ For the importance of preaching, see David G. Peterson, The Acts of the Apostles The Pillar New Testament Commentary (PNTC; Grand Rapids, MI: Eerdman's, 2009), 142, 144, 158. For the divine presence, see Ibid., 132, 133, 148. 286.

${ }^{4}$ Scobie, The Ways of Our God, 582; Webber, ed. The Renewal of Sunday Worship,

${ }^{5}$ Grudem, Systematic Theology, 820-821, 1006-1008; Reymond, A New Systematic Theology of the Christian Faith, 873-874.

${ }^{6} \mathrm{R}$. Dean Davis, The Heavenly Court Judgment of Revelation 4-5 (New York: University Press of America, 1992), 20; Stefanovic, "The Background and Meaning of the Sealed Book of Revelation 5", 95. 
about the liturgist, then the liturgical actions, the encounter, and the response to the encounter; all of which comprise the necessary steps to outlining the Biblical Sanctuary Model.

Then, I will apply the phenomenological exegetical methodology to the liturgical components found in each passage to unfold the meaning found therein. I will explore how each passage makes a contribution to the overall understanding of the divine presence and each liturgical component. Lastly, I will examine the implications of the Scripture passages in this and the previous Chapter for the biblical ecumenical search for unity in liturgy.

\section{Divine Presence}

As I describe and analyze what each passage reveals about the divine presence, I will build upon the insights gained in the previous Chapter concerning Being while looking for indicators of Being in the NT. I will now follow the canonical order.

Acts 2:1-47

\section{Description}

Luke makes reference to Being in this Pentecostal passage by noting that "the

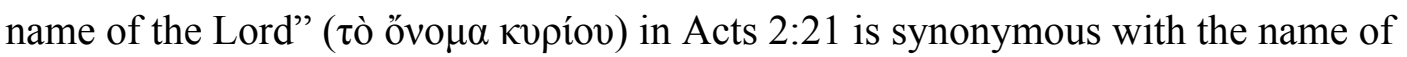

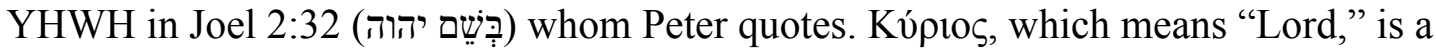
euphemism in the LXX for YHWH, but YHWH is God's personal name. Hence, Kúpıs, is translated as Lord in Acts 2:20, 21, 25, 34, and 36, and refers to God's Being. ${ }^{7}$

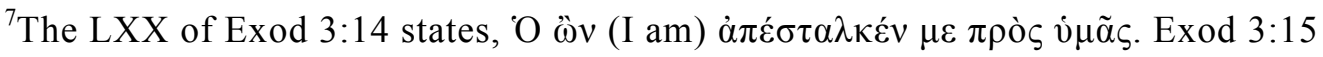

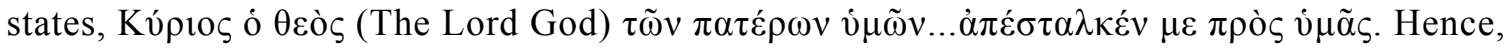
the I am (O $\hat{\omega} v)$ of Exod 3:14 is synonymous with the Lord (Kúpı̧) of Exod 3:15, which means that Lord also refers to God's Being. Furthermore, according to Exod 3:15 it is God's 
One can also specifically link the concept of Being directly with the Father and the Son, and indirectly with the Holy Spirit in Acts 2 . For instance, the word Lord is linked with both Father and Son in Acts 2:34. It reads, "The Lord (יהוה) (ó kúpros LXX)

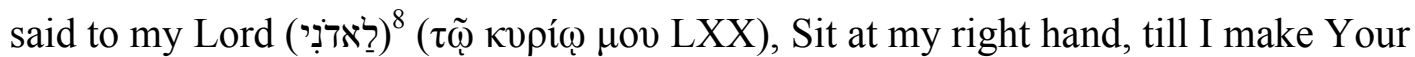
enemies Your footstool." It's clear that Jesus applied the personal name YHWH to both the Father and himself. ${ }^{9}$ Moreover, Luke further uses the "right hand" imagery in Psalm 110:1 to refer to both Father and Son in Acts 2:25, 30, 33, 34 where Christ is seated on the right hand of the Father's throne in the heavenly sanctuary. ${ }^{10}$ Although Acts 2 is noted for the prominent role of the Holy Spirit, we can only indirectly link the Holy Spirit

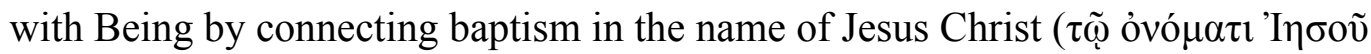

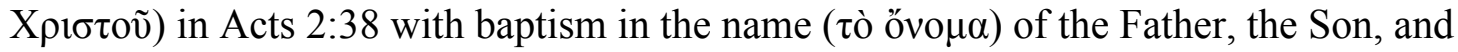
the Holy Spirit in Matt 28:19. Moreover, although the name YHWH is not directly attributed to the Holy Spirit in Acts 2, Paul states in 2 Cor 3:17 that "the Lord is the Spirit

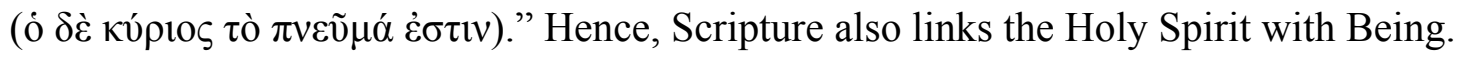
In addition, Acts 2:25, 30-34 links the Trinity to presence and omnipresence by first noting that Christ is sitting at the right hand of the Father in heaven. In Acts 2:33

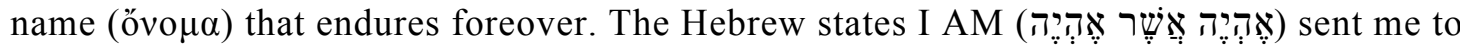
you in Exod 3:14, and in Exod 3:15 it states the Lord God (יהוה אֶלהיהי) sent me to you. Hence, The name of the Lord (דּּשֶׁם יהוה) in Joel 2:32 (3:5 Hebrew Bible) must then refer to the I AM. Moreover as King She notes "the referent of óvo $\mu \alpha$ is the Tetragammaton." King She, The Use of Exodus in Hebrews, 23; Joseph A. Fitzmyer, The Acts of the Apostles: A New Translation with Introduction and Commentary AB 31 (New York: Doubleday, 1998), 253-254.

${ }^{8}$ See this dissertation page 248 footnote 114 for the linguistic connections between YHWH and ADONAI.

${ }^{9}$ See "The Lord said unto my Lord" $S D A B C$ 3:880.

${ }^{10}$ As we compare Acts 2:30 with 2:34, sitting on God's throne and sitting on God's right hand seem to be synonymous. See also, Eph 1:20; Col 3:1; Heb 1:3; 8:1; 10:12;12:2; 1 Pet 3:22. 
Christ's exaltation and enthronement in heaven is linked with the outpouring of the omnipresent Spirit to Pentecost in Jerusalem and to the entire world throughout the centuries as a result of the promise in Acts 2:39.

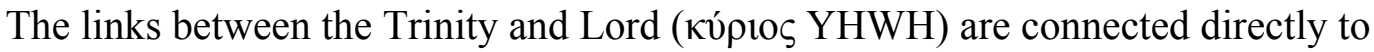
God's infinite analogous temporal Being in Exod 3:14. As a result, divine presence and omnipresence in the Godhead unites the Old and New Testaments via a temporal historical framework thereby obliterating the dichotomy between the Old Testament God and the New Testament God, as well as the subjectivity and difficulty involved that would place any other theme but God as the center of Scripture. ${ }^{11}$

\section{Analysis}

We will now briefly examine the presence of Father and Son in the heavenly sanctuary. We previously noted that Christ is seated at the right hand of the Father. Moreover God's infinite analogou temporal Being is the ground from which we interpret the historical acts of Father and Son that are noted in this Chapter such as: (1) Christ was

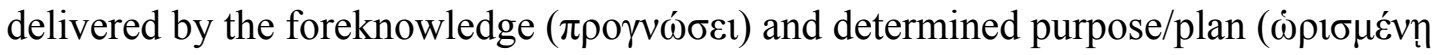

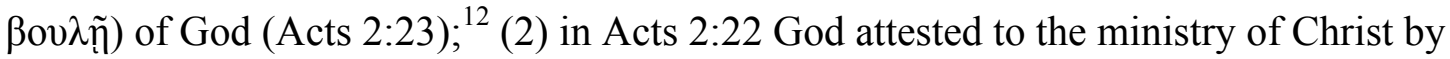
miracles, signs and wonders; (3) God raised Christ from the dead (Acts 2:23) so that he could sit on his throne (Acts 2:30) at his right hand (Acts 2:33); (4) afterward, Christ received the promise of His Father to pour the Holy Spirit on his people (Acts 2:33).

\footnotetext{
${ }^{11}$ See Gerhard F. Hasel, Old Testament Theology: Basic Issues in the Current Debate, Fourth ed. (Grand Rapids, MI: Eerdmans, 1991), 139-171.

${ }^{12}$ Foreknowledge logically precedes predestination when viewed from within God's infinite analogous temporal Being (Rom 8:29-30). For a view that takes into consideration God's infinite analogous temporal Being in the issues of foreknowledge and predestination, see Canale, Basic Elements of Christian Theology: Scripture Replacing Tradition, 104-164.
} 
We will now analyze the hermeneutical effects of this sequence of historical events from the perspective of God's infinite analogous temporal Being. First, there is no Platonic ontological gap between a timeless heaven and a temporal earth since Christ's enthronement in heaven is the cause of the outpouring of the Holy Spirit on earth. Moreover, all of the four actions of the Trinity noted above took place within a spatiotemporal context, each depending on the other for its fulfillment. Second, in contrast to the Sacramental model's view that Christ is still omnipresent during the Incarnation, a phenomenological reading of Acts 2:30,33-34 (1) implies that Christ was not seated, exalted to the throne or told to sit at his Father's right hand until after his death and resurrection, and (2) while currently ministering as our high priest in heaven, Christ's presence is located there, which means that he and the Father are not omnipresent in immanence. Instead, it is the Holy Spirit whose presence is located in heaven and in Acts 2:1-11 He is poured out on the disciples in Jerusalem, and to all who respond to the Lord's call throughout the centuries (Acts 2:39).

We will now draw the following deductions about the nature of the omnipresent Holy Spirit. First, since the Holy Spirit is also the I AM, the possible connections between the Spirit, wind, and fire in Acts 2:2-3 do not refer to the Spirit's Being. Just as God's Being was revealed to Moses through his words and not through the burning bush, so the Holy Spirit's Being is also strongly connected to speech through the words uttered by the disciples as symbolized through tongues ${ }^{13}$ (Acts 2:3, 4-11); by the preaching of

\footnotetext{
${ }^{13}$ The passage in Acts 2:3 mentions tongues of fire and verse 4 mentions that the Holy Spirit filling the disciples is the cause and the effect is that they spoke with other tongues. Linguistically, the word tongue is either an organ of speech or a known language. See Gerhard F. Hasel, Speaking in Tongues: Biblical Speaking in Tongues and Contemporary Glossolalia, (Berrien Springs, MI: Adventist Theological Society, 1991).
} 
Peter whose sermon is saturated with the $\mathrm{OT}^{14}$ (Acts $2: 17-21 ; 25-35$ ); and by the word utterance $^{15}(\dot{\alpha} \pi \circ \varphi \theta \dot{\varepsilon} \gamma \gamma \varepsilon \sigma \theta \alpha \mathrm{l})$ in Acts 2:4.

Second, the integral connection between the Spirit's Being and speech reveals that the Spirit is not an amoral panentheistic force but rather a personal moral entity whose ministry is to set the seal on the reality of the life Christ lived on earth and of his ministry in heaven. Moreover, the Spirit's integral connection with Speech reveals that his omnipresence is only revealed when liturgists like Peter connect the worshipers with the ministry of Christ as disclosed through Scripture.

Third, since the Holy Spirit is also Lord (YHWH кúpıs), there is no dichotomy between the Spirit's revealed presence and his moral character, which is revealed by the fact that the Spirit teaches, convicts, guides all into the truth, and brings the presence of Jesus to his people (John 14:16-18, 26; 16:7-14).

Heb 12:18-29

\section{Description}

Some have alleged that the author of Hebrews employs Philo's writings as a

${ }^{14}$ The passage in Acts 2:17-21 is a reference to Joel 2:28-32; Acts 2:25-28 is a reference to Psalm 16:8-11; Acts 2:29 references the death and burial of David; Acts 2:30 is based on the sworn oath that the Messiah would come from the fruit of David's body in 2 Sam 7:12 and Psalm 132:11 and fulfilled in Luke 1:32, Rom 1:3 and 2 Tim 2:8; Acts 2:31 is based on Psalm 16:11; Acts 2:33 is based on Psalm 68:18 and 110:1; Acts 2:34-35 is a reference to Psalm 110:1.

${ }^{15}$ In Acts 2:4 it states that the Spirit gave them utterance ( $\left.\dot{\alpha} \pi \circ \varphi \theta \varepsilon \dot{\varepsilon} \gamma \gamma \varepsilon \sigma \theta \alpha \mathrm{l}\right)$. In Acts 2:14 Peter addressed ( $\dot{\alpha} \pi \varepsilon \varphi \theta \dot{\varepsilon} \gamma \xi \alpha \tau o)$ them by speaking and quoting from the OT. Also Paul speaks $(\dot{\alpha} \pi \circ \varphi \theta \dot{\varepsilon} \gamma \gamma \circ \mu \alpha)$ the words of truth and righteousness. Hence, the Spirit giving them utterance implies a cognitive function that results in speech. The same word is used in the LXX to denote prophesying. See 1 Chr 25:1; Eze 13:19; Zech 10:2. 
possible source. ${ }^{16}$ Yet, Hebrews neither employs Philo's writings nor his timeless ontology. ${ }^{17}$ As we build our exegesis of Heb 12:18-29 on the insights of the previous passages, we will likewise see that this epistle reveals God's infinite analogous temporal Being in the following ways.

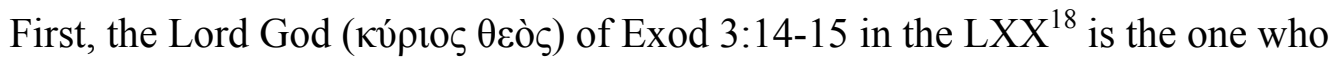
spoke the Ten Commandments at the earthly mount Sinai mentioned in Heb 12:18-21. Accordingly, within the hermeneutical framework of God's infinite analogous temporal Being, worshippers receive the divine presence through God who speaks from earth and from heaven (Heb 12:19, 20, 25-26; cf. Deut 4:36, 39). Hence, God's direct speech assumes and is inextricably linked to God's Being.

Second, the $\theta \varepsilon$ ò of Exod 3:15 is referenced in Heb 12:22, 23, 28, and 29. Third,

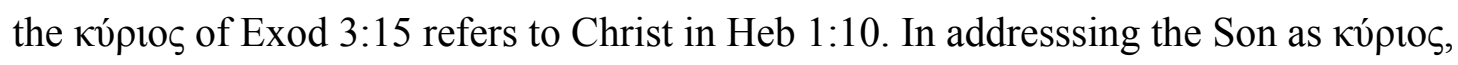
the Father acknowledges him as the I AM prior to his act in creation and that he will continue to exist after heaven and earth perish (Heb 1:11). Moreover, although "they will

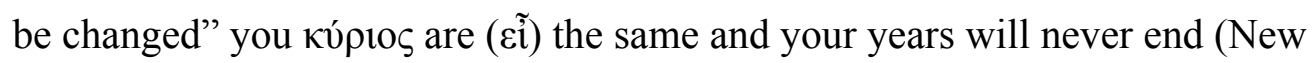

\footnotetext{
${ }^{16}$ Bateman states, "Although this is possible, it seems unlikely since internal or external supporting evidence is speculative." See Herbert W. Bateman, "Jewish and Apostolic Hermeneutics: How the Old Testament is Used in Hebrews" (PhD dissertation, Dallas Theological Seminary, 1993), 232.

${ }^{17}$ For a refutation of Hebrews' use and dependence on Philo, see Félix Cortez, "Creation in Hebrews," Andrews University Seminary Studies (AUSS) 53, no. 2 (2015): 279320. King She states, "In sum, by his conscious rejection of Greek ontology which is present in his reception of the history of the interpretive influence of Exod 3:14, Auctor actually brings out his determination to ground his ontology by the Mosaic-biblical metanarrative." King L. She, The Use of Exodus in Hebrews, 119.

${ }^{18}$ YHWH (יהוה) does not appear to be consistently translated in the LXX. For

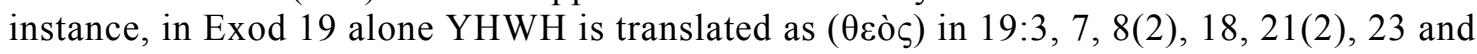

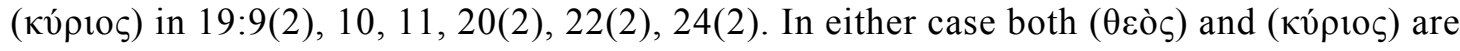
integrally connected with the I AM. King She notes that "the LXX translates in Exod 3:15 as אúpios and Auctor refers to Jesus Christ by the same title throughout Hebrewsкúplos (Heb 2:3; 7:14; 8:2; 13:20), King L. She, The Use of Exodus in Hebrews, 35.
} 
International Version [NIV] Heb 1:12). Consequently, "Jesus Christ is the same yesterday, today, and forever" (Heb 13:8; $\mathrm{cf} \mathrm{Heb} \mathrm{7:3).}{ }^{19}$ Thus, Heb 1:10-12 reveals that the unchanging nature of God's being remains unchanged even though creation will change, and even though God interacts with creation. However, even as the heavens are changed into new heavens and a new earth (2 Pet 3:12-13), as are human beings (1 Cor 15:51, 52) and the animal kingdom (Isa 11:6-7), these only remove the effects of sin; they do not indicate that the specific immutable characteristics that make up their realities changes. $^{20}$

Fourth, Heb 11:6 states, "for he who comes to God must believe that He is (ö $\tau 1$

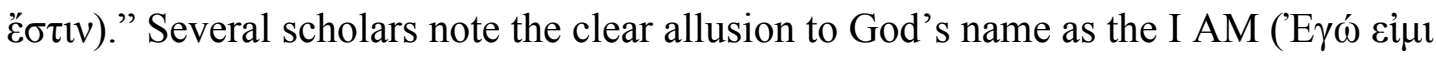
LXX) of Exod 3:14. ${ }^{21}$ Moreover, She also connects "his name (övo $\alpha$ )" in Heb 13:15 to the Tetragrammaton. ${ }^{22}$ Since God's Being is immutable, there is no room for timeless Being to interpret ह̌ $\sigma \tau \imath$ (is/exists) in Heb 11:6. ${ }^{23}$

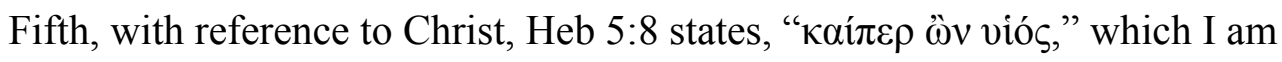

${ }^{19}$ Under the influence of timeless Being, Aelred Cody notes that

The 'yesterday, today, and forever' of Hebrews' acclamation is temporal only in relation to earthly history. On the part of Christ as the Son of the Father it is all a matter of the timeless today of eternity, which measures the life which is His outside of time and history (Aelred Cody, The Heavenly Sanctuary and Liturgy in the Epistle to the Hebrews, 88).

${ }^{20}$ King She notes that Hebrews' philosophy of history rejects the Greek and modern Western framework (Kant), noting that the auctor constructs his theo-ontological constitution on the basis of Scripture. King L. She, The Use of Exodus in Hebrews, 94. Ibid., 35 .

${ }^{21}$ King She mentions seven scholars who see that Heb 11:6 alludes to Exod 3:14. See

${ }^{22}$ Ibid., 23.

${ }^{23}$ King She states,

If the Being of God (theos) and His relation to reality (ontos) are revealed in Exod 3:14, the Being of God and divine relation to reality are not to be changed. Hence, one can say that Auctor's pedagogy reflects the biblical view of nature and supernature because he uses Exod 3:14 pedagogically in Heb 11:6 (Ibid., 124). 
translating as "though being a Son." ${ }^{24}$ There is also Heb 1:3 which speaks of Christ as

"who being (ڤ̂v) the brightness of His glory" (NKJV) "and the exact representation of his

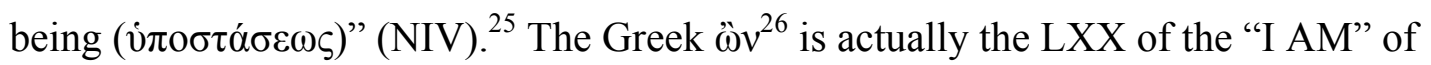
Exod 3:14 while vं interpreted from God's infinite analogous temporal Being. ${ }^{28}$

Sixth, God's infinite analogous temporal Being lays the groundwork for our understanding of tà $\alpha \iota \omega v ı \alpha$, which is translated as worlds or ages (Heb 1:2;11:3) and

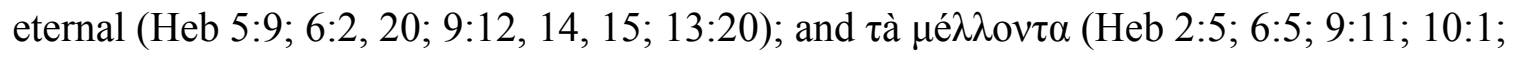
$11: 20 ; 13: 14),{ }^{29}$ which refers to things to come in the future. Conseqeuntly, God's infinite analogous temporal Being forms the foundation from which we interpret the actions of

${ }^{24}$ With reference to Heb 5:8, I am indebted to Félix Cortez for bringing to my awareness another example of èv, the present participle of eíuí that hearkens back to Exod 3:14 and which establishes God's infinite analogous temporal Being.

${ }^{25}$ The two phrases "the brightness of his glory" and "the exact representation of his being" complement the participle ôv ("being"). See Gareth Lee Cockerill, The Epistle to the Hebrews New International Commentary on the New Testament (NICNT) (Grand Rapids, MI: Eerdmans, 2012), 94.

${ }^{26}$ Although the participle ( $\left.ڤ \mathrm{v}\right)$ affirms the permanence of the divine essence, Ellingworth assumes timeless Being when he states that Heb 1:3 shifts from a temporal focus "to the timelessness of the Son's relationship to God." Quoted in Jonathan I. Griffiths, Hebrews and Divine Speech (New York: Bloomsbury, 2014), 45 footnote 48. Yet when we apply the epoché, and consider the text in light of a phenomenological exegesis of Exod 3:14 as we have done, we do not find timelessness; instead it expresses God's infinite analogous temporal Being.

${ }^{27}$ Ibid., 45 footenotes 48 and 46. Also, the Son is an "exact representation of God's

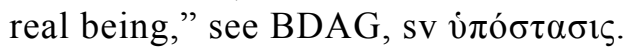

${ }^{28}$ For an example of those who see $\dot{\pi} \pi \sigma \tau \alpha \dot{\sigma \varepsilon} \omega \varsigma$ as a philosophical term yet interpret it from a Greek philosophical perspective, see Harold Attridge, The Epistle to the Hebrews Hermeneia (Philadelphia: Fortress Press, 1989), 43-44.

${ }^{29}$ Aelred Cody has brought these texts to my attention, yet in the footnotes below he has interpreted them under the influence of timeless Being. Aelred Cody, The Heavenly Sanctuary and Liturgy in the Epistle to the Hebrews, 132-144. 
God and Christ in creation, ${ }^{30}$ redemption, ${ }^{31}$ and our future inheritance in the world to come.

\section{Analysis}

Now that we have established God's infinite analogous temporal Being in Heb 12:18-29, we can see how this framework hermeneutically guides us in our understanding of the issues surrounding God's presence. We will first focus briefly on God speaking since his presence is revealed through his words. Heb 12:25-26 states, "See that you do not refuse Him who speaks. For if they did not escape who refused Him who spoke on earth, much more shall we not escape if we turn away from Him who speaks from heaven." A phenomenological exegesis of this passage reveals that God's direct speech and Scripture are inextricably linked in Hebrews. ${ }^{32}$ As a result, since God's infinite analogous temporal Being eliminates any ontological dichotomy between heaven and earth one can only conclude that there is no difference between the content of the

\footnotetext{
${ }^{30}$ Under the influence of timeless Being, Cody notes that in Heb 1:2;11:3 God has already made $\tau$ ov̀ $\alpha^{\prime} \tilde{i} \tilde{v} \alpha \varsigma_{\varsigma}$ through the Son, and the result is that "there is not an age left to be made in the future," Ibid., 132. Hence, God will not create a new heavens and a new earth as Scripture teaches (Isa 65:17) for everything has already been timelessly generated.

${ }^{31}$ In shedding the blood of the everlasting covenant (Heb 13:20) offered through the eternal Spirit (Heb 9:14; cf 9:12). Yet, under timeless Being, Cody notes "it is everlasting because it is eternal, because in it the order of salvation is fixed in a world of changeless realities." Ibid., 134. Cody asserts that this eternal divine force is not limited by the flux of time because "eternal" here is identical with divine and celestial, and is not divisible into past, present, and future." Ibid., 134. Redemption also includes becoming the cause ( $\alpha$ il $\tau 10 \varsigma$ ) of our salvation through suffering (Heb 5:8-9). Cody, again reinterprets this as occurring in

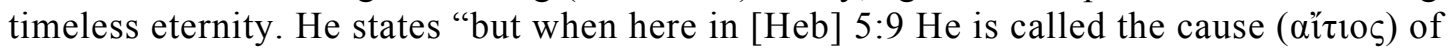
salvation the perspective is the vertical one of the author's Alexandrian heritage," Ibid., 136. Redemption also includes judgment (Heb 6:2), and becoming a high priest of good things to come (Heb 9:11).

${ }^{32}$ See Félix H. Cortez, “"See that you do not refuse the one who is speaking”: Hearing God Preach and Obedience in the Letter to the Hebrews," Journal of the Adventist Theological Society, 16 no. 1-2 (2008): 101-104 for the numerous examples that underscore the integral relationship between God's speech and Scripture.
} 
messages that God speaks from heaven and those he speaks on earth. ${ }^{33}$ Moreover, the passing of time - even centuries — neither alters the immutability of Christ's nature (Heb 1:10-12) nor the immutable nature of God's direct speech in Hebrews. Consequently, the messages of God's direct speech first spoken in specific times and places constitute a universal quality applicable throughout time. God's infinite analogous temporal Being thus grounds the certainty and universality of God's direct speech thereby contradicting the claim that God's word is solely the product of any particular culture or time in history and therefore only applicable to the local situation in which it was spoken. In addition, the statement that "our God is a consuming fire" in Heb 12:29 also speaks to our understanding of the divine presence via the clear allusion to Deut 4:23 in which God admonishes Israel not to make a carved image "For the Lord your God is a consuming fire, a jealous God." Since God's Being is revealed through his words, we should not confuse the being of God with the being of creation.

The revelation of Jesus as the mediator of the new covenant (Heb 12:22-24) and the blood of sprinkling (Heb 12:24) assume that Christ's presence consists of the divine and the human, the latter of which plays a prominent role in this epistle (Heb 2:9, 16-18; $5: 7-19 ; 10: 5-10)$. Hence, another issue requiring further analysis is the interpretation of Christ's divine and human natures from the hermeneutical framework of the sanctuary that temporally grounds the relationship between the divine and the human. ${ }^{34}$ We have

\footnotetext{
${ }^{33}$ Moreover, Heb 12:26 reveals that God's voice that operates in the framework of space and time can simultaneously shake heaven and earth. This assumes that the reality of heaven consists of things that can be shaken and that there is no Platonic dichotomy between heavenly and earthly realities.

${ }^{34}$ King She notes that God's infinite analogous temporal Being noted in Exod 3:14 hermeneutically guides the interpretation of Exod 25:40 and Heb 8:5, all of which function
} 
already noted how Christ is the I AM and thus divine through our analysis of Christ's

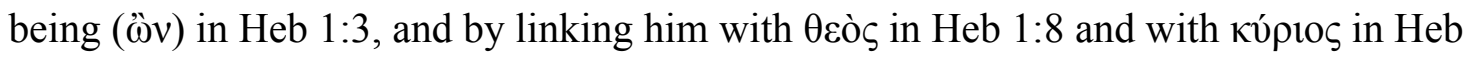
1:10 (cf. $2: 3 ; 7: 14 ; 8: 2 ; 13: 20$ ). Another evidence of Christ's divinity comes from the context of the sanctuary itself. Here Jesus as our high priest enters into the most holy place with blood (Heb 9:7) that he sprinkles (Heb 12:24) on the mercy seat $\left(i \lambda \alpha \sigma \tau \text { ṕp }{ }^{35}\right)^{35}$ that covers the Ten Commandments. Since the presence of God is only revealed by his words that are summarized by the Ten Commandments ${ }^{36}$, then only the I AM can provide atonement. Any being lesser than the I AM would compromise his words and his divine presence.

In addition to establishing Christ's divinity, the linkage between Being (œ̂v) and Son (being) in Heb 5:8 $8^{37}$ yields important insights regarding the relationship between Father and Son prior to creation. First, since ồ unfolds a temporal eternity and immutability, and is joined to the word Son, it renders groundless any notion that the Son was timelessly generated from the Father in timeless eternity, ${ }^{38}$ or that he ever became a

as important biblical presuppositions in establishing a Christology. See King L. She, The Use of Exodus in Hebrews, 27, 161, 162, 166, 167.

${ }^{35}$ (i $\left.\lambda \alpha \sigma \tau \eta ́ \rho ı v\right)$ is only mentioned in two places in the NT. In Heb 9:5 it is translated as mercy seat, referring to the place where the blood was sprinkled. In Rom 3:25 Jesus himself is the propitiation (i $\left.\lambda \alpha \sigma \tau \eta \dot{\rho} \rho v^{\prime}\right)$ so that through faith in his blood his righteousness

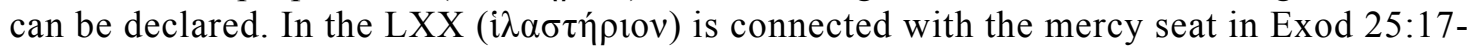
22 and with the mercy seat and the Ten Commandments in Exod 25:21;31:7; Lev 16:13.

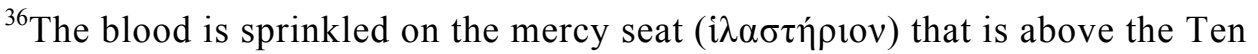
Commandments in LXX Lev 16:13-15.

${ }^{37}$ Paul Ellingworth notes that the likely meaning of the translation of Heb 5:8 is, "Although he has (eternally) the status of (God's) Son." Ellingworth, The Epistle to the Hebrews New International Greek Testament Commentary (NIGTC) s.v. Heb 5:8. "Jesus is not an ordinary son... but the eternal son." Harold Attridge, The Epistle to the Hebrews Hermeneia, 152.

${ }^{38}$ Roger Olson points out that this was the case concerning the Logos with Theophilus of Antioch, Origen, and Athanasius. See Olson, The Story of Christian Theology, 65, 109-110, 168. 
Son at some point in a temporal eternal past thereby contradicting the divine Son's eternity and immutability. Both of these options imply what the text in Heb 5:8 denies, which is an ontological subordination of the Son's being to the Father, or that the Son's being and life is derived from the Father. Second, since Father and Son are connected to

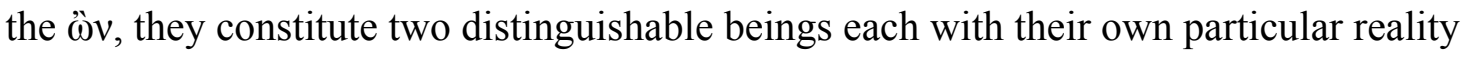
and center of consciousness that should not be blended or confused with the other. Third, "the relationship between the Father and Son exists both at the level of transcendence and immanence. ${ }^{\prime 39}$ Consequently, on the basis that Being (ڤ̂v) is linked with Son (being), the ground for establishing the relational structure between Father and Son lies with this broadest of all presuppositions which points to transcendence.

Having now established the connection between God's infinite analogous temporal Being and Christ's divinity we will now analyze how it is possible for the eternal and immutable I AM to experience a change in his being by taking upon himself human nature. After creation, Christ's infinite analogous temporal Being made it possible for him to accommodate himself in order to relate with the created intelligences we find in Heb 12:22. Moreover, the heavenly sanctuary (Heb 12:22) and the earthly sanctuary reveal that Christ accommodates himself to spatio-temporal structures and intelligences through his own personal presence and through his word that communicates his will. ${ }^{40}$ Thus far, this does not involve a change in his being.

However, in the incarnation Christ's infinite analogous temporal Being makes it possible for his divine presence to experience a change that is metaphysically impossible

\footnotetext{
${ }^{39}$ Fernando Canale, "Doctrine of God," 125.

${ }^{40}$ Within the framework of Christ's infinite analogous temporal Being, Heb 1:3 reveals that it is through the Word that Christ relates with the universe, "upholding ( $\varphi \varepsilon ́ p \omega v)$ all things ( $\tau \grave{\alpha} \pi \alpha ́ v \tau \alpha)$ by the word of His power."
} 
within the parameters of timeless ontology. ${ }^{41}$ The nature of this change is introduced in Heb 5:8-9, which reveals that the eternal and immutable divine/human Son learned

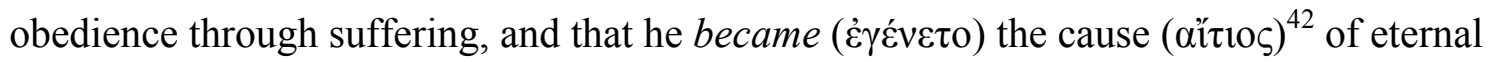
salvation to all who obey him. There is no change here at the level of Being (ڤ̂v) (Heb 5:8), which encompasses transcendence and the incarnation in immanence. Yet within the parameters of Being, Christ's pre-incarnate being can have new experiences as he interacts with creation and his creatures thereby denying impassibility; all of this does not involve a change in his being. However, the use of the words "learned" and "became" in the context of Heb 5:8, 9 assume the incarnation, which fully integrates humanity with divinity. As a result, adding humanity to divinity points to a change in Christ's being. Yet, since Being (⿳亠丷厂) is applied to the divine Son (being), which implies immutability, the incarnation does not alter the reality of Christ's divinity. Moreover, since God's infinite analogous temporal Being renders groundless the hermeneutical effects of timeless Being, Christ learning and becoming the cause of salvation reveal that Christ's human nature is not determined and ordered by his divine nature. This means that the cause of salvation lies in the decisions he as fully God made in the limitations and weaknesses of his human nature that involved the risk of failure. ${ }^{43}$

In John 1:14, Christ's infinite analogous temporal Being links with sanctuary terminology, which makes philosophically possible John's declaration, “the Word

\footnotetext{
${ }^{41}$ See my analysis of the divine presence in the previous models, which illustrates how the incarnation poses a problem for timeless ontology.

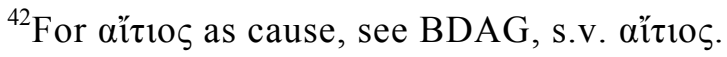

${ }^{43}$ This is diametrically opposed to Cody's assertion where he states, "but when here

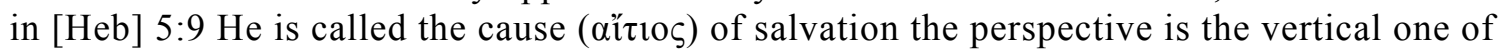
the author's Alexandrian heritage." Aelred Cody, The Heavenly Sanctuary and Liturgy in the Epistle to the Hebrews, 136.
} 


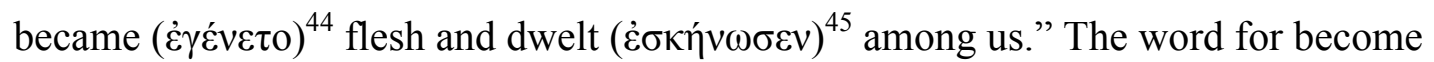

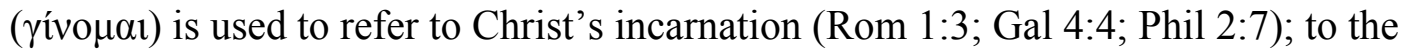

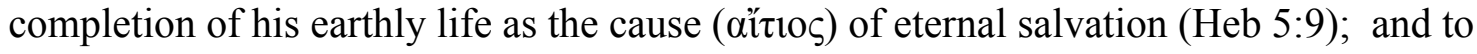
his high priestly ministry (Heb 2:17; 5:5; 6:20; 7:16, 20-22; 9:11). Scripture employs the word $\gamma \varepsilon v v \alpha \dot{\omega} \omega$ to primarily describe Christ's birth within a narrative context, ${ }^{46}$ as well as to point to his enthronement in the heavenly sanctuary as a key event in salvation history. ${ }^{47}$ Accordingly, the use of " $\gamma$ ívo $\mu$ l" functions as an ontological indicator to draw our attention to the fact that it is philosophically possible for the immutable ${ }^{48}$ and eternal "I

${ }^{44}$ The word denotes being and manner of being, which, according to BDAG places it

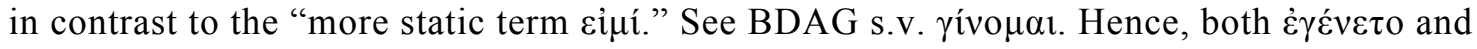
ciú are viewed from the perspective of ontology, albeit timeless ontology. Hence, we should view the usage of $\dot{\varepsilon} \bar{\varepsilon} v \varepsilon \tau$ o as a philosophical indicator of a change in Christ as the divine presence that is possible within a temporal ontological framework.

${ }^{45}$ The connection between the noun ( $\left.\sigma \kappa \eta v \eta ́\right)$ and the sanctuary is outlined here in Hebrews: Heb 8:2, 5; 9:2, 3, 6, 11, 21. Bouyer notes that the structure of the ark itself is

less a chest than a throne, the throne of an invisible presence, but one which is attested by the cherubim prostrate before it....Even though this presence of the God of heaven with Israel in His sanctuary is invisible and unrepresented, it will still be conceived as being very real, living and active.... This presence... was called the Shekinah by the rabbis, a term derived from shakan, that is, 'to live under a tent.' The Greek $\sigma \kappa \eta v \eta$ is derived from this, not by way of translation but through transliteration. And it is quite remarkable that the term used by St. John in the prologue of his Gospel to explain the Incarnation refers specifically to it: 'The Word was made flesh and dwelt amongst us'-

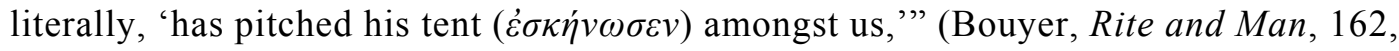
163; cf. Allen, 1, 2 Chronicles CCSOT, 233-234).

${ }^{46}$ For the usages of $\gamma \varepsilon v v \alpha$ á $\omega$ in a narrative context, see Matt $1: 16,20 ; 2: 1,4$; Luke 1:35; John 18:37. Unlike the philosophical and theological context of John 1:14; Rom 1:3; Gal 4:4; Phil 2:7 and Heb 2:17, the texts in the gospels occur in a narrative context in which

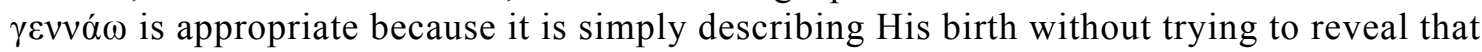
His divinity has just done the impossible by taking on humanity.

${ }^{47}$ See LXX Psalm 2:7; Acts 13:33; Heb 1:5; 5:5

${ }^{48} \mathrm{I}$ 'm drawing on my exegesis of the divine presence in Exod 3:14 for the following insights. Christ's infinite analogous temporal Being is immutable in the sense that we cannot change it without contradiction. Also, He's immutable in the sense that in His Divinity (1) He's still invisible (1 Tim 1:17) yet has become visible, (2) He's still ontologically distinct from creation yet has become human, (3) He's still part of the Trinity yet the Trinity itself has become changed as a result of the Incarnation, and (4) He's still omnipresent in His 
AM" of Exod 3:14 to be made flesh without involving a contradiction. It is also possible for Christ to refuse to exercise His omnipresence in His relationship with the universe in immanence ${ }^{49}$ in order to become our mediator.

The sanctuary imagery of John 1:14 temporally grounds the relationship between Christ's divinity and humanity. Similarly, God's Being in Exod 3:14 provides the framework for the way in which the divine presence relates to spatio-temporal realities in the heavenly sanctuary in Exod 25:40 and Heb 8:5. Hence, Christ's infinite analogous temporal Being and subsequent incarnation allow for divinity to not only interact with history and matter, which is what takes place in the sanctuary; it also allows divinity to be integrated with a free human nature ${ }^{50}$ in such a way that humanity and divinity remain distinct while at the same time they are mysteriously blended together in one person. Without this, Christ could not be a mediator who could fully identify with God and humans. As a result, the concept of a mediator necessarily involves the proper interpretation of the relationship between divinity and humanity. ${ }^{51}$ Jesus as high priest after the order of Melchizedek further exemplifies this relationship between divinity and humanity. ${ }^{52}$ Moreover, in contrast to the view that the presence of Christ is ubiquitous

transcendence (beyond the universe) yet He suspends His omnipresence in His relationship with the universe in immanence. See my exegesis of the divine presence in Heb 12:18-29, Rev 4-5, and Acts 2:1-47.

${ }^{49}$ See footnote 48 above on how omnipresence relates to transcendence and immanence.

${ }^{50}$ Aelred Cody's view of the body of Christ is that the humanity of Christ is the instrumental cause of salvation while His divinity is the efficient cause. Aelred Cody, The Heavenly Sanctuary and Liturgy in the Epistle to the Hebrews, 163-165.

${ }^{51}$ Our purpose here is not to develop a full blown Christology but rather to trace the hermeneutical role of Christ's infinite analogous temporal Being on how divinity and humanity relate to each other.

${ }^{52}$ Although there is much speculation concerning the identity of Melchizedek, it is possible to regard him as a historical figure in which there is no record of his birth, the 
and thus omnipresent after the incarnation, ${ }^{53}$ a phenomenological exegesis of Heb 12:2224 reveals that the presence of Christ and of God is localized in the heavenly sanctuary.

Lastly, since certain panentheists create a dichotomy between the ground of the divine that is not personal but is the cause of personhood, ${ }^{54}$ the following points reveal that the divine presence in Heb 12:18-29 is ethical and moral. First, the sanctuary temporally grounds the attributes of God, thereby eliminating the dichotomy just mentioned. Second, since a covenant is based on the Ten Commandments, which constitutes a moral code; referring to Jesus as the mediator of a better covenant (Heb $12: 24)$ implies that the presence of Jesus is a moral divine presence. Third, by referring to God as one who speaks (Heb 12:25, 26) and judges (Heb 12:23), attention is further drawn to God's moral qualities that are inextricably linked to his presence.

Rev 4-5

\section{Description}

Since the book of Revelation brings to completion concepts that were previously revealed in the OT, we will note that God's infinite analogous temporal Being is primarily revealed by comparing Rev 4:8 with Exod 3:14-15. These two passages place

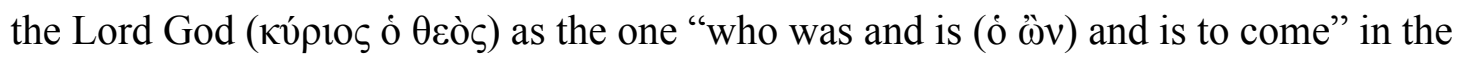

identity of his parents, his death, or of any genealogy with reference to the priesthood such as the Aaronic priesthood required. See William L. Lane, Hebrews 1-8 WBC 47A (Dallas, TX: Word Books, 1991), s.v. Heb 7:3. These indicators in Heb 7:3 clearly point to Jesus' divinity, who has no beginning of life nor end of days, who has an indestructible life (Heb 7:16) and who did not arise as a high priest after Aaron but after Melchizedek.

${ }^{53}$ See my analysis of the divine presence of the Sacramental model in Chapter 4 of this dissertation, pages 109-110.

${ }^{54}$ Cooper, Panentheism The Other God of the Philosophers, 28. 
context of past, present and future. ${ }^{55}$ For instance in Exod 3:14 God introduces himself as the I AM (o $̂$ ov). Yet, in Exod 3:15 God tells Moses that the I AM was the Lord God

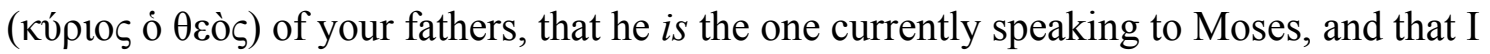

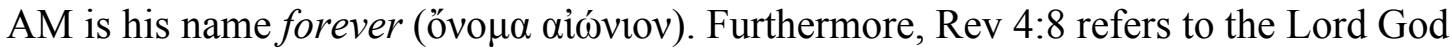

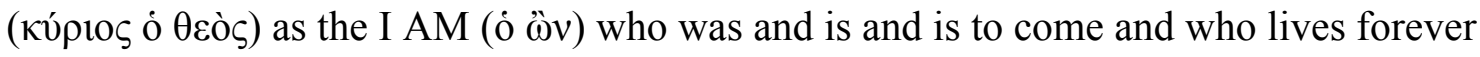

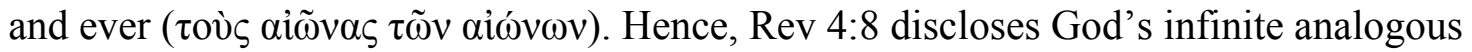
temporal Being. ${ }^{56}$

In addition to being perfectly compatible with the past, present and future, the heavenly sanctuary context of Rev 4-5 makes the I AM compatible with space. ${ }^{57}$ In Rev 4-5, John connects the sanctuary with the Father who sits on the throne, most likely in the

${ }^{55} \mathrm{Of}$ the five passages that contain God as the one who is was and is to come, four of them begin with who is (Rev $1: 4,8 ; 11: 17 ; 16: 5)$, while Rev $4: 8$ begins with who was; and depending upon which manuscripts are employed Rev 11:17 and 16:5 leave off "who is to come."

${ }^{56}$ See Russell S. Morton, One Upon the Throne and the Lamb: A Tradition Historical/Theological Analysis of Revelation 4-5 Studies in Biblical Literature (New York: Peter Lang, 2007), 113. For connections between the I AM of Rev 1:4, 8; 4:8; 11:17 and 16:5 with Exod 3:14, 15 see TDNT, s.v. Ei 1 ; David E. Aune, Revelation 1-5 WBC 52a (Dallas, TX: Word Books, 1997), s.v. Rev 4:1; Brevard Childs, The Book of Exodus, OTL,

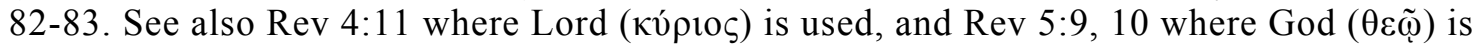
used. Both Lord and God are connected with the I AM of Exod 3:14, 15.

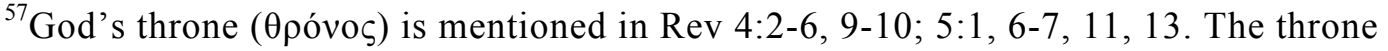
is specifically connected to the sanctuary in the following OT texts (LXX): Psalm 11:4; 1 Kgs 22:19; Isa 6:1; 14:13; Jer 17:12; Dan 7:9; Ezek 1:26; 10:1. See de Souza on the connection between these OT texts and the heavenly sanctuary, "The Heavenly Sanctuary/Temple Motif in the Hebrew Bible." Other than the throne, some of imagery connected with the heavenly sanctuary includes an open door $(\theta v \rho \alpha)$ in heaven $(\operatorname{Rev} 4: 1)$. In the LXX door can signify both the door to the tent of meeting (Exod 29:4, 11, 32, 42) and the door to the most holy place in the temple (1 Kgs $6: 31,32 ; 7: 50 ; 2 \mathrm{Chr} 4: 22)$; seven lamps of fire (Rev 4:5) signify the lampstand in Exod 37:17-24; the four living creatures that have six wings who cry holy, holy, holy are most likely a combination of Isa 6:2-3 and Ezek 1. See Lazlo Gallusz, "Thrones in the Book of Revelation Part 1: Throne of God," Journal of the Adventist Theological Society 23 no. 2 (2012): 45. Also, that there are four living creatures matches the number in Solomon's temple. For instance there were two cherubim entirely of gold connected to the ark (Exod 37:6-9) and then two more larger ones made of wood and overlaid with gold (1 Kgs 6:23-28); there's the Lamb (Rev 5:6) which is a prominent sacrificial animal that points to Christ (John 1:29). 
most holy place of the heavenly sanctuary; ${ }^{58}$ the Son who is symbolized as the Lamb, a

prominent sanctuary animal that is standing ( $\operatorname{Rev} 5: 6)$ in the presence of the one seated

on the throne; and the Holy Spirit that is represented by seven lamps of fire (Rev 4:5),

which also signifies a sanctuary symbol (Exod 37:17-24) located in the holy place. ${ }^{59}$

\begin{abstract}
${ }^{58}$ The following lines of evidence lead me to conclude that the throne is in the most holy place of the heavenly sanctuary: (1) the throne is not described as being in motion throughout the book of Revelation. Despite the many similarities between the living creatures in Ezek 1 and Rev 4, the living creatures in Rev 4 make no mention of wheels (Ezek 1:15-16) and neither do they bear the throne (Ezek 1:22,26). Davis notes that

in Ezekiel the throne is traveling, while in Revelation it is stationary. In order for the throne to move in all directions, it is logical for the 'living creatures' who bear it to have faces in all directions. For this same reason, there are no wheels mentioned in connection with the stationary throne in Rev 4-5... Therefore, the closest temple-related model would be that of the Most Holy Place, where the cherubim served in a stationary position as the 'covering cherubim' and guardians of the ark/throne (1 Kgs 6:23-29) (See Davis, The Heavenly Court Judgment of Revelation 4-5, 127, 128, 131).
\end{abstract}

As a result, the geographical location of the throne is in the center as evidenced by the

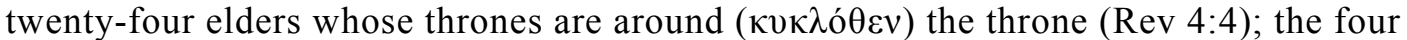

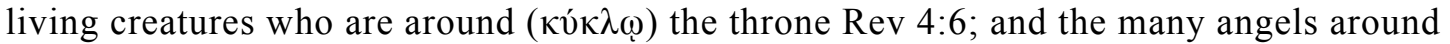

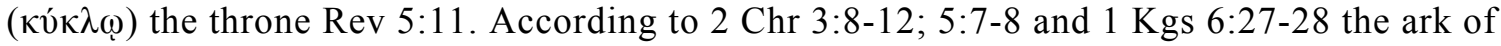
the covenant had to be in the center of the most holy place. For more on the Ark/throne as the symbol of God's presence, see this dissertation, page 243 note 93, (2) the four living creatures match the number of cherubim in Solomon's temple that are located in the most holy place (1 Kgs 6:23-28; 2 Chr 3:8-12; cf. Exod 37:6-9), and (3) the open door of Rev 4:1 (cf. Rev 3:7-8) explains how the temple of God is opened in heaven so that John could see the ark of the covenant in Rev 11:19, which is also in the most holy place.

${ }^{59}$ In Exod 27:20-21 (cf. Lev 24:1-4), the location of the lamp was in the holy place "outside the veil which is before the Testimony." Furthermore, "Aaron and his sons shall tend it from evening to evening before the Lord." Hence, the lamp is in the holy place before the Testimony, which means before the Lord who is in the most holy place. Although the lamps appear in the holy place "before the throne" (Rev 4:5), the open door of Rev 4:1 makes it such that the throne is visible from the holy place. Hence the lamps appear before the throne or in the presence of the throne. Moreover, the table of showbread (Lev 24:5-8), the altar of sacrifice (Exod 29:42), the killing of the sacrifice (Lev 1:11), blood on the horns of the altar of incense (Lev 4:7), grain offering (Lev 6:14), and other numerous references appear "before the Lord." Thus while "before the Lord" signifies the presence of God, it does not specify that his presence is necessarily located in the place where the articles were just mentioned. In other words, these references do not specify the location of his presence. In the same way the seven lamps before the throne reveal the location of the lamps in the holy place; this is not the same as saying that the throne is in the holy place any more than killing the sacrifice before the Lord meant that the throne was in the courtyard in Lev 1:11. "'Before' the throne is the traditional position of the golden lampstand of the holy place. 
We will now outline how the Lord God as the I AM (ô œ̂v) in Revelation is ascribed to the Trinity. I AM (ồv) is directly attributed to the Father in Rev 1:4, 4:8, 11:17 and 16:5. Rev 1:8 also contains the I AM; yet, even though certain scholars primarily attribute it to the Father, we can also clearly connected it to the Son when we combine it with Rev 22:13. ${ }^{60}$ We can also connect the I AM to the Holy Spirit by comparing the LXX of Zech 4:10 with Rev 5:6. In Zech 4:10, the seven eyes are the eyes

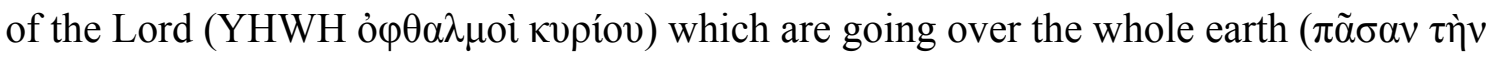
$\gamma \tilde{\eta} v)$ while in Rev 5:6 the seven eyes are the seven Spirits of God ( $\tau \dot{\alpha}[\dot{\varepsilon} \pi \tau \grave{\alpha}] \pi v \varepsilon v ́ \mu \alpha \tau \alpha$

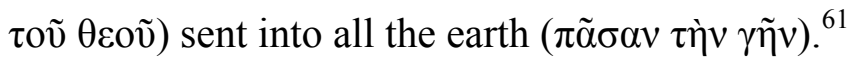

This lampstand is located in front of, or 'before,' the most holy place - the shrine where the throne is," Davis, The Heavenly Court Judgment of Revelation 4-5, 71 (cf. 124 note 19).

${ }^{60}$ The following evidences link the Son with I AM. ̋̀v is the present participle of

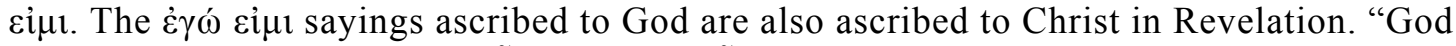

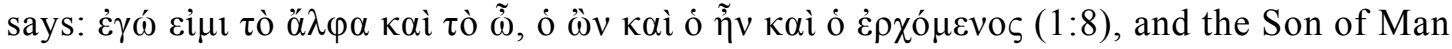

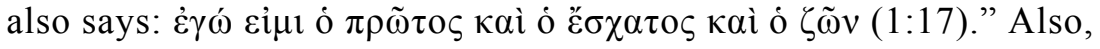

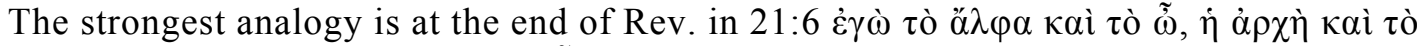

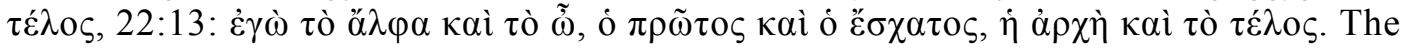
two I-sayings say exactly the same thing. In the one, however, the speaker is God, and in the other Christ.

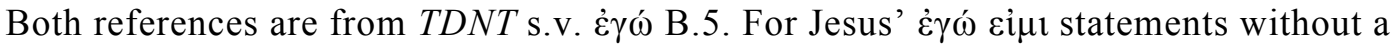

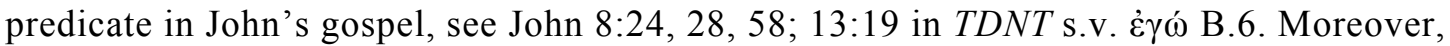
since Jesus is the King of Kings and Lord of lords (Rev 17:14), and since the Lord is the I AM, we conclude that Jesus is the I AM. See also my exegesis of Heb 12:18-29.

${ }^{61}$ For the comparison between Zech 4:10 and Rev 5:6, see Ingo Willy Sorke, "The Identity and Function of the Seven Spirits in the Book of Revelation" (PhD dissertation, Southwestern Baptist Theological Seminary, 2009), 230. Another way to connect the I AM with the Holy Spirit is by comparing the hearing formula in Ezek 3:27 (LXX) with the messages to the seven churches of Revelation. For instance, Ezekiel introduces the hearing

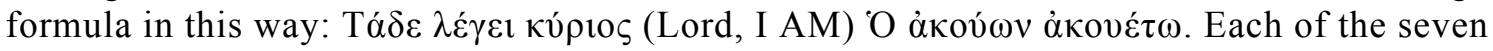

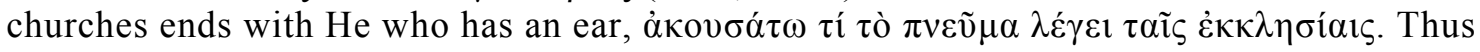

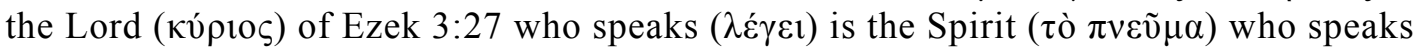
( $\lambda \dot{\varepsilon} \gamma \varepsilon 1)$ to the seven churches (Rev 2:7, 11, 17, 29; 3:6, 13, 22), Ibid., 71. Also, the Lord's utterances in Isa 6:8-10 and Psalm 95:7-11 are attributed to the Holy Spirit in Acts 28:25-27 and Heb 3:7-9 thereby equating the Lord (YHWH) with the Holy Spirit, see Canale "Doctrine of God," 134. Lastly, in 2 Cor 3:17 Paul states, "the Lord is the Spirit." Hence,

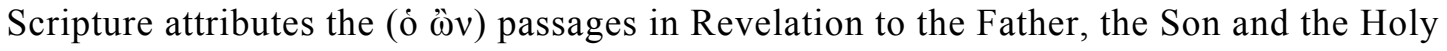
Spirit. See also my exegesis of Acts 2 for further connections between Being and the Spirit. 


\section{Analysis}

I will now briefly trace the effects of the temporal interpretation of God's Being on the Trinity. God's infinite analogous temporal Being grounds the being of the Father, the being of the Son and the being of the Holy Spirit as three separate and distinct realities as is shown throughout Rev 4-5. This discovery eliminates any ontological subordination on the part of the Son to the Father since the Son's being is not derived from the Father. The same applies to the sending of the Holy Spirit in Rev 5:6, which we should interpret in the context of salvation history and not that the Spirit was timelessly generated from the Father's being. However, the fact that Father and Son share one throne, ${ }^{62}$ and that Rev 11:15 and 22:3-4 refers to Father and Son with singular rather than plural pronouns, reinforces that they constitute the One God. ${ }^{63}$ The oneness between Christ and the Spirit is revealed in the following ways. In symbolic imagery, Rev 5:6 states that the Lamb has seven horns and seven eyes. However, the passage also states that the seven horns and seven eyes are the seven Spirits. This is an obvious reference to the divine attributes of omnipotence and omniscience. Here we have two distinguishable entities, namely the Lamb and the seven Spirits. However, the fact that the Lamb has seven horns and seven eyes which are the seven spirits of God emphasizes that they constitute the One God. The unity between the Lamb and the Spirit is also seen in the messages to the seven churches in which Christ speaks ( $\left.\lambda \varepsilon^{\prime} \gamma \varepsilon \imath\right)$ a message to each church

\footnotetext{
${ }^{62}$ See Rev 3:21 and Rev 22:3

${ }^{63}$ In Rev 11:15 we read, "The kingdoms of this world have become the kingdoms of our Lord and of His Christ, and He shall reign forever and ever!" Rev 22:3-4 states, "And there shall be no more curse, but the throne of God and of the Lamb shall be in it, and His servants shall serve Him. They shall see His face, and His name shall be on their foreheads." See Ekkehardt Mueller, "Christological Concepts in the Book of Revelation-Part 2: Christ's Divinity," Journal of the Adventist Theological Society 22 no. 1 (2011): 79.
} 
(Rev $2: 1,8,12,18 ; 3: 1,7,14)$. Yet, each message ends with an appeal to hear what the Spirit says $(\lambda \dot{\varepsilon} \gamma \varepsilon 1)$ to the churches $(\operatorname{Rev} 2: 7,11,17,29 ; 3: 6,13,22)$. Since the divine presence is revealed through God's words, the same message given by Christ and the Spirit gives evidence that they constitute the One God. Moreover, since Christ is in the sanctuary, his promise to be with the believers until the end (Matt 28:18-20) is accomplished by the Holy Spirit who is sent out into all the world (Rev 5:6). Hence, the presence of the Holy Spirit represents the presence of Christ giving further evidence that they constitute the One God. ${ }^{64}$

Since the revelation of the divine presence occurs in the context of the heavenly sanctuary, we will now explore how the sanctuary grounds the temporal relationship between the presence of the Father, the presence of the Son, and the presence of the Holy Spirit. However, before we proceed, we must keep in mind that the glorious heavenly scenes of Rev 4-5 are in the realm of immanence and not transcendence. ${ }^{65}$ Moreover, God's infinite analogous temporal Being (1) precludes the kind of ontological dichotomy between transcendence and immanence that is found in the other models, ${ }^{66}(2)$ assumes

${ }^{64}$ For further evidence of the oneness that exists between Jesus and the Holy Spirit, see Sorke's dissertation where he notes the parallels between Jesus and the Paraclete in the gospel of John, and the comparison of Jesus with the Spirit in the gospel of John, Sorke, "The Identity and Function of the Seven Spirits in the Book of Revelation," 235-236, 267.

${ }^{65}$ According to our exegesis of $1 \mathrm{Kgs} 8: 27$, the realm of God's transcendence lies beyond the universe and is an uncreated spatio-temporal reality to which only Father, Son and Holy Spirit reside in and experience. Accordingly, the Trinity is omnipresent in the realm of transcendence. This means that the glorious heavenly scenes of Rev 4-5 are in the realm of immanence.

${ }^{66}$ In classical theism such as we find in the Sacramental model prior to Vatican II and in the Kerygmatic model, transcendence is always timeless and ontologically distinct from creation, which is material and historical. In panentheism, which we find in the Sacramental model after Vatican II and in the Emergent portion of the Charismatic model, transcendence is subsumed within immanence meaning within creation. 
that the Trinity is transcendent and immanent all at the same time, ${ }^{67}$ (3) that God's

presence in immanence, that is in the universe, is permanent, ${ }^{68}$ and (4) that God's infinite analogous temporal Being in the heavenly sanctuary is the starting place for determining that transcendence is not timeless but involves an uncreated spatio-temporal reality that only the Trinity shares.

We will first begin our analysis of Father in the worship scenes in Rev 4 and 5 by noting the entities that are linked to him. The sanctuary temporally grounds the relationship between the Father, the articles of furniture that are directly associated with him, and the actions concerning which he is directly involved in the heavenly sanctuary. For instance, the Father is inextricably linked with the throne in the book of Revelation, ${ }^{69}$ which is most likely located in the most holy place ${ }^{70}$ of the heavenly sanctuary. Here we

${ }^{67}$ See Gulley, Systematic Theology: God as Trinity, 64.

${ }^{68}$ See 1 Kgs 8:27; 2 Chr 2:6; 2 Chr 6:18; Jer 23:23-24; Psalm 139:7. In other words, God does not exclusively dwell in transcendence (outside the universe) and then on occasion visit the universe in immanence. Instead, his presence occupies the entire universe.

${ }^{69}$ The following passages portray the Father on the throne in Revelation, see Rev 1:4; $3: 21 ; 4: 4-6,9-10 ; 5: 1,6-7,11,13 ; 6: 16 ; 7: 9-11,15,17 ; 8: 3 ; 11: 16 ; 12: 5 ; 14: 3,5 ; 16: 17$; $19: 4-5 ; 20: 11 ; 21: 5 ; 22: 1,3$. Furthermore, outside of the Revelation passages in the NT, the right hand is located right beside the throne where the Father sits in the following passages, see Acts 2:34; Heb 8:1; 12:2. The right hand is used in the following passages, which are assumed to be by the throne even though not explicitly stated, see Mark 16:19; Acts 2:33; 5:31; 7:55-56; Rom 8:34; Eph 1:20; Heb 1:3, 13; 10:12; 1 Pet 3:22.

${ }^{70}$ The first line of evidence for the throne in the most holy place of the sanctuary comes from the OT. Treiyer notes that the throne of God is integrally connected with the footstool of the heavenly king in the following passages, $1 \mathrm{Chr} 28: 2$; Psalm 99:1, 5; 132: 78; Lam 2:1; and Isa 60:13. He then states that both the throne and footstool "was represented by the ark of the testimony which was found in the Most Holy Place." Treiyer, The Day of Atonement and the Heavenly Judgment from the Pentateuch to Revelation, 438-439. The ark also represents the foundation of the throne where God dwells between the cherubim, Exod 25:22; 1 Sam 4:4; 6:2; 2 Kgs 19:15; Isa 6:1; Jer 3:16-17; and Ezek 43:7, Ibid., 35 note 40. Treiyer also links the throne of God with the place and foundation (מקום) of the sanctuary, see Jer 17:12; Dan 8:11 cf Psalm 89:14 and 97:2, Ibid., 440. De Souza furthermore links Dan 7 and 8 together. Hence an attack on the place of God's sanctuary in heaven by the little horn in Dan 8:11 is also an attack on the law of God that is in the ark of the covenant by the same power in Dan 7:25, de Souza, "The Heavenly Sanctuary/Temple Motif in the 
have a specific article of furniture that is located in a specific location. Moreover, he has a scroll in his right hand that is sealed with seven seals ( $\operatorname{Rev} 5: 1,7)$. There is the Lamb, the incarnate Christ, ${ }^{71}$ who takes the scroll from him, to open its seals, and to read real messages communicated in symbolic language ( $\operatorname{Rev} 5: 7,9 ; 6: 1-17 ; 8: 1)$. Consequently, the elders cast their crowns and direct their worship toward the specific location of the throne where the Father is seated and not to some ubiquitous and unidentifiable nonentity (Rev 4:9-11). Hence, the Revelation passages do not describe the Father to be omnipresent in immanence, ${ }^{72}$ even though he is omnipresent in transcendence. Since there is no dichotomy between Being and appearance, the appearance of the one seated on the throne constitutes a real being and presence. Hence, even while the Father accommodates himself by sitting on a throne, his appearance is the reality. These are not spiritualized descriptions that are mere human constructs of timeless realities. Instead, there is an analogy between a human being and a divine being, between human and

Hebrew Bible," 459. The second line of evidence comes from the fact that the throne is in the center of all the activities taking place in Rev 4-5. The throne is in the center of the four living creatures, the twenty-four elders and the myriads of angels, see Rev 4:4, 6; 5:11. Moreover, according to $2 \mathrm{Chr} 3: 8-12 ; 5: 7-8$ and $1 \mathrm{Kgs} 6: 27-28$ the ark of the covenant, which represents the throne, had to be in the center of the most holy place. R. Dean Davis also states that the throne could be the equivalent of "the ark of the covenant in the most holy place of the temple (Exod 25:22, $1 \mathrm{Kgs}$ 6:19; $1 \mathrm{Kgs}$ 8:27-29)." Davis, The Heavenly Court Judgment of Revelation 4-5, 39 (cf. 21, 41, 119). Regarding the earthly temple Bouyer notes,

We are thus brought back again to the emptiness of the Holy of Holies that is only emphasized by the whole structure of the ark itself. Speaking properly, it is less a chest than a throne, the throne of an invisible presence, but one which is attested by the cherubim prostrate before it (Louis Bouyer, Rite and Man, 162).

${ }^{71}$ The implication is clear: if the Lamb refers to a real entity, then one must conclude that the One on the throne is also a real entity distinct from the Lamb.

${ }^{72}$ This description of the Father seated on the throne seems to suggest that throughout much of salvation history he is not pictured as omnipresent in immanence, see Psalm 110:1; Mark 16:19; Acts 2:30, 33-34; Eph 1:20; Col 3:1; Heb 1:3; 8:1; 10:12; 12:2; 1 Pet $3: 22$; Rev $1: 4 ; 3: 21 ; 4: 2-6,9-10 ; 5: 1,6-7,11,13$. 
divine sitting, ${ }^{73}$ human and divine thrones, human and divine right hands, human and heavenly scrolls, and earthly thrones and the one seated on the throne. ${ }^{74}$

Furthermore, God's infinite analogous temporal Being in Rev 4:8 assumes that the presence of the Father neither exists in the past, nor in the future: The same applies to the Son and the Holy Spirit since the I AM applies to them as well. This deduction is based on the sanctuary setting of Rev 4-5 that grounds the temporal interpretation of the relationship between the Trinity and creation. The spatio-temporal framework that all realities are immutably connected to holds them together in such a way that they all pass through the sequence of past, present and future at the same time. Accordingly, the divine presence can no more exist in the past or in the future than can creation.

As I begin to analyze what Rev 4-5 reveals about the Lamb, I will justify the reasons for using God's infinite analogous temporal Being and the heavenly sanctuary as presuppositions to interpret (1) Christ as a divine/human being, (2) the relationship between Christ's divine and human natures, and (3) outline the implications for his presence.

The throne is mentioned nineteen times in Rev 4-5. The justification for employing God's infinite analogous temporal Being and the heavenly sanctuary as foundational presuppositions is based on the little horn's attack on God's throne, his

${ }^{73}$ The examples in the book of Revelation that refer to God sitting on the throne such as Rev $5: 1 ; 6: 16 ; 20: 11 ; 19: 4$ cf. $7: 10 ; 12: 5$ "indicate that John was not reluctant to use anthropomorphic language when referring to God sitting on the throne." Ranko Stefanovic, Revelation of Jesus Christ: Commentary on the Book of Revelation. Berrien Springs, MI: Andrews University Press, 2002), 189. Unfortunately, the timeless conception of God lies at the basis for the conclusion that God sitting on a throne is anthropomorphic language. As a result, the language used to describe the act of sitting and the throne does not point to real events that are analogous to human sitting and human thrones.

${ }^{74}$ King She correctly notes, "The denial of classical analogia entis does not deny the value of analogy but simply calls for a redefinition and reconstruction." King L. She, The Use of Exodus in Hebrews, 84. 
sanctuary and the implications for the three issues I raised above. In Dan 8:11 the little horn casts down the place (מכון) of God's sanctuary. In Psalm 89:14[15] and 97:2 righteousness and justice constitute the foundation (מכון) of his throne. ${ }^{75}$ Moreover, God's throne is located where the ark of the covenant is, which is in the most holy place. The similarities between Dan 7 and 8 also suggest that the little horn's attack in Dan 7:25 is an attack on the law of God located in the most holy place of the heavenly sanctuary. Hence, when we combine Dan 7 and $8,{ }^{76}$ an attack on the place of his sanctuary is an attack on his throne, his law, and the nature of his presence. The sanctuary thus links all these together.

Since, the attack on the place of his sanctuary (Dan 8:11) is the heavenly sanctuary and not the earthly, ${ }^{77}$ and since the little horn arose from the western Greeks in Italy — the birthplace of Greek philosophy — and not from Alexander's empire, ${ }^{78}$ the

${ }^{75}$ See de Souza, "The Heavenly Sanctuary/Temple Motif in the Hebrew Bible," 459.

${ }^{76}$ Medo-Persia is symbolized by the bear that raised itself up on one side in Dan 7:5 and by the ram that had two horns with the higher horn coming up last in Dan 8:5, 20 . Greece is symbolized by a leopard with four wings and four heads in Dan 7:6 and by the male goat in Dan 8:5; and the reference to the notable horn between its eyes is none other than Alexander the Great (Dan 8:21). The pagan Roman empire is symbolized by the dreadful and terrible beast with iron teeth and with ten horns in Dan 7:7 and the Roman Church is symbolized by the little horn in Dan 7:8. In Dan 8:9-14 the little horn symbolizes the Roman empire and the Roman Church. In Dan 7:25 the little horn intends to change times and laws and in Dan 8:11 he casts down the place of God's sanctuary, meaning the foundational hermeneutical role that the sanctuary plays in theology. For the connection between Dan 7:25 and 8:11, see de Souza, "The Heavenly Sanctuary/Temple Motif in the Hebrew Bible," 459.

${ }^{77}$ de Souza points out that the sanctuary is the heavenly, and that the attack must be a metaphorical and theological attack instead of a literal or military attack on the earthly sanctuary. See Ibid., 459.

${ }^{78}$ See Edwin de Kock, 7 Heads and Ten Horns (Edinburg, TX: Edwin de Kock, 2012), 145-160. De Kock outlines the following historical, philosophical, contextual and grammatical reasons for why the little horn arose from the western Greeks in Italy and not from Alexander's empire. The first concerns the number of Hellenistic kingdoms. In 311 B.C. there were actually five kingdoms after Alexander's death, and only ten years later in 301 B.C. were the five reduced to four. However, from 281 B.C. historians now 
nature of the attack is philosophical. Yet, this should not detract from the political and military influence of the little horn that resulted in much persecution (Dan 8:9, 23-25). Edwin de Kock reveals from history and from Scripture how the western Greeks profoundly influenced the Roman Church $^{79}$ through philosophers like Parmenides and Pythagoras whose concept of timeless Being was assumed by the Sacramental, Kerygmatic and Charismatic models. The assumption of timeless Being not only nullifies God's infinite analogous temporal Being, it also renders groundless the role of the sanctuary, the throne and God's law from functioning as the hermeneutical framework from which to construct Christ's presence. The reason is that spatio-temporal structures are mere Platonic shadows that are culturally conditioned with no hermeneutical

unanimously affirm only three substantial kingdoms: The Antigonids who ruled in Macedonia and Greece, the Seleucids in Asia and Syria, and the Ptolemids in Egypt. These controlled the eastern Mediterranean until the Roman conquest, Ibid., 145-146. This produces a problem since Dan 8 refers to four kingdoms and not three. In order to solve this historical problem, expositors have pointed out that on the basis of Hebrew grammar the little horn actually arises from one of the winds rather than from one of the horns. Although de Kock acknowledges the validity of this grammatical point, he points out several reasons for why the little horn can simultaneously proceed from a compass point and from a horn. Ibid., 150-151. First, the rise of recent historical information not available in centuries past (Ibid., 147-150) depicts the close historical and philosophical connections between Greece and Rome leading to the discovery of the western Greeks in Italy. Second, the prophetic connections between Greece and Rome outlined in Dan 2, 7, 8, 11, and Rev 13 provide the biblical context for establishing the close connection between Greece and Rome (Ibid., 99104) providing the context for the rise of the little horn in a Grecian context, Ibid., 151. Third, since the four horns were destined to come up "toward the four winds of heaven" (Dan 8:8), one of them must lie in the west. However, all of the Hellenistic kingdoms of Alexander were situated to the east of the Greek peninsula, Ibid., 152-153. Fourth, the prophecy does not state that the original horn was split into four. It instead points out that when the great horn was broken or plucked up (Dan 11:4), four horns came up instead of it toward the four winds of heaven (Dan 8:8). The focus then is on the Greeks as a whole and not just on the kingdoms that resulted from the breakup of Alexander's empire, Ibid., 152153. Thus, since Greek philosophy began with the western Greeks, and since the little horn arose from there, the attack on the heavenly sanctuary is a philosophical attack.

${ }^{79}$ Edwin de Kock brings out the close relationship between Greece and Rome in history and in Scripture, and also reveals the massive influence of Greek philosophy on the Roman Church through history as well as through the book of Daniel chapters 2, 7, 8, 11, and Revelation chapter 13. Edwin de Kock, 7 Heads and Ten Horns, 99-144. 
authority. ${ }^{80}$ Thus, the solution to the little horn's attack is for Bible students to replace timeless Being with God's infinite analogous temporal Being from Scripture so that they can employ the heavenly sanctuary as the hermeneutical foundation from which to construct a Scriptural view of Christ's presence.

The description of the Lamb in Rev 5:6 is a symbol referring to Christ's divine/human nature. ${ }^{81}$ While his humanity is evident through the fact that he was slain and that his blood is the means of redeeming the saints (Rev 5:6, 9-10, 12), the initial evidence of his divinity is that he is the recipient of universal worship. ${ }^{82}$

I will now employ the throne as the symbol of the controversy between Christ and Satan over God's unchangeable law in order to further establish Christ's divinity. The phrase "in the midst of the throne" (Rev 4:6; 5:6) is the precise location where we first see the Lamb (Rev 5:6). According to Grabiner, "in the midst of the throne" signifies the presence of God (Ezek 1:4, 5, 14 LXX) from where Lucifer, the covering cherub was

\footnotetext{
${ }^{80}$ When timeless Being is assumed, the sanctuary is reduced from a spatio-temporal reality to metaphor and a culturally conditioned phenomenon. For an explanation of how timeless Being renders groundless the hermeneutical role of the sanctuary, see Fernando Canale, "Philosophical Foundations and the Biblical Sanctuary," 183-206.

${ }^{81}$ The description of the Lamb is obviously a figure that stands for Christ. At one point Christ is in a standing position bearing the marks of His crucifixion (Rev 5:6). Next, Christ "came and took the scroll out of the right hand of Him who sat on the throne" (Rev $5: 7)$. Here are the evidences for why the Lamb is a symbol of Christ: (1) the Lamb is standing, (2) the Lamb has seven horns and seven eyes, (3) the Lamb takes the scroll out of the hand of Him who sat on the throne, (4) the Lamb receives worship from the 24 elders and 4 living creatures because He has redeemed humans, and (5) the sanctuary setting helps us to understand what John the Baptist understood when referring to Jesus he stated, "Behold the Lamb of God who takes away the sin of the world" (John 1:29).

${ }^{82}$ Twice, John is prohibited from worshiping an angel who admonishes him to worship God. See Rev 19:20 and 22:9. Moreover, there are seven hymns in the book of Revelation, two of which are directed exclusively to Jesus (Rev 5:9-10,12), and two that are directed to both the Father and the Son (Rev 5:13 and 7:10). See Mueller, "Christological Concepts in the Book of Revelation-Part 2," 74-79. The implication is clear; Christ must be divine.
} 
described as walking "in the midst" (Ezek 28:14) of the stones of fire ${ }^{83}$ It was from this position in the divine council that Satan made his accusations against the throne, which is synonymous with the ark of the covenant that contains the law of $\operatorname{God}^{84}$ that perfectly expresses the character of God. ${ }^{85}$ In Isa 14:13, Lucifer sought to exalt his throne-his administration - above the stars of God. Hence, the controversy revolves around the throne as the symbol of God's right to rule based on his unchangeable law. After Adam's sin, the only way to save the human race and at the same time maintain the throne and the unchanging integrity of the law and character of God is by the death of One who is equal to the law and who is the Creator of the human race (John 1:1-3; Heb 1:10) and can thus represent all of us (1 Cor 15:20-22; cf. Heb 7:9-10). Lucifer's absence in Rev 4-5 from his prior position in the midst of the throne signifies his utter defeat by the Lamb. ${ }^{86}$

${ }^{83}$ God's throne is mentioned 19 times between Rev 4-5. "The throne is a powerful image within the book, pointing to the conflict theme revolving around God's right to rule.... The contrast of Satan's throne following the first mention of God's throne (Rev 1:4) highlights the spiritual conflict that is inherent in the book." Steven Grabiner, Revelation's Hymns: Commentary on the Cosmic Conflict (New York: Bloombury, 2015), 38-39.

${ }^{84}$ The passage in Rev 12:7 notes that there was war in heaven, and almost the rest of the chapter notes that this war that began in heaven has continued on earth. According to Rev 12:17 the dragon attacks the law of God and those who adhere to it. In Dan 8:11 the little horn seeks to destroy the place of God's sanctuary where God's presence is located, and in Dan 7:25 the little horn attacks God's law.

${ }^{85}$ God is love (1 John 4:8) and his law is love (Rom 13:9-10); God is perfect (Matt 5:48) and his law is perfect (James 1:25; Psalm 19:7), God is holy (Rev 4:8) and his law is holy (Rom 7:12), God is eternal (Psalm 90:2) and his law is eternal (Psalm 111:7-8), God is truth (Deut 32:4) and his law is truth (Psalm 119:142, 151), God is good (Luke 18:19) and his law is good (Rom 7:12), God is spiritual (John 4:24) and his law is spiritual (Rom 7:14), God is just (Rom 3:26) and his law is just (Rom 7:12).

${ }^{86}$ Concerning the phrase "in the midst of the throne" (Rev 4:6; 5:6). This phrase according to Grabiner signifies the presence of God (Ezek 1:4, 27 LXX). Also, the covering cherub of Ezek 28:14 walked "in the midst" of the stone of fire and he will be destroyed from the midst of the stone of fire (Ezek 28:14 LXX). From Revelation's perspective, this exalted angel is no longer portrayed as part of the divine council. It was from the privileged position "in the midst" that the covering cherub first engaged in his work of deception and rebellion, seeking to supplant God's government. Yet, from Revelation's perspective he is conspicuously absent from his former position "in the midst and around the throne" from 
Hence, the vision of the Lamb as it had been slain unmistakably reveals Christ as a divine being whose life and death has merit to atone for the sins of the world while at the same time maintain the immutability of the law of God and the integrity of the throne. No other being in the universe but a divine one could have accomplished this. Moreover, the $2^{\text {nd }} 3^{\text {rd }}$ and $4^{\text {th }}$ Commandments in the law of God interpret Christ's divinity as essentially distinct from creation while at the same time his divinity is linked with his moral character. ${ }^{87}$ This differs significantly from panentheism where God is considered to be a non-entity that is impersonal and amoral; it also differs from the timeless analogy of being promulgated by thirteenth century Roman Catholic theologian Thomas Aquinas.

In addition to establishing and interpreting divinity, the throne and the great controversy also broadly interpret Christ's human nature as one that is free to choose outside of the divine will. Lucifer's basic argument in his polemic ( $\pi$ ó $\lambda \varepsilon \mu$ $\mu$ ) against God (Rev 12:7) revolved around overthrowing God's law (Rev 12:17) and establishing his own administration (Isa 14:13). Since worship is such a vital part of the book of Revelation, intelligent agencies must not be coerced or metaphysically determined to worship either God or Satan. Hence, in taking on human nature Christ must be free to go against the divine will and thus place himself and the throne at risk. As a matter of fact, the phrase "you shall not" in the law of God presupposes the possibility of doing the very things that the law prohibits; otherwise the prohibition makes no sense. This interpretation of a human nature capable of disobeying the divine will is metaphysically

which he made his accusations against God. See Grabiner, Revelation's Hymns, 81-82. For other examples of the conflict between Christ and Satan from the Hymnic pericopes in Rev 4:8-11 and 5:9-14, see Ibid., 84-104.

${ }^{87}$ See my previous exegesis of Lev 19:30; 26:1-2; Exod 19-20; Deut 4-5; 1 Kgs 8:1266 and $2 \mathrm{Chr} 5-7$ in Chapter 5 for how the law of God further interprets the divine presence. 
impossible for Christ in the other models. Moreover, the use of the word Lamb to refer to the Son of God in Rev 22:3 after the eradication of sin reveals that he will retain his human nature forever. ${ }^{88}$ This conclusion is based on the sanctuary symbol of a lamb that John first applied to Christ before the cross (John 1:29), during his heavenly ministry $(\operatorname{Rev} 5: 6)$, and after the elimination of $\sin$ from the universe $(\operatorname{Rev} 22: 3) .{ }^{89}$

I will now briefly analyze the relationship between Christ's divine and human natures in the incarnation. God's inifite analogous temporal Being allows the sanctuary to temporally ground the relationship between the divine presence and all realities including heavenly and earthly. The result is that the divine presence and every other reality temporalize themselves and interact with each other. While each reality interacts with the others, it maintains its own essential being without becoming confused with the essential being of other realities. Neither is the being of any other reality compromised during the interaction in such a way that it loses the distinct characteristics of its reality. This lays the groundwork for the sanctuary to ground the temporal relationship between the divine

${ }^{88}$ This is in complete contrast to Aelred Cody who closely applies Plato's cosmology to Christ's essential divine nature that hermeneutically controls all aspects of salvation. Moreover, "Christ as man is made completely perfect ( $\tau \varepsilon \lambda \varepsilon 1 \varsigma)$ when He reaches His celestial

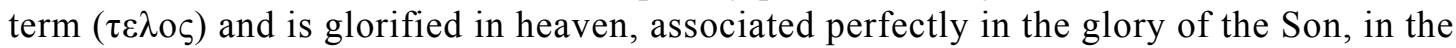
divine presence," Aelred Cody, The Heavenly Sanctuary and Liturgy in the Epistle to the Hebrews, 89, cf.91.

${ }^{89}$ In Rev 21:3 we read, "The tabernacle of God is with men, and He will dwell

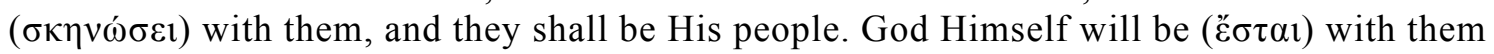
and be their God." There was a visible real presence of Christ among His disciples in the Gospels, and there is a visible real presence of the Lamb (Rev 21:3;22:3) when sin is finally dealt with in the hereafter. The Greek verb to dwell is used before (John 1:14) and after the destruction of $\sin (\operatorname{Rev} 21: 3$ ). Moreover, the Lamb is used both before (John 1:29) and after sin (Rev 22:3) to denote Christ's human nature. Since the description of the Lamb, which denotes Christ's visible real presence remains unchanged we conclude that He will forever retain His human nature. 
and human aspects of the Lamb in the incarnation. As a result, the I AM became flesh. ${ }^{90}$ This necessarily involves a change in Christ's being during the incarnation without involving a contradiction at the level of Being. This also allows the divine aspect of his nature to retain all of the essential elements of divinity as well as to retain all essential aspects of humanity without compromising either of them in the incarnation as the Sacramental model did.

I will now briefly examine the implications for the issues concerning the presence of the Lamb. In the early centuries of the Sacramental model, timeless Being was the driving force for the view that Christ was omnipresent after the incarnation. However, although the Lamb retains his omnipresence in transcendence, his incarnation and his specific location in the midst of the throne, and in the midst of the four living creatures and elders ( $\operatorname{Rev} 5: 6$ ) reveals that he is a real divine/human being whose real presence ${ }^{91}$ is currently in the most holy place where he is standing. Hence, these indicators that point to specific locations where the Lamb is present reveal that he is not omnipresent in immanence.

We will now employ the heavenly sanctuary's symbols that are linked with the Holy Spirit as the hermeneutical lens through which to analyze what Rev 4-5 reveals about the nature and function of the Holy Spirit and the issues related to presence and omnipresence. In Rev 1:4 and 4:5 the Holy Spirit is introduced from his close association

${ }^{90}$ See my exegesis of the divine presence in Heb 12:18-29.

${ }^{91}$ Christ's real presence is the reality, since there is no longer any dichotomy between Being and appearance. For those who make a dichotomy between Being and appearance, see Canale A Criticism of Theological Reason: Time and Timelessness as Primordial Presuppositions, 352-364. 
to the throne. From this it would seem that the function ${ }^{92}$ of the Spirit is inextricably linked with all that the throne encapsulates. For instance, although the Spirit is also the I $\mathrm{AM}$ and thus a divine being worthy of worship, yet he is not the recipient of the kind of universal worship that the Father and Son receive in any of the seven hymns in Revelation. ${ }^{93}$ Accordingly, as one who is before the throne instead of on it, his function is to exalt Christ who shares the throne with his Father. Furthermore the Spirit's close association to the throne reveals that his purpose is to work in close association with Christ (Rev 5:6) ${ }^{94}$ and to draw attention to Christ's victory concerning the immutability of the law in the ongoing controversy over who has the right to rule and thus sit on the throne. This controversy is further illustrated by the phrase the "seven Spirits of God" $(\operatorname{Rev} 3: 1 ; 4: 5 ; 5: 6)$ that are sent out into all the earth (Rev 5:6). For example, under the hermeneutical direction of God's infinite analogous temporal Being, the Spirit's being is not derived from the Father since he is also the I AM. ${ }^{95}$ Thus, within the great controversy framework, there is the Holy Spirit who is before the throne and there is

${ }^{92}$ Sorke points out that the location of the throne from where the Spirit is introduced and identified "forms a significant facet of defining the Spirits' identity and function." Sorke, "The Identity and Function of the Seven Spirits in the Book of Revelation," 279 cf. 228.

${ }^{93}$ Of the seven hymns in the book of Revelation, none are directed to the Holy Spirit. The first in Rev 4:8 is sung to the Father, the second in Rev 4:11 is also to the Father, the third in Rev 5:9-10 is to Jesus, the fourth in Rev 5:12 is also to Jesus, the fifth in Rev 5:13 is directed to both Father and Son, the sixth in Rev 7:10 is directed to Father and Son, and the seventh hymn in Rev 7:12 is directed to the Father. See Mueller, "Christological Concepts in the Book of Revelation-Part 2: Christ's Divinity," 74-79.

${ }^{94}$ The passage in Rev 5:6 pictures the Lamb "having ("丷 $\left.\chi \omega v\right)$ seven horns and seven eyes, which are the seven Spirits of God.” BDAG, s.v. "̈ $\chi \omega$ notes that the participle may mean to stand in a close relationship to someone, or to be closely associated with that person. Thus, the Spirit is in very close relationship to Christ and bears no relation to Satan and the work that he is doing to undermine God's right to rule according to the unchanging nature of God's law.

${ }^{95}$ See this dissertation pages 319 footnote 61 . 
Satan and his evil spirits whose thrones (Rev 2:13; 13:2) are in opposition to God's throne.

In addition to the throne imagery, the seven eyes of the Spirit (Rev 5:6) denoting intelligence, and the moral messages sent to the seven churches that require an ethical response, ${ }^{96}$ speak to the morality and personhood of the Spirit.

Furthermore, on the basis of my previous exegesis of Exod 3:14-15, the descriptions of the Holy Spirit in symbolic language such as seven lamps of fire (Rev 4:5) and having seven horns and seven eyes (Rev 5:6) indicate the Spirit's function; they do not speak to the issue of his essence or to the issue of Being. Accordingly, unlike the real visible presence of the Father and Son who are the recipients of universal worship in Rev 5:11-14, these symbols of the Holy Spirit may actually point to his invisible real presence. In this sense, the visible symbol of fire would alert John and the reader to the invisible real presence of the Holy Spirit who is before the throne (Rev 4:5) and at the same time throughout all the earth (Rev 5:6).

I will now analyze how the Spirit relates to the issues of presence and omnipresence. In Rev 1:4 and 4:5, the Spirit is before the throne, which symbolizes God's Ten Commandments. ${ }^{97}$ The law of God is a hermeneutical tool that interprets the Spirit's omnipresence within the wider temporal framework of transcendence and immanence. For instance, the $2^{\text {nd }}$ commandment prohibits one from embedding the being of the Spirit in creation such as in panentheism. This eliminates the timeless view of

${ }^{96}$ In fact, each of the seven churches ends with "He who has an ear, let him hear what the Spirit says to the churches" (Rev 2:7, 11,17, 29; 3:6, 13,22). The ability to speak is a characteristic that persons possess. See Sorke, "The Identity and Function of the Seven Spirits in the Book of Revelation," 72.

${ }^{97}$ See this dissertation page 243 footnote 93 for the link between the ark/throne and the Ten Commandments. 
transcendence within immanence. The $3^{\text {rd }}$ commandment temporally grounds the relationship between the name/Being of the Spirit and his moral character (Exod 34:5-7). The $4^{\text {th }}$ commandment also places an essential distinction between the being of creation and the Spirit's being through God's power to create the universe; and it further links the Spirit's being with time instead of with matter. Although the Spirit is omnipresent, the revelation of his invisible, personal, moral presence in the earth (Rev 5:6) occurs through the Scriptures. ${ }^{98}$

\section{Liturgist}

As we now begin our description and analysis of the liturgist, we will take into account the ways in which God's infinite analogous temporal Being and the sanctuary significantly shape Scripture's view of the liturgist in the following NT passages.

Luke 4:16-30; Acts 2:1-47; 13:13-52

\section{Description}

As Jesus begins his ministry in Luke 4 he is the main liturgist ${ }^{99}$ whose legitimate claim to be the Messiah constitutes his authority as liturgist. Furthermore, the word Lord (кupíov) in Luke 4:18 and the context of the Sabbath that grounds the temporal relationship between God and humans provides us with the proper framework to interpret

${ }^{98}$ See my exegesis of the liturgical actions in Rev 4-5. Moreover, in the letters to the

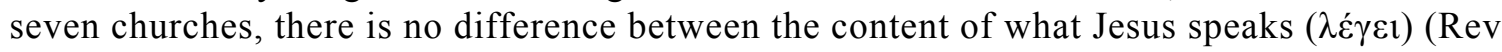
$2: 1,8,12,18 ; 3: 1,7,14)$ to each individual church and what the Holy Spirit speaks $(\lambda \varepsilon \dot{\gamma \varepsilon \varepsilon})$ to the churches (Rev $2: 7,11,17,29 ; 3: 6,13,22)$.

${ }^{99}$ In addition to Jesus as the main liturgist, Luke 4:17 records that there was a "deacon, or chazzan, whose duty it was to remove the sacred scrolls from the ark and hand them to the reader, and to return them to the ark at the close of the reading. Thus in harmony with synagogue ritual, the chazzan took the roll of the Prophets from the ark, removed the cover and handed it, unopened, to Jesus." $S D A B C$ s.v. Luke 4:17 
the divine and human natures of Jesus as the liturgist in this narrative. ${ }^{100}$

The main liturgist on the Day of Pentecost (Acts 2:14-40) is the apostle Peter whose authority as liturgist does not merely reside in being one of the twelve whom Jesus chose; neither is Peter's authority derived from an alleged apostolic succession that is based on Matt 16:18. ${ }^{101}$ Instead as a liturgist who exercises legitimate authority, Peter's confession, repentance and willingness to spend time with Jesus (Acts 4:13) was necessary in making Jesus' choice effectual. Moreover, our exegesis of the divine presence in Acts 2 points to God's infinite analogous temporal Being. Accordingly, this points to Peter as a temporal being, which is supported by the fact that righteous king David is still in the grave awaiting the resurrection. ${ }^{102}$

Moreover, a temporal view of human nature combined with the use of the Sola Scriptura principle leads to the deduction that Hades (Acts 2:27, 31) is the grave, and that the soul represents the integrated nature of a temporal being. This is based on Peter's reference to the LXX of Psalm 16:9-10 where "soul" refers to the whole person including

${ }^{100}$ For the Sabbath as the ground of the temporal relationship between God, humans and the cosmos, see this dissertation pages 229-234, 253-256, 264-268. See my exegesis of Heb 12:18-29 and Rev 4-5 of the section on the divine presence for an application to Christology.

${ }^{101}$ Aside from the exegetical problems involved in interpreting Peter as the rock of Matt 16:18, apostolic succession can only be valid through the sacrament of holy orders at ordination, which assumes the timeless view of God's being and actions and the timeless view of the soul that is ontologically enhanced at ordination. Thus, once the timeless view of God and humans is replaced by God's infinite analogous temporal Being and the temporality of humans in Scripture, the foundation and basis upon which apostolic succession depends collapses.

${ }^{102} \mathrm{Body} / \mathrm{soul}$ dualism is the cause of the teaching that the body is the prison house of the timeless soul that is released at death, which greatly undermines the reality of a bodily resurrection. See Oscar Cullmann, Immortality of the Soul or Resurrection of the Dead? The Witness of the New Testament (New York: The Macmillan Company, 1958); John R.W. Stott and David Lawrence Edwards, Essentials: A Liberal-Evangelical Dialogue (London: Hodder \& Stoughton, 1988), 319-320; Bacchiocchi, Immortality or Resurrection? A Biblical Study on Human Nature and Destiny, 110-114. 
all the components that make up the heart and the flesh. ${ }^{103}$

In the Acts 13:13-52 passage, the apostle Paul is the main liturgist whose authority as liturgist is derived not only by direct revelation on the road to Damascus ${ }^{104}$ but also by the Holy Spirit working through the church in Antioch. Luke informs us that as Barnabas and Saul ministered ( $\lambda \varepsilon \imath \tau o v \rho \gamma o v ́ v \tau \omega v)$ to the Lord, the Holy Spirit stated that they should be set apart by the laying on of hands ${ }^{105}$ for the work of taking the gospel to the Gentiles (Acts 13:1-3). In our exegesis of the divine presence, the words Lord and the Holy Spirit in Acts 13:2 refer to God's infinite analogous temporal Being. Also the word ministered ( $\lambda \varepsilon \imath \tau o v \rho \gamma o v ́ v \tau \omega v)$ in Acts 13:2 occurs in a sanctuary context that describes the activities of the priests in the OT. ${ }^{106}$ Its usage in Acts 13:2, however, denotes a different kind of priestly work comprised of a prophetic teaching ministry that includes prayer and fasting performed by prophets and teachers. ${ }^{107}$ This is under the direction of the Holy

${ }^{103}$ The passage in Acts 2:27, 31 obviously refers back to Psalm 16:10 where hades in the LXX is equal to Sheol. Commenting on Psalm 16:10 Galenieks points out that "therefore" in Psalm 16:9 refers to the whole person, which is evident in the following statement: "my heart is glad," "my glory rejoices," and "my flesh will rest in hope." Eriks Galenieks, "The nature, function, and purpose of the term Sheol in the Torah, prophets, and writings" (PhD dissertation, Andrews University, 2005), 322. These aspects of humanity comprise the soul, which is the whole person, Ibid., 326. Furthermore, Galenieks states, "both terms Sheol and...("pit") comprise a synonymous parallelism and both refer to the grave." Ibid., 324-325.

${ }^{104}$ See Acts $9: 1-8 ; 22: 6-21 ; 26: 12-18$ where Paul's conversion is recorded, and where God tells him that he will make him a minister and send him to the Gentiles.

${ }^{105}$ In 1 Tim 4:14 Paul counseled Timothy not to neglect the gift he received "with the laying on of the hands of the eldership." Setting apart new elders by a council of elders seemed to be a common practice in the NT. See also Acts 14:23 where Paul and Barnabas appointed elders in every church.

${ }^{106}$ See LXX Num 4:12, 26; 7:5; 18:2, 4, 6; and Heb 10:11 for the connection between

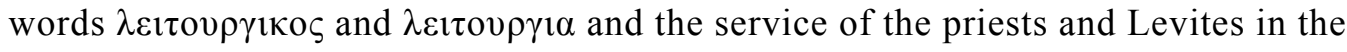
sanctuary.

${ }^{107}$ The Acts 13:2 reference is the first passage "to attest a transfer of the important OT cultic term to the purely spiritual Christian service of God... where $\lambda \varepsilon \varepsilon \tau o v \rho \gamma \varepsilon \tilde{\imath} v$ is used 
Spirit who works in unison with the work of Christ in the heavenly sanctuary. ${ }^{108}$ In the Biblical Sanctuary Model, we learned that the sanctuary temporally grounds all of the liturgical components. As we apply this hermeneutical principle to the OT priests and the NT prophets and teachers who perform priestly functions, we discover that the temporal interpretation of the liturgist precludes the Sacramental model's view that the laying on of hands at ordination in Acts 13:1-3 results in creating an ontological distinction between liturgist and laity. Accordingly, the laying of hands at ordination has no connection to the Sacramental model's practice of apostolic succession in which the liturgist's authority is ultimately grounded in the church rather than in Scripture.

\section{Analysis}

As we continue our analysis of the liturgist in the aforementioned passages, we will observe that Jesus, Peter, and Paul took OT Scriptures and applied them to their context. In Luke 4:18 Jesus as a liturgist interpreted the content of Isa 61:1. The result was that his life and ministry as the Messiah fulfilled Isaiah's prophecy. On the day of Pentecost Peter interpreted various OT passages that resulted in the fulfillment of those prophecies that pointed to Jesus resurrection and to His high priestly ministry. ${ }^{109}$ Also, in Acts 13:13-52 Paul took the OT Scriptures and interpreted them being fulfilled by Jesus thereby proving that he is the Messiah. ${ }^{110}$

for a fellowship of prayer, which is indirectly described as a spiritualised priestly ministry." See TDNT s.v. $\lambda \varepsilon \imath \tau o v \rho \gamma \varepsilon \dot{\epsilon} \omega$.

${ }^{108}$ To see the close cooperation between Christ, the Holy Spirit and the human liturgist, see the exegesis of the liturgist in Heb 12:18-29 and Rev 4-5.

${ }^{109}$ See this dissertation page 305 footnote 14 .

${ }^{110}$ The passage in Acts 13:23 is a reference to Psalm 132:11; Acts 13:27 points back to the voices of the prophets that are read every Sabbath; Acts 13:33 is a reference to Psalm 
In all cases, the act of application by the liturgist necessarily involves an interpretation of Being, the divine presence, and human nature. The interpretive nature of what a liturgist does is emphasized by Luke in Acts 17:2-3 where Paul reasoned $(\delta ı \varepsilon \lambda \dot{\varepsilon} \xi \alpha \tau o),{ }^{111}$ explained $(\delta เ \alpha v o i ́ \gamma \omega v),{ }^{112}$ and demonstrated $(\pi \alpha \rho \alpha \tau \imath \theta \varepsilon \dot{\varepsilon} \mu \varepsilon v o \varsigma)^{113}$ from the OT Scriptures that Jesus is indeed the Messiah. Since the passages in Luke and Acts uncover a temporal view of the divine presence and humans, the work of Jesus, Peter, and Paul in applying the OT Scriptures indicates that reason interprets the fulfillment of these prophecies within a temporal framework instead of within a timeless one. ${ }^{114}$ This discloses the close connection between a temporal framework, prophecy, and reason working within a temporal framework. Accordingly, the correct interpretation of the text depends upon the liturgist's ability to recognize and apply the proper principles inherent in the text and throughout Scripture. This means that the liturgist's authority is inseparably bound to how accurately he interprets Scripture. In the Biblical Sanctuary Model the application and interpretation of Scripture by the liturgists constitutes the efficient cause of liturgy. This interpretive process that has the potential for errors and mistakes by the liturgist signifies that authority is grounded in Scripture. This is in stark contrast to the Sacramental model that grounds a liturgist's authority in the church

2:7; Acts 13:34 references Isa 55:3; Acts 13:35-37 references Psalm 16:10; Acts 13:41 references Hab 1:5; and Acts 13:47 references Isa 42:6; 49:6.

${ }^{111}$ With reference to Paul's activities as a liturgist, $\delta 1 \alpha \lambda \varepsilon ́ \gamma o \mu \alpha \iota$ is also found in Acts $17: 17 ; 18: 4,19 ; 19: 8 ; 20: 7,9 ; 24: 12$. The usage of this word in these contexts reveals the highly interpretive nature of Paul's work as a liturgist. See also, BDAG sv $\delta 1 \alpha \lambda \varepsilon ́ \gamma o \mu \alpha 1$.

${ }^{112}$ According to BDAG, the meaning of the word explain $\delta$ iavoi $\gamma \omega$ signifies to explain and interpret in Acts 17:3 and Luke 24:32, both of which refer to interpretations of Scripture.

${ }^{113}$ The meaning of the word is to demonstrate or point out, BDAG sv $\pi \alpha \rho \alpha \tau i \theta \eta \mu$.

${ }^{114}$ For examples of how timeless reason works, see this dissertation pages 141-142, 208. 
through apostolic succession by which the liturgist does not interpret but rather acts as a conduit for transmitting timeless truths that are guaranteed by the church.

Heb 12:18-29

\section{Description}

The heavenly sanctuary interconnects three different types of liturgists ${ }^{115}$ that we will refer to as Divine, angelic, and human. We begin with the divine liturgists. In the epistle to the Hebrews, it is clear that the Father speaks; ${ }^{116}$ the Son speaks ${ }^{117}$ and is

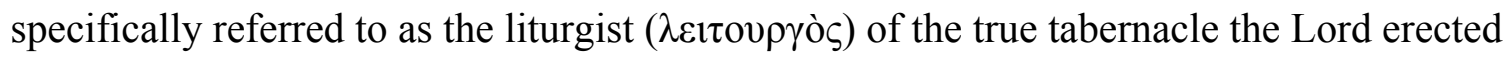
in heaven (Heb 8:2), and the Holy Spirit speaks. ${ }^{118}$ Yet, scholars disagree over whether

${ }^{115}$ The LXX connects the sanctuary services performed by Levites with the Greek words associated with liturgy, see $T D N T$, sv $\lambda \varepsilon \iota \tau o v \rho \gamma \varepsilon \dot{\varepsilon} \omega$.

${ }^{116}$ Hebrews 1:5 quoting Psalm 2:7, Heb 1:6, quoting LXX Deut 32:43/Psalm 97:7 [LXXPs 96:7], Heb 1:7, quoting Psalm 104:4 [LXX Ps 103:4], Heb 1:8-9; Psalm 45:6-7 [LXX Ps 44:7-8], Heb 1:10-12, quoting Psalm 102:25-27 [LXX Ps 101:26-28], Heb 1:1314; quoting Psalm 110:1 [LXX Ps 109:1]), Heb 5:5 quoting Psalm 2:7, Heb 5:6 quoting Psalm 110:4 [LXX Ps 109:4], Heb 8:8-12 quoting Jer 31:31-34 [LXX Jer 38:31-34], Heb 10:30 quoting Deut 32:35,36, Heb 10:37-38 quoting Hab 2:3-4, Heb 12:5 quoting Prov 3:1112, Heb 12:26 quoting Hag 2:6, Heb 13:5 quoting Deut 31:6, 8.I am indebted to Félix H. Cortez for these observations. See Félix H. Cortez, "'I will put My trust in Him': The Faithful Son and the Family of Godin Hebrews" (Presidential Address, Adventist Theological Society, Atlanta, GA Nov 20, 2015).

${ }^{117}$ Ibid. Hebrews 2:12 quoting Psalm 22:22 [LXX 21:23], Heb 2:13 quoting Isa 8:17, 18 and 2 Sam 22:3, Heb 10:7 quoting Psalm 40:7-8 [LXX Psalm 39:8-9]. See also Heb 1:2; $2: 3$.

${ }^{118}$ For the Holy Spirit speaking, see Heb 3:7-11; For Heb 10:15, see William L. Lane, Hebrews 9-13 WBC 47B (Dallas, TX: Word Books, 1991), s.v. Heb 10:15; James Moffat, A Critical and Exegetical Commentary on the Epistle to the Hebrews International Critical Commentary (ICC; Edinburg: T. \& T. Clark, 1952), s.v. Heb 3:7. Also Heb 9:8 uses the word $\delta \eta \lambda o \tilde{v} v \tau o \varsigma$, which means to make something clear to the understanding, to explain, to clarify, see BDAG sv $\delta \eta \lambda$ ó $\omega$. Although $\delta \eta \lambda$ ó $\omega$ is connected with revelation, which takes place in the mind, the author of Hebrews in Heb 12:27 uses the same Greek word to make explicit what is implicit in Hag 2:6. Consequently, there is a strong connection between what the Holy Spirit as the divine liturgist reveals, and what the human liturgist such as the author of Hebrews explains to those who hear the epistle. See Paul Ellingorth, The Epistle to the Hebrews: A Commentary on the Greek Text NIGTC (Grand Rapids, MI: Eerdmans, 1993), s.v. Heb 9:8 $\Delta \eta \lambda$ ó $\omega$. In this way, what the Holy Spirit revealed, the human liturgist 
God, the sprinkled blood of Jesus, or Jesus himself is the one who is speaking the exhortation in Heb 12:25 where it states, "See that you do not refuse Him who speaks

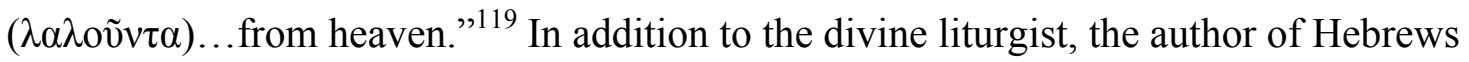

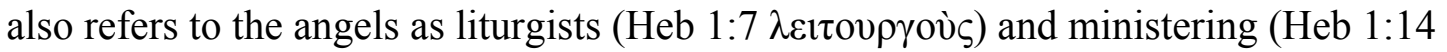

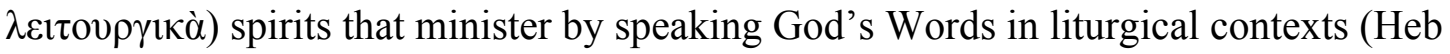
2:2). ${ }^{120}$ Lastly, as a liturgist, the "author [of this epistle] refers to his own authoritative proclamation seven times $(2: 5,5: 11,6: 9,8: 1,9: 5,11: 32,13: 6)$ with either $\lambda \alpha \lambda \dot{\varepsilon} \omega$ or $\lambda \varepsilon \dot{z}\left({ }^{, 121}\right.$ In Heb 13:7 he also admonishes congregations to remember those who rule also explains through writing or speech. Hence, revelation is inextricably linked with speech.

${ }^{119}$ For representative scholars who advocate these possibilities, see Gene Smillie, "'The One Who Is Speaking' in Hebrews 12:25," Tyndale Bulletin (TynBul) 55 no. 2 (2004): 275-294. While it would be an interesting problem to solve the question of who is speaking in this passage, it would not change the temporal nature of divine speech as the revelation of God's presence that our phenomenological exegesis has uncovered. Griffiths' solution to the identity of the speaker in 12:25 is interesting. He points out that although there is continuity between the blood of sprinkling speaking ( $\lambda \alpha \lambda_{0}$ ũv $\left.\tau 1\right)$ in 12:24 and the speaking of 12:25 ( $\lambda \alpha \lambda \mathrm{ou} v \tau \alpha)$, the subject of the participle is not the same in 12:24 and $12: 25$. He notes that the ambiguity of the identity of the subject of the participle in 12:25 is intentional since God speaks through different agents like Jesus (1:1-2), angels (2:2), Moses (3:5), and the writer of the epistle. Consequently, although God is ultimately the speaker throughout 12:25, he accomplishes the task of speaking through the preacher, who "evidently saw himself standing before his addresses as God's spokesman, delivering his words." See Griffiths, Hebrews and Divine Speech, 149, cf. 147-148. If we combine Griffith's insights with God's infinite analogous Temporal Being and the sanctuary that temporally grounds the relationship between God and his speaking agents, the ambiguity of the identity of the subject is understandable since the combination of the blood in 12:24 with other agents (divine, angelic, and human) are involved in the speaking.

${ }^{120}$ The passage in Heb 2:2 mentions that the word at Mt. Sinai during the Ten Commandments was also "spoken through angels," Victor (Sung-Yul) Rhee, "Christology and The Concept of Faith in Hebrews 1:1-2:4," Bibliotheca Sacra (BSac) 157 (2000): 185; William L. Lane, Hebrews 1-8 WBC 47A (Dallas, TX: Word Books, 1991), s.v. Heb 2:2. See also Gal 3:19; Acts 7:53. Since the involvement of angels at the proclamation of God's Word at Mount Sinai is mentioned in Heb 12:18-22, we can also assume that as Christ speaks from heaven (Heb 12:24, 25), the angels are also involved since the author of Hebrews is drawing a comparison between divine speaking at Sinai and Christ's speaking from the context of the heavenly sanctuary. 276 note 2 .

${ }^{121}$ Gene Smillie, “'The One Who Is Speaking' in Hebrews 12:25.” TynBul (2004): 


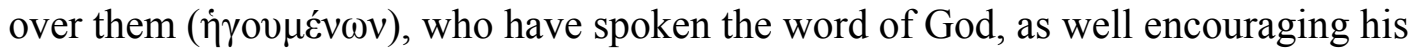
audience to "exhort one another" Heb $3: 13 ; 10: 25$. In addition to ruling or leading, $\dot{\eta} \gamma o v \mu \varepsilon ́ v \omega v$ means to engage in an intellectual process, to think, consider, and regard. ${ }^{122}$ This intellectual process becomes the method by which overseers manage. Hence, a human liturgist's ability to lead is in direct proportion to his ability to think and interpret correctly. This involves the decision to apply the Sola Scriptura principle to the liturgical components that are involved in liturgy.

\section{Analysis}

Although there are divine, angelic, and human liturgists, we need to explore the nature of their connection to each other. Hebrews informs us that Christ is the liturgist ( $\lambda \varepsilon$ ıı 0 pyòs) (Heb 8:2) who speaks from heaven through the blood of sprinkling (Heb $12: 24)$ in the heavenly sanctuary. ${ }^{123}$ His liturgical actions point to "important underlying concepts and presuppositions" ${ }^{124}$ such as his infinite analogous temporal Being and the hermeneutical role of the sanctuary in temporally grounding the liturgical components. Moreover, these biblical presuppositions that constitute the foundation for Christ's liturgical actions have not been discerned by biblical and systematic theologies ${ }^{125}$ on

${ }^{122} \mathrm{BDAG}, \mathrm{sv} \dot{\eta} \gamma \varepsilon \dot{\varepsilon} \mathrm{\mu} \alpha \mathrm{l}$.

${ }^{123}$ See Griffiths, Hebrews and Divine Speech, 143-146.

${ }^{124}$ “'Ritual texts generally prescribe or describe concrete actions connected to particular space, time, objects, and sounds and involve specific participants. In other words, they show a practice (at least from the perspective of the author[s] of the text) that points to important underlying concepts and presuppositions." See Klingbeil, Bridging the Gap: Ritual and Ritual Texts in the Bible, 228-229.

${ }^{125}$ Klingbeil, Bridging the Gap: Ritual and Ritual Texts in the Bible, 227. 
account of the presuppositions that stem from timeless Being. ${ }^{126}$

This speaking through the liturgical actions of the sanctuary seems to be confirmed by Heb 4:2, which states, "for we had good news proclaimed to us just as they did" (Net English Translation [NET]). From the perspective of God's infinite analogous

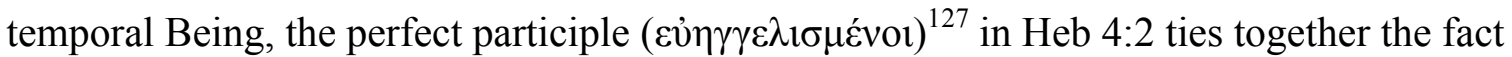
that Christ spoke through the liturgical actions of priests and Levites in the earthly sanctuary that functioned as copies of the heavenly (Heb 9:24); and that he continues to speak through the liturgical actions he performs in the heavenly sanctuary, which is the original type. ${ }^{128}$ These liturgical actions in the heavenly sanctuary assume his death on the cross, ${ }^{129}$ which is an indispensable prerequisite for his ministry in the holy place and for the blood of sprinkling (Heb 12:24) that occurs in the most holy place. Hence, when Christ speaks as liturgist from heaven, he does so through the liturgical actions that he performs in the heavenly sanctuary.

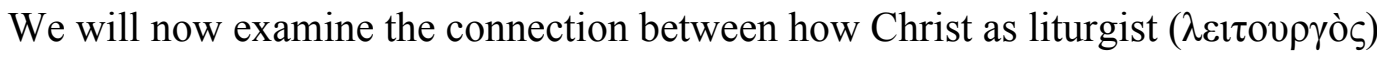
(Heb 8:2) speaks from heaven through the liturgical actions he performs in the sanctuary

${ }^{126} \mathrm{~K}$ lingbeil notes that biblical books like Leviticus are scarcely cited by early Christian commentators such as Origen, who interprets the sanctuary as an allegory of the Christian church, and who also allegorizes the Day of Atonement. Ibid., 91, 96-99.

${ }^{127}$ See King She for the importance of Heb 4:2 and the continuity of the message between the OT and NT. The Use of Exodus in Hebrews, 142-143.

${ }^{128}$ With reference to the sanctuary, the Greek $\tau$ vo $\pi$ o $\varsigma$ is found in Acts 7:44 and Heb $8: 5$, which refers to the great original in heaven from which the earthly sanctuary constitutes a copy $(\dot{\alpha} v \tau i \tau v \pi \alpha)$ (Heb 9:24). See Richard Davidson "Typological Structures in the Old and New Testaments" (PhD dissertation, Andrews University, 1981). Treiyer also notes that the gospel is preached today through Christ's actions occurring in the very reality of heaven, just as it was preached through the ministration of the earthly sanctuary. Alberto Treiyer, The Day of Atonement and the Heavenly Judgment from the Pentateuch to Revelation, 418.

${ }^{129} \mathrm{Cody}$ is correct when he states that even though the death of Christ takes place on earth, outside the heavenly sanctuary, it is just as integral to the liturgy of the heavenly sanctuary as the immolation of bulls and goats was integral to the Day of Atonement in Lev 16. Aelred Cody, The Heavenly Sanctuary and Liturgy in the Epistle to the Hebrews, 170. 
and how the Holy Spirit speaks as liturgist. In Heb 9:6-8, ${ }^{130}$ the author of Hebrews establishes a link between the high priest's work in the two apartments of the heavenly

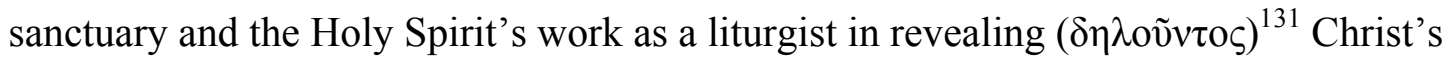
liturgical actions in the heavenly sanctuary to the mind of the earthly liturgist. At this point the word $\delta \eta \lambda$ oṽvนo $\varsigma$ becomes integrally connected with the human liturgist whose function is to declare Christ's liturgical actions as revealed by the Holy Spirit. ${ }^{132}$ Furthermore, the Holy Spirit's function as liturgist is further illustrated in Heb 3:7-11 and 9:8. Moreover, in Heb 10:15-17 where the Spirit speaks the new covenant promise, which is also linked with the heavenly sanctuary.

The apostle Paul employs two terms that connect earthly liturgists with the Holy Spirit's revelation of Christ's work in the sanctuary. First, Paul refers to himself as a

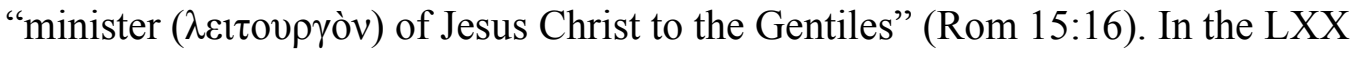
( $\lambda \varepsilon ı \tau o v \rho \gamma o ̀ v)$ was intricately connected with the work of priests and Levites regarding the earthly sanctuary. ${ }^{133}$ Second, in the remaining part of Rom 15:16, Paul is "ministering

${ }^{130}$ The passage in Heb 9:7-8 reads, "But into the second part the high priest went alone once a year, not without blood, which he offered for himself and for the people's sins committed in ignorance; the Holy Spirit indicating this ( $\delta \eta \lambda \mathrm{ov} v \tau \mathrm{\sigma} \varsigma)$, that the way into the Holiest of All was not yet made manifest while the first tabernacle was still standing."

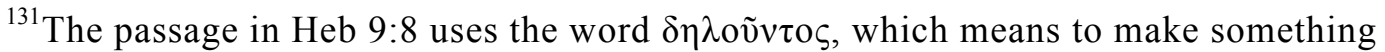
clear to the understanding, to explain, to clarify, see BDAG s.v. $\delta \eta \lambda$ ó $\omega$.

${ }^{132}$ Although $\delta \eta \lambda$ ó $\omega$ is connected with revelation, which takes place in the mind, the author of Hebrews in Heb 12:27 uses the same Greek word to further clarify and expand what is implicit in Hag 2:6. Consequently, there is a strong connection between what the Holy Spirit as the divine liturgist reveals, and what the human liturgist such as the author of Hebrews explains to those who hear the epistle. See Ellingworth, The Epistle to the Hebrews NIGTC, s.v. Heb 9:8 $\Delta \eta \lambda$ ó $\omega$. In this way, what the Holy Spirit revealed, the human liturgist also explains through writing or speech. Hence, revelation and illumination is inextricably linked with speech, which necessarily inovles the Holy Spirit and the human agent as cooperating liturgists.

${ }^{133}$ The LXX connects the sanctuary services performed by Levites with the Greek words associated with liturgy, see TDNT, sv $\lambda \varepsilon \imath \tau$ cov $\gamma \varepsilon \dot{\varepsilon} \omega$. 


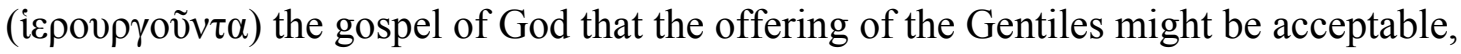

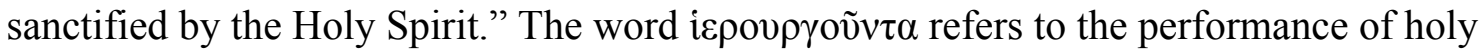

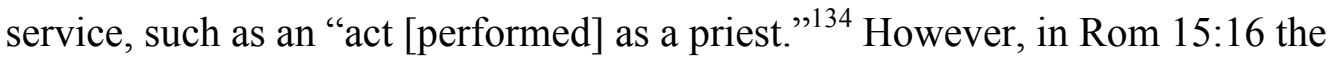

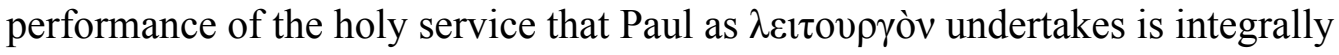
connected with the preaching of the gospel that is linked with Christ's work in the heavenly sanctuary instead of with the animal sacrifices of the earthly sanctuary. Consequently, Heb 13:7 admonishes congregations to remember those who rule over them, who have spoken the word of God. Human liturgists thereby speak the word of God when they minister the gospel of God (Rom 15:16) by speaking his words/thoughts through the priestly ${ }^{135}$ act of preaching. This liturgical ministry of the word is inextricably linked with Christ's performance of liturgical actions in the heavenly sanctuary via the Holy Spirit's illumination of these actions in the mind of the liturgist.

We will now apply the principle that the heavenly sanctuary grounds the temporal relationship of the liturgical components to how we might understand the relationship between the divine, angelic, and human liturgists, how they exercise authority, and issues relating to the cause of liturgy.

First, unlike the other models that assume an ontological dichotomy that produces timeless and temporal speech, there is no difference in the theological content between

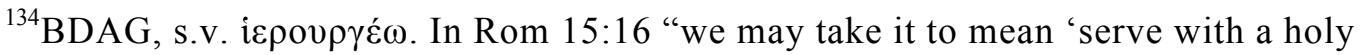
service.' To preach the gospel is to be engaged with a holy thing and fulfill a holy ministry." C. E. B. Cranfield, A Critical and Exegetical Commentary on the Epistle to the Romans. Vol.2 ICC (New York: T \& T Clark, 1979), s.v. Rom 15:16.

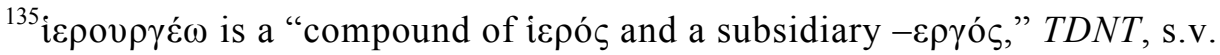

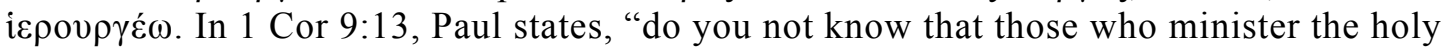

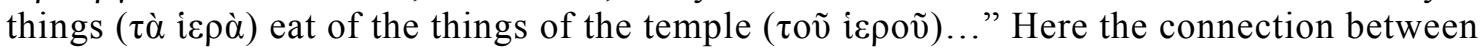
holy things and the temple is established. Paul is clearly comparing the work of priests and Levites in the OT sanctuary with the priestly work of the gospel minister who ministers

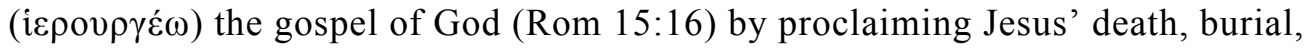
resurrection, and high priestly ministry in the heavenly sanctuary in the NT. 
divine, angelic and human speech in the Biblical Sanctuary Model. As a result, the temporal ontological framework of this model lays the groundwork for the divine, angelic, and human liturgists to cooperate together in ministering the Word of God.

Second, the earthly liturgists derive their authority from Christ, the word of God, whose blood speaks through the liturgical service in the heavenly sanctuary; and through the Holy Spirit who reveals this to the liturgist, and who speaks the word through the human liturgist. Hence, the church (liturgists) does not give birth to the word; rather, in ministering the gospel of God (Rom 15:16) from the sanctuary context, the church derives its authority from the Word. Neither does the Holy Spirit have authority to contradict the word, since the Spirit's work as liturgist is integrally connected to Christ's liturgical actions in the sanctuary above.

Third, although the human liturgist is still the cause of liturgy, the divine and angelic liturgists function as the indispensable conditions of liturgy. ${ }^{136}$ For instance, as liturgist, Christ is the Word incarnate (John 1:1-3, 14) whose sprinkled blood speaks better things than that of Abel (Heb 12:24). Consequently, liturgists should not create theological content; rather, they should correctly interpret the theological content already created by Christ's fulfillment of the OT types that point forward to his inauguration (Exod 29:20; Heb 1:3; 9:21), his mediation in the holy place (Lev 4:17; Num 19:14; Heb

${ }^{136}$ This of course only applies where human, divine, and angelic liturgists are involved. For instance in Rev 4-5, the only human involved in the heavenly worship scene is John the Revelator. This assumes that the twenty-four angels are not human, something we will explore as we exegete the liturgist in Rev 4-5. Hence, in Rev 4-5 the angels would function as the cause of liturgy since the scene is a heavenly one where only John is involved. 
9:23-25), and the Day of Atonement ritual service ${ }^{137}$ in the most holy place (Lev 16:14, $15,19 ;$ Heb $9: 25 ; 12: 24)$. Each of these events in the heavenly sanctuary is symbolized by the blood of sprinkling that speaks (Heb 12:24). This requires that we apply the Sola Scriptura principle to the interpretation of Christ and the Holy Spirit as divine presence and as liturgist. A failure to make this application will result in distorting the theological content.

\section{Rev 4-5}

\section{Description}

Similar to the book of Hebrews, the scene in the heavenly sanctuary in Rev 4-5 includes divine, angelic, and human liturgists. The divine liturgists include the One seated on the throne with a scroll in his right hand $(\operatorname{Rev} 5: 1)$; The Lamb who takes the scroll from the right hand of him who sat on the throne and opens its seals; $;{ }^{138}$ and the seven Spirits of God sent out into all the earth (Rev 4:5; 5:6).

${ }^{137}$ Gerald Kingbeil points out that "rituals are the "Sistine Chapels" of communication....They express and systematize beliefs." Klingbeil, Bridging the Gap: Ritual and Ritual Texts in the Bible, 241. Moreover, it should be noted that scholars do not agree on the timing of the ministry of Christ's blood in passages such as Heb 9:13, 23-25, and 12:24. Richard Davidson argues that Heb 9:24 mostly refers to the inauguration by drawing on the parallels between OT inaugurations of the wilderness sanctuary and the heavenly sanctuary. However, he does concede that Heb 9:24-28 "could also have reference to the Day of Atonement." Richard Davidson, "Christ's Entry "Within the Veil" in Hebrews 6:19-20: The Old Testament Background," Andrews University Seminary Studies 39 no. 2 (Autumn 2001): 187. I have already pointed out the influence of timeless Being in limiting the application of Christ's blood to the cross or to the inauguration in this dissertation, see pages 368-373. Alberto Treiyer represents those who assert that the ministry of blood in OT liturgy refers to the application of Christ's blood during the inauguration, and in the holy and most holy places. He states, "the cleansing of "the heavenly things themselves" is linked with the ministry of blood that Jesus performs in the heavenly sanctuary (cf. [Heb 9] vv. 2426), and with the antitypical final judgment of the Day of Atonement, after which the High Priest comes out of the sanctuary to bless the congregation ([Heb 9] vv. 27-28." Treiyer, The Day of Atonement and the Heavenly Judgment from the Pentateuch to Revelation, 427.

${ }^{138}$ See Rev 5:6-7, 9; 6:1, 3, 5, 7, 9, 12; 8:1. 
With reference to human liturgists, Christ speaks to the angel/human liturgist ${ }^{139}$ of each individual church in the letters to the seven churches. ${ }^{140}$ The end result is that the Spirit speaks to the churches ${ }^{141}$ through the human liturgist. Similarly, what Christ accomplishes on the cross, signified by the slain Lamb (Rev 5:6, 9, 12), and continues in the heavenly sanctuary before the One seated on the throne, the seven Spirits communicate to the churches on earth $(\operatorname{Rev} 5: 6){ }^{142}$

We now turn to two different angelic liturgists revealed in Rev 4-5. The first of the angelic liturgists is the four living creatures; and although many interpret the twentyfour elders as humans, ${ }^{143}$ there are pointers in the book of Revelation for viewing them as

${ }^{139}$ The Greek ö $\gamma \gamma \varepsilon \lambda \mathrm{\alpha}$ can also refer to human messengers (Matt 11:10; Mark 1:2; Luke 7:24, 27; 9:52). See BDAG, s.v. ö $\gamma \gamma \varepsilon \lambda$ os. Hence, it seems most probably that these messages are sent to the elders or overseers of the churches in John's time.

${ }^{140}$ Christ speaks $(\lambda \dot{\gamma} \gamma \varepsilon 1)$ a message to each church $(\operatorname{Rev} 2: 1,8,12,18 ; 3: 1,7,14)$

${ }^{141}$ Each of Jesus' messages ends with an appeal to hear what the Spirit says ( $\left.\lambda \dot{\varepsilon} \gamma \varepsilon 1\right)$ to the churches (Rev 2:7, 11, 17, 29; 3:6, 13,22)

${ }^{142}$ In Heb 12:24 the blood of sprinkling speaks; first through Christ's death and liturgical action in the heavenly sanctuary as an event, and second through the human liturgist. In Rev 5:1-14, Christ as high priest is approaching the Father in the most holy place, and the seven Spirits sent out into all the earth constitute the liturgist that reveals that message to the human liturgist (See my exegesis on the liturgist in Hebrews) who then speaks it to the churches. For Rev 4-5 as a scene in the most holy place of the heavenly sanctuary, see my exegesis of Rev 4-5 on the divine presence. For the connections between Rev 4-5 and Rev 14:1-12 that outline the Holy Spirit working through angelic and human instrumentalities, see this dissertation Tables 1 and 2.

${ }^{143}$ Stefanovic summarizes the following arguments from Feuillet which allege that the twenty four elders are redeemed humans and not angels, "The Background and Meaning of the Sealed Book of Revelation 5," 211 footnote 2: (1) angels are never called elders, however a case may be made for angels as elders in connection with the judgment in the heavens above and the Kings of the earth below in Isa 24:23. Treiyer's translation reads, "and before his elders he [God] will manifest his glory" cf Matt 24:29 and Rev 6:12-13. See Treiyer, The Day of Atonement and the Heavenly Judgment from the Pentateuch to Revelation, 536; (2) angels are never described as sharing God's throne, yet in Rev 4:4 they don't sit on God's throne, they have their own; (3) angels are never described as wearing white robes, however see footnote 144 below; (4) angels don't wear golden crowns that are appropriate for overcoming believers, yet angels also fought against Satan and his angels (Rev 12:7-9). In addition the numeral 24 may suggest a link with the 12 gates named after the tribes of Israel and with the 12 apostles of the Lamb, Stefanovic, "The Background and 
angelic beings. ${ }^{144}$ The following points draw attention to the role of the four living creatures and the twenty-four elders as liturgists. First, the fact that the four living creatures and the elders occupy the closest geographical proximity to the throne points

Meaning of the Sealed Book of Revelation 5," 211 footnote 2. Treiyer also notes that the elders as humans might be confirmed, yet the reading in Rev 5:10 as "have made them" instead of "us" is found in most of the manuscripts (Majority text), The Day of Atonement and the Heavenly Judgment from the Pentateuch to Revelation, 523. The following scholars list several influential representatives of the view that the twenty-four elders constitute either glorified and redeemed saints or that they consist of the Fathers of ancient Israel. Ibid., 523; Stefanovic, "The Background and Meaning of the Sealed Book of Revelation 5," 211; Grant R. Osborne, Revelation Baker Exegetical Commentary on the New Testament (BECNT; Grand Rapids, MI: Baker Academic, 2002), 228.

${ }^{144}$ I believe the following clues point to the twenty-four elders as a class of ruling angels that are distinct from the four living creatures in the midst of the throne (Rev 4:6) and from the vast angelic throng (Rev 5:11). First, in Rev 5:5 and 7:13-17 an elder instructs John. In every other instance where John is instructed in Revelation, it is by an angel. See Rev 10:8-10;11:1;17:1, 7-18;19:9-10;21:9 and 22:8-11. Since angels predominantly communicate in Revelation, the strong angel who asks, "Who is worthy to open the scroll and to loose its seals?" is also most likely one of the elders. Hence, if John was instructed by an angel in all of these instances, then it begs the question as to why the elder who instructs John in Rev 5:5; 7:13-17 is also not an angel. See Osborne, Revelation BECNT, 229, 252; Craig R. Koester, Revelation: A New Translation with Introduction and Commentary The Anchor Yale Bible (AYB) 38A (New Haven, CT: Yale University Press, 2014), 362, 375; Martin Kiddle, The Revelation of St. John Moffat New Testament Commentary (London: Hodder and Stoughton, 1952), 97; Jürgen Roloff, The Revelation of John Continental Commentaries (Minneapolis, MN: Fortress Press, 1993), 77; R. H. Charles, A Critical and Exegetical Commentary on the Revelation of St. John. 2 vols ICC (Edinburgh: T \& T Clark, 1959), s.v. Rev 4:10; 5:5; Aune, Revelation 1-5 WBC 52A, s.v. Rev 5:5a. Second, the order of communication flows from Jesus to his angel, and then to his servant John (Rev 1:1; 22:6) without any mention of a human instructor. This makes more plausible the assertion that the elders are angels. Third, the description of the elders clothed in white ( $\lambda \varepsilon v \kappa o i \varsigma) ~(R e v$ 4:4) also matches how the angels are clothed. For instance, Rev 19:14 states that the armies

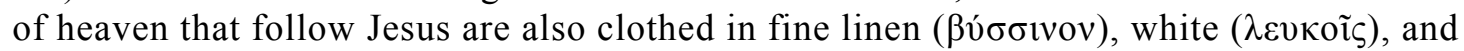
clean. For other references that describe the angels in white ( $\lambda \varepsilon v \kappa o ́ \varsigma)$ see Matt 28:3; Mark 6:5; Acts 1:10. Moreover, in Rev 15:6 the seven angels having the seven plagues are clothed in pure bright linen ( $\lambda$ ívov $\kappa \alpha \theta \alpha \rho o ̀ v ~ \lambda \alpha \mu \pi \rho o ̀ v)$, which closely matches white in color. See also Acts 10:3, 30. For angels wearing white in Rev 15:6, see Koester, Revelation AYB 38A, 362, 363; "Linen” SDABC 7:s.v. Rev 15:6; Charles, ICC, s.v. Rev 4:4c; David E. Aune, Revelation 6-16 WBC 52B (Dallas, TX: Word Books, 1998), s.v. Rev 15:6b. Fourth, the priestly function of offering incense by the elders (Rev 5:8) closely matches that of the angel in Rev 8:3-5 and of the role that the seraphim played in Isa 6:6-7. See Koester, Revelation AYB 38A, 362; Osborne, Revelation BECNT, 259; Charles, ICC s.v. Rev 4:10; Aune, Revelation 1-5 WBC 52A, s.v. Rev 5:8. Grant Osborne mentions over ten scholars in addition to himself who believe that the elders are angelic beings, Osborne, Revelation BECNT, 229, 230. 
out that they fill leadership positions as liturgists. ${ }^{145}$ Second, in the smaller setting of Rev $4^{146}$ the four living creatures proclaim God's holiness ( $\left.\operatorname{Rev} 4: 8\right)$ and give him glory, honor, and thanks $(\operatorname{Rev} 4: 9)$. In $\operatorname{Rev} 4: 10$, the twenty-four elders not only act as worshippers that respond to the proclamations and liturgical leadership of the four living creatures, ${ }^{147}$ their response as authoritative liturgists and worshippers provides leadership for the kinds of responses that are acceptable to the One seated on the throne. ${ }^{148}$ Third, in Rev 5:8 the living creatures and the elders play on harps while they sing a new song to the Lamb (Rev 5:9-10) that is then echoed by the myriads of angels around the throne (Rev 5:11-12), and then by the entire universe (Rev 5:13); this discloses their leadership role as liturgists. Fourth, the fact that they have golden bowls full of incense, which are the prayers of the saints (Rev 5:8) also points to their priestly function as liturgists. Fifth, after the Lamb opens each seal, each one of the four living creatures says, "come and see" (Rev 6:1, 3, 5, 7 Majority Text). This not only draws our attention to the contents of

${ }^{145}$ John actually depicts the four living creatures as being "in the midst of the throne and around the throne" (Rev 4:6 cf. 5:6). Furthermore, the elders sit on their own thrones, which are located around the central throne $(\operatorname{Rev} 4: 4)$. The crowns of gold also indicate the authority of the elders that they cast before the One seated on the throne (Rev 4:4, 9-10). The passage in Rev 12:7-9 records warfare between the angels in heaven. Hence, the crowns that the elders wear are possibly the result of victories won that resulted in re-establishing the authority of God's throne in heaven.

${ }^{146}$ The scene in Rev 4 only includes the One seated on the throne (Rev 4:2-6, 9-10), the twenty-four elders (Rev 4:4 10-11), and the four living creatures (Rev 4:6-9); whereas the following indicators in Rev 5 expand to a more universal setting: (1) that no one in heaven or on the earth or under the earth is able to open the scroll (Rev 5:3), (2) the myriads upon myriads of angels that are now seen as around the throne, and around the four living creatures and the elders (Rev 5:11), and (3) "every creature that is in heaven and on the earth and under the earth" sing the final doxology in Rev 5:13.

${ }^{147}$ For the leadership role of the four living creatures and their relationship in worship with the elders, see Charles, ICC, s.v. Rev 4:4.

${ }^{148}$ In Rev 5:14, the four living creatures and the twenty-four elders play a leading role in guiding worshipers with respect to appropriate responses. For instance, the living creatures say, "Amen," and the twenty-four elders fall down and worship, see also Rev 7:11; 11:15-19; 19:4. 
the scroll, it further discloses their leading role as liturgists.

\section{Analysis}

Since the divine, angelic and human liturgists are integrally connected with the sanctuary, ${ }^{149}$ we will now apply the principle that the heavenly sanctuary grounds the temporal relationship of the liturgical components to the following issues surrounding the liturgist: the relationship between the divine, angelic, and human liturgists; the nature of the authority that each exercises; and issues relating to the cause of liturgy.

Let's first look at the relationship between the liturgists. The goal of liturgy, which is the encounter, would be compromised if each of the liturgists - divine, angelic, and human —-were not cooperating together as an indispensible precondition for liturgy to occur within the spatio-temporal framework that encompasses heaven and earth. For instance, as one of the divine liturgists the Father, who may have originated the messages in the scroll contained in his right hand, is seated on his throne (Rev 5:1). The Son, who originated the messages to the seven churches, is now as a liturgist performing a liturgical action in the most holy place of the heavenly sanctuary where he takes the book and receives universal praise from the four living creatures, the twenty-four elders and the vast angelic throng (Rev 5:6-14). The Holy Spirit who is represented by the lamps of fire burning before the throne ( $\operatorname{Rev} 4: 5$ ) reveals these heavenly liturgical actions throughout

${ }^{149}$ The divine presence and the sanctuary is mentioned on this page and the next page. The living creatures and elders are also placed in the same geographical proximity with the divine presence in the sanctuary since they are around the throne (Rev 4:4, 6-10; $5: 6$ ). The human liturgist (angel of the church Rev 2:1, 8, 12, 18; 3:1, 7, 14) is the recipient of the message that Jesus sends from midst of the seven lampstands (Rev 1:13;2:1) located in the heavenly sanctuary. Similarly, when the Holy Spirit is sent out into all the earth from the heavenly sanctuary ( $\operatorname{Rev} 5: 6$ ), he is sent out to communicate through earthly liturgists the amazing scenes in Rev 4-5. 
the entire earth where he is sent $(\operatorname{Rev} 5: 6) .{ }^{150}$ As a result, the writing contained in the book, the words and hymns sung by the living creatures, the elders and the myriads of angels, are not timeless communications; they occur within the temporal ontological framework that connects heaven and earth together. Hence, the heavenly sanctuary temporally grounds the distinct actions of the Father, Son and angelic liturgists in heaven as being indispensible for the Holy Spirit who then communicates these real events in heaven to the congregations on earth through the earthly liturgists.

One major implication of this temporal grounding between heavenly and earthly liturgists involves the highly interpretive task that liturgists perform as they conduct liturgical actions. As we apply the Sola Scriptura principle to the divine and angelic liturgists as entities, to their spoken and written words, their music, and their deportment, we discover that the heavenly liturgists are not timeless entities that transmit timeless truths. ${ }^{151}$ Instead they are temporal entities functioning within a temporal sanctuary framework. Consequently, the heavenly liturgists and the liturgical actions they perform constitute a historical model that the earthly liturgist must apprehend and then apply. ${ }^{152}$ The basis for this is that the sanctuary as a model ${ }^{153}$ reveals that there is an analogy

${ }^{150}$ When comparing Heb 12:24 to Rev 5, we can conclude that the liturgical actions that Christ performs in the heavenly sanctuary speak and thus become vital data for the Holy Spirit to disseminate to the world.

${ }^{151}$ This would mean that through the use of higher criticism the liturgist's task would be to discard anything spatio-temporal in order to get to the timeless essence of heavenly liturgy.

${ }^{152} \mathrm{G} . \mathrm{K}$. Beale, The Book of Revelation: A Commentary on the Greek Text NIGTC (Grand Rapids, MI: Eerdmans, 1999), s.v. Rev 4:4.

${ }^{153}$ The word model assumes the temporal interpretation of reality as well as the sanctuary that grounds the temporal relationship between the heavenly and the earthly. All of this is what makes the analogy between the heavenly and the earthly possible. At the same time, the analogy implies differences between the heavenly and the earthly. However, the more (heavenly) never contradicts the less (earthly). The passage in Heb 8:2 reveals the 
between the heavenly and the earthly realities. Moreover, since human liturgists possess historical hermeneutical minds, they must continually apply the Sola Scriptura principle to all of the liturgical components so that they can reduce the possibility of mistakes. ${ }^{154}$

Let's now look at the nature of the authority that each liturgist exercises so that we can determine whether the authority of the liturgist resides in the church, in the Spirit, or in Scripture. A phenomenological reading of Rev 4-5 allows for God's infinite analogous temporal Being, which in turn makes the historical conflict between Christ and Satan a metaphysical possibility. This conflict over who can rightfully exercise authority is revealed by the throne, which has been the object of Satan's attacks. ${ }^{155}$ Furthermore, the nineteen references to the throne in Rev 4-5 emphasize its great significance.

The following points outline how the authority of all divine, angelic, and human liturgists is grounded in Scripture via the central throne. ${ }^{156}$ Let's first begin with the divine liturgists. The praise only offered to Father ${ }^{157}$ and Son who share the throne together ${ }^{158}$ occurs in a universal context that combines the inhabitants of heaven and

heavenly original and Heb 9:24 states that the earthly are copies. See Richard Davidson "Typological Structures in the Old and New Testaments."

${ }^{154} \mathrm{On}$ the concept of the hermeneutical spiral and the possibility of mistakes see, Peckham, Canonical Theology, 212-217. On ritual mistakes and failure, see Ronald L. Grimes, "Infelicitous Performances and Ritual Criticism” Semeia 41 (1988): 103-122.

${ }^{155}$ For the connection between the throne and Satan's attacks, see the divine presence in Rev 4-5.

${ }^{156}$ The authority of the throne is illustrated by the very fact that the throne is in the center of the vision of Rev 4-5, see this dissertation page 318 footnote 58 .

${ }^{157}$ In Rev 4, it is the Father who takes precedence on the throne. Moreover, it is the Father who is predominantly associated with the throne. For some examples, see Rev 1:4; $4: 2-6,9-10 ; 5: 1,7,13 ; 6: 16$. Gallusz notes that 36 of 47 throne references in Revelation are attributed to the Father, see Gallusz, "Thrones in the Book of Revelation Part 1," Journal of the Adventist Theological Society 23 no. 2 (2012): 30-31.

${ }^{158}$ According to Gallusz Rev 22:1, 3 portray both God and the Lamb conjointly on the throne whereas Rev 3:21 and 7:17 have individual references to God and to the Lamb. 
earth (Rev 5:3,13-14; cf. Rev 7:9-12). Moreover, we noted previously that there is no ontological subordination of either the Son or Spirit to the Father since each member of the Trinity is the I AM. However, only the Father and Son share the throne whereas the Spirit is twice mentioned by his location before the throne ( $\operatorname{Rev} 1: 4 ; 4: 5)$. Accordingly, although the Spirit is equal to the other members of the Trinity and does not derive his being from them, his description as being before the throne instead of on it indicates that he exercises a subordinate role within the context of liturgy. This universal context that Scripture opens to our view reveals that the authority that the Spirit exercises on earth (Rev 5:6) is in harmony with the sovereign rule of Father and Son in heaven, and in accordance with the Ten Commandments that are linked with the throne. ${ }^{159}$ The heavenly sanctuary context therefore temporally grounds the relationship between the authority that each member of the Trinity exercises in heaven and earth by the manner in which each one relates with the throne.

Regarding the four living creatures, although they are in closest proximity to the throne (Rev 4:6; 5:6), they never occupy it; instead they worship God and the Lamb showing their submission to the throne. The twenty-four elders have thrones that surround the central throne and they cast their crowns before the throne $(\operatorname{Rev} 4: 4,10)$, indicating that their authority is also grounded in the central throne.

The liturgists on earth to whom the Spirit reveals the heavenly scenes of Rev 4-5 are likewise subject to the Father, the Son, and the Ten Commandments that are all associated with the throne. The hermeneutical minds of earthly liturgists create the

The remaining throne references apply to the twenty-four elders (Rev $4: 4 ; 11: 16)$, to the saints (Rev 20:4), to Satan ( $\operatorname{Rev} 2: 13$ ) and to the beast (Rev 13:2;16:10). Ibid., 31.

${ }^{159}$ For the link between the Ten Commandments and the ark/throne, see this dissertation page 243 footnote 93 . 
potential for misinterpreting the heavenly scene and thus exercising authority that is out of harmony with Scripture and with the Trinity. Consequently, ultimate authority must be grounded in Scripture and not in human interpretations of the Spirit that twist Scripture and ignore his loyalty to the throne; authority should neither be grounded in the church as represented by the liturgist.

Let's now briefly look at issues relating to the cause of liturgy from within a temporal ontological framework. In the Biblical model as seen in Rev 4-5, the Father and Son are the indispensible conditions for liturgy while the living creatures and the elders function as the cause of liturgy.

\section{Liturgical Setting and Actions}

I will now begin to describe the liturgical setting and actions of the Biblical Sanctuary model looking at what the representative New Testament texts reveal about them before I begin to analyze how the sanctuary grounds the temporal relationship between the divine presence and the specific liturgical actions in the Biblical passages.

Luke 4:16-30; Acts 13:13-52; 17:1-4; 18:1-8

\section{Description}

Preaching is the central liturgical action in the Luke and Acts passages. Other than the synagogue setting, which is strongly associated with expounding the Scriptures, ${ }^{160}$

\footnotetext{
${ }^{160}$ See Matt 4:23; 9:35; 13:54; Mark 1:21, 22, 39; 6:2; Luke 4:15, 16, 20, 44; 6:6; 13:10; John 18:20; Acts 9:20; 13:5, 13-15; 14:1; 15:21; 17:1-3, 17; 18:4, 19, 26; 19:8.

During the centuries that followed the Captivity...there was scarcely a city without its Jewish community (Acts 15:21) ... and synagogue.... Services were held there each Sabbath day, at which the reading and exposition of the Law and the Prophets constituted the center of attention.... The main room of the synagogue was provided with a reading desk, a seat for the expounder, and a chest, or ark, that contained the rolls of the Law and the Prophets ("The Synagogue" SDABC 5:56).
} 
there are several points that emphasize preaching as the central action in Luke 4:16-30. First, the attendant's role (Luke 4:17,20) was that of one who functions as a helper in a subordinate capacity ${ }^{161}$ whose function is to assist the one who will read and expound the Scripture ${ }^{162}$ thereby pointing to the centrality of preaching and teaching. Second, the immediate context in Luke 4:15 notes that Jesus "taught in their synagogues, being glorified by all." Third, the one reading the text "stood up to read" (Luke 4:16) and then for the sermon "sat down" (Luke 4:20, 21). ${ }^{163}$ Lastly, the entire narrative revolves around the text Jesus read (Isa 61:1-2) and his application of that text to his ministry.

Regarding Acts 13:13-52, the following items point to preaching as central. First, the context in Acts 13:5 states, "And when they arrived in Salamis, they preached the word of God in the synagogue of the Jews." Second, when Paul went into the synagogue in Antioch of Pisidia, he was encouraged to speak after the reading of the Law and the Prophets (Acts 13:15). ${ }^{164}$ Third, Paul's sermon begins in Acts 13:16 and ends in v.41. The passage in Acts 13:44 states that the following Sabbath the whole city came together to "hear the word of God" spoken by Paul (Acts 13:45) and which was accompanied by further appeals (Acts 13:46-52). In Acts 17:1-4, Paul reasoned (Acts 18:4), explained and demonstrated from the OT Scriptures that Jesus is the Messiah thereby pointing to proclamation as the central liturgical action.

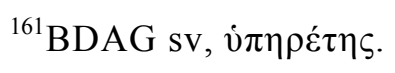

${ }^{162}$ The chazzan's duty was to remove the sacred scrolls from the ark and hand them to the reader (Luke 4:17), "Delivered unto him" SDABC 4:727; Bouyer, Rite and Man, 168.

163“"It was customary in Palestine (but not in the Diaspora) to sit down to preach." “The Synagogue" SDABC 5:58.

${ }^{164}$ Fitzmyer notes that after the reading of the law and the prophets, "a sermon was preached." Fitzmyer, The Acts of the Apostles, AB 31, 509. 


\section{Analysis}

In addition to preaching or teaching as the central liturgical action, the Luke and Acts passages in this section combine the Sabbath as the main observance dealing with time with the synagogue as the main worship dealing with space. ${ }^{165}$ Let's note the relationship between the divine presence, the Sabbath, and preaching. First, God is present and omnipresent, and the close association between the Sabbath, synagogue and temple combines the presence of Father and Son in the heavenly sanctuary ${ }^{166}$ with the omnipresence of the Holy Spirit on the seventh day throughout creation through speech. Hence, it is fitting that the Sabbath and preaching are inextricably linked in the gospels and Acts. ${ }^{167}$ Second, God is invisible; ${ }^{168}$ the Sabbath being linked with time instead of with any material object also mediates God's invisible being; and the invisibility of preaching (Cf. John 6:63) also mediates the divine presence (John 1:1-3, 14). Third, God is eternal; the Sabbath will continue into the eternal future (Isa 66:22,23) as the fitting symbol of God's temporal eternity; and God's word is eternal. ${ }^{169}$ Fourth, God is immutable; ${ }^{170}$ the Sabbath is an immutable sign (Exod 31:13; Ezek 20:12, 20) that originated by God's word (Gen 2:2-3) and mediates God's immutable nature (Heb 1:10-

${ }^{165}$ Synagogue and Sabbath are mentioned in the following passages, Luke 4:16; Acts $13: 14 ; 17: 1-2 ; 18: 4$.

${ }^{166}$ See this Chapter on the divine presence on Rev 4-5. In Luke 4:16-30, Jesus is functioning as a liturgist on earth, yet after the gospels, he is seated on the throne with his Father.

${ }^{167}$ For the close connection between Sabbath, preaching and teaching, see Mark 1:21; 6:2; Luke 4:16, 31; 6:6; 13:10; Acts 13:27, 42, 44; 15:21; 16:13; 17:2; 18:4.

${ }^{168}$ See Rom 1:20; Col 1:15, 16; 1 Tim 1:17; Heb 11:27.

${ }^{169}$ See, Psalm 111:7-9; 119:89; Isa 40:8; 1 Pet 1:23, 25.

${ }^{170}$ See this dissertation pages 227-228, 247 for an explanation of God's immutability from an infinite analougs temporal view of God's Being. 
12); and God's words are as unchangeable as his being. ${ }^{171}$ Hence, the Sabbath temporally grounds the relationship between the divine presence and the preaching of God's Word.

As we now consider the place of liturgy in the NT, we must keep in mind that the heavenly temple still functions as the predominant place of liturgy. With this in mind let's examine the synagogue, not as the setting that replaces the temple for normative principles of liturgy, but as a setting that draws its characteristics from the temple. For instance, the synagogue is not only strongly related to the Sabbath, it is also architecturally and functionally related to the temple, which "seems to have been taken as a model for the synagogue. ${ }^{, 172}$ We will now note the following similarities between the Temple and the synagogue. The Shekinah is in the midst of those who gather to listen to the reading of the Torah. ${ }^{173}$ "The Shekinah is invisibly present to those who remain faithful to it." 174 "The liturgical reading is thus found assimilated to the direct utterance of the divine voice which was thought to come forth from the presence of Sion." "175 "In all ancient synagogues, the building was so constructed that the apse marked the direction of Jerusalem. Thus in the prayer of the liturgy, the people and the rulers were found turned toward the sole naos in which the presence was believed to dwell with Israel."176

${ }^{171}$ See Psalm 89:34; Matt 5:17 (cf. Luke 16:17).

${ }^{172}$ Baker Encyclopedia of the Bible, s.v. synagogue. "The cult of the synagogue... was therefore plucked like a ripened fruit from the cult of the temple rather than substituted for it.... since it was still dedicated to the presence found in a very special way in the temple." Bouyer, Rite and Man, 166, 167.

\footnotetext{
${ }^{173}$ Bouyer, Rite and Man, 165.

${ }^{174}$ Ibid., 168.

${ }^{175}$ Ibid., 168.

${ }^{176}$ Ibid., 168.
} 
"Between the bema ${ }^{177}$ and the apse was placed a chest, which soon was called the "ark." This chest contained the scrolls of the law and the prophets." "178 "A veil had been introduced, concealing this ark as it had that in Jerusalem. To complete the resemblance, the menorah, or seven-branched candlestick, was placed between it and the lectern."179 Moreover, "The menorah and the veil before the new ark and the entire orientation on the debhir of Jerusalem are a striking indication of these parallels." 180

Since there is a structural and functional correspondence between the earthly, and heavenly temples, and since the synagogue of the Gospels and Acts of the Apostles is structurally related to the earthly temple, we conclude that the synagogue is also structurally and functionally related to the heavenly sanctuary. In the exegesis of the OT texts that had the sanctuary as the place of liturgy, ${ }^{181}$ we noted that the main liturgical action involved various forms of the communication of God's words to the people such as the delivery of a message (Exod 3:7-22; 20:1-17), a dedication and address (2 Chr 6:142), and the offering of sacrifices ( $2 \mathrm{Chr} 7: 1,12 ; 29: 27)$ that consist of a ritualized form of speech (Exod 12:1-11, 12, 13, 23, 27; 13:11-16). Since the Sabbath and the sanctuary

\footnotetext{
${ }^{177}$ The apse remained empty.
}

The rabbi who presided over the assembly with the assistance of the 'ancient,' presbyteroi, was seated near the center of the nave on a platform known in Greek as a bema. His seat, which was called the 'chair of Moses,' was placed at the center of the bema. About this 'chair of Moses,'... were benches arranged in a semi-circle for the presbyters. When praying, all, including the people, faced the empty apse (Bouyer, Rite and Man, 167-168).

${ }^{178}$ Bouyer, Rite and Man, 168. "Later, but apparently not before the beginning of the Christian era, the ark was built of stonework and was gradually pushed back into the apse itself, where it may be seen in modern synagogues," Ibid., 168.

$$
\begin{aligned}
& { }^{179} \text { Ibid., } 168 . \\
& { }^{180} \text { Ibid., } 168 .
\end{aligned}
$$

${ }^{181}$ See Chapter 5 liturgical actions for Exod 19-20; Deut 4-5; $1 \mathrm{Kgs} 8: 12-66$; 2 Chr 57; and Isaiah 6:1-13. 
involve all of the liturgical components, they play a leading role in temporally grounding the relationship between all of the liturgical components. Our purpose in this section noted how they temporally ground the relationship between the divine presence and preaching as the central ritual action in the Gospels and in Acts.

Acts $2: 1-47$

\section{Description}

The following points support the deduction that preaching is the central liturgical action on the Day of Pentecost. Peter's sermon begins in Acts 2:14 and ends in v.40, which effectively takes up the vast majority of Acts 2 . Moreover, the outpouring of the Holy Spirit that was manifested by the disciples speaking with other tongues (languages) ${ }^{182}$ the wonderful works of God (Acts 2:11) attracted the attention of the multitudes that were there "from every nation under heaven" (Acts 2:5). Consequently, Peter's sermon provided the answer to the question that was upper most in their minds regarding the unusual events of the day, which was "Whatever could this mean?" (Acts 2:12). Peter's sermon explained that it was Christ's inauguration as high priest at the right hand of God in the heavenly sanctuary (Acts 2:33) that was directly connected to the outpouring of the Holy Spirit that made it possible for them to speak in all of these languages.

Some of the preparatory activities included meeting in the upper room (Acts 1:13) in order to continue with one purpose or mind in prayer and supplication (Acts 1:14). The passage in Acts 2:1 records that they were in one accord and in one place. This provided

\footnotetext{
${ }^{182}$ For a biblical studies exegetical approach to speaking in tongues as languages, see Hasel, Speaking in Tongues.
} 
the conditions for the Holy Spirit to be poured out (Acts 2:2-4) that led to the disciples speaking in tongues God's wonderful works, and then eventually to Peter's sermon.

With regard to liturgical time, interpreters vary on when the day of Pentecost occurred. ${ }^{183}$ However, the majority of the references in Acts that refer to liturgy occur on Sabbath. ${ }^{184}$ Nevertheless, although the Day of Pentecost deals with time, it is the typological link between the seven major festivals in Lev 23 and the sanctuary that ultimately grounds its meaning within the overall time frame of salvation history rather than its connection with any particular day of worship. ${ }^{185}$

\footnotetext{
${ }^{183}$ The Sadducees in the first century
}

interpreted the sabbath in the phrase 'the morrow after the sabbath' (Lev 23:15) as the weekly Sabbath....The Pharisees, however, took the 'Sabbath' of Lev 23:15 to be the festival day of unleavened bread...in this case Pentecost would always fall on the same day of the month...but not on the same day of the week (F. F. Bruce, The Book of the Acts NICNT (Grand Rapids, MI: Eerdmans, 1988), 49 note 3; Fitzmyer, The Acts of the Aposles AB 31, 233).

F.F. Bruce also notes that "Christian tradition accordingly has fixed the anniversary of the descent of the Spirit on a Sunday (the "fifty days" of Lev. 23:15 being reckoned inclusively)." F. F. Bruce, The Book of the Acts NICNT, 49 footnote 3. While the descent of the Spirit on Sunday is a possibility, there is no support for assigning sacredness to Sunday on this account. See "Pentecost" $S D A B C$ 6:s.v. Acts 2:1. Others believed that Pentecost always fell on a Friday but that we should not place a lot of weight on the dating of Pentecost since it does not necessarily belong to the substance of the story. Hans Conzelmann, Acts of the Apostles Hermeneia (Philadelphia: Fortress Press, 1987), 13, 16.

${ }^{184}$ See Acts $13: 14 ; 16: 13 ; 17: 1-2 ; 18: 4$. An exception is Acts $20: 7-12$, yet if we employ the Bible as the interpretive tool for the "first day of the week," then it is clear that this took place on Saturday night. See C. K. Barrett, A Critical and Exegetical Commentary on the Acts of the Apostles Vol.2 ICC (New York: T \& T Clark, 1998), s.v. Acts 20:7; John B. Polhill, Acts The New American Commentary 26 (Nashville, TN: Broadman \& Holman, 1992), s.v. Acts 20:7. See also Norman H. Young's critique of S.R. Llewelyn's use of Acts 20:7 as a justification for Christians who regularly met together on the first day of the week. “"The Use of Sunday for Meetings of Believers in the New Testament' A Response," Novum Testamentum 45 (2003): 118.

${ }^{185}$ There is the Passover (Lev 23:5); unleavened bread (Lev 23:6); the beginning of the barley harvest or first fruits (Lev 23:10-15); Feast of Weeks or Pentecost (Lev 23:1516); Feast of Trumpets (Lev 23:24); Day of Atonement (Lev 23:27-32); and Feast of Tabernacles (Lev 23:33-37). These all typologically point to different events in salvation history. Since Acts 2 does not go beyond Pentecost, I will not attempt to illustrate the typological fulfillment of the rest of the festivals. Prior to Pentecost is Passover, which 
As far as the liturgical setting is concerned, the text merely points out that the disciples were in "one place" (Acts 2:1), which was most likely not the temple but possibly a more private setting such as the large upper room in which the Lord's Supper was eaten (Acts 1:13). ${ }^{186}$ However, regardless of their precise location, there is a

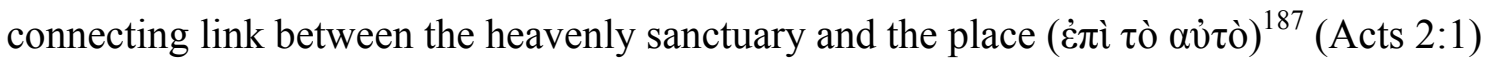
where the disciples met. The evidence for the connection revolves around the event of Christ's inauguration as high priest at the right hand of God in the heavenly sanctuary, ${ }^{188}$ and the outpouring of the Holy Spirit on the disciples as the evidence of that inauguration on earth. $^{189}$

Christ fulfilled by his death on the cross (1 Cor 5:7) while the feast of weeks or Pentecost was fulfilled fifty days later when the disciples met for prayer and supplication (Acts 2:1; cf. $1: 14)$. Hence, the significance of Pentecost for liturgical time lies in where it occurs within the overall history of salvation.

${ }^{186}$ See Fitzmyer, The Acts of the Apostles AB 31, 238; Darrell L. Bock, Acts BECNT (Grand Rapids, MI: Baker Academic, 2007), 94; David G. Peterson, The Acts of the Apostles PNTC, 132.

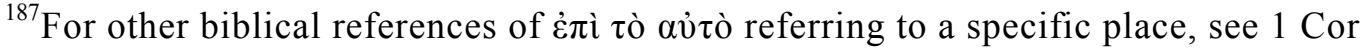
11:20, which refers to Christians coming together in one place to eat the Lord's Supper; 1 Cor 14:23 refers to a liturgical context where the church comes together in one place. Acts 2:44 in Young's Literal Translation states, "and all those believing were at the same place, and had all things common"; whereas other translations state that those who believe were together, see NKJV, NET, NIV, and English Standard Version. However, since the sanctuary temporally grounds the relationship between the components, we should seek to combine the unity between the heavenly sanctuary and the earthly locations of liturgy with the spiritual unity between the heavenly and the earthly, instead of making a dichotomy between the physical location and spiritual unity.

${ }^{188}$ The passage in Acts 2:33 states, "Therefore being exalted to the right hand of God, and having received from the Father the promise of the Holy Spirit, He poured out this which you now see and hear." In Psalm 110:1 The Lord (Father) said to my Lord (Son) "Sit at my right hand, Till I make Your enemies Your footstool." In Psalm 110:4 The Lord (Father) has sworn and will not relent, "You (Son) are a priest forever According to the order of Melchizedek." Hence, to sit at the right hand means to be installed as the high priest in the heavenly sanctuary.

${ }^{189}$ The exaltation of Christ that took place in heaven on the Day of Pentecost was communicated to the world through the outpouring of the Holy Spirit on the disciples. Peter then drew the attention of his hearers to the fact that Christ was alive and at the right hand of God, see Acts 2:25, 30,34, and Eph 1:20; Col 3:1; Heb 1:3; 8:1;10:12; 1 Pet 3:22 and 


\section{Analysis}

It's the heavenly sanctuary that temporally grounds the relationship between the divine presence of Father and Son in the heavenly sanctuary with the revelation of the Holy Spirit's presence at the location where the disciples met on earth. The events of the Day of Pentecost reveal that locations chosen for liturgy on earth must be in harmony with the events that occur in salvation history in the heavenly sanctuary such as Christ's inauguration in the heavenly temple. Since the heavenly sanctuary is really the great center, one is not limited to certain locations on earth as long as the structural ${ }^{190}$ (architectural), functional (liturgical actions), and spiritual connection with the heavenly sanctuary is maintained.

The heavenly sanctuary also temporally grounds the relationship between literal and historical events that focus on Christ as divine presence in the heavenly sanctuary. These events include Christ's inauguration that is revealed by the central ritual action of preaching that is accompanied by the Holy Spirit. The ministry of the Spirit legitimizes what takes place in heaven with the conviction that listeners experience on earth. Another reason for preaching as the central liturgical action in Acts 2 revolves around the fact that historical events that occur in heaven can only reach us here on earth through a form of cognitive communication instead of through material representations. Furthermore, the Spirit only expresses itself through words, speech or writings that comprise the means of

Rev 3:21. These texts connect the throne of God with the right hand of God where Christ is sitting. Hence, the "gift of the Holy Spirit" (Acts 2:38) was meant to draw attention to the fact that Christ was alive and had just been inaugurated as our great high priest.

${ }^{190}$ Structural function is maintained when earthly places set apart sacred spaces whose sole purpose is for the worship of God instead of having an all purpose room where the worship of God is mingled with other less sacred functions in the same place. I draw this from the observation that the heavenly sanctuary contains a holy and a most holy place where Christ performs specific functions in each respective location. 
communicating the divine will and of experiencing a spiritual encounter. Hence, in Acts 2 preaching is the indispensible liturgical action for communicating what Christ is doing in the heavenly sanctuary.

Heb 12:18-29

\section{Description}

The following points indicate that the spoken Word is the central liturgical action in this passage. First, Heb 12:18-21 points back to God speaking the Ten Commandments. The Heb 12:19 reference also mentions two things that are directly related to the spoken word. The first is the "voice of words" ( $\varphi \omega v \tilde{n} \dot{\rho} \eta \mu \alpha ́ \tau \omega v)$ describing God's speech, and the second is that the worshippers at Sinai begged that the "word ( $\lambda$ ó $\gamma$ ov) should not be spoken anymore for they could not endure what was commanded" ( $\left.\delta 1 \alpha \sigma \tau \varepsilon \lambda \lambda o_{\rho} \mu \varepsilon v o v\right)$.

Second, Heb 12:22-24 points to the importance of speech by revealing that Jesus'

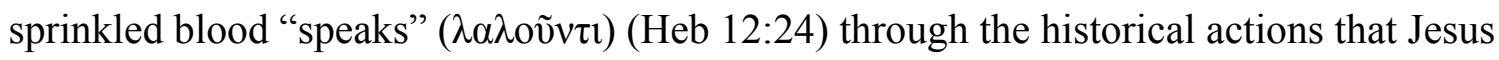
performs as the high priest in the heavenly sanctuary. As a result, this reference to Jesus' sprinkled blood that "speaks" provides the hermeneutical key for interpreting the ritual actions surrounding the sacrifices performed by the priests in the OT as a form of ritualized speech. The book of Hebrews thus interprets the shed blood of the OT sacrifices as being typologically fulfilled by Christ whose sprinkled blood speaks via his death, his inauguration (Exod 29:20; Heb 1:3; 9:21), and his ministry in the holy (Lev 4:17; Num 19:14; Heb 9:23-25) and most holy places of the heavenly sanctuary (Lev 16:14, 15, 19; Heb 9:25; 12:24).

Third, the appeal in Heb 12:25-26 informs us that God speaks ( $\tau$ òv $\lambda \alpha \lambda \circ \tilde{v} v \tau \alpha$ ) 
from heaven stating that He will shake earth and heaven. Fourth, something that is entirely unique to Hebrews' use of Scripture is the fact that almost all quotations from the OT are quotations of God's divine utterances rather than quotations of written OT passages. ${ }^{191}$ This unique contribution of Hebrews emphasizes that only God's Word mediates his presence. ${ }^{192}$ Moreover, only within the framework of God's infinite analogous temporal Being is it even possible for God to simultaneously speak to heaven and earth (Heb 12:25-26).

With regard to liturgical time, Heb 12:18-29 does not contain any information regarding the exact time when worshipers gather, yet Heb 4:9 informs us that there remains therefore a rest ( $\sigma \alpha \beta \beta \alpha \tau \imath \sigma \mu o ̀ \varsigma)$ for the people of God. This text alludes to weekly Sabbath gatherings for worship ${ }^{193}$ without at the same time limiting congregations from assembling at other times.

${ }^{191}$ Cortez, "See that you do not refuse the one who is speaking,"101-104. Pamela Michelle Eisenbaum, quoted in Cortez' article, identifies the following quotations as being direct speech where the numbers in parenthesis refer to OT passages quoted from the LXX: Heb 1:5a (Ps 2:7); 1:5b (2 Sam 7:14); 1:6b (Deut 32:43); 1:7 (Ps 103:4); 1:8-9 (Ps 44:7-8); 1:10-12 (Ps 101:26-28); 1:13 (Ps 109:1); 2:12 (Ps 21:23); 2:13a (Isa 8:17=2 Sam 22:3); $2: 13 \mathrm{~b}$ (Isa $8: 18$ ); 3:7-11 (and several times in the section; Ps 94:7-8); 5:5 (Ps 2:7); 5:6 (Ps 109:4); 6:14 (Gen 22:17); 7:21 (Ps 109:4); 8:5 (Exod 25:40); 8:8-12 (Jer 38:31-34); 9:20 (Exod 24:8); 10:5-7 (Ps 39:7-9); 10:16-17 (Jer 38:31-34); 10:30a (Deut 32:35); 10:30b (Deut 32:36); 10:37a (Isa 26:20-21); 10:37b (Hab 2:3-4); 11:18 (Gen 21:12); 12:5-6 (Prov 3:11-12); 12:21 (Deut 9:19); 12:26 (Hag 2:6); 12:29 (Deut 4:24); 13:5 (Deut 31:8); 13:6 (Ps 117:6).

\footnotetext{
${ }^{192}$ Cortez states,
}

This immediacy of the word of God in Hebrews is very important for its hortatory argument. By means of the quotation of the word of God as direct speech, Hebrews has made a 'theological redescription of time and space.' In other words, it has constructed through Scripture a world where the readers - or, hearers - stand in the presence of God and hear him speak (Ibid., 104).

${ }^{193}$ For the strong links between ( $\left.\sigma \alpha \beta \beta \alpha \tau \imath \sigma \mu o ̀ \varsigma\right)$ and the Seventh-day Sabbath, see Erhard Gallos, "K $\alpha \tau \alpha \pi \alpha v \sigma i \varsigma$ and $\Sigma \alpha \beta \beta \alpha \tau 1 \sigma \mu \mathrm{o} \zeta$ in Hebrews 4" (PhD dissertation, Andrews University, 2011). See also Luke 4:16; Acts 13:14; 17:2; 18:4 for the link between weekly gatherings on Sabbath for worship at the synagogues. 
With reference to liturgical space, our passage in Heb 12:18-29 informs us that there are two locations where worshippers gather; one earthly and the other heavenly. First, the statement, "but you have come to Mount Zion...the heavenly Jerusalem" (Heb 12:22) assumes that the earthly worshippers can conceivably be located throughout the entire empire (Heb 13:23-24; Col 1:23) in house gatherings, ${ }^{194}$ synagogues, ${ }^{195}$ churches, and groups of churches; ${ }^{196}$ as well as throughout the entire world today. Second, regardless of each church's local setting, the one central location that all worshipers spiritually approach ${ }^{197}$ unto is "Mount Zion...the city of the living God, the heavenly Jerusalem" (Heb 12:22) where Jesus is Mediator of the new covenant through the blood of sprinkling (Heb 12:24). It is here that the "spirits of just men [are] made perfect" (Heb 12:23). Hence, in this Hebrews passage, the heavenly sanctuary plays a grounding role by revealing preaching as the central liturgical action that earthly places of liturgy must imitate.

\section{Analysis}

Since the heavenly sanctuary plays such a vital hermeneutical role in this Hebrews passage, there are several ways that it temporally grounds the relationship

${ }^{194}$ House gatherings (Rom 16:5; 1 Cor 16:19; Col 4:15; Phlm 1:2).

${ }^{195}$ Synagogues (Acts 13: 5, 15; 17:1-4; 18-18).

${ }^{196}$ For churches (Acts 13:1; 1 Cor 1:2; 1 Pet 5:13; Rev 1:11). Moreover the following texts refer to a group of churches (Acts 9:31; Rom 16:4, 16; 1 Cor 11:16;14:33; 16:1, 19; 2 Cor 8:2; Gal 1:2, 22; 2 Thess 1:4).

${ }^{197}$ The passage is addressed to living Christians and not to those in all ages in the past. Thus, the living spiritually approach heaven in much the same way that those who are in need can "come boldly unto the throne of grace" (Heb 4:16). 
between the divine presence and the liturgical actions. ${ }^{198}$ First, the heavenly sanctuary temporally grounds the relationship between itself as the place that worshippers ultimately approach with places of liturgy all over the world such as house gatherings, synagogues, churches, and groups of churches. This ensures that there is not a dichotomy between the structure of the heavenly sanctuary and earthly places of worship, which means that earthly locations should mediate the heavenly.

Second, the heavenly sanctuary temporally grounds the relationship between heavenly speech (Heb 12:24, 25) and the worshipers who are able to hear it ensuring that there is no dichotomy between the content of heavenly speech and that of earthly speech. ${ }^{199}$

Third, the heavenly sanctuary temporally grounds the relationship between the divine/human natures of Jesus as the mediator of the new covenant (Heb 12:24) and the historical act of Jesus in sprinkling his blood in the heavenly sanctuary (Heb 12:24) with the central liturgical action of speaking to the worshippers on earth (Heb 12:24-26). There are several different ways of speaking to the worshippers on earth. The first, and the main one, occurs through the illumination of the Holy Spirit in the mind of the human

${ }^{198}$ Aelred Cody notes, "The Alexandrian dualism which plays so important a part in the theological speculation of the Epistle to the Hebrews in general is most explicit and most important in the author's speculation on the heavenly and the earthly sanctuaries." Aelred Cody, The Heavenly Sanctuary and Liturgy in the Epistle to the Hebrews, 145. In basing his interpretation of the relationship between the earthly and heavenly sanctuaries on Alexandrian dualism, Cody places an ontological dichotomy between the heavenly and the earthly sanctuaries. As a result, the description of the heavenly sanctuary in Hebrews is not of a real structure that is analogous to the earthly sanctuary. Instead, the heavenly is a cultural and historical description of a timeless reality. Such a view, however, makes it impossible for the heavenly sanctuary to function in such a way that it temporally grounds the relationship between heaven and earth.

${ }^{199}$ This is in clear contrast to Cody who states that Christ's sacrifice has "eternal value "speaking' for us" in which he clearly assumes the Alexandrian view of a timeless heavenly speaking. See Aelred Cody, The Heavenly Sanctuary and Liturgy in the Epistle to the Hebrews, 200. 
liturgist (Heb 9:6-8) who then proclaims a message about Christ as mediator of the new covenant (Heb 12:24; cf. 10:15-17), and about Christ's actions as high priest in the heavenly sanctuary (Heb 12:24). The author of Hebrews who authoritatively proclaims his message with either $\lambda \alpha \lambda \dot{\varepsilon} \omega$ or $\lambda \dot{\varepsilon} \gamma \omega$ (Heb 2:5, 5:11, 6:9, 8:1, 9:5, 11:32, 13:6) reinforces this mode of proclamation.

Since God speaks in various ways (Heb 1:1), the second way in which Jesus' sprinkled blood "speaks" to worshippers on earth is through the Lord's Supper. This NT ordinance thematically connects with Heb 12:24 and with the OT sacrifices. ${ }^{200}$ As a result, the historical enactment of the OT sacrifices that are a form of ritualized speech lays the groundwork for us to view the historical enactment of the Lord's Supper as a ritual that is pregnant with meaning that is integrally connected with the blood of Christ. Furthermore, the connections between Heb 12:24, the OT sacrifices, proclamation, and the Lord's Supper can also be extended to baptism, foot washing, and anointing with oil as modes of speech in which God "speaks from heaven" (Heb 12:25) to worshippers on earth. Since the heavenly sanctuary grounds the temporal relationship between Jesus' sprinkled blood that speaks and the OT sacrificial rituals, the sacramental interpretation of proclamation, the Lord's Supper, baptism, foot washing, and anointing with oil that the other models espouse is rendered groundless. Moreover, there is no dichotomy between historical personages and events in heaven with the Holy Spirit who

\footnotetext{
${ }^{200}$ The thematic connections between Heb 12:24, the OT sacrifices, and the Lord's Supper are as follows. The OT sacrifices included lambs representing Christ (John 1:29) and blood that was shed for forgiveness of sins (Heb 9:21-22) within the context of the old covenant (Exod 24:3-8). The Lord's Supper has bread and wine that represent Christ, in which wine represents Christ's blood that is shed for the forgiveness of sins in the context of the new covenant (Matt 26:26-28; 1 Cor 11:23-26). The Heb 12:24 passage refers to Jesus as the mediator of the new covenant, and to his sprinkled blood that speaks better things than that of Abel, including forgiveness of sins.
} 
works in concert with the human liturgists who preach God's word (Heb 13:7) to

congregations on earth. Furthermore, the invisible omnipresence of the Holy Spirit who

reveals himself through Scripture safeguards the fact that only God's Word mediates his presence. $^{201}$

Rev 4-5

\section{Description}

The heavenly sanctuary setting of this Rev 4-5 vision temporally grounds the relationship between God's infinite analogous temporal Being as Trinity and the liturgical actions. ${ }^{202}$ It also temporally grounds the relationship between heavenly liturgical actions and earthly liturgical actions. ${ }^{203}$ Under the influence of timeless Being,

${ }^{201}$ For further connections between the Holy Spirit's revelation of Christ's work in the sanctuary and the human liturgist, see the commentary on the liturgist in Heb 12:18-29 in this Chapter.

${ }^{202}$ Aelred Cody specifically applies the following insight to the relationship between the heavenly temple and liturgy. He states,

Sacred rites take place in sacred places, and to a great extent the sacred places will determine the orientation of the rites or liturgies which take place in them. All of what follows in this chapter on the theme of a celestial liturgy must be seen in connection with the theme of a celestial sanctuary. The two go together and presuppose one another for their mutual understanding (Aelred Cody, The Heavenly Sanctuary and Liturgy in the Epistle to the Hebrews, 47).

Unfortunately, he applies Philo's Greek interpretation to the nature of the celestial sanctuary, which then hermeneutically determines the nature of celestial liturgy. Ibid., 77.

${ }^{203}$ In clear opposition to the biblical view that assumes a correspondence between heavenly liturgical actions and earthly liturgical actions, Cody notes that no correspondence is possible between

a ritual in that tent [Moses' Tent] and some ritual in the heavenly sanctuary...nor does the development of the them in Wis. 9:8 postulate a correspondence of ritual or of liturgical action, because the heavenliness in that text does not involve any dimensions of time or space or volume (Aelred Cody, The Heavenly Sanctuary and Liturgy in the Epistle to the Hebrews, 48).

Hence, timeless Being automatically eliminates any correspondence while the biblical view assumes that God's infinite analogous temporal Being and the heavenly sanctuary temporally grounds the heavenly with the earthly liturgical actions. Regarding the 
the previous models spiritualize away the spatial specifications, the architecture, and the articles of furniture in the heavenly temple. ${ }^{204}$ Consequently, some scholars (1) reduce the heavenly sanctuary to the presence of God; ${ }^{205}$ (2) ignore or eliminate the reference to

Alexandrian influence on Hebrews, Treiyer states that "the general trend of those who adopt consciously or unconsciously the Greek pattern of criteria, is that of reducing, in some way, the value of the typological correspondence between the two systems [Levitical typology and the heavenly ministry of Christ] of worship." Alberto Treiyer, The Day of Atonement and the Heavenly Judgment from the Pentateuch to Revelation, 406 footnote 150.

${ }^{204}$ Scott Hahn points out that "the Temple theme is perhaps the richest in all biblical theology," Hahn Temple and Contemplation, 8. Hahn also states that the purpose of Temple and Contemplation is to contemplate the beautiful mysteries that are associated with it. However, it is clear that Hahn is working from the Sacramental Model's view since each article in the sanctuary assumes the massive influence of timeless Being on the Temple itself. For instance, Gary Anderson explored "how Israel came to believe that the holiness of God's invisible presence infused the architecture and furniture of God's dwelling, making these physical objects bearers of the divine presence." Ibid., 8-9. Under the influence of dynamic timeless Being Jean Cardinal Daniélou explores how all of creation and indeed the universe constitutes a Temple "where we are at home with God in the cool of the evening, where man comes forward, silent and composed, absorbed in his task of perpetual liturgy, attentive to that presence which fills him with awe and tenderness." Daniélou, "The Sign of the Temple: A Meditation," 258-259, cf. 256. Thus, timeless Being's interpretation of the Temple becomes the hermeneutical framework to interpret (1) the Temple of Christ, Anderson, "To See Where God Dwells," 33-34; Daniélou, "The Sign of the Temple: A Meditation," 265-268; (2) the Temple of the Church, Anderson, "To See Where God Dwells," 33; Daniélou, "The Sign of the Temple: A Meditation," 268-273; (3) the interpretation of the soul as the point of contact with the divine presence, Daniélou, "The Sign of the Temple: A Meditation," 279-283; (4) the heavenly liturgy of the Mass as the real presence that constitutes "a mystery abstracted from time," Daniélou, "The Sign of the Temple: A Meditation," 285; Scott W. Hahn, "Temple, Sign, and Sacrament: Towards a New Perspective on the Gospel of John," 107-109, 142; (5) "the Temple of time "desires" to be engulfed in the Temple of eternity," Yves Congar, "Church, Kingdom, and the Eschatological Temple," in Temple and Contemplation: God's Presence in the Cosmos, Church, and Human Heart, ed. Scott W. Hahn (Steubenville, OH: St. Paul Center for Biblical Theology, 2008), 297; and (6) the eschatological goal is summed up in the following way:

the great story of God's presence to his creatures...begins by momentary contacts and visits, then passes through the stage of external meditations that draw God ever nearer to mankind, and finally reaches the state of perfectly stable and intimate communion. Whether it be through the Temple, the sacrifice, or the priesthood, God's plan moves towards a communion of such intimacy that the duality between man and God, and therefore their external separation from one another, are both overcome in so far as this is possible without a meaningless confusion of beings or pantheism (Ibid., 315).

${ }^{205}$ Cody states, 
doors (Rev 4:1, cf. 3:7-8) ${ }^{206}$ and historical liturgical actions; ${ }^{207}$ (3) state that the exact

location of the scenes of Rev 4-5 is not critical in interpreting the vision; ${ }^{208}$ and (4) merge

There is no more special 'place' in heaven which is a temple, because there is no more corresponding special place on earth which is a temple; the process of universalization and interiorization of God's presence and of sanctity is complete, and all that is set in the glory of God and the Lamb is in the true temple of heaven (Aelred Cody, The Heavenly Sanctuary and Liturgy in the Epistle to the Hebrews, 44).

For more examples, see also Alberto Treiyer, The Day of Atonement and the Heavenly Judgment from the Pentateuch to Revelation, 373 note 17; King L. She, The Use of Exodus in Hebrews, 171-173; G.K. Beale, The Temple and the Church's Mission: A Biblical Theology of the Dwelling Place of God NSBT, 25, 48, 335-364.

${ }^{206}$ Treiyer correctly notes that Greek philosophical ideas lie at the basis of those who state that God cannot be confined to one room, or that there are no rooms separated by doors, or that doors are metaphors. See Alberto Treiyer, The Day of Atonement and the Heavenly Judgment from the Pentateuch to Revelation, 480, 481.

${ }^{207}$ Aelred Cody clearly states that when Christ and the saints reach the celestial Jerusalem

there are no more rites or formularies or harps or censers... There is no more incessant repetition because the dimensions of motion and time are no more, and the sentiments of the erstwhile pilgrims are fixed in the ecstasy of eternity.... God is contemplated chiefly as being what $\mathrm{He}$ is. There is, then, at the end of the pilgrimage, no more liturgical action.... The liturgical action of the Church on earth and of the Church and the angels, concerned with the government of the world, in heaven will cease when all as a group have reached the celestial term of their motion as a group (Aelred Cody, The Heavenly Sanctuary and Liturgy in the Epistle to the Hebrews, 70).

208“The exact location [of the vision of Rev 4-5] does not seem to be critical to the interpretation of the vision." Moreover,

The word 'whenever' [Rev 4:9] makes it clear that this scene in Rev 4 is not a particular point in time (such as A.D. 31 or 1844). Rather, it portrays the ongoing nature of heavenly worship. Chapter 4 is not a one-time event, but the basic setting for all activity in the heavenly throne-room (Jon Paulien, "The Seven Seals," in Symposium on Revelation-Book I, ed. Frank Holbrook (Silver Spring, MD: Biblical Research Institute, General Conference of Seventh-day Adventists, 1992), 221, 215 cf. "Every Creature" $S D A B C$ 7:s.v. Rev 5:13).

Treiyer correctly notes that "the temporal and spatial projections of Revelation are eliminated following Greek postulates," which constitutes the "real problem behind these interpretations," Alberto Treiyer, The Day of Atonement and the Heavenly Judgment from the Pentateuch to Revelation, 669 footnote $17 \mathrm{cf}$. 524 footnote 280. Strand states that the primary importance of the throne motif is to signify the divine presence and authority and "is not basically an indicator of a specific locale (and certainly not 'geographical' confinement!). The concept is not that the throne fixes God's location, but rather the reverse: Where God is, there is the throne!" Kenneth Strand "Victorious Introduction' Scenes" in Symposium on Revelation-Book I, ed. Frank Holbrook (Silver Spring, MD: Biblical 
the two apartments of the sanctuary to just one room. ${ }^{209}$ Moreover, timeless Being's

hermeneutical control over the nature of God logically limits the blood of the slain Lamb

(Rev 5:6) to the manifestation in time of God's timeless eternal act $^{210}$ that is only realized

Research Institute, General Conference of Seventh-day Adventists, 1992), 58 footnote 11. (emphasis original). Strand seems to be assuming Parmenides' and Plato's ontological gap when he strips the throne of any geographical significance as well as any real significance by merely employing it as a symbol of the divine presence.

209 "On the basis of a possible analogy with the thought expressed concerning the 'veil' or 'curtain' in Heb 10:20 (with its too-frequently-overlooked historical backdrop of the rent-asunder veil in Matt 27:51) there could be in Revelation an underlying concept of one room in the heavenly temple, but the functional significance of the two-room model is nevertheless present in Revelation." Kenneth Strand "“Victorious Introduction' Scenes," 58 footnote 11. (emphasis original). However, the following evidences point to two doors and thus two rooms. First, Moses' tabernacle speaks of the door/veil entering into the sanctuary (Exod 29:4, 11, 32, 42; Num 3:26) and the door/veil that separates the holy from the most holy place (Exod 26:31-35; Lev 16:2; Heb 9:3). Likewise Solomon's temple speaks of a door/veil that enters into the sanctuary, and a door that separates the holy place from the most holy place ( $1 \mathrm{Kgs} 6: 31-35 ; 7: 50$ ). These earthly copies, given through inspiration (Exod 25:8, 9 40; 1 Chr 28:12, 19; Heb 8:1-5; 9:23-24), point to two doors/veils in the heavenly sanctuary in the book of Revelation. Second, in the earthly sanctuary, prior to the Day of Atonement the door to the most holy place is closed (Lev 16:2) while the door into the holy place is open so that earthly priests can minister therein. However, on the Day of Atonement, the door to the holy place is closed (Lev 16:17) while the door to the most holy place is opened so that the high priest alone (Heb 9:7) can enter in and perform his work (Lev 16:12-13, 15-18). When the work of the high priest is done, he exits the sanctuary (Lev 16:17b-18). Third, regarding the heavenly sanctuary, Christ as high priest is ministering in the holy place in Rev 1:12-13 among the seven golden candlesticks. The ability of Christ to open and shut in Rev 3:7 pertains to a door in Rev 3:8 that only he can open and shut. Since, Christ is already ministering in the holy place, that door is open. As a result, to set before his people an open door ( $\operatorname{Rev} 3: 8$; cf. 4:1;11:19) implies that it had been closed during his holy place ministry, which closely matches Lev $16: 2,17$. Hence, setting before his people an open door (Rev $3: 7-8 ; 4: 1 ; 11: 19$ ) must refer to the door that separates the holy from the most holy place. During Christ's work in the most holy place, the door into the sanctuary remained closed (Lev 16:17; Rev 15:5). Yet, at the close of Jesus' ministry in the most holy place, we learn in Rev 15:5-8 that the door into the sanctuary that was closed at the beginning of his most holy place ministry is now opened. The seven angels having the seven last plagues now exit the sanctuary, and just like Lev 16:17b-18, Jesus as our high priest exits the sanctuary and comes to bless his waiting people (Num 6:24-26; Matt 25:34). For more on the doors of the sanctuary, see Alberto Treiyer, The Apocalyptic Expectations of the Sanctuary, (Alberto Treiyer, 2008), 101-130. The tendency to ignore the OT data and the book of Revelation better harmonizes with the hermeneutical role of timeless Being's reduction of the spatial and geographical indicators that the text clearly provides.

${ }^{210}$ Commenting on Heb 9:12 where Christ through his blood has entered the sanctuary once and for all, Cody states, 
in a timeless heaven in the enthronement. ${ }^{211}$ Accordingly, it is philosophically impossible to even consider that the events of Rev 4-5 might take place after the crucifixion and enthronement since this implies a succession of events in time and space.

In contrast, God's infinite analogous temporal Being makes room for the possibility of the passing of time between the blood that was shed on the cross and its application (Heb 12:24; Rev 5:6) ${ }^{212}$ on the antitypical Day of Atonement in the heavenly

The historical acts of salvation are done, and yet something of them has gone over into glory, into the celestial, eternal sphere, and is prolonged in eternity, outside the limits of space and time... Christ's offering of Himself in expiatory sacrifice in time is confronted in eternity by the power of the eternal spirit (9.12); the blood of the atonement shed in history is efficacious because it is in confrontation with divine power, which is itself measured not by time but by eternity. The saving action of Christ remains forever.... The acts of salvation are thus wrought in history up to the term of the Ascension, where they are brought in confrontation with eternity-not as the Passion alone (which is itself a unity comprising a plurality of acts), nor as the Resurrection or the Ascension alone, but as the unified whole of the one act of salvation, with each of its component acts, however, keeping its own value in the whole. This is objective redemption (Aelred Cody, The Heavenly Sanctuary and Liturgy in the Epistle to the Hebrews, 195, 196).

This effectively eliminates any succession in time or movement in space. Thus it is this perspective that grounds the scenes of Rev 4-5 to the inauguration.

${ }^{211}$ Cody again states,

On the side of eternal spirit there is no time-gap. The blood of Calvary speaks now not from Calvary but in the heavenly world, not from time but on the level of eternity, where it has been situated by the Ascension and Session, as the atoning blood of aspersion, eternally present to God in His celestial sanctuary (Aelred Cody, The Heavenly Sanctuary and Liturgy in the Epistle to the Hebrews, 198 cf. 200).

Treiyer perceives the hermeneutical effects of timeless Being when he notes that those who deny or diminish the typological correspondence between the heavenly and earthly sanctuaries and ministrations limit the performance of the covenant and the Day of Atonement to either the death of Christ on the cross or to Christ's inauguration of the heavenly sanctuary. Alberto Treiyer, The Day of Atonement and the Heavenly Judgment from the Pentateuch to Revelation, 420.

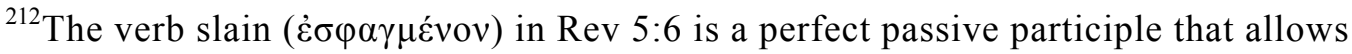
for a completed action in the past to have ongoing results. See Beale, The Book of Revelation NIGTC s.v. Rev 5:6a; Robert H. Mounce, The Book of Revelation NICNT (Grand Rapids, MI: Eerdmans, 1977), 146. Viewed from the context of God's infinite analogous temporal Being, this allows for Christ's blood to be shed at one point in time while it is applied at another point in time. For Heb 12:24 as Day of Atonement as well as inauguration, see this dissertation, page 346. For limiting Heb 9:13, 23-25, and 12:24 to the inauguration, see this dissertation, pages 368-373. 
sanctuary. Moreover, the sanctuary geography and spatial arrangements in the heavenly sanctuary are similar to what was revealed to Moses. ${ }^{213}$ As such, the spatial and architectural indicators in Rev 4-5 refer to real entities in heaven that are analogous to their earthly counterparts. ${ }^{214}$ Hence, the Biblical Sanctuary Model will employ the articles of furniture associated with the heavenly sanctuary in the Rev 4-5 vision as foundational phenomenological exegetical principles that provide the hermeneutical framework for understanding the relationship between the nature and actions of the divine presence, and the specific liturgical actions in this heavenly scene. ${ }^{215}$

Before I begin my analysis, I will note that there are differences of opinion regarding the liturgical setting of Rev 4-5. However, I will restrict my description and analysis to the relationship between the divine presence and liturgical space, liturgical time, and the nature of the content of the sealed scroll. First, with respect to the relationship between the divine presence and liturgical space, does this vision take place in the first or in the second apartment of the heavenly sanctuary? Or does the vision of the throne do away with doors in heaven since confining God to one room is impossible

${ }^{213}$ This is very clear in King She, The Use of Exodus in Hebrews, 132.

${ }^{214}$ Under the influence of timeless Being on the heavenly sanctuary, King She notes that God's throne is considered to be non-spatiotemporal. However, after his deconstruction of the effects of timeless Being on the heavenly sanctuary, his construction reveals that the ark of the covenant and the altar of incense in the heavenly sanctuary constitute spatiotemporal realities. See Figures 20 and 21 in King L. She, Ibid., 172, 173.

${ }^{215}$ Treiyer emphasizes that it is especially important to understand the "temporal and spatial dimensions" of Rev 4-5 in order to correctly interpret the content of the vision. In contrast, "the Christological spiritualizations of the temple and the furnishings must not occupy the place and the time corresponding to the typology of its ministry." Alberto Treiyer, The Day of Atonement and the Heavenly Judgment from the Pentateuch to Revelation, 474, 478 cf 383-405. 
to reconcile with His omnipresence ${ }^{216}$ The second difference of opinion concerns liturgical time and is closely related to the first problem noted above, namely, does this vision occur as an enthronement scene after Christ's resurrection ${ }^{217}$ or does it reveal a Day of Atonement judgment scene taking place before Christ's second advent? Since the heavenly sanctuary in the Biblical Sanctuary Model temporally grounds the liturgical actions in heaven with those that should occur on earth, discovering when this vision takes place provides an important context for the church that seeks to draw its principles of liturgy from the heavenly vision.

Having therefore established the hermeneutical importance of sanctuary geography and architecture, the key to establishing the location (liturgical space), as well as the time ${ }^{218}$ of the vision of Rev 4-5 is the throne that is mentioned in the context of the

${ }^{216}$ Those who place the vision of Rev 4-5 completely in the holy place view the table of showbread as a symbol of the throne. Treiyer, however, points out ten problems with this assertion that the reader is encouraged to investigate. See Ibid., 476-479.

${ }^{217}$ Some of the main arguments for the inaugural view include: (1) the structural view of Revelation in which the first half of the book constitutes the historical aspect and the latter half of the book constitutes the eschatological aspect. See Kenneth Strand, "Victorious Introduction Scenes"; (2) there is only one book in Rev 5 instead of many books as in the judgment scene of Dan 7 implying an enthronement scene similar to the ones in the OT such as in Deut 17:14-20; (3) Christ is allegedly seated during this enthronement in Rev 5 ; (4) there is the absence of judgment language in Rev 4-5; and (5) the symbol chosen to represent Christ is the Lamb as opposed to a goat on the Day of Atonement. For a representative of the enthronement view, see Ranko Stefanovic, "The Background and Meaning of the Sealed Book of Revelation 5," 206-217. For a representative of the Day of Atonement view, see Alberto Treiyer, The Day of Atonement and the Heavenly Judgment from the Pentateuch to Revelation, 476-488.

${ }^{218}$ In the heavenly sanctuary, it is the architectural symbols that are spatially located in the Holy and Most Holy places that are causally linked with the timing of the vision. Treiyer points out that

the 'copy and shadow of the heavenly sanctuary' had not only to do with the building, but also with the priestly ministry (Heb 8:3-5=RSV). There was not only correspondence between the two buildings, but also between two ministries. This is the reason why the relation between the earthly and heavenly things is seen at the same time in a dimension from past to future, or from promise to fulfillment, and not in a Greek relation of time 
open door in Rev 4:1. ${ }^{219}$ We find the first line of evidence regarding the location of the throne in Rev 3:7-8 and 4:1 where we notice the existence of two doors in the heavenly temple. The statement of $\operatorname{Rev} 4: 1$ indicating that there is a door $(\theta \dot{v} \rho \alpha)$ standing open in heaven assumes that it had been closed before, probably after the heavenly temple was inaugurated (Dan 9:24; Acts 2:33). This would match the sequence performed during the inauguration of the earthly temple/sanctuary in which both doors/veils were open during the inauguration but then the door/veil to the most holy place was closed while priests ministered in the holy place. ${ }^{220}$ The only other occasion on which the door/veil to the most holy place was opened was on the Day of Atonement, and on that day no one but the high priest was permitted to come into most holy place (Lev 16:1-2, 17). This implies that the door separating the courtyard from the holy place was closed, which prevented anyone from entering therein. Thus in the earthly ministration there is one door open and one door closed on the Day of Atonement; this is also what we find in Rev 3:7-8 and 4:1. Furthermore, the septet series involving the churches, seals, trumpets and plagues reveals that the throne of God in Rev 4:1 is in the exact same location as the ark of the covenant in Rev 11:19. Each septet series ends in a throne room scene that consists of lightnings,

and timelessness (The Day of Atonement and the Heavenly Judgment from the Pentateuch to Revelation, 420).

${ }^{219}$ The throne is mentioned 14 times in Rev 4 and 5 times in Rev 5, thus it is "clearly central to the visionary description [of] (Rev 4-5)." See Jon Paulien, "The Seven Seals," 206.

${ }^{220}$ In an inaugural setting, all of the articles of furniture are anointed with oil signifying that both doors are open such as what we find in Exod 29:43-44; 30:26-29; 40:916, 34-35; Lev 8:10-12; 9:23-24; 1 Kgs 8:10-11; 2 Chr 5:11-14; 7:1-2. However, the passages in Rev 3:7-8; 4:1; and 11:19 indicate that one door is closed while another is opened. This closely matches the work of the high priest on the Day of Atonement in which the door to the most holy place was opened while the entrance into the tent of meeting was closed (Lev 16:2,17). See Alberto Treiyer, The Day of Atonement and the Heavenly Judgment from the Pentateuch to Revelation, 483-485. 
thunderings and voices $(\operatorname{Rev} 4: 5 ; 8: 5 ; 11: 19 ; 16: 18) .{ }^{221}$ Since the seventh seal, the seventh trumpet, and the seventh plague all depict scenes of judgment in connection with the Second Coming of Christ, it is logical to assume that the seventh church leading into the throne room scene of Rev 4 is speaking of the same location and event as the seventh trumpet in Rev 11:15-19. Furthermore, Rev 11:15 depicts the twenty-four elders who sit on their thrones worshipping God on his throne. In the same scene the temple of God is opened and now attention is drawn to the ark of the covenant (Rev 11:19), which is in the same location as the throne where we just saw the twenty-four elders seated on their thrones. In Rev 4:4, 10 we find the same twenty-four elders worshipping God on the throne as they do in Rev 11:15. Hence, the immobile throne in both Rev 4:1 and 11:15-19 indicates that these are complementary descriptions of the same location and event. Rev 11:19 indicates that when this door is opened one can see the ark of the covenant in the most holy place from the perspective of one standing in the holy place. In the LXX door ( $\theta \dot{v} \rho \alpha)$ can signify both the door/veil to the tent of meeting (Exod 29:4, 11, 32, 42) and the door to the most holy place in the temple (1 Kings 6:31, 32, 34; 7:50; 2 Chr 4:22). Accordingly, on the basis of Rev 3:7-8, 4:1 and 11:19 it must be the door to the most holy place that is opened while the door to the holy place is closed. This places the throne of Rev 4-5 in the most holy place.

Second, the call for John to come up here in Rev 4:1 can be understood on the basis that the most holy place is higher in elevation than the rest of the temple. In Solomon's temple, the Lord added new details to the plan of the sanctuary (1 Chr 28:19)

\footnotetext{
${ }^{221}$ For an outline of the recapitulative literary structure of Revelation 1-11 that involves further explanations of each septet series in relation to the throne of God and the judgment, see Alberto Treiyer, Apocalyptic Expectations of the Sanctuary, 302-311.
} 
revealing that the most holy place is higher than the rest of the temple (1 Kings 6:2, 20), which has been confirmed by archaeological discoveries. ${ }^{222}$ Hence, the call to "come up here" in Rev 4:1 is a call to enter into the most holy place of the heavenly temple. ${ }^{223}$

Third, despite the many similarities between the living creatures in Ezek 1 and Rev 4, the living creatures in Rev 4 make no mention of wheels (Ezek 1:15-16) and neither do they bear the throne (Ezek 1:22, 26). Davis notes that "in Ezekiel the throne is traveling, while in Revelation it is stationary." 224 Moreover, the central location of the throne in the heavenly temple is emphasized by the following facts: (1) the rainbow is

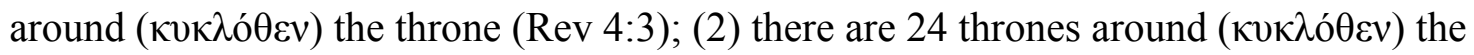

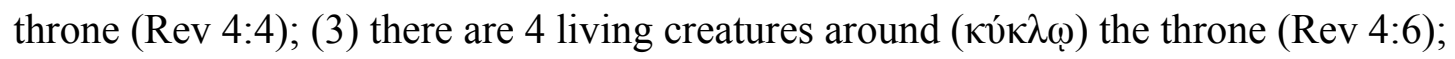

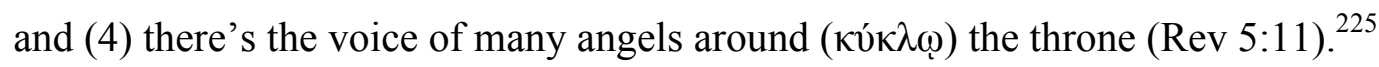
Accordingly, the immovable throne that is in the center of the heavenly temple in the most holy place corresponds to the ark of the covenant that was in the center of the most

${ }^{222}$ For biblical and archaeological evidence confirming that the most holy place is higher in elevation than the rest of the temple, see Alberto Treiyer, The Apocalyptic Expectations of the Sanctuary, 114-118.

${ }^{223}$ Similarly, the throne in Isaiah's vision was "high and lifted up" (Isa 6:1 KJV). Jeremiah stated, "a glorious high throne from the beginning is the place of our sanctuary" (Jer 17:12 KJV). Treiyer joins these references to Rev 4:1 when John was called to "come up" where he saw the throne. See Alberto Treiyer, The Apocalyptic Expectations of the Sanctuary, 115.

${ }^{224}$ Davis, The Heavenly Court Judgment of Rev 4-5, 128. Moreover, "In order for the throne to move in all directions, it is logical for the 'living creatures' who bear it to have faces in all directions," Ibid. The mention of wheels in Ezek 1:15-16 also indicates motion. However,

there are no wheels mentioned in connection with the stationary throne in Rev 4$5 . .$. Therefore, the closest temple-related model would be that of the Most Holy Place, where the cherubim served in a stationary position as the 'covering cherubim' and guardians of the ark/throne (1 Kgs 6:23-29) (Ibid., 128, 131).

${ }^{225}$ All activities are "oriented to the throne of God. They are referred to as "upon the throne' (v.2), 'around the throne' (vv. 3, 4, 6; cf 5:11), 'from the throne' (v.5), 'before the throne' (vv. 5-6, 10), or 'in the midst of the throne' (v. 6; 5:6)." Ranko Stefanovic, Revelation of Jesus Christ, 187. 
holy place in the earthly temple. ${ }^{226}$ In the earthly temple, Solomon added two larger cherubim to make a total of four (Exod 25:18-20; 1 Kings 6:23-28) that surrounded the ark of the covenant in the most holy place. This matches the four living creatures that surround the throne in Rev 4:6. Moreover, since the open door leads to the most holy place, and since the immovable throne revealed therein can be seen from the holy place, the seven lamps of fire burning before the throne ( $\operatorname{Rev} 4: 5)$ do not indicate that the location of the throne is in the holy place. ${ }^{227}$ Also, the ark of the testimony in the most holy place where the Law of God was kept represents the throne. ${ }^{228}$

Fourth, only the high priest can remove the veil/door that separates the holy from the most holy place and enter into the immediate presence of God in the most holy place once a year on the Day of Atonement (Lev 16:2, 17, 34; Heb 9:7). Similarly, only Christ has the key to open the door to the most holy place and shut the door to the holy place (Rev 3:7-8; cf 4:1;11:19). Christ is also the only being in the universe to enter into God's immediate presence to take the scroll (Rev 5:3,6,13). Moreover, just as the high priest stood in order to perform his work in the most holy place that required blood (Heb 9:7), so the Lamb as having been slain appears standing before the Father (Rev 5:6, 13; cf. $14: 1)^{229}$

${ }^{226}$ See $1 \mathrm{Kgs} 6: 19-28$ and $2 \mathrm{Chr} 3: 8-12 ; 5: 7-8$. The passage in $1 \mathrm{Kgs} 6: 20$ points out that the inner sanctuary was 20 cubits long, 20 wide, and 20 high. Moreover, the wings of the cherubim were 10 cubits each, and their wings "touched each other in the middle of the room" (1 Kgs 6:27). As a result, the "middle of the room" would be the most logical place for the ark of the covenant. See Alberto Treiyer, The Apocalyptic Expectations of the Sanctuary, 155.

${ }^{227}$ See this dissertation page 318 footnotes 58 and 59 .

${ }^{228}$ See this dissertation page 243 footnote 93.

${ }^{229}$ Zech 6:11 speaks of crowns instead of just one crown indicating two coronations. The one crown is to be placed on the head of Joshua the son of Jehozadak, the high priest. In the inauguration of the heavenly temple, the Messiah was crowned as high priest according 
Thus, these evidences point to the possibility that the location of this vision occurs in the most holy place after Christ's continual ministry in the holy place. Since the heavenly sanctuary points to liturgical time on the basis of liturgical space, and since only one door is open while the other is closed indicating that the heavenly sanctuary has already been inaugurated — an event that requires both doors to be open — the most holy place setting is linked with the antitypical Day of Atonement as the possible setting for an examination of the scroll as the central liturgical action.

There are several liturgical actions in Rev 4-5. ${ }^{230}$ However, the following points indicate that revealing the content of the scroll that is written inside and on the back is actually the central liturgical action in this heavenly scene. First, there's the loud

to the order of Melchizedek. The passage in Zech 6:13 points out that he "shall sit and rule upon his throne; So He shall be a priest upon His throne." However, at the end of his priestly ministry, He will be crowned as the Davidic King (Dan 7:14, 18, 27; Rev 11:15-19). See Alberto Treiyer, The Apocalyptic Expectations of the Sanctuary, 141 footnote 5. In Revelation Jesus sits on the throne after his ascension, which we refer to as his inauguration as high priest ( $\operatorname{Rev} 3: 21)$. After this ( $\operatorname{Rev} 4: 1)$ he is described as standing (Rev 5:6) in the midst of the throne, living creatures and elders. The following passages assume that he remains in this standing position until the $2^{\text {nd }}$ Coming Rev 5:6; 6:16; 7:17; 19:4. According to Rev 14:14 Jesus is seated at his second coming, see also Matt 25:31. The high priest in Lev 16:13-20 is standing. See Treiyer, The Day of Atonement and the Heavenly Judgment from the Pentateuch to Revelation, 476. Moreover, standing is a theme associated with judgment in the book of Daniel (Dan 1:4, 5, 19; 12:1). See Scott Burgess, The Stand: Jesus in the Book of Daniel (Scott K. "Brother" Burgess, 2016). Furthermore Rev 5:7 states that the Lamb came and took the scroll out of the right hand of the One seated on the throne. The fact that the Lamb came to the Father implies that when the scene began in Rev 4 he was not there. The Lamb's absence is also emphasized by the fact that no one initially came forward to respond to the strong angel who asked "Who is worthy to open the scroll and to loose its seals?" (Rev 5:3). This observation about the order of the Father appearing before the Son also fits the judgment context of Dan 7 where the Ancient of days first appears (Dan 7:9-10) before the Son of man comes to him and they bring "him near before him" (Dan 7:13).

${ }^{230}$ The content in Rev 4-5 shows several liturgical actions such as the trumpet-like voice that seems to function as a call to worship (Rev 4:1); the four living creatures who say ( $\lambda \dot{\varepsilon} \gamma o v \tau \varepsilon \varsigma)$ "holy, holy, holy, Lord God Almighty..." (Rev 4:8), and who give the One on the throne glory, honor and thanks (Rev 4:9); one of the elders who encourages John not to weep but rather to behold the One who has prevailed to open the scroll and to loose its seven seals (Rev 5:5); the Lamb who takes the scroll out of the right hand of the One who sat on the throne (Rev 5:6-7); and the four living creatures and the twenty-four elders who lead the angelic host in praise accompanied by harps (Rev 5:8-14). 
proclamation of the strong angel who cries out, "Who is worthy to open the scroll and to loose its seals" (Rev 5:2)? This cry seems to go unchallenged by the entire universe (Rev 5:3), which points to a universal interest in the contents of the scroll. Second, the fact that John is weeping reveals that he is most anxious to know the content of the scroll that he believes contains vital information (Rev 5:4). Third, the scene crescendos into universal praise at the moment the Lamb takes the scroll out of the right had of him who is seated on the throne indicates that this is the apex of this heavenly scene (Rev 5:7-14).

As we now look at the actual content of the scroll, we note that the content has been interpreted in various ways. ${ }^{231}$ However, there seems to be unity among those who see the various parts of the Bible as the content of the scroll; these parts include the cosmic controversy and God's plan and purpose for the human race and the entire universe, the law and the covenant, the book of inheritance, the book of destiny and history of the world in prophecy, and the book of life for believers. ${ }^{232}$ As I further build on the content of the sealed scroll as the Bible, I will follow the lead of those who see "compelling evidence...that the sealed scroll is closely related to the book of Revelation itself ${ }^{, 233}$ by examining overlooked parallels between Rev 4-5 and Rev $14^{234}$ that are

\footnotetext{
${ }^{231}$ For a comprehensive list of views concerning the sealed scroll, see Ranko Stefanovic, "The Background and Meaning of the Sealed Book of Revelation 5," 2.

${ }^{232}$ See Jon Paulien, "The Seven Seals," 216-220; Ranko Stefanovic, Revelation of Jesus Christ, 176; Idem, "The Background and Meaning of the Sealed Book of Revelation 5," 8-117, 246-255; Alberto Treiyer, The Day of Atonement and the Heavenly Judgment from the Pentateuch to Revelation, 280-296, 553-567.

${ }^{233}$ Ranko Stefanovic, Revelation of Jesus Christ, 176; Jon Paulien, “The Seven Seals," 216-217.

${ }^{234}$ Both Paulien and Stefanovic draw attention to what they see as the parallels between Rev 1 and 4-5. See Ranko Stefanovic, Revelation of Jesus Christ, 177; Jon Paulien, "The Seven Seals," 216-217. Although there are indeed parallels between these chapters, my research shows that there are more numerous parallels between Rev 4-5 and Rev 14 that merit closer examination when considering the content of the sealed scroll.
} 
outlined in Tables 1 and 2. This will help me to outline the relationship between the content of the scroll in heaven with preaching the three angels messages of Rev 14:6-12 as the central liturgical action for the revelation of the content here on earth.

Table 1. Thematic parallels between Rev 4-5 and Rev 14

\begin{tabular}{|c|c|}
\hline Rev 4-5 & Rev 14 \\
\hline Throne - mentioned 19 times & Throne v.3, 5 \\
\hline Thunder and voices $4: 5$ & Voice of loud thunder v.2 \\
\hline Four living creatures $4: 6-8 ; 5: 8,14$ & Four living creatures v. 3 \\
\hline Twenty-four elders $4: 4,9 ; 5: 8,14$ & Elders v.3 \\
\hline New Song 5:9 & New Song v.3 \\
\hline $\begin{array}{l}\text { Father seated on the throne } 4: 2,3,9,10 \text {; } \\
5: 1,7,13\end{array}$ & Father is on the throne v. 3,5 \\
\hline Lamb is standing 5:6, 13 & Lamb is standing on Mt. Zion v.1 \\
\hline $\begin{array}{l}\text { Worship him that lives forever and ever } \\
4: 10 ; 5: 14\end{array}$ & $\begin{array}{l}\text { Smoke of those who worship the beast } \\
\text { and his image ascends forever and ever } \\
\text { v.11 }\end{array}$ \\
\hline Worship God as Creator 4:10-11 & $\begin{array}{l}\text { Worship him who made heaven and earth } \\
\text { v. } 7\end{array}$ \\
\hline $\begin{array}{l}\text { Worship Lamb as Redeemer who } \\
\text { redeems humans from every tribe, } \\
\text { tongue, people, and nation 5:9-14 }\end{array}$ & $\begin{array}{l}\text { The everlasting gospel goes to every } \\
\text { nation, tribe, tongue, and people; and } \\
144,000 \text { are redeemed from the earth v.3, } \\
7\end{array}$ \\
\hline $\begin{array}{l}\text { Jesus appears as high priest on the } \\
\text { antitypical Day of Atonement or } \\
\text { investigative judgment } 5: 6-12\end{array}$ & $\begin{array}{l}\text { Worship him who made...springs }(\pi \eta \gamma \eta \text { s }) \\
\text { of water v. } 7 \text {. A reference to God's } \\
\text { judgment at the flood where the } \\
\text { fountains }(\pi \eta \gamma \eta) \text { of the deep were broken } \\
\text { up Gen } 7: 11\end{array}$ \\
\hline $\begin{array}{l}\text { Seven Spirits sent out into all the earth to } \\
\text { reveal the content of the scroll } 5: 6\end{array}$ & $\begin{array}{l}\text { The everlasting gospel of the Three } \\
\text { Angels Messages is sent to every nation, } \\
\text { tribe, tongue, and people v.6-12. The } \\
\text { Spirit declares that those who labor in } \\
\text { giving these universal messages may rest } \\
\text { v. } 13 \text {, as opposed to those who have no } \\
\text { rest v. } 11 \text {. }\end{array}$ \\
\hline
\end{tabular}


Table 2. Doctrinal parallels between Rev 4-5 and Rev 14

\begin{tabular}{|c|c|}
\hline Rev 4-5 & Rev 14 \\
\hline \multicolumn{2}{|c|}{ Trinity } \\
\hline Father on the throne $4: 2 ; 5: 1$ & Father on the throne $14: 3,5$ \\
\hline Son as Lamb 5:6 & Son as Lamb 14:1 \\
\hline Holy Spirit 4:5; 5:6 & Spirit $14: 13$; cf. $5: 6 ; 14: 6-12$ \\
\hline Creation Rev 4 & Creation 14:7 \\
\hline Gospel and Redemption Rev 5 & Gospel and Redemption 14:6-7 \\
\hline Judgment Setting Rev 4-5 & Judgment 14:7 \\
\hline \multicolumn{2}{|c|}{ Throne as Symbol of Controversy between Christ and Satan } \\
\hline $\begin{array}{l}\text { As a result of the Lamb's victory, Satan's } \\
\text { absence from the "midst of the throne" } \\
(4: 6 ; 5: 6 ; \text { cf. } 12: 10-11) \text { indicates that God } \\
\text { is the rightful ruler of the universe. }\end{array}$ & $\begin{array}{l}\text { The beast's throne }(13: 2) \text { fails to prevail } \\
\text { against the } 144,000 \text { who are before } \\
\text { God's throne }(14: 3,5) \text {. }\end{array}$ \\
\hline \multicolumn{2}{|c|}{ Throne - The Ten Commandments } \\
\hline $\begin{array}{l}\text { The open door in heaven }(4: 1 \text {; cf } 3: 7-8) \\
\text { where the throne is located }(4: 2) \text { is the } \\
\text { exact location where John sees the Law of } \\
\text { God when the temple of God is opened in } \\
\text { heaven }(11: 19) \text {. }\end{array}$ & $\begin{array}{l}\text { Our attention is called to those who keep } \\
\text { the commandments of God (14:12) thus } \\
\text { declaring their allegiance to the throne. }\end{array}$ \\
\hline
\end{tabular}

Furthermore, the pattern of Jesus, angels and the Holy Spirit in the messages to the seven churches ${ }^{235}$ is repeated in our comparison of Rev 4-5 and Rev 14. For instance, Jesus reveals the content of the scroll to those in heaven beginning with the breaking of the seals in Rev 6.The Three Angels preach (Rev 14:6) the everlasting gospel by speaking $\lambda \dot{\varepsilon} \gamma \omega v(\operatorname{Rev} 14: 7,8,9)$ their distinctive message to every nation, tribe, tongue, and people on earth. The Holy Spirit witnesses the content of the scroll in heaven and is sent into all the earth to reveal it (Rev 5:6) by means of the human messengers who preach the Three Angels Messages. In Rev 14:13 the Spirit says $\lambda \dot{\varepsilon} \gamma \varepsilon 1$ regarding the dead

\footnotetext{
${ }^{235}$ In order to further establish the links between the Holy Spirit speaking the words of Jesus, we note the following parallels regarding the seven churches in Rev 2-3. Jesus speaks $(\lambda \dot{\varepsilon} \gamma \varepsilon \imath)$ a message to each church that is sent to the angel of each church $(\operatorname{Rev} 2: 1,8$, $12,18 ; 3: 1,7,14)$. The angel (elder/overseer) of each church communicates that message to the churches. The end result is an appeal to hear what the Spirit says to the churches (Rev $2: 7,11,17,29 ; 3: 6,13,22)$.
} 
who die in the Lord from now on that they may rest from their labors and that their work of preaching the everlasting gospel of the Three Angels messages follows them. Those whom the Spirit says may rest $\alpha v \alpha \pi \alpha \eta ́ \sigma o v \tau \alpha$ from their labors are the ones who worship God (Rev 14:7) and keep his commandments (Rev 14:12); Moreover, they are placed in opposition to those who have no rest $\dot{\alpha} v \alpha$ á $\alpha v \sigma v v$ who worship the beast and his image (Rev 14:11). Thus, we have Jesus revealing the content of the scroll in heaven and the Three Angels (human messengers) who proclaim the content of the heavenly scroll through the Three Angels Messages. The end result is that the Spirit proclaims the everlasting gospel of the Three Angels to the entire world (Rev 5:6;14:6-12, 13). Hence, a comparison of Rev 4-5 with Rev 14 reveals that preaching ought to be the main liturgical action of the church on earth, which is based on the reception and revealing of the sealed scroll in heaven as the central liturgical action.

\section{Analysis}

In light of the rich sanctuary imagery in Rev 4-5, there are several ways that the heavenly sanctuary temporally grounds the relationship between the divine presence and the liturgical actions. ${ }^{236}$ First, the heavenly sanctuary temporally grounds the relationship between the place of heavenly worship that provides the structural and functional pattern

\footnotetext{
${ }^{236}$ Against Plato's two worlds theory, Davis asserts that the scenes in Rev 4-5 constitute an ontological cosmic unity that includes the throne as the central point that is connected with the "whole," which includes "heaven with its myriads of angels, the earth with its inhabitants, and the sea with all of its creatures." He states, "heaven and earth belong inseparably together in the book of Revelation. The earthly arena is not a mere shadow of the heavenly; it is a part of the larger whole....A combined heaven and earth forms a complete whole." Davis, The Heavenly Court Judgment of Revelation 4-5, 156-157. Also,

one of the purposes of the church meeting on earth in its weekly gatherings (as in 1:3,9) is to be reminded of its heavenly existence and identity by modeling its worship and liturgy on the angels' and the heavenly church's worship of the exalted lamb as vividly portrayed in chs. 4-5 (Beale, The Book of Revelation NIGTC, s.v. Rev 4:4).
} 
for the liturgical actions performed there with the place of earthly worship throughout the world signified by "the seven Spirits of God sent out into all the earth" (Rev 5:6). This grounds the hermeneutical priority for liturgical actions on earth in the heavenly sanctuary ${ }^{237}$ Consequently, there should be a structural and functional correspondence between the heavenly place of liturgy and the earthly one rather than a dichotomy between the heavenly place and the earthly place. In other words, earthly locations and structures should seek to mediate the structure revealed in the heavenly sanctuary.

Second, the heavenly sanctuary also temporally grounds the analogical relationship between the divine content of the original sealed scroll in heaven and the divine content of the Scriptures and the Three Angels Messages of Rev 14 here on earth. ${ }^{238}$ The analogical relationship between the heavenly scroll and the Three Angels' Messages implies similarity and dissimilarity in scope and content. ${ }^{239}$ There is also an

${ }^{237}$ Davis points out that although "a combined heaven and earth forms a complete whole," "heaven is still central." Davis, The Heavenly Court Judgment of Revelation 4-5, 157.

${ }^{238}$ In a subsection that Treiyer refers to as "correspondence between the records of the earthly sanctuary and of the heavenly one," he notes, "In order better to understand the value and purpose of the heavenly files, it is necessary to study the value and function of the earthly copies, and the manner in which they represented the heavenly originals." Alberto Treiyer, The Day of Atonement and the Heavenly Judgment from the Pentateuch to Revelation, 281.

${ }^{239}$ For the content of the heavenly scroll, see pages $379-383$. The scope of the heavenly scroll involves the entire universe $(\operatorname{Rev} 5: 3,13)$ that also includes its history from the beginning all the way to the end whereas the scope of the messages in Rev 14 occur just before Christ comes (Rev 14:6-14) and are limited to the inhabitants of the earth. Also, the heavenly scroll consists of the entire Bible including the book of Revelation as opposed to the limited content of the Three Angels Messages in Rev 14. As a result: (1) the controversy between God and Satan over God's right to rule the universe includes the entire history of the cosmic conflict that began in heaven (Isa 14:12; Ezek 28:14), and which encompass all areas of our lives (see this dissertation pages 417-418). This conflict has a universal application in the heavenly scroll that includes all heavenly intelligences (Rev 12:7-9) whereas the controversy over worshipping God versus worshipping the beast, his image and his mark (Rev 14:7, 9-11) is limited to the just before the second coming of Christ (Rev 14:14) and only involves the inhabitants of the earth; (2) the heavenly scroll includes all 
analogical relationship between heavenly scrolls and earthly ones, as well as an

analogical relationship between heavenly writing, language, and speech with earthly

writing, language and speech. ${ }^{240}$ This grounds the universal nature of the content that can

be understood by all created intelligences regardless whether they are in heaven or on

earth, dispelling the dichotomy between heavenly timeless content and historical

culturally conditioned content.

Third, the heavenly sanctuary temporally grounds the relationship between the divine presence and preaching as the central liturgical action. It specifically grounds the real visible presence of the One seated on the throne and the Lamb in the sanctuary above with the invisible omnipresence of the Holy Spirit who works with angelic and human liturgists to preach the gospel. ${ }^{241}$ As a result, only speech can mediate the divine presence to the angelic host and human congregations.

kinds of prophecies whereas the prophecies concerning the beast's identity (Rev 13:1-10) that culminate in the controversy over the mark of the beast (Rev 14:9) are limited to the end; (3) the heavenly scroll doubtless contains a history of the gospel throughout the centuries whereas the everlasting gospel in Rev 14:6 is placed in the context of the Three Angels Messages; and (4) the law of God that has been the foundation of God's throne throughout the ages receives special emphasis in Rev 14:12 as the test of loyalty.

${ }^{240}$ The speech content includes the following: Rev 4:1 "Come up here, and I will show you things which must take place after this." The words to the first hymn in Rev 4:8 "Holy, holy, holy, Lord God Almighty, Who was and is and is to come." The words to the second hymn in Rev 4:11, "You are worthy, O Lord, To receive glory and honor and power; For You created all things, And by Your will they exist and were created." The proclamation of the strong angel in Rev 5:2, "Who is worthy to open the scroll and to loose its seals?" The encouragement John was given by one of the elders in Rev 5:5, "Do not weep. Behold, the Lion of the tribe of Judah, the Root of David, has prevailed to open the scroll and to loose its seven seals." The new song, which is the third hymn in Rev 5:9-10, "You are worthy to take the scroll, And to open its seals; For You were slain, And have redeemed us to God by Your blood Out of every tribe and tongue and people and nation, And have made us Kings and priests to our God; And we shall reign on the earth." The fourth hymn in Rev 5:12, "Worthy is the Lamb who was slain To receive power and riches and wisdom, And strength and honor and glory and blessing!" The fifth hymn in Rev 5:13, "Blessing and honor and glory and power Be to Him who sits on the throne, And to the Lamb, forever and ever!"

${ }^{241}$ To see the connections between the Holy Spirit and human liturgists and speech, see this dissertation pages 339 footnote 118 ; 342-346, 366-368, 382-385. 


\section{Encounter}

Thus far we have described and analyzed the divine presence, the liturgist and the ritual actions in the Biblical Sanctuary Model; all of which are external to the consciousness of the worshipper. Each passage that I will analyze in this section assumes God's infinite analogous temporal Being and the sanctuary that temporally grounds the relationship between the divine presence and some form of speech as the central liturgical action. Moreover, these indispensible presuppositions determine the nature of the worshippers, which then lays the groundwork for an analysis of the nature of the encounter. Hence, I will examine and analyze what each passage reveals about the nature of the worshiper and the nature of the encounter.

Luke 4:16-30; Acts $2: 1-47 ; 13: 13-52 ; 17: 1-4 ; 18: 1-8$

\section{Analysis}

In Acts 2 , the heavenly sanctuary is the place of liturgy. Yet, the connections between the synagogue and the sanctuary that we previously uncovered point to the fact that the synagogue setting of Luke 4:16, Acts 13:14, 17:1-2, and 18:4 is also connected to the heavenly sanctuary as the place of liturgy. As a result, the role of the heavenly sanctuary in temporally grounding the relationship between the divine presence, the centrality of preaching, and the temporality of the worshippers applies to the NT passages.

Since preaching is the main liturgical action in all these passages, worshippers employ auditory means to receive the messages. The following observations reveal a temporal human nature and a cognitive encounter that includes a spiritual dimension in which a worshipper not only understands but also freely chooses to respond in 
accordance with the message conveyed. Luke points out that the worshippers at Nazareth ultimately began to doubt and oppose Jesus' message, even to the point of throwing Him over the cliff (Luke 4:22-30). This reveals that Jesus' application of Isa 61:1-2 to himself as the Messiah was understood but unwelcome. In Acts 2, the answer to the question "Whatever could this mean?" (Acts 2:12) was provided by Peter's sermon. The response of the worshippers to continue in the apostle's doctrine (Acts $2: 42$ ) reveals that they understood and accepted Peter's message about Christ being alive and at the right hand of God (Acts 2:32-33); and that they wanted to be baptized in the name of Jesus Christ (Acts 2:38). Paul, in Acts 13:16-39 sets forth the OT evidence of Jesus as the Messiah, his death and resurrection. This message was rejected by many of the Jews and accepted by the Gentiles. The passage in Acts 17:4 records that some of the Jews and a great many of the devout Greeks were persuaded ${ }^{242}$ about Jesus as the Messiah as the result of Paul's preaching. These events assume a cognitive and spiritual encounter that lays the groundwork for a spiritual response.

Heb 12:18-29

\section{Analysis}

There are several factors that clearly point to a spiritual encounter in Heb 12:23. First, the use of the adjective "first-born ones" ( $л \rho \omega \tau о \tau o ́ \kappa \omega v)$, and the phrase the "spirits of the rightous" ( $\pi v \varepsilon v ́ \mu \alpha \sigma l \delta 1 \kappa \alpha i \omega v)$ clearly point to the spiritual nature of the worshippers as the primary component in human nature in which the encounter occurs. Second, the passive participle $\alpha \pi \sigma \gamma \varepsilon \gamma \rho \alpha \mu \mu \varepsilon \dot{v} \omega \nu$ signifies that the names of the worshippers are not registered/enrolled ( $\dot{\alpha} \pi \mathrm{\sigma} \gamma \varepsilon \gamma \rho \alpha \mu \mu \varepsilon \dot{\varepsilon} \nu \omega \nu)$ on earth by themselves or by

\footnotetext{
${ }^{242}$ See also Acts 18:4, which states that Paul persuaded both Jews and Greeks.
} 
other human beings; Rather they are enrolled in heaven ( $\dot{\varepsilon} v$ oủpavoĩ $)$ by the Lord himself or under his direct authority. Third, the passive participle $\tau \varepsilon \tau \varepsilon \lambda \varepsilon 1 \omega \mu \varepsilon \dot{v} \omega v$ signifies that it is the Lord who perfects the spirits of the righteous who approach the heavenly Jerusalem. The spiritual nature of the encounter is further emphasized by the fact that the three aforementioned factors are integrated with heaven as the primary location where the encounter occurs.

The epistle to the Hebrews illustrates the temporal nature of the worshippers and the temporal cognitive encounter in the following ways. First, the heavenly sanctuary temporally grounds the content that the divine, angelic and human liturgists speak with the temporal nature of the worshippers that receive the words. ${ }^{243}$ This framework ensures a temporal cognitive encounter. As a result, an examination of the use of the word pneuma in the book of Hebrews itself discards the notion that the "spirits (pneuma) of just men made perfect" (Heb 12:23) refers to immaterial souls devoid of the body. ${ }^{244}$ Instead, it refers to living holy people ${ }^{245}$ who by faith approach the heavenly Jerusalem

\footnotetext{
${ }^{243}$ See this dissertation pages 365-368 for an explanation regarding how the heavenly sanctuary grounds the nature of the content spoken between divine, angelic, and human liturgists.

${ }^{244}$ Gallos notes that the use of pneuma in the phrase "spirits of the righteous made perfect" (Heb 12:23) refers to human beings who are alive. See Heb 4:12 and 12:9. Next, the term "righteous" also refers to living persons. See Heb 10:38 and 11:4. Finally, "made perfect" refers to Christ (Heb 2:10; 5:9; 7:28); also, the law cannot make perfect the conscience of the worshipper (Heb 7:19; 9:9; 10:1); moreover, only twice in Hebrews are human beings perfected. First, Heb 10:14 states, "For by a single offering he [Christ] has perfected for all time those who are sanctified" and second in Heb 12:23 it is the spirits of the righteous that are perfected. "Thus, the object of perfection are human beings not bodiless beings in a metaphysical sphere." Erhard Gallos, "The Spirits of the Righteous Made Perfect" (Paper presented to the Adventist Sola Scriptura Research Group at Andrews University Berrien Springs, MI, Oct 14, 2016), 6-7.

${ }^{245}$ Gallos notes that the phrase "assembly of the firstborn" which could be in synonymous parallelism with the following phrase "who are enrolled in heaven" (Heb $12: 23)$
} 
from every continent on the globe as they worship God. ${ }^{246}$

Other specific evidences within the epistle that illustrate the temporal nature of the worshippers and the temporal spiritual encounter that is mediated by revealed knowledge from God to humans include the admonition not to reject the One who speaks (Heb 12:25). This assumes that worshippers are free to hear and reject the message and that God will judge them on how they responded (Heb 12:25-29).

The heavenly sanctuary also grounds the integrated relationship between the spiritual and physical elements of the worshippers. As a result the spirits of just men (Heb 12:23) comprise the spiritual component of human nature, which comprises the location where the encounter occurs. Moreover, the heart and mind (Heb 8:11; 10:22), as well as the conscience (Heb 9:13-14; 10:22), also refers to the location where the encounter occurs. Consequently, in the encounter, God's law and the blood of sprinkling enter into the heart, mind, and conscience of the worshipper (Heb 8:11; 12:24; cf. 9:13$14 ; 10: 22$ ). The sprinkling of blood is a form of speech (Heb 12:24; cf. 4:2) that covers his inauguration (Exod 29:20; Heb 1:3), his holy place ministry (Lev 4:17; Num 19:14; Heb 9:20-24), and his most holy place ministry where he sprinkles his blood on the

indicates that the phrase refers to human beings. The image of righteous people being enrolled in the heavenly books is common in Scripture (Exod 32:32; Ps 69:28; Dan 12:1; Luke 10:20; Rev 13:8; 17:8; cf. Phil 3:20)....Thus the 'spirits of the righteous made perfect' should be interpreted as human beings rather than bodiless spiritual beings. They are most likely other Christians still alive who are righteous since 'the righteous one shall live by faith' (Heb 10:38) or people like those mentioned in the encomium of Hebrews 11 whose names are enrolled in heaven (Ibid., 7).

${ }^{246}$ The passage in Heb 4:16 states, "Let us therefore come boldly to the throne of grace, that we may obtain mercy and find grace to help in time of need." One can only approach the "throne of grace" in a spiritual manner since that throne is in heaven. This supports the view that the worshippers in Heb 12:22 enter spiritually where their names, which represent their characters, are enrolled in heaven (Heb 12:23). 
mercy seat where his law is located (Lev 16:14, 15, 19; Heb 12:24). ${ }^{247}$ It is thus foundational for worshippers to grasp the meaning of his ministry in heaven so that they can become perfected (Heb 12:23). What then is mediated to the mind, heart, and conscience of the worshipper is the meaning of Christ's life and death, and his historical actions that comprise the application of his blood to the demands of the broken law. The effect of this encounter on the worshipper is manifested in a cleansed conscience (Heb 9:13-14) that leads to service and worship (Heb 12:28). Hence, perfection here (Heb $12: 23)$ primarily refers to a spiritual unity between the worshipper and Christ that is manifested in obedience to the Ten Commandments, as well as in service and worship.

Moreover, the strong connection between the heavenly sanctuary and the new covenant (Heb 12:24; cf. Heb 8:6-12; 10:16-17) reveals that the nature of the encounter between God and worshippers is a relational one that is based on placing the Scriptures in our minds and hearts; it is not an ontological encounter in which worshippers experience the being of God in their human nature.

\section{Rev 4-5}

\section{Analysis}

The universal setting of Rev 4-5 sets the stage for our analysis of the encounter. Viewed from this background, the sanctuary plays a grounding role in establishing principles regarding the nature of the encounter for the worshippers in heaven and on earth. Since the main liturgical action revolves around the unsealing of the scroll and its contents, worshipers employ auditory and hermeneutical means in order to understand the

\footnotetext{
${ }^{247}$ For Heb 12:24 as Day of Atonement as well as inauguration, see this dissertation, page 346. For limiting Heb 9:13, 23-25, and 12:24 to the inauguration, see this dissertation, pages $368-373$.
} 
content communicated through words, and through the ritual actions performed. ${ }^{248}$

The heavenly sanctuary setting of Rev 4-5 plays a grounding role in universalizing the temporal nature of the worshippers to include the angels in heaven, and every creature that is in heaven and on earth (Rev 4:9-11; 5:8, 11, 13; cf. 7:9-13). Furthermore, the analogical relationship between the content of the scroll and the Three Angels Messages on earth ${ }^{249}$ ensures a universal temporal cognitive and spiritual encounter encompassing heaven and earth. Also, the battle between Satan's throne (Rev $2: 13 ; 13: 2$; cf. Isa 14:13) and the throne scenes in Rev 4-5 illustrate the controversy between God and Satan over God's right to rule the universe on the basis of his immutable law. ${ }^{250}$ For worshippers, a spiritual and intellectual understanding of the controversy is foundational for a cognitive encounter, and for the mind as the place where the encounter occurs.

Finally, the heavenly sanctuary context of Rev 5 grounds the temporal relationship between the cognitive/spiritual and affective encounter in heaven that serves as a universal model for the kind of encounter that worshippers on earth should also experience.

\section{Response to the Encounter}

Each passage that I will analyze in this section assumes God's temporal divine

\footnotetext{
${ }^{248}$ Likewise, the blessing pronounced in Rev 1:3 is on "he who reads and those who hear the words of this prophecy, and keep those things which are written in it; for the time is near."

${ }^{249}$ For the connections between Rev 4-5 and Rev 14, and the relationship between the sealed scroll in heaven and the Three Angels Messages on earth, see Chapter 6, Tables 1 and 2 .

${ }^{250}$ For the links between the controversy over God's right to rule the universe, see this dissertation pages 327-329.
} 
presence, some form of speech as the central liturgical action, and a temporal cognitive encounter. Moreover, the sanctuary temporally grounds the relationship between these indispensible prerequisites and the response to the encounter. As a result, I will examine and analyze what each passage reveals about the response to the encounter.

Luke 4:16-30; Acts 13:13-52; 17:1-4; 18:1-8

\section{Description}

The worshippers at Nazareth first responded by marveling at Christ's gracious words, then by expressing doubt about his Messianic claim as they asked, "Is this not Joseph's son?" (Luke 4:22). Then "all those in the synagogue" thrust him out of the city and attempted to throw him down over the cliff (Luke 4:29). In contrast to the complete rejection of Christ's message at Nazareth, worshippers responded to Paul's messages in Acts 13,17 , and 18 by accepting them and rejecting them. ${ }^{251}$

\section{Analysis}

The synagogue and Sabbath setting of these messages temporally grounds the relationship between the divine presence and worshippers who possess hermeneutical, non-determined minds. The result is that worshippers are free to interpret and then choose

${ }^{251}$ The response to the message in Acts 13 first included favorable responses by the Jews (Acts 13:43). However, when they saw almost the whole city come out to hear God's word, they contradicted, blasphemed, and opposed the things spoken by Paul (Acts 13:45). The Jews also stirred up the influential people of the city and succeeded in expelling Paul and Barnabas from their region (Acts 13:49-50). The Gentiles responded by begging that these words might be preached to them the next Sabbath (Acts 13:42). In Acts 13:48 the Gentiles responded by being glad, glorifying the word of the Lord, and believing the word of the Lord. In Acts 17, the text notes that those who were persuaded included a great multitude of devout Greeks that also included the leading women (Acts 17:4). Yet, the Jews "who were not persuaded" ended up gathering a mob against them and arraigning them before the rulers of the city (Acts 17:5-9). In Acts 18 the Jews responded by opposing Paul and blaspheming (Acts 18:6). However Justus and Crispus, the ruler of the synagogue, believed on the Lord; and many of the Corinthians, hearing, also believed (Acts 18:7-8). 
to accept the messages, which constitutes the goal of a spiritual encounter. Those who reject the messages experience a cognitive encounter but their willful rejection of the messages indicates that they have not experienced a spiritual encounter. Moreover, the temporal content also assumes that the Sabbath and the synagogue temporally and spatially grounds the relationship between the messages and the responses of the worshipers. This ensures the causal relationship between the two.

Acts 2:1-47

\section{Description}

The outpouring of the Holy Spirit and Peter's sermon on the Day of Pentecost produced a variety of responses. The international crowd at first responded in amazement at hearing the disciples speak the wonderful works of God in their native tongues (Acts 2:11-12). Near the end of Peter's sermon, Luke records that the worshippers asked, "What shall we do?" (Acts 2:37). After an additional exhortation, they "gladly received his word and were baptized" (Acts 2:41). The worshippers continued steadfastly (even daily Acts 2:46) in the apostles' teaching, in fellowship, in the breaking of bread, and in prayers (Acts 2:42). They drew together into closer unity (Acts 2:46) among themselves by pooling their resources together, selling their possessions, and then distributing them to those who were in need (Acts 2:44-45). Finally, they responded by continuing daily with one accord in the temple and breaking bread from house to house, eating their food with gladness and simplicity of heart, and praising God (Acts 2:46-47). These responses encompass the spiritual, mental, physical, and social aspects of each worshipper.

\section{Analysis}

The heavenly sanctuary setting temporally grounds the relationship between the 
divine presence, the sermon, and the biblical view of human nature that integrates the mental, physical, social, and spiritual faculties of the worshipper as the basis for the varied responses to the encounter. A cognitive communication from God is thus foundational for worshippers that choose to experience a spiritual encounter. Such an encounter results in and is causally related to the varied active responses that are grounded in the spiritual, mental, physical and social nature of each worshipper.

\section{Heb 12:18-29}

\section{Description}

The passage in Heb 12:22 reads, "But you have come to Mount Zion...the heavenly Jerusalem." There appear to be no indicators that would confine the application of Heb 12:22 to worshippers located in certain geographical locations or that limit the passage to only certain historical periods. It is thus possible for worshippers across the centuries to approach "the heavenly Jerusalem" from various locations throughout the world. Moreover, worshippers are exhorted to respond by obeying the One who speaks

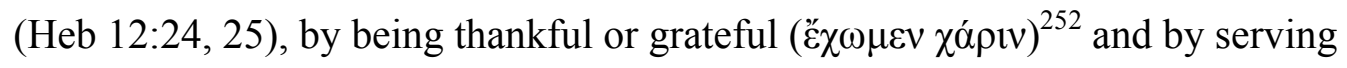
$(\lambda \alpha \tau \rho \varepsilon v ́ \omega \mu \varepsilon v)$ God acceptably with reverence and awe, for our God is a consuming fire (Heb 12:28, 29).

\section{Analysis}

The following evidence reveals that the heavenly sanctuary temporally grounds the presence of God and Christ (Heb 12:23, 24) with the worshippers' responses. First, encouraging worshippers to obey the One who speaks assumes a temporal human nature

\footnotetext{
${ }^{252}$ See Luke 17:9; 1 Tim 1:12; 2 Tim 1:3 where a similar construction is used, $S D A B C$ s.v. Heb 12:26.
} 
that is non-determined. This structure constitutes the foundation for a cognitive communication that results in a spiritual encounter that leads to a spiritual response.

Second, God's infinite analogous temporal Being, his direct speech, and the new covenant promise to place God's laws in our hearts and minds (Jer 31:33-34) provides the

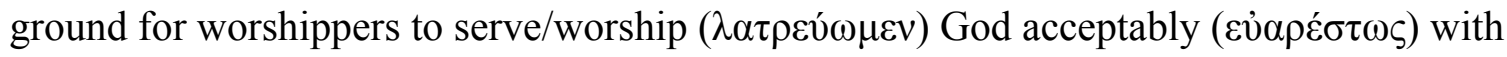
reverence and awe (Heb 12:28, 29). As a result, worshipers respond to this cognitive encounter by (1) keeping his Commandments, (2) presenting their bodies to God as an act of service ( $\lambda \alpha \tau \rho \varepsilon i ́ \alpha v)$ (Rom 12:1), and (3) doing good and sharing with others as an

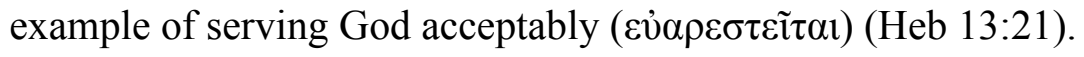

Third, constructing idols to represent the divine presence conflates the divine presence with creation. In confusing his presence with creation, worshippers incorrectly assume that the divine presence is revealed through nature (Lev 26:1) instead of through revelation as indicated by the I AM in Lev 26:2. The responses to the worship of the golden calf indicate that conflating the divine presence with nature does not lead to serving/worshipping God acceptably with reverence and godly fear (Heb 12:28). The statement in Heb 12:29 that "our God is a consuming fire" is also found in Deut 4:23; and it was spoken as a warning to those who would forget that when God spoke His Law, no one saw a form, they only heard a voice (Deut 4:12-15). God is thus a consuming fire to all those who assume that his presence is revealed through nature (Deut 4:23; Heb 12:29) instead of through his word. Hence, to serve and worship God acceptably means to reverence his spoken Word as the revelation of his invisible presence instead of constructing an idol to represent his divine presence.

Fourth, each of these active responses are causally related to Christ our high priest 
and mediator of the new covenant (Heb 12:24) who speaks to us through the ritual actions of the heavenly sanctuary (Heb 12:24, 25).

\section{Rev 4-5}

\section{Description}

In the smaller scene of Rev $4,{ }^{253}$ the four living creatures act as liturgists by proclaiming God's holiness and by giving him glory, honor, and thanks ( $\operatorname{Rev} 4: 8,9)$ while the twenty-four elders respond in three main ways: (1) they fall down $(\pi \varepsilon \sigma o \tilde{v} v \tau \alpha 1)$ before the One who sits on the throne and worship ( $\pi \rho \circ \sigma \kappa v v \eta ́ \sigma o v \sigma ı) ~ h i m ~(\operatorname{Rev} 4: 10),(2)$ they cast their crowns before the throne (Rev 4:10), and (3) they verbally respond with the words recorded in $\operatorname{Rev} 4: 11^{254}$

This smaller scene establishes the worshiping pattern for the universal scene of Rev 5, which includes the myriads upon myriads of angels around the throne (Rev 5:11) and every creature in heaven, on earth, under the earth and in the sea (Rev 5:13). As John's attention is focused in the midst of the throne (Rev 5:6) he sees the four living creatures and the twenty-four elders fall down $(\varepsilon \pi \varepsilon \sigma \alpha \nu)$ before the Lamb as he takes the scroll (Rev 5:8). As liturgists/worshippers, the four living creatures and twenty-four elders sing a new song accompanied by harps (Rev 5:8,9-10). Next, as if in response to the new song sung, the myriads of angels say with a loud voice, "Worthy is the Lamb who was slain..." (Rev 5:12). Next, all of creation chimes in saying "Blessing and honor and glory and power be to Him who sits on the throne and to the Lamb forever and ever"

\footnotetext{
${ }^{253}$ The scene in Rev 4 only includes the One seated on the throne (Rev 4:2-6, 9-10), the twenty-four elders ( $\operatorname{Rev} 4: 410-11)$, and the four living creatures ( $\operatorname{Rev} 4: 6-9)$.

${ }^{254 ،}$ Y ou are worthy, O Lord, To receive glory and honor and power; For You created all things, And by Your will they exist and were created" (Rev 4:11).
} 
(Rev 5:13). The four living creatures finally respond by saying, "Amen," and the twenty-

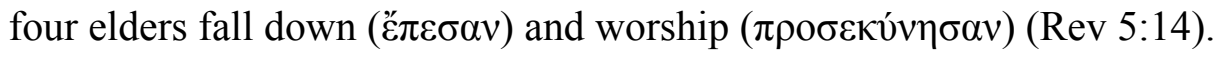

\section{Analysis}

The rich sanctuary imagery temporally grounds the relationship between responses to the divine presence in heaven that function as a model ${ }^{255}$ for responses to the divine presence on earth. As a model the heavenly sanctuary reveals an analogical relationship between divine and human sitting; divine and human thrones; specific locations in heaven with specific locations on earth; and heavenly beings who fall down and worship and humans who do the same. Consequently, the response of the elders to the encounter characterized by falling down and casting their crowns before the throne in a specific location (Rev 4:10) should serve as a model that earthly worshipers should learn from and emulate as they respond to the encounter on earth.

Other examples of how activities in the heavenly sanctuary serve as a model for earthly responses include the causal relationship between God's holiness (Rev 4:8) and the prostrated position of the elders ( $\operatorname{Rev} 4: 10)$; the causal relationship between the actions of the Lamb in salvation history that qualify Him to take the scroll from the One seated on the throne and the prostrated position of the four living creatures and the elders (Rev 5:8); and the causal connection between the actions of God as Creator and the elders who respond by stating the Lord is worthy "to receive glory and honor and power; for you created all things..." (Rev 4:11). In addition to this, the heavenly sanctuary also temporally grounds the non-determined nature of all the heavenly worshipers with the

${ }^{255}$ See Heb 8:5; 9:23 BDAG, s.v. vं $\pi$ ó $\delta \varepsilon 1 \gamma \mu \alpha$. Also, for the sanctuary as a model that makes a correspondence between heaven and earth within God's infinite analogous temporal

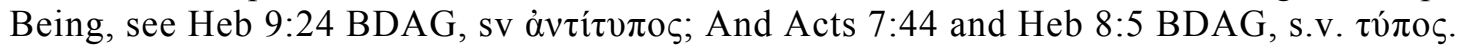


non-determined nature of all earthly worshippers throughout the ages.

The universal nature of the heavenly scene reveals that earthly worshippers must construct their understanding of the worship response, as well as all of the other liturgical components, on the basis of Scripture instead of culture, tradition, or human philosophy. The Holy Spirit's role is to take the universality of the scene in Rev 5 and educate earthly worshippers to emulate the responses in these heavenly scenes (Rev 5:6).

\section{Biblical Search for Unity}

In our exegesis of the biblical texts we discovered that preaching the Scriptures constitutes the central liturgical action in the Biblical Sanctuary model. Moreover, it is the only liturgical action that mediates the presence of God. The aim of this section is to explore the biblical search for liturgical unity by analyzing how the divine presence, the liturgist, and the liturgical actions are inseparably connected to preaching the Scriptures as the indispensable prerequisite in achieving a cognitive and spiritual encounter that leads to a unified response. In order to realize this aim, I will employ God's temporal Being and the heavenly sanctuary as hermeneutical guidelines.

As the first hermeneutical guideline, God's infinite analogous temporal Being is absolutely foundational for why preaching the Scriptures is the central liturgical action for achieving liturgical unity in the Biblical model. This is brought out by Exod 3:14-15 which reveals that God's Being is present and at the same time revealed through his words; and that God's presence, cannot be grasped apart from his words. ${ }^{256}$ Consequently, in complete contrast with the other models, there can be no dichotomy

\footnotetext{
${ }^{256}$ Canale, A Criticism of Theological Reason: Time and Timelessness as Primordial Presuppositions, 361 footnote 2.
} 
between God's Being and his presence, and God's Being and his words.

The heavenly sanctuary, which functions as the second hermeneutical guideline, has always been the location where all worshippers in heaven and earth approach in liturgy. ${ }^{257}$ Moreover, earthly liturgists ultimately mediate the realities of the liturgical actions in the heavenly temple through preaching the Scriptures as the central liturgical action. ${ }^{258}$ In light of this, I will first employ the sanctuary as a hermeneutical tool to analyze how the divine presence is inseparably connected to preaching the Scriptures as the central action that lays the foundation for a cognitive encounter and a unified response. The heavenly sanctuary provides the framework for helping us to understand how each member of the Trinity is involved in the central and unified task of preaching the Scriptures. In Rev 5:1 the Father holds the scroll in his right hand, which represents God's Words to the entire universe (Rev 5:7). The Lamb takes the scroll, opens it and looses its seals thereby unfolding its meaning (Rev 5:7-8; 6:1-17; 8:1). Heb 12:24-26 points out that the Lamb also speaks through the liturgical actions he performs in the heavenly sanctuary. The seven Spirits that are sent out into the world reveal these heavenly scenes and search the content of the scroll in order to reveal these things to the earthly worshippers (Rev 5:6; cf. 1 Cor 2:9-10). Since the heavenly sanctuary grounds the temporal relationship between heaven and earth, God's words in heaven and his words on earth reveal a single universal meaning (Heb 12:22-26; cf. Deut 4:36-39). Consequently, the various churches, theologians, and cultures do not originate the meaning of Scripture, nor do they provide the proper tools to interpret it.

\footnotetext{
${ }^{257}$ See our exegesis of the liturgical actions in $1 \mathrm{Kgs} 8: 12-66$; Isaiah 6; Heb 12:22-24.

${ }^{258}$ For the central role of preaching in the context of the sanctuary, see this dissertation pages $271,279,359,363-364,379-385,547-549$. For the central role of preaching in the context of the synagogue, see page 354-355.
} 
In addition to the Trinity and preaching, the sanctuary also provides the framework for helping us to understand how the divine, angelic, and human liturgists are all connected to the centrality of preaching, and to the issues surrounding liturgical

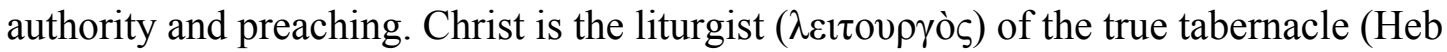
$8: 2)$ who speaks from heaven by generating the messages to the seven churches (Rev $1: 12,20 ; 2: 1)$, revealing the content of the heavenly scroll, and by performing liturgical actions in the sanctuary (Heb 12:24-25; Rev 5:6-8). In Heb 9:7-8, the Holy Spirit reveals Christ's liturgical actions in the two apartments of the heavenly sanctuary to the mind of

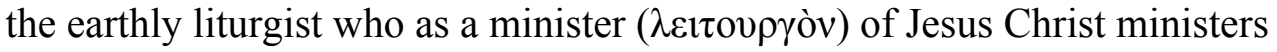

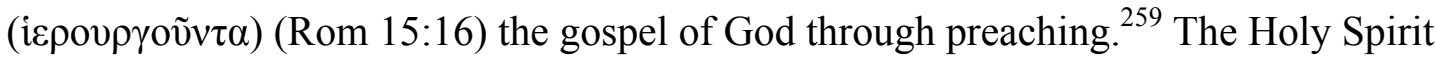

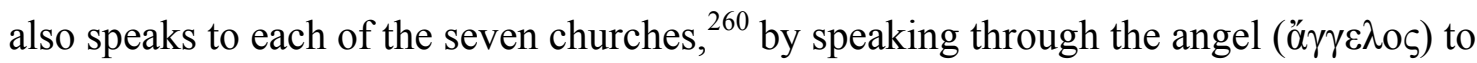
whom Jesus sent each message. Since ä $\gamma \gamma \varepsilon \lambda o \varsigma$ also refers to human messengers (Matt 11:10; Mark 1:2; Luke 7:24, 27; 9:52) it is likely that the Spirit spoke to each church through the earthly liturgist. Similarly, just as ö $\gamma \gamma \varepsilon \lambda o \varsigma$ refers to angelic and human liturgists, the Spirit that is sent out into all of the earth reveals the content of the sealed scroll to the worshippers on earth (Rev 5:6) through the earthly liturgist that preaches the Three Angels Messages of Rev 14. ${ }^{261}$ In Heb 1:7, 14 the angels are referred to as

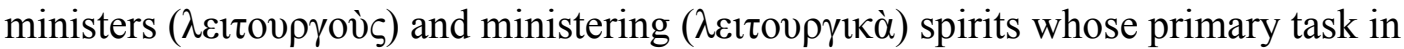

${ }^{259}$ See this dissertation pages 342-344. The Holy Spirit speaks the new covenant promise (Heb 10:15-17), which is connected to the heavenly sanctuary (Heb 9:11-15). See also Heb 13:7 regarding earthly liturgists who lead the congregation through engaging in an intellectual process as the key method to overseeing (page 356 of this dissertation). Also, each of the messages to the seven churches are delivered to the angel, or liturgist/overseer of the seven churches, see Rev 2:1, 8, 12, 18; 3:1, 7, 14 .

${ }^{260}$ See Rev 2:7, 11, 17, 29; 3:6, 13, 22.

${ }^{261}$ For the connections between Rev 5 and Rev 14, see Tables 1 and 2 of this dissertation. 
liturgy is to minister the spoken word. Scripture states that God spoke the Ten

Commandments. Yet in addition to God alone speaking, Heb 2:2 points out that God also spoke "through ${ }^{262}$ angels" comprising one of the various ways in which God speaks (Heb $1: 1) .{ }^{263}$ We can also assume that angels will speak from heaven (Heb 12:24-26; cf. Rev 14:6-12) in cooperation with Christ, just as they spoke on earth when the Law was proclaimed. $^{264}$ Thus, in addition to Heb 2:2 that further clarifies one of the many ways in which God spoke in times past (Heb 1:1), other passages in Hebrews such as Heb 12:21 $1^{265}$ and Heb 3:7-11 266 illustrate that events described by writers in the OT are further

\footnotetext{
${ }^{262}$ God spoke through the angels and by the angels, see Ellingworth, The Epistle to the Hebrews NIGTC s.v. Heb 2:2.

263،“'The word spoken through angels' is reminiscent of 1:1, which states that God spoke in former days in many and various ways. It seems, then, that in 2:2 the author illustrated one aspect of the many and various ways God spoke, namely, through angels," Victor (Sung-Yul) Rhee. "Christology and The Concept of Faith in Hebrews 1:1-2:4" BSac 157 (2000): 185. Also, "In Hebrews "the message delivered by angels" is an alternate expression for the word that God spoke through the prophets (1:1b)," Lane, Hebrews 1-8 WBC 47A, s.v. Heb 2:2. In Heb 2:2 as in Gal 3:19 and Acts 7:38 "the function of angels in the revelation of the Law at Sinai is assumed." Moffat, A Critical and Exegetical Commentary on the Epistle to the Hebrews ICC s.v. Heb 2:1-4. See also Debbie Hunn, "“Why Therefore the Law?" The Role of the Law in Galatians 3:19-20" Neotestamentica 47 no.2 (2013): 368; Hindy Najman, "Angels at Sinai: Exegesis, Theology and Interpretive Authority," Dead Sea Discoveries 7 no. 3 (2000): 320-323.

${ }^{264}$ There seems to be a close connection between angelic and human liturgists through the use of the word angel, which refers to both angelic beings and humans. See, for instance, each message to the seven churches is given to the angel of the church (Rev 2:1, 8, $12,18 ; 3: 1,7,14)$. Also, in Rev 14 another angel preaches to those on earth $(14: 6)$; who is followed by another angel "saying Babylon is fallen" (14:8); and then a third angel "saying with a loud voice..." (Rev 14:9). Just as in the messages to the seven churches, these are directed to angels who along with humans minister these messages.

${ }^{265}$ When one reads the account of the Ten Commandments recorded in Exod 20 and Deut 4-5 there is no mention of Moses fearing and trembling, yet Heb 12:21 records the words of Moses where he stated, "I am exceedingly afraid and trembling."

${ }^{266}$ With the exception of the first half of Heb 3:7, which states, "Therefore, as the Holy Spirit says," the rest of Heb 3:7-11 is a direct quotation from Psalm 95:7-11. However, the antecedent to "His voice" in Psalm 95:7 is the Lord (YHWH) in v. 6 and God (Elohim) in v.7 with no mention of the Holy Spirit. When we combine Psalm 95:7-11 with Heb 3:711, we realize that we cannot exclude the Holy Spirit from speaking the words in those passages simply because the author of Psalm 95:7-11 did not mention the Holy Spirit. The
} 
clarified in such a way that one must combine all of the details recorded in Scripture to formulate an accurate picture of the event under consideration.

With regard to liturgical authority and preaching, there are three main ways in which the authority of all liturgists including angels and humans is grounded in the divine presence. The first is provided by the heavenly sanctuary context that encompasses the work of the Holy Spirit in setting apart human liturgists. The passage in Acts 13:2 reveals that as Barnabas and Paul ministered ( $\lambda \varepsilon ı \tau o v \rho \gamma o v ́ v \tau \omega v)$ to the Lord, the Holy Spirit said that they should be set apart for the work of proclaiming the gospel to the Gentiles. Although $\lambda \varepsilon i \tau o v \rho \gamma o v ́ v \tau \omega v$ occurs in a sanctuary context that describes the work of the priests in the $\mathrm{OT},{ }^{267}$ the NT now applies the same term to the work of proclaiming the gospel to the gentiles (Acts 13:2;15:16). This work is accomplished under the authority of Christ, the minister ( $\lambda \varepsilon i \tau o v \rho \gamma o \varsigma$ Heb 8:2) in heaven, who sends the Holy Spirit into all the earth (Rev 5:6) in order to set apart earthly liturgists. Hence, liturgical authority flows from Christ to the Holy Spirit who then directs the church on earth to set apart those like Paul and Barnabas for the task of preaching the gospel. Consequently, liturgical authority is not grounded in the church, but in God himself. ${ }^{268}$

The second way in which the connection between liturgical authority and preaching is grounded in the heavenly sanctuary is through the central throne that the Father shares with his Son, and through the divine origin of the content of the scroll in Rev 5:1. The passages in Rev 4:6; 5:6 describe the four living creatures that are in the

same principle applies to God speaking the Ten Commandments in Exod 20:1. We must combine all Scriptures that refer to the event, including Heb 2:2, in order to get the most accurate picture of what actually took place.

${ }^{267}$ See this dissertation page 336 footnotes 106 and 107.

${ }^{268}$ See this dissertation pages $352-354$. 
midst of the throne yet never occupy it. The twenty-four elders sit on thrones that surround the central throne and they cast their crowns before it indicating their submission to the One seated on it $(\operatorname{Rev} 4: 4,10)$. Even the Holy Spirit is mentioned by his location before the throne ( $\operatorname{Rev} 1: 4 ; 4: 5)$ that he never occupies indicating that the exercise of his authority is in service to the One seated on the throne and in harmony with the Ten Commandments as well as with the content of the scroll.

The third way in which the connection between liturgical authority and preaching is grounded in the heavenly sanctuary is through the divine origin of the content of the scroll in Rev 5:1. The ark of the covenant that contains the Ten Commandments (Rev 11:19) is the place of God's throne where the sealed scroll is located. ${ }^{269}$ Moreover, a comparison between Rev 5:6 in which the Spirit is sent out in all the earth and the Three Angels Messages of Rev 14:6-12 that are proclaimed to every nation, tribe, tongue, and people reveals that the meaning of Scripture must be grounded in the heavenly scroll's content. Accordingly, although Scripture is historically constituted, which means that its divine message was revealed in certain times, places and cultures, its principles are transcultural; they are not grounded in culture, tradition, science, or the teachings of any church.

We will now briefly outline how the liturgical actions of the heavenly sanctuary and the Sabbath are linked to preaching as the indispensible means of achieving liturgical unity. The sanctuary constitutes the place of worship where God chooses to reveal himself by placing his name there. ${ }^{270}$ As a result, worshippers come to a specific place, whether to Jerusalem in the OT (1 Kings 8:12-66) or to the "heavenly Jerusalem" (Heb

\footnotetext{
${ }^{269}$ See this dissertation page 243 footnote 93 .

${ }^{270}$ See Deut 12:5, 11, 21; 16:2, 6; $1 \mathrm{Kgs} \mathrm{8:16,} 29$.
} 
12:22). Moreover, the place of worship provided by the sanctuary merges with the

Sabbath as the time in which worship occurs (Heb 4:9). Consequently, both the sanctuary and the Sabbath, which are linked with preaching, unite worshippers all over the globe in one place and at one time in order to hear the Word.

The central role of preaching in the Biblical Sanctuary Model unquestionably points to a cognitive and spiritual encounter that occurs in the mind of the worshipper. The heavenly sanctuary and new covenant context ${ }^{271}$ point to a relational encounter that is based on worshippers applying the Scripture to their minds and hearts; ${ }^{272}$ it is not an ontological encounter in which worshippers experience the being of God in their human nature. As a result, the foundational goal of the encounter is to reveal God's presence and His will through an understanding of Scripture.

Just as the heavenly sanctuary grounds the temporal relationship between the divine presence and the liturgist, and the ritual actions and the encounter; it also grounds the relationship to the worshippers' response as well. There is a clear causal connection in Scripture between the divine presence, an undetermined human nature, the cognitive encounter, and the response of the worshippers. This causal and integrated connection is illustrated by: (1) free mental decisions to obey the message, ${ }^{273}$ (2) decisions to disobey

\footnotetext{
${ }^{271}$ For the connection between the heavenly sanctuary and the new covenant, see Heb $8: 1-13 ; 9: 11-15 ; 12: 22-24$. See also this dissertation page 242 footnote 88 .

${ }^{272}$ See Heb 8:6-13; 9:11-15.

${ }^{273}$ For instance, the Gentiles in Acts 13:48 chose to believe God's word. The Acts 17:4 passage informs us that the devout Greeks responded by choosing to be persuaded. The Acts 18:7-8 passage records that Justus, Crispus and many Corinthians chose to believe in the Lord. After Peter's Day of Pentecost sermon to worshippers from many nations, believers who were baptized chose to continue to study the apostle's teaching (Acts 2:42). The epistle to the Hebrews exhorts worshippers to obey and not turn away from the One who speaks from heaven (Heb 12:25). Worshippers are to obey the specific instruction in the Ten Commandments through the blood of Jesus who is the mediator of the new covenant
} 
the message, ${ }^{274}$ (3) verbal responses, ${ }^{275}$ (4) kinesthetic responses, ${ }^{276}$ (4) affective

(Heb 12:24). Moreover they are to respond to the word by serving and worshiping God through their mental and spiritual faculties by reverencing God's spoken word as the revelation of his invisible presence.

${ }^{274}$ Examples of worshippers who chose to disobey include those at Nazareth who expressed doubts concerning Jesus' Messianic claims (Luke 4:22) and wanted to throw him over the cliff (Luke 4:29); the Jews who first responded favorably to Paul's sermon (Acts 13:43) but then contradicted, blasphemed, and opposed the things spoken by Paul (Acts 13:45), finally expelling him from the region (Acts 13:49-50; cf. 17:4-9; 18:6).

${ }^{275}$ Examples of verbal responses include Moses' initial answer to God's call (Exod $3: 4)$, his questions, calls for clarifications, his request for greater evidence of God's call to deliver the Israelites, feelings of inadequacy, his refusal, and his final acceptance of the call to deliver his people (Exod 3:11, 13; 4:1, 10, 13, 18-19). After God proclaimed his Law on Sinai the Israelites begged Moses not to let God speak to them lest they die, but that Moses should communicate to them God's message (Exod 20:19; Deut 5:23, 25, 27). Verbal responses also include singing to the accompaniment of music such as when the Israelites sang "For He is good, for His mercy endures forever" (2 Chr 7:3) in response to God's glory that was manifested in the temple. Those who respond in Acts 2 comprise a more universal audience (Acts 2:7-11). As a result, through Peter's sermon they begin to respond in a unified manner that includes them gladly receiving Peter's word, praying, praising God, and going from house to house to share what they had heard (Acts 2:41, 42, 46). The Gentiles responded by begging that the words they heard would be preached the following Sabbath (Acts 13:42). The twenty-four elders respond by praising God for his creative power as the basis for why he is worthy of worship (Rev 4:11), and the four living creatures respond by saying "Amen" (Rev 5:14). The universal scene in heaven provides the context in which the four living creatures and the twenty-four elders sing a new song accompanied by harps (Rev 5:8-10). Moreover all of the angels and beings in the universe respond by ascribing praise, honor, glory and power to him who sits on the throne and to the Lamb (Rev 5:12-14).

${ }^{276}$ Examples of kinesthetic responses include Moses removing his shoes while in God's presence and hiding his face in fear of God (Exod 3:5, 6). When God proclaimed his Law on Sinai Moses trembled in fear (Heb 12:21) yet unlike the Israelites who stood far from the physical location of Mt Sinai (Exod 20:18; Deut 5:25), he drew near to the thick darkness where God was (Exod 20:21). After Solomon's dedication speech, the Israelites responded by sacrificing peace offerings (1 Kgs 8:62-63) at which time the Israelites stood ( $2 \mathrm{Chr} 7: 4-6$ ). Moreover, in response to the fire and the glory of the Lord filling the temple, the Israelites bowed their faces to the ground and worshipped ( $2 \mathrm{Chr} 7: 3$ ). The Gentiles who believed Paul's sermon chose to come back and worship on the Sabbath day to hear more (Acts 13:42). Those who responded to Peter's message on the Day of Pentecost were baptized (Acts 2:41). The twenty-four elders fall down and worship God (Rev 4:10; 5:14), and they cast their crowns before the throne (Rev 4:10). The four living creatures also fall down before the Lamb (Rev 5:8). These kinesthetic responses of the twenty-four elders and the four living creatures that are conducted in a universal setting comprise the pattern that earthly worshippers should follow since they are causally related to the divine presence and the sealed scroll. 
responses, ${ }^{277}$ and (5) social responses. ${ }^{278}$ The varied active responses in the biblical model differ from the other models in two main ways. The first is that they are grounded in the mental, spiritual, physical, and social aspects of a fully integrated humanity, and the second is that they are causally related to the divine presence through preaching. In addition, it is important to keep in mind that the responses of the beings in the heavenly sanctuary ground the nature of the responses that human worshippers should seek to emulate. Accordingly, these responses do not have their ground and origin in human culture, which means that they apply to all humans at all times and places.

At the basis of each response in the Biblical Sanctuary Model is God's infinite analogous temporal Being, which forms the foundation for Scripture as the revelation of his presence and his will through preaching. Also, the Trinity, the angels and human liturgists work together in harmony to deliver God's word, which alone mediates his presence as the basis for a cognitive communication with worshippers who then choose to experience a spiritual encounter that leads to a biblical response. The Sabbath and the sanctuary not only help to temporally ground all of the liturgical components, they also function to bring all of God's worshippers to one place (the heavenly sanctuary) at one time (the Sabbath). This practice of worshipping every Sabbath in the heavenly sanctuary will continue into eternity long after the sin problem has been resolved. ${ }^{279}$ The response

\footnotetext{
${ }^{277}$ Examples of affective responses include the Gentiles in Acts 13:48 who after hearing Paul's sermon responded with gladness. Also, after Peter's sermon, worshippers ate their food with gladness and simplicity of heart (Acts 2:46) after gladly receiving God's word (Acts 2:41).

${ }^{278}$ Examples of social responses include worshippers who continued in fellowship together, who ate together, who drew into close unity with each other, and who pooled their financial resources together to help those in need (Acts 2:42, 44-47).

${ }^{279}$ The passage in Isa 66:22-23 reveals that all flesh, which includes all of God's people from different languages and nationalities throughout all time shall come and
} 
of each worshipper is thus causally related to the cognitive encounter, which precludes a plurality of responses. The universal nature and scope of this liturgical phenomenon is best illustrated in Heb 12:18-29 and Rev 4-5.

\section{Conclusion}

This Chapter on the survey of NT data builds on and assumes the same temporal interpretation of God's Being as the OT by the use of Kúpıø/Lord for Yahweh (Acts $2: 20,21,25,34,36 ;$ Heb $1: 10 ; 2: 3 ; 7: 14 ; 8: 2 ; 13: 20 ;$ Rev 4:8); by the use of $\theta \varepsilon$ ò $/$ God for Elohim (Heb 12:22, 23, 28, 29; Rev 4:8); by connecting God's name (ővo $\mu \alpha$ ) in Acts

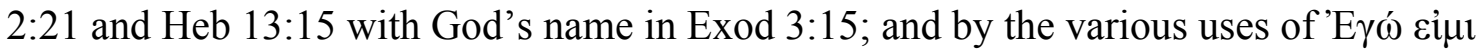
as the LXX translation of I AM in Exod 3:14 found in Heb 1:3; 5:8; 11:16, and Rev 4:8.

As we consider the divine presence, the NT builds on the observations and conclusions of the OT but at the same time there are several ways in which the NT brings greater precision and clarity to the divine presence. First, the NT connects each member of the Trinity to the I AM of Exod 3:14. The Father is connected to the I AM by Kúpios

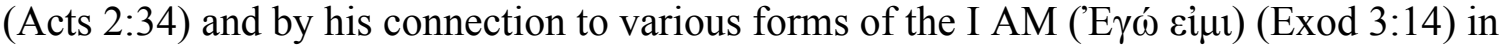
Rev $1: 4,4: 8 ; 11: 17 ; 16: 5$. The Son is connected to the I AM by Kúpros (Acts 2:34; Heb $1: 10 ; 7: 14 ; 8: 2 ; 13: 15)$, and by associations with the various forms of I AM ('E $\gamma \omega$ cìu)

worship him from Sabbath to Sabbath. Also, in Rev 7:9-17 and 22:1-5 we see a heavenly sanctuary context. Both passages include the central throne, which is a prominent sanctuary fixture (Rev 7:9, 10,11(2), 15(2), 17; 22:1,3.) Moreover, Rev 22:3 states that his servants shall serve Him while Rev 7:15 states, "Therefore they are before the throne of God, and serve Him day and night in His temple." This further solidifies the sanctuary setting. Other similar items that revolve around the throne include the following: Rev 22:1 states there is a pure river of water of life clear as crystal proceeding from throne and Rev 7:17 states "the Lamb who is in the midst of the throne will shepherd them and lead them to living fountains of waters." The Rev 22:2 passage states that the tree of life has twelve fruits while Rev 7:16 states "They shall neither hunger anymore nor thirst anymore." Also, Rev 22:2 points out that the nations are there while Rev 7:9 points out that there will be a great multitude that no man can number from all nations around the throne. 
(Exod 3:14) in Heb 1:3; 5:8; 11:6; Cf. 13:8; Rev 1:8 and 22:13; John 8:24, 28, 58; 13:19. The Holy Spirit is connected to the I AM by Kúptos in 2 Cor 3:17, and by noting that Lord/ Kúpros in the LXX of Isa 6:8-10 and Psalm 95:7-11 is the Holy Spirit in Acts 28:25-27 and Heb 3:7-11. Moreover, Lord/ Kúpıos in Zech 4:10 is the seven Spirits in Rev 5:6, and Lord/ Kúplos in the hearing formula of Ezek 3:27 is the Spirit who speaks each of the messages to the churches in Rev $2: 7,11,17,29 ; 3: 6,13,22$. The Holy Spirit is also associated with the God's name (Exod 3:15) in the baptismal formula (Matt 28:19). Consequently, all three have existed as the One God throughout the eternal ages without coming into being and without having the being of Son or Holy Spirit derived in some way from the Father. Moreover, connecting the word Son to God's infinite

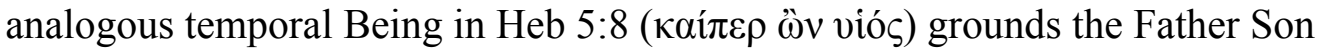
relationship in transcendence.

Second, the heavenly sanctuary gives clarity and precision to the way in which each member of the Godhead relates with divine presence and omnipresence. For instance, while the Godhead is omnipresent in transcendence, the Father and Son have a localized presence in the heavenly sanctuary (Acts 2:33; Heb 12:23-24; Rev 5:1,6) while only the Holy Spirit is omnipresent in immanence (Acts 2:33, 39; Rev 5:6).

Third, God's infinite analogous temporal Being makes it possible for the Son to become flesh without contradicting God's Being (Heb 5:8-9); and God's infinite analogous temporal Being combined with the heavenly sanctuary becomes the framework from which to interpret Christ's divinity, his humanity, and how we view their relationship in the incarnation as the prerequisite to his role as high priest and mediator (Heb 12:24). 
The NT further clarifies and gives precision to the different ways in which the divine, angelic, and human liturgists carry on their ministry. For instance, the Father speaks (Heb 1:5-14), and he originates the content of the scroll in his right hand (Rev 5:1). The Son speaks (Heb 1:2; 2:3, 12-13), he originates the messages to the churches (Rev $2: 1,8,12,18 ; 3: 1,7,14)$, and he speaks through the liturgical actions he performs in the heavenly sanctuary (Heb 12:24; Rev 5:6, 9, 12; cf. Heb 4:2) that were prefigured by the ministry of the priests in the OT. The Holy Spirit speaks through Scripture (Heb $3: 7-11 ; 10: 15-17)$, through the messages that are delivered by the human angel/messenger to each of the churches $(\operatorname{Rev} 2: 7,11,17,29 ; 3: 6,13,22)$, through the Three Angels Messages (Rev 14:6-12, 13) spoken by human liturgists, and through Christ's liturgical actions that he reveals to human liturgists (Heb 9:6-8; Rev 5:6; cf. 1 Cor 2:9-10). Angels are ministering spirits (Heb 1:7, 14) that minister in liturgical contexts in heaven (Rev 5:8-9) and on earth (Heb 2:2).

Liturgical authority is grounded in the words and actions of Christ in the heavenly sanctuary, in the scroll that is in the hand of the Father, and in the central heavenly throne that all are subject to. While human liturgists are the cause of liturgy, the divine and angelic liturgists are the indispensible conditions of liturgy.

With reference to the liturgical setting and actions, the heavenly sanctuary constitutes the primary location that worshippers ultimately approach unto (Acts 2:33; Heb 12:22-24; Rev 5:6) regardless of where they are located on earth. The Sabbath constitutes the time in which liturgy occurred in the NT, and which often took place in synagogues. There are several factors that point to preaching as the central liturgical action in the NT. First, there are the sermons of Jesus (Luke 4:16-30), Peter (Acts 2:14- 
40), and Paul (Acts 13:13-52; 17:1-4; 18:1-8). Second, the spatio-temporal structure of the heavenly sanctuary is the context in which Jesus performs his mediatorial and liturgical tasks as our high priest. These mediatorial and liturgical actions constitute the basis for the content of the sermons that liturgists preach. For instance Jesus' inauguration as our high priest was communicated by Peter's sermon on the Day of Pentecost (Acts 2:14-40). There is also the analogical relationship between the revelation of the contents of the scroll in heaven (Rev 5) and the preaching of the everlasting gospel of the Three Angels Messages (Rev 14) on earth. A third factor that points to the centrality of preaching is the reference to the blood of sprinkling that speaks (Heb 12:24). This effectively joins together the sacrificial system of the OT with the Lord's Supper, baptism, and anointing, all of which comprise different forms of ritualized proclamation. The choice of the harp as an accompanying instrument points to musical characteristics in the heavenly scene of Rev 4-5 that contain a strong melodic line accompanied by rich harmonies.

The heavenly sanctuary grounds the temporal relationship between the content that worshippers receive in the encounter and the spiritual location of the heart and mind of the worshipper in which the encounter occurs. The encounter is a cognitive and spiritual encounter that reveals the words of God to the worshipper. As a result, an encounter does not consist of receiving the being of God. The analogical relationship between the content of the sealed scroll in Rev 5 in heaven and the content of the Three Angels Messages of Rev 14 on earth reveals a universal cognitive and spiritual encounter that all worshippers in heaven and earth experience.

The varied responses in the NT include verbal (Acts 2:37), affective (Acts 2:41; 
Heb 12:28, 29), kinesthetic ( $\operatorname{Rev} 4: 10 ; 5: 8,14)$ mental, and social (Acts 2:42) that led to various forms of service (Heb 12:28, 29). These responses are grounded in the physical, mental, spiritual, and social components of the worshippers that are all causally related to each other. These responses assume a cognitive communication and a hermeneutical mind that leads to a spiritual encounter and a spiritual response. The responses to the encounter that occur in the heavenly sanctuary by the worshippers there serve as a universal model that ground all earthly responses.

In the biblical search for unity in the Biblical Sanctuary Model, God's infinite analogous temporal Being (Exod 3:14-15; Rev 4:8) and the heavenly sanctuary (Heb 12:22-24; throne references in Rev 4-5) constitute the two major macro-hermeneutical principles for fashioning each liturgical component to the preaching of the gospel as the chief means of achieving liturgical unity.

Each member of the Trinity (Rev 5:1-6), the angels (Heb 2:2; Rev 4:8-11; 5:814), and human beings (Rev 5 and 14:6-12,13) are all harmoniously involved and interconnected with the ministry of God's Word. Liturgical authority is grounded in the Trinity as expressed by the way in which each member is associated with the central throne (Rev 5:1, 6; cf. 4:5) and ark of the covenant (Rev 11:19; cf. 4:2), and with the content of the heavenly scroll (Rev 5:1; cf. 6:1-17; 8:1).

The heavenly sanctuary where God places his name by revealing his presence there (1 Kings 8:16-20, 29; Heb 12:22-24) combines with the Sabbath as the time in which God's presence is revealed (Heb 4:9). Thus, the heavenly sanctuary and the Sabbath unite worshippers all over the globe in one place and at one time to hear the Word. 
The centrality of ministering God's Word assumes a cognitive communication (Acts $2: 12,14-40)$ that is paramount in achieving a spiritual encounter. The adjective "first-born ones," the phrase "the spirits of the righteous," and the names enrolled in heaven in Heb 12:23 all point to the spiritual component of worshippers that are essential for achieving a spiritual encounter.

The varied and free verbal, kinesthetic, affective, and social responses to the encounter are causally connected to the centrality of the ministry of God's word; and they are grounded in the mental, spiritual, physical, and social aspects of a fully integrated humanity.

Thus, there's an inseparable and causal connection between the divine presence, the liturgist, the liturgical actions, and preaching the Scriptures as the main liturgical action in the biblical search for unity. These elements constitute the indispensible prerequisites for achieving a cognitive and spiritual encounter that leads to a unified response to the encounter. However, even though the responses are varied, they are all grounded in the message conveyed and in the integrated physical, mental, spiritual, and social nature of each worshipper. 


\section{CHAPTER 7}

\section{THE BIBLICAL SANCTUARY MODEL}

\section{Introduction}

In Chapters 4, 5, and 6 this study generated large amounts of data that described and analyzed how each model interprets the five liturgical components and the ecumenical search for unity within each model. The aim of this Chapter is to first present an outline of the Biblical Sanctuary Model that will be summarized from the survey of Old and New Testament data that was generated in Chapters 5 and 6. This theological and systematic outline seeks to establish the possibility of developing a biblical view of the divine presence as the starting point for interpreting the complex interrelationships between the liturgical components.

I will then describe each of the four models as a self-contained unit.

Next, this Chapter seeks to ascertain the cause of liturgical pluralism in Christianity, and suggests how to overcome it by applying Thomas Kuhn's insights between paradigms and data to Being and the liturgical components. ${ }^{1}$ Within Kuhn's wider framework, I will summarize the main points of timeless Being's determinative role in interpreting the liturgical components in the Sacramental, Kerygmatic, and Charismatic Models. I will then summarize the main points of the Biblical Sanctuary

${ }^{1}$ In Chapter 3 of this dissertation, I pointed out five ways in which Kuhn's insights on the relationship between paradigms and data apply to Being and the liturgical components, see this dissertation pages 94-98. 
Model by noting the hermeneutical role of God's infinite analogous temporal Being on the liturgical components. I will then compare the three models with the Biblical Sanctuary Model. ${ }^{2}$

\section{Systematic Role of God's Temporal Being and the Heavenly Sanctuary}

Before I begin my systematic outline of the Biblical Sanctuary Model, I will briefly describe this model's temporal interpretation of God's Being and then trace the hermeneutical results that arise as a result of it. Exod 3:14-15 grounds the temporal interpretation of God's Being in the Biblical Sanctuary Model. Since, I AM (hyh/o öv) in Exod 3:14 is God's name (Exod 3:15) and is synonymous with Lord (Yahweh/Kúpros) and God (Elohim/ó $\theta \varepsilon \dot{s} \varsigma$ ) in Exod 3:15, all of the occurrences of the words attributed to God such as Lord, God, name, and Ø̋v carry with them the temporal interpretation of God's Being. Hence, this broadest of all possible presuppositions is found in all of the liturgical settings that were uncovered in the Old and New Testaments passages in Chapters 5 and 6.

There are two hermeneutical results that ensue from this observation. The first is that the Biblical Sanctuary Model renders groundless the timeless view of Being that determined the content of the divine presence and of the rest of the liturgical components that each of the models in Chapter 4 assumes. As a result, the dichotomies inherent in all of the liturgical components of the Sacramental, Kerygmatic, and Charismatic Models disappear from all the components of the Biblical Sanctuary Model when Scripture is allowed to unfold its interpretation of Being as temporal. The dichotomies that plagued

\footnotetext{
${ }^{2}$ In order to make the Chapter more concise, I will largely avoid providing references in this analysis since references have already been provided in Chapters 5 and 6 .
} 
the models in Chapter 4 are neither sustained by God's infinite analogous temporal Being nor by the specific content of the biblical passages under investigation in Chapters 5 and 6.

This leads to the second hermeneutical result, which is that God's infinite analogous temporal Being allows the heavenly sanctuary to temporally ground the relationship between the divine presence and the rest of the liturgical components that are found throughout heaven and earth. This hermeneutical framework interprets each of the five liturgical components that include their subcomponents and the issues intrinsic to them, as well as the interrelationships between the five liturgical components. The end result is that the spatio-temporal framework of the heavenly sanctuary integrates all of the liturgical components thus eliminating the dichotomies of the previous models.

This Chapter will now outline how these hermeneutical presuppositions systematically and theologically outline the manner in which the complex parts inherent within each of the liturgical components relate to each component, as well as to the biblical search for unity.

\section{Divine Presence}

Since God's Name/Presence (Exod 3:14-15; 2 Chron 20: 8-9) is revealed in the Sanctuary (Deut 12:5, 11, 21; 16:2, 6; 1 Kings 8:29; 2 Chron 7:16; Acts 2:33; Rev 4-5), our purpose is to describe the hermeneutical impact of the I AM on the divine presence as Trinity; to outline the interrelationships between Sola Scriptura, the sanctuary and the divine presence as Trinity; to bring to view the way in which the sanctuary discloses the function of the Trinity in liturgy; and the manner in which God is present in liturgy. We will also examine the hermeneutical role of the sanctuary in interpreting transcendence 
and immanence, presence and omnipresence, Christ's divinity, Christ's humanity, and the relationship between divinity and humanity in the incarnation. We will finally note the consequences of abandoning the sanctuary as the place of liturgy for our understanding of the divine presence.

\section{The I AM and the Divine Presence as Trinity}

In the Biblical Sanctuary Model, the heavenly sanctuary reveals the complimentary roles of the Trinity in liturgy (Rev $4: 5 ; 5: 1,6)$ as the divine presence since each of them are inextricably linked to the I AM of Exod $3: 14^{3}$. This linkage of each member of the Trinity with the I AM reveals that they are coeternal and immutable. Even though the designations Father and Son disclose a relational structure between two distinguishable divine realities that operate in transcendence and immanence (Heb 5:8), there is no ontological subordination on the part of the Son to the Father since the Son's being is in no way derived from the Father (Heb 5:8). The same also applies to the sending of the Holy Spirit in Rev 5:6, which is a reference to the Spirit's activity in liturgy rather than a description of the Spirit's being as coming forth from the being of the Father.

\section{Sola Scriptura, the Sanctuary, and the Divine Presence as Trinity}

The language of Heb 9:1-8 clearly assumes that some articles of furniture belong in the holy place while others articles belong in the most holy place of the sanctuary. The

\footnotetext{
${ }^{3}$ This is a representative and not an exhaustive list of references that connects each member of the Trinity with the I AM: Father (Rev 1:4; 4:8; 11:17; 16:5); Son (Rev 1:8 with 22:13; Heb 5:8; John 8:24,28, 58; 13:19); Holy Spirit (LXX of Zech 4:10 with Rev 5:6; LXX of Ezek 3:27 with Rev 2:7, 11, 17, 29; 3:6, 13, 22; Isa 6:8-10 with Acts 28:25-27; Psalm 95:7-11 with Heb 3:7-11).
} 
application of the Sola Scriptura principle clearly implies that these are distinguishable entities that are in specific locations pertaining to the earthly and heavenly sanctuaries.

Moreover, in the heavenly sanctuary scene of Rev 4-5 the door to the most holy place is open ( $\operatorname{Rev} 4: 2 ;$ cf. $3: 7-8 ; 11: 19)$. In this setting, the Father occupies the throne ( $\operatorname{Rev} 5: 1)$, the Son appears standing before the throne (Rev 5:6,13), and the Spirit is before the throne in the holy place ( $\operatorname{Rev} 4: 5)$ and also in all the earth $(\operatorname{Rev} 5: 6)$.

If the application of the Sola Scriptura principle leads to the deduction that the articles of furniture in the heavenly sanctuary are distinguishable entities, then one should also conclude that the Godhead consists of three distinguishable entities on the basis that John specifies the location of each member of the Godhead to a different place in the heavenly sanctuary. Only an allegorical/mystical reading of the I AM of Exod 3:14-15 and of the heavenly sanctuary would preclude the sanctuary from exercising its hermeneutical role in interpreting the Trinity as three distinguishable entities.

\section{The Sanctuary and the Function of the Trinity in Liturgy}

The heavenly worship scene in Rev 4-5 further discloses the function of each member of the Trinity in liturgy from his proximity to the central throne (Rev 4:6; 5:6, 11). Here the Father is on the throne with the scroll in his right hand $(\operatorname{Rev} 5: 1)$ while the universe anxiously awaits to know the content contained in the scroll (Rev 5:3-4). The Son stands before the Father so that he can ultimately receive the scroll (Rev 5:6-8), open it ( $\operatorname{Rev} 5: 9)$, and read it $(\operatorname{Rev} 5: 4)$ before the inhabitants of heaven ( $\operatorname{Rev} 5: 13)$. The Holy Spirit is before the throne ( $\operatorname{Rev} 1: 4 ; 4: 5)$ and communicates what occurs in heaven to the inhabitants of earth (Rev 5:6; cf. $\operatorname{Rev} 2: 1,7,8,11,12,17,18,29 ; 3: 1,6,7,13,14,22)$. 


\section{The Sanctuary Distinguishes the Divine Presence from the Word}

When it comes to liturgy God as Trinity is present in a temporal, historical, and relational manner as evidenced by the location of each member of the Trinity within the heavenly sanctuary. The worshippers in heaven already see Father and Son in the sanctuary, yet they still await to hear the content of the scroll that will unfold still greater revelations of his will. The sanctuary thus makes a vital distinction between the divine presence and the scroll that reveals further information about the divine presence.

In accordance with Rev 5:6, the Holy Spirit is present in earthly liturgy. Yet in keeping with the heavenly scene his presence is distinct from the words that the liturgists speak. Furthermore, God's presence is only revealed by those who speak God's words. There is also no Platonic dichotomy between God's Being and his words; or between God's presence and his words, even though God's words are not his being.

\section{The Sanctuary Interprets Transcendence and Immanence}

The placing of God's name in the sanctuary (Deut 12:5, 11, 21; 16:2, 6; 2 Chron 20:8-9; 1 Kings 8:29), which signifies that he reveals his presence there, constitutes the starting place for interpreting God's presence in immanence and transcendence (1 Kings $8: 27)$. Immanence refers to God's presence in relation to the universe and transcendence refers to God's presence beyond or outside the universe (1 Kings 8:27) in a reality that only the Trinity experience. ${ }^{4}$

Since God is infinitely temporal, the sanctuary is allowed to ground the temporal

\footnotetext{
${ }^{4}$ See this dissertation, 239-242, 245-248.
} 
relationship between the Trinity in immanence and in transcendence thereby rendering groundless the possibility of a Platonic ontological gap between transcendence and immanence. Furthermore, the sanctuary also eliminates the Platonic gap between the heaven of heavens (immanence) and earth (immanence). God is thus present in transcendence and immanence at the same time.

\section{The Sanctuary Interprets Divine Presence and Omnipresence}

The location of each member of the Trinity in the heavenly sanctuary, such as the Father on the throne (Rev 5:1), the Son standing in the immediate presence of the Father (Rev 5:6), and the Holy Spirit before the throne and throughout the world (Rev 4:5: 5:6), addresses the way in which the Trinity relates to the issues surrounding God's presence and omnipresence. As we apply the Sola Scriptura principle to the aforementioned descriptions, the heavenly sanctuary specifies that the real holy passible visible moral and personal presence of Father and Son are localized in the heavenly sanctuary (Acts 2:33; Heb 12:22-24; Rev 5:1, 6) while the real holy passible invisible moral and personal omnipresence of the Holy Spirit is sent into the earth (Acts 2:33; Rev 5:6).

\section{The Sanctuary Interprets Christ's Divinity}

In addition to establishing Christ's divinity, God's infinite analogous temporal Being and the heavenly sanctuary also interpret Christ's divinity, his humanity, and their relationship in the incarnation. The throne imagery in the heavenly sanctuary reveals a controversy between God and Satan over God's character as expressed by his immutable law, the Ten Commandments. Since God's being is as immutable as his law, only a divine being could atone for its transgression without at the same time altering or 
diminishing God's law in any way; this establishes the divinity of Christ. ${ }^{5}$

\section{The Sanctuary Interprets Christ's Humanity}

The controversy over God's law regarding who has the right to receive worship implies that the human nature of Christ must not be dominated, coerced, or determined by his divine nature; such a course would vindicate the claims of Satan. Thus on the basis of the controversy surrounding the throne in the heavenly sanctuary, Christ's human nature must be free to choose whom he will serve. ${ }^{6}$

\section{The Sanctuary Interprets Relationship between Christ's Divinity and Humanity}

Regarding the relationship between Christ's divine and human natures, God's Being in Exod 3:14 allows him to relate to the spatio-temporal realities in the sanctuary without compromising his being, or the intelligible beings and material realities contained therein (Exod 25:40; Heb 8:5). This provides the template for the blending of divinity and humanity in the incarnation without compromising the reality of either nature so that Christ can truly be a mediator that is fully able to identify with divinity and humanity (Heb 12:24). Consequently, since Christ is eternal and immutable (Exod 3:14; John 8:58; Rev 1:8 and 22:13; Heb 5:8), he retains his omnipresence in transcendence during the incarnation. However, the heavenly sanctuary reveals that he is not omnipresent in immanence during the incarnation. Furthermore, the designation of the word "Lamb" (a sanctuary symbol) that John employs in Rev 22:1, 3 to describe Christ after the sin

\footnotetext{
${ }^{5}$ For support on the controversy over the throne, see this dissertation, 327-329.

${ }^{6}$ See this dissertation, 329-331 for the relationship between the sanctuary and Christ's human nature.
} 
problem has been resolved at the end of the millennium assumes that Christ will retain his human nature into the unending ages (Rev 22:1, 3; cf. Zech 13:6).

\section{Abandoning the Sanctuary: Implications for the Divine Presence}

Just before the golden calf incident Moses drew the attention of the reader to the sanctuary (Exod 31:1-11) and the Sabbath (Exod 31:12-17). The author of 1 Kings also draws our attention to the importance of Solomon's temple as the place where God chose to put his name (1 Kgs 8:29; $2 \mathrm{Chr} 7: 16$ ), thus revealing his presence (2 $\mathrm{Chr} 20: 8-9)$ in that specific location. There are several ways in which the golden calf incident of Exod 32 and Jeroboam's worship of the golden calves in 1 Kings 12:25-33 reveal that one's interpretation of the divine presence will be distorted if the appointed place in which liturgy is conducted is ignored.

First, the advice that Jeroboam received to make golden calves and place them in Dan and Bethel $(1 \mathrm{Kgs} 12: 28,29)$ for the people to worship did not come from Scripture (Lev 26:1-2; Deut 4:12-15) but rather from the philosophy and culture of the time period in which he lived. This step allowed human philosophy and culture rather than Scripture (Exod 3:14-15) to play a dominant role in determining the content of the divine presence.

Second, the sanctuary as the place where God reveals his presence was cast aside when Jeroboam conflated the divine presence with the golden calves, and when he directed God's people to go to Dan, Bethel, and other "high places (2 Chr 11:15; 1 Kings 12:32) to worship instead of to the sanctuary in Jerusalem (1 Kings 12:28). Now that scripture and the sanctuary have been stripped of their hermeneutical role, the result is that the divine presence is synonymous with nature. Since the divine presence is what 
makes anything holy (Exod 3:4-6), one must now conclude that all places are holy on the basis that the divine presence is inextricably linked with creation. Such a view also limits God to the universe whereas 1 Kings 8:27 asserts that God has a reality that is outside the universe. $^{7}$

Third, the heavenly sanctuary has always been the one central location that all earthly worship is oriented toward, even during OT liturgy. ${ }^{8}$ However, with the destruction of the earthly temple, the central role of the heavenly sanctuary as revealed by the NT (Acts 2:33; Heb 12:18-29; Rev 4-5) has come into more prominent focus. Our analysis of Chapter 4 of this dissertation reveals that the consequence of neglecting the macro-hermeneutical role of the heavenly sanctuary in interpreting the divine presence results in conflating the divine presence with creation.

Hence, Jeroboam's rejection of the earthly sanctuary as the place of worship involved a wholesale reinterpretation on the sources of revelation that are then integrally involved in interpreting the divine presence. Similarly, those Models of liturgy that I analyzed in Chapter 4 of this dissertation that neglected the hermeneutical role of the heavenly sanctuary as the place of liturgy have also interpreted the divine presence in such a way that is inextricably linked with the creation.

\section{Liturgist}

Our analysis of the liturgist will involve tracing the Biblical Sanctuary Model's interpretation of the divine presence that we just covered with the issues that are intrinsic to the liturgist. We will specifically outline how the heavenly sanctuary grounds the

\footnotetext{
${ }^{7}$ See this dissertation, 239-242, 245-248.

${ }^{8}$ For examples of OT liturgy directed and grounded in the heavenly sanctuary, see this dissertation, 240-241, 272-274, 276-278, 280-282.
} 
temporal relationship between (1) the divine, angelic, and human liturgists, (2) the divine presence, God's law, and the content in the heavenly scroll regarding the issues relating to liturgical authority, and (3) the combined characteristics of human nature that are involved in mediating the divine presence. We will also briefly examine the hermeneutical effects of abandoning the sanctuary as the place of liturgy for our understanding of the liturgist

\section{The Sanctuary and the Divine, Angelic, and Human Liturgists}

The following points disclose the divine liturgists. The Father speaks throughout the epistle to the Hebrews, and in Rev 5:1 he sits on the throne and most likely originated

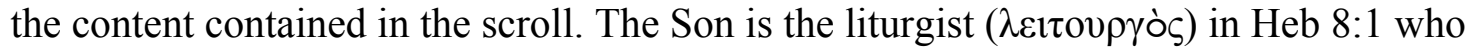
speaks through the blood of sprinkling (Heb 12:24), referring to the liturgical actions he performs in the heavenly sanctuary. These liturgical actions of Christ in the heavenly sanctuary constitute the model (Heb 8:5; 9:24) from which the OT priests proclaimed the gospel through the ritual actions connected to the sanctuary (Heb 4:2) and from which the NT liturgists preach the gospel (Acts 13:1-3; Rom 15:16; Heb 5:11; 8:1; 9:5). Christ also spoke messages to the seven churches in Revelation and he reveals the meaning of the scroll to the on looking worshippers in Rev 5.

While the liturgical actions of Father and Son take place in the heavenly sanctuary, the Holy Spirit reveals the real historical actions and content contained in the heavenly scenes and in the scroll to the inhabitants of earth (Rev 5:6). This is only possible if the heavenly sanctuary temporally grounds the actions and content that occur in heaven with the work of the Holy Spirit who is able to disclose the heavenly liturgical actions and content to the human liturgist (Heb 9:6-8; Rev 5:6; cf. Heb 8:1). Moreover, 
this transmission of the content must occur without distorting the heavenly meaning.

In the doctrinal and thematic comparisons between Rev 4-5 and the Three Angels Messages of Rev $14,{ }^{9}$ we find that the Holy Spirit being sent out into all the earth is disclosed by the cooperation between angels and earthly liturgists who preach these messages (Rev 5:6; 14:6-12 and especially 14:13). We also find angelic cooperation with the divine liturgist in the giving of the Ten Commandments (Heb 2:2), and in the vision of Isaiah where angels ministered God's words to the prophet (Isa 6:3, 6-7).

\section{The Sanctuary and God's Word as Basis for Liturgical Authority}

The heavenly sanctuary also grounds the temporal relationship between the divine presence, God's law and the scroll regarding the issues pertaining to liturgical authority. In Acts 13:1-3 Paul, Barnabas and other prophets and teachers ministered

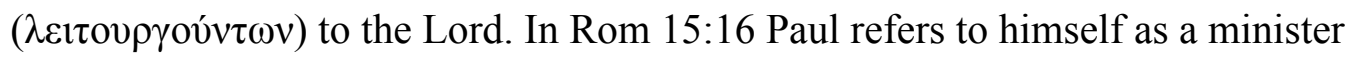
( $\lambda \varepsilon$ เाoupyòv) of Jesus Christ to the Gentiles, ministering the gospel of God. Since the Greek word for liturgy was consistently used to describe the work of priests and Levites in the OT in the context of the earthly sanctuary, its use in Acts 13:1-3 and Rom 15:16 assumes that the heavenly sanctuary is the context in which NT ministers and teachers speak concerning the riches of the gospel (Acts 13:13-52). These facts draw our attention to the divine and human liturgists whose authority must be in harmony with the throne ( $\operatorname{Rev} 4: 2$ ), which is also the location of the ark of the covenant and the Ten Commandments (Rev 3:7-8; 4:2;11:19), and with the content of the scroll (Rev 5:1). Accordingly liturgical authority is grounded in the One who is seated on the throne who

\footnotetext{
${ }^{9}$ See Tables 1 and 2 in Chapter 6 of this dissertation.
} 
shares that throne with his Son. This means that Paul's authority, and the even the Holy

Spirit's authority mentioned in Acts 13:1-3 is exercised in harmony with the throne, God's law, and with the content of the heavenly scroll $(\operatorname{Rev} 5: 1)$.

\section{The Sanctuary, Mediation, and Issues Over Liturgical Authority}

Since the heavenly sanctuary also grounds the temporal relationship between the divine presence and the human liturgist, the nature of the human liturgist is also temporal. The integrated components associated with a temporal human nature include personal attitudes, ethical choices, beliefs, and spiritual gifts; all of which are integrated and causally connected to the immutability of maleness and femaleness. Moreover, all of these aspects are involved in mediating the divine presence, although in different ways. For instance, the immutability of maleness and femaleness mediates the immutability of Gods' nature while the hermeneutical mind of the liturgist interprets the divine content concerning the divine presence before communicating it to the worshippers.

There are two major reasons for why liturgical authority resides in Scripture.

First, since the heavenly sanctuary grounds the temporal relationship between the divine presence, the Ten Commandments, and the scroll, the revelation of his presence as codified in the Ten Commandments and in the scroll reveals that the ground for liturgical authority resides in Scripture, not in spiritual gifts, nor in the liturgist or the church. Second, the human liturgist in the Biblical Sanctuary Model possesses a hermeneutical mind that can choose whether to interpret the divine presence through nature or through revelation (Lev 26:1-2). Consequently, the human liturgist is the cause of liturgy, and the divine presence and the rest of the liturgical components constitute the indispensible conditions of liturgy. Even though the liturgist should choose to interpret the divine 
presence through Scripture, the possibility of errors in interpretation with a hermeneutical mind signifies that liturgical authority must not be grounded in the liturgist, in the church, or in the exercise of spiritual gifts but in Scripture. Moreover, since the throne discloses the controversy over God's character and law that includes deceptive angelic spirits that are loyal to Satan's throne (Rev 12:4, 7-9; 2:13; 13:2), liturgical authority should not be grounded in the Holy Spirit. The reason for this is that some claim the Holy Spirit as their source of authority while they divorce the Spirit's authority from scripture and the Ten Commandments.

\section{Abandoning the Sanctuary: Implications for Mediation and Authority}

The hermeneutical importance of the place of liturgy, which was abandoned in Jeroboam's day (1 Kings 12:28-30, 32), had a corresponding effect on the interpretation and qualifications of the liturgist. Jeroboam appointed priests to officiate who were not of the sons of Levi (1 Kings 12:31). Moreover, Jeroboam, who also was not a priest of the tribe of Levi transgressed and offered upon the altar and burned incense (1 Kings 12:33;

13:1-10). Since God's presence was now to be revealed in places outside of the Jerusalem temple (1 Kings 12:29, 32), the barrier that the sanctuary held in check regarding the interpretation of his holy presence, along with where God revealed his holy presence was now set aside. This directly led to the idea that all places are now holy since the divine presence is now associated with all nature. Moreover, Scripture as a source of authoritative content was also discarded by the abandonment of the temple as the place of God's revealed presence, and as the interpreter of God's presence and omnipresence.

Similarly, the effect of abandoning the temple as the place of liturgy, and the 
discarding of the scriptural qualifications of the priests as descendants of Aaron (Exod $28: 1 ; 40: 12-15)$ led to the following qualifications as the only prerequisites for the new priesthood: (1) anyone who has ability and wealth, ${ }^{10}$ and (2) adherence to Jeroboam's vision $^{11}$ and a willingness to implement it. Since the divine presence is ubiquitous in nature and in humanity, all the people are now holy and there is no causal relationship between obedience to the scriptural qualifications as a fitness for priestly duties and holiness. ${ }^{12}$ This involves an interpretation of human nature in which holiness as fitness for office is equated with the essence of a human being that stems from the divine presence that is inherent in humans rather than with adherence to the scriptural qualifications. As a result, since religious teaching constitutes one of the main functions of the priest (Lev 10:11; Deut 33:10; Eze 44:23), the new priests will mediate their interpretations of God's Being and presence on the basis of non-Scriptural sources.

${ }^{10}$ In 2 Chron 13:9 we read,

Have you not cast out the priests of the Lord, the sons of Aaron, and the Levites, and made for yourselves priests, like the peoples of other lands, so that whoever comes to consecrate himself with a young bull and seven rams may be a priest of things that are not gods?

Thus anyone who can provide the bullock and rams can serve.

${ }^{11}$ The 2 Chron 11:15 passage reveals that Jeroboam had "appointed for himself priests of the high places." The passage actually points out that the priests and their worship were appointed for demons. Hence, all of the appointed priests must be in harmony with Jeroboam's vision. Therefore they mediate satanic and spiritualistic concepts of God and his presence. In contrast, Heb 2:17 and 5:1 point out that priests are appointed to serve in things pertaining to God, not to ideas of men.

${ }^{12}$ If holiness does not involve adherence to scriptural qualifications, then the following scriptural qualifications for priests were likely discarded without in any way affecting their holiness since all that was required was to provide a bullock and rams (2 Chron 13:9). The priests were to be supported exclusively by tithes and offerings and not engage in gainful occupation (Lev 10:12-15; 23:17-20; Num 18:11; Deut 18:3-5); physically defective priests, or priests that were temporarily unclean were not to minister at the altar (Lev 21:1-4, 21-23); while ministering at the sanctuary they were to wear distinct clothing (Exod 28:40-42; 1 Sam 22:18); the high priest only could enter the holy of holies (Lev 16:2, $3,17,33,34)$; priests also must adhere to specific characteristics regarding who they marry, not a harlot, a defiled, or divorced woman, but a virgin (Lev 21:7, 13-14). 
Moreover, the dichotomy between holiness and adherence to scriptural qualifications directly results in priests that mediate God's holiness in such a way that it is separated from his word, and his law. This is the exact opposite of teaching them the difference between the holy and the unholy (Ezek 44:23).

Similarly, all who neglect the central hermeneutical role of the heavenly sanctuary in interpreting the nature, authority, and mediation of the liturgist will experience the same results as those who followed Jeroboam's policy. Hence, one cannot neglect the hermeneutical role of the place of worship without (1) reinterpreting the nature of the liturgist, (2) abandoning scripture as the ground of the liturgist's authority, (3) discarding the scriptural qualifications of the liturgist, and (4) mediating non-Scriptural views of the God's Being, his presence and omnipresence.

\section{Liturgical Setting and Actions}

With reference to the liturgical setting, the heavenly sanctuary and the Sabbath constitute the place and the time of liturgy throughout the OT and NT periods. However, since the heavenly sanctuary and the Sabbath ground the temporal relationship between the divine presence and preaching as the central liturgical action, they play a much larger hermeneutical role than merely providing the place and time in which liturgy occurs.

We will examine this larger hermeneutical role that the sanctuary and the Sabbath play by (1) outlining the integral relationship between the heavenly sanctuary, the divine presence, and speech as the central and only liturgical action that reveals God's presence (2) examining the relationship between the Sabbath, the divine presence and preaching, (3) noting that the heavenly sanctuary grounds the universal meaning of the content of speech, and (4) noting that the architectural style of earthly places of worship should be 
grounded in the heavenly sanctuary. We will also briefly examine the hermeneutical effects of abandoning the sanctuary as the place of liturgy for our understanding of what constitutes the central liturgical action, and how we interpret the content of speech.

\section{The Sanctuary and Speech as Central Liturgical Action}

The Lord stated that he would choose the specific place where he would place his name (Deut 12:5, 11, 21;16:2, 6), which would be the Temple in Jerusalem (1 Kings 8:29) as well as the heavenly temple (1 Kings $8: 30,39,43,49)$. When the Lord stated he would place his name in the temple, it signified that his presence would dwell there (2 Chron 20:8-9). With reference to liturgy on earth, God's presence, as well as his actions is only revealed by his words (Exod 3:1-6; Deut 4:11-15; Acts 2:33; Heb 12:24-25; Rev 5 compared with Rev 14). In the heavenly sanctuary, Father and Son are visibly present while the Holy Spirit is invisibly present. However, the content in the scroll that the Lamb reveals to the heavenly universe reveals very important information concerning the controversy that surrounds the throne. ${ }^{13}$ Thus in earthly and heavenly liturgy there is an integral relationship between the sanctuary, the divine presence, and the centrality of speaking God's words.

\section{The Sabbath and Speech as Central Liturgical Action}

We will now outline the integral relationship between the Sabbath, the divine presence and the centrality of preaching. As an invisible institution (Gen 2:1-3), the Sabbath links together God's invisible presence (1 Tim 1:17) with invisible auditory

\footnotetext{
${ }^{13}$ For more on the controversy over the throne, see this dissertation, 327-329.
} 
communication. As an institution that will continue into eternity (Isa 66:22-23), the Sabbath links God's eternity (Exod 3:14) with God's eternal words (Psalm 111:7-9; 117:2). As a holy institution (Exod 20:8-11), the Sabbath links together God's holy presence (Exod 3:1-6) with God's holy word (Jer 23:9; John 17:17; Rom 7:12). As an immutable sign (Gen 2:1-3; Isa 66:22-23), the Sabbath links together God's immutable nature (Mal 3:6; Heb 1:12; 13:8) with his immutable words (Psalm 89:34). Lastly, the Sabbath as an institution reminds us that God created ("And God said...") through speech (Exod 20:8-11) and that we can remember the acts of salvation history through speech (Deut 5:12-15).

\section{The Sanctuary and the Universal Meaning of Speech}

As we now examine the nature of the content concerning the divine presence, we find that the heavenly sanctuary grounds the temporal relationship between the content of the Word in heaven with the content of God's words on earth. For instance, Heb 12:18-21 hearkens back to the sanctuary context on Mt Sinai where God spoke his Law. In this setting, God's words came from heaven (Exod 20:22; Deut 4:36; Neh 9:13) as well as from the midst of the fire on earth (Deut 4:12, 15, 33, 36; 5:4, 22, 24, 26; 9:10; 10:4). Heb 12:24-25 also mentions that God speaks from heaven and from earth. Furthermore, the heavenly sanctuary grounds the temporal and analogical relationship between the content of heavenly scroll (Rev 5:1) and the content of the Three Angels Messages of Rev 14. There is thus no dichotomy between the theological content of God's word in heaven and the words God speaks on earth, just as there is no dichotomy between the Lord himself who is simultaneously "God in heaven above and on earth beneath" (Deut $4: 39)$. 
Furthermore, the heavenly sanctuary grounds the temporal relationship between all of the spiritual and physical realities in the universe and the words that are used to communicate them. Another important deduction is that speech is the universal method for disclosing the presence of God, which spans throughout all time, as well as throughout all of heaven and earth. Moreover, since the heavenly sanctuary is the place where worshippers approach (Heb 12:22-24), the liturgists who convey the historical actions of Christ (Acts 2:30, 33; Heb 12:24; Rev 5:6-7), God's Law (Rev 11:19), and the content of the sealed scroll through the preaching of the Three Angels Messages, can theoretically be found anywhere in the earth. The Sabbath also discloses a specific time that is made holy by the Holy Spirit's invisible omnipresence that is revealed to the worshippers through God's words. As a result, the heavenly sanctuary and the Sabbath ground the temporal relationship between the message conveyed and the various locations in which liturgists convey the message.

\section{The Heavenly Sanctuary and Earthly Places of Worship}

With respect to architecture, the heavenly sanctuary temporally grounds the relationship between the place of heavenly worship and the place of earthly worship. Consequently, the heavenly place of worship provides structural and functional patterns that serve as a model for earthly places of worship to draw principles from. For instance, liturgical space in the heavenly sanctuary includes a holy and a most holy place in which specific liturgical actions are performed in each place. ${ }^{14}$ Hence, liturgical space is

\footnotetext{
${ }^{14}$ This is a broad outline of what occurs in the holy and most holy places in which the ministry of the Word is common in both and yet there are differences. Jesus stands in the midst of the seven golden candlesticks (Rev 1:13) in the holy place in heaven that represent
} 
integrally connected with liturgical function. This correlation between liturgical space that is consecrated to certain liturgical functions should serve as a model for earthly places of worship. As a result, earthly places of worship should set aside liturgical space within their meetinghouses for the sole purpose of worship concerning which the ministry of the Word is central.

\section{Abandoning the Sanctuary: Implications for Speech}

Lastly, when Jeroboam set the sanctuary aside as the place in which God revealed his presence by setting up worship centers in Dan and Bethel (1 Kings 12:28-30), it led to the following results: (1) God's Being as revelation that occurs through speech (Exod 3:1-6, 14-15) is discarded since idols (Exod 32:4; 1 Kings 12:28) do not speak (Psalm 115:4-5; 135:15-17; Isa 46:7; Jer 10:15; Hab 2:18; 1 Cor 12:2), (2) Nature is the predominant bearer of God's revelation since God's Being is conflated to the calves, ${ }^{15}$ and (3) the main liturgical actions are thus music (Exod 32:6, 17-19) and all forms of art. Just as Jeroboam set aside the earthly sanctuary as the place of liturgy, the Sacramental, Kerygmatic, and Charismatic Models have done the same by interpreting Exod 3:14-15 and the heavenly sanctuary in an allegorical manner. As a result, the NT passages (Acts 2:33; Heb 12:18-29; Rev 4-5) that reveal the hermeneutical role of the

the seven churches (Rev 1:20) on earth. While in the holy place, Jesus originates messages of hope, instruction, correction, rebuke, and encouragement to the seven churches (Rev 2-3). In Rev 4-5 the apex of that liturgical service that occurs in the most holy place involves the unrolling of the scroll to the inhabitants of heaven and earth (Rev 5:6). Thus, heavenly liturgy involves different ministrations of the Word in accordance with liturgical space. For Rev 4-5 as a most holy place setting see this dissertation, 373-379.

${ }^{15}$ It seems that transubstantiation is similar to Jeroboam's policy of equating the divine presence with the calves in that it links the substance of the divine presence with the bread and wine thus limiting the divine presence to nature. This interpretation of the divine presence is unfortunately assumed by the other models, see Chapter 4 of this dissertation. 
heavenly sanctuary and the direct relationship between God's liturgical actions and speech as the central liturgical action have been set aside by those models.

\section{Encounter}

The purpose of this section on the encounter is to (1) take note of the hermeneutical role of the sanctuary in interpreting the relationship between the necessary components involved in the encounter, (2) outline how the covenant interprets the nature of the encounter that worshippers in heaven and earth experience with the divine presence, and (3) discover the goal of the encounter. I will then briefly examine the hermeneutical effects of abandoning the sanctuary as the place of liturgy for our understanding of the encounter.

\section{Hermeneutical Role of the Heavenly Sanctuary in the Encounter}

The Biblical Sanctuary Model assumes a biblical view of the macrohermeneutical presuppositions that function as prerequisites for understanding the nature of the encounter. These presuppositions include God's infinite analogous temporal Being, speech as the central liturgical action, and the correct interpretation of the worshippers. In the Biblical Sanctuary Model, the heavenly sanctuary grounds and articulates the relationship between God's infinite analogous temporal Being, the temporal nature of the worshippers, and the temporal and universal content of God's words as the central liturgical action; all of which constitute the indispensible prerequisites for a cognitive/spiritual encounter that also includes emotions. 


\section{The Covenant Interprets the Nature of the Encounter}

Since there is a close connection between the sanctuary and the covenant (Exod 24:1-11; 34:10-34; Heb 8-9; 12:24), the covenant provides additional principles for affirming the cognitive/spiritual nature of the encounter with God's words rather than a sacramental encounter with God's being. First, the Ten Commandments provide the framework from which to interpret God's nature and the worshippers' nature. The second Commandment prohibits worshippers from conflating the divine presence with creation (Exod 20:4-6; Lev 26:1), which also means that humans do not posses the being of God in their humanity. The fourth Commandments posits an ontological distinction between the being of God, and the being of nature that also includes the being of the worshippers. Hence, an encounter with the divine presence does not include an encounter with God's being.

Second, the covenant brings further clarity to the nature of the encounter by revealing that God's words are placed in our hearts and minds (Heb 8:10) not his being, even though God is present during the encounter. Hence, the covenant reveals that the nature of the encounter is a cognitive encounter with God's words.

Furthermore, since the heavenly sanctuary grounds the relationship between the temporal worshippers in heaven (Rev 4:8-11; 5:8-14; cf. Heb 12:22-25) with the temporal worshippers on earth, the cognitive nature of the encounter is universal because speech is the universal method in which God reveals himself to the worshippers in heaven and on earth (Heb 12:22-25). 


\section{The Heavenly Sanctuary and the Goal of the Encounter}

The sprinkled blood of Jesus (Heb 12:24) represents the entirety of Christ's ministry in the heavenly sanctuary, from inauguration (Exod 29:20; Heb 1:3) to the application of the blood to the broken law on the Day of Atonement (Lev 16:14, 15, 19; Heb 12:24; cf. Heb 9:13). ${ }^{16}$ As a result, it is the meaning connected to Christ's liturgical actions in the heavenly sanctuary that is mediated to the conscience of the worshippers through liturgical preaching and teaching (Heb 12:24; cf. Heb 9:13-14; 10:22). It is this meaning that comes as a result of a cognitive encounter that leads to a spiritual union with the divine presence as the goal of the encounter. In Heb 12:23 the earthly worshippers who by faith approach unto the heavenly Jerusalem (Heb 12:22) are referred

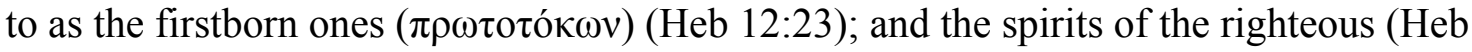
$12: 23)$

This emphasis on the spiritual nature of the worshipper who becomes born again by the agency of God's word shows that the goal of the encounter is manifested in a spiritual unity with God (the Judge of all), Jesus (the Mediator of the new covenant), the innumerable company of angels, and with fellow earthly worshippers; and that the basis for that unity is the Ten Commandments while the power to effect that unity is the blood of sprinkling that speaks better things than that of Abel (Heb 12:22-25).

The word of God (Heb 12:24, 25) is thus the universal method for achieving a cognitive and spiritual encounter that is manifested in obedience of faith to God's law written in the heart (Heb 8:11). In order for this goal to be reached by earthly worshipers

\footnotetext{
${ }^{16}$ For Heb 12:24 as Day of Atonement as well as inauguration, see this dissertation, page 346 . For limiting Heb 9:13, 23-25, and 12:24 to the inauguration, see this dissertation, pages 368-373.
} 
who assemble in various earthly locations for worship, they must cooperate with Christ's ministry in the heavenly sanctuary by appropriating Christ's ministry to their consciences (Heb 9:13-14; 10:22; Heb 12:22-25).

\section{Abandoning the Sanctuary: Implications for the Encounter}

When Jeroboam abandoned the sanctuary as the place of liturgy (1 Kings 12:2829; cf. Exod 31:1-11; Exod 32), it affected the encounter in the following ways. First, God's Being was conflated with nature through the imagery of the golden calves (1 Kings 12:28; Exod 32:1-4). As a result, God's revelation through speech is no longer the predominant liturgical action. In Aaron's day and in Jeroboam's day music that was predominantly rhythmic (Exod 32:17) and art (Exod 32:4; 1 Kings 12:28) became the vehicles of God's revelation. In the Sacramental Model, the Eucharist could also be viewed as a bearer of divine revelation.

Second, the ritual services of the OT are no longer viewed as forms of ritualized speech that point forward to Christ as Mediator and liturgist in the heavenly sanctuary (Heb 12:24; cf. 8:1-2), instead the entire Hebrew cult is interpreted sacramentally. This sets the stage for a sacramental interpretation of the following NT liturgical actions: the preaching of the Word (Acts 2; 13:13-52; 17:1-4; 18:1-8), baptism (Rom 6:4; Col 2:12), the Lord's Supper (Matt 26:26-29; Mark 14:22-25; 1 Cor 11:23-26), anointing the sick with oil (James 5:13-16), foot washing (John 13:1-20), and the laying on of hands in ordination (Acts 13:3; 1 Tim 4:14; 5:22; 2 Tim 1:6). The end result of removing the sanctuary as the hermeneutical ground is that the encounter becomes a non-cognitive power encounter. All of the aforementioned liturgical actions in the NT would merely 
constitute the material conveyors of this non-cognitive power encounter.

\section{Response to the Encounter}

In order to evaluate the responses to the encounter we will briefly outline how the heavenly sanctuary grounds the relationship between the divine presence and the response, the interpretation of human nature and varied responses, the relationship between speech as the central liturgical action and the response, and the relationship between a cognitive/spiritual encounter and the response. Moreover, we will note that the responses in the heavenly sanctuary ground and provide the pattern for responses in earthly liturgy. Lastly, we will consider the consequences of abandoning the sanctuary as the place of liturgy on the response to the encounter.

\section{Sanctuary Grounds Relationship between Divine Presence and Response}

The first step in examining the response to the encounter is the Biblical Sanctuary Model's view of God as infinitely temporal. This interpretation of the divine presence constitutes the first major macro-hermeneutical presupposition that lays the groundwork for evaluating the responses that I will outline in this section.

\section{Sanctuary Grounds Relationship between Human Nature and Varied Responses}

The second step in examining the response to the encounter arises from the Biblical Sanctuary Model's view of human nature, which constitutes the second major macro-hermeneutical presupposition that is involved in the response to the encounter. Since God's infinite temporality along with the heavenly sanctuary integrates heaven and 
earth, one result is the elimination of the kinds of ontological dichotomies that arise from Greek philosophy that riddled the Models of Chapter 4 of this dissertation.

Moreover, integrating heaven and earth lays the groundwork for interpreting human nature as the integration of the physical, mental, spiritual, and social aspects, which is corroborated by Gen 1:27;2:7. This integration of the components of human nature not only eliminates the body/soul dualism of the other models, it lays the ground work for the varied but unified responses that are then grounded in the physical, mental, spiritual, and social natures of the worshippers. For instance, some brief examples of varied responses that are grounded in the Biblical Sanctuary Model's view of human nature include verbal (Acts 2:37), affective (Acts 2:41; Heb 12:28, 29), kinesthetic (Rev $4: 10 ; 5: 8,14)$ mental, and social (Acts 2:42). These responses lead to various forms of service (Heb 12:28, 29).

Moreover, since worshippers posses hermeneutical minds that are capable of choosing how they respond, or whether they will respond at all, the responses to the encounter in the Biblical Sanctuary Model are all active.

\section{Sanctuary Grounds Relationship between Speech and the Response}

God's infinite analogous temporal Being that is inherent in the Biblical Sanctuary Model's view of the divine presence can only be revealed through a form of ritualized speech via the OT sacrificial services, or through verbal communication spoken by either divine, angelic, or human liturgists. Furthermore, the attributes of God, the great controversy that surrounds the throne in all its varied complexity in salvation history, and the manifold aspects of all created realities can be best revealed and understood through 
speech. Hence, speech provides the bridge to describing and understanding all realities. It is this bridge between all realities and speech that lays the groundwork for the causal connection between speech and specific responses to the encounter.

The varied responses in this Model corresponding to the physical, mental, spiritual, and social natures of the worshippers constitute broad categories that include specific responses that are causally connected to speech as the central liturgical action. For instance, some examples include God admonishing Moses to remove his sandals (Exod 3:5); Moses was exceedingly afraid and trembling after God spoke His Law (Heb $12: 21)$; the Israelites bowed their faces to the ground and praised the Lord after fire came down to consume the sacrifice (2 Chr 7:3); NT believers were baptized (Acts 2:41) after Peter's Day of Pentecost sermon, and they pooled their resources together in order to help those in need of assistance who became Christians (Acts 2:44-45). ${ }^{17}$

\section{Sanctuary Grounds Relationship between Encounter and Response}

The cognitive nature of speech as the central liturgical action leads directly to a spiritual encounter. As a result, we should view the varied responses that have been previously covered in this section on the response to the encounter that are grounded in the harmonious interpretation of the physical, mental, spiritual, and social aspects of worshippers as spiritual responses. These varied spiritual responses are causally related to the God's infinite analogous temporal Being that then interprets all of the liturgical components that precede the response to the encounter.

\footnotetext{
${ }^{17}$ For other specific examples of worshippers whose response to the encounter was causally related to speech as the central liturgical action, see this dissertation, 290-295, 392398.
} 


\section{Heavenly Sanctuary as a Model for \\ Earthly Responses to the \\ Encounter}

The heavenly sanctuary grounds the relationship between the responses to the encounter in heaven and the responses that earthly worshippers should seek to emulate here on earth. The following heavenly responses are grounded in the causal connection between the divine presence, including divine liturgical actions, and the varied responses of the angelic host: they fall down and worship the One seated on the throne (Rev 4:10) and they fall down before the Lamb (Rev 5:8); they cast their crowns before the throne (Rev 4:10); they verbally respond with words of praise (Rev 4:11; 5:14); and they respond with singing that is accompanied by harps (Rev 5:8-13). The heavenly music consists of a strong melodic line that John clearly hears (Rev 5:11) being sung by the angelic throng. These responses constitute a universal model that earthly worshippers should copy as they respond to liturgy conducted on earth.

\section{Abandoning the Sanctuary: Implications for the Response}

We have already covered the implications for setting aside the sanctuary as the hermeneutical ground for interpreting all the previous liturgical components ranging from the divine presence to the encounter. Each of those liturgical components constitutes the hermeneutical presuppositions for interpreting the response to the encounter. When Jeroboam abandoned the sanctuary as the place of God's revealed presence, it directly led to a non-cognitive encounter through music and art (1 Kings 12:28; cf. Exod 32:1-4, 1718). This leads to the deduction that there is no causal relationship between a noncognitive encounter and the response to the encounter. The worship of the golden calf in 
Aaron's day was expressed by responses that were entirely kinesthetic and affective, and included eating, drinking, sensual gratification (Exod 32:6), music that Joshua described as the noise of war characterized by a predominance of rhythms (Exod 32:17), and dancing (Exod 32:19).

The neglect of the Charismatic Model to employ the heavenly sanctuary as the hermeneutical ground from which to interpret the response to the encounter has also assumed that there is no causal connection between a non-cognitive encounter and the response to the encounter. Consequently, the predominantly affective and kinesthetic responses of the worshippers in the Charismatic Model are similar to the worshippers at Aaron's golden calf. ${ }^{18}$

\section{Biblical Search for Unity}

In our quest for discovering the biblical search for unity, God's infinite analogous temporal Being and the heavenly sanctuary that grounds the relationship between all of the liturgical components constitute the two indispensible macro hermeneutical principles in the Biblical Sanctuary Model. We will now explore the ways in which each of the various aspects that are integrally connected with the five major liturgical components converge around the proclamation of God's Word as the principal liturgical action and the condition for the biblical search for unity in the Biblical Sanctuary Model.

We will also assess the implications of abandoning the sanctuary as the place of liturgy for the biblical search for unity by examining whether neglecting the hermeneutical role of the sanctuary has led to a unified view of each liturgical component

\footnotetext{
${ }^{18}$ For many specific examples of affective and kinesthetic responses in the Charismatic Model, see this dissertation, 209-211.
} 
or whether it has produced conflicting views of the liturgical components.

\section{Sanctuary and Trinity: Unity in Originating and Revealing the Word}

Exod 3:14-15 grounds the temporal interpretation of God's Being, which is only revealed through God's words. Each member of the Trinity constitutes the divine presence, and each person is intimately involved in originating and revealing the Word in complimentary ways. The Father speaks (Heb 1:5-14); he originates the content in the heavenly scroll (Rev 5:1) in the sanctuary.

Also from the context of the heavenly sanctuary, the Son speaks through the liturgical actions he performs (Heb 12:24), he speaks messages to the seven churches (Rev 2:1, 8, 12, 18:3:1, 7, 14), and he opens and reveals the content of the scroll (Rev $5: 5-7 ; 6: 1)$.

The Spirit reveals the close connection between the sanctuary and the sacrificial and liturgical services conducted therein as a form of ritualized speech (Exod 31:1-11; 1 Chron 28:12-19) in the OT. The Holy Spirit was also involved in portraying to John the Revelator the scenes in the heavenly sanctuary that OT liturgy points to where Christ our high priest and liturgist (Heb 8:1-2) performs liturgical actions (Heb 9:6-8; cf. Heb 12:24; Rev 1:10-20; 4:1-2). Heb 9:6-8 and Rev 5:6 also point out that the Holy Spirit illuminates the minds of those seeking to understand heavenly liturgy to the inhabitants of earth (Rev 5:6; cf. 1 Cor 2:9-10). Thus, the Sanctuary provides the hermeneutical framework for the complimentary ways in which the Trinity is involved in the task of originating and revealing the Word as the only basis for achieving unity. 


\section{Sanctuary and Liturgists: Unity in Ministering the Word}

In the Biblical Sanctuary Model, the heavenly sanctuary grounds the relationship between the divine, angelic, and human liturgists that cooperate in order to minister the Word to worshippers. In addition to the divine liturgists, angels that are referred to as ministering spirits (Heb 1:14), minister God's words in liturgical contexts (Heb 2:2; Isa 6:6-7); and, as they cooperated in ministering the word at Sinai (Heb 2:2; cf. Heb 12:1821), they also cooperate with Christ in ministering the word from the heavenly Jerusalem (Heb 12:22, 24, 25) on the basis of the comparison between hearing God's word from earth (Heb 12:18-21) and hearing it from heaven (Heb 12:24-26).

Moreover, John the Revelator outlines additional evidence of the cooperation between divine, angelic, and human liturgists that minister the Word from the context of the heavenly sanctuary. In the messages to the seven churches, Christ originates each message from the location of the seven lampstands and delivers it to the angel of each church $(\operatorname{Rev} 2: 1,8,12,18 ; 3: 1,7,14)$. Christ's reference to the "angel of the church" suggests a cooperation between angels as ministering spirits, the earthly liturgist who delivers each message, and the Holy Spirit. ${ }^{19}$ When the earthly liturgist delivers Christ's message, an appeal is made to listen to what the Holy Spirit says to the churches (Rev

\footnotetext{
${ }^{19}$ Treiyer states,
}

The fact that what Jesus says to the seven churches is also said in the seven instances by the Spirit, is significant (Rev 2:7, 11, 17, 29; 3:6, 13, 20). And these messages are written to the seven angels or spirits who watch over the seven churches (Rev 2:1, 8, 12 , $18 ; 3: 1,7,14)$. Although to human eyes, this interaction between heaven and earth does not always appear in its right perspective, in the vision of John the veil is drawn back, and it is seen that the angels, the churches, the Son of Man and God Himself, maintaining an intimate communion, made possible through the Holy Spirit (Treiyer, The Day of Atonement and the Heavenly Judgment from the Pentateuch to Revelation, 502). 
$2: 7,11,17,29 ; 3: 6,13,22)$. Interpreters conclude that these messages to the churches not only applied to the churches in Asia Minor in John's day, they also apply to the history of the Christian church. ${ }^{20}$

This unity in ministering the Word by the divine, angelic, and, human liturgists is further illustrated by the connection between Rev 5:6 and Rev 14:6-13. In Rev 5:6 the Holy Spirit is sent out into the world to the reveal the content of the scroll. The thematic links between Rev 4-5 and Rev 14 link the content of the scroll of Rev 5 with the content of the Three Angels Messages of Rev 14:6-13. ${ }^{21}$ Similar to the messages of the seven churches, there exists a cooperation between the Holy Spirit (Rev 14:13), the angels in Rev 14:6, 8, 9, and the human beings who deliver these messages.

\section{Sanctuary and Sabbath: Unity of Place and Time in Ministering the Word}

With reference to the liturgical setting, the sanctuary constitutes the place where God places his name (1 Kings 8:29), meaning where he reveals his presence (2 Chron 20:8-9) through his words. The heavenly sanctuary functions as the place of liturgy (Heb $12: 22-24)$ where the Father and Son's real, visible, presence is located; and it constitutes the location from where Christ speaks through the liturgical actions he performs (Heb 12:24). The real, invisible omnipresence of the Holy Spirit is revealed where the preaching of the Word is connected with the work of Christ in the heavenly sanctuary (Acts 2:1-13, 14-40, especially v.33; Heb 5:11; 8:1; 9:5; Rev 5:6 with Rev 14:6-12, 13).

In addition to the heavenly sanctuary that connects heavenly and earthly worshipers to one place, the Sabbath also integrates and connects heavenly and earthly

\footnotetext{
${ }^{20}$ Ibid., 501.

${ }^{21}$ See Tables 1 and 2 for the links between Rev 4-5 and Rev 14.
} 
worshippers with a specific time for liturgy. For instance, the omnipresence of the Holy Spirit is the cause for why the Sabbath day is holy, ${ }^{22}$ which provides the justification to keep it holy (Exod 20:8). The invisibility of the Sabbath is also linked to God's Word as the only vehicle by which the Holy Spirit reveals himself to all worshippers.

\section{Sanctuary and Covenant: Unity in Cognitive/Spiritual Encounter with the Word}

Regarding the encounter, all of the components we have discussed thus far, plus the close connection between the sanctuary and the covenant (Exod 24:1-11; 34:10-34; Heb $8-9 ; 12: 24)$ are foundational for worshippers to experience a cognitive/spiritual encounter. The encounter thus occurs between God's words as the only vehicle capable of revealing his presence and the hermeneutical minds of the worshippers who receive them; and who are capable of misinterpreting and/or rejecting them. There is no ontic encounter with God's being within the being of the worshippers. This is clearly revealed by the new covenant promise where God states, "I will put My laws in their mind and write them on their hearts" (Heb 8:10; cf. Heb 10:16).

\section{Sanctuary and Worshippers: Ground for a Unified Response to the Word}

The varied responses by worshippers in the heavenly sanctuary ${ }^{23}$ dispel the notion that a unified response to Christ's liturgical actions must mean that there is only one way to respond. Moreover, these varied responses by worshippers in the heavenly sanctuary

\footnotetext{
${ }^{22}$ See this dissertation, 229, 232-234 for the links between Sabbath and the divine presence. 396-397.

${ }^{23}$ For examples of varied responses from heavenly worshippers, see this dissertation,
} 
provide the ground for unified response by worshippers on earth. Further evidence for a varied but unified response with respect to earthly worshippers is based on the sanctuary that grounds the relationship between (1) the divine presence and the response, (2) the integrated nature of humans that is made up of physical, mental, spiritual, and social aspects as the ground for the verbal, kinesthetic, and affective responses, and (3) a cognitive and spiritual encounter that is comprised of specific information conveyed through speech that leads to various responses. Hence, God's infinite analogous temporal Being and the heavenly sanctuary formulate the indispensible macro hermeneutical presuppositions for God's word as the only vehicle in bringing meaning and unity in the Biblical Sanctuary Model.

\section{Abandoning the Sanctuary: Implications for the Biblical Search for Unity}

In this section I will briefly outline how abandoning the sanctuary as the place of liturgy has led to divergent views of the divine presence and the rest of the liturgical components, which has resulted in confusion, and in conflicts among nations.

Pantheism and Conflicting Views of the Divine Presence

We have noted that the direct result of abandoning the sanctuary as the place of liturgy is that the divine presence is now synonymous with nature (1 Kgs 12:28; Exod 32:1-4). Jeroboam set up golden calves for worship in Dan and Bethel (1 Kgs 12:29) in addition to setting up houses of worship (bayit) in the high places. This resulted in 
dividing God's people between the idolatrous ${ }^{24}$ northern kingdom ${ }^{25}$ and the southern kingdom.

Confusing the divine presence with nature has often led to gods that are defined by national boundaries. ${ }^{26}$ Some of these gods are even further subdivided into small locations such as gods of hills and valleys (1 Kgs 20:23, 28). While the one common thread that pervades the gods of the nations is some form pantheism, scripture reveals that the nations who resettled in Samaria continued to make gods of their own $(2 \mathrm{Kgs}$ 17:29-31). Thus, each god was "produced" defined and restricted to each nation and possessed the attributes and characteristics that are intrinsic to that nation. This pantheistic yet nationalistic conception of divinity has led to much conflict among the nations who pride themselves on the fact that their gods are superior ( $2 \operatorname{Kgs~18:33-35).~}$ This pantheistic national conception of the deity is in contrast to the infinite temporal God of scripture whose presence not only fills heaven and earth (Jer 23:24), ${ }^{27}$ but also transcends heaven and earth (1 Kings 8:27). ${ }^{28}$ Hence, abandoning the sanctuary as the

\footnotetext{
${ }^{24}$ The gods of the nations are idols (1 Chr 16:26; Psalm 96:5).

${ }^{25}$ The northern prophets Amos and Hosea denounced the calf worship of Samaria that was instituted by Jeroboam, Amos 4:4; 5:5-6; 7:9; Hosea 8:4-6

${ }^{26}$ Some brief examples of the gods of the nations (Deut 29:18) are the gods of Egypt (Exod 12:12), gods of the Amorites (Josh 24:15), gods of Syria, gods of Sidon, gods of Moab, gods of the people of Ammon, gods of the Philistines (Judg 10:6; cf. 1 Kgs 11:33), god of Ekron (2 Kgs 1:2, 3, 6, 16); gods of Seir (2 Chr 25:14, 20 (Edom)), and gods of Damascus (2 Chr 28:23).

${ }^{27}$ God is also Possessor of heaven and earth (Gen 14:19, 22); He is Creator of heaven and earth (Exod 20:11; 2 Kgs 19:15; 2 Chr 2:12; Psalm 115:15; 121:2; 124:8; 134:3; 146:6; Isa 37:16; Acts 4:24; Rev 14:7). He is Lord of heaven and earth (Matt 11:25; Luke 10:21; Acts 17:24). And He is the God of heaven, see Gen 24:3, 7; 2 Chr 36:23; Ezra 1:2; 5:11, 12; $6: 9,10 ; 7: 12,21,23(2 x)$, Neh 1:4, 5; 2:4, 20; Psalm 136:26; Dan 2:18, 19, 37, 44; Jonah 1:9; Rev 11:13; 16:11.

${ }^{28}$ For evidence of the divine presence transcending heaven and earth within the framework of God's infinite analogous temporal Being, see this dissertation, 239-242, 245 248.
} 
place of liturgy leads to a pantheistic conception of the divine presence that results in national deities that war against each other.

\section{Pantheism and Conflicting Views of the} Liturgist's Ministry

The following evidences point to the universal scope of the liturgists' work in the Biblical Sanctuary Model. Liturgists are appointed by the God of heaven and earth to serve all humanity. ${ }^{29}$ Moreover, he acknowledges them as his ministers, ${ }^{30}$ they minister to him, ${ }^{31}$ he pays them for their service (Num 18:21), they mediate his holy infinite analogous temporal Being by living holy lives, ${ }^{32}$ and they teach his laws and commandments $^{33}$ that apply to all humans. ${ }^{34}$

The following characteristics illustrate the disunity that results from abandoning the sanctuary as the place of liturgy for the liturgist. The ministry of these liturgists is not

${ }^{29}$ The work of the liturgist extends beyond Israel. This is seen in the references to the stranger who chooses to sojourn among the Israelites to keep the Passover (Exod 12:48), the Day of Atonement (Lev 16:29), the Feast of Weeks (Deut 16:11), the Feast of Tabernacles (Deut 16:14), and the Sabbath (Exod 20:10). Moreover, the use of the word $\lambda \varepsilon 1 \tau o v \rho \gamma$ ó $\varsigma$ by Paul in the NT carries on the priestly function used to describe the work of the liturgist in ministering the gospel to the Gentiles (Rom 15:16), see this dissertation, 343-344.

${ }^{30}$ Melchizedek is priest of the Most High God (Gen 24:18; Heb 7:1); they are called priests of the Lord (1 Sam 22:17,21); God refers to them as my ministers (Jer 33:21)

${ }^{31}$ Aaron and his sons, they "minister to Me as priest" (Exod 28:1, 3, 4, 41; 29:1, 44; 30:30; 40:13, 15; cf. Eze 44:13, 15).

${ }^{32}$ Holiness involves physical aspects (Lev 21:5, 16-21), marriage (Lev 21:7, 13-15; Eze 44:22), teaching the difference between holy and unholy, clean and unclean (Lev 10:10), not drinking wine or intoxicating drink (Lev 10:9; Isa 28:7; Eze 44:21), not eating unclean foods (Lev 11:1-20), not touching carcasses (Lev 11:24-46), not defiling themselves with the dead (Lev 21:1-4, 10-12).

${ }^{33}$ Lev 10:11; Deut 33:10; Eze 44:23; 2 Chr 15:3; 17:8-9; 31:4; Neh 8:2, 9, 13.

${ }^{34}$ There is one law for the Israelite and the stranger with reference to observing the Passover (Exod 12:49), the Sabbath (Exod 23:12), eating blood (Lev 17:8-12), and observing prohibitions against all forms of sexual immorality (Lev 18:26). All just laws also apply to the stranger (Num 35:15; Deut 24:17) who was to be taken care of by the tithe of the increase of the third year (Deut 26:12,13). 
universal; rather it is limited to the individuals and nations that employ them. Liturgists are not appointed by God but by individuals or kings ${ }^{35}$ that represent personal or national interests ${ }^{36}$ whose conceptions of the deity were inspired by demonic spirits; ${ }^{37}$ and that fight with God's people (2 Chr 13:8-18) and change employers for greater opportunity ${ }^{38}$ or alter their message $\mathrm{e}^{39}$ for more financial gain (Micah 3:11). These liturgists do not minister on God's behalf but on behalf of the high places (1 Kgs 13:33), king Jeroboam (2 Chr 11:15; cf. Ahab 2 Kgs 10:11), and Baal (2 Kgs 10:19; 11:18).

After the Assyrians conquered Samaria, they brought in people from Babylon, Cuthah, Ava, Hamath, and Sepharvaim (2 Kgs 17:24) who then made their own gods (2 Kgs 17:29-31) and appointed for themselves priests of the high places from all classes of people (2 Kgs 17:32). There is a direct link between national gods and priests who will mediate the national understanding of these gods to their own people. What the author of Judges rightly concludes about everyone doing what is right in their own eyes when

\footnotetext{
${ }^{35}$ For instance, Micah of Ephraim consecrated the young Levite as his priest (Judg 17:12). Jeroboam made and installed priests from all classes of people (1 Kgs 12:31, 32; $13: 33)$.

${ }^{36}$ Micah's son became his priest (Judg 17:5); Jeroboam appointed for himself priests
} for the high places (2 Chr 11:15); there was Poti-Phera, priest of On (Gen 41:45, 50), priests of Dagon (1 Sam 5:5), priests of the high places (1 Kgs 12:32;13:2, 33; 2 Kgs 17:32), priests of Ahab (2 Kgs 10:11), and priests of Samaria and Beth Aven (Hos 10:5).

${ }^{37}$ The passage in 2 Chr 11:15 (cf. Lev 17:7; 1 Cor 10:20) reveals that Jeroboam appointed for himself priests for the high places, for the demons and for the calf idols. Thus demons would also be connected with the priests of the high places (1 Kgs 12:32; 13:2, 33;

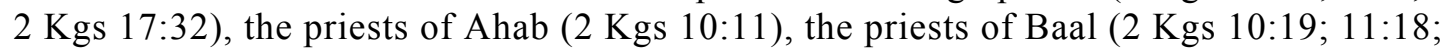
Zeph 1:4), and of Samaria and Beth Aven (Hos 10:5). The Gentiles sacrifice to demons (1 Cor 10:20).

${ }^{38}$ The young Levite who used to be paid by and sustained by Micah left to join the Danites, and when Micah found out he wanted to take the young Levite back by force but saw that he could not prevail against the Danites (Judg 17:10;18:4, 19-20). The young Levite thought it better to work for an entire tribe rather than one individual.

\footnotetext{
${ }^{39}$ The passage in $2 \mathrm{Kgs}$ 17:24-31 reveals that each liturgist taught the rituals that were connected with each of the local deities.
} 
Micah's son mediated the personal and pantheistic concepts of the household idols of Micah's shrine (Judg 17:5) equally applies to the priests who settled back into Samaria after the Assyrian conquest.

Pantheism and Altars that Mediate Conflicting Content

In the Biblical Sanctuary Model the altar of the Lord ${ }^{40}$ could not be removed from its location in the sanctuary. ${ }^{41}$ This is because the divine presence would only be revealed in the chosen place, which is where the Lord directed the animals that were sacrificed on the altar (Deut 12:5-6). The altar of the Lord thus mediates God's infinite analogous temporal Being and the sanctuary's view of the plan of salvation that is linked with the sacrificial service. The altars that Jeroboam set up are referred to as Jeroboam's altar (1 Kgs 12:32, 33) and the altar in Bethel (1 Kgs 13:4, 32; 2 Kgs 23:17; Amos 3:4). These altars mediate the pantheistic conception of the deity that in turn mediates a counterfeit view of salvation (1 Kgs 12:32-33.

God commanded Israel to destroy the altars of the gods of the nations (Deut 7:1;

Judg 2:2; $2 \mathrm{Chr} 31: 1)$ that were located on the high mountains, on the hills and under every green tree (Deut 12:2-3). The rejection of the sanctuary as the place of liturgy resulted in an increase of altars (Hos 10:1) that were located in many places (Deut 12:2-3; 2 Chr 28:24; Eze 6:13). Hosea noted that the result of the proliferation of all these altars

\footnotetext{
${ }^{40}$ References to the altar of the Lord include Lev 17:6; Deut 12:27; 26:4; Josh 22:29; $1 \mathrm{Kgs} 8: 22,54$.

${ }^{41} \mathrm{~A}$ civil war almost began when the children of Israel learned that the tribes of Reuben, Gad, and Manasseh built an altar near Jordan. However, it was not an altar of sacrifice but an altar of witness that would ensure to future generations that the tribes of Reuben, Gad, and Manasseh were indeed worshippers of the God of Israel (Josh 22:10-34).
} 
was a divided heart in which they feared the Lord and served their local gods (Hos 10:1; cf. 2 Kgs 17:32, 33, 41).

In Solomon's temple God's infinite analogous temporal Being could communicate specific messages by means of the sacrificial services of the sanctuary that constitute a form of ritualized speech conducted by the priests. In bypassing the altar of the Lord (1 Kgs 8:22, 54), and building rival altars in Dan and Bethel, Jeroboam linked those altars with the pantheistic view of God that they mediated. This is idolatry, and according to scripture idols don't speak. ${ }^{42}$ Consequently the content communicated by Jeroboam's altars did not arise from scripture but from the surrounding nations. ${ }^{43}$ Each nation was then left free to devise their own view of the sacrifices on the altar that mediated their own gods. The passage in $2 \mathrm{Kgs}$ 17:29-33 reveals that the content concerning the rituals involved in sacrificing on altars arose from each nation $(2 \mathrm{Kgs}$ 17:29-33). Thus a pantheistic view of the divine presence produces different gods that are mediated by altars in all locations. When Israel worshipped at altars in many different locations the result was Baal worship (1 Kgs 16:32; 18:26; 2 Kgs 21:3; Judg 6:25, 28, 30; $2 \mathrm{Chr} 33: 3 ; 34: 4)$ and the worship of foreign gods (2 $\mathrm{Chr} 14: 3 ; 28: 24)$.

Pantheism and No Divine Revelation in Encounter and Lack of Unity in Response

Since the divine presence is linked with all of nature via the symbol of the golden calves, this also links the divine presence with music. Since idols do not speak, each

\footnotetext{
${ }^{42}$ On the inability for idols to speak, see this dissertation, 285-286, 291-292.

${ }^{43}$ When Jeroboam received counsel to make calves of gold (1 Kgs 12:28), it was the surrounding nations that produced this content that conflated the divine presence with creation. Thus, Jeroboam's altar mediates content that arises from the other nations, not scripture (Deut 4:12-15).
} 
person and nation is left free to interpret the encounter in accordance with their own personal and national conceptions. This creates a dichotomy between the encounter and the way in which worshippers respond to the encounter. The end result is a worship response that is out of control, shameful (Exod 32:25 NIV), and anything but unified. ${ }^{44}$ This has the potential to ground responses in individuals, larger groups, and nations. I will now give a description of each model as a unit.

\section{Description of the Models}

Just before I begin to compare and analyze the Biblical Sanctuary Model with the Sacramental, Kerygmatic, and Charismatic Models, I will briefly describe each model as a unit. The description will include each model's interpretation of Being, as well as the main subcomponents that are associated with the divine presence, liturgist, liturgical setting and actions, encounter, response to the encounter, and the search for unity. I will begin with the Sacramental Model.

\section{Sacramental Model}

The divine presence in the Sacramental Model is inextricably linked with the Eucharist, which is comprised of the following four elements: (1) fermented wine, (2) unleavened or leavened bread, (3) the words "This is my body" spoken by the presider, and (4) Christ's human and divine natures that replace the substance of the bread and wine after the prayer of consecration. The Sacramental Model champions the transubstantiation hypothesis that stems from timeless Being as the major macro hermeneutical principle that interprets the divine presence as completely static and

\footnotetext{
${ }^{44}$ For examples see this dissertation, 292.
} 
timeless prior to Vatican II and timeless and temporal after Vatican II.

Timeless Being hermeneutically orders the Sacramental Model's view of the liturgist in the following ways. Christ is the efficient cause of liturgy and the liturgist is the instrumental cause. The timeless soul that is permanently marked at ordination qualifies the liturgist to mediate sacred tradition, and is at the same time the cause of the ontological distinction between liturgists and laity. Moreover, the timeless soul grounds episcopal ordination, apostolic succession, and infallibility so that liturgical authority resides in the church through Peter and his successors.

Transubstantiation is the macro hermeneutical presupposition that determines the following liturgical setting and actions (1) the central location of the altar as well as the prayer of consecration as the central liturgical event that predominantly occurs in the basilica, (2) the celebration of the Eucharist on Sunday, which is the soul of the other days and the image of eternity, (3) the whispered prayer of the presider who served with his back to the people, the content of the prayers that include intercessions for the dead and the refreshment of souls that assume the timeless soul, the elevation of the host and chalice, the worship and adoration of the host, the disinclination to receive the chalice for fear of spilling the divine presence, Gregorian chant, and Latin as the official liturgical language. Dynamic timeless Being hermeneutically guides (1) the permission to use the mother tongue that was based on a formal translation of the Latin text, and (2) liturgical inculturation that includes the indigenous music, art, dance, and architecture of all cultures, and the proliferation of all kinds of different masses.

With respect to the encounter, the timeless view of the divine presence and human nature results in a timeless cognitive encounter in which the divine presence and grace is 
mediated to the soul through visual, auditory, and gustatory means that function as the historical and material conveyors of the divine presence.

Since Christ is the efficient cause of liturgy, all responses in this model are passive, even those that appear to be active like the contemplation of God, moral virtues, and music.

The ecumenical search for unity in the Sacramental Model prior to Vatican II is based on the definition of unity as uniformity derived from Plato's two worlds theory. As a result, the Roman rite, the Tridentine rite, the use of Latin, and Gregorian chant represent the near perfect duplication of the eternal and timeless Forms that remained unchanged for centuries. The post Vatican II view of unity is unity in essentials and diversity/pluralism in non-essentials that derives from the ontological dichotomy between the timeless and temporal realms. The essentials constitute transubstantiation as the basis for defining the real presence in the Eucharist and for the celebration of it, the role of Tradition in interpreting Scripture, and the infallible teaching authority of the Pope and magisterium. The nonessentials consist of music, architecture, art, and the mode of baptism.

\section{Kerygmatic Model}

The divine presence in the Kerygmatic Model refers to Christ who is inextricably linked with preaching the Scriptures, the Incarnation, and the Word within the sacrament. Although the Kerygmatic Model professes to adhere to the Sola Scriptura principle, the uncritical assumption of the transubstantiation hypothesis reveals that timeless Being is still the macro hermeneutical presupposition.

The choice and qualifications of the liturgist is based on the priesthood of all 
believers. However, the Lord chooses only certain men who are set aside and ordained by the entire church, and whose primary task is preaching the Word and administering the sacraments. The authority of the liturgist does not depend upon episcopal ordination in the historic apostolic succession. In spite of the discovery of the priesthood of all believers, God and not the liturgist is the efficient cause of liturgy, and of the liturgist's authority.

The rediscovery of the Scriptures led directly to the centrality of the pulpit, the huge size of the pulpit, galleries for the purpose of hearing the Word preached, and the simplicity of Kerygmatic meetinghouses. Preaching justification by faith is the central ritual action of the Kerygmatic Model. However, the adoption of timeless Being has led to the deduction that observing the Seventh-day Sabbath, the sacraments, and medieval rites are nonessential; but Sunday observance should nevertheless be maintained.

In the encounter it is the timeless soul, which includes reason, that ultimately receives and processes the messages that are preached. This can only occur if the soul's capabilities are ontologically enhanced. Since the divine presence and action are timeless, the cognitive content of preaching is stripped of anything historical or material.

In the response the encounter worshippers understand the preached Word, contemplate the divine presence, give praise to God, exercise their will by making decisions based on the sermon, overthrow error, and preserve ecclesiastical institutions. However, Christ is the efficient cause of justification, grace, and the faith that worshippers' exercise in response to preaching. This means the response of the worshippers constitutes the instrumental cause, and is thus a passive response.

With respect to the ecumenical search for unity, the Kerygmatic Model's adoption 
of the transubstantiation hypothesis has led to disunity over (1) justification by faith as God's work alone or whether humans play a cooperative role, (2) the Lord's Supper as the real presence or as memorial, and (3) adult versus infant baptism. The uncritical assumption of timeless Being has also led to the definition of unity as unity in essentials and diversity/pluralism in nonessentials. As a result, the Sabbath, the sacraments, art, and architecture are nonessential issues. Moreover, the influence of the Liturgical and Ecumenical movements has led to supplementing preaching with the Eucharist. This calls into question the ability of preaching to achieve unity in this model.

\section{Charismatic Model}

The divine presence in the Charismatic Model refers to the Holy Spirit who is inextricably linked to music. However, the Emerging and Emergent streams of the Charismatic Model also link the divine presence with the sacramental rituals of the early church. Moreover, while the Pentecostal, Charismatic, and Emerging streams of this model adhere to the static timeless view of the divine presence, the Emergent stream assumes the panentheistic view of the divine presence. Nevertheless, all streams within this model refer to music as the real presence, sacramental, the sacramentalization of music, and musical transubstantiation.

The Charismatic Model employs the priesthood of all believers as the lens through which it understands the liturgist. This model refers to its liturgists as worship leaders instead of priests and pastors. Among its Emerging and Emergent streams, the current aim of this model is to overcome the sacred secular split by making all of life holy. The results of this panentheistic view of human nature on the liturgist is that everyone who has the Spirit's gifts and passion for ministry, irrespective of gender and 
sexual orientation is qualified to be a liturgist. Liturgical authority is thus grounded in the Spirit.

With respect to the liturgical setting, timeless Being hermeneutically shapes two principles in this model that pertain to architecture. The first is that the inside of a church building is essential while the outside is of little importance, and the second is the blending of transcendence and immanence that fuses the style of the ancient cathedral with immanent liturgical symbols such as the Eucharistic table, the pulpit, and the baptismal font.

As far as liturgical time is concerned, Sunday is a time-honored custom. Yet, among Emergents Sunday is honored on account of its close connection to the Eucharist. Also, Sunday provides meaning and authenticity among worshippers today because it is linked with God's presence and with the components of liturgy.

With respect to the Eucharist, the assumption of timeless Being is the cause for bringing the Eucharist into prominence in this model and for viewing it as the real presence rather than a memorial as it once did. Moreover, timeless Being leads to the sacramental and functional view of preaching that strips away from Scripture any cognitive content.

Pentecostal and Charismatic music mediates the Holy Spirit resulting in a dichotomy between the divine presence and music. The panentheistic framework of Emergent music blends the changeable rhythms of Pentecostal and Charismatic music with what is considered the unchangeable chants, Taizé music, organ, and hymns. Also, the sounds of music in the panentheistic framework correspond to the changeable aspects of the divine presence whereas the mathematical basis of music corresponds to the 
unchangeable aspects of the divine presence.

In the encounter, worshippers directly experience the Holy Spirit through music. For Pentecostals and Charismatics who uphold the split between the sacred and the secular, the encounter is a non-cognitive affective power encounter with the Holy Spirit. For Emergents who assume a panentheistic framework, the mathematics of music provides the basis for a cognitive encounter while the sonorous aspects of music communicate a non-cognitive affective encounter. The Pentecostal and Charismatic renewal primarily aimed at the soul as the place for the encounter while only hinting at the body whereas the Emergent stream of this model places due emphasis on mind, body, heart, and soul as the place where the encounter occurs.

The response to the encounter for Pentecostals and Charismatics consists of a plurality of kinesthetic and affective responses, all of which assume a non-cognitive encounter. In this context, speaking in tongues is the ideal non-cognitive response. For Emergents, the mathematical portion of music provides the basis for a contemplative response that leads to the possibility of moral development in which the soul is scaled to the Pythagorean ratios that tune the heavenly bodies. The sonorous aspects of music merely provide cultural and sociological value.

In the ecumenical search for unity, the Charismatic Model adheres to the definition of unity as unity in essentials and diversity/pluralism in non-essentials. The predominantly non-cognitive encounter in this model directly results in a plurality of doctrinal beliefs, musical styles, and responses to the encounter. The assumption of timeless Being has also led to viewing the Lord's Supper as the real presence instead of a memorial; and it has also led to its more frequent celebration alongside music. These 
developments call into question music's ability to achieve unity in this model.

\section{Biblical Sanctuary Model}

There are two macro hermeneutical principles that play a grounding role in the Biblical Sanctuary Model. First, God's name in Exod 3:14-15 grounds the temporal interpretation of God's Being. As a result, all of the OT and NT passages under consideration in this dissertation also assume God's infinite analogous temporal Being. ${ }^{45}$ Second, God's infinite analogous temporal Being allows the heavenly sanctuary to function as the major macro hermeneutical principle that systematizes and interprets the relationship between the divine presence and the rest of the liturgical components.

With respect to the divine presence, the Biblical Sanctuary Model connects each member of the Trinity to the I AM of Exod 3:14-15. ${ }^{46}$ In liturgy, God is present (Exod 3:2-3; 19:16-18), yet his presence is only revealed by his words (Exod 3:3-6; Deut 5:2332) and not by material representations (Deut 4:12, 15). Moreover, God reveals his name/presence in the sanctuary (Deut 12:5, 11; $1 \mathrm{Kgs} 8: 29 ; 2 \mathrm{Chr} 20: 8-9$ ) as the starting point for showing that (1) the Godhead is omnipresent in transcendence (1 Kings 8:27), and (2) in immanence Father and Son have a localized personal presence in the heavenly

${ }^{45}$ Old Testament passages include Exod 3:14-15; Lev 19:30 and 26:1-2; Exod 19-20 and Deut 4-5; $1 \mathrm{Kgs} 8: 12-66$ and $2 \mathrm{Chr} 5-7$; and Isa 6:1-13. New Testament passages include Acts 2:1-47; Heb 12:18-29; and Rev 4-5.

${ }^{46}$ The Father is connected to the I AM by Kúpıs (Acts 2:34) and by his connection

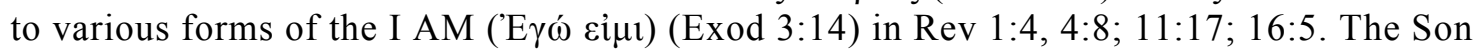
is connected to the I AM by Kúpros (Acts 2:34; Heb 1:10; 7:14; 8:2; 13:15), and by

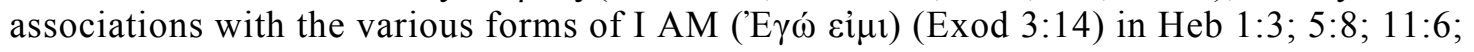
Cf. 13:8; Rev 1:8 and 22:13; John 8:24, 28, 58; 13:19. The Holy Spirit is connected to the I AM by Kúpios in 2 Cor 3:17, and by noting that Lord/ Kúpıৎ in the LXX of Isa 6:8-10 and Psalm 95:7-11 is the Holy Spirit in Acts 28:25-27 and Heb 3:7-11. Moreover, Lord/ Kúpios in Zech 4:10 is the seven Spirits in Rev 5:6, and Lord/ Kúpios in the hearing formula of Ezek 3:27 is the Spirit who speaks each of the messages to the churches in Rev 2:7, 11, 17, $29 ; 3: 6,13,22$. The Holy Spirit is also associated with the God's name (Exod 3:15) in the baptismal formula (Matt 28:19). 
sanctuary while the Holy Spirit is personally omnipresent (Acts 2:33; Rev 5:1, 6). The heavenly sanctuary thus systematizes and interprets all of the issues that are linked with the divine presence in liturgy such as transcendence, immanence, presence, omnipresence, holiness, eternity, immutability, and the Incarnation.

With respect to the liturgist, there are divine liturgists that speak $;^{47}$ there are angelic ministering spirits (Heb 1:7, 14) that cooperate with divine liturgists in heaven (Rev 5:8-9) and on earth (Heb 2:2); and there are human liturgists who speak. God's infinite analogous temporal Being and the heavenly sanctuary ground the various ways in which the divine, angelic, and human liturgists cooperate with each other in liturgy. Liturgical authority is grounded in (1) the words and actions of Christ in the heavenly sanctuary (Heb 12:24, Rev 2-3, 4-5), (2) in the scroll that is in the Father's hand (Rev $5: 1$ ), and (3) in the central heavenly throne that all liturgists are subject to. ${ }^{48}$ All the components of the human liturgist are integrated and are essential in mediating the divine presence (Gen 1:26, 27; 2:7). Furthermore, human beings constitute the efficient cause of liturgy while the divine and angelic liturgists are the indispensible conditions of liturgy.

The heavenly sanctuary constitutes the definitive liturgical setting that worshippers ultimately approach unto (2 Chron 30:27; Isa 6:1-8; Acts 2:33; Heb 12:2224; Rev 5:6) regardless of where they are located on earth. The Sabbath constitutes the

\footnotetext{
${ }^{47}$ The Father speaks (Heb 1:5-14), and he originates the content of the scroll in his right hand (Rev 5:1). The Son speaks (Heb 1:2; 2:3, 12-13), he originates the messages to the churches (Rev $2: 1,8,12,18 ; 3: 1,7,14)$, and he speaks through the liturgical actions he performs in the heavenly sanctuary (Heb 12:24; Rev 5:6, 9, 12; cf. Heb 4:2) that were prefigured by the ministry of the priests in the OT. The Holy Spirit speaks through Scripture (Heb 3:7-11; 10:15-17), through the messages that are delivered by the human angel/messenger to each of the churches (Rev 2:7, 11, 17, 29; 3:6, 13, 22), through the Three Angels Messages (Rev 14:6-12,13) spoken by human liturgists, and through Christ's liturgical actions that he reveals to human liturgists (Heb 9:6-8; Rev 5:6; cf. 1 Cor 2:9-10).

${ }^{48}$ The throne is mentioned 19 times in Rev 4-5.
} 
time in which liturgy occurs (Exod 20:8-11; Heb 4:9), and which often took place in synagogues (Luke 4:16-30; Acts 13:13-52; Acts 17:1-4; 18:1-8). The central liturgical action constitutes two forms of speech expressed by (1) the ritual actions of priests in the OT (2 Chr 7:1, 12; 29:27) that prefigured the ritual actions of Christ as high priest in the heavenly sanctuary (Heb 12:24; cf Heb 4:2; Rev 5:1-14), and (2) public proclamation (Luke 4:16-30; Acts 2:1-40; 13:13-52; 17:1-4; 18:1-8; Heb 2:5; 5:11; 6:9; 8:1; 11:32; 13:6; $\operatorname{Rev}(2: 1,7,8,11,12,17,18,29 ; 3: 1,6,7,13,14,22 ; \operatorname{Rev} 5: 6$ and Rev 14:6-12, 13).

The heavenly sanctuary along with the covenant grounds the encounter in two main ways. First, since worshippers in heaven (Rev 5:1-14) and earth (Rev 14:6-12, 13) receive God's words in their hearts and minds (Heb 8:10) and not his being, the principles of this cognitive and spiritual encounter are universal. The purpose of instrumental music ( $\operatorname{Rev} 5: 8$ ) is to provide an affective encounter that compliments the revelation of God's will through the words that are sung; music does not convey the divine presence.

Responses to the encounter in this model consist of verbal (Exod 3:4; 20:19; Deut 5:23, 25, 27; Acts 2:37), affective (1 Chr 15:16; 2 Chr 29:30; 30:21; Acts 2:41; Heb 12:28, 29), kinesthetic (Exod 3:6; 2 Chr 7:3; Rev 4:10; 5:8, 14) mental, social (Acts 2:42), and various forms of service (Heb 12:28, 29). Responses to the encounter are grounded in the integrated natures of the worshippers (Gen 1:27; 2:7). Also, the cognitive and spiritual response of the worshippers in heaven serves as the universal model that grounds the nature of earthly responses.

In the biblical search for unity, all of the liturgical components are centered on the 
communication of God's word. For instance, the Trinity (Rev 5:1-6), the angels (Heb 2:2; Rev 4:8-11; 5:8-14), and human beings ( $\operatorname{Rev} 5$ and 14:6-12,13) are all harmoniously involved and interconnected with the ministry of God's Word; and liturgical authority is grounded in the central throne (Rev 5:1, 6; cf. 4:5) and ark of the covenant (Rev 11:19; cf. 4:2), and with the content of the heavenly scroll (Rev 5:1; cf. 6:1-17; 8:1). The heavenly sanctuary is the one place where the universe worships (Heb 12:24; Rev 7:9-13) and the Sabbath constitutes the one time in which the universe worships (Isa 66:22-23). Also, the encounter with God's word produces a cognitive and spiritual encounter, and the varied responses to the encounter are causally connected to the central ministry of God's word. We will now compare and analyze the models.

\section{Comparing and Analyzing the Models: Hermeneutical Role of Being}

As we compare and analyze the four models we will keep in mind Thomas Kuhn's insight on the relationship between paradigms and data, which we associated with Being (paradigms) and the liturgical components (data). In this section I will first compare and analyze the various ways in which Timeless Being in the Sacramental, Kerygmatic, and Charismatic Models creates diverging views of the divine presence, the other liturgical components, and the ecumenical search for unity. Then I will contrast those views with the way in which God's infinite analogous temporal Being interprets the divine presence, the other liturgical components and the biblical search for unity.

\section{Divine Presence}

As I compare and analyze the divine presence among all four models, I will keep in mind Thomas Kuhn's important discovery that data cannot exist apart from paradigms, 
and that paradigms necessarily interpret data. ${ }^{49} \mathrm{I}$ will first trace the large hermeneutical role of timeless Being on the irreconcilable views of divine presence in the Sacramental, Kerygmatic, and Charismatic Models. Then I will trace the large hermeneutical role of God's infinite analogous temporal Being on the divine presence in Biblical Sanctuary Model. After that I will compare the Biblical Sanctuary Model's view of the divine presence with the Sacramental, Kerygmatic, and Charismatic Models views.

\section{Sacramental, Kerygmatic, and Charismatic Models}

Transubstantiation's Dominant Role in Interpreting the Divine Presence

The Sacramental, Kerygmatic, and Charismatic Models operate under the paradigm stemming from a timeless interpretation of Being. However, of the three models, the Sacramental model is the only one that technically grounds the interpretation of the divine presence, not on the basis of Scripture, but on transubstantiation as understood through Aristotle's ontological concept of "form," which is the equivalent of Plato's concept of "Idea." 50

A large portion of the Kerygmatic model rejects transubstantiation as the mode in which Christ is made present; it also rejects the ability of the priest to make Christ present. However, in spite of that, neither the Kerygmatic model nor the Charismatic model challenges or develops an alternative interpretation of the divine presence in contradistinction to the Aristotelian interpretation of transubstantiation in the Sacramental model. The evidence for this is that all three models employ identical terminology to

\footnotetext{
${ }^{49}$ Kuhn, The Structure of Scientific Revolutions, 3rd ed. (Chicago: University of Chicago Press, 1966), 7, 68, 69, 76.

${ }^{50}$ See this dissertation, 104-105.
} 
describe the divine presence without providing contrasting analyses. For instance, all the models refer to the divine presence with the terms real presence and sacrament, while the Sacramental and Charismatic models add transubstantiation and musical transubstantiation. Thus, each of the three models assumes the dominant role of timeless Being via the Aristotelian interpretation of the divine presence that is championed by the Sacramental model. ${ }^{51}$

Conflicting Sacraments, Mediation, and the Divine Presence

I will now outline how Timeless Being produces conflicting interpretations among the Sacramental, Kerygmatic, and Charismatic Models that are related to the divine presence and the sacraments that mediate it. Each model claims that there is an exclusive and causal relationship between the divine presence and the Eucharist, preaching Scripture, and music. ${ }^{52}$ However, since Timeless Being produces an ontological dichotomy between the divine presence and creation, it automatically creates the possibility for the divine presence to be mediated by these three divergent vehicles.

Moreover, by switching to Dynamic Timeless Being, Vatican II laid the groundwork for the Emerging Church to anticipate an almost endless possibility of sacraments to be vehicles of the divine presence. However, the switch to Dynamic Timeless Being has produced conflicting interpretations that revolve around the vehicles employed that mediate the divine presence within the Sacramenta ${ }^{53}$ and Charismatic

\footnotetext{
${ }^{51}$ For transubstantiation's dominant role in interpreting the divine presence among the three Models, see this dissertation, 33-35, 43, 64-66, 89, 151-154, 183-184.

${ }^{52}$ See this dissertation, 19-26.

${ }^{53}$ For the switch dynamic timeless Being in the Sacramental Model, see this dissertation, 103.
} 
models. ${ }^{54}$ For instance, although the Sacramental model exclusively maintains that bread and wine constitute the main vehicles of mediating the divine presence in liturgy, other voices within that model that are under the influence of Dynamic Timeless Being ${ }^{55}$ argue that the vehicles of the divine presence should include local ethnic food and drink. ${ }^{56}$

The switch to Dynamic Timeless Being produces similar problems in the Charismatic Model. Under Static Timeless Being, music constitutes the main sacrament amongst Pentecostals and Charismatics. However, Emergents who operate within the framework of Dynamic Timeless Being not only restore the ancient sacraments of the early church, ${ }^{57}$ they also declare that the entire universe is potentially sacramental for liturgy. ${ }^{58}$ Thus, under the paradigm of Timeless Being, what began by an exclusive and causal relationship between the divine presence and only one sacrament has ended by the possibility that anything in creation can become a vehicle for the divine presence.

\section{Conflicting Interpretations of the Divine}

\section{Presence}

I will now outline how Timeless Being produces conflicting interpretations of the divine presence among the Sacramental, Kerygmatic, and Charismatic Models. The Sacramental model prior to Vatican II, the Kerygmatic model, the Pentecostal and

\footnotetext{
${ }^{54}$ For the use of dynamic timeless Being in the Charismatic Model, see this dissertation, 184-217.

${ }^{55}$ For the influence of timeless Being in the form of panentheism on some within the Sacramental Model, see François Kabasele Lumbala, Celebrating Jesus Christ in Africa: Liturgy and Inculturation, (Maryknoll, NY: Orbis Books, 1998), 3-5.

${ }^{56}$ For the direct link between the Static Timeless Being of Plato and Aristotle and bread and wine; and the replacement of static timeless Being to Dynamic Timeless Being and the connection to local food and drink, see Ibid., 50, 53-56.

${ }^{57}$ See this dissertation, 182-183.

${ }^{58}$ See this dissertation, $184-185$.
} 
charismatic movements, and the emerging stream of the Emerging Church movement adhere to a transcendent view of the divine presence that is entirely static and timeless. ${ }^{59}$ As a result, this corresponds to the God of classical theism.

In an attempt to deal with modernism, Vatican II integrated modernity with classical theism. ${ }^{60}$ As a result, the post Vatican II Sacramental model and the Emergent stream of the Emerging Church adhere to a dynamic panentheistic view of the divine presence, in which God comes to an awareness of himself through the process of evolution. ${ }^{61}$ This view combines being and becoming, transcendence and immanence, eternity and time, and immutability and change as essential components of the divine presence. Timeless Being has thus produced two irreconcilable interpretations of the divine presence.

\section{Conflicting Focus of Liturgy}

Jesus Christ exclusively represents the divine presence in the Sacramental and Kerygmatic models, and the Holy Spirit exclusively represents the divine presence in the Charismatic model.

\section{Conflicting Christology}

I will briefly outline the hermeneutical effects of timeless Being on Jesus Christ

${ }^{59}$ For Sacramental Model prior to Vatican II, see this dissertation, 103-110. For the Kerygmatic Model, see this dissertation, 151-156. For the Pentecostal and Charismatic movements, see this dissertation, 182-183. For the emerging stream of the Emerging Church Movement, see this dissertation, 182-183.

${ }^{60}$ This integration of modernity with classical theism is referred to by the architects of Vatican II as a synthesis, see this dissertation, 114-117.

${ }^{61}$ For examples dynamic panentheism in post Vatican II Sacramental Model, see this dissertation, 114-117. For examples of dynamic panentheism in the Emergent stream of the Charismatic Model, see this dissertation, 182-187. 
and the Holy Spirit. The paradigm of Static Timeless Being, which is the pre-Vatican II view, interprets the relationship between Jesus' divine and human natures in the following ways. Since his divine nature is timeless and immutable, his human nature is passive, not possessing its own center of consciousness. ${ }^{62}$ Moreover, since his omnipresence is timeless and immutable, he still remains omnipresent during the incarnation. $^{63}$

In contrast to this, $20^{\text {th }}$ century Christology which is under Dynamic Timeless Being begins with a completely free human Jesus who has his own center of will and consciousness. Eventually, Jesus' divine nature actualizes itself in history as the human Jesus through the evolutionary process. ${ }^{64}$ The bread and wine in the Sacramental Model thus represent conflicting interpretations of Jesus Christ as the divine presence.

\section{Conflicting Pneumatology}

In the Charismatic Model, the Holy Spirit is timeless, transcendent and immutable for Pentecostals, Charismatics, and the emerging stream of the Emerging Church. This view of the Holy Spirit produces a dichotomy between the divine presence and musical style. $^{65}$

For Emergents transcendence becomes subsumed within immanence. ${ }^{66}$ As a result, the transcendent aspect of the Holy Spirit constitutes the inaudible mathematical

\footnotetext{
${ }^{62}$ For the influence of static timeless Being on the interpretation of Christ's divine and human natures in the Incarnation, see this dissertation, 107-109.

${ }^{63}$ For the influence of static timeless Being on the ubiquity of Christ's presence after the Incarnation, see this dissertation, 109-110 110-113.

${ }^{64}$ For the influence of dynamic timeless Being on Christology, see this dissertation,

${ }^{65}$ See this dissertation, 184-185.

${ }^{66}$ See this dissertation, $184-185$.
} 
portion of music while the immanent aspect of the Holy Spirit constitutes the audible musical portion. ${ }^{67}$

\section{Hermeneutical Effects on the Trinity}

There are two conclusions we can draw from this brief analysis of the hermeneutical effects of Timeless Being on Jesus Christ and the Holy Spirit. The first is that the paradigm of Timeless Being produces conflicting views of Jesus Christ in the Sacramental Model and conflicting views of the Holy Spirit in the Charismatic Model.

Second, if God is simple as Aquinas asserts ${ }^{68}$ and "as perfect timeless-spaceless reality demands, we can conceive his being only as one, not three. ${ }^{, 69}$ Accordingly, despite the Sacramental and Charismatic Models' affirmation of the Trinity, one wonders if any significant qualitative differences exist between the Static Timeless conception of Jesus Christ, who remains omnipresent after the incarnation, and that of the Holy Spirit. Perhaps the hermeneutical impact of timeless Being on God as one being in liturgy is the reason why Karl Rahner states, "should the doctrine of the Trinity have to be dropped as false, the major part of religious literature could well remain virtually unchanged." 70

Conflicting View of the Word of God, Scripture, and Tradition

One final area that constitutes the divine presence involves the words that the presider speaks at the Eucharist and the words that the preacher preaches. Under the

${ }^{67}$ See this dissertation, 184-185, 202-203.

${ }^{68}$ ST First Part, Question 3, Articles 1-7.

${ }^{69}$ Fernando Canale, Basic Elements of Christian Theology: Scripture Replacing Tradition (Berrien Springs, MI: Andrews University Lithotech, 2005), 78.

${ }^{70}$ Karl Rahner, The Trinity, (New York: Herder and Herder, 1970), 10-11. 
paradigm of Static Timeless Being, the Sacramental Model adheres to the distinction between Scripture and Tradition as sources involved in the words that the presider speaks during the prayer of consecration when he states, "This is My Body." In this setting, the words of Jesus come from Scripture, yet their meaning is derived from philosophy and tradition. ${ }^{71}$ Hence, there is a sharp pre-Vatican II distinction between Scripture and Tradition as elements that constitute the divine presence.

However, under the paradigm of Dynamic Timeless Being that was assumed at Vatican II, Scripture and Tradition are now complementary elements that constitute the Word of God. Scripture and Tradition are allegedly no longer in opposition to each other; however, under the influence of Timeless Being, philosophy and Tradition still hermeneutically guide the interpretation of the Word of God. ${ }^{72}$

The Kerygmatic Model claims to go by Scripture alone in its view of the divine presence, however, in practice Static timeless Being controls the interpretation of the divine presence. ${ }^{73}$

\section{Biblical Sanctuary Model}

Now that we have summarized the hermeneutical role of Timeless Being in the three models, we will turn to the Biblical Sanctuary Model. Kuhn notes that when new paradigms are discovered, they are diametrically opposed to and completely incompatible with the old paradigms they just replaced. ${ }^{74}$ Accordingly, the I AM of Exod 3:14-15,

${ }^{71}$ See this dissertation, 113-114.

${ }^{72}$ See this dissertation, 114-117.

${ }^{73}$ See this dissertation, 151-156.

${ }^{74}$ Kuhn, The Structure of Scientific Revolutions, 3rd ed. (Chicago: University of Chicago Press, 1966), 6, 7, 92; Brand, Faith, Reason, and Earth History, 52. 
which is God's name, grounds the temporal interpretation of God's Being in the Biblical Sanctuary Model while rendering groundless the timeless view of Being.

Temporal Being's Dominant Role in Interpreting the Divine Presence

We discovered that the Lord God of Exod 3:15 is synonymous with the I AM of Exod 3:14. Hence, the numerous references containing Lord and God in our analysis of the divine presence refer to God's infinite analogous temporal Being. The I AM ('E $\gamma \omega$ ' si $\mu \mathrm{LXX}$ ) of Exod 3:14 is also clearly connected to the one who believes that God exists

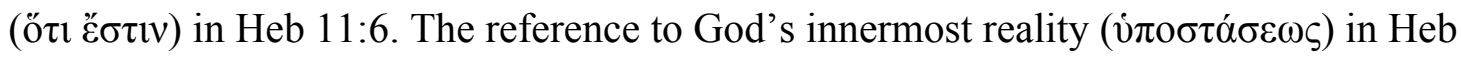
1:3 should also be grounded in Exod 3:14. The references to ôv translated as "being" in Heb $1: 3$ and translated as "is" in Rev $1: 4,8 ; 4: 8 ; 11: 17 ; 16: 5$ also hearken back to the $̋$ v of Exod 3:14. Moreover, since I AM constitutes God's name, the references to the name

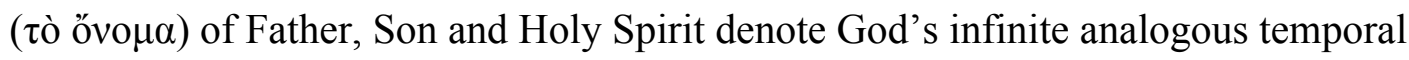
Being (Matt 28:19; cf. Acts 2:38; Heb 13:15).

Focus on the Trinity

I will now outline how the I AM grounds God's infinite analogous temporal Being and how the heavenly sanctuary temporally grounds the relationship among the Trinity as the fundamental presuppositions for interpreting the divine presence in the context of liturgy. In the Biblical Sanctuary Model, each member of the Trinity constitutes the $\mathrm{I} \mathrm{AM} .{ }^{75}$ While there is no ontological subordination on the part of any one of the Godhead to the other, the heavenly sanctuary does outline the different roles each of them plays in liturgy (Heb 9:6-8; 12:24-25 and Rev 4-5), without which liturgy would

\footnotetext{
${ }^{75}$ See this dissertation, 338-339.
} 
not be possible. This emphasis on the Trinity as the divine presence in liturgy is contrasted with the singular focus on Jesus Christ in the Sacramental and Kerygmatic Models and the Holy Spirit in the Charismatic Model.

The Trinity, Transcendence, and Immanence

In 2 Chron 20:8-9 (cf. 1 Kings 8:16, 29) God's name (Exod 3:14) signifies that his presence is revealed in the context of the sanctuary. Solomon's statement in 1 Kings 8:27 assumes that God can dwell in the temple on earth and in heaven, and that God occupies or resides in a reality that only he has access to (transcendence), which is not to be connected with the universe. The notion of transcendence is implied by the statement that the universe cannot contain him (1 Kings 8:27). ${ }^{76}$ Accordingly, since the sanctuary connects God's ability to dwell in earthly and heavenly temples, in the universe (immanence) as well as in transcendence, the interpretation of transcendence is grounded from the context of God's immanence as revealed by his ability to dwell in the sanctuary. Since Scripture reveals that the being of God is infinitely temporal and cannot be contained in immanence (Exod 3:14; 1 Kings 8:27), the biblical notion of transcendence as an uncreated, infinite and eternal reality that only the Trinity occupies must not be confused with the timeless view of transcendence that the other models espouse. God is thus simultaneously transcendent and immanent.

\section{The Trinity Presence and Omnipresence}

The I AM and the heavenly sanctuary also temporally grounds how the Trinity

\footnotetext{
${ }^{76}$ For more information on 1 Kings 8:27 and the issues of transcendence and immanence, see this dissertation, 239-242, 245-248.
} 
relates to the issues of presence and omnipresence. After creation and prior to the incarnation, the members of the Trinity did not experience a change in their being as they accommodated themselves to the universe. However, God's infinite analogous temporal Being allowed Christ to become a human being and thus experience a fundamental change in his being that did not involve a contradiction at the level of Being. Unlike the Sacramental Model that destroys the integrity of Christ's humanity before Vatican II and then the integrity of his divinity after Vatican II, the Biblical Sanctuary model mysteriously blends divinity with humanity without violating the integrity of either nature. $^{77}$

Thus, in opposition to the Sacramental Model, Christ is not omnipresent in immanence during the incarnation. The heavenly sanctuary scene of Rev 4-5 reveals that he is ministering in the most holy place in the direct presence of his Father who is consistently described as seated on the throne and is also not represented as omnipresent in immanence. ${ }^{78}$ Since, the Father and Son's real visible presence in the sanctuary does not involve the totality of their being, which we can infer from Exod 3:14 and 1 Kings 8:27, they along with the Spirit are omnipresent in transcendence.

The symbols that describe the Holy Spirit do not communicate anything about his being, but rather these symbols describe his function within salvation history. As a result, the Holy Spirit is a real yet invisible omnipresence in immanence. Moreover, just as the ground for interpreting transcendence has its basis in the sanctuary as well as in the law of God that forms the basis for the covenant, the biblical view of the relationship between the omnipresent Spirit and creation negates panentheism since it violates the second

\footnotetext{
${ }^{77}$ For an outline of these issues, see this dissertation, 310-316, 327-331.

${ }^{78}$ See this dissertation, 322-324.
} 
commandment. Thus, panentheism not only confuses the Spirit's reality with creation, it also limits the Spirit to creation (immanence). ${ }^{79}$

Divine Presence Only Revealed by God's Word

In the other models timeless Being not only produces conflicting views of the divine presence, it also produces conflicting vehicles that mediate the divine presence. The Biblical Sanctuary Model posits that God is present; this was brought out in the theophanies of the burning bush (Exod 3), and at Sinai (Exod 19-20). However, Moses only discerned God's presence when God spoke to him. Also, even though the Israelites knew that God was at Mount Sinai amidst all of the physical phenomena (Exod 19:1619), it was God's proclamation at Sinai that clearly revealed his presence to the Israelites (Deut 5:23-27). ${ }^{80}$ Christ's incarnation is also a theophany; yet, his physical presence among the two disciples was not the means of revealing his identity (Luke 24:13-24). His true identity, and thus his divine presence, was only revealed when he began to reveal Scripture's interpretations of the events that surrounded the crucifixion (Luke 24:25-32).

Hence, unlike the other models, God's presence is only revealed through his words (Exod 3:1-6, 14-15); it is not revealed in creation, which would constitute idolatry (Deut 4:12-15; cf. Exod 20:4-6). Just as divinity and humanity in the incarnation are mysteriously blended without compromising their integrity, Scripture, as the revelation of

${ }^{79}$ See this dissertation, 331-334.

${ }^{80}$ Elijah's experience also exemplifies that God's word only reveals his presence. When Elijah was told to "Go out, and stand on the mountain before the Lord," God was present; but he was not in the wind, or in the earthquake, or in the fire (1 Kings 19:11-12). Elijah only discerned his presence after he heard "a still small voice" (1 Kings 19:12), after which he reverently responded by wrapping "his face in his mantle" (1 Kings 19:13). 
his presence, is also made up of the mysterious blending of the divine mind that reveals divine content and of the human mind that received the divine content and communicated it in writing. Scripture thus constitutes the only source from which to properly interpret his presence. Table 3 compares the divine presence among the four models.

\section{Liturgist}

Thomas Kuhn informs us that the discovery of a new paradigm renders it incompatible with the old one. Therefore, one must choose since blending the two paradigms together is impossible. ${ }^{81}$ Kuhn also reveals that holding on to old paradigms prevents scientists from seeing that anomalous data can lead to the discovery of new paradigms and further breakthroughs. ${ }^{82}$ Under timeless Being, the Sabbath and the sanctuary are considered as anomalous data that are then interpreted metaphorically.

I will now examine the ways in which timeless and temporal Being significantly shape our understanding of the liturgist, the cause of liturgy, liturgical authority, and issues surrounding mediation in all four models. I will also employ the Sabbath and the sanctuary as important principles that lead to new discoveries regarding the liturgist in the Biblical Sanctuary Model.

\section{Sacramental, Kerygmatic, and Charismatic Models}

\section{Conflicting Cause of Liturgy}

The interpretation of the human liturgist in the Sacramental, Kerygmatic, and 94-97.

${ }^{81}$ For more details on the impossibility of blending paradigms, see this dissertation,

${ }^{82}$ Kuhn, The Structure of Scientific Revolutions, 3rd ed. (Chicago: University of Chicago Press, 1966), 53, 56, 60, 61, 68-71. 
Table 3. Divine Presence

\begin{tabular}{|c|c|c|c|c|}
\hline & \multicolumn{3}{|c|}{$\begin{array}{c}\text { Timeless Being } \\
\text { Static Timeless Being \& Dynamic Timeless Being }\end{array}$} & \multirow{2}{*}{$\begin{array}{c}\text { Temporal Being } \\
\text { Based on Exod 3:14- } \\
15 \\
\text { Biblical Sanctuary } \\
\text { Model }\end{array}$} \\
\hline & Sacramental Model & $\begin{array}{c}\text { Kerygmatic } \\
\text { Model }\end{array}$ & $\begin{array}{c}\text { Charismatic } \\
\text { Model }\end{array}$ & \\
\hline Essence & $\begin{array}{l}\text { Transubstantiation } \\
\text { hypothesis grounded } \\
\text { in Aristotle's Form } \\
\text { and Plato's Idea }\end{array}$ & $\begin{array}{l}\text { Assumes trans... } \\
\text { hypothesis }\end{array}$ & $\begin{array}{l}\text { Assumes trans... } \\
\text { hypothesis }\end{array}$ & $\begin{array}{l}\text { Trans hypothesis } \\
\text { rendered groundless. } \\
\text { Father \& Son visibly } \\
\text { present in heavenly } \\
\text { sanctuary. Holy Spirit } \\
\text { invisibly omnipresent }\end{array}$ \\
\hline Vehicle & $\begin{array}{l}\text { Pre Vatican II: Bread } \\
\& \text { Wine } \\
\text { Spoken words "This is } \\
\text { My Body." } \\
\text { Vatican II: Church, } \\
\text { priest, music, prayer, } \\
\text { sacraments, Word of } \\
\text { God }\end{array}$ & Scripture & $\begin{array}{l}\text { Pentecostal \& } \\
\text { Charismatic: } \\
\text { Music } \\
\text { Emerging Church: } \\
\text { Potentially all of } \\
\text { creation }\end{array}$ & Scripture only \\
\hline 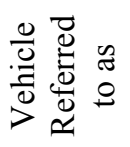 & $\begin{array}{l}\text { Sacrament, real } \\
\text { presence, } \\
\text { transubstantiation }\end{array}$ & $\begin{array}{l}\text { Sacrament, real } \\
\text { presence }\end{array}$ & $\begin{array}{l}\text { Sacrament, real } \\
\text { presence, musical } \\
\text { trans... }\end{array}$ & $\begin{array}{l}\text { Scripture, the Word of } \\
\text { God. }\end{array}$ \\
\hline Focus & Jesus Christ & Jesus Christ & Holy Spirit & The Trinity \\
\hline 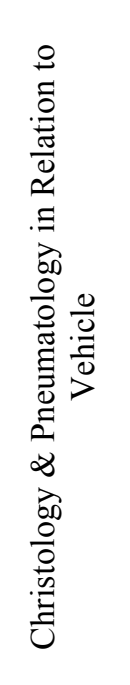 & $\begin{array}{l}\text { Christology: } \\
\text { Pre Vatican II: } \\
\text { Divinity is timeless \& } \\
\text { immutable. Humanity } \\
\text { is passive, not having } \\
\text { own center of } \\
\text { consciousness. } \\
\text { Omnipresent after the } \\
\text { incarnation. } \\
\text { Vatican II: } \\
\text { Active human nature. } \\
\text { Divinity evolving } \\
\text { through evolution. }\end{array}$ & $\begin{array}{l}\text { Christology: } \\
\text { Divinity is } \\
\text { timeless \& } \\
\text { immutable. } \\
\text { Humanity is } \\
\text { passive, not } \\
\text { having own } \\
\text { center of } \\
\text { consciousness } \\
\text { Omnipresent } \\
\text { after the } \\
\text { incarnation. }\end{array}$ & $\begin{array}{l}\text { Pneumatology } \\
\text { Pentecostal \& } \\
\text { Charismatic: } \\
\text { Spirit is timeless } \\
\text { \& immutable. } \\
\text { Music is entirely } \\
\text { culturally } \\
\text { conditioned } \\
\text { Emerging Church: } \\
\text { Spirit is timeless } \\
\text { and temporal, } \\
\text { immutable and } \\
\text { changeable. Math } \\
\text { of music is } \\
\text { timeless aspect. } \\
\text { Sounds of music is } \\
\text { temporal aspect }\end{array}$ & $\begin{array}{l}\text { Christology: Divinity } \\
\text { and humanity } \\
\text { perfectly blended } \\
\text { without violating } \\
\text { integrity of either one. } \\
\text { Not omnipresent after } \\
\text { incarnation. Scripture } \\
\text { is also perfectly } \\
\text { blended and not } \\
\text { culturally conditioned }\end{array}$ \\
\hline
\end{tabular}


Table 3-Continued.

\begin{tabular}{|c|c|c|c|c|}
\hline & \multicolumn{3}{|c|}{$\begin{array}{c}\text { Timeless Being } \\
\text { Static Timeless Being \& Dynamic Timeless Being }\end{array}$} & $\begin{array}{c}\text { Temporal Being } \\
\text { Based on Exod 3:14- } \\
15\end{array}$ \\
\hline & Sacramental Model & $\begin{array}{l}\text { Kerygmatic } \\
\text { Model }\end{array}$ & $\begin{array}{l}\text { Charismatic } \\
\text { Model }\end{array}$ & $\begin{array}{c}\text { Biblical Sanctuary } \\
\text { Model }\end{array}$ \\
\hline 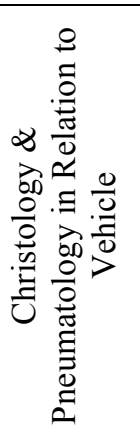 & $\begin{array}{l}\text { Substance of Eucharist } \\
\text { is timeless and } \\
\text { unchangeable. Bread } \\
\text { and wine is temporal } \\
\text { and unchangeable. } \\
\text { Substance of Word is } \\
\text { timeless and } \\
\text { unchangeable. All else } \\
\text { is culturally } \\
\text { conditioned }\end{array}$ & $\begin{array}{l}\text { Substance of } \\
\text { Word is timeless } \\
\text { and } \\
\text { unchangeable. } \\
\text { All else is } \\
\text { culturally } \\
\text { conditioned }\end{array}$ & & $\begin{array}{l}\text { Pneumatology: } \\
\text { Spirit is omnipresent } \\
\text { and reveals his } \\
\text { presence through the } \\
\text { Word. Scripture is not } \\
\text { the divine presence; } \\
\text { it's the only vehicle } \\
\text { that reveals the divine } \\
\text { presence }\end{array}$ \\
\hline
\end{tabular}

Charismatic Models stems from Timeless Being and involves a dichotomy between the timeless soul, which includes reason, and the temporal body. With respect to the cause of liturgy, the divine presence acts timelessly, or in the "eternal now" in these Models. As a result, since timelessness causes, orders, and conditions temporal phenomena, Christ in the Sacramental and Kerygmatic Models and the Holy Spirit in the Charismatic Model always constitute the efficient cause of liturgy while the liturgist is the instrumental cause. ${ }^{83}$

\section{Conflicting Views Regarding Authority}

The dichotomy between the timeless soul and the temporal body of the liturgist also produces conflicting views among the three Models over the issues of authority. The authority of the liturgist to preside over the Eucharist in the Sacramental model is grounded in Christ granting authority to Peter, and then through apostolic succession to all of Peter's successors who receive the grace of the Holy Spirit during the sacrament of

\footnotetext{
${ }^{83}$ See this dissertation, 117-118, 158-159, 188-189.
} 
holy orders at their ordination. The permanent mark in the soul received by the priests during ordination creates an ontological dichotomy between clergy and laity that further restricts authority to the priesthood. ${ }^{84}$ Moreover, Platonic duplication constitutes the ground for an all male priesthood in this model. In Plato's two worlds theory the earthly realm is a duplicated copy of the heavenly realm. Similarly, Pope Leo who ministered in Peter's See on earth informs us that the most blessed apostle Peter is always present in Peter's See when the church assembles ${ }^{85}$ Thus, the Sacramental Model ultimately grounds the authority for liturgy in the church.

The validity of the Kerygmatic and Charismatic models does not depend on episcopal ordination in the historic apostolic succession; instead the priesthood of all believers grants authority and legitimizes the liturgical function of the liturgist while eliminating the ontological distinction between clergy and laity. The Kerygmatic model also refers to their liturgists as pastors or ministers instead of priests while the Charismatic model refers to them simply as worship leaders. However, despite the turn to the biblical notion of the priesthood of all believers, neither model has developed an ontology of human nature on the basis of the Bible. ${ }^{86}$

The Charismatic model grounds the authority and legitimacy of the liturgist in the

${ }^{84}$ See this dissertation, $118-120$.

${ }^{85}$ Pope Leo states, "The most blessed Apostle Peter...has not deserted your devotion, in whose honour you are met together. And so he rejoices over your good feeling and welcomes your respect for the Lord's own institution as shown towards the partners of His honour, commending the well ordered love of the whole Church which ever finds Peter in Peter's See," NPNF, Second Series 12:116 Sermon 2.2. Leo also points out, "On Wednesday and Friday therefore let us fast; and on Saturday keep vigil all together in the presence of the most blessed Apostle Peter, by whose merits and prayers we are sure God's mercy will be vouchsafed to us in all things through our Lord Jesus Christ," NPNF, Second Series 12:199 Sermon 88.5.

\footnotetext{
${ }^{86}$ See this dissertation, 156-159, 187-191.
} 
gifts of the Holy Spirit that are revealed by anyone who can facilitate worship irrespective of race, ethnicity, socio-economic status, sexual orientation, or gender identity. The Charismatic model's assumed distinction between body and soul eliminates any causal connection between sexuality, gender identity, and the gifts of the Holy Spirit among liturgists. As a result, the elimination of the clergy-laity distinction among liturgists in the Charismatic model is also grounded in the ontological dichotomy between the gifts of the Holy Spirit on the one hand and status, sexual orientation and gender identity on the other. Liturgical authority is thus grounded in the Spirit. ${ }^{87}$

\section{Conflicting View of Mediation}

The dichotomy between the timeless soul and the temporal body also lies at the foundation for the conflicting ways in which the Sacramental and Charismatic models mediate the divine presence to the congregation. In the Sacramental model, the soul of the priest that is marked at ordination receives timeless truths that he transmits without any interpretation on his part to the congregation. As a result, the personal attitude, deportment, ethical choices, and personal beliefs of the liturgist play no role in mediating the divine presence in liturgy. The reason for this is that there is no causal connection between the personal attitude, deportment, ethical choices, or personal beliefs of the liturgist and the timeless truths he transmits. In the Charismatic model, status, sexual orientation and gender identity belong to the body; accordingly, the dichotomy between body and soul leads to the deduction that these things are inconsequential when it comes to mediating the divine presence.

\footnotetext{
${ }^{87}$ See this dissertation, 189-191.
} 


\section{Biblical Sanctuary Model}

The first major departure concerning the liturgist in the Biblical Sanctuary Model when compared to the previous models is that the liturgist consists of divine, angelic, and human liturgists that all cooperate together. ${ }^{88}$ I will now examine the way in which the Biblical Sanctuary Model interprets the nature of the liturgist, the cause of liturgy, authority issues, and issues regarding mediation.

Nature of the Liturgist and Ministry of the Word in OT and NT

We will first begin our analysis with the nature of the liturgist. While Exod 3:1415 grounds the biblical view of God's infinite analogous temporal Being, the sanctuary and the Sabbath ground the temporal relationship between the divine, angelic, and human liturgists. This important hermeneutical key leads to the following insights. The first is that the Sabbath and sanctuary integrate all the physical, spiritual, mental, and social aspects of the liturgist that we find in Gen 1:27 and 2:7. The Biblical Sanctuary Model thus renders groundless the body and soul dichotomy of the other models that separate spiritual gifts from biological sex, and which create the ontological superiority of liturgist over laity. $^{89}$

Second, in liturgy, the divine, angelic, and human liturgists predominantly minister the Word. In this endeavor, the heavenly sanctuary temporally grounds the relationship between all the liturgists and the temporal content of Scripture that is universal in scope and application.

Third, with reference to human liturgists, the temporal grounding of the sanctuary

\footnotetext{
${ }^{88}$ See this dissertation, 334-354.

${ }^{89}$ See this dissertation, 253-257.
} 
delineates the similarities and differences between OT and NT liturgists in the following way. Scripture reveals that the priestly liturgists that minister in the OT and NT eras do so within the context of the sanctuary. However, while the OT priestly liturgists perform a ritualized form of speech connected with the sacrificial system in the context of the earthly sanctuary, ${ }^{90} \mathrm{NT}$ priestly liturgists exercise a prophetic teaching and preaching ministry that includes prayer and fasting performed by prophets and teachers (Acts 13:2). This occurs under the direction of the Holy Spirit who works in unison with Christ in the heavenly sanctuary. ${ }^{91}$

\section{Liturgist is Efficient Cause}

We now move on to issues relating to the cause of liturgy. In the Biblical model, the sanctuary and the Sabbath temporally ground the relationship between the divine, angelic, and human liturgists. This means that the liturgist is the cause of liturgy, whether the liturgist is divine, angelic, or human. When, however, the liturgist is human, the divine liturgist functions as the indispensible condition of liturgy. This is illustrated in Rev 4-5 beginning with the Father who originated the content in the book that he holds in his right hand ( $\operatorname{Rev} 5: 1)$. The Lamb then receives the scroll, opens its seals and begins to disclose the content. The Holy Spirit reveals to earthly liturgists what Christ is doing in heaven (Heb 9:8; Rev 5:6). Moreover, the comparisons between Rev 5 and Rev 14 show that the preaching of the Three Angels Messages in Rev 14 represents the unrolling of the scroll in Rev $5 .{ }^{92}$ Thus, Christ is the efficient cause of liturgy in heaven since he is the one who receives the scroll, opens its seals and begins to reveal its content to the

\footnotetext{
${ }^{90}$ See this dissertation, 276-277.

${ }^{91}$ See this dissertation, 336-337.

${ }^{92}$ For a comparison of Rev 4-5 with Rev 14, see Tables 1 and 2.
} 
heavenly worshippers. The Father who originated the content of the scroll is the indispensible condition of liturgy. However, the cause of liturgy here on earth is the human agent who preaches the Three Angels Messages while the Trinity constitutes the indispensible conditions of liturgy. ${ }^{93}$

\section{Authority of Liturgist Based on Scripture}

In the previous models, a liturgist's authority is derived from the church or the Spirit. The following points in the Biblical Sanctuary model reveal that Scripture is the basis for the liturgist's authority. First, Rev 4-5 reveals that all liturgical authority is grounded in the central throne that the Father shares with his Son and that the four living creatures and elders submit to. ${ }^{94}$ Since the heavenly sanctuary is a model (Heb 8:5; 9:24) authority flows from the heavenly liturgist to the earthly, which means that earthly liturgists derive their authority from the One who sits on the throne. Also, the location of the Holy Spirit before the throne (Rev 1:4; 4:5), and not on it reveals that the Spirit only exercises authority in harmony with the One seated on the throne. Since the throne in Revelation is the place of ark of the covenant $(\operatorname{Rev} 3: 7-8 ; 4: 2 ; 11: 19),{ }^{95}$ the Ten Commandments and the scroll, and since there is a connection between the scroll and the Three Angels Messages of Rev 14, the authority exercised by all liturgists, including their

\footnotetext{
${ }^{93}$ Concerning Rev 4-5 and Rev 14 regarding liturgy on earth, the Father who originates the scroll, the Son who reveals its contents to the worshippers in heaven, and the Holy Spirit who reveals the content of the scroll to the liturgists on earth all constitute the indispensible conditions of liturgy.

${ }^{94}$ Evidence of their submission to the central throne is indicated by their location and their activity. For instance, the 24 elders that surround the throne (Rev 4:4) cast their crowns before the throne ( $\operatorname{Rev} 4: 10)$; and the 4 living creatures are around the throne ( $\operatorname{Rev} 4: 6)$, and they sing holy, holy, holy to the One seated on the throne (Rev 4:8).

${ }^{95}$ For more detailed support for the throne as the place that is synonymous with the ark of the covenant and the Ten Commandments, see p. 243 note 93 and page 322 notes 69 and 70 .
} 
interpretations of Scripture, must be in harmony with the universal meaning revealed by the Law of God and the scroll in the Father's hand.

Second, the book of Hebrews refers to Christ as $\lambda \varepsilon i \tau o u p \gamma o ̀ \varsigma$ (Heb 8:2) who speaks from heaven through the blood of sprinkling (Heb 12:24) in the heavenly sanctuary. In Heb 9:6-8, the Holy Spirit reveals Christ's liturgical actions in heaven to the mind of the bible writer. Then the Holy Spirit illuminates the mind of the earthly liturgist who reads

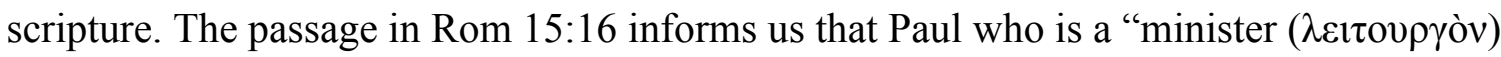

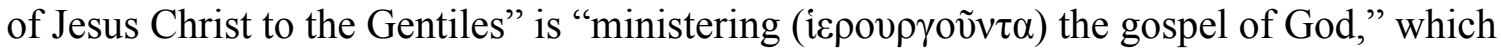
means that he is performing the priestly act of preaching the gospel by grounding it in Christ's work in the heavenly sanctuary. The authority of the earthly liturgist is thus grounded in his ability to correctly interpret Scripture, specifically, Christ's work in heaven. Also, the authority of the Holy Spirit to set aside those who are ministering

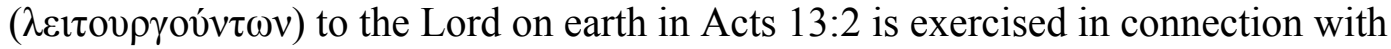
Christ's work as liturgist in the heavenly sanctuary. For these reasons, liturgical authority in the Biblical Sanctuary Model resides in Scripture, not in the church or the Spirit.

\section{Mediation Based on Nature of Liturgist}

I will now examine the issues that relate to how the liturgist mediates the divine presence. The passage in Gen 1:27 states that God created them "male and female," which means that human sexuality is inextricably linked with identity. Consequently, the immutable nature of the divine presence is mediated by the immutable nature of the liturgists' identity that is grounded in and inseparable from their biological sex.

Furthermore, Gen 2:7 reveals that all of the physical, mental, spiritual and social aspects of human beings constitute one integrated whole. As a result, the mediation of the divine 
presence in the Biblical Sanctuary Model includes the personal attitude, deportment, ethical choices, and personal beliefs of the liturgist.

Human liturgists have autonomy to mediate the divine presence in accordance with how God has revealed himself in Scripture or to distort and misinterpret the divine presence such as at the golden calf. Moreover, since the characteristics of heavenly music differ from those at the golden calf, human liturgists can choose to mediate the heavenly or the earthly. It is this autonomy that testifies to the biblical fact that human liturgists possess hermeneutical minds. This goes contrary to the other models in which liturgists merely act as conveyors of timeless truths that they simply transmit without interpreting. Table 4 compares how each model interprets the liturgist.

\section{Liturgical Setting and Actions}

As we now compare the liturgical actions among all the models, we will keep in mind how Kuhn's observations about paradigms and data relate to Being and the issues that revolve around liturgical actions.

\section{Sacramental, Kerygmatic, and Charismatic Models}

The hermeneutical impact of Timeless Being on the Sacramental, Kerygmatic, and Charismatic Models produces conflicting views of the central liturgical action; it also produces conflicts with respect to architecture, and conflicts concerning the relationship between the divine presence, the central liturgical action, and other liturgical actions.

\section{Conflicting Liturgical Centers}

These three Models assume the transubstantiation framework hypothesis of the divine presence. Consequently, Timeless Being produces the following contradiction that 


\section{Table 4. Liturgist}

\begin{tabular}{|c|c|c|c|c|}
\hline & \multicolumn{3}{|c|}{$\begin{array}{c}\text { Timeless Being } \\
\text { Static Timeless Being \& Dynamic Timeless Being }\end{array}$} & \multirow{2}{*}{$\begin{array}{c}\text { Temporal Being } \\
\text { Based on Exod 3:14-15 } \\
\text { Biblical Sanctuary } \\
\text { Model } \\
\end{array}$} \\
\hline & Sacramental Model & $\begin{array}{l}\text { Kerygmatic } \\
\text { Model }\end{array}$ & $\begin{array}{c}\text { Charismatic } \\
\text { Model }\end{array}$ & \\
\hline 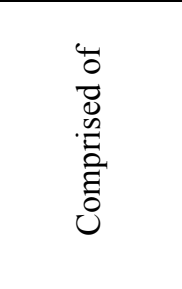 & $\begin{array}{l}\text { Human Only with } \\
\text { Timeless soul } \\
\text { (reason) and } \\
\text { temporal body }\end{array}$ & $\begin{array}{l}\text { Human Only } \\
\text { with Timeless } \\
\text { soul (reason) and } \\
\text { temporal body }\end{array}$ & $\begin{array}{l}\text { Human Only with } \\
\text { Timeless soul } \\
\text { (reason) and } \\
\text { temporal body }\end{array}$ & $\begin{array}{l}\text { Divine, angelic, and } \\
\text { human. Sanctuary and } \\
\text { Sabbath temporally } \\
\text { ground physical, } \\
\text { mental, spiritual and } \\
\text { social aspects in human } \\
\text { liturgist }\end{array}$ \\
\hline $\begin{array}{l}\text { Cause of } \\
\text { Liturgy }\end{array}$ & $\begin{array}{l}\text { Christ is efficient } \\
\text { cause and liturgist is } \\
\text { instrumental cause }\end{array}$ & $\begin{array}{l}\text { Christ is efficient } \\
\text { cause and } \\
\text { liturgist is } \\
\text { instrumental } \\
\text { cause }\end{array}$ & $\begin{array}{l}\text { Holy Spirit is } \\
\text { efficient cause and } \\
\text { liturgist is } \\
\text { instrumental cause }\end{array}$ & $\begin{array}{l}\text { Liturgist is efficient } \\
\text { cause of liturgy. If } \\
\text { human liturgist is } \\
\text { cause, divine and } \\
\text { angelic liturgists are } \\
\text { indispensible } \\
\text { conditions }\end{array}$ \\
\hline Authority & $\begin{array}{l}\text { Grounded in the } \\
\text { Church through } \\
\text { apostolic succession } \\
\text { at ordination. Clergy } \\
\text { ontologically } \\
\text { superior to laity due } \\
\text { to permanent mark } \\
\text { in the soul. Male } \\
\text { priesthood based on } \\
\text { Platonic duplication } \\
\text { and participation } \\
\text { between the apostle } \\
\text { Peter in heaven and } \\
\text { the priest on earth }\end{array}$ & $\begin{array}{l}\text { Grounded in } \\
\text { priesthood of all } \\
\text { believers. } \\
\text { Ordained and } \\
\text { set-aside by the } \\
\text { entire church. } \\
\text { Ability to preach } \\
\text { and administer } \\
\text { sacraments. No } \\
\text { ontological } \\
\text { superiority. }\end{array}$ & $\begin{array}{l}\text { Grounded in } \\
\text { Spirit. Qualified } \\
\text { by spiritual gifts. } \\
\text { Body/soul } \\
\text { dichotomy is the } \\
\text { basis for anyone to } \\
\text { be worship leader } \\
\text { regardless of } \\
\text { sexual orientation } \\
\text { or gender identity }\end{array}$ & $\begin{array}{l}\text { Grounded in Scripture } \\
\text { through the throne. All } \\
\text { earthly and heavenly } \\
\text { liturgists including the } \\
\text { Spirit exercise } \\
\text { authority in harmony } \\
\text { with the throne, } \\
\text { Scripture, Law of God } \\
\text { and Christ's liturgical } \\
\text { actions in sanctuary. }\end{array}$ \\
\hline $\begin{array}{l}\text { Referred to } \\
\text { as }\end{array}$ & Priest & Minister, Pastor & Worship Leader & $\begin{array}{l}\text { Elder, overseer, } \\
\text { prophet, teacher }\end{array}$ \\
\hline Mediation & $\begin{array}{l}\text { Priest mediates the } \\
\text { divine presence in } \\
\text { the Eucharist and } \\
\text { sacraments. Personal } \\
\text { attitude, deportment, } \\
\text { choices, and beliefs } \\
\text { are inconsequential } \\
\text { in mediating } \\
\text { timeless view of } \\
\text { divine presence. }\end{array}$ & $\begin{array}{l}\text { Minister } \\
\text { mediates the } \\
\text { divine presence } \\
\text { in the gospel as } \\
\text { timeless truths } \\
\text { that are } \\
\text { contained in } \\
\text { Scripture. }\end{array}$ & $\begin{array}{l}\text { Worship leader } \\
\text { mediates divine } \\
\text { presence in music. } \\
\text { Sexual orientation } \\
\text { and gender } \\
\text { identity are } \\
\text { inconsequential in } \\
\text { mediating timeless } \\
\text { truths. }\end{array}$ & $\begin{array}{l}\text { Immutable nature of } \\
\text { divine presence is } \\
\text { mediated by liturgist's } \\
\text { identity grounded in } \\
\text { immutability of male } \\
\text { and female. } \\
\text { Mediation of divine } \\
\text { presence includes } \\
\text { personal attitude, } \\
\text { deportment, choices } \\
\text { and beliefs of liturgist. }\end{array}$ \\
\hline
\end{tabular}


revolves around what constitutes the central liturgical action. On the one hand, each Model produces three conflicting centers in Christian liturgy consisting of the Eucharist, preaching, and music in which each claims a direct causal connection between the liturgical action and the divine presence.

On the other hand, when applied to God, the via negativa of Parmenides ${ }^{96}$ assumes an ontological dichotomy between God and the material creation. One of the hermeneutical effects of the via negativa is that there is no causal relationship between God and the material creation, which also includes history. ${ }^{97}$ Since the divine presence within the sacrament is interpreted as timeless while the material aspect of the sacrament is temporal, timeless Being creates a dichotomy between the transcendent divine presence and the material aspects of the sacrament that mediates it. This dichotomy between an utterly transcendent divine presence embedded within each sacramental vehicle ultimately justifies the existence of each of the diverging sacraments that have been competing for the liturgical center. Hence, the assumption of timeless Being produces an exclusive causal connection with each sacrament as well as an ontological dichotomy

\footnotetext{
${ }^{96}$ Canale, A Criticism of Theological Reason: Time and Timelessness as Primordial Presuppositions, 79-85

${ }^{97}$ Regarding Bultmann's view of the transcendence of God, Canale asserts that Bultmann's view that God is not an objective entity results from a radical application of the via negativa. Moreover,
}

this usage of the via negativa is required by the Kantian pattern of reason according to which entities as objects are cognitively constituted by the a priori concepts of the understanding. And, since these concepts apply only to what is given to the understanding through the forms of sensibility (phenomena), it follows that entities can only pertain to the phenomenal world of the Parmenidean doxa. In this context, it is obvious God, in his timeless transcendence, cannot belong to the phenomenal world. Therefore, God cannot be an entity, since entities are only temporal. Consquently, within the Kantian pattern for intelligibility, the via negativa is to be applied consistently even to the idea of entity which is to be denied as pertaining to God's being. In this way Bultmann expresses, briefly and clearly, the timeless dimensionality of God's being over against the temporality of secular reality (Ibid., 218-219). 
between each sacrament and the divine presence that justifies the three competing sacraments.

\section{Conflicting Architectural Styles}

Another area in which timeless Being leads to conflicting practices is in architecture. The Sacramental Model reveals the causal connection between the transubstantiated host, the central ornately decorated altar upon which the king is allegedly sacrificed, and the magnificent and grand basilicas that communicate transcendence. $^{98}$

The Kerygmatic Model uncovers the causal connection between the real presence in Scripture and the large central pulpits from which the Word is preached. The meetinghouses of the Kerygmatic Model are constructed in such a way that worshippers can hear the Word from various locations and their meetinghouses are modest and plain. ${ }^{99}$

The Charismatic Model reveals the causal connection between musical transubstantiation and the worship bands that occupy the central location. However, the lack of a causal connection between the inside and the outside of buildings explains why buildings in this model resemble Hindu temples, giant huts, and warehouse buildings. Moreover, under the influence of Dynamic Timeless Being, Emerging Churches blend transcendence and immanence by buildings that fuse together ancient cathedrals with more relational seating and contemporary architectural styles. ${ }^{100}$ Hence, timeless Being produces (1) a causal connection between the divine presence and architectural symbols,

\footnotetext{
${ }^{98}$ See this dissertation, 23-25, 121-122.

${ }^{99}$ See this dissertation, 159-162.

${ }^{100}$ See this dissertation, 192-193.
} 
(2) a dichotomy between the inside of buildings and the outside, and (3) blending between transcendent and immanent architectural elements.

\section{Conflicting Relationship between Divine}

Presence and Other Liturgical Actions

We will now explore the conflicting ways in which the divine presence relates to other ritual actions. In the Sacramental model there is a direct causal relationship between the divine presence via transubstantiation and the following ritual actions: Sunday worship; the whispered prayer of the presider during the prayer of consecration; the presider with his back to the people to preserve the sacredness of the mass; the content of the prayer that includes intercession for the dead and refreshment for souls in purgatory; the elevation of the host and chalice combined with the disinclination to receive the chalice for fear of spilling the blood of Christ; Latin as the liturgical language; and Gregorian chant as the standard in music. ${ }^{101}$ With respect to music, the closer it approaches to the chant the more universal, moral, and sacred it is. ${ }^{102}$ The concept of musical universals associated with the chant is entirely based on the Platonic and Aristotelian conception where the divine presence is conceived as being simple with no parts. Accordingly, the chant is monophonic.

However, under the influence of Dynamic Timeless Being, Vatican II blended the timeless and temporal in the following areas. The chant is now accompanied by the everchanging sounds of the music of all cultures, ${ }^{103}$ and the transcendent Latin language

\footnotetext{
${ }^{101}$ See this dissertation, 122-132.

${ }^{102}$ See this dissertation, 130-131.

${ }^{103}$ See this dissertation, 133-134.
} 
guided the translation into the vernacular. ${ }^{104}$ Dynamic Timeless Being produces a dichotomy between the mathematical basis of music and its sonorous qualities. ${ }^{105}$ Consequently, the morality of music as well as its universality and sacredness is restricted to the timeless mathematical basis of its sonorous qualities. Rhythm, melody, and harmony are thus not causally connected to morality, universality or sacredness; this ensures that the morality, universality, and sacredness of music that assumes Timeless Being can be engrafted into the music of all cultures. In addition, the mass is now celebrated with the presider facing the people, and the laity can now receive the bread and the wine. Hence, Timeless Being not only produces two conflicting views of the divine presence; it also leads to conflicting views on liturgical language, music, and rubrics.

In the Kerygmatic model, static timeless Being produces a dichotomy between the essential aspect of preaching justification by faith and the adiaphora, which includes the seven sacraments, medieval rites, the seventh day Sabbath, the mode of baptism, and musical style. ${ }^{106}$

The predominant characteristic of Pentecostal and Charismatic movements is music that mediates the Holy Spirit. ${ }^{107}$ While the Holy Spirit constitutes the form in Aristotle's form and matter philosophy, music constitutes the matter, expressed by all varieties of musical styles, though often featuring a predominance of rhythm. ${ }^{108}$ It is timeless Being that creates this dichotomy between the mediation of the Holy Spirit

\footnotetext{
${ }^{104}$ See this dissertation, 127-129.

${ }^{105}$ See this dissertation, 202-203.

${ }^{106}$ See this dissertation, 162-165.

${ }^{107}$ See this dissertation, 201.

${ }^{108}$ See this dissertation, 200-201.
} 
through the music of various styles.

Under the influence of Dynamic Timeless Being, Emergent music blends the chant, Taizé music, organ, and hymns with the many varieties of the earlier Pentecostal and charismatic music. Dynamic timeless Being also blends together sacraments and musical forms that were never a part of the Charismatic model's worship style. ${ }^{109}$

\section{Biblical Sanctuary Model}

I will now move to the hermeneutical role of God's infinite analogous temporal Being, the sanctuary, and the Sabbath as foundational presuppositions for the liturgical actions in the Biblical Sanctuary Model. We will specifically outline the role of the Sabbath and the sanctuary regarding the centrality of speech.

Sabbath and the Centrality of Speech

The following seven points illustrate the causal relationship between God's infinite analogous temporal Being, the Sabbath and the communication of God's Word as the central liturgical action. First, the words God spoke to Moses when he introduced himself as the I AM constitute the only vehicle capable of disclosing his presence, revealing a causal link between God's infinite analogous temporal Being and the communication of God's word as the central ritual action.

Second, God is invisible (1 Tim 1:17), the Sabbath is linked with the invisibility

of time (Gen 2:1-3) ${ }^{110}$, and preaching utilizes words and not material objects as the vehicle for revealing the divine presence. The invisibility of auditory communication thus

\footnotetext{
${ }^{109}$ See this dissertation, 201-203.

${ }^{110}$ See Jiř́ Moskala' "The Sabbath in the First Creation," Journal of the Adventist Theological Society 13 no. 1 (2002): 55-56.
} 
best represents his invisible presence.

Third, God's eternity is comprised of unending time (Exod 3:14-15), the Sabbath will continue into the eternal future (Isa 66:22-23), and God's words are eternal (Psalm $111: 7-9 ; 117: 2)$. As the I AM, his eternal past precedes creation, thereby pointing to the dissimilarity between his being and that of creation. Since God is infinitely more complex than nature, and since his presence is only revealed by his words, speech thus communicates much more information about the divine presence than creation ever can. For instance, Rom 1:20 only refers to revelation of his eternal power and divine existence, which has unfortunately been used to establish a natural theology that assumes Timeless Being's hermeneutical role in interpreting many of God's attributes on the basis of reflections about nature. ${ }^{111}$ Natural theology is an interpretive enterprise that humans perform, whereas general revelation is a revelatory activity of God in which he declares his infinite power and existence. ${ }^{112}$ Consequently, nature is extremely limited in what it can say about God, while his revelation in Scripture reveals the truth about the divine presence and all realities.

Fourth, the Sabbath is holy (Exod 20:8-11) and God's holy presence is revealed through his words (Exod 3:1-6), which also are holy (Jer 23:9; Rom 7:12).

Fifth, God is immutable (Mal 3:6), and as an immutable sign the Sabbath (Isa 66:22-23) reveals God's immutable nature and the world's immutable nature (Gen 1-2). God's words are also as immutable as his being (Psalm 89:34).

Sixth, the words, "And God said" in Gen 1 constitute the vehicle by which the

${ }^{111}$ See Fernando Canale, The Cognitive Principle of Christian Theology: A Hermeneutical Study of the Revelation and Inspiration of the Bible (Berrien Springs, MI: Andrews University Lithotech, 2005), 33-36.

${ }^{112}$ Ibid., (general revelation) 30-33; (natural theology) 33-34. 
world was created, of which the Sabbath is a reminder. This links the command to remember God's acts with speech (Exod 20:8-11).

Seventh, the Sabbath also reminds us of God's acts in salvation history (Deut 5:12-15). The multiplicity of issues and events connected with salvation history can best be remembered through speech.

These seven points possibly constitute the reasons for the close connection between Sabbath, preaching, and teaching in the NT. ${ }^{113}$ Thus, the Sabbath grounds the temporal relationship between God, all created realities, and the manifold complex interrelationships between them. As a result, the temporal nature of speech is the only effective means capable of bridging the gap between God and all created realities (ontological realities), their interrelationships, and our understanding of them (epistemology).

Sanctuary and the Centrality of Speech

The hermeneutical role of the heavenly sanctuary grounds the temporal relationship between the divine presence and the centrality of speech in the following ways. God said that he would place his name at the temple, which signified that he would reveal his presence in that location (2 Chron 20:8-9). The sacrificial service conducted in the wilderness sanctuary and later in Solomon's temple constituted a form of ritualized speech in which God's name was proclaimed. ${ }^{114}$

In Hebrews Christ speaks from heaven through the liturgical actions he performs

\footnotetext{
${ }^{113}$ For the close connection between Sabbath, preaching and teaching, see Mark 1:21; 6:2; Luke 4:16, 31; 6:6; 13:10; Acts 13:27, 42, 44; 15:21; 16:13; 17:2; 18:4.

${ }^{114}$ For the sacrificial service as ritualized speech in the OT, see this dissertation, 276277.
} 
therein (Heb 12:24) and worshippers on earth are exhorted to obey his word (Heb 12:25).

The author of Hebrews connected his authoritative proclamations with Christ's liturgical actions in the heavenly sanctuary. ${ }^{115}$ New Testament preaching was conducted in the synagogue, which was structurally and functionally related to the temple. ${ }^{116}$ The angel or elder of each of the seven churches in Rev 2-3 was to proclaim to the churches each message originated by Christ who was in the midst of the seven golden candlesticks of the heavenly temple (Rev $1: 10-13 ; 2: 1)$.

Moreover, the content of the scroll in Rev 5 is communicated to all the inhabitants on earth by preaching the everlasting gospel of the Three Angels Messages of Rev $14 .^{117}$ In the other Models there is a dichotomy between timeless truths/realities and the material and historical garb that convey them. However, the Biblical Sanctuary Model temporally integrates all the complex aspects of reality and their interrelationships with the divine presence, which is communicated through speech. This complex relationship between the divine presence and all of reality universalizes the content of Scripture which effectively renders groundless a culturally conditioned approach to Scripture in which universality only applies to timeless truths.

\footnotetext{
${ }^{115}$ In Heb 2:5 he states we speak of Christ being made a little lower than the angels for the suffering of death so that he could also become our high priest (Heb 2:14-17). Heb 5:11 states we have much to say about Christ as high priest after the order of Melchizedek. Heb 8:1 points that the main thing of which "we are saying" is that we have a high priest who ministers in the heavenly sanctuary. In Heb 9:5, the author speaks of cherubim of glory overshadowing the mercy seat.

${ }^{116}$ For the synagogue as the place of preaching in the NT, see this dissertation, 354 note 160 . For the structural and functional relationship of the synagogue to the temple, see this dissertation, 357-359.

${ }^{117}$ For the links between Rev 4-5 and Rev 14, see Table 1 and 2 of this dissertation.
} 
Sanctuary, the Holy Spirit and the

Centrality of Speech

There are several ways in which the heavenly sanctuary integrates the Holy Spirit with the centrality of speech. The groundwork for these connections is laid in the OT where it is the Holy Spirit that gifted the artisans to be able to construct the tabernacle of meeting with all the articles of furniture (Exod 31:1-11). It was also the Lord, the Holy Spirit who gave the plans to David so that Solomon could build the temple (1 Chr 28:12, 19). Since the temple is the place of God's presence, the ritualized speech conveyed by the sacrificial service is intricately linked to the Spirit who provided the plans for it.

There are three main ways in which John in the Revelation picks up the close association between the Holy Spirit, the sanctuary and speech. The first is through direct speech. We see this in Rev 1:10 where John is in the spirit on the Lord's day and hears a voice (Jesus) speaking to him from the midst of the seven golden candlesticks in the heavenly temple (Rev 1:10-19). Moreover, in each case where the phrase "in the spirit" (દ่ $\pi v \varepsilon v ́ \mu \alpha \tau \imath)$ is employed (Rev 1:10; 4:1-2;17:1-3; and 21:9-10), John hears a voice that speaks to him. This strengthens the close association between the Spirit and speech.

A second example of the Spirit's direct speech from the context of the Sanctuary comes from the conclusion of each message to the seven churches where the churches are admonished to hear what the Spirit says $(\lambda \dot{\varepsilon} \gamma \varepsilon \imath)$ to the churches (Rev 2:1, 7, 11, 17, 29; $3: 6,13,22)$.

A third example of direct speech from the heavenly sanctuary arises from the comparison of Rev 5:6 with the Three Angels Messages of Rev 14:6-12. In this comparison, Rev 14:13 (cf. Rom 10:4-8) reveals that the voice from heaven and the Spirit encourage those who preach the Three Angels Messages to rest from their labors. 
A fourth way in which the Spirit speaks from the context of the heavenly sanctuary is through the hymns sung by the four living creatures, the twenty-four elders, the vast angelic throng, and the entire universe found in Rev 4:8, 11, 5:9-10, 12, and 13 .

The second main way in which the Spirit speaks from the context of the sanctuary is when readers read what John wrote (Rev 1:11).

The third way in which the Spirit speaks is by revealing to John the heavenly sanctuary and the liturgical actions performed therein such as when John was in the spirit (Rev 4:2) and saw the wonderful scenes of the heavenly sanctuary contained in Rev 4-5 that he then wrote down for us. ${ }^{118}$ The sanctuary thus links the Spirit with the centrality of speech.

Sanctuary and Architecture

In the Biblical Sanctuary Model, the heavenly sanctuary constitutes the place from which heavenly liturgical activity occurs, thus functioning as the model and pattern (Heb 8:5) for liturgy on earth. As such, it serves to temporally ground the relationship between the architecture and geography of the heavenly sanctuary and all earthly places of liturgy. In the previous models it is the interpretation of the divine presence as transcendence and immanence that is directly related to architectural style whereas in the Biblical Sanctuary Model the ministry of the divine presence in the heavenly sanctuary serves as a model (Heb 8:5; 9:24). Accordingly, the heavenly sanctuary directly links liturgical space with very specific functions. It is this relationship between liturgical space and function that should guide the patterning of earthly structures. Table 5 compares the liturgical setting and actions among the four models.

\footnotetext{
${ }^{118}$ See this dissertation, 557-560.
} 
Table 5. Liturgical Setting and Actions

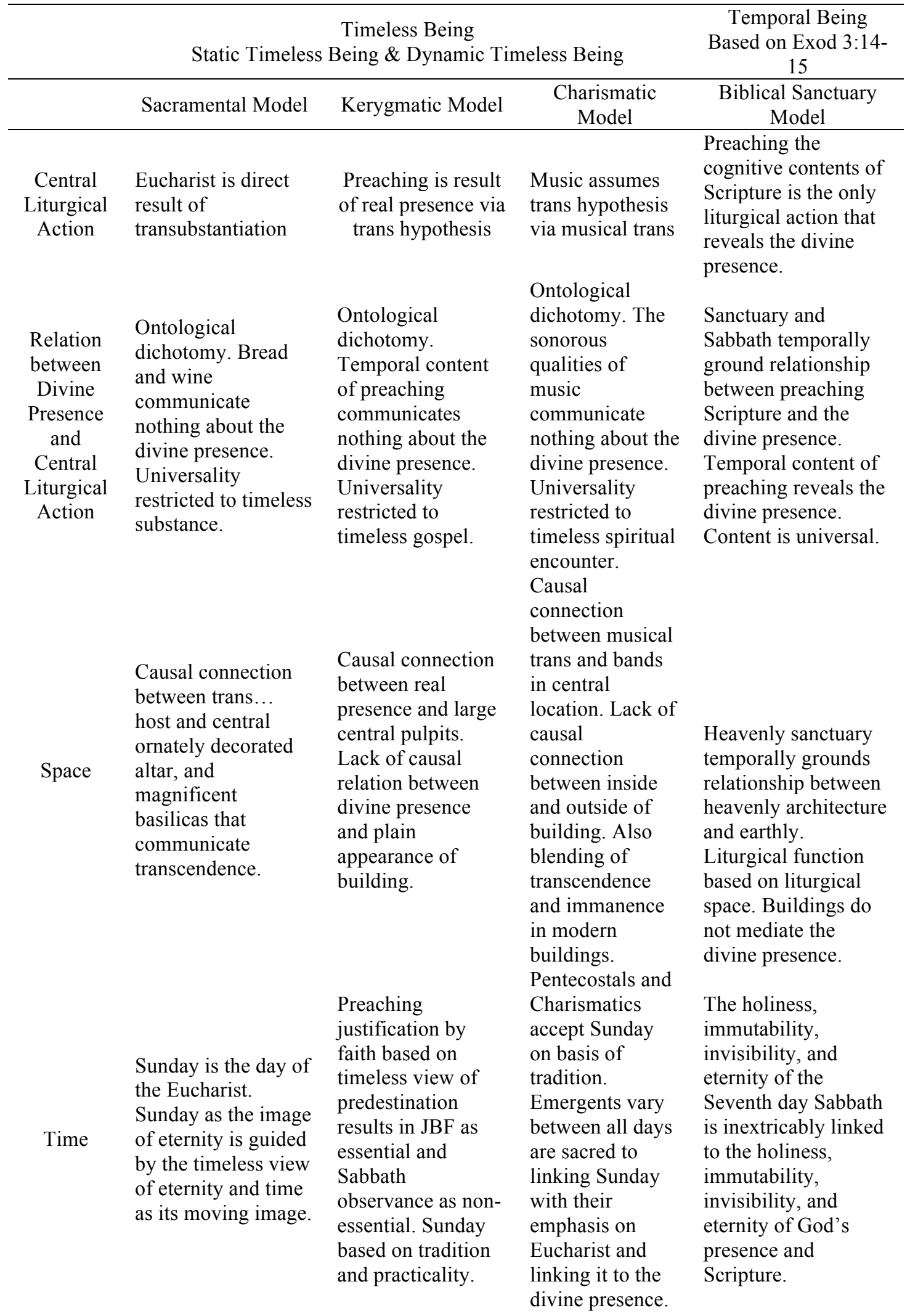


Table 5-Continued.

\begin{tabular}{|c|c|c|c|c|}
\hline & \multicolumn{3}{|c|}{$\begin{array}{c}\text { Timeless Being } \\
\text { Static Timeless Being \& Dynamic Timeless Being }\end{array}$} & \multirow{2}{*}{$\begin{array}{c}\text { Temporal Being } \\
\text { Based on Exod 3:14- } \\
15 \\
\text { Biblical Sanctuary } \\
\text { Model }\end{array}$} \\
\hline & Sacramental Model & Kerygmatic Model & $\begin{array}{l}\text { Charismatic } \\
\text { Model }\end{array}$ & \\
\hline $\begin{array}{l}\text { Other } \\
\text { Ritual } \\
\text { Actions }\end{array}$ & $\begin{array}{l}\text { Pre Vatican II: } \\
\text { Direct causal } \\
\text { relationship between } \\
\text { trans... host and } \\
\text { various liturgical } \\
\text { actions, and Latin as } \\
\text { liturgical language. } \\
\text { Vatican II: Latin } \\
\text { guides translation } \\
\text { into vernacular on } \\
\text { basis of Dynamic } \\
\text { Timeless Being. } \\
\text { Presider faces } \\
\text { people, laity now } \\
\text { receive bread and } \\
\text { wine. }\end{array}$ & $\begin{array}{l}\text { JBF is essential, } \\
\text { and the seven } \\
\text { sacraments, and } \\
\text { medieval rites are } \\
\text { non-essential. }\end{array}$ & $\begin{array}{l}\text { Emerging } \\
\text { Church: all } \\
\text { matter is } \\
\text { potentially } \\
\text { sacramental and } \\
\text { can be used since } \\
\text { it is infused with } \\
\text { the divine } \\
\text { presence. }\end{array}$ & $\begin{array}{l}\text { Sabbath and } \\
\text { Sanctuary temporally } \\
\text { grounds the } \\
\text { relationship between } \\
\text { divine presence and } \\
\text { all liturgical actions } \\
\text { (eg. prayer, baptism, } \\
\text { Lord's Supper, } \\
\text { ordination, etc...) }\end{array}$ \\
\hline Music & $\begin{array}{l}\text { Pre Vatican II: } \\
\text { causal connection } \\
\text { between Plato's } \\
\text { timeless world and } \\
\text { the chant as the } \\
\text { unchangeable } \\
\text { duplication of it. } \\
\text { Morality of music } \\
\text { depends on how } \\
\text { closely it adheres to } \\
\text { the chant. } \\
\text { Vatican II: timeless } \\
\text { math is sacred, } \\
\text { moral and universal. } \\
\text { Music of all cultures } \\
\text { is thus accepted } \\
\text { based on ontological } \\
\text { dichotomy between } \\
\text { mathematical basis } \\
\text { and sound. }\end{array}$ & $\begin{array}{l}\text { JBF is essential, } \\
\text { and musical style is } \\
\text { non-essential. } \\
\text { Implication is that } \\
\text { music is morally } \\
\text { neutral. }\end{array}$ & $\begin{array}{l}\text { Pentecostal and } \\
\text { Charismatic: } \\
\text { Timeless Being } \\
\text { manifests itself } \\
\text { in rock and its } \\
\text { derivatives with } \\
\text { a predominance } \\
\text { of rhythm. } \\
\text { Sounds of music } \\
\text { are morally } \\
\text { neutral } \\
\text { Emerging } \\
\text { Church: } \\
\text { Dynamic } \\
\text { Timeless Being } \\
\text { blends Taize } \\
\text { music, organ, } \\
\text { hymns, and all } \\
\text { varities of rock } \\
\text { and its } \\
\text { derivatives. } \\
\text { Morality } \\
\text { restricted to } \\
\text { mathematical } \\
\text { basis, not the } \\
\text { sounds. }\end{array}$ & $\begin{array}{l}\text { See appendix: } \\
\text { Choice of harp in } \\
\text { heavenly sanctuary } \\
\text { temporally grounds } \\
\text { relationship between } \\
\text { heavenly music and } \\
\text { creation. No } \\
\text { dichotomy between } \\
\text { math of music and its } \\
\text { sounds. } \\
\text { Melodic music } \\
\text { grounded in complex } \\
\text { harmony has } \\
\text { potential to be sacred } \\
\text { and moral. Context of } \\
\text { Rev } 5 \text { is universal. } \\
\text { No Scriptural basis } \\
\text { for the chant as moral } \\
\text { music or for morality } \\
\text { to be confined only to } \\
\text { math of music. }\end{array}$ \\
\hline
\end{tabular}




\section{Encounter}

As I now analyze the encounter, I will apply Kuhn's observations about paradigms and data to Being and the encounter in liturgy by first looking at how the Sacramental, Kerygmatic, and Charismatic Models differ with regard to (1) the place where the encounter occurs, (2) the means employed in abstracting the divine presence, (3) who the main divine person of the encounter refers to, and (4) the nature of the encounter.

\section{Sacramental, Kerygmatic, and Charismatic Models}

Conflicting Views Over the Place of the Encounter

In the Sacramental and Kerygmatic Models, and in the Emerging Church, the encounter occurs in the realm of reason, which is a timeless function of the soul. However, since the divine presence in the Emerging Church is ubiquitous, the encounter also occurs in the temporal aspects of the mind and body. In contrast, for Pentecostals and Charismatics, the encounter takes place in the realm of feeling, which after Kant is located in the timeless soul. ${ }^{119}$ Hence, Static Timeless Being creates a contradiction between reason and feeling as the place of the encounter while Dynamic Timeless Being allows for an encounter in timeless reason and in the temporal mind and body.

Conflicting Means Employed in Receiving the Encounter

The key ritual action in the Sacramental model is the Eucharist and the predominant means employed in receiving the divine presence from the Eucharist is

\footnotetext{
${ }^{119}$ See this dissertation, 166-168, 204-208.
} 
visual. The key ritual action in the Kerygmatic model is preaching and the predominant means employed in receiving the divine presence from preaching is auditory. The key ritual action in the Charismatic model is music, which functions as an auditory icon or sacrament. The predominant means employed in receiving the divine presence from the music is auditory. As a result, the ontological dichotomy between the timeless divine presence and the temporal human means of hearing and seeing that are employed to receive it into the timeless soul, leads directly to conflicting ways in which worshippers interpret the divine presence.

Conflicting Views of the Divine Person Received in the Encounter

In the Sacramental and Kerygmatic models, Christ is the divine presence that worshippers receive in the encounter. Moreover, the nature of the encounter is cognitive yet timeless. In the Charismatic model, the Holy Spirit constitutes the divine presence in the encounter.

\section{Conflicting View of the Nature of the} Encounter

For Pentecostals and charismatics the nature of the encounter is timeless but affective, meaning that it is non-cognitive. For Emergents the nature of the encounter is timeless and cognitive on the one hand, and temporal and affective on the other hand.

Interpretive Dissonance

Thus, timeless Being produces a conflict as to whether worshippers receive Christ or the Holy Spirit during the encounter. Moreover, regardless of whatever differences exist between Christ and the Holy Spirit, a timeless divine presence received into a 
timeless soul only allows for one divine being; yet, timeless Being provides two beings: namely, Christ and the Holy Spirit. Moreover, by switching the place where the encounter occurs from reason to feeling, static timeless Being produces a discrepancy as to whether the encounter is timeless and cognitive or timeless and affective. Under the influence of dynamic timeless Being, there is a discrepancy as to whether the encounter is timeless and cognitive or temporal and affective.

As we continue in our summary of the encounter, we will now move from the paradigm of Timeless Being to the heavenly sanctuary that temporally grounds the relationship between the divine presence and the angelic and human worshippers.

\section{Biblical Sanctuary Model}

We will specifically look at the following areas in the Biblical Sanctuary Model that are associated with the encounter: (1) the nature of the encounter, (2) the place of the encounter, and (3) God's Word and the encounter.

Sanctuary and the Nature of the Encounter

In the Biblical Sanctuary Model, the divine content of the message that integrates all aspects of reality is revealed through speech to the cognitive faculties of the worshippers whose hermeneutical minds are made up of imagination, creativity, reason, judgment and memory. ${ }^{120}$ Consequently, worshippers can interpret the divine content correctly or incorrectly; and even if they interpret it correctly, they are capable of refusing to obey it. Hence, they are active during the encounter. The universal nature of the cognitive encounter in the heavenly sanctuary provides the template for the temporal

\footnotetext{
${ }^{120}$ See this dissertation, 286-287.
} 
nature of the earthly encounter with the divine presence.

Sanctuary, Covenant, and the Place of the Encounter

When we apply the principle that temporal grounding integrates rather than dichotomizes the elements of human nature, we conclude that the faculties of worshippers are interrelated. Consequently, the command for worshippers to consecrate themselves is causally related to the holiness of God and to the manner in which worshippers receive and interpret the divine message. ${ }^{121}$ The covenant reveals that God's words constitute the vehicle by which he communicates his thoughts into the minds and hearts of the worshippers (Heb 8:10).

Sanctuary, Covenant, and the Encounter with God's Words Not His Being

The sanctuary and covenant setting ensures that the nature of the encounter is a cognitive one involving thought and language and not one in which worshippers experience the being of God in their human nature (Heb 8:10). The spiritual and intellectual understanding of the controversy over God's throne and his right to rule is foundational for a cognitive encounter. The leadership role of the twenty-four elders as worshippers (Rev 4:9-11; 5:8-10, 14) grounds the universal nature of the cognitive encounter that earthly worship should seek to emulate. Table 6 compares the encounter among the four models.

\section{Response to the Encounter}

As we keep in mind Kuhn's insights on paradigms and data, we will trace the

${ }^{121}$ See this dissertation, 270. 
hermeneutical role of Being in the response to the encounter in two main areas, the nature of the response and the connection between the response and the divine presence.

Table 6. Encounter

\begin{tabular}{|c|c|c|c|c|}
\hline & \multicolumn{3}{|c|}{$\begin{array}{c}\text { Timeless Being } \\
\text { Static Timeless Being \& Dynamic Timeless Being }\end{array}$} & $\begin{array}{c}\text { Temporal Being } \\
\text { Based on Exod 3:14- } \\
15\end{array}$ \\
\hline Models & Sacramental Model & $\begin{array}{l}\text { Kerygmatic } \\
\text { Model }\end{array}$ & $\begin{array}{c}\text { Charismatic } \\
\text { Model }\end{array}$ & $\begin{array}{c}\text { Biblical Sanctuary } \\
\text { Model }\end{array}$ \\
\hline $\begin{array}{l}\text { Place of } \\
\text { Encounter }\end{array}$ & Timeless reason & Timeless reason & $\begin{array}{l}\text { Pentecostal \& } \\
\text { Charismatic: } \\
\text { Timeless Feeling } \\
\text { Emerging Church: } \\
\text { Timeless reason } \\
\text { and temporal mind } \\
\text { and body }\end{array}$ & $\begin{array}{l}\text { Sanctuary and } \\
\text { covenant point to the } \\
\text { mind and heart. } \\
\text { Hermeneutical mind } \\
\text { that integrates all } \\
\text { cognitive components }\end{array}$ \\
\hline $\begin{array}{l}\text { Means of } \\
\text { receiving } \\
\text { Divine } \\
\text { Presence }\end{array}$ & $\begin{array}{l}\text { Visual - based on } \\
\text { Eucharist }\end{array}$ & $\begin{array}{l}\text { Auditory - based } \\
\text { on preaching }\end{array}$ & $\begin{array}{l}\text { Auditory - based } \\
\text { on music }\end{array}$ & $\begin{array}{l}\text { Auditory based on } \\
\text { preaching }\end{array}$ \\
\hline $\begin{array}{l}\text { Divine } \\
\text { Presence } \\
\text { Received } \\
\text { in the } \\
\text { Encounter }\end{array}$ & Jesus Christ & Jesus Christ & Holy Spirit & $\begin{array}{l}\text { Only the words of } \\
\text { God are received in } \\
\text { the encounter, not the } \\
\text { being of God. }\end{array}$ \\
\hline $\begin{array}{l}\text { Nature of } \\
\text { the } \\
\text { Encounter }\end{array}$ & Cognitive yet timeless & $\begin{array}{l}\text { Cognitive yet } \\
\text { timeless }\end{array}$ & $\begin{array}{l}\text { Pentecostals \& } \\
\text { Charismatics: } \\
\text { Affective, non- } \\
\text { cognitive and } \\
\text { timeless } \\
\text { Emerging Church: } \\
\text { Cognitive yet } \\
\text { timeless; and } \\
\text { temporal and } \\
\text { affective }\end{array}$ & $\begin{array}{l}\text { Cognitive temporal } \\
\text { with divine presence } \\
\text { See appendix: With } \\
\text { music: mental yet } \\
\text { mediates creation, and } \\
\text { affective. } \\
\text { Affective grounded in } \\
\text { mental on basis of } \\
\text { melody and harmony }\end{array}$ \\
\hline
\end{tabular}

\section{Sacramental, Kerygmatic, and Charismatic Models}

As the efficient cause in the Sacramental, Kerygmatic, and Charismatic Models, the divine presence produces two kinds of passive responses. 


\section{Passive Response}

I will refer to the first as a non-response. The reason behind this classification is that after the encounter the only effect on the worshipper is that participating in the Eucharist has now healed original sin. ${ }^{122}$ Moreover, worshippers neither contemplate the divine presence nor appear to respond in any visible way to the encounter. In this setting the transubstantiated host causes certain ritual actions that only produce a passive response. $^{123}$

Conflicting Active Responses that are Passive

The second kind of passive response gives the appearance of an active response but in reality is passive since the divine presence and not the worshipper is the cause of it. All three models produce these kinds of active responses that we can categorize as cognitive, affective, and kinesthetic.

Cognitive responses involve all three models and include contemplation of the divine presence, understanding the message, giving praise to God, making decisions and overthrowing error. A cognitive response is also caused by the divine presence when worshippers abstract it from the material and historical vehicles that convey it. ${ }^{124}$ This means that value judgments are only moral when worshippers respond to the abstracted divine presence. In other words, one can have a moral response to the divine presence in the Eucharist but not necessarily to the wine and the bread. Similarly, one can have a moral judgment concerning the timeless divine presence in the Scripture, but not to the

${ }^{122}$ ST Part III Q49 Art 5.

${ }^{123}$ See this dissertation, $142-144$.

${ }^{124}$ See the response to the encounter for each of the three models in Chapter 4 of this dissertation. 
history, narratives, and statements on origins. Moreover, a moral judgment with music is limited to the scope of the divine presence that is linked to the inaudible mathematics of music, but not to its rhythm, melody, and harmony. Hence, judgments concerning the material and historical aspects of the Eucharist, preaching, and music are considered cultural judgments that are not universal in scope. The basis for this deduction lies in the ontological distinction between the timeless divine presence and the particular sacrament in which it is embedded.

Affective responses, of which speaking in tongues is the most characteristic, only apply to the Pentecostal and charismatic movements while kinesthetic responses mainly apply to the Pentecostal and charismatic movements and to the Sacramental model. Since the Holy Spirit is the cause of liturgy in the Charismatic Model, the affective and kinesthetic responses are thus still passive even though they appear to be active. In the pre-Vatican II Sacramental Model, the responses of the worshippers were truly passive since they were merely present during the encounter. Timeless Being produces an ontological dichotomy between the timeless non-cognitive affective encounter and the wide varieties of affective and kinesthetic responses to that encounter. Hence, there is no causal connection between a timeless non-cognitive affective encounter and responses such as such as clapping, swaying, dancing, applause as a praise offering, raising hands, joining hands in prayer, extending hands towards those in need, bowing, kneeling, standing and sitting. Other bodily manifestations include falling to the floor under the power of the Spirit, walking around in a trance-like state, laughing uncontrollably, 
behaving as if drunk, and even imitating the noises of certain animals. ${ }^{125}$

Thus, in summary, Timeless Being causes a passive non-response, a contemplative response, and a wide range of affective and kinesthetic responses. The worshippers that respond with a wide variety of affective and kinesthetic responses are the instrumental causes of their response while the divine presence in the sacrament is the efficient cause of the response. Furthermore, during the encounter, it is timeless aspect of the sacrament that is mediated to the timeless soul of the worshipper. This creates a dichotomy between the timeless non-cognitive encounter and the manifold ways in which each worshipper can express the encounter.

\section{Biblical Sanctuary Model}

As we now move to the Biblical Sanctuary Model, we will summarize how the heavenly sanctuary temporally grounds the relationship between the divine presence revealed through speech as the central liturgical action and the response to the encounter.

Active and Varied Responses

Responses in this model are all based on the cognitive nature of the encounter and include verbal, kinesthetic, affective, mental assent, social, evangelistic, and ethical aspects. ${ }^{126}$ The heavenly sanctuary temporally grounds the relationship between the

\section{dissertation.}

${ }^{125}$ See the response to the encounter in the Charismatic Model in Chapter 4 of this

${ }^{126}$ Verbal responses are of two categories. The first of these constitutes a dialogue made in response to a message heard, as in the case of Moses at the burning bush (Exod 3), or Isaiah's response, "Woe is me" (Isa 6:5). The second category of responses is liturgical responses, such as singing praises to God's name and saying Amen (2 Chron 7:3; Rev 4:11; 5:12-14). Kinesthetic responses include fear and trembling (Exod 20:18), drawing near to God (Exod 20:21), sacrificing peace offerings (1 Kings 8:62-63), worshippers bowing their faces to the ground (2 Chron 7:3), standing in his presence (2 Chron 7:4-6), rejecting the message by attempting to kill the messenger (Luke 4:22,29), being baptized (Acts 2:41), 
divine presence that is revealed by speech as the central liturgical action and the verbal, kinesthetic, affective, social, evangelistic, and ethical responses of the worshippers. The author of Hebrews exhorts Christians of all ages to obedience by saying, "See that you do not refuse Him who speaks" (Heb 12:24). The heavenly sanctuary renders groundless the ontological dichotomy between the divine presence and the response. As a result, there is a causal connection between the message revealing the divine presence and the response to the encounter.

Active Responses and Integrated View of Human Nature

The heavenly sanctuary setting temporally grounds the relationship between the divine presence and the integrated view of human nature. Hence, the varieties of responses reveal that the mental, spiritual, physical, and social aspects of human beings are integrated rather than dichotomized. Moreover, although understanding the message is foundational for the goal of liturgy, this aim will not be achieved if the response does not include all of the faculties that belong to a biblical view of human nature. The variety of responses mentioned above are all hermeneutically guided by the sanctuary that temporally grounds the relationship between the divine presence revealed in the message and the responses. ${ }^{127}$

and prostrating oneself before God and casting crowns at his throne (Rev 4:10). Affective responses include gladly receiving the message (Acts 2:41), eating with gladness (Acts 2:4647), and being thankful (Heb 12:28-29). Mental responses include accepting the apostles' teaching (Acts 2:42). Social responses include breaking of bread and fellowship (Acts 2:42), drawing together into closer unity (Acts 2:46). Evangelistic responses include going from house to house (Acts 2:42-46-47) and continuing in the apostles' teaching. Ethical responses include reverence and service, not just in the immediate context of liturgy but in all aspects of life, which should be grounded in God's law; they also include doing good and sharing with those in need and reverencing his word (Acts 2:44-45; Heb 12:28-29).

${ }^{127}$ See this dissertation, 392-398. 


\section{Response as Universal Moral Judgment}

In the Biblical Sanctuary Model, moral judgments as responses to the encounter include the complex interrelationships between the divine presence, and angelic and human worshippers throughout heaven and earth. Since morality is based on the immutability of moral and natural laws, one can make judgments on what Scripture reveals about the manifold ways in which God relates with all of his creation.

As liturgists and worshippers in the heavenly sanctuary, the four living creatures and the twenty-four elders respond by singing with harp accompaniment. This leadership function gives the universal pattern for worship responses, resulting in the vast angelic throng responding with singing "Worthy is the Lamb" (Rev 5:12-13). These universal responses provide the pattern for the human response here on earth. Moreover, earthly worshippers can evaluate how closely earthly musical characteristics emulate the heavenly characteristics. Table 7 compares the response to the encounter among the four models.

\section{Biblical Search for Unity}

We will again apply Kuhn's observations on paradigms and data to the various ways in which Being interprets the biblical search for unity among all the Models by first beginning with the Sacramental, Kerygmatic, and Charismatic Models.

\section{Sacramental, Kerygmatic, and Charismatic Models}

The Sacramental model has produced two conflicting definitions of unity. In the pre-Vatican II era, unity was defined as complete uniformity while in the post-Vatican II era unity is defined as unity in essentials and diversity or pluralism in non-essentials. 


\section{Unity as Uniformity}

The basis for defining unity as uniformity lies in Plato's two world's theory in which history and the material world constitute the near perfect duplication of the timeless Forms. Consequently, data in the historical and material world that are not directly caused by the heavenly world are anomalous, impossible, and call into question

Table 7. Response to the Encounter

\begin{tabular}{|c|c|c|c|c|}
\hline & \multicolumn{3}{|c|}{$\begin{array}{c}\text { Timeless Being } \\
\text { Static Timeless Being \& Dynamic Timeless Being }\end{array}$} & \multirow{2}{*}{$\begin{array}{c}\text { Temporal Being } \\
\text { Based on Exod 3:14-15 } \\
\text { Biblical Sanctuary } \\
\text { Model } \\
\end{array}$} \\
\hline Models & Sacramental Model & $\begin{array}{l}\text { Kerygmatic } \\
\text { Model }\end{array}$ & Charismatic Model & \\
\hline $\begin{array}{l}\text { Nature of } \\
\text { the } \\
\text { Response }\end{array}$ & $\begin{array}{l}\text { Trans...host causes } \\
\text { ritual actions that } \\
\text { lead to passive } \\
\text { non-response. } \\
\text { Also, cognitive } \\
\text { response appears } \\
\text { active but is } \\
\text { passive. }\end{array}$ & $\begin{array}{l}\text { Cognitive } \\
\text { response appears } \\
\text { active but is } \\
\text { passive. }\end{array}$ & $\begin{array}{l}\text { Pentecostal \& } \\
\text { Charismatic: } \\
\text { Affective \& } \\
\text { kinesthetic. } \\
\text { Appears active but } \\
\text { passive. } \\
\text { Emerging Church: } \\
\text { Cognitive response } \\
\text { appears active but } \\
\text { is passive. Also } \\
\text { affective and } \\
\text { kinesthetic. }\end{array}$ & $\begin{array}{l}\text { Cognitive encounter is } \\
\text { foundational for verbal, } \\
\text { kinesthetic, affective, } \\
\text { mental assent, social, } \\
\text { evangelistic, and ethical } \\
\text { responses. Some of } \\
\text { these responses occur } \\
\text { during the worship } \\
\text { event but others occur } \\
\text { in life situations after } \\
\text { the worship event. }\end{array}$ \\
\hline $\begin{array}{l}\text { Relation } \\
\text { to Divine } \\
\text { Presence }\end{array}$ & $\begin{array}{l}\text { Causally related to } \\
\text { the divine presence }\end{array}$ & $\begin{array}{l}\text { Causally related } \\
\text { to the divine } \\
\text { presence }\end{array}$ & $\begin{array}{l}\text { Pentecostal \& } \\
\text { Charismatic: No } \\
\text { causal relationship } \\
\text { to divine presence } \\
\text { Emerging Church: } \\
\text { No causal } \\
\text { relationship and } \\
\text { causal relationship }\end{array}$ & $\begin{array}{l}\text { Heavenly sanctuary } \\
\text { temporally grounds } \\
\text { relationship between } \\
\text { content of message, } \\
\text { integrated human } \\
\text { nature, and the varied } \\
\text { responses. Music is a } \\
\text { response here and not } \\
\text { the cause of the } \\
\text { response. Thus } \\
\text { responses are causally } \\
\text { related to divine } \\
\text { presence. }\end{array}$ \\
\hline $\begin{array}{l}\text { Moral } \\
\text { Judgment } \\
\quad \text { as } \\
\text { Response } \\
\end{array}$ & $\begin{array}{l}\text { Applies only to } \\
\text { abstracted divine } \\
\text { presence from } \\
\text { Eucharist }\end{array}$ & $\begin{array}{l}\text { Applies only to } \\
\text { abstracted divine } \\
\text { presence from } \\
\text { Scripture }\end{array}$ & $\begin{array}{l}\text { Applies only to } \\
\text { abstracted divine } \\
\text { presence (math) } \\
\text { from music }\end{array}$ & $\begin{array}{l}\text { Moral judgments can } \\
\text { apply to all aspects of } \\
\text { reality including music } \\
\text { (see appendix) }\end{array}$ \\
\hline
\end{tabular}


the entire Platonic framework. Similarly, the unchanging nature and practice of the Roman and Tridentine rites and the use of Latin and Gregorian chant constitute the near perfect duplication on earth of the timeless Forms in Plato's heavenly world. At one point, they could not be abandoned without overturning the foundations of the Sacramental model. This might explain why they were left unchanged for centuries. ${ }^{128}$

Unity in Essentials and Diversity in Non-Essentials: Sacramental Model

In the post-Vatican II era, ecumenism became the main motivational force for the Sacramental model to expand to a worldwide context. Consequently, this called for a change in the definition of unity to unity in essentials and diversity or pluralism in nonessentials. The philosophical basis for this new definition of unity lies in the ontological distinction between the timeless and the temporal found in Aristotle's philosophy, Neoplatonism, and panentheism.

In this post-Vatican II definition of unity, the unconditional acceptance of the Eucharist as the sacrament of unity is inextricably linked with the following nonnegotiable essentials: transubstantiation as the basis for defining the real presence in the Eucharist, the role of timeless Being and Tradition in interpreting Scripture and in providing the basis for the intercessory role of Mary, and the infallible teaching authority of the Pope and the magisterium.

The non-essentials are, for instance, musical style, architecture, art, and the mode of baptism. Hence, in the post-Vatican II definition of unity, the essentials are timeless, immutable and theological while the non-essentials are aesthetic, cultural, sociological

\footnotetext{
${ }^{128}$ See this dissertation, $145-146$.
} 
and changeable. This ontological dichotomy between the timeless and the temporal is in conflict with the pre-Vatican II view of unity that posits a direct causal connection between the timeless forms and the earthly duplication of them. ${ }^{129}$

Unity in Essentials and Diversity in

Non-Essentials: Kerygmatic Model

The Kerygmatic model posits that preaching justification by faith constitutes the basis for unity in Christendom. Since the real presence assumes the transubstantiation hypothesis, unity in this model assumes that preaching may be viewed as the earthly duplication of the timeless real presence. However, in declaring the preaching of justification by faith as essential and the adiaphora as non-essential during the adiaphoristic controversy, the Kerygmatic model also subscribes to the definition of unity as unity in essentials and diversity or pluralism in non-essentials. ${ }^{130}$ Thus, the Kerygmatic model shares the post Vatican II definition of unity as unity in essentials and diversity in non-essentials.

Moreover, with respect to justification by faith as the essential component of unity in the Kerygmatic Model, the uncritical acceptance of timeless Being's interpretation of the divine presence and human nature forms the foundation for why the adherents of this model differ sharply on whether God causes the faith in justification that humans experience or whether the human agent is the cause. ${ }^{131}$ Also with respect to the non-essentials there is a conflict as to whether the Lord's Supper constitutes the real

\footnotetext{
${ }^{129}$ See this dissertation, 146-150.

${ }^{130}$ See this dissertation, 162-165.

${ }^{131}$ See this dissertation, 172-173.
} 
presence or a memorial; and there are conflicting modes of baptism. ${ }^{132}$

There are two main factors that hinder the Kerygmatic Model from achieving unity in Christendom. The first is that critics such Horton Davies assert that preaching has not unified Christendom. Instead, he states that preaching has "accelerated the momentum towards splintering so characteristic of the history of Protestantism."133

The second factor that undermines the role of preaching as the means of unity is that the sacramental view of the Word effectively eliminates preaching as the only vehicle of the divine presence by creating an opening for this model to accept the agenda of the Liturgical and Ecumenical movements. The purpose of this agenda is to achieve unity by exalting the Eucharist and denigrating preaching. Consequently, by failing to apply the Sola Scriptura principle to preaching as well as to the other liturgical components, the Kerygmatic model has allowed the hermeneutical role of timeless Being to place the Eucharist alongside preaching as the prerequisite for unity in Christendom. This effectively places in jeopardy its own existence as a model. ${ }^{134}$

Unity in Essentials and Diversity in Non-Essentials: Charismatic Model

The definition of unity to which the Charismatic model formally adheres is unity within diversity. In this definition the Spirit constitutes the divine presence, which is embedded and connected to a plurality of cultures and denominations, as well as a plurality of doctrinal beliefs, musical styles, and responses to the encounter. The ontological dichotomy between the Spirit and the aforementioned items justifies and

\footnotetext{
${ }^{132}$ See this dissertation, 173-177.

${ }^{133}$ Davies, The Ecumenical Century, 433.

${ }^{134}$ See this dissertation, 178-190.
} 
explains how unity in diversity functions in the Charismatic model. ${ }^{135}$

Moreover, although music has played the central role in the Charismatic model, the growing acknowledgment of the real presence in the Lord's Supper has led some Pentecostals to recommend a more frequent celebration of the Eucharist as well as to make it more central to worship. Emergents also believe that the Eucharist does a better job in meeting the intellectual and affective needs of worshippers whereas music only seems to meet their affective needs. ${ }^{136}$ Hence, just as preaching needed to be supplemented with the Eucharist to achieve unity, the hermeneutical role of timeless Being also points to the insufficiency of music in and of itself to achieve unity in Christendom unless it is combined with the Eucharist.

\section{Disunity and Confusion}

In summary, there are two contradictory definitions of unity that have their basis in Timeless Being. The first is that unity is uniformity and the second definition is unity in essentials and diversity or pluralism in non-essentials. The first definition is grounded in Platonic duplication and only utilized by the pre-Vatican II Sacramental model and the second assumes the ontological gap between the timeless and the temporal, which we find in the post-Vatican II Sacramental model as well as the other models. Each of the three models differs on what they consider to be the essential sacrament that will prove to be indispensible for unity; and they differ on the non-essentials. Moreover, by including the Eucharist in their liturgies, the Kerygmatic and Charismatic models have placed their existence in jeopardy.

\footnotetext{
${ }^{135}$ See this dissertation, 214-215.

${ }^{136}$ See this dissertation, 215-217.
} 


\section{Biblical Sanctuary Model}

As we now move to the Biblical Sanctuary Model, we will consider the hermeneutical role of God's infinite analogous temporal Being and the heavenly sanctuary as the presuppositions for a definition and search for unity.

Heavenly Sanctuary as Ground for Establishing Unity

The passage in Exod 3:14-15 reveals that God's infinite analogous temporal Being is absolutely foundational for the centrality of preaching the Scriptures as the means of achieving unity since his words constitute the only vehicle of revealing his

presence and his will. ${ }^{137}$ Furthermore, since the heavenly sanctuary is the location where God reveals his presence by placing his name there, all liturgy conducted on earth and in heaven is ultimately oriented toward it. ${ }^{138}$ Consequently, along with God's Being, the heavenly sanctuary plays a large hermeneutical role in the search for unity in the Biblical Sanctuary Model. This study will now outline the ways in which the hermeneutical role of the heavenly sanctuary is indispensible for unity.

\section{Heavenly Sanctuary Unites Heaven and} Earth

First, the heavenly sanctuary temporally grounds the relationship between all of heaven and earth, ${ }^{139}$ which obliterates the ontological dichotomy between a timeless heaven and a temporal earth that became the template for the other models.

Consequently, as the central place of liturgy the heavenly sanctuary expands the scope of

\footnotetext{
${ }^{137}$ See this dissertation, 262-263.

${ }^{138}$ See this dissertation, 272-274, 280-282.

${ }^{139}$ See this dissertation, 350-352, 390-391, 397-398.
} 
unity to a universal level that embraces all of heaven and earth as well as all time instead of limiting the application of unity to a certain time, a certain geographical location or even all of earth.

Heavenly Sanctuary Integrates Divine Presence with All Created Realities

Second, in the other Models, the basis of unity and its meaning derives from a timeless and spaceless divine presence that fails to integrate reality but rather creates dichotomies that result in conflicting ways in which those Models express unity. In the Biblical Sanctuary Model, God's word reveals that all aspects of reality are integrated with the divine presence on the basis of immutable laws that govern all things. ${ }^{140}$ As a result, the meaning of unity applies to the complex integrated relationships between the divine presence and all realities throughout heaven and earth revealed by God's word.

Heavenly Sanctuary Unites All Liturgists in Task of Ministering the Word

Third, the heavenly sanctuary temporally grounds the relationship between the divine, angelic and human liturgists that are all connected to the centrality of preaching. ${ }^{141}$ Christ as liturgist speaks from heaven (Heb 12:24), the angels are liturgists who assist in speaking God's words (Heb 1:7, 14; Isa 6:7), and the Holy Spirit speaks by first revealing to the biblical authors Christ's liturgical actions and messages from the context of the heavenly sanctuary $(\operatorname{Heb} 9: 8 ; \operatorname{Rev} 2: 1,8,12,18 ; 3: 1,7,14)$ that are then

\footnotetext{
${ }^{140} \mathrm{I}$ am here employing the strong connection between the sanctuary and the covenant that was uncovered in this dissertation, 242 note 88 . Within this structure the sanctuary is connected to the divine presence and all aspects of reality, yet the divine law that is the basis of the covenant reveals the specific principles that govern the ways in which the divine presence relates to all of reality.
}

${ }^{141}$ See this dissertation, 339-341. 
written in Scripture. The Holy Spirit then speaks by illuminating the mind of the liturgist who reads those bible passages before preaching the content to the worshippers on earth. As the liturgists preach, worshippers are admonished to listen to the what the Holy Spirit says $(\lambda \dot{\varepsilon} \gamma \varepsilon 1)$ to the churches $(\operatorname{Rev} 2: 7,11,17,29 ; 3: 6,13,22)$. Hence, all Divine, angelic, and human liturgists cooperate together in ministering the word to worshippers.

Heavenly Sanctuary Unites Time and Place

Fourth, since God's infinite analogous temporal Being, the sanctuary, and the Sabbath are all linked together; the heavenly sanctuary provides the one place to which all worshippers approach (Heb 12:22-25), while the Sabbath provides the time when worshippers gather together (Heb 4:9). Moreover, while the visible presence of Father and Son is located in the heavenly sanctuary (Acts 2:33; Heb 12:22-24; Rev 5) and is associated with God speaking from heaven, the invisible omnipresence of the Holy Spirit is revealed on earth through human liturgists who preach God's words (Rev 5:6; 14:6-12, $13)$.

Heavenly Sanctuary and Encounter with God's Word

Fifth, the sanctuary and the new covenant context point to a cognitive and relational encounter through the application of God's words to the minds and hearts of the worshippers (Heb 8:10). The worshipper does not receive the being of God in human nature. The goal of the encounter is to reveal God's presence and will through an understanding of Scripture. As a result, establishing meaning and understanding in the mind of the worshipper is foundational for all other responses that were covered in this Model since they are causally connected to the divine presence. 
Heavenly Sanctuary and Response to the Word

Sixth, the heavenly sanctuary temporally grounds the relationship between the divine presence and the response of the worshippers. This ensures a non-determined and free response that applies to all humans everywhere, as well as to angelic worshippers. Even though there are a variety of responses that appeal to the integrated nature of the mental, physical, spiritual and social aspects of the worshipper, the temporal relationship between the divine presence and the worshipper ensures that the specific content communicated in the encounter is intended to produce specific responses in the worshippers. The response is thus causally related to the specific content revealed through the revelation of God's words leading to a varied but unified response.

Heavenly Sanctuary and Liturgical Authority

Seventh, liturgical authority is grounded in the One who is seated on the throne. In the heavenly sanctuary context, the Holy Spirit exercises his authority to set aside human liturgists (Acts 13:2) in cooperation with the One seated on the throne and with the Lamb who sent him (Rev 4-5). Moreover, since the central throne is synonymous with the Ark of the Covenant, the law contained in the Ark provides the ultimate authority for all liturgists in heaven and on earth. Hence, liturgical authority is grounded in the One seated on the throne, in the Lamb, and in the immutable law. ${ }^{142}$

\section{Heavenly Sanctuary: Ground for True} Unity in Diversity

In light of the foregoing points, the Biblical Sanctuary Model's definition of unity

\footnotetext{
${ }^{142}$ See this dissertation, 336-337, 343-344, 352-354.
} 
is unity in diversity. However, it differs from the previous Models that share the same definition in that it integrates all reality with the divine presence whereas the others distinguish between essential and non-essential liturgical components. Moreover, the divine presence hermeneutically shapes all of the issues that surround the liturgist, the liturgical actions, the nature of the encounter, and the response to the encounter. Table 8 compares the ecumenical search for unity among the four models.

\section{Conclusion}

The massive hermeneutical role of timeless Being on the interpretation of the liturgical components and the ecumenical search for unity in the Sacramental, Kerygmatic, and Charismatic models can hardly be overemphasized. The Sacramental model's intentional use of timeless Being provided the matrix from which to interpret all of the liturgical components, including the definitions of unity for the ecumenical search for unity. Specifically, the transubstantiation dogma for the divine presence was paramount in establishing this matrix that exercised a controlling influence on how each model interpreted the divine presence, and then the rest of the components.

The Sacramental model was thus able to dominate by providing the theological meaning for all of the components, while at the same time rendering the central ritual actions of preaching and music as insufficient in providing the basis for worship and unity in Christendom when compared to the Eucharist. Although the Kerygmatic model began turning to Scripture, its failure to deconstruct the massive hermeneutical role of timeless Being and to construct its interpretation of the liturgical components on the basis of Scripture ensured that it, along with the Charismatic model, would be trapped inside the matrix of meaning provided by the Sacramental model. 
Table 8. Ecumenical Search for Unity

\begin{tabular}{|c|c|c|c|c|}
\hline & \multicolumn{3}{|c|}{$\begin{array}{c}\text { Timeless Being } \\
\text { Static Timeless Being \& Dynamic Timeless Being }\end{array}$} & $\begin{array}{c}\text { Temporal Being } \\
\text { Based on Exod 3:14- } \\
15\end{array}$ \\
\hline & Sacramental Model & $\begin{array}{l}\text { Kerygmatic } \\
\text { Model }\end{array}$ & $\begin{array}{l}\text { Charismatic } \\
\text { Model }\end{array}$ & $\begin{array}{l}\text { Biblical Sanctuary } \\
\text { Model }\end{array}$ \\
\hline $\begin{array}{l}\text { Definition } \\
\text { of Unity }\end{array}$ & $\begin{array}{l}\text { Pre-Vatican II: Unity } \\
\text { is uniformity } \\
\text { Vatican II: Unity in } \\
\text { essentials and } \\
\text { diversity in non- } \\
\text { essentials }\end{array}$ & $\begin{array}{l}\text { Unity in } \\
\text { essentials and } \\
\text { diversity in non- } \\
\text { essentials }\end{array}$ & $\begin{array}{l}\text { Unity in essentials } \\
\text { and diversity in } \\
\text { non-essentials }\end{array}$ & $\begin{array}{l}\text { Unity in diversity: } \\
\text { Everything is } \\
\text { essential }\end{array}$ \\
\hline $\begin{array}{l}\text { Basis of } \\
\text { Definition }\end{array}$ & $\begin{array}{l}\text { Pre-Vatican II: } \\
\text { Platonic duplication } \\
\text { Vatican II: ontological } \\
\text { dichotomy between } \\
\text { timeless and temporal }\end{array}$ & $\begin{array}{l}\text { ontological } \\
\text { dichotomy } \\
\text { between timeless } \\
\text { and temporal }\end{array}$ & $\begin{array}{l}\text { ontological } \\
\text { dichotomy } \\
\text { between timeless } \\
\text { and temporal }\end{array}$ & $\begin{array}{l}\text { Heavenly sanctuary } \\
\text { temporally grounds } \\
\text { divine presence and } \\
\text { all reality on the } \\
\text { basis of immutable } \\
\text { laws. No ontological } \\
\text { dichotomies. }\end{array}$ \\
\hline Essentials & Eucharist & Preaching & Music & $\begin{array}{l}\text { Preaching } \\
\text { Heavenly sanctuary } \\
\text { as the place Sabbath } \\
\text { as the time }\end{array}$ \\
\hline $\begin{array}{c}\text { Non- } \\
\text { Essentials }\end{array}$ & $\begin{array}{l}\text { Pre-Vatican II: } \\
\text { Everything is essential } \\
\text { Vatican II: musical } \\
\text { style, architecture, art, } \\
\text { mode of baptism }\end{array}$ & $\begin{array}{l}\text { The adiaphora: } \\
\text { sacraments, } \\
\text { medieval rites, } \\
\text { Sabbath }\end{array}$ & $\begin{array}{l}\text { All musical styles } \\
\text { within this model, } \\
\text { architecture, day } \\
\text { of worship }\end{array}$ & $\begin{array}{l}\text { All is essential since } \\
\text { there are no } \\
\text { ontological } \\
\text { dichotomies }\end{array}$ \\
\hline $\begin{array}{l}\text { Scope of } \\
\text { Unity }\end{array}$ & $\begin{array}{l}\text { Pre-Vatican II: limited } \\
\text { to Western Europe } \\
\text { Vatican II: Universal } \\
\text { but no mention of } \\
\text { angelic hosts }\end{array}$ & Limited to Earth & $\begin{array}{l}\text { Emerging Church: } \\
\text { Universal but no } \\
\text { mention of angelic } \\
\text { hosts }\end{array}$ & $\begin{array}{l}\text { Universal, uniting } \\
\text { heavenly and earthly } \\
\text { worshippers }\end{array}$ \\
\hline Results & $\begin{array}{l}\text { Eucharist maintained } \\
\text { as essential }\end{array}$ & $\begin{array}{l}\text { Preaching } \\
\text { Justification by } \\
\text { Faith } \\
\text { supplemented } \\
\text { with Eucharist }\end{array}$ & $\begin{array}{l}\text { Music } \\
\text { supplemented with } \\
\text { Eucharist }\end{array}$ & $\begin{array}{l}\text { Preaching the entire } \\
\text { Bible is essential by } \\
\text { using the heavenly } \\
\text { sanctuary and } \\
\text { covenant to integrate } \\
\text { God with all realities }\end{array}$ \\
\hline
\end{tabular}

The ultimate result of timeless Being on the three models in Christendom has been contradictory views of the divine presence; the qualifications, role, and authority of the liturgist as well as issues that concern mediation; the issue concerning which ritual action is central; the nature of the encounter; the response to the encounter; and the conflicting views of unity. 
Kuhn alerts us to the fact that certain data are considered to be anomalous within failing paradigms. This certainly was the case for the Sabbath and the heavenly sanctuary under timeless Being, which stripped them of exercising their hermeneutical function in the interpretation of the liturgical components. However, a phenomenological exegesis of Exod 3:14-15 uncovered God's infinite analogous temporal Being, which in turn allowed the Sabbath and the heavenly sanctuary to interpret all of the liturgical components that are connected to it. Kuhn also emphasized that the discovery of a new paradigm, which in this case is God's infinite analogous temporal Being, is completely incompatible with the old one - timeless Being. ${ }^{143}$ Consequently, the Biblical model produced a harmonious interpretation of the divine presence as Trinity; the role of divine, angelic and human liturgists that grounded authority in Scripture and in the throne; the preaching of Scripture as the main liturgical action that is inextricably linked to God's Being; a cognitive encounter that grounds and mediates God's words and not his being; the varied yet harmonious responses to the encounter that are grounded in the cognitive encounter; and the biblical search for unity that unites heaven and earth around the heavenly sanctuary (Rev 5:11-14; cf. 7:9-13) and that combines the work and function of all the components by connecting them to the centrality of the Word; all of these are diametrically opposed to the manner in which the three models of Christendom interpret the same liturgical components.

\footnotetext{
${ }^{143}$ If we are to be historically accurate, Moses as a philosopher preceded Parmenides, Plato, and Aristotle. Hence, his interpretation of Being was really first. However, there are two reasons why I associate the Three Models as the old paradigm. First, the Sacramental, Kerygmatic, and Charismatic Models have always assumed that timelessness has been the only way to interpret Being. However, in Chapters 5 and 6 we noted that both the Old and New Testaments reveal God's infinite analogous temporal Being. Second, those who adhere to the Sola Scriptura principle have been slow to realize God's infinite analogous temporal Being and its guiding role in theology and liturgy.
} 


\title{
CHAPTER 8
}

\section{SUMMARY, CONCLUSIONS, AND RECOMMENDATIONS}

This last Chapter concludes this dissertation by summarizing, concluding, and making recommendations for further research.

\begin{abstract}
Summary
The divine presence constitutes the most fundamental aspect of liturgy, and its interpretation affects how we understand all of the components that are involved in liturgy as well as the ecumenical search for unity. Chapter 1 illustrated that in spite of the liturgical crises that have taken place within Christianity over many centuries, especially the turbulent worship wars that have occurred since Vatican II, all agree that the real purpose of liturgy is to enter into God's presence, which is predominantly organized around the Lord's Supper, preaching, or music. As a result, the purpose of this study described how the three diverging interpretations related the presence of God to liturgy, ascertained the cause/s of the divergence by focusing on the divine presence as the central component, and sought to overcome these issues by examining the possibility of developing a theology of the divine presence on the basis of Scripture. The significance of this study lies in the pivotal role of how the interpretation of the most general concept of Being (reality) shapes the divine presence and liturgical components. Then the Chapter indicated a brief methodology, outline of the study, and delimitations.
\end{abstract}


Chapter 2 briefly surveyed a history of liturgy that was limited to the focus of liturgy, the Eucharist, Preaching, and Music. For centuries the focus of liturgy and the chief means of experiencing the divine presence was the Eucharist. In the sixteenth century, the Reformers shifted the focus to preaching the Word. With the advent of Pentecostalism and the Charismatic movement in the twentieth century, the focus of liturgy shifted yet again to music via the worship bands. The differences in the focus of liturgy led to different architectural symbols that expressed each particular focus.

Although the Eucharist is regarded as the sacrament of unity, Eucharistic practices differ widely among Christians, resulting in controversy. In addition, controversy over the Eucharist also revolves around the mode of Christ's presence in the sacrament, the subsequent connection to salvation, and whether it is a real presence or a memorial, the explanation of transubstantiation as a viable explanation of the manifestation of the real presence, whether it is a sacrifice, whether it can be adored, and the nature of its connection to unity.

The conflicts over preaching, mostly among Protestants, revolve around the aim and purpose of preaching, the methods of preaching, qualifications for preaching, frequency and length of sermons, and the issue of language or God-talk. Perhaps, however, the most contentious battles over the centuries, and especially recently, have been fought over music. The worship wars in music have raged around the use of instruments, secular influences, musical style, congregational and participatory versus professional with passive listening by the congregation, and the purpose of music.

The most pertinent observation revealed in this brief history of liturgy is that the interpretation of the divine presence via transubstantiation championed by the Catholic 
Church has never been challenged by Protestants, or by Charismatics who employ the terms real presence and musical transubstantiation without providing an alternative interpretation from the Catholic view of the divine presence.

Chapter 3 presented the methodological foundations of this study, which consist of a model method, a phenomenological method, and a hermeneutical method. The purpose of the model method in this study was to simplify and differentiate complex realities, such as historical, biblical, phenomenological, theological, and philosophical elements by grouping them around the divine presence as the fundamental component of each model. This study noted that the Eucharist, preaching the Word, and music comprise the major vehicles by which congregations experience God's presence in liturgy. As a result, these three vehicles correspond to the Sacramental, Kerygmatic, and Charismatic models.

The purpose of the phenomenological method was to discover the constitutive parts of the liturgical event that each model interprets in the controversies over liturgy. We discovered that a phenomenological description of liturgy comprises the following five indispensible components: the divine presence, the liturgists who lead out in liturgy, the liturgical setting that includes the time and place in which liturgy occurs as well as the liturgical actions, the encounter between the divine presence and the worshippers, and the response to the encounter. We also clarified that liturgy is objective and necessary for worship, and that worship is the subjective experience of liturgy.

The main purpose for developing a hermeneutical method is to discover the interpretive foundations that each model assumes. Since models only generate hypotheses concerning the divine presence and liturgical components, the hypotheses generated 
constitute interpretations that should be tested against the criteria in Scripture.

The hermeneutical method then linked the conditions that are always involved in any method with the components of liturgy that are also inextricably linked with the liturgical event. This study then linked Kuhn's observations about data and paradigms to the two interpretations of Being (paradigms) and the liturgical components (data). Kuhn's observations about the relationship between paradigms and data provided the framework from which to analyze the way in which the two conflicting interpretations of Being significantly shape the divine presence and the liturgical components by evaluating them on the basis of Scripture.

Chapter 4 described and analyzed the divine presence, liturgist, the liturgical setting and actions, encounter, response to the encounter, and the ecumenical search for unity in the Sacramental, Kerygmatic, and Charismatic models. The purpose for this description and analysis in this Chapter was to generate information that could be utilized to discover the cause of liturgical conflict in Christendom.

This Chapter noted the many ways in which timeless Being shaped and produced conflicting views on (1) the divine presence and its relationship to each sacrament; (2) the legitimacy, authority, and cause of liturgy in the liturgist; (3) which sacrament holds priority and conflicting practices concerning liturgical space, time, and frequency; (4) the place where the encounter occurs in the worshipper, the means employed to abstract the divine presence, and the nature of the content that worshippers receive in the encounter; (5) whether the response is passive or active, whether it is affective, kinesthetic or contemplative, and whether the response is causally connected to the divine presence or not; and (6) the ways in which unity was defined as well as what liturgical aspects each 
model considered as essential and which ones were non-essential.

Before I summarize the OT and NT data in Chapters 5 and 6, I would first like to point to three criteria that qualify the Biblical Sanctuary model to be the only model presented in Scripture. The first criterion is completeness. The Biblical Sanctuary model takes into consideration the broadest possible components that must be accounted for in order for liturgy to exist at all. These constitute the five liturgical components that each model has interpreted: the divine presence, liturgist, liturgical setting and actions, encounter, and the response to the encounter.

The second criterion is universality in scope. The heavenly sanctuary provides the ground and foundation for all of the liturgical components that engage in liturgy and worship in heaven and on earth. As a result, the heavenly sanctuary opens to view the fact that each liturgical component should be understood in a universal way. For instance, the divine presence as Trinity is infinitely temporal in immanence (in relation to the universe) and in transcendence where transcendence is beyond the universe in a place that only the Trinity occupy and which is analogous to the spatio-temporal reality of the universe. The liturgist includes the Trinity, angelic beings, and human beings who cooperate with each other in their ministry in the heavenly sanctuary and in multiple locations on earth. The administration of the Word in liturgy is the central and universal means of revealing the divine presence in heaven and earth. The heavenly sanctuary is the one place where all liturgy in heaven and earth is oriented toward, and the Sabbath constitutes the time in which all worshippers in heaven and in earth can meet. The encounter for all worshippers in the universe is a cognitive and spiritual encounter, and 
the worshippers in the heavenly sanctuary ground the kinds of acceptable responses that worshippers on earth should emulate.

The third criterion for why the Biblical Sanctuary model is the only model presented in Scripture is unity in administering the Word. The Trinity originates and reveals the Word. The angels and human liturgists all cooperate with the Trinity in administering the Word. The heavenly sanctuary constitutes the place where God reveals his presence through the liturgical actions Christ performs, and through messages that he conveys to the churches via the earthly liturgist. The invisibility of the Sabbath is also linked to the Word as the only vehicle by which the Holy Spirit reveals himself to all worshippers. The cognitive encounter only happens when worshippers understand the Word, and then choose to have a spiritual encounter by obeying the Word as they respond to the encounter.

Chapter 5 conducted a phenomenological exegesis of the selected Old Testament passages in the Biblical Sanctuary Model. The purpose of this Chapter was to unfold Scripture's interpretation of Being and thus ascertain the macro hermeneutical presuppositions contained therein that comprise the foundation for describing and analyzing the divine presence, liturgist, liturgical setting and actions, encounter, response to the encounter, and the biblical search for unity. The phenomenological exegesis of Exod 3:14-15 unveiled the Lord (YHWH) God's (Elohim) temporal Being, which was found at the basis of each passage that was exegeted in this Chapter.

Chapter 5 reveals the following insights concerning the divine presence. God's name, which is synonymous with his presence, is located in the specific places where he chooses to reveal himself, which primarily included the earthly and heavenly temples. 
However, while God is present in those specific locations, his presence is only revealed by his spoken words and not by material representations. Moreover, it is his presence that makes any place holy. While Exod 3:14-15 unfolds the temporal interpretation of God's Being, the sanctuary functions as the place that grounds the temporal relationship between transcendence and immanence, and presence and omnipresence.

The Old Testament reveals that liturgists can either be divine, angelic, or human, and that the liturgist is the cause of liturgy while the other liturgical components constitute the indispensible conditions. Human liturgists possess hermeneutical minds and all of the characteristics and abilities they possess are integrated into the immutability of their male and female natures. Liturgists in the OT primarily consisted of the family of Aaron as priests and the Levites.

With respect to the liturgical setting, all OT liturgy assumes that the heavenly sanctuary is the place to which liturgy is oriented; and although there were various set times, the seventh-day Sabbath constitutes an important time in which liturgy occurs. The central liturgical action assumes some form of speech, and music included singers who were accompanied by stringed instruments.

The survey of OT data assumed a cognitive encounter where worshippers received the words and thoughts of God into their minds on the basis of the covenant and its relation to the sanctuary. When the divine presence is conflated with nature, worshippers experience a non-cognitive emotional power encounter.

The response to the encounter involves verbal, kinesthetic, and affective elements; and it is always active and causally related to the specific content conveyed in the cognitive encounter. 
Chapter 6 conducted a phenomenological exegesis of the selected New Testament passages in the Biblical Sanctuary Model. God's temporal Being revealed in Exod 3:1415 was found at the basis of each NT passage that was exegeted. As a result, the temporal interpretation of the macro hermeneutical presuppositions of the OT forms the foundation for the NT description and analysis of the divine presence and the liturgical components.

With respect to the divine presence, there are several ways in which the NT builds on the foundation and insights of the OT. The NT connects all members of the Trinity with the I AM. The heavenly sanctuary then provides the hermeneutical template for (1) disclosing their complimentary roles in liturgy, (2) providing the basis for the Father and Son whose real, moral, passible, visible presence is localized in the heavenly sanctuary, and for the real, moral, passible, invisible omnipresence of the Holy Spirit, (3) explaining how God's being can change during the incarnation without involving a contradiction regarding God's infinite analogous temporal Being, and (4) for the temporal view of the incarnation in which both natures are combined in one person without distorting the integrity of either divinity or humanity.

The liturgists in the NT include divine, angelic, and human liturgists. Moreover, the NT understanding of the liturgists builds on the OT in the following ways. New Testament liturgists preach and teach under the direction of the Holy Spirit who works in harmony with Christ in the heavenly sanctuary. Yet, in contrast to the OT priests, the priestly work that they perform is comprised of a prophetic teaching ministry. The NT also discloses the close cooperation that exists between the Trinity, angels, and human liturgists in delivering God's Words to the worshippers. Liturgical authority in the NT is grounded in Scripture via the central throne. 
The predominant liturgical setting in the NT was the synagogue, yet the heavenly temple functioned as the ultimate place to which liturgy was oriented, and still functions as such today. The time in which liturgy took place was the seventh-day Sabbath. The central liturgical action was didactic speaking, which took on a more dominant role in the NT and has its basis in the liturgical actions of the Trinity in the heavenly temple.

The NT continues to affirm the temporal nature of the worshippers in the encounter who possess hermeneutical minds that are capable of misinterpreting and rejecting a cognitive encounter that they experience with God's words and not his being.

The NT further expands the ways in which worshippers respond to the encounter, some of which include baptism, continuing in the apostles' teaching, fellowship, breaking of bread, prayers, drawing together in unity, selling their possessions, evangelism, acceptable worship and service, and obedience to God's law.

The biblical search for unity assumes God's infinite analogous temporal Being and the heavenly sanctuary as the macro hermeneutical presuppositions that function in such a way that each liturgical component is integrally connected to some form of didactic speaking as the central liturgical action in the pursuit of spiritual unity.

Chapter 7 utilized God's infinite analogous temporal Being and the heavenly sanctuary as the major macro hermeneutical principles from which to systematically and theologically outline the manner in which all of the liturgical components, including their subcomponents, interrelate with each other.

While God's infinite analogous temporal Being in Exod 3:14-15 is connected to each member of the Trinity, ensuring that each member is a distinct divine reality, the heavenly sanctuary (1) is the place where God reveals his name/presence, (2) discloses 
the different roles of the Trinity in liturgy, (3) interprets transcendence and immanence, and presence and omnipresence in relation to each member of the Trinity, and (4) interprets Christ's divine/human natures. Moreover, Aaron's and Jeroboam's golden calf worship reveals that revelation that comes from Scripture is integrally connected to God's infinite analogous temporal Being in the context of the sanctuary. When Scripture as revelation is replaced by human philosophy and culture, the results are: (1) the sanctuary is abandoned as the place of liturgy, and (2) the divine presence is conflated with nature.

With respect to the liturgist, the heavenly sanctuary interconnects and temporally grounds the relationship between the liturgical activities of the divine, angelic, and human liturgists. The heavenly sanctuary grounds liturgical authority in God's law and in the heavenly scroll, not in spiritual gifts or in the church. Furthermore, all of the components associated with human liturgists are integrated and involved in mediating the divine presence. The golden calf incident of Jeroboam reveals that when Scripture as revelation is replaced by human philosophy and culture, and when the sanctuary is abandoned as the place of liturgy, the nature of the liturgist is reinterpreted, the Scriptural qualifications for human liturgists are set aside, and non-Scriptural views of God's Being, his presence and omnipresence are mediated to the congregation.

Regarding the liturgical setting and actions, the heavenly sanctuary and the Sabbath play a much larger role than merely providing the place and time of liturgy. The heavenly sanctuary and the Sabbath are interpretive doctrines that integrate the temporal relationship between the divine presence and the centrality of speaking God's words. The heavenly sanctuary ensures that there is no dichotomy between the theological content of God's words spoken in heaven and on earth and points to speech as the universal method 
of disclosing the divine presence. ${ }^{1}$ When the sanctuary is abandoned, cognitive revelation of God's presence as speech is discarded. Instead, nature becomes the predominant bearer of non-cognitive revelation of God's presence which mostly occurs through music and art.

The encounter assumes all of the insights noted above. Moreover, the close connection between the sanctuary and the covenant functions as the hermeneutical framework for interpreting the cognitive nature of the encounter with God's words being placed into our minds and not his being. The heavenly sanctuary also grounds the nature of the encounter just described between the angelic host in heaven and the worshippers on earth.

The response to the encounter assumes all of the insights previously noted concerning all of the liturgical components. Moreover, the heavenly sanctuary grounds the temporal relationship between all that has been mentioned including the integrated components of each worshipper that encompass their physical, mental, spiritual, and social natures. The worshippers in heaven also provide the model for how worshippers on

\footnotetext{
${ }^{1}$ At this point in salvation history humans cannot access the direct presence of God in the same way that angels have access to his presence in heaven. However, in spite having access to God's presence in heaven, the following points reveal that his presence is further revealed to the angels through his word: (1) although in the presence of God, the unrolling of the scroll that no one else is able or qualified to open and read (Rev 5:3-4) further revealing God's plan is the apex of the liturgical service in Rev 4-5, (2) 1 Pet 1:12 notes that the angels desire to look into the great truths of the plan of salvation (Eph 3:10), and (3) there are appears to be a close connection between God's presence and his word in the book of Jonah. For instance, Jon 1:1-2 reveals that the word of the Lord came to Jonah, saying, go to Nineveh and cry out against it. In Jon 1:3, 10 it states that when Jonah refused to obey the word of the Lord that he fled "from the presence of the Lord." If refusing to obey God's word is synonymous with fleeing his presence, then hearing and obeying it should be synonymous with abiding in his presence; this is what we find in Hag 1:1, 12. Hence, in spite of having direct access to God's presence, the synonymous nature between his Word and his presence leads to the conclusion that his Word is still the universal method of disclosing his presence.
} 
earth should respond to the encounter. When the sanctuary is abandoned as the place of liturgy, there is no causal connection between the encounter and the response.

Lastly, in the biblical search for unity, all of the aforementioned principles center on the proclamation of God's Word as the principal liturgical action and the condition for unity in the Biblical Sanctuary Model.

Chapter 7 also summarized and compared the results of the data generated about the liturgical components of all the models brought forth in Chapters 4, 5, 6 and the first part of Chapter 7. The following observations from Kuhn were particularly pertinent in providing a framework for the aim of this Chapter: (1) data cannot exist without paradigms, (2) paradigms shape and interpret data, (3) new paradigms are incompatible with old ones and must replace them (4) anomalous or conflicting data are symptomatic of a paradigm in crisis and needing replacement, and (5), holding on to old paradigms prevents scientists from seeing that anomalous data can function as the prelude to the discovery of new paradigms. Kuhn's observations about paradigms and data provided the framework from which to contrast the manner in which timeless Being shaped the conflicting views of the liturgical components within the three models with God's infinite analogous temporal Being that shaped in a harmonious way all of the liturgical components in the Biblical Sanctuary model.

\section{Conclusions}

This dissertation has addressed a three-fold purpose. First, it has given a brief historical description of the liturgical crises in Christendom over the centuries and across denominational lines. The research primarily focused on the three divergent ways in which congregations experience God's presence; namely, the Eucharist, preaching, and 
music, which I have referred to as the Sacramental, Kerygmatic, and Charismatic models.

Second, in determining the cause of all of the divergent expressions that are linked to the divine presence in the three models, this study revealed the significant role of timeless Being that functioned as the hermeneutical ground for the transubstantiation hypothesis of the divine presence that was championed by the Sacramental model and knowingly or unknowingly assumed by the Kerygmatic and Charismatic models. This was the cause of the conflicting and irreconcilable positions on the divine presence such as the transcendent static view of classical theism (pre-Vatican II, Kerygmatic, and Pentecostal and Charismatic movements) and the dynamic panentheistic view of God coming to an awareness of himself via the evolutionary process (post Vatican II Sacramental model, and Emergent movement). Classical theism is the result of static timeless Being and panentheism is the result of dynamic timeless Being.

The pre-Vatican II Sacramental model championed the causal connection between the divine presence and the Eucharist for centuries before the other models followed suit by also asserting a causal connection between the divine presence and preaching (Kerygmatic model) and the divine presence and music (Charismatic model). However, the post Vatican II Sacramental model provided a philosophical justification for these divergent expressions by exploiting the ontological dichotomy between the timeless divine presence and sacraments such as the Eucharist, the Word, music, the priest, architecture, and the assembled worshippers. There are two reasons why this ontological dichotomy ultimately functions as the cause of liturgical pluralism. First, it justifies the three divergent sacraments (Eucharist, Word, and music) as vehicles of the divine 
presence and creates room for even more such vehicles, since the entire cosmos is potentially sacramental.

Second, it also justifies and thereby destroys any causal connection between the divine presence, the ritual actions, and the response to the encounter, which is a contradiction. It does this by assuming the panentheistic nature of the divine presence and the rituals that are used to disclose it. For instance, the timeless aspect of the divine presence constitutes the unchangeable, theological, and essential part while the rituals used to disclose the divine presence are cultural and changeable. In this framework, the timeless divine presence functions as the efficient cause of the changeable aspects of the divine presence that is associated with the rituals and which function as the instrumental cause. As a result, there appears to be a causal connection between the timeless divine presence and the material divine presence. However, since the divine presence is infused into all nature, and since there is an ontological dichotomy between the timeless divine presence and the temporal divine presence, it becomes difficult to escape the conclusion that the multiplicity of rituals (temporal divine presence) one can potentially use are not causally related to the timeless divine presence.

Hence, this study identifies the following factors as the cause of liturgical pluralism in Christianity: (1) The intentional use of timeless Being by the Sacramental model in the formulation of the divine presence; (2) The uncritical assumption of the transubstantiation hypothesis by the Kerygmatic and Charismatic models; and (3) The failure of the Kerygmatic model to deconstruct the transubstantiation hypothesis, which goes hand in hand with the failure to apply the Sola Scriptura principle, that it alleges to 
uphold, in order to construct a Biblical view of the divine presence and its relationship to the other liturgical components.

Third, after having deconstructed the three previous models, this study demonstrated that it is possible to overcome liturgical pluralism by conducting a phenomenological exegesis of the Scriptures with reference to the divine presence, the rest of the liturgical components in the liturgical event, as well as the biblical search for unity. I applied Kuhn's observation about anomalous data and crises within paradigms to the problems that the other models experienced under the hermeneutical influence of timeless Being. Moreover, I also applied Kuhn's concept of the incompatibility of blending new paradigms with old ones to the concept of Being.

A phenomenological exegesis of Exod 3:14-15, which ruled out the assumption that the text was based on timeless Being, created room for the discovery of a new paradigm (God's infinite analogous temporal Being) that is actually older than the old paradigm because it is in Scripture. I refer to this as the Biblical Sanctuary Model. The exegesis of Exod 3:14-15 was the explicit and implicit foundation for all of the biblical texts that were exegeted in this dissertation. This Biblical model was not only incompatible with the other three models, it also allowed the heavenly sanctuary and the Sabbath to play a large hermeneutical role in shaping a new interpretation of the divine presence, and also of the relationship between the divine presence and the other liturgical components. The Biblical model posits a view of the divine presence that includes the Trinity performing different functions in the liturgical event. Moreover, each attribute, such as eternity, immutability, invisibility and holiness are interpreted from within the spatio-temporal structure of God's infinite analogous temporal Being and the heavenly 
sanctuary that temporally grounds the relationship between each divine attribute, especially God's presence and omnipresence.

The heavenly sanctuary also played a significant role in framing and interpreting the definition of unity by temporally grounding in a causal relationship all of the liturgical components. This large hermeneutical role of the heavenly sanctuary was impossible under timeless Being. This research thus provides the groundwork for further systematic and exegetical study for those wishing to build their understanding of Christian liturgy on the Sola Scriptura principle.

\section{Recommendations for Further Research}

Having established a biblical framework for the divine presence and its relationship to liturgy, there are several areas both of a systematic and an exegetical nature that can further elucidate, build upon and correct what I have begun here.

I will first begin with issues related to the divine presence itself. Since this dissertation restricted itself to a study of the divine presence within certain liturgical events in the OT and NT, more research should be done by exegeting other liturgical events in Scripture not included in this study, ${ }^{2}$ as well as Scriptural instruction concerning $\operatorname{liturgy}^{3}$

More study is needed regarding the relationship between the divine presence and the Word of God, which could further clarify, correct, build on and support the findings in this study. There is also a need to further clarify and elucidate the ways in which the Trinity itself is involved in the liturgical event.

\footnotetext{
${ }^{2}$ Examples are Lev 8 and 9; John 6:22-71.

${ }^{3} 1$ Tim 2:8-15; 1 Cor 11:1-9.
} 
The development of a more thorough Christology on the basis of the Sola Scriptura principle and the way in which it relates to liturgy would also be helpful.

The following issues are related to the liturgist. Further exegetical systematic work is needed in order to further elucidate the ways in which the divine, angelic, and human liturgists cooperate together in the liturgical event.

There is need for a more thorough exploration of ecclesiology, based on the Sola Scriptura principle, in order to determine the working relationship between ecclesiology and the role of the liturgist in liturgy, as well as how liturgy fits within the broader scope of ecclesiology.

The concept of the liturgist mediating our conception of the divine presence through a comparison between the divine nature and human nature, conducted according to the Sola Scriptura principle, would shed more light on the nature and role of the liturgist in the Biblical model.

The following issues are related to the ritual actions. While God's infinite analogous temporal Being and the heavenly sanctuary that temporally grounds the relationship of all the liturgical components is foundational for developing a biblical philosophy of music; a greater survey of materials that deal with a philosophy of music is required in order to establish a phenomenological description of music. In addition to this, a more precise phenomenological description of human nature is required since interpretations of music and human nature form the building blocks for a more thorough analysis of the nature of the encounter with music and the response to music. All of this is foundational for further addressing the issues of music, meaning, and morality. The approach described here would be similar to the methodology employed in describing a 
phenomenological description of liturgy in Chapter 3 of this dissertation. Also, more exegetical and systematic work on building on the current biblical framework in this dissertation is needed in working toward a biblical philosophy of music and the role of music in liturgy.

Since the heavenly sanctuary serves as a model, more study is needed to determine the precise ways in which earthly meetinghouses should imitate the divine heavenly pattern.

The following issues relate to the encounter. Since liturgy involves an encounter, more exegetical work both inside and outside the liturgical event regarding union with Christ that combines phenomenological and biblical exegesis could shed more insight on the nature of the encounter. 


\title{
APPENDIX A
}

\section{Music in the Biblical Sanctuary Model}

\author{
Introduction
}

All that I have written thus far is foundational for the preliminary remarks that I will make here. In this appendix I will begin to describe and analyze music from the perspective of the Biblical Sanctuary model. In doing so, I will follow the methodology that I have employed throughout this dissertation. I will first describe and analyze music from the perspective of the applicable liturgical components thus closely following what I did in Chapters 5 and 6. Then, just as I did in Chapter 7, I will use the data that was generated to construct a theological and systematic outline of music in the Biblical Sanctuary model.

\section{Liturgist}

\section{Kgs 8:12-66 and 2 Chr 5-7}

In David's time God chose the Levites as singers and musicians ${ }^{1}$ in addition to serving the priests and the work that pertains to the tabernacle of meeting (Num 3:5-9). In $1 \mathrm{Chr} 25: 1$ it states that the sons of Asaph, Heman, and Jeduthun should "prophesy with harps, stringed instruments, and cymbals.” After discussing various unsatisfying

1،Like the words, place, times and instruments for the sacred song, the agents for its performance were prescribed by royal statute (1 Chr 6.32; $2 \mathrm{Chr} 8.14 ; 23.18 ; 29.25$; 35.15a)." Kleinig, The Lord's Song, 89. See also $1 \mathrm{Chr} 25$. 
interpretations of this passage, ${ }^{2}$ Kleinig brings out four ways in which the singing by the temple choir was a form of prophetic proclamation. First, since they stood in God's presence, their status and authority was prophetic in that they spoke for God to his people, yet without a corresponding prophetic oracle. Second, the manner of their proclamation was prophetic in that they addressed the people in poetry and song. Third, the association with the burnt offering was prophetic in purpose in that they proclaimed the Lord's acceptance of his people and admonished them to act appropriately. Fourth, the proclamation was prophetic in power since it communicated God and his strength to the people (2 Chr 30:21). Hence, "their musical performance was regarded by the Chronicler as a 'kind of ritualized prophecy' 'in which God spoke to his people.",3

The use of the word prophesy suggests that those chosen as musicians should understand the role of music in providing a spiritual experience for the worshippers. ${ }^{4}$ Moreover, in order for musicians to assist the congregation in achieving a biblical

\footnotetext{
${ }^{2}$ Kleinig notes that those who argue for a figurative sense of "prophecy" take the verb as a technical term for the performance of sacred song. Yet, he adds that it's an obscure way to say what could be more clearly said by other verbs. Others note that prophecy refers to the manner of performance, specifically the practice of improvisation, the inspiration of the musicians, the ecstatic singing, and the power to arouse religious enthusiasm in the audience. However, Kleinig notes that these interpretations fall short since prophecy is never used figuratively in Chronicles, and since the passage points to what singers were meant to do rather than how they did it. Moreover, although most scholars agree that the songs sung in the choral service function as a kind of prophecy, there is disagreement as to how this occurred. For instance, some believe that the musicians delivered inspired prophetic utterances in which they addressed the congregation with God's word in a blessing, or a declaration of forgiveness, or an oracle given in answer to prayer. However, Kleinig notes that this goes beyond the evidence in $1 \mathrm{Chr} 25: 1$ that merely refers to the prophetic character of the regular choral service. Lastly, since the words of the psalms were regarded as divinely inspired, they had prophetic power when accompanied by musical instruments in order to create success and well being in those who heard them. As Kleinig notes, this assertion is too limited in scope, Ibid., 154-155.

${ }^{3}$ Ibid., 156.

${ }^{4}$ Kleinig notes that the choice of the those performing the music at the Temple "was not merely a matter of good order but of ritual necessity, since choral music had to be performed by the right people, if it was to serve the welfare of the people." Ibid., 89.
} 
spiritual experience, the heavenly sanctuary must function as the ground from which we construct music's role in achieving a spiritual experience. The major reason for why the sanctuary should function as the ground is that OT liturgy is ultimately oriented toward the heavenly sanctuary. ${ }^{5}$

In the other models, the sounds of music simply constitute the material role by which the timeless spiritual reality of God encounters the timeless spiritual reality of the human soul. ${ }^{6}$ Since music simply functions as a vehicle that is similar to the bread and wine in the Eucharist, musical style is inconsequential when it comes to mediating the divine presence. However, in the Biblical Sanctuary Model, music performed by the Levites is referred to as a ministry ${ }^{7}$ that is performed before the $\operatorname{Lord}^{8}(1 \mathrm{Chr} 16: 7)$, and

${ }^{5}$ As Solomon prays, he repeatedly asks God to hear from heaven $(1 \mathrm{Kgs} 8: 30,32,34$, $36,39,43,45,49)$. Hence, liturgy is oriented toward the heavenly sanctuary. Moreover, there is a dynamic interaction between the heavenly sanctuary and the earthly in $1 \mathrm{Kgs} 8$. See de Souza, "The Heavenly Sanctuary/Temple Motif in the Hebrew Bible," 217-222. The temporal view of Being allows for a correspondence between the heavenly and the earthly.

${ }^{6}$ See this dissertation pages 129-134, 180-187, 199-203, especially 207-208.

${ }^{7}$ Kleinig contends that the performance of sacred song and the transportation of the ark by the Levites are ministries to the Lord (1 Chr 15:2).

Hence the musicians were appointed initially to 'minister' both before the ark in Jerusalem (1 Chr 16:4, 37) and the tent of meeting in Gibeon (1 Chr 6:32). Later the Levitical musicians 'ministered' at the temple by giving thanks and praise to the Lord (2 Chr 31:2). The Levites were chosen as musicians, because their performance of music was to be a 'ministry' akin to the care of the ark (Kleinig, The Lord's Song, 91).

Furthermore the Levites 'minister' to the tabernacle (Num 1:50) and at the tabernacle (Num $8: 26$ ). They minister to the priests by their service at the tabernacle (Num $3: 6 ; 18: 2$ ), and in their ministry they also represent the people (Num 16:9; cf. Num 3:40-51; 8:5-26).

This understanding of the Levites as the ritual representatives of the congregation... is assumed by the description of the musicians' duties as ministry in Chronicles. Just as the Levites who acted as ritual substitutes for all the first-born Israelites, helped to make atonement by doing 'service' for the people of Israel at the tabernacle (Num 8:19), so the Levitical musicians also helped in the sacrificial ritual by performing the 'service' of song for them (1 Chr 6:32; 25:1, 6; 2 Chr 30:22). Like their fellow Levites they ministered before the priests at the temple (2 Chr 8:14) (Ibid., 91-92).

${ }^{8}$ Besides $1 \mathrm{Chr} 16: 7$, further support that the Levites performed their ministry to the Lord is seen in $1 \mathrm{Chr}$ 16:4 and 37 where the Chronicler notes that the Levites ministered 
the people. Since God is infinitely temporal and thus passible, music plays a constitutive role in his experience of this ministry performed to him, as well as in the spiritual experience of worship that the congregation experience. Hence, to prophesy with instruments means to understand that God himself appreciates and experiences the music offered to him, which is not possible for the timeless God of the other models; and that music itself plays an important role in the spiritual experience of the worshipper. The sanctuary thus temporally grounds the relationship between the music performed by the Levites and the experience of that music by God and the congregation. Also, the heavenly sanctuary makes room for an analogy between heavenly and earthly music. As a result, earthly musicians should seek to ascertain the role and nature of heavenly music and to copy $^{9}$ the reality of heavenly music, as did the Levites in Chronicles.

Moreover, liturgists who perform music have historical hermeneutical minds that must make a choice to apply the Sola Scriptura principle to the biblical data that contains the description of heavenly liturgy (Rev 4-5). A failure to do this will result in misrepresenting the heavenly realities.

\section{Liturgical Setting and Actions}

\section{Kgs 8:12-66 and 2 Chr 5-7}

"The books of Chronicles often mention, or allude to, liturgical music at the

before the ark, which is the place of God's presence. See this dissertation page 243 footenote 93 for the ark as the place of God's presence.

${ }^{9}$ In Heb 8:2 we find that the heavenly sanctuary is the great original and that the earthly sanctuary is a copy (Heb 9:24) of the heavenly. This implies that there is a correspondence between the structural reality of the heavenly sanctuary and that of the earthly one. Since the heavenly realities in the sanctuary include music (Rev 4-5), the earthly liturgy should approach as close as possible to the heavenly reality. 
temple in Jerusalem. ${ }^{, 10}$ A brief examination of the books of Chronicles reveals that music never took on a central role in liturgy as it does in the Charismatic model. Instead, the Chronicler reveals that the choral service is integrally connected with the sacrifices. ${ }^{11}$ Let's now examine the music at the dedication of the temple. Although there are no recordings of the music, the sanctuary temporally grounds the relationship between the liturgical functions of the sanctuary instruments (trumpet, cymbal, stringed instruments, and harp) and creation. I will now describe each instrument, its ritual usage, its role in sanctuary liturgy, and pointers toward a philosophy of music.

The trumpet wִצִצִָּרה was first connected with liturgy in Num 10:9-10 as a memorial before God. In addition, it (1) proclaimed the Lord's presence at the ark in Jerusalem (1 Chr 16:6, 42); (2) it announced the Lord's entrance into the temple at its dedication (2 Chr 5:12-14); ${ }^{12}$ and (3) in worship it gave the signal for the prostration of the congregation during the burnt offering and the performance of the choral service. ${ }^{13}$ Josephus described the trumpet as a straight tube a little less than a cubit long and ending in a bell. ${ }^{14}$ Since they had no valves, "their range was probably limited to three or four

\footnotetext{
${ }^{10}$ Liturgical music is dealt with in $1 \mathrm{Chr} 6: 31-47 ; 9: 14-16,33 ; 15: 1-16 ; 23.2-5,25-$ $32 ; 25: 1-31 ; 2$ Chr 5:11-14; 7:1-6; 8:12-15; 20:18-30; 23:12-13, 18; 29:25-30; 30:21-22; 31:2; 34:12-13; and 35:15. See Kleinig, The Lord's Song, 14.

11“"The book of Chronicles shows that the choral service of the Levitical singers was connected ritually both with the presentation of the public burnt offering (1 Chr 16:39-40; $23: 30-31 ; 2$ Chr 8:12-14;23:18;29:20-30;31:2) and with the presentation of private thankofferings (2 Chr 7:4-6; 30:21-22; 31:2)." Ibid., 21. "As described in Chronicles, the Lord's song was a part of the comprehensive ritual of sacrifice at the temple. It had no independent significance, since it... was elucidated by the more general ritual with which it was associated." Ibid., 133.

${ }^{12}$ Kleinig, The Lord's Song, 81.

${ }^{13}$ Ibid., 79-80.

${ }^{14}$ In AD 70 when the Romans erected an arch for Titus after his conquest of Jerusalem, the trumpet was among the objects they robbed from the temple that "corresponded exactly to the description of Josephus and also to the many trumpets on
} 
tones which were used in different combinations of intensity and duration." ${ }^{, 15}$

Thus, the trumpet's function in sanctuary liturgy is to announce the divine presence by signaling the coming as well as the presence of the ark (1 Chr 15:24, 28; $16: 6) ;{ }^{16}$ it is not to mediate the timeless divine presence through the sounds it transmits, which is what occurs in the other models. The biblical sanctuary view implies that the being of the trumpet and the corresponding sound that emanates from it cannot be confused with the divine presence. A phenomenological reading of the Chronicles texts assumes that the divine presence is located at the ark whereas the trumpets are located at the east end of the altar (2 Chr 5:12).

Moreover, since the purpose of the trumpet is to announce and proclaim the divine presence, it must grab the attention of the worshippers who may conceivably be located at distances that are far. This implies a specific timbre and intensity that worshippers must correctly interpret in order to worship. ${ }^{17}$ Thus, there appears to be a direct relationship between the purpose of the trumpet to announce the divine presence and the specificity of its sounds in achieving that purpose. This contrasts with the other models that allege that musical sounds are mere conveyors of a timeless divine presence that is mediated to the timeless soul of the worshippers. In those models the specificity of the sounds is not causally connected with goal of achieving a timeless encounter with the timeless divine presence. Consequently, any sound will do. However, in the Biblical

Egyptian reliefs and paintings." Curt Sachs, The History of Musical Instruments (New York: W. W. Norton \& Company, 1940), 113.

${ }^{15}$ Kleinig, The Lord's Song, 79.

${ }^{16}$ Ibid., 79.

${ }^{17}$ Kleinig notes that "The trumpets, which were instituted by the Lord through Moses, announced the presentation of the burnt offering at the temple and called for the prostration of the people." The Lord's Song, 87. 
Sanctuary Model the specific timber and intensity of the trumpet is causally connected to its purpose in giving its sound, which is to proclaim the Lord's presence so that worshippers will know what to do.

Moreover, the trumpet's liturgical use in the sanctuary as a sounding instrument disqualifies it as an instrument that clearly points to establishing a biblical philosophy of music. This is true even though the trumpet itself was capable of playing three to four pitches and possibly more depending on the different techniques used thus having the potential to create harmonic music if several of them are tuned to different but complimentary pitches.

We will now describe the cymbals and then analyze their liturgical function. The

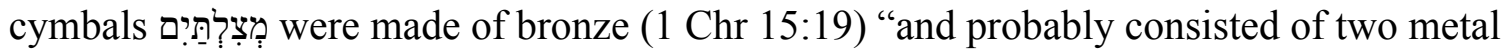
plates with reflexed rims about 20-30 cm wide. When these were struck together vertically, they produced a ringing, tinkling sound."18 They were mainly employed to announce the beginning of a song or a stanza in the song instead of being used to beat out the rhythm of the song; and the three heads of the guilds would sound the cymbals $(1 \mathrm{Chr}$ 15:19) thereby calling for the attention of the congregation to the performance of sacred song. ${ }^{19}$ Moreover, "the use of hišmîa in connection with the sounding of the cymbals also

\footnotetext{
${ }^{18}$ Ibid., 82. Lilliane Doukhan notes that ancient near eastern cymbals were small idiophones consisting of pairs of bell-shaped bronze disks approximately 2.5 to 4.5 inches in diameter. Doukhan, In Tune with God, 110.

${ }^{19}$ “"The practical function of the cymbals was to call for the attention of the congregation to the performance of sacred song. This is borne out by the use of hišmîa to describe their function and significance. Musically speaking, one could translate this by the verb 'sound'. Hence the head of the guild (1 Chr 16:5) or the three heads of the guilds are said to 'sound' the cymbals (1 Chr 15:19). Since both the trumpets and cymbals were played together to announce the beginning of the song, the players of both are called 'sounders' in 1 Chr 16:42. Jones (1968:108) therefore proposes that $1 \mathrm{Chr}$ 16:5b should be translated: 'Asaph was calling for attention with cymbals." Kleinig, The Lord's Song, 83. See also
} 
indicates their ritual significance. When used absolutely, the verb normally means 'to make proclamation.",20 Hence, "by their connection with the trumpets and the instruments which accompanied the song, they proclaimed the Lord's gracious presence with his people at the temple." 21

Hence, like the trumpet, the primary role of the cymbal in sanctuary liturgy is to announce the divine presence; it is not to mediate the divine presence. Its secondary role is to announce the beginning of a song or a stanza in the song. The cymbal must also have a specific timbre that is causally connected to the fulfillment of its purpose of announcing the divine presence; otherwise worshippers may not grasp the connection between its specific sound and its stated purpose. Thus, the specific quality of the sound produced carries with it the meaning that "announced the performance of the sacred song by the Levitical choir," 22 whereas in the other models, worshippers abstract the timeless divine presence from its sounds, which leads to the deduction that the specificity of the sounds is inconsequential to achieving a timeless encounter.

Cymbals also were not used to beat out the rhythm of the song such as how modern drummers play the cymbals. ${ }^{23}$ This deduction is based on: (1) their size was

Doukhan, In Tune with God, 110-111; Alfred Sendrey, Music in Ancient Israel, (New York: Philosophical Library, 1969), 376-377.

${ }^{20}$ Kleinig, The Lord's Song, 83, 84.

${ }^{21}$ Ibid., 84.

${ }^{22}$ Ibid., 87; Alfred Sendrey, Music in Ancient Israel, 377.

${ }^{23}$ Alfred Sendry notes that many commentators share the opinion that the cymbals in sanctuary liturgy were used in such a way as to beat out the time. However, he asserts that this is an incorrect conclusion since

Jewish, and in general Oriental, song was not strictly metrical like our Western music, but represented an accentual cantillation with many intentional and unintentional irregularities. The musical phrase, the melodic structure, were not governed by ironclad measures or groups of measures (a system unknown to Orientals), therefore marking of 
much too small for them to be heard as resonating cymbals; ${ }^{24}(2)$ they were worn on the tips of two fingers of one hand like castanets and were clashed together by finger action; $^{25}$ (3) only the chief music leaders were to sound the cymbals, pointing to their function as sounders; ${ }^{26}$ (4) cymbals were not sounded during the singing. ${ }^{27}$ and (5) Doukhan asserts that the Hebrew word tseltselim that was used to describe the cymbal in earlier texts (2 Sam 6:5), and which was associated with pagan Canaanite cults was no longer used for the Hebrew liturgy; instead the Chronicler used the word metsiltayim "probably to avoid any connotation with pagan practices." 28 If this is the case, the change of name for the cymbal in the Hebrew temple liturgy indicates a change in its use and function from pagan practices. These points regarding the use of the cymbal effectively eliminate a syncopated and/or persistent rhythmic emphasis for the music conducted at the sanctuary.

We will now describe and analyze the stringed instruments. The harp referred to as kithara and kinyra in the $\mathrm{LXX}^{29}$ Their ten strings were plucked with a plectrum and were probably tuned pentatonically without semitones through two octaves. $^{30}$ The nevel was a stringed instrument that had twelve strings that were plucked

the 'beats,' as we understand it, could not be applied in the music of the Temple (Alfred Sendrey, Music in Ancient Israel, 377).

${ }^{24}$ Doukhan, In Tune with God, 110; Sendrey, Music in Ancient Israel, 377.

${ }^{25}$ Doukhan, In Tune with God, 110.

${ }^{26}$ Ibid., 110-111; Kleinig, The Lord's Song, 83.

${ }^{27}$ Doukhan, In Tune with God, 110-111.

${ }^{28}$ Ibid., 111.

${ }^{29}$ Curt Sachs, The History of Musical Instruments, 106-107.

${ }^{30}$ Ibid., 107. 
with bare fingers and which was possibly a zither, a lyre, or a harp. ${ }^{31}$ According to Kleinig, the stringed instruments and harps were called the instruments of song ( $2 \mathrm{Chr}$ 5:13) or the instruments of God's song (1 Chr 16:42) and were thus "always used together in the choral service." ${ }^{32}$

Since the kinnor and the nevel were always used together in the choral service, I will first describe the strings in sanctuary liturgy before I look at the role of choral music and the role of strings in sanctuary liturgy. The following items point to the stringed instruments and harp as accompanying instruments: (1) the use of the plectrum for the harp $^{33}$ which is an accompanying ${ }^{34}$ instrument where happy melodies ${ }^{35}$ are emphasized; (2) the kinnor and nevel are "tools of singing"

${ }^{31}$ Josephus states that it had twelve strings plucked with the fingers. Sachs notes that Amos 6:5 combines nevel with parat as in to pluck fruit, see Sachs, The History of Musical Instruments, 115. For further support for plucking the string, see also HALOT, s.v. פרט. Nevel is also translated seventeen times as psalterion, which points to this instrument as a harp, see Sachs, The History of Musical Instruments, 115-116.

${ }^{32}$ Kleinig, The Lord's Song, 84.

${ }^{33}$ Sachs, The History of Musical Instruments, 108.

${ }^{34}$ According to Sachs the fact that the kinnor is an accompanying instrument "is confirmed by 1 Chronicles 16:42, where kinnor and nevel...[as] 'tools of singing,' are contrasted to trumpets and cymbals. This could also mean 'melody instruments'; but as II Chronicles 9:11, and $1 \mathrm{Kgs} 12$ call the kinnor and the nevel instruments...' belonging to the singers,' the significance, 'instruments of accompaniment,' cannot be doubted." Sachs, The History of Musical Instruments, 108.

${ }^{35}$ For instance, Curt Sachs states,

The melodies that the kinnor played or accompanied were gay and unsuited for sorrow; the Jews refused to play that instrument during the Babylonian Exile. They suspended their kinnorim on the willows; how should they 'sing the Lord's song in a strange land?' The kinnor was gay, and when the prophets admonished the people they threatened that the kinnor, symbol of joy and happiness, would be silenced unless the people desisted from sin. Instruments still were bound to well-defined occasions and moods (Sachs, The History of Musical Instruments, 108).

${ }^{36}$ Ibid., 108. 
cymbals $^{37}$ that are noted as instruments that sound or that announce; and (3) 2 Chr 9:11

reveals that they are instruments "belonging to the singers," 38 instruments of song ( $2 \mathrm{Chr}$ 5:13), or the instruments of God's song (1 Chr 16:42) the purpose of which was "to accompany the songs of praise and thanksgiving to the Lord (1 Chr 23:5; 2 Chr 5:13; $7: 6) ., 39$

I will now describe and analyze the role of choral music in the sanctuary. On account of the close relationship between the divine name and presence in Chronicles, ${ }^{40}$ Kleinig notes that "the most important element of sacred song was the proclamation of the holy name" "to announce the Lord's presence." 42 Thus, "through their song the singers remembered YHWH (1 Chr 16:4) by proclaiming (1 Chr 16:8), thanking (1 Chr 16:35) and glorying in his holy name (1 Chr 16:10)." "43 However, praise went beyond "the

\footnotetext{
${ }^{37}$ Ibid., 108.

${ }^{38}$ Ibid., 108.

${ }^{39}$ Ibid., 108; Kleinig, The Lord's Song, 86.

${ }^{41}$ John W. Kleinig, The Lord's Song, 64.

${ }^{42}$ Ibid., 69.

${ }^{43}$ Ibid., 65 .
}

${ }^{40}$ For the close connection between God's name and presence, see Sara Japhet, The Ideology of the Book of Chronicles and Its Place in Biblical Thought, 50-56; also see pages 239-245 of this dissertation.

According to Chronicles, David decreed that the holy name, which had been instituted for Israel's worship by the Lord himself through Moses at Mt Sinai, should be proclaimed in thanksgiving and praise (1 Chr 16:4). By these two verbs he determined the basic shape and content of sacred song (Ibid., 66).

Thanksgiving and praise

usually refer to the performance of sacred song. They are, in fact, virtually synonymous in Chronicles, and are often used interchangeably without any appreciable difference in meaning. Thus the thanksgiving refrain is used not only to 'thank' the Lord ( $1 \mathrm{Chr}$ $16: 34,41 ; 7: 3,6)$ but also to praise him $(2 \mathrm{Chr} 5: 13 ; 7: 6 ; 20: 21)$. Nor do they refer to two different ritual practices, such as praise during the presentation of the burnt offering and thanksgiving during the presentation of thank-offerings, since the singing during the burnt offering is described as 'praising' (2 Chr 8:14; 29:30), 'thanking' (1 Chr 16:41), 
mere recitation of his name; it related his acts ([1Chr 16]:8b, 9b, 12, 14, 21, 23, 26b, 31b, 33c), his words ([1Chr 16]: 15-19, 22), his gifts (11a, 27b, 34b), his status (25), and his attributes $(27 \mathrm{a}, 34 \mathrm{a})$. All these were part of his name and so were to be proclaimed with it as they revealed his nature and will."44 The scope of this proclamation of God's name in sacred song was to extend far beyond Israel (1 Chr 16:9-22), embracing all the nations of the earth (1 Chr 16:23-33). ${ }^{45}$

Moreover, the function and significance of the choral music conducted at the sanctuary was determined by the location of the singers in the temple, which was before the ark (1 Chr 16:4, 37) that represented the Lord's presence; before the altar as the place of atonement (1 Chr 21:26-22:1) that was actually east of the altar (2 Chr 5:12); and before the tent of meeting in Gibeon (1 Chr 16:39-41). ${ }^{46}$ The fact that the singers were stationed before the altar to sing each morning and evening as the burnt offering was presented (1 Chr 23:30-31; 2 Chr 29:27-28) indicates that their ministry of song "was subordinate to the priestly ritual which was enacted there."

and 'thanking and praising' ( $1 \mathrm{Chr} 23: 30)$, while singing during the thank-offering is described as 'thanking' and 'praising' (2 Chr 7:6) as well as 'praising' (2 Chr 30:20). Taken together, they describe the verbal content of sacred song (Ibid., 66-67).

${ }^{44}$ Ibid., 145-146. "Through the proclamation of his name in word and song, the Lord presented himself to his people at Jerusalem." Ibid., 146.

${ }^{45}$ Ibid., Kleinig divides $1 \mathrm{Chr}$ 16:8-34 into five major sections. The first is a general call to thanksgiving in $1 \mathrm{Chr}$ 16:8. The second is Israel's praise in $1 \mathrm{Chr} 16: 9-22$. The third is International praise in $1 \mathrm{Chr} 16: 23-30$, the fourth is cosmic praise in $1 \mathrm{Chr} 16: 31-33$, and the fifth is a final call to thanksgiving in $1 \mathrm{Chr} 16: 34$, Ibid., 143-144; cf. 146. "In their praise they invited both the Israelites and the peoples of the world to seek the Lord's presence and his benefits in their common worship of him." Ibid., 148, cf. 180. Thus, the Chronicler is extending the invitation given to the stranger to appear in the place where God chooses to place his name to all of the peoples of the earth. Hence, $1 \mathrm{Chr}$ 16:23-33 builds upon Exod 12:48, 49; Num 9:14 Deut 16:11, 14.

${ }^{46}$ Ibid., 70-71.

${ }^{47}$ Ibid., 73. The institution of sacred song and it synchronization with the presentation of the burnt offering is mentioned in 1 Chr 16:39-41, and as a part of the 
Since the sanctuary provides the context for the song of the Lord (2 Chr 29:27), it also temporally grounds the relationship between the divine presence, the music provided by the Levitical musicians, and the public burnt offering ( $2 \mathrm{Chr} 29: 25-30)$. Consequently, the most important role of music in sanctuary liturgy is to proclaim the divine presence by singing the words that reveal his name, and thus his nature and his will. Since the public burnt offering is a form of "ritualized prophecy in which God spoke to his people, ${ }^{48}$ and which was synchronized with the music, this also supports the primary role of sanctuary music in proclaiming the divine presence by the words that helped to further elucidate the meaning inherent in the burnt offering. ${ }^{49}$

The choice of stringed accompaniment in the sanctuary context leads to the conclusion that the primary musical characteristics are melody grounded in harmony; a point to which we shall return later. Such an emphasis supports the melodic line that proclaims God's name without overpowering it or distorting it. Since the sanctuary temporally grounds the relationship between (1) the divine presence communicated by the singers, (2) the instruments chosen under divine direction (2 Chr 29:25), (3) the musical style in which rhythm does not dominate melody and harmony so as not to

reorganization of the Levites for their new duties at the temple in $1 \mathrm{Chr} 23: 30-31$ where the Levitical musicians were to offer thanks and praise whenever the public burnt offerings were offered. Ibid., 108-109. Since the burnt offering constituted the chief part of the ritual service

it would seem that, for Chronicles, the performance of praise somehow complemented the presentation of the burnt offerings. It was thus not a peripheral undertaking, conducted, as it were, at the fringes of the sacrificial system, but it was attached to the very centre, around which everything else revolved (Ibid., 109, cf. 112-113).

${ }^{48}$ Ibid., 156.

${ }^{49}$ In 2 Chr 29:27 we read, "And when the burnt offering began, the song of the Lord also began, with the trumpets and with the instruments of David king of Israel." The synchronization between the burnt offering and the music is also apparent in Rev 5:6-13 where the Lamb appears; and when he does, the four living creatures and twenty-four elders who have harps sing a new song to the Lord. 
distort the proclamation of the divine name, and (4) the universal scope of all of these elements in the proclamation of God's name to all nations (1 Chr 16:23-33), there is no room for the kind of contextualization by non-Israelites that creates a dichotomy between the divine presence and the proliferation of all kinds of musical styles.

Consequently, the goal of the musical accompaniment is to enrich the spiritual experience of the worshippers; and since God is infinitely temporal, he also experiences this ministry performed before him. Therefore, changing the melodic and harmonic accompaniment to the singing of the divine name not only risks conflating the divine presence with the music itself; it also potentially destroys the kind of joy (1 Chr 15:16), gladness (2 Chr 29:30), and power ( $2 \mathrm{Chr} 30: 21)$ that worshipers experience through the prescribed sanctuary liturgy by substituting it merely with a rhythmic sensory experience.

I will now examine the supportive role of the kinnor and the nevel in accompanying the choral music that provides pointers toward a philosophy of music. The supportive and accompanying role of stringed instruments and harps further emphasize that it is the singing that mediates the divine presence that must be distinctly heard as well as experienced by the worshippers. Hence, the role of the strings is to support and accompany the singers in sanctuary liturgy. This supportive role of the strings reveals the following implications: First, the intensity or loudness of the strings must not overpower the voices of the singers that mediate the divine presence through the proclamation of God's name and his revealed will. In this respect it is interesting to note that Scripture declares the words in musical events when the sanctuary is the context in which music is 
performed. ${ }^{50}$ This implies that the one who wrote down the account the Chronicler compiled was able to clearly hear the words that the singers sang suggesting that there was a proper balance between the volume of the singers and the volume of the accompanying strings. Moreover, that the words were clearly heard reinforces the fact that the divine presence is communicated via the words that are sung.

In contrast to this, the golden calf narrative of Exod 32 does not record the words that were being sung even though Moses informed Joshua that the noise he was hearing (Exod 32:17) was the result of singing (Exod 32:18). The fact that Joshua heard the music but could not discern the words being sung, allegedly to God (Exod 32:5, 18), illustrates that the predominant rhythmic emphasis that Joshua described as the noise of war (Exod $32: 17)^{51}$ overpowered the words so that they could not be heard in his case (Exod 32:18).

${ }^{50}$ Some examples are: (1) The song of Moses at the Red Sea in Exod 15:1-18. Although this did not take place in the physical context of an immediate earthly sanctuary, de Souza notes several ways in which the heavenly sanctuary (Exod 15:17) forms the context of this song, de Souza, "The Heavenly Sanctuary/Temple Motif in the Hebrew Bible," 148-154. Moreover, even though Miriam took up the timbrel with dances, the words are still recorded in Exod 15:21. As a result, the manner in which the song was sung, including the timbrel accompaniment, did not detract from the divine presence communicated through the words in Exod 15:21. This was not the case at the golden calf of Exod 32, which mentions singing (Exod 32:18) but no words are recorded in the narrative, (2) $1 \mathrm{Chr}$ 16:7-36, which takes place in the context of the "tabernacle of the Lord at the high place that was at Gibeon" (1 Chr 16:39), (3) 1 Chr 25:1 notes that the sons of Asaph, Heman, and Jeduthun, should prophecy with harps, stringed instruments, and cymbals in the "house of the Lord" "for the service of the house of God" (1 Chr 25:6). As they prophesied they addressed the people in poetry and song. See Kleinig, The Lord's Song, 156, (4) $2 \mathrm{Chr}$ 5:11-14 and 7:1-6, (5) 2 Chr 20:5, 20-22, 28, (6) 2 Chr 29:25-30, and (7) Rev 5:9-10, 12-13.

${ }^{51}$ The music at the golden calf was driven by rhythms. Evidence for this is that Joshua described the music as the noise of war in the camp (Exod 32:17). This means that unlike Moses he did not discern that they were actually singing (Exod 32:18). Since Joshua described what he heard as the noise of war, the emphasis was clearly on rhythms, which overpowered the words being sung to the Lord (Exod 32:5, 6); the emphasis was not on melody and harmony. Britan makes the following observation concerning martial music. He states,

it is the strong, stirring rhythm that forms the principal and unvarying characteristic of such [martial] music.... Though the melody in this music may differ, and the harmony be 
The primary emphasis of the rhythms ${ }^{52}$ also produced a sensual ${ }^{53}$ and entertaining ${ }^{54}$ worship service that was accompanied by dancing (Exod 32:19) and resulted in worshipers being out of control (Exod 32:25 NIV). Consequently, the sensual and entertaining nature of the golden calf worship cancelled out the message of the words even if they could be heard. The rhythms of the golden calf incident clearly illustrate that the music, not the words, constituted the vehicle for their idolatrous view of the divine presence. This matches the other models in which music is simply a vehicle for the divine presence, and that changes in music have no causal effect on the timeless divine presence or on the timeless worship encounter.

A second implication regarding the supportive and accompanying role of strings is that they make "one sound to be heard in praising and thanking the Lord...saying for he is good, for his mercy endures forever" (2 Chr 5:13). Since the purpose of the "one sound" culminates in and includes the message shared by the singers, the following observations ensue regarding the role of music at the sanctuary.

good or poor, the rhythm, if strongly accented, and of the proper sort, will almost suffice alone to produce the characteristic reaction (Britan, The Philosophy of Music, 68).

${ }^{52} \mathrm{~A}$ predominance of rhythms (evidenced by the noise of war in Exod 32:17) in which dancers move in very sensual ways (Exod 32:6, 19, 25) are characterized by a continual emphasis on the $2^{\text {nd }}$ and $4^{\text {th }}$ beats in music that is in $4 / 4$ time and comprised of an eighth note feel, or on the $4^{\text {th }}$ beat in music that is in $6 / 8$ time which has a triplet note feel. Moreover, "Since they had already replaced the living Lord with a golden calf that they called by the same name, they also felt free to improvise in their celebration." NIBC, s.v. Exod 32:1-6.

${ }^{53}$ The description of the worship at the golden calf as rising up to play (Exod 32:6) denotes sensuality. See Ashby, Exodus ITC, 131. According to HALOT, s.v. צחק combined with means to dally with, to fondle a woman. This is what Isaac was doing with Rebekah that convinced the king that she was indeed his wife in Gen 26:8. For the connections between Exod 32:6 and Gen 26:8, see NIBC, s.v. Exod 32:6. This kind of sensuality characterized the worship at the golden calf, and with respect to music it is the predominance of rhythms that creates this sensuality.

${ }^{54}$ See Judges 16:25 where the Philistines sought to entertain themselves by bringing out Samson, HALOT, s.v.צחק . 
First, strings are capable of producing a plurality of pitches, and choirs can also sing more than one individual pitch. While it is possible that "one sound" refers to many singers accompanied by the strings, all of which produce one unified pitch; it is more probable that the capabilities of many strings and many voices points to harmony ${ }^{55}$ since Scripture itself supports the idea that the concept of one (ehad) can refer to a plurality. ${ }^{56}$

Second, since the purpose of "one sound" is to be heard by the worshippers, the text assumes that it is possible to make many sounds that appear contradictory to those who hear them. If "one sound" refers to a plurality of pitches, then it raises the following problems: (1) how do we determine what pitches we will group together so that worshippers can experience them as "one sound"? And (2) on what basis will we make this decision? The problem of determining how various pitches should combine with each

${ }^{55}$ Kleinig notes that

The reference to 'one voice' in this verse [2 $\mathrm{Chr} 5: 13$ ] is not, as has been traditionally argued, to the performance of music in unison, but rather to a synchronized mass performance, in which the instrumental music combined with the singing to achieve a unified, harmonious effect (Kleinig, The Lord's Song, 87).

The following facts point toward the possibility of harmony. The kinnor "may have had two kinds of strings: the upper, tuned strings for producing a sweet clear sound (cf. Ps 81:3), and the lower, untuned strings for 'resonance'." Kleinig, The Lord's Song, 85. One proposal regarding the description of the nevel that comes from Josephus points out that "it had twelve tones... and was played with the fingers." Ibid. "For the transferal of the ark, eight musicians played harps, while six played lyres (1 Chr 15:20-21). Since harps probably made a deeper, louder sound than the lyres, they would have dominated the proceedings." Ibid., 86. Since the nevel, according to Alfred Sendrey "is supposed to have been the larger, therefore lower sounding instrument, the kinnor generally had the lead, which means that the kinnor doubled the melody, while the nebel had a more subordinate, accompanying function." Music in Ancient Israel, 282.

${ }^{56}$ The phrase "one flesh" refers to Adam and Eve in Gen 2:24; In Judg 20:8 all the people arose as "one man"; In Zeph 3:9 those who call upon the name of the Lord will serve him with "one shoulder" meaning shoulder to shoulder; In Gen 34:16 the men of Shechem suggest intermarriage with Jacob's children in order to become "one people" see Theological Wordbook of the Old Testament, s.v. number 61 . . Furthermore, since the I AM of Exod 3:14 is the Lord God of Exod 3:15, the Shema of Deut 6:4 also points to the Trinity since each member is integrally connected to the I AM as the One God. See Chapter 6 of this dissertation where I outline the ways in which the Trinity connects with the I AM as the One God in page 319, and especially 316-319. 
other should be solved by a phenomenological approach that ascertains what the stringed instrument itself reveals concerning this problem. The problem should not be solved by any methods that would contradict what a phenomenological approach reveals concerning how and why pitches should be grouped together. These methods and presuppositions can arise from personal, cultural, or philosophical considerations that span all cultures throughout the centuries. Allowing the strings themselves to reveal how pitches should be arranged with each other follows the methodology of this dissertation by applying a phenomenological method to strings just as we applied it to the words associated with the divine presence where we bracketed out presuppositions that contradicted what the Scriptural words themselves revealed.

As we apply the phenomenological method to the strings we discover that the overtone series $^{57}$ explains how the divinely ordained choice of strings (2 Chr 29:25) solves the problem of determining the nature of the "one sound"; it does this by grounding the music that arises from strings in the laws of physics.

According to the overtone series, the choice of stringed ${ }^{58}$ accompaniment

\footnotetext{
${ }^{57}$ The overtone series was first described at the beginning of the $18^{\text {th }}$ century. It gives much new insight into the Pythagorean principles of consonance and dissonance, and it greatly extends our capacities for acoustical analysis. It has been described as a kind of Periodic Table, but of musical tones instead of chemical elements. Hence, like the "periodic table of chemical elements, the overtone series is a part of creation's order - given, enduring, and constant," Blackwell, The Sacred in Music, 55, 56. After deconstructing the Charismatic model, it should clear that there is a difference between the overtone series itself - a phenomenon of the natural world - and the sacramental or panentheistic interpretation of the overtone series by Blackwell. As in the case with Aristotle's causes, a phenomenological description of the overtone series need not be conflated with Blackwell's panentheistic interpretation of the overtone series. Jeremy Begbie, who is not a panentheist, provides another example of the grounding role of the overtone series and how it discloses the reality of sound. Jeremy Begbie, Resounding Truth: Christian Wisdom in the World of Music (Grand Rapids, MI: Baker Academic, 2007), 225-236.

${ }^{58}$ Stringed instruments and harps produce harmonic overtones. In the overtone series the tones produced by strings that are accessible to the human ear first begin with the
} 
produces harmonic overtones ${ }^{59}$ that give the potential for creating one harmonious sound composed of a plurality of pitches whereas non-harmonic overtones such as cymbals, bells and other percussive instruments produce extremely complex overtones that do not lend themselves to producing harmonies. ${ }^{60}$ Moreover, in sanctuary liturgy cymbals were not used to accompany the singing, only the strings were used.

Thus, the divinely ordained choice of stringed accompaniment points to harmonic music that worshippers experience as one unified sound. Kleinig argues that the

octave, then the perfect fifth, the fourth, and the major third before eventually moving toward tones that are inaccessible to the human ear. As a result, the closer the tones are to the fundamental note that is played, the more consonant they sound in relationship to the fundamental note. Conversely, the further they are away from the fundamental note, the more dissonant they sound in relation to the fundamental note. These relationships are all expressed in terms of vibrational frequency in which the octave's lower tone vibrates half as rapidly as the upper tone $(1: 2)$; the tones of the perfect fifth are related in the ratio of $2: 3$; the fourth $3: 4$; the major third $4: 5$, the minor third 5:6; the major whole tone $8: 9$; and the minor whole tone 9:10. See Blackwell, The Sacred in Music, 54. Cultures that use instruments that produce periodic vibrations such as strings tend to produce music that is predominantly harmonic, "consisting in sustained tones that sound simultaneously in chords, as is the case with most music deriving from the post-medieval European culture." Ibid., 59.

${ }^{59}$ The overtone series includes harmonic overtones that are produced by strings, keyboards, brass, and woodwind instruments of a symphony orchestra. The vibrations from strings produce regular periodic harmonic overtones that include the Pythagoreans' monochord. We can illustrate this series of tones from the tone $\mathrm{C}$ (two octaves below middle $\mathrm{C})$, although any pitch can generate an exactly equivalent series. When that low $\mathrm{C}$ is struck, the next tone that is naturally heard without being struck is $\mathrm{C}$ an octave above. On Pythagoras' monochord the octave represents a ratio of 1:2 where the octave's lower tone vibrates half as rapidly as the upper tone. After $\mathrm{C}$ comes $\mathrm{G}$, a perfect fifth, which represents a ratio of $2: 3$; then $C$ again, a perfect fourth with a ratio of $3: 4$; then $E$, a major third with a ratio of $4: 5$; then $\mathrm{G}$, a minor third with a ratio of $5: 6$; then $\mathrm{B}$ flat another minor third; then $\mathrm{C}$, a major whole tone with a ratio of 8:9; then $\mathrm{D}$ followed by $\mathrm{E}$, followed by $\mathrm{F}$ sharp, which are major whole tones; then $\mathrm{G}$, a minor whole tone with a ratio of 9:10; then A another major whole major whole tone; then $\mathrm{B}$ flat, followed by $\mathrm{B}$ natural, followed by $\mathrm{C}$ which are all minor whole tones. Ibid., 54, 56, 57, 59.

${ }^{60} \mathrm{Cymbals}$ and other percussive instruments also produce overtones, but unlike the harmonic overtones produced by strings they are non-regular, non-harmonic, and often extremely complex. Ibid., 57. Cultures that primarily employ these instruments as accompanying instruments do not produce melodic music that is grounded in rich harmony. The reason is that the overtones from percussive instruments do not lend themselves to regular, periodic, and harmonic overtones. Blackwell notes that cultures that produce nonperiodic vibrations such as with cymbals produce melodic music "consisting in transient tones that sound successively, as is the case with many folk musics of the world." Ibid., 59. 
"instruments of power belonging to the Lord" (2 Chr 30:21) are powerful because of "their effect upon the people." ${ }^{, 61}$ From the perspective of sanctuary liturgy, powerful music is characterized by moving melodies and harmonies instead of by a predominance of rhythms. This characterization of sanctuary music effectively eliminates the kind of strong rhythmic emphasis (Exod 32:17) that we see at the golden calf that produced confusion among the worshippers (Exod 32:25), the enemies of YHWH, and Joshua (Exod 32:17). As a result, there is a causal connection between the choice of the instrument that points to harmonic music, and the experience of the worshippers who hear the "one sound" and experience "the affective power of the song.", models that allege that music is merely a vehicle for the divine presence sever this causal connection on account of the ontological dichotomy between the divine presence and the music. Consequently, there is no causal relationship in those models between musical style and the reception of the timeless divine presence by worshippers who experience God's presence in their timeless soul.

The fact that strings are grounded in harmonic overtones provides a justification for a melodic emphasis that is grounded in harmony, which assumes that the sanctuary temporally grounds the relationship between the liturgical usage of the instruments with the natural laws that are in accordance with physics. The role of music in the sanctuary thus points to a biblical philosophy of music that is not based on the kinds of music actually performed by the Israelites in the past or present but on the potential for grounding melodic music in harmony arising from the choice of strings as revealed in Scripture.

\footnotetext{
${ }^{61}$ Kleinig, The Lord's Song, 88.

${ }^{62}$ Ibid., 86.
} 


\section{Rev 4-5}

In the heavenly worship scene of Rev 4-5, there are only two instruments that are mentioned that I will now describe. In Rev 4:1 we find the trumpet and in Rev 5:8 we

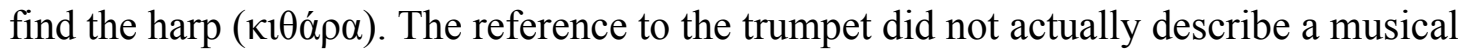
instrument but a voice that spoke, inviting John to "come up here..." (Rev 4:1; cf. 1:10). Hence, the function of the voice John heard that sounded like a trumpet was to draw his attention to the scenes in the throne room that were soon to take place. The function of the trumpet-like voice is thus similar to the role of the trumpets in Chronicles that would announce the Lord's presence at the ark in Jerusalem (1 Chr 16:6, 42) and announce the Lord's entrance into the temple during its dedication (2 Chr 5:12-14). ${ }^{63}$ Since the heavenly sanctuary grounds the temporal relationship between heavenly harps and earthly harps, the heavenly harp in Rev 5:8 is analogous to the earthly harp, which is a ten stringed instrument whose strings were plucked and probably tuned pentatonically without semitones through two octaves. ${ }^{64}$ The kinnor in Chronicles is referred to as kithara and kinyra in the LXX. ${ }^{65}$

Let's look at the musical characteristics in Rev 4-5 and then draw out the implications for the role of music in heavenly sanctuary liturgy. As a worshipper, John notes the instrumental accompaniment provided by the harp (Rev 5:8). However, John distinctly hears the words that are sung by the angels (Rev 5:11) as well as the words

\footnotetext{
${ }^{63}$ See this dissertation pages 541-543.

${ }^{64}$ Curt Sachs, The History of Musical Instruments, 107.

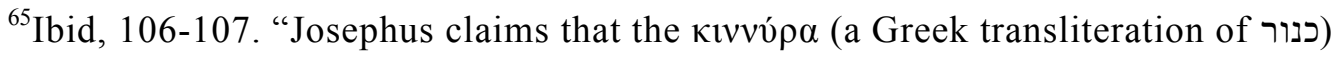
has ten strings that were struck with a plectrum, while the vó $\beta \lambda \alpha$ (a Greek transliteration of נבל) had twelve strings that were plucked with the fingers." David E. Aune, Revelation 1-5 WBC 52a, s.v. Rev 5:8b. For the kinnor in a temple context in Chronicles, see $1 \mathrm{Chr}$ 15:16, 21,$28 ; 16: 5 ; 25: 1,3,6 ; 2$ Chr 5:12; 9:11; 20:28; 29:25; Neh 12:27.
} 
sung by every creature in the universe (Rev 5:13). It is evident that the instrumental accompaniment functions in a supportive role instead of overpowering or muddying up the words that are sung. Since the heavenly sanctuary grounds the temporal relationship between the divine presence and all liturgical actions, the Holy Spirit does not reveal himself or speak through instrumental music in the book of Revelation as this would conflate the divine presence with creation.

The Charismatic Model asserts that instrumental music reveals the Spirit to worshippers. However, the book of Revelation declares that speech is the only mode of the Spirit's revelation to worshippers in liturgy. There are three main ways in which the Spirit speaks in Revelation. First, the Spirit speaks through direct speech. We see this in Rev $1: 10 ;{ }^{66}$ we see it at the conclusion of each message to the seven churches; ${ }^{67}$ we see it as we compare Rev 5:6 with the messages of the Three Angels of Rev 14:6-12, and with the benediction spoken by the voice from heaven and by the Spirit in Rev $14: 13 ;{ }^{68}$ and we see it as we compare Rev 5:6 with everlasting gospel of Rev 14:6-12 and Rom 10:1418. ${ }^{69}$ The Spirit also speaks through the words contained in the five hymns that are sung

\footnotetext{
${ }^{66}$ In each case where the phrase "in the spirit" ( $\left.\varepsilon v \pi v \varepsilon v ́ \mu \alpha \tau\right)$ is employed (Rev 1:10; $4: 1-2 ; 17: 1-3$; and 21:9-10), John hears a voice that speaks to him. This strengthens the close association between the Spirit and speech.

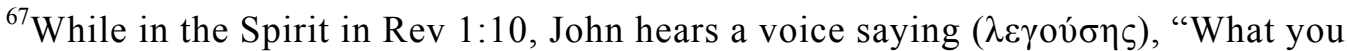
see, write in a book and send it to the seven churches." At the end of each message, the churches are admonished to hear what the Spirit says ( $\lambda \dot{\varepsilon} \gamma \varepsilon 1)$ to the churches (Rev 2:1, 7, 11 , $17,29 ; 3: 6,13,22)$. Hence, in Rev 1:10 John is brought into a state of being where he can hear Jesus speaking to him, thereby establishing the link between the Spirit and speech. Also, in the seven churches, the Spirit speaks to the churches when the liturgist speaks to each local church the message that Jesus originated.

${ }^{68}$ See Tables 1 and 2 for the connections between Rev 5:6, the messages of the Three Angels of Rev 14:6-12, and the Spirit in Rev 14:13. In this comparison, the Spirit is sent out into the world to speak through the proclamation of these messages.

${ }^{69}$ A comparison of Rom 10:14-18 with Rev 5:6 yields the following linguistic and thematic parallels. The passage in Rom 10:15 states, "And how shall they preach unless they
} 
by the four living creatures, the twenty-four elders, the vast angelic throng, and the entire universe found in $\operatorname{Rev} 4: 8,11,5: 9-10,12$, and $13 .^{70}$

Second, since John was admonished to write in a book what he saw (Rev 1:11) and send it to the seven churches, the Spirit also speaks when others read what John was commanded to write.

The third way in which the Spirit speaks is by revealing to John the heavenly sanctuary and the liturgical actions performed therein. For instance, John heard the voice of Jesus speaking to him saying ( $\lambda \dot{\varepsilon} \gamma \omega v)$, "Come up here, and I will show ( $\delta \varepsilon \dot{\xi} \xi \omega)$ you things which must take place after this" (Rev 4:1). "Immediately I was in the Spirit; and behold a throne set in heaven..." (Rev 4:2). John here is in a state of being through which the Spirit can show him things that are revealed in the context of the heavenly sanctuary in Rev 4-5. In connecting the work of the Spirit in showing or revealing the temple, John is building upon several OT passages that combine with Heb 8:5 (cf. Acts 7:44). ${ }^{71}$

are sent ( $\dot{\alpha} \pi \circ \sigma \tau \alpha \lambda \tilde{\omega} \sigma \iota v)$ "? Moreover, the "sound" that is composed of the "words" (Rom 10:18) of those who preach the gospel of peace (Rom 10:15) has "gone out into all the earth (Eis $\pi \tilde{\alpha} \sigma \alpha \nu \tau \eta \dot{v} v \gamma \tilde{\eta} v)$ " (Rom 10:18). As liturgists preach, the worshippers hear the word of God (Rom 10:17). In Rev 5:6 the seven Spirits are "sent ( $\dot{\alpha} \pi \varepsilon \sigma \tau \alpha \lambda \mu \varepsilon \dot{\varepsilon} v o 1)$ out into all the earth ( $\varepsilon i \zeta \pi \tilde{\alpha} \sigma \alpha \nu \tau \eta \dot{\nu} v \tilde{\eta} v)$." As we think of the seven churches in Revelation, the Spirit speaks through the angel of each church; and he who has an ear must hear what the Spirit says to the churches (Rev 2:1, 7, 11, 17, 29; 3:6, 13, 22). Hence, when the Spirit is sent out into all the earth, he is sent to preach the everlasting gospel (Rev 14:6-12) through human messengers.

${ }^{70}$ For a description of the hymns in Revelation, see Mueller, "Christological Concepts in the Book of Revelation-Part 2: Christ's Divinity," 74-79.

${ }^{71}$ The Lord said, "And let them make Me a sanctuary, that I may dwell among them.

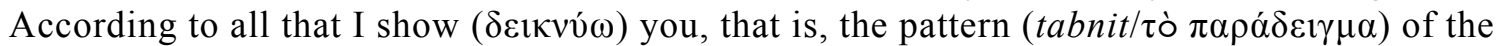

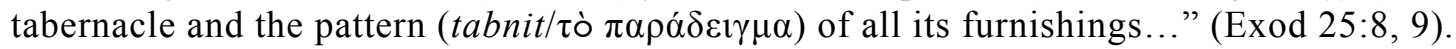
"And see to it that you make them according to the pattern (tabnit/ $\tau$ ò $\pi \alpha \rho \alpha \dot{\alpha} \delta \varepsilon \gamma \mu \alpha)$ which was shown ( $\delta \varepsilon \delta \varepsilon 1 \gamma \mu \varepsilon \dot{v}$ ov) you on the mountain" (Exod 25:40). The Lord spoke to Moses (Exod 31:1) saying I have filled Bezalel "with the Spirit of God" (Exod 31:3) in order to design and build the tabernacle of meeting (Exod 31:7). 1 Chr 28:11 David gave Solomon

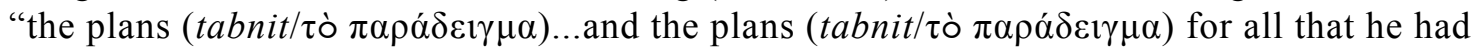
by the Spirit...(1 Chr 28:12)." In 1 Chr 28:19 "All this...the Lord made me understand in 
Furthermore, Jesus told his disciples that he would send the Spirit (John 14:26; 15:26; 16:7), and that the Spirit would declare things to come (John 16:13; cf. 1 Cor 2:9). In Rev 5:6 the Spirit is sent out into all the earth to speak. Thus, in addition to speaking via direct speech and through writing, the Spirit speaks by showing or revealing the heavenly sanctuary as the place where one learns about liturgy, and other important themes. This links together the Spirit, speech, and the sanctuary.

Since the heavenly sanctuary grounds the temporal relationship between the divine presence and all the liturgical actions in Rev 4-5, the nature of the speech is temporal, whether it is direct speech, reading an epistle, or being shown the liturgical actions that take place in the heavenly sanctuary. This renders groundless the sacramental interpretations of the sanctuary as a mode of timeless speech. Hence, contrary to what the Charismatic Model asserts, the divine presence can only be mediated in choral music through the words that are sung and not by the instrumental music.

We will now briefly explore the role of choral music in Rev 5. In 2 Chr 29:27, the Levites perform the choral music at the same time that the burnt offering is on the altar. Thus the purpose of the choral music is to draw attention to the message contained in the sacrifice that pertains to the burnt offering. We find a similar synchronization in the heavenly worship scene in Rev 5 between the Lamb as the antitype of the burnt offering, and the heavenly music. First, our attention is drawn to a Lamb standing as though it had

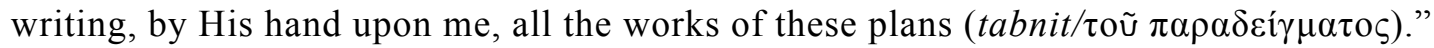
"See that you make all things according to the pattern ( $\tau$ òv $\tau \hat{\pi} \pi \circ v)$ shown ( $\delta \varepsilon \imath \chi \varepsilon \dot{\varepsilon} v \tau \alpha)$ you on the mountain" (Heb 8:5; cf. Acts 7:44). In these passages it is the Lord who showed Moses the pattern yet the Spirit, who is also the Lord in the Chronicles passage made David understand the pattern that was shown to Moses. The Spirit also gave wisdom to build the wilderness sanctuary. This connection between the Lord/Spirit who shows the sanctuary is found in Rev 4:1-2. John builds on the OT passages that connect the work of the Spirit in showing the temple. 
been slain, who then takes the scroll (Rev 5:6,7). Right after that, the four living creatures and the twenty-four elders sing a new song accompanied by the harp (Rev 5:8) in which they proclaim that the Lamb is worthy to take the scroll and open its seals because he was slain and his blood redeems people from all over the world (Rev 5:9-10). Since the divine presence and will is only communicated through speech, the choral music plays a subordinate role to the accomplishments of the Lamb and to his ability to reveal the content of the scroll as the key liturgical action in this worship scene. Hence, the purpose of the instrumental music is to provide an affective experience for the worshipper that compliments the communication of God's presence and will that occurs by the words that are sung.

The worship scene of Rev 5 further reveals the following insights into the nature of the music performed there and its role. In short, the music reveals a strong melodic line and harmonic emphasis that communicates emotions that compliment the content of the words. We shall now briefly describe and analyze each of these points. Although there are myriads of angels (Rev 5:11), Scripture records that John heard the voice (Rev 5:11) — singular — of many angels saying with a loud voice (singular): "Worthy is the Lamb....." (Rev 5:12). The fact that John heard clearly and distinctly the words that were sung as one voice and not many differing voices indicates that the music consisted of a strong melodic line with the potential of supportive harmony provided both by voices and by the harp.

Moreover, many angels and the rest of creation singing with one voice is reminiscent of the choral music at the dedication of the temple in $2 \mathrm{Chr} 5: 13$ where all the musicians were "as one, to make one sound to be heard in praising and thanking the 
Lord." Many voices and at least twenty-eight harps (Rev 5:8) all uniting as one voice lends itself more to a strong melodic line that is accompanied by rich harmony rather than all singing and playing the same note. Also, the movement from a few voices - the four living creatures and the twenty four elders in Rev 5:9-10 - to myriads of angelic voices ( $\operatorname{Rev} 5: 11)$, and then to the voices of the entire universe (Rev 5:13) reveals the finality of the Lamb's victory over Satan's attempt to sit on the throne. Consequently, in my opinion, a rich harmonic style capable of modulating keys and ending with a sense of finality (Rev 5:13,14) better captures the intensity of Christ's warfare in securing the throne rather than all singing and playing the same note. ${ }^{72}$

While the words reveal the divine presence, the specific content of the words speak of universal triumph and victory combined with overwhelming gratitude. The probability of expressing the powerful emotions attached to this scene is far greater by the accompaniment of a strong melodic line with rich harmony that includes key changes and a sense of finality, rather than by voices and harps that merely sing and play in unison. Consequently, the purpose of instrumental accompaniment is to add beauty, pathos, and power that worshipers can experience that will not detract from the message that the words convey. Since the heavenly sanctuary grounds the temporal relationship between the divine presence and musical accompaniment, the objective of heavenly music can be achieved by selecting earthly music that presents a balance of the musical elements while emphasizing a strong melodic line accompanied by rich harmonies, and avoiding styles with a predominance of rhythm that obscures the meaning and focus of worship. Dominant rhythms such as those at the golden calf (Exod 32) conflate the divine

\footnotetext{
${ }^{72}$ See this dissertation pages 552-556 regarding the plausibility of one sound as composed of harmony instead of sounding one note in unison.
} 
presence with music itself and also create dichotomies between the divine presence and musical style that were found in the other models.

Another important characteristic of heavenly worship involves participation by everyone. Although the four living creatures and the twenty-four elders took a leading role in $\operatorname{Rev} 5: 9-10$, the participation of the angels ( $\operatorname{Rev} 5: 11)$, and of every creature in the universe (Rev 5:13) strongly reveals that the role of choral music is designed to involve all; it is not a performance in which some sing and play while others remain silent.

We will now briefly examine the choice of the harp, and the implications for a philosophy of music, but first, a phenomenological description of music is in order. According to Blackwell, music consists of tone that is composed of pitch, timbre, loudness, and duration; and that musical patterns consist of melody, harmony, rhythm, tempo, and compositional structure. However, the great discovery of Pythagoras that was later confirmed in the $18^{\text {th }}$ century through the discovery of the overtone series was that "number underlies musical pitch." ${ }^{, 73}$ This naturally raises the question of how the mathematical numbers are related to musical tones and patterns. Timeless Being creates an unnecessary dichotomy between the eternal (timeless) numbers and the musical tones and patters. This has led to the mistaken conclusion that the unchangeable aspects of music refer to the mathematics that underlie the music whereas the cultural and changeable elements belong to the musical tones and patterns.

In opposition to this, the heavenly sanctuary temporally grounds the relationship between heavenly music and earthly music through the choice of the harp (Rev 5:8). This choice reveals an analogical relationship between heavenly harps and earthly ones,

\footnotetext{
${ }^{73}$ Blackwell, The Sacred in Music, 53. For more on the overtone series, see Ibid., 5467; Begbie, Resounding Truth, 225-236.
} 
between heavenly music and earthly music, between heavenly matter and earthly matter, and between the heavenly overtone series and the earthly overtone series. Since the use of the heavenly harp mediates the overtone series by producing harmonic overtones instead of percussive instruments and bells that produce disharmonic ones; the choice of strings reveals a heavenly musical philosophy that emphasizes melody that is grounded in harmony as foundational over a predominance of rhythm. ${ }^{74}$

Moreover, the context that combines all of heaven and earth (Rev 5:8-14) reveals the universal nature of this heavenly musical philosophy that we on earth should seek to emulate. The heavenly musical philosophy embraces the following characteristics: a strong melodic line in which the words are clearly heard accompanied by supportive harmonies that communicate the specific kinds of emotions that compliment the universal triumph and victory of the Lamb.

Furthermore, when we apply the temporal grounding of the relationship between heavenly and earthly music to the phenomenological description of music, we find that there can be no dichotomy between musical tones, patterns and the mathematics that undergirds them. To create this dichotomy would destroy the temporal grounding as revealed in the choice of the harp as an instrument that mediates the harmonic overtones in the overtone series.

\section{Encounter}

\section{Lev 19:30 and 26:1-2}

Since the divine presence was conflated to the calf (Exod 32:1, 4), the little

\footnotetext{
${ }^{74}$ See this appendix for more on the overtone series and the sanctuary instruments.
} 
cognitive content experienced by singing ${ }^{75}$ was largely overpowered by the non-cognitive power encounter ${ }^{76}$ that the worshippers experienced a predominantly rhythmic music. ${ }^{77}$

\section{Kgs 8:12-66 and 2 Chr 5-7}

Moreover, with respect to music, the divine presence is only mediated through the words sung, ensuring a cognitive encounter. Yet, when combined with the accompanying instrumental music, the Lord's song (2 Chr 29:27) produced a joyous (1 Chr 15:16), glad (2 Chr 29:30), and powerful (2 Chr 30:21) affective encounter that did not distort or nullify the cognitive encounter received by the proclamation of the divine name.

\footnotetext{
${ }^{75}$ In Exod 32:18, Moses informs Joshua that he hears the sound of singing. Thus it is plausible that the words they sang were sung to the Lord since Aaron informed them that "tomorrow is a feast to the Lord" (Exod 32:5). This would provide the basis for a cognitive encounter, yet when accompanied by war-like rhythms, the word was overpowered.

${ }^{76}$ Doukhan points out that rhythm gives us a feeling of power. Doukhan, In Tune with God, 29. Britan points out that if the basis of the music is predominantly rhythmic, then it does not matter how "catchy" the melody is nor how rich the harmonies are, because the rhythmic elements will still overshadow both of them, Britan, The Philosophy of Music, 69. Britan also notes that when warlike or martial music

is accompanied by words, they also must be recognized as having a part in the total effect produced. But they are not essential, as all instrumental music shows....Certain it is that after all proper allowances are made for the effect of words, melody, and harmonization, there remains enough left over to justify us in attributing to rhythm the characteristic quality which belongs to music of this sort [martial music]. Rhythm not only retains, but it exerts its pristine qualities, moving the spirit in a direct and powerful way to a reaction that is inherently emotional (Ibid., 68).

${ }^{77}$ Britan notes that
}

the stimulus is the same though veiled beneath some melodic and harmonic factors, and the nervous system still is sensitive to such stimulus; the effect, therefore, must be like in kind though somewhat restrained by the conventionalities of an older civilization.....[Hence] all that we are contending for is that the so-called popular music makes great use of rhythm, depends greatly upon it, and that the psychological effect of rhythm upon the mind is still as it has always been. This constant and invariable effect... is an emotional modification of consciousness (Ibid., 70).

"If the rhythm is sufficiently impressive, this reflex response [exhilaration and pleasure] may so overshadow all else that the character of the response as a whole is determined more by this than by other musical elements." Ibid., 79. 


\section{Rev 4-5}

In addition to the messages contained in the sealed scroll, the encounter in Rev 45 includes the instrumental music provided by the harp (Rev 5:8) that accompanies Revelation's seven hymns. ${ }^{78}$ In the other models the sole purpose of music is to merely act as a sonorous physical conveyor of the timeless divine presence to the timeless soul of the worshipper during the encounter. Furthermore, since music is a temporal phenomenon, the particular style of music is inconsequential since a temporal phenomenon cannot be mediated to the timeless soul. Thus, the other models preclude any kind of emotion communicated through music from having anything to do with the purpose of achieving a timeless encounter.

In contrast to this, Revelation 4 and 5 demonstrate that the goal of music is to provide an environment in which the worshiper may experience a spiritual encounter that takes into consideration (1) the words of Revelation's hymns that are set to a strong melodic line accompanied by rich harmonies, and (2) the nature of the worshippers that are found throughout the entire universe. The goal of achieving a spiritual encounter is achieved by the words sung that constitute the only medium of revealing the divine presence. Yet, the nature of every worshipper in the universe also includes emotions. In the worship scene of Rev 5, the words sung with a "loud voice" (Rev 5:12) create a powerful worship experience including emotions such as profound gratitude, love, and

\footnotetext{
${ }^{78}$ Although the first ( $\left.\operatorname{Rev} 4: 8\right)$ and second (Rev 4:11) hymns are sung to the Father, the harp is not mentioned. However, the third hymn (Rev 5:9-10) sung to Jesus specifically includes the harp (Rev 5:8). It is also plausible that the fourth hymn (Rev 5:12) sung to Jesus and the fifth (Rev 5:13) sung to both Father and Son are accompanied by the harp in Rev 5:8. The sixth hymn (Rev 7:10) directed to Father and Son, and the seventh hymn in Rev 7:12 directed to the Father do not mention the harp. See Mueller, "Christological Concepts in the Book of Revelation-Part 2: Christ's Divinity," 74-79.
} 
joy, combined with honor, respect, and reverence. ${ }^{79}$

This powerful heavenly worship experience was also found in temple worship that produced a joyous (1 Chr 15:16), glad (2 Chr 29:30), and powerful (2 Chr 30:21) cognitive/spiritual, and emotional encounter. Thus, the purpose of instrumental music is to compliment the emotions revealed through the words by having the music communicate the same joyous and reverent emotions. In this way, worshippers that possess cognitive, spiritual, and emotional faculties can experience a cognitive/spiritual encounter with the words while also experiencing an affective encounter in which the music communicates gratitude, love, and joy, combined with honor, respect, and reverence.

The ability of the harp to produce a joyous and reverent affective encounter is based on the capabilities inherent in its design and in its ability to accompany a strong melodic line with rich harmony. The choice of the harp and its primary emphasis on melody and rich harmony is grounded in the overtone series. ${ }^{80}$ Thus, by design, harps have the potential to produce harmonic overtones that produce melodic music with rich harmonies whereas percussive instruments produce complex non-harmonic overtones whose music is either driven by the persistent rhythms of the golden calf or melodic music "consisting of transient tones that sound successively, as is the case with many folk

${ }^{79} \mathrm{John}$ first experiences grief since no one was found worthy to take the scroll (Rev $5: 4)$. Yet, his grief is turned into profound gratitude, love, and joy combined with honor, respect, and reverence that is expressed through the words sung by the four living creatures, the twenty-four elders, the angels, and the entire creation (Rev 5:8-13). Reverence is also communicated by the four living creatures and the elders who fall down before the Lamb and worship him (Rev 5:8,14).

${ }^{80}$ For further explanations of the overtone series, see this appendix. 
musics of the world." ${ }^{, 81}$ As a result, the lack of a harmonic emphasis at the golden calf, and folk music does not seem to be associated with, or to resemble the universal vocal participation witnessed in Rev 5.

On the basis of the information provided in Rev 5, it thus appears that the musical characteristics that will produce joyous and reverent emotions in the encounter are those derived from a musical philosophy that emphasizes melody grounded in harmony whereas persistent rhythms produce emotions related to sexual pleasure, anger, and irreverence. $^{82}$

In the Biblical Sanctuary Model music is no longer the vehicle for the divine presence as it was in the other models. Rather, part of its purpose is to communicate emotions such as those we uncovered previously in Rev 5. This raises the question as to how to interpret music as a sonorous reality. Moreover, one can also question whether a specific emphasis of musical characteristics, such as melody grounded in rich harmony in Rev 5, can indeed communicate specific emotions in an encounter, or whether any musical style can communicate any emotion.

Under Kant's epistemology, the sonorous aspects of music constitute a temporal

${ }^{81}$ Blackwell, The Sacred in Music, 59. It should be noted that I am not arguing for rejecting the use of percussive instruments. My point here is that if the only two instruments that existed in the world were harps and percussive instruments (gongs, bells, drums: not xylophones and marimbas), it would be possible to develop a harmonic tradition in music with a harp whereas it would not be possible to develop such a tradition with percussive instruments.

${ }^{82}$ The word "play" in Exod 32:6 includes sexual gratification (Gen 26:8), amusement and entertainment (Judg 16:25), see HALOT, s.v. מחך. In describing the music as the noise of war (Exod 32:17), we deduce that the sound emitted emotions akin to anger and strife that are closely associated with war. Conflating the divine presence with nature, and thus with the calf (Exod 32:1, 4-5) is idolatrous. Irreverence is also indicated by sensual dancing (Exod 32:19) and by worshippers described as being out of control (Exod 32:25). These bodily movements are in complete contrast to those in Rev 4-5, where worshippers prostrate themselves before the Lamb denoting reverence (Rev 5:8, 14). 
phenomenon, which can technically be interpreted in a universal way. ${ }^{83}$ However, musical sounds are only conveyors of the divine presence and thus have nothing more to do with a timeless spiritual encounter in the Charismatic model. In postmodern epistemology, objectivity and universality concerning the natural world is entirely removed, ${ }^{84}$ which means that musical phenomenon $\mathrm{x}$ (which no longer conveys the divine presence) can be interpreted in as many ways as there are worshippers.

Although music involves sociological and cultural elements, Jeremy Begbie rightfully observes that reducing music to merely a cultural or sociological phenomenon fails to take into consideration that music possesses its own integrity and reality that is grounded and articulated by the overtone series. ${ }^{85}$ Begbie furthermore maintains that our

\footnotetext{
${ }^{83}$ In Canale's analysis of Kant's epistemology, he notes that the Aristotelian categories of matter and form that are grounded in the subject constitute the basis for the necessary objective knowledge that is now limited to spatio-temporal reality, Canale, $A$ Criticism of Theological Reason: Time and Timelessness as Primordial Presuppositions, 103. This means that music's objective and universal qualities are grounded in the subject and not in their own reality.

${ }^{84}$ Jeremy Begbie connects the postmodern ethos to the view that "there are no universal norms by which music can be interpreted and assessed...an approach with its tendency to question the very notion of an original, independent truth or reality to which the arts, morality, or indeed any kind of 'discourse' could refer." Jeremy Begbie, Resounding Truth, 14. See also Stanley Grenz, A Primer on Postmodernism (Grand Rapids, MI: Eerdmans, 1996).

${ }^{85}$ Begbie asks if we can account for musical traditions on the basis of universal features of the physical world; or can individual, cultural and sociological factors account for these musical traditions? He states:
}

The evidence suggests that this is not a simple either-or. Two points should be made. First, to say that different people hear a piece of music in different ways does not of itself prove that this music is to be thought of as an entirely human product, wholly contingent for its effect on the variable factors of taste and convention. Similarly, because some patterns of notes are not found universally does not of itself say anything about the rooting of these patterns in factors that transcend human making. Second, despite massive variety, it seems that certain constants can be found in the music of almost all cultures - strategies, forms, intervals (stable and unstable), and so forth. Moreover, a plausible case can be made for holding that the basis of at least some of these and of our response to them lies in phenomena I have described under the term "sonic order" - the integrities of the sound-producing materials, sound waves, the 
views of consonance and dissonance cannot be solely explained by cultural or sociological factors. Consequently, the overtone series provides an acoustical basis for our perception of consonance and dissonance ${ }^{86}$ Moreover, while not ignoring the context in which particular chords are found ${ }^{87}$ physicist and musician Donald Hall concludes that there is an "acoustical basis" for why "consonance in minor chords is considerably weaker than in major chords." ${ }^{88}$

The Biblical Sanctuary Model employs a phenomenological reading of the sanctuary, concluding that all the realities connected with the sanctuary are indeed different distinguishable entities that temporalize themselves. The sanctuary framework thus provides the basis to interpret the sounds that are produced by music. As a result, the various possible musical styles that we are capable of creating within a temporal framework produce various acoustical realities. In order for music to communicate

human body, time, or temporality - phenomena that are not culture- or individual-specific. This is hardly surprising. Indeed, there is something decidedly odd about insisting that music making and music hearing must be accounted for solely in terms of human construction if everyone inhabits essentially the same sonic order. (Jeremy Begbie, Resounding Truth, $49 \mathrm{cf}$. 225-236 for an explanation of how the overtone series works).

${ }^{86}$ Begbie asks, "When I hear a chord and call it dissonant rather than consonant, what is going on? Am I doing any more than expressing my culture's (or perhaps simply my own) preferences? Is the beauty of consonance all in the ear of the beholder? Or am I, at least in part, reacting to something there in the notes?" Refining the question a little further, he asks, "Is our judgment that this interval or chord is more consonant (or dissonant) than another based on anything more than individual or cultural preference? The answer is almost certainly yes." He then states that his conclusion "can be best accounted for at least in part by the harmonic series." Ibid. 230.

${ }^{87}$ Although much of the meaning of harmonic gesture would be lost if the standard of dominant-tonic is weakened - as in atonality- "the meaning of a chord, or of a relation between two chords, is not an intrinsic or absolute property; it depends also on the framework established by the other chords in relations that preceded it. We cannot always judge intervals and chords entirely in isolation; they must be considered in context." Donald E. Hall, Musical Acoustics: An Introduction (Belmont, CA: Wadsworth Publishing Company, 1980), 473.

${ }^{88}$ Ibid. 471. For a more thorough and technical explanation, see Ibid, 469-473; Jeremy Begbie, Resounding Truth, 230-233. 
emotions with precision, musical reality $\mathrm{x}$ must be perceived by the worshipper as communicating emotion $\mathrm{x}$ and not $\mathrm{y} .{ }^{89}$

Manfred Clynes ${ }^{90}$ notes that the precise interpretation and perception of color, ${ }^{91}$ as well as emotions ${ }^{92}$ communicated by tone of voice, gestures, and especially music ${ }^{93}$ is

${ }^{89}$ Although Jeremy Begbie alerts us to the perplexities involved in linking music with emotion, he nevertheless maintains that "music is undeniably one of the most emotionally potent media we know." Jeremy Begbie, Resounding Truth, 294. He goes on to say that "music can play its part in educating, shaping, and reshaping us emotionally." Ibid. 302 (emphasis original). Begbie presses his point even further when he states, "If we have argued along the right lines, music would seem to be an especially powerful resource available to the Holy Spirit for remaking us according to the image of Christ's perfected emotional life." Ibid. 304.

\footnotetext{
${ }^{90}$ Yehudi Menuhin states,
}

Dr. Manfred Clynes is recognized as one of the keenest and most creative intellects working in science today. He holds degrees in neuroscience (D. Sc.) from the University of Melbourne and a M.S. in music from the Juilliard School of Music in New York, as well as an engineering degree, and did graduate work at Princeton University in the psychology of music....An eminent authority on dynamic emotion communication, in music, the arts and in personal life, his book, Sentics, is regarded as a classic today (Manfred Clynes, Sentics: The Touch of the Emotions (New York: Avery Publishing Inc.), from the Introduction by Yehudi Menuhin).

${ }^{91}$ For instance, "the quality of red has a distinct physiologic code representation in the brain that displays crucial similarities across all people. This comes close to saying that all people see red similarly." Ibid., 5-6 Moreover, "This similarity of data processing is not learned culturally but is genetically programmed as part of human nature." Ibid., 6 . The quality of redness has stability. Clynes points out, "It is very likely that two thousand years ago people saw red the same way as we see it today. Indeed if they did not this would indicate a genetic change for which we have no evidence on any grounds." Ibid., 9.

${ }^{92}$ The stability and uniqueness of emotions is the same as redness. Clynes states, "We have spoken of qualities and of unique existences as genetically programmed." These qualities or entities are linked with the "the motor system as an integral part of their spatiotemporal existence. It is because of this inherent link to the motor system that these qualities can be communicated. This class of qualities is referred to commonly as emotions." Ibid., 13 (emphasis original).

\footnotetext{
${ }^{93}$ Clynes points out,
}

In the first chapter of this book, we showed how the stability of the quality of red and of similar idiologs that are one-to-one translations of the physiologic code demonstrate the high degree of precision of our nervous system. Idiologs of qualities and emotions as portrayed by music may show a perhaps even more astonishing precision (Ibid., 87).

Essentic form is a form in time. How may one capture such a form so that it can be experienced again?....Music is the invention that answers this question....It partakes of 
genetically programmed into every human being. In other words, the precision with which music communicates emotion is not culturally conditioned. ${ }^{94}$ Hence, one cannot express the profound gratitude, joy and reverence documented in Rev 5 with any musical expression.

\section{Summary}

The ritual use of the music at the dedication of the temple (2 Chr 5:11-13) indicates that the use of stringed instruments accompanied the singers who carried the divine message via the words sung ( $2 \mathrm{Chr} 5: 13 ; 7: 6)$. Moreover, the choice of strings as accompanying instruments reveals a philosophy of music in which the primacy of melody is grounded in harmony. However, the harmony of OT music probably did not reach the richness of what we experience today.

The choice of the harp ${ }^{95}$ as an accompanying instrument points to musical

the precision of essentic form. That music is largely an expression of inner gesture and song is widely understood (Ibid., 75).

${ }^{94}$ Clynes refers to specific emotional states as sentic states. Ibid., 17. An essentic form refers to a particular motor output chosen to express a sentic state that is governed by a brain program or algorithm specific for that state. Ibid., 18. His research concerning American, Japanese, and Balinese cultures

confirmed the similarity of different cultural groups and supported the view that specific essentic forms are characteristic of human nature, regardless of race and culture. This is, of course, of inestimable value for the communication of emotions and qualities among all people of the earth. It is a documentation of our brotherhood, in terms of our common inheritance of unchanging, pure qualities of emotions and their expressive forms, which are potentially programmed, so it seems, into every man (Ibid., 50-51).

${ }^{95}$ The reason for specifically mentioning the harp instead of referring to instruments of worship is based the following factors: (1) the harp constitutes data specifically mentioned by John in Rev 5:8; 14:2; 15:2 as an accompanying instrument, (2) the sanctuary introduces the concept that it, along with all that is connected to it, constitutes a model that reveals an analogy between the heavenly and the earthly (between heavenly thrones and earthly ones, heavenly and earthly altars, etc...), and also between heavenly and earthly harps, (3) all other physical objects mentioned by John point beyond themselves to heavenly realities; this is the way that we can know something of the nature of those heavenly realities that are analogous with the earthly ones, (4) although it is easier to conceptualize 
characteristics in the heavenly scene of Rev 4-5 that contain a strong melodic line accompanied by rich harmonies.

In the hymns of Rev 5, the words constitute the basis for a cognitive and spiritual encounter while the instrumental music (Rev 5:8) provided by the harp produces an emotional encounter. The specific emotions contained in the words found in Rev 5:9-14 that primarily include profound gratitude, love, and joy, combined with honor, respect, and reverence should be matched and not contradicted by the music. In the Biblical Sanctuary Model, the purpose of instrumental music is to provide an affective encounter that compliments the revelation of God's will through the words that are sung; music does not convey the divine presence.

\section{Theological and Systematic Outline of Music}

Thus far we have generated data that we can now use in order to construct a theological and systematic outline of music in the Biblical Sanctuary model. In the section below on liturgical setting and actions, we will note how the heavenly sanctuary grounds the relationship between heavenly and earthly music that points to the predominant musical characteristics involved in music and in the issues between music and morality.

the reality of physical objects that can be seen than it is to conceptualize the reality of sounds we have never heard, it is important to reason from the data (in this case the harp) and then ask ourselves what the data itself reveals about the nature of heavenly sound. I have relied here on the overtone series and how the choice of strings have potential to produce harmonic sounds, and (5) one cannot spiritualize away, minimize, or distort the data that the Bible writers have given to us. To do this is to destroy our conceptions of the realities to which they point, and to build upon the presuppositional structure of the models I have deconstructed in Chapter 4 of this dissertation. 


\section{Liturgical Setting and Actions}

\section{The Sanctuary Grounds Relationship between Heavenly and Earthly Music}

In addition to the communication of God's words as the central liturgical action, music is also a prominent liturgical action. The heavenly sanctuary grounds the temporal relationship between the components that make up music, namely: rhythm, melody, harmony, tempo, compositional structure, pitch, timbre, loudness, duration, and mathematics which has its basis in the overtone series. Moreover, on the basis of the analogy between heavenly harps and earthly harps, the heavenly sanctuary grounds the temporal relationship between heavenly music that serves as model for earthly liturgists to emulate in their music on earth. The role of the Holy Spirit is to reveal these principles that have their basis in the heavenly sanctuary (Rev 5:6).

\section{The Sanctuary, Musical Characteristics, and Morality}

Before discussing the relationship between the sanctuary, musical characteristics, and morality, I would like to briefly go over the basis for morality in music in the previous three models; and I would like to examine some of the arguments for music as amoral. In the pre-Vatican II Sacramental model music is considered to be holy, sacred, and moral when it closely adheres to the chant; yet in the post-Vatican II Sacramental model and in the Charismatic model the morality of music is based on the mathematical numbers of music, not on its actually sounds. ${ }^{96}$ It appears that the assumptions of timeless

\footnotetext{
${ }^{96}$ See Chapter 4 of this dissertation. Also, upon considering the relatioinship between truth and music, Harold Best states, "Unlike truth, which is transcultural, absolute, and unchangeable, music can shift in meaning from place to place and time to time." Harold M.
} 
Being in these models lies at the basis for the view that music is merely a cultural or sociological phenomenon. Consequently, the Sacramental and Charismatic models after Vatican II prepare the way for some to conclude that music is an amoral phenomenon, and that there is an ontological dichotomy between truth and music, and between ethics and $^{\text {aesthetics. }}{ }^{97}$

The arguments for the amorality of music are (1) the multiplicity of responses to the same style of music points to the worshipper as the cause for morality, ${ }^{98}(2)$ music is an object comparable to a tree or a rock that cannot transmit moral principles to the

Best, Music Through the Eyes of Faith (New York: HarperCollins, 1993), 54. It appears that this statement has its basis in the asumptions of the Sacramental and Charismatic models that posit an ontological dichotomy between the timeless (truth) and the historical and changeable (music).

${ }^{97}$ For the dichotomy between truth and music, see note 96 above. Harold Best asserts,

the beauty of God is not aesthetic beauty but moral and ethical beauty. The beauty of creation is not moral beauty; it is aesthetic beauty, artifactual beauty. Aesthetic beauty lies in the way or quality with which something is made or said. Truth lies in what is said....Being emotionally moved by music is not the same as being spiritually or morally shaped by it. (Best, Music Through the Eyes of Faith, 43, 44, 151).

Under the assumption of timeless Being, one can read Best as assuming that aesthetics belongs only to creation but not to God because God is timeless and spaceless. There is furthermore a dichotomy between emotions and spirituality, leading to the deduction that there is no causal connection between being emotionally moved and being spiritually or morally shaped. This assumes a timeless interpretation of the divine presence and Scripture that is mediated to the timeless soul, and in which music merely moves us emotionally but is not causally connected to spirituality/morality on account of the ontological dichotomy between soul (spirituality) and body (emotions). Doukhan also appears to assume a similar dichotomy between a spiritual experience that pertains to the mind and the senses versus a religious experience in which a life is connected to God. This dichotomy between the spiritual and the religious grounds Doukhan's distinction between ethics (God and Scriptural truth) and aesthetics (the sounds of music: rhythm, melody, and harmony). Doukhan, In Tune with God, 48. Consequently, ethics deals with unchanging ethical principles that can either be derived from Scripture or from the mathematical portions of music whereas the sonorous aspects of music are changeable and thus belong to aesthetics.

${ }^{98}$ See Doukhan, In Tune with God, 59. 
hearer, ${ }^{99}$ and (3) the failed attempts to ground morality in music that are based on Greek philosophical assumptions about God, the world, and human nature. ${ }^{100}$

However, except for the last point, the previous two arguments are based on the following interrelated points: (1) the uncritical assumption of the modern and postmodern view of ontology (in this case, the nuts and bolts of what actually constitutes music), (2) the modern/postmodern view of epistemology where meaning and morality are solely based on the socio-cultural context of worshippers/listeners as they interact with events and develop associations, and ${ }^{101}(3)$ the failure to distinguish between the nature of the encounter, and the response to the encounter. ${ }^{102}$

${ }^{99}$ Ibid. 48. There are four problems with this approach. First, lumping together objects such as rocks, trees, and music fails to take into consideration their different realities and the nature of the encounter between all of these realities and human beings. Second, by lumping all music together it assumes that all the musics of the world constitute one big monolithic reality instead various realities that temporalize themselves in different ways that then have diverse causal effects on the nature of the encounter. Third, by minimizing the differences between these objects, it fails to construct a phenomenological description of each reality. Consequtnly, it assumes the modern/postmodern view of epistemology where meaning and morality is solely determined by the worshipper. Fourth, Doukhan is correct in stating that music cannot directly transmit morality into our souls through the act of contemplation - a view based on timeless Being's interpretation of eternity, reality, and the soul, which she correctly criticizes. Ibid. 48-53. However, Harold Best's view that there is no causal connection between being emotionally moved by music - a temporal phenomenon - and being spiritually uplifted by God and his Word (footnote 97 above) appears to be based on the ontological dichotomy between the soul that receives its morality from God, his word, and the mathematical portion of music; and the emotions that can be moved by music. It is this severing of the harmonious connection between that which impacts the emotions (music) and spirituality/morality that has its basis in timeless Being's influence over these issues.

${ }^{100}$ See Doukhan, In Tune with God, 48-53. See Chapter 4 of this dissertation for a deconstruction of of these views in Christian liturgy.

${ }^{101}$ For examples of the subject/worshipper as the one who solely determines meaning, see Doukhan, In Tune with God, 57, 60, 66-70. For a correction to the view that meaning is solely derived from the subject/worshipper, or that meaning solely arises from cultural and sociological factors, see Begbie in footnote 85 above.

${ }^{102}$ See my analysis of the encounter and response to the encounter in the Biblical Sanctuary model in Chapters 5 to 7. Since those Chapters inform us that we have hermeneutical minds, we are free to respond or not respond to the nature of the encounter. 
The Biblical Sanctuary Model points to the following deductions about the characteristics of music. Earthly harps produce harmonic overtones. Thus on the basis of the analogy between heavenly and earthly harps, heavenly harps also produce harmonic overtones that are similar in nature to earthly harmonic overtones. Consequently, these harmonic overtones constitute the basis for a melodic music that is grounded in rich harmony. Instrumental music does not mediate the presence of God but the creativity of the liturgist that interprets and arranges the melodies and harmonies that arise from the harmonic overtones that strings produce and which have their basis in the laws of physics ( $\operatorname{Rev} 5: 8)$. The words that are sung mediate the divine presence and action (Rev 5:9-10). The heavenly sanctuary thus grounds a melodic emphasis in the context of rich harmony as a universal philosophy of music that is enjoyed by the combined inhabitants of heaven and earth in Rev 4-5 and which should be emulated by earthly liturgists today. A temporal grounding of all the components of music eliminates the dichotomy between the mathematics of music and music's actual sounds. In this sense, instrumental music is moral when it emphasizes melody grounded in rich harmony since it is in accordance with the choice of the harp which produces harmonic overtones.

However, choosing not to respond to the nature of the encounter does not alter what was ultimately being communicated to the worshiper during the encounter. Consequently, basing the amorality of music on the response to the encounter does not take into consideration the potential for emotional communication through music to influence the actions and spirituality of an individual. In the Biblical Sanctuary model's interpretation of human nature there is no dichotomy between emotions and the potential to influence character and spirituality; however, as we have noted in footnotes 97 and 99 above, timeless Being posits an ontological dichotomy between emotions and spirituality. Under the Biblical Sanctuary view, it is possible for emotions to influence character since these components are integrated, but in the other models there is no causal connection between emotions directed to the body through music, and morality directed to the timeless soul through contemplation of God, Scripture, or the mathematics of music (see footnotes 97 to 99 above). 


\section{Sanctuary and the Nature of Music}

I will now describe the nature of music in this Model on the basis that the heavenly sanctuary serves as the model for earthly liturgists to understand and apply. First, since only God's words reveal his presence, we must conclude that heavenly harp music does not communicate anything about the divine presence. Instead, in the context of the heavenly sanctuary the choice of the harp in Rev 5:8 temporally grounds the relationship between heavenly music and creation. Harp playing thus discloses the overtone series, which is grounded in creation; ${ }^{103}$ it also discloses the liturgist's creative abilities.

Second, the analogy between heavenly music and earthly music revolves around the choice of the harp in heaven ( $\operatorname{Rev} 5: 8$ ), and is based on the grounding of the temporal relationship between heavenly music and earthly music. This grounding reveals an analogical relationship between heavenly harps and earthly harps. Consequently, we know that strings produce harmonic overtones in which the most consonant intervals consist of the octave, the perfect fifth, the perfect fourth, and the major third. These intervals make up the basic building blocks of all harmonic music. ${ }^{104}$ Accordingly, on the basis of the analogy between heavenly and earthly harps, there must also exist an analogy between earthly and heavenly melody and harmony. This points to a heavenly musical philosophy that has a melodic emphasis that is rich in harmony. Since this philosophy is grounded in universal physical laws thereby making it universal, the liturgists of all cultures should adopt it when creating music in liturgy.

Third, music consists of (1) tones that are composed of pitch, timbre, loudness,

\footnotetext{
${ }^{103}$ For more on the overtone series, see this dissertation, 206, and this appendix.

${ }^{104}$ See this appendix.
} 
and duration; (2) patterns that consist of melody, harmony, rhythm, tempo, and compositional structure; and (3) mathematics that are grounded in the overtone series. ${ }^{105}$ The temporal grounding of the relationship between these three areas eliminates the possibility of creating a dichotomy between the timeless mathematical basis of music and the tones and patterns of music. Such a dichotomy would destroy the analogical relationship between heavenly and earthly music that Scripture reveals through the choice of the harp as the heavenly instrument that discloses the heavenly philosophy of music.

Fourth, when combined with singing, the words sung in the hymns of Rev 4-5 reveal his presence while the music reveals the creative ways in which musicians interpret musical raw materials associated with the overtone series. Moreover, the recorded words in those chapters point to the fact that the presence of God revealed through the words are paramount and that the strings are accompanying instruments whose function is never to communicate the divine presence but to support and complement the singing response to the divine presence rather than to overpower, compete with, or distract from it. The supportive role of music is also brought out by the fact that the singers and musicians stood at the east end of the altar (2 Chr 5:12) and only began to sing and play after the burnt offering (2 Chr 29:27). Since the heavenly sanctuary serves as a model that temporally grounds the relationship between heavenly and earthly music, earthly liturgists should seek to emulate these heavenly musical characteristics in their worship.

Given this background, I will point out the following reasons why music is not morally neutral in the Biblical Sanctuary Model. Since music does not mediate the divine

\footnotetext{
${ }^{105}$ Blackwell, The Sacred in Music, 53.
} 
presence, it must be grounded in creation's natural and physical laws as understood by the choice of the harp that produces harmonic overtones. God created natural and spiritual laws. Grounding morality in natural and physical laws is thus related to but distinct from the laws that govern the way in which spiritual beings should relate to each other, such as what we find in the Ten Commandments. In the Biblical Sanctuary Model, the possibility of producing melodic music that is grounded in complex harmony has the potential to be moral and sacred. Moreover, since universality is an essential distinguishing feature of natural and physical laws (morality), the spiritual and universal context of Rev 4-5 also gives the musical characteristics of melody grounded in rich harmony a universal scope. There is thus no Scriptural basis for restricting sacred and moral music to the chant, whose claim to universality is rendered groundless. ${ }^{106}$ Equally problematic is the Vatican II view that the music of all cultures is thus sacred and moral on the basis of the dichotomy between the timeless mathematics that all music assumes and the rhythm, melody and harmony of the music of all cultures.

\section{Encounter}

I will now briefly examine the hermeneutical role of the sanctuary for providing the ground for analyzing the nature of the worshippers' encounter with music.

${ }^{106}$ The temporal grounding of the heavenly sanctuary replaces and is incompatible with the Platonic worldview that justifies the chant as the most perfect example of sacred music. The entire concept of musical universals is flawed since it is based on the idea that each earthly note imitates or duplicates the ideal heavenly note. This Platonic conception undermines and spiritualizes away the hermeneutical role of the heavenly sanctuary in pointing to harmonic overtones based on the choice of the harp. Moreover, Jeremy Begbie notes that one of the biggest consequences of the Great Tradition (Pythagorean and Platonic theories) is that of "imposing too comprehensive a theory of sound (and thus of music) on the physical world." Begbie, Resounding Truth, 92 (emphasis original). Consequently, these supposedly God-given theories "do not allow sufficient space for the realites of sound to reveal themselves as they are." Ibid. 


\section{The Heavenly Sanctuary Interprets the Encounter with Music}

When earthly and heavenly musicians make music_choral, vocal, or instrumental - it is only the words that reveal the divine presence since God is not present in music as the Sacramental and Charismatic Models assert. Instrumental music communicates emotions that should match the emotions conveyed by the words being sung. For instance $1 \mathrm{Chr}$ 15:16; 2 Chr 29:25-30; and Neh 12:27 point out that the singers who were accompanied by the stringed instruments sang their songs in the presence of God with joy and gladness. This is matched by the joy and gladness of the heavenly worshippers who sing a new song accompanied by harps (Rev 5:8) in which they celebrate Christ's worthiness and triumph over Satan (Rev 5:9-14). Hence, the content of the words that point to emotions should be matched by similar emotions produced by music. The heavenly sanctuary thus grounds the relationship between the emotions communicated in the text with the emotions communicated through music.

The nature of the encounter with music is an emotional encounter that is subservient to the cognitive spiritual encounter provided by the words. The subservient and supportive nature of the emotional encounter with instrumental music in comparison with the cognitive/spiritual encounter with the burnt offering as a ritualized form of speech is revealed by the order in which they appear in 2 Chron 29:27. The text points out that the song of the Lord that was accompanied by instruments began only after the burnt offering began. There is a similar order in Rev 5:6-14 that also discloses the relationship between the cognitive/spiritual encounter revealed by the liturgical actions of the Lamb and the emotional encounter revealed by the instrumental accompaniment to the new song. In that passage the new song of Rev 5:9-14 began only after the slain 
Lamb took the scroll out of the hand of the one seated on the throne.

\section{Sanctuary and Issues with Music in the Encounter}

With regard to music, a cognitive encounter with the divine presence through instrumental music is not possible since instrumental music reveals the way in which musicians interpret the overtone series. In other words, music functions as a window into creation's laws as liturgists arrange the sounds that are derived from the overtone series by playing their instruments. This means that music can provide a window into the liturgists' creative abilities. For instance, an instrument such as the harp can produce rich music with complex harmony that is based on mathematics and physics derived from the overtone series. As a result, one can use the mind to apprehend and analyze these complexities in an encounter. However, since music does not mediate the divine presence, using the mind to analyze the melodies and harmonies of the music only reveals the creative mind of the musician. Moreover, worshippers can also receive affective communications that come from the distinct sounds that are produced. ${ }^{107}$

Thus, an encounter with instrumental music includes the mental and emotional aspects of human worshippers where the mental faculties are capable of deducing complex melodic and harmonic relationships that are grounded in the overtone series; and where the emotional aspects of worshippers can experience the sounds. The affective experience of instrumental music should be governed by and grounded in a philosophy of music where melody and harmony are the predominant characteristics. ${ }^{108}$ The heavenly sanctuary temporally and universally grounds the mental and affective experience of the

\footnotetext{
${ }^{107}$ See this appendix.

${ }^{108}$ See this appendix.
} 
music in heaven as a pattern for what worshippers should experience on earth. 


\section{BIBLIOGRAPHY}

$1 \& 2$ Kings; 1 \& 2 Chronicles; Ezra; Nehemiah; Esther; Additions to

Esther; Tobit; Judith. 3 of 12 vols. The New Interpreter's Bible. Nashville, TN: Abingdon Press, 1994.

Abbott, Walter M., ed. Decree on Ecumenism: Unitatis Redintegratio, Documents on Vatican II. New York: Herder and Herder, 1966.

, ed. Dei Verbum, The Documents of Vatican II. New York: Herder and Herder, 1966.

, ed. Sacrosanctum Concilium, The Documents of Vatican II. New York:

Herder and Herder, 1966.

Adams, Michael. Vatican II on Ecumenism. Chicago: Scepter Books, 1966.

Albrecht, Daniel E. Rites in the Spirit: A Ritual Approach to Pentecostal/Charismatic Spirituality. Sheffield, England: Sheffield Academic Press, 1999.

. "Pentecostal Spirituality: Looking through the Lens of Ritual." Pneuma 14, no. 2 (Fall 1992): 107-125.

Allchin, Arthur M. "The Liturgical Movement and Christian Unity." In Liturgical Renewal in the Christian Churches, edited by Michael J. Taylor. Baltimore, MD: Helicon, 1967.

Allen, Bob. "Baptist Church Ordains Transgender Woman." The Christian Century 131, no. 16 (2014): 12-13.

Allen, Diogenes, and Eric O. Springstead. Philosophy for Understanding Theology. Louisville, KY: John Knox Press, 2007.

Allen, Leslie C. 1, 2 Chronicles Communicator's Commentary Series Old Testament. Waco, TX: Word Books, 1986.

Allmen, J.-J. von. Worship: It's Theology and Practice. New York: Oxford University Press, 1965. 
"The Altar [Isaiah 6:6]." In Seventh-Day Adventist Bible Commentary, edited by F.D. Nichol, 4:128-129. Washington, DC: Review and Herald, 1976-1980.

Anderson, Gary A. "To See Where God Dwells: The Tabernacle, the Temple, and the Origins of the Mystical Tradition." In Temple and Contemplation: God's Presence in the Cosmos, Church, and Human Heart, edited by Scott W. Hahn.

Steubenville, OH: St. Paul Center for Biblical Theology, 2008.

Anderson, Paul. "Balancing Form and Freedom." In Changing Lives through Preaching and Worship: 30 Strategies for Powerful Communication, edited by Marshall Shelley. Nashville, TN: Moorings, 1995.

Anderson, Ray S. An Emergent Theology for Emerging Churches. Downer's Grove, IL: InterVarsity Press, 2006.

Aquinas, Thomas. Summa Theologica. Translated by The Fathers of the English Dominican Province. 3 vols. New York: Benziger Brothers, Inc., 1947.

Aristotle. Metaphysics. Oxford: Clarendon Press, 1948.

Armstrong, Chris. "The Future Lies in the Past." Christianity TodayFebruary 15, 2008, 22-29.

Ashby, Godfrey. Exodus: Go out and Meet God International Theological Commentary. Grand Rapids, MI: Eerdmans, 1998.

Ashton, Ruth Ann. God's Presence through Music. South Bend, IN: Lesea, 1993.

Attridge, Harold W. The Epistle to the Hebrews Hermeneia. Philadelphia: Fortress Press, 1989.

Augustine. "The Confessions of St. Augustine." In The Nicene and Post-Nicene Fathers, edited by Philip Schaff. 14 vols. Grand Rapids, MI: Eerdmans, 1988.

Aune, David E. Revelation 1-5 Word Biblical Commentary 52a. Dallas, TX: Word Books, 1997.

Revelation 6-16 Word Biblical Commentary 52b. Dallas, TX: Word Books, 1998.

Bacchiocchi, Samuele. The Christian and Rock Music : A Study on Biblical Principles of Music. Berrien Springs, MI: Biblical Perspectives, 2000.

. Immortality or Resurrection? A Biblical Study on Human Nature and Destiny. Berrien Springs, MI: Biblical Perspectives, 2001. 
Baker, Jonny, and Doug Gay. Alternative Worship: Resources from and for the Emerging Church. Grand Rapids, MI: Baker Books, 2003.

Baldovin, John F. "Christian Worship to the Eve of the Reformation." In The Making of Jewish and Christian Worship, edited by Paul F. Bradshaw and Lawrence A. Hoffman. South Bend, IN: University of Notre Dame Press, 1991.

Baptism, Eucharist and Ministry. Faith and Order Paper No. 111. Geneva: World Council of Churches, 1982.

Barbour, Ian G. Myths, Models, and Paradigms: A Comparative Study in Science and Religion. New York: Harper \& Row, 1974.

. Religion and Science: Historical and Contemporary Issues. San Francisco: HarperSanFrancisco, 1997.

Barna, George. "Worship in the Third Millennium." In Experience God in Worship. Loveland, CO: Group Publishing, 2000.

Barrett, C. K. A Critical and Exegetical Commentary on the Acts of the Apostles. Vol. 2 International Critical Commentary. New York: T \& T Clark, 1998.

Barth, Karl. Church Dogmatics. Translated by G.T. Thomson. 5 vols. Edinburgh: T \& T Clark, 1957.

Bartlett, David L. "Worship." In New and Enlarged Handbook of Christian Theology, edited by Donald W. Musser and Joseph L. Price. Nashville, TN: Abingdon Press, 2003.

Bateman, Herbert W. "Jewish and Apostolic Hermeneutics: How the Old Testament is Used in Hebrews 1:5-13." PhD dissertation, Dallas Theological Seminary, 1993.

Bauckham, R. J. "Sabbath and Sunday in the Post-Apostolic Church." In From Sabbath to Lord's Day: A Biblical, Historical and Theological Investigation, edited by D.A. Carson. Grand Rapids, MI: Zondervan, 1982.

. "Sabbath and Sunday in the Protestant Tradition," In From Sabbath to Lord's Day: A Biblical, Historical and Theological Investigation, edited by D.A. Carson. Grand Rapids, MI: Zondervan, 1982.

Bauer, Walter, F.W. Danker, W.F. Arndt, and F.W. Gingrich, eds. A Greek-English Lexicon of the New Testament and Other Early Christian Literature. 3rd ed. Chicago: University of Chicago Press, 2000.

Bea, Augustin Cardinal S.J. The Way to Unity after the Council. New York: Herder and Herder, 1967. 
Beale, G.K. The Book of Revelation: A Commentary on the Greek Text New International Greek Testament Commentary. Grand Rapids, MI: Eerdmans, 1999.

. The Temple and the Church's Mission: A Biblical Theology of the Dwelling Place of God New Studies in Biblical Theology. Downer's Grove, IL: InterVarsity Press, 2004.

Becker, Matthew L. The Self-Giving God and Salvation History: The Trinitarian Theology of Johannes Von Hofmann. New York: T \& T Clark International, 2004.

Beeck, Franz Jozef van. Catholic Identity after Vatican II: Three Types of Faith in the One Church. Chicago: Loyola University Press, 1985.

Begbie, Jeremy. Music in God's Purposes. Edinburgh: Handsell Press, 1989.

. "Theology and Music." In The Modern Theologians: An Introduction to Christian Theology since 1918, edited by David F. Ford and Rachel Muers. Malden, MA: Blackwell, 2005.

. Resounding Truth: Christian Wisdom in the World of Music. Grand Rapids: Baker Academic, 2007.

Berkouwer, G.C. Studies in Dogmatics: Faith and Justification. Grand Rapids, MI: Eerdmans, 1954.

. The Second Vatican Council and the New Catholicism. Grand Rapids, MI: Eerdmans, 1965.

Best, Harold M. Music Through the Eyes of Faith. New York: HarperCollins, 1993.

Bevins, Winfield H. "A Pentecostal Appropriation of the Wesleyan Quadrilateral." Journal of Pentecostal Theology 14, no. 2 (2006): 229-246.

Bierly, Steve. "Sparring over Worship." Leadership (Winter 1997).

Blackwell, Albert. The Sacred in Music. Louisville, KY: John Knox Press, 1999.

Blazen, Ivan T. "Salvation." In Handbook of Seventh-Day Adventist Theology, edited by Raoul Dederen. Hagerstown, MD: Review and Herald, 2000.

Block, Daniel I. "'That They May Hear": Biblical Foundations for the Oral Reading of Scripture in Worship." Journal of Spiritual Formation \& Soul Care 5 no.1 (2012): 5-34.

Bloesch, Donald G. The Church: Sacraments, Worship, Ministry, Mission. Downer's Grove, IL: InterVarsity Press, 1997. 
. The Holy Spirit: Works and Gifts. Downer's Grove, IL: InterVarsity Press, 2000.

. Holy Scripture: Revelation, Inspiration \& Interpretation. Downer's Grove, IL: InterVarsity Press, 2006.

Blume, Friedrich. Protestant Church Music: A History. New York: W.W. Norton, 1974.

Bock, Darrell L. "A Theology of Luke-Acts." In A Biblical Theology of the New Testament, edited by Roy B. Zuck. Chicago: Moody Press, 1994.

. Acts Baker Exegetical Commentary on the New Testament. Grand Rapids, MI: Baker Academic, 2007.

Bolich, G. G. Crossdressing in Context: Dress, Gender, Transgender, and Crossdressing Vol. 4. Raleigh, NC: Psyche's Press, 2008.

Bouyer, Louis. Rite and Man: Natural Sacredness and Christian Liturgy. South Bend, IN: University of Notre Dame Press, 1963.

Brand, Leonard. Faith, Reason, and Earth History. Berrien Springs, MI: Andrews University Press, 1997.

Brierley, Michael. "Naming a Quiet Revolution: The Panentheistic Turn in Modern Theology." In In Whom We Live and Move and Have Our Being: Panentheistic Reflections on God's Presence in a Scientific World, edited by Philip Clayton and Arthur Peacocke. Grand Rapids, MI: Eerdman's, 2004.

Britan, Halbert Hains. The Philosophy of Music: A Comparative Investigation into the Principles of Musical Aesthetics. New York: Longman's, Green, and Co., 1911.

Broadus, John A. Lectures on the History of Preaching. New York: A.C. Armstrong and Son, 1902.

Bruce, F. F. The Book of the Acts. Revised ed. New International Commentary on the New Testament. Grand Rapds, MI: Eerdmans, 1988.

Bruckner, James K. Exodus New International Biblical Commentary 2. Peabody, MA: Hendrickson, 2008.

Brugh, Lorraine. "The Trinitarian Journey: Music as Gift and Sounded Word." Currents in Theology and Mission 35 no.3 (June 2008): 187-191.

Buchler, Justus. The Concept of Method. New York: Columbia University Press, 1961. 
Bugnini, Annibale. The Reform of the Liturgy 1948-1975. Translated by Matthew J. O'Connell. Collegeville, MN: The Liturgical Press, 1990.

Burgess, Scott K. The Stand: Jesus in the Book of Daniel: Scott K "Brother" Burgess, 2016.

Burgess, Stanley M., ed. Pentecostal and Charismatic Timeline, The New International Dictionary of Pentecostal and Charismatic Movements. Grand Rapids, MI: Zondervan, 2002.

Burns, Robert A. Roman Catholicism after Vatican II. Washington, DC: Georgetown University Press, 2001.

Butler, Christopher. The Theology of Vatican II: The Sarum Lectures 1966. London: Darton, Longman and Todd, 1966.

Byars, Ronald P. The Future of Protestant Worship: Beyond the Worship Wars. Louisville, KY: John Knox Press, 2002.

Cairns, Ian. Deuteronomy: Word and Presence International Theological Commentary. Grand Rapids, MI: Eerdmans, 1992.

Cairus, Aecio E. "The Doctrine of Man." In Handbook of Seventh-Day Adventist Theology, edited by Raoul Dederen. Hagerston, MD: Review and Herald, 2000.

Calvin, John. Institutes of the Christian Religion. Translated by Ford Lewis Battles, Edited by John T McNeill. Philadelphia: The Westminster Press, 1960.

Campenhousen, Hans Von. Ecclesiastical Authority and Spiritual Power in the Church of the First Three Centuries. Translated by J.A. Baker. Stanford, CA: Stanford University Press, 1969.

Canale, Fernando. A Criticism of Theological Reason: Time and Timelessness as Primordial Presuppositions Andrews University Seminary Doctoral Dissertation Series 10. Berrien Springs, MI: Andrews University Press, 1987.

. "Doctrine of God." In Handbook of Seventh-Day Adventist Theology, edited by Raoul Dederen. Hagerstown, MD: Review and Herald, 2000.

. Back to Revelation - Inspiration. New York: University Press of America, 2001.

. "Interdisciplinary Method in Theology? In Search of a Working Proposal." Neue Zeitschrift für systematische Theologie und Religionsphilosophie 43 no.3 (2001): 366-389. 
. Basic Elements of Christian Theology: Scripture Replacing Tradition. Berrien Springs, MI: Andrews University Lithotech, 2005.

. The Cognitive Principle of Christian Theology: A Hermenuetical Study of the Revelationa and Inspiration of the Bible. Berrien Springs, MI: Andrews University Lithothec, 2005.

. Creation, Evolution, and Theology. Berrien Springs, MI: Andrews University Lithotech, 2005.

. "From Vision to System: Finishing the Task of Adventist Biblical and Systematic Theologies-Part II." Journal of the Adventist Theological Society, no. 16/1-2 (2005): 1-29.

. "From Vision to System: Finishing the Task of Adventist Theology Part III Sanctuary and Hermeneutics." Journal of the Adventist Theological Society, no. 17/2 (2006): 1-45.

. "Principles of Worship and Liturgy." Journal of the Adventist Theological Society 20/1-2 (2009): 89-111.

. "The Emgerging Church--Part IV: Levels of Change." Journal of the Adventist Theological Society 23/2 (2012): 161-189.

. "Philosophical Foundations and the Biblical Sanctuary." Andrews University Seminary Studies 36, no. 2 (Autumn 1998): 183-206.

Carter, Jerry M. Jr. "The Audible Sacrament: The Sacrament of Gardner C. Taylor's Preaching." Ph.D. dissertation, Drew Theological School, 2007.

Catechism of the Catholic Church. Revised ed. London: Burns and Oates, 1999.

The Catechism of the Council of Trent. 1st American ed. Baltimore, MD: J. Murphy, 1829.

Caudill, Norah Whipple. "The Presence of God in the Exodus Narrative: Purposes, Means and Implications." Ph.D. dissertation, Fuller Theological Seminary, September 2006.

Chafer, Lewis Sperry. Systematic Theology. 8 vols. Grand Rapids, MI: Kregel Publications, 1948, 1976.

Charles, R. H. A Critical and Exegetical Commentary on the Revelation of St. John. 2 vols. International Critical Commentary. Edinburgh: T \& T Clark, 1959. 
Chatham, James O. Enacting the Word: Using Drama in Preaching. Louisville, KY: Westminster John Knox Press, 2002.

Chauvet, Louis Marie, and François Kabasele Lumbala. Liturgy and the Body. London: Student Christian Movement Press, 1995.

Cherry, Constance M. "Merging Tradition and Innovation in the Life of the Church: Moving from Style to Encountering God in Worship." In The Conviction of Things Not Seen: Worship and Ministry in the 21st Century, edited by Todd E. Johnson. Grand Rapids, MI: Brazos Press, 2002.

Childs, Brevard. The Book of Exodus: A Critical, Theological Commentary Old Testament Library. Philadelphia: Westminster Press, 1974.

Christian, Ed. Joyful Noise. Hagerstown, MD: Review and Herald, 2003.

Christina, Craig Collier. "Calvin's Theology of Preaching: The Activity of the Holy Spirit in the Preaching Event." Ph.D. dissertation, The Southern Baptist Theological Seminary, May 2001.

Chua, Daniel K.L. Absolute Music: And the Construction of Meaning. Cambridge: Cambridge University Press, 1999.

Chupungco, Anscar J. "History of the Liturgy until the Fourth Century." In Handbook for Liturgical Studies: Fundamental Liturgy, edited by Anscar J. Chupungco. Collegeville, MN: Liturgical Press, 1997.

. "History of the Roman Liturgy until the Fifteenth Century." In Handbook for Liturgical Studies: Fundamental Liturgy, edited by Anscar J. Chupungco. Collegeville, MN: Liturgical Press, 1997.

. "Introduction." In Handbook for Liturgical Studies: Fundamental Liturgy, edited by Anscar J. Chupungco. Collegeville, MN: Liturgical Press, 1997.

Clements, Ronald E. Exodus Cambridge Bible Commentary. Cambridge: Cambridge University Press, 1972.

Clynes, Manfred. Sentics: The Touch of the Emotions. New York: Avery Publishing Group Inc., 1989.

Cobb, Peter G. "The Architectural Setting of the Liturgy." In The Study of Liturgy, edited by Cheslyn Jones, Geoffrey Wainwright, Edward Yarnold and Paul Bradshaw. New York: Oxford University Press, 1992. 
. The History of the Christian Year The Study of Liturgy, Edited by Cheslyn Jones, Geoffrey Wainwright, Edward Yarnold and Paul Bradshaw. New York: Oxford University Press, 1992.

Cockerill, Gareth Lee. The Epistle to the Hebrews New International Commentary on the New Testament. Grand Rapids, MI: Eerdmans, 2012.

Cody, Aelred. Heavenly Sanctuary and Liturgy in the Epistle to the Hebrews: The Achievement of Salvation in the Epistle's Perspective. St. Meinrad, IN: Grail Publications, 1960.

Cogan, Mordechai. 1 Kings: A New Translation with Introduction and Commentary The Anchor Bible 10. New York: Doubleday, 2001.

Cole, R. Alan. Exodus: An Introduction and Commentary Tyndale Old Testament Commentary. Downer's Grove, IL: InterVarsity Press, 1973.

Collins, Peter, and Pink Dandelion. "Wrapped Attention: Revelation and Concealment in Nonconformism." In Materialising Religion: Expression, Performance and Ritual, edited by Elisabeth Arweck and William J.F. Keenan. Burlington, VT: Ashgate Publishing, 2006.

Congar, Yves. "Church, Kingdom, and the Eschatological Temple." In Temple and Contemplation: God's Presence in the Cosmos, Church, and Human Heart, edited by Scott W. Hahn. Steubenville, OH: St. Paul Center for Biblical Theology, 2008.

Conzelmann, Hans. Acts of the Apostles Hermeneia. Philadelphia: Fortress Press, 1987.

Cooke, Bernard J. The Distancing of God: The Ambiguity of Symbol in History and Theology. Minneapolis, MN: Fortress Press, 1990.

Coomaraswamy, Rama P. The Destruction of Christian Tradition. Bloomington, IN: World Wisdom, 2006.

Cooper, John W. Panentheism the Other God of the Philosophers: From Plato to the Present. Grand Rapids, MI: Baker Academic, 2006.

Cortez, Félix H. "'See That You Do Not Refuse the One Who Is Speaking": Hearing God Preach and Obedience in the Letter to the Hebrews." Journal of the Adventist Theological Society 19, no. 1-2 (2008): 98-108.

. "'I Will Put My Trust in Him": The Faithful Son and the Family of God in Hebrews." Presidential Address, Adventist Theological Society, Atlanta, GA, Nov $20,2015$. 
. "Creation in Hebrews." Andrews University Seminary Studies 53 no. 2 (2015): 279-320.

Costa, Marcio. "The Omnipresence of God in the Views of Strong and Pannenberg Compared to a Biblical Analysis." Hermenêutica 8 (2008): 85-109.

Cox, Darrel W. "Physiological Phenomena Which Occurred in Connection with Manifestations of the Presence of God: Biblical and Theological Investigations." Ph.D. dissertation, Trinity International University, June 1997.

Craig, William Lane. Time and Eternity: Exploring God's Relationship to Time. Wheaton, IL: Crossway Books, 2001.

Craigie, Peter C. The Book of Deuteronomy New International Commentary on the Old Testament. Grand Rapids, MI: Eerdmans, 1976.

Cranfield, C. E. B. A Critical and Exegetical Commentary on the Epistle to the Romans. Vol. 2 International Critical Commentary. New York: T \& T Clark, 1979.

Crichton, J.D. The Church's Worship: Considerations on the Liturgical Constitution of the Second Vatican Council. New York: Sheed and Ward, 1964.

. "A Theology of Worship." In The Study of Liturgy, edited by Geoffrey Wainwright Cheslyn Jones, Edward Yarnold, Paul Bradshaw. New York: Oxford University Press, 1992.

Cullmann, Oscar. Christ and Time: The Primitive Conception of Time and History. Philadelphia: Westminster Press, 1950. . Early Christian Worship. London: Student Christian Movement Press, 1953. . Immortality of the Soul or Resurrection of the Dead? The Witness of the New Testament. New York: The Macmillan Company, 1958.

Daniélou, Jean. "The Sign of the Temple: A Meditation." In Temple and Contemplation: God's Presence in the Cosmos, Church, and Human Heart, edited by Scott W. Hahn. Steubenville, OH: St. Paul Center for Biblical Theology, 2008.

Dargan, Edwin Charles. From the Apostolic Fathers to the Great Reformers, A.D. 701572. Vol. 1 of A History of Preaching. New York: Hodder and Stoughton, 1905.

. From the Close of the Reformation Period to the End of the Nineteenth Century 1572-1900. Vol. 2 of A History of Preaching. New York: Hodder and Stoughton, 1912. 
Davidson, Richard M. "Typological Structures in the Old and New Testaments." PhD dissertation, Andrews University, 1981.

. "Biblical Interpretation." In Handbook of Seventh-Day Adventist Theology, edited by Raoul Dederen. Hagerstown, MD: Review and Herald, 2000.

. "Christ's Entry "Within the Veil" in Hebrews 6:19-20: The Old Testament Background, Andrews University Seminary Studies 39 no. 2 (Autumn 2001): 175190.

Davies, Horton. Crisis and Creativity, 1965-Present. Vol. 6 of Worship and Theology in England. Grand Rapids, MI: Eerdman's, 1996.

. The Ecumenical Century, 1900-1965. Vol. 5 of Worship and Theology in England. Grand Rapdis, MI: Eerdman's, 1996.

. From Andrewes to Baxter and Fox. Vol. 2 of Worship and Theology in England. Grand Rapids, MI: Eerdman's, 1996.

. From Cranmer to Hooker. Vol. 1 of Worship and Theology in England. Grand Rapids, MI: Eerdman's, 1996.

. From Watts and Wesley to Maurice. Vol. 3 of Worship and Theology in England. Grand Rapids, MI: Eerdman's, 1996.

Davies, J.G. Liturgical Dance: An Historical, Theological and Practical Handbook. London: Student Christian Movement Press, 1984.

Davis, R. Dean. The Heavenly Court Judgment of Revelation 4-5. New York: University Press of America, 1992.

Davis, Thomas J. This Is My Body: The Presence of Christ in Reformation Thought. Grand Rapids, MI: Baker Academic, 2008.

Dawn, Marva J. Reaching out without Dumbing Down: A Theology of Worship for the Turn-of-the-Century Culture. Grand Rapids, MI: Eerdman's, 1995.

Dawn, Marva J., and Daniel Taylor. How Shall We Worship? Biblical Guidelines for the Worship Wars. Wheaton, IL: Tyndale House, 2003.

de Chardin, Pierre Teilhard. The Phenomenon of Man. New York: Harper and Row, 1959.

. Hymn of the Universe. Translated by Simon Bartholomew. New York: Harper and Row, 1965. 
de Kock, Edwin. 7 Heads and 10 Horns. Edinburg, TX: Edwin de Kock, 2012.

de Souza, Elias Brasil. "The Heavenly Sanctuary/Temple Motif in the Hebrew Bible: Function and Relationship to the Earthly Counterparts." Ph. D. dissertation, Andrews University, 2005.

"Delivered Unto Him [Luke 4:17]." In Seventh-Day Adventist Bible Commentary, edited by F.D. Nichol, 4:727. Washington, DC: Review and Herald, 1976-1980.

Devine, Mark. "The Emerging Church: One Movement--Two Streams." In Evangelicals Engaging Emergent: A Discussion of the Emergent Church Movement, edited by William D. Henard and Adam W. Greenway. Nashville, TN: B \& H Publishing Group, 2009.

Dix, Gregory. The Shape of the Liturgy. New York: Continuum, 2005.

Donkor, Kwabena. Tradition, Method, and Contemporary Protestant Theology: An Analysis of Thomas C. Oden's Vincentian Method. Lanham, MD: University Press of America, 2003.

Douglas, Walter B. "The Sabbath in Puritanism." In The Sabbath in Scripture and History, edited by Kenneth A. Strand. Hagerstown, MD: Review and Herald, 1982.

Douglass, Herbert E. Truth Matters. Nampa, ID: Pacific Press, 2006.

Doukhan, Lilianne. In Tune with God. Hagerstown, MD: Autumn House Publishing, 2009.

Duffield, Guy P., and Nathaniel M. Van Cleave. Foundations of Pentecostal Theology. San Dimas, CA: L.I.F.E. Bible College, 1983.

Duffy, Stephen. "Catholicism's Search for a New Self-Understanding." In Vatican II: Open Questions and New Horizons, edited by Gerald M. Fagin, 137. Wilmington, DE: Michael Glazier, 1984.

Dulles, Avery. Models of the Church. exp. ed. Garden City, NY: Image Books, 1987. . Models of Revelation. Maryknoll, NY: Orbis Books, 1992.

. The Craft of Theology: From Symbol to System. New Expanded ed. New York: Crossroad, 1995.

Dyrness, William A. A Primer on Christian Worship: Where We've Been, Where We Are, Where We Can Go. Grand Rapids, MI: Eerdman's, 2009. 
Economou, Elly Hélène. "The Greek Orthodox Church and Her Relations with the Heterodox Churches: A Historico-Dogmatic Study on the Problem of Intercommunion." Ph.D. dissertation, University of Strasbourg, Faculty of Protestant Theology, 1975.

Eichrodt, Walther. Theology of the Old Testament. Translated by J.A. Baker. 1 of 2 vols. Philadelphia: Westminster Press, 1961.

Ellingworth, Paul. The Epistle to the Hebrews: A Commentary on the Greek Text New International Greek Testament Commentary. Grand Rapids, MI: Eerdmans, 1993.

Engle, Paul E., ed. Understanding Four Views on Baptism. Grand Rapids, MI: Zondervan, 2007. , ed. Understanding Four Views on the Lord's Supper. Grand Rapids, MI: Zondervan, 2007.

Erickson, Millard J. Christian Theology. 2nd ed. Grand Rapids, MI: Baker Book House, 1998.

. The Word Became Flesh. 1st paperback ed. Grand Rapids, MI: Baker Books, 2000 .

Etherington, Charles L. Protestant Worship Music: Its History and Practice. New York: Holt, Rinehart and Winston, 1962.

Everett, William Johnson. The Politics of Worship: Reforming the Language and Symbols of Liturgy. Cleveland, OH: United Church Press, 1999.

"Every Creature [Rev 5:13]." In Seventh-Day Adventist Bible Commentary, edited by F.D. Nichol, 7: s.v. Rev 5:13. Washington, DC: Review and Herald, 1976-1980.

Farhadian, Charles E., ed. Christian Worship Worldwide: Expanding Horizons, Deepening Practices. Grand Rapids, MI: Eerdman's, 2007.

Fenwick, John, and Bryan Spinks. Worship in Transition: The Liturgical Movement in the Twentieth Century. New York: Continuum, 1995.

Ferrone, Rita. Liturgy: Sacrosanctum Concilium Rediscovering Vatican II, Edited by Christopher M. Bellitto. New York: Paulist Press, 2007.

Finger, Thomas N. A Contemporary Anabaptist Theology: Biblical, Historical, Constructive. Downer's Grove, IL: InterVarsity Press, 2004. 
Fisher, J.D.C., and E.J. Yarnold. "The West from About Ad 500 to the Reformation." In The Study of Liturgy, edited by Cheslyn Jones, Geoffrey Wainwright, Edward Yarnold and Paul Bradshaw. New York: Oxford University Press, 1992.

Fitzmyer, Joseph A. The Acts of the Apostles: A New Translation with Introduction and Commentary The Anchor Bible 31. New York: Doubleday, 1998.

Foley, Edward, Nathan Mitchell, Joanne M. Pierce, Liturgy Catholic Academy of, and Commissions Federation of Diocesan Liturgical. A Commentary on the General Instruction of the Roman Missal: Developed under the Auspices of the Catholic Academy of Liturgy and Cosponsored by the Federation of Diocesan Liturgical Commissions. Collegeville, MN: Liturgical Press, 2007.

Froom, Leroy Edwin. The Conditionalist Faith of Our Fathers. 2 vols. Washington, DC: Review and Herald, 1966.

Galenieks, Eriks. "The Nature, Function, and Purpose of the Term Sheol in the Torah, Prophets, and Writings." PhD dissertation, Andrews University, 2005.

Gallos, Erhard. "K $\alpha \tau \alpha \pi \alpha v \sigma ı \varsigma$ and $\Sigma \alpha \beta \beta \alpha \tau \iota \sigma \mu \circ \varsigma$ in Hebrews 4." PhD dissertation, Andrews University, 2011.

. "The Spirits of the Righteous Made Perfect." Paper presented to the Adventist Sola Scriptura Research Group, Andrews University Berrien Springs, MI, Oct 14, 2016.

Gallusz, Lazlo. "Thrones in the Book of Revelation Part 1: Throne of God." Journal of the Adventist Theological Society 23, no. 2 (2012): 30-71.

Gane, Roy. Ritual Dynamic Structure Georgias Dissertations Religion 2. Piscataway, NJ: Gergias Press, 2004.

. "Leviticus." In Zondervan Illustrated Bible Backgrounds Commentary Vol. 1, edited by John H. Walton. Grand Rapids, MI: Zondervan, 2009.

Ganssle, Gregory E., ed. God and Time: Four Views. Downer's Grove, IL: InterVarsity Press, 2001.

Garratt, James. Palestrina and the German Romantic Imagination. New York: Cambridge University Press, 2004.

Geisler, Norman. Systematic Theology: Church, Last Things. Minneapolis, MN: Bethany House Publishers, 2003.

. Systematic Theology: God: Creation. Minneapolis, MN: Bethany House Publishers, 2003. 
General Articles on the Bible; General Articles on the Old Testament; Genesis; Exodus; Leviticus. 1 of 12 vols. The New Interpreter's Bible. Nashville, TN: Abingdon Press, 1994.

Gibbs, Eddie, and Ryan K. Bolger. Emerging Churches: Creating Christian Community in Postmodern Cultures. Grand Rapids, MI: Baker Academic, 2005.

González, Justo. From Augustine to the Eve of the Reformation. Vol. 2 of A History of Christian Thought. Nashville, TN: Abingdon Press, 1987.

. From the Beginnings to the Council of Chalcedon. Vol. 1 A History of Christian Thought. Nashville, TN: Abindgon Press, 1987.

. From the Protestant Reformation to the Twentieth Century. Vol. 3 A History of Christian Thought. Nashville, TN: Abingdon Press, 1987.

Grabiner, Steven. Revelation's Hymns: Commentary on the Cosmic Conflict Library of New Testament Studies, Edited by Chris Keith. New York: Bloomsbury T\&T Clark, 2015.

Grenz, Stanley J. Theology for the Community of God. Nashville, TN: Broadman \& Holman, 1994. . A Primer on Postmodernism. Grand Rapids, MI: Eerdman's, 1996.

Grenz, Stanley J., and John R. Franke. Beyond Foundationalism: Shaping Theology in a Postmodern Context. Louisville, KY: John Knox Press, 2001.

Grenz, Stanley J., and Roger E. Olson. 20th Century Theology: God \& the World in a Transitional Age. Downers Grove, IL: InterVarsity Press, 1992.

Griffiths, Jonathan I. Hebrews and Divine Speech. New York: Bloomsbury, 2014.

Grimes, Ronald L. "Infelicitous Performances and Ritual Criticism." Semeia 41 (1988): 103-122.

Grudem, Wayne. Systematic Theology. Grand Rapids, MI: Zondervan, 1994.

Guice, John. From Pentecostal to Episcopalian: The Confusing World of Protestant Worship. Indiannapolis, IN: Dog Ear, 2010.

Gulley, Norman R. Christ Is Coming! Hagerstown, MD: Review and Herald, 1998.

. Systematic Theology: Prolegomena. Berrien Springs, MI: Andrews University Press, 2003. 
. Systematic Theology: God as Trinity. Berrien Springs, MI: Andrews

University Press, 2011.

. Systematic Theology: Creation, Christ, Salvation. Berrien Springs, MI:

Andrews University Press, 2012.

Gushee, David P. "Reconciling Evangelical Christianity with Our Sexual Minorities:

Reframing the Biblical Discussion." Journal of the Sociey of Christian Ethics 35, no. 2 (2015): 141-158.

Hahn, Scott. The Lamb's Supper: The Mass as Heaven on Earth. New York: Doubleday, 1999.

. Temple and Contemplation: God's Presence in the Cosmos, Church, and Human Heart Letter \& Spirit, Edited by Scott W. Hahn. Steubenville, OH: St. Paul Center for Biblical Theology, 2008.

. "Temple, Sign, and Sacrament: Towards a New Perspective on the Gospel of John." In Temple and Contemplation: God's Presence in the Cosmos, Church, and Human Heart, edited by Scott W. Hahn. Steubenville, OH: St. Paul Center for Biblical Theology, 2008.

Hall, Christopher A. Worshiping with the Church Fathers. Downer's Grove, IL: IVP Academic, 2009.

Hall, Donald E. Musical Acoustics: An Introduction. Belmont, CA: Wadsworth Publishing Company, 1980.

Halliburton, R.J. "The Patristic Theology of the Eucharist." In The Study of Liturgy, edited by Cheslyn Jones, Geoffrey Wainwright, Edward Yarnold and Paul Bradshaw. New York: Oxford University Press, 1992.

Hammond, Peter. Liturgy and Architecture. New York: Columbia University Press, 1961.

Hanley, Catriona. Being and God in Aristotle and Heidegger. Lanham, MD: Rowman \& Littlefield, 2000.

Hardinge, Leslie. With Jesus in His Sanctuary: A Walk through the Tabernacle Along His Way. Harrisburg, PA: American Cassette Ministries, 1991.

Hardison, O.B. Christian Rite and Christian Drama in the Middle Ages: Essay in the Origin and Early History of Modern Drama. Baltimore, MD: Johns Hopkins Press, 1965.

Hardman, Oscar. A History of Christian Worship. Nashville, TN: Cokesbury Press, 1937. 
Hart, D. G. Recovering Mother Kirk: The Case for Liturgy in the Reformed Tradition. Grand Rapids, MI: Baker Academic, 2003.

Hartley, John E. Leviticus Word Biblical Commentary 4. Dallas, TX: Word Books, 1992.

Hartshorne, Charles. Omniopotence and Other Theological Mistakes. Albany, NY: State University of New York Press, 1984.

Hasel, Frank M. "Scientific Revolution: An Analysis and Evaluation of Thomas Kuhn's Concept of Paradigm and Paradigm Change for Theology." Journal of the Adventist Theological Society 2, no. 2 (1991): 160-177.

Hasel, Gerhard F. "The Sabbath in the Pentateuch." In The Sabbath in Scripture and History, edited by Kenneth A. Strand. Washington, DC: Review and Herald, 1982.

. Biblical Interpretation Today. Washington, DC: Biblical Research Institute, 1985.

. Old Testament Theology: Basic Issues in the Current Debate. Fourth ed. Grand Rapids, MI: Eerdmans, 1991.

. Speaking in Tongues: Biblical Speaking in Tongues and Contemporary Glossolalia. Berrien Springs, MI: Adventist Theological Society, 1991.

. "Recent Models of Biblical Theology: Three Major Perspectives." Andrews University Seminary Studies 33, no. 1-2 (1995): 55-75.

Hatchett, Marion J. Sanctifying Life, Time, and Space: An Introduction to Liturgical Study. New York: Seabury Presss, 1976.

Hendershedt, James L. "The Sermon: A Tool for Evangelism." Trinity Seminary Review 7 no 2 (Fall 1985): 23-29.

Heschel, Abraham. The Sabbath: Its Meaning for Modern Man. New York: Farrar, Straus and Young, 1051.

Hill, Brennan. Exploring Catholic Theology: God, Jesus, Church, and Sacraments. Mystic, CT: Twenty-Third Publications, 1999.

Hirschberger, Johannes. The History of Philosophy. 2 vols. Milwaukee, WI: Bruce Publishing, 1958.

Hislop, D.H. Our Heritage in Public Worship. Edinburgh: T \& T Clark, 1935. 
Hocken, Peter. "Charismatic Movement." In The Encyclopedia of Christianity, edited by Erwin Fahlbusch and Geoffrey Bromiley. Grand Rapids, MI: Eerdmans, 19992003.

. The Challenges of the Pentecostal, Charismatic and Messianic Jewish Movements. Burlington, VT: Ashgate, 2009.

Hodge, Charles. Systematic Theology. 3 vols. Grand Rapids, MI: Eerdmans, 1952.

Holeton, David R. "Ecumenical Liturgical Consensus: A Bumpy Road to Christian Unity Presidential Address." Studia Liturgica 38, no. 1 (2008): 1-16.

Hollenweger, Walter J. Pentecostalism: Origins and Developments Worldwide. Peabody, MA: Hendrickson, 1997.

Hope, D.M. "The Medieval Western Rites." In The Study of Liturgy, edited by Cheslyn Jones, Geoffrey Wainwright, Edward Yarnold and Paul Bradshaw. New York: Oxford University Press, 1992.

Horton, Michael S. In the Face of God. Dallas, TX: Word Publishing, 1996.

Howell, Clifford. "From Trent to Vatican II." In The Study of Liturgy, edited by Cheslyn Jones, Geoffrey Wainwright, Edward Yarnold and Paul Bradshaw. New York: Oxford University Press, 1992.

Hunn, Debbie. "'Why Therefore the Law?" The Role of the Law in Galatians 3:19-20." Neotestamentica 47, no. 2 (2013): 355-372.

Hustad, Donald. Jubilate! Music in the Evangelical Tradition. Carol Stream, IL: Hope, 1981.

Janiszewski, Timothy A. "Trinity and Temple: Implications of Early Christian and Second Temple Worship for Doxological Access to God in Contemporary NonChristian Religions." Ph.D. dissertation, Trinity International University, May 2002.

Japhet, Sara. The Ideology of the Book of Chronicles and Its Place in Biblical Thought. Winona Lake, IN: Eisenbrauns, 2009.

Jeffery, Peter. "Chant East and West: Toward a Renewal of the Tradition." In Music and the Experience of God, edited by Mary Collins, David Power and Mellonee Burnim. Edinburgh: T \& T Clark, 1989.

Johansson, Calvin M. Discipling Music Ministry: Twenty-First Directions. Peabody, MA: Hendrickson, 1992. 
John Paul II. Sources of Renewal: The Implementation of the Second Vatican Council. 1st US ed. San Francisco: Harper \& Row, 1980.

John Paul II. Ut Unum Sint: On Commitment to Ecumenism. Boston, MA: St. Paul Books and Media, 1995.

. Apostolic Letter Dies Domini of the Holy Father John Paul II To the Bishops, Clergy and Faithful of the Catholic Church on Keeping the Lord's Day Holy, Vatican, May 31,1998.

Johnson, Maxwell E. "The Loss of a Common Language: The End of EcumenicalLiturgical Convergence?" Studia Liturgica Vol. 37 (2007): 55-72.

Johnstone, William. 1 and 2 Chronicles Journal for the Study of the Old Testament Supplemental Series 253. Sheffield, England: Sheffield Academic Press, 1997.

Jordan, Anne. Christianity and Moral Issues. Cheltenham, United Kingdom: Stanley Thornes, 1999.

Jungmann, Josef A. The Early Liturgy to the Time of Gregory the Great. South Bend, IN: University of Notre Dame Press, 1966.

Kabasele Lumbala, François. Celebrating Jesus Christ in Africa: Liturgy and Inculturation Faith and Cultures Series. Maryknoll, NY: Orbis Books, 1998.

Kamien, Roger. Music an Appreciation. IV ed. New York: McGraw Hill 1988.

Kant, Immanuel. Kant's Critique of Practical Reason and Other Works on the Theory of Ethics. Translated by Thomas Kingsmill Abbott. London: Longmans, Green \& Co., 1788.

. Critique of Pure Reason. Translated by J.M.D. Meiklejohn. London: Henry G. Bohn, 1855.

Kärkkäinen, Veli-Matti. Pneumatology. Grand Rapids, MI: Baker Academic, 2002.

Kauffman, Richard A. "Beyond the Battle for the Organ: Robert Webber Calls a Truce to the "Worship Wars"." Christianity Today 41 no 12 (1997): 25-26.

Kaufman, Gordon D. An Essay on Theological Method. Third ed. Atlanta, GA: Scholars Press, 1975.

Kavanagh, Aidan. On Liturgical Theology. Collegeville, MN: Liturgical Press, 1992.

Kiddle, Martin. The Revelation of St. John Moffat New Testament Commentary. London: Hodder and Stoughton, 1952. 
Kiesler, Herbert. "The Ordinances: Baptism, Foot Washing, and Lord's Supper." In Handbook of Seventh-Day Adventist Theology, edited by Raoul Dederen. Hagerstown, MD: Review and Herald, 2000.

Killinger, John. "Holydays and Holidays." In Mastering Worship. Portland, OR: Christianity Today, 1990.

Kilmartin, Edward J. "Christ's Presence in the Liturgy." In Bread from Heaven, edited by Paul J. Bernier. New York: Paulist Press, 1977.

Kimball, Dan. The Emerging Church: Vintage Christianity for New Generations. Grand Rapids, MI: Zondervan, 2003. . Emerging Worship: Creating Worship Gatherings for New Generations. Grand Rapids, MI: Zondervan, 2004.

Kittel, Gerhard and Gerhard Friedrich, eds. Theological Dictionary of the New Testament. 10 vols. Grand Rapids, MI: Eerdmans, 1964-1976.

Klauser, Theodor. A Short History of the Western Liturgy: An Account and Some Reflections. 2d ed. New York: Oxford University Press, 1979.

Klein, Ralph W. 2 Chronicles: A Commentary Hermeneia. Philadelphia: Fortress Press, 2012.

Kleinig, John W. The Lord's Song: The Basis, Function and Significance of Choral Music in Chronicles Journal for the Old Testament Supplemental Series 156. Sheffield, United Kingdom: JSOT Press, 1993.

Klingbeil, Gerald A. A Comparative Study of the Ritual of Ordination as Found in Leviticus 8 and Emar 369. Lewiston, NY: Edwin Mellen Press, 1998.

. Bridging the Gap: Ritual and Ritual Texts in the Bible. Vol. 1 Bulletin for Biblical Research Supplements, Edited by Richard S. Hess. Winona Lake, IN: Eisenbrauns, 2007.

Knight, Teman W. III. "The Presence of God in the Old Testament." Ph.D. dissertation, New Orleans Baptist Theological Seminary, March1992.

Koester, Craig R. Revelation: A New Translation with Introduction and Commentary The Anchor Yale Bible 38a. New Haven, CT: Yale University Press, 2014.

Köhler, Ludwig, Walter Baumgartner, M.E.J. Richardson and Johann Jakob Stamm, eds. The Hebrew and Aramaic Lexicon of the Old Testament. Translated by and edited by M.E.J. Richardson. 5 vols. Leiden: E.J. Brill, 1994. 
Kuhn, Thomas. The Structure of Scientific Revolutions. 3rd ed. Chicago: University of Chicago Press, 1966.

Küng, Hans. Infallible? An Enquiry. Translated by Edward Quinn. Garden City, NY: Doubleday, 1971. . Theology for the Third Millennium: An Ecumenical View. New York: Doubleday, 1988.

Kung, Matias H. "The Ritual Dimensions in the Tabernacle Worship and Their Missiological Implications." Ph.D. dissertation, Trinity International University, May 2001.

Lane, David. The Phenomenon of Teilhard: Prophet for a New Age. Macon, GA: Mercer University Press, 1996.

Lane, William L. Hebrews 1-8 Word Biblical Commentary 47a. Dallas, TX: Word Books, 1991.

. Hebrews 9-13 Word Biblical Commentary 47b. Dallas, TX: Word Books, 1991.

Lang, Bernhard. Sacred Games: A History of Christian Worship. New Haven, CT: Yale University Press, 1997.

Liesch, Barry. People in the Presence of God: Models and Directions for Worship. Grand Rapids, MI: Ministry Resources Library, 1988.

. The New Worship: Straight Talk on Music and the Church. Grand Rapids, MI: Baker Books, 1996.

Lightfoot, J.B., and J.R. Harmer. The Apostolic Fathers. London: Macmillan \& Co., 1891.

Lindbeck, George A., ed. Dialogue on the Way. Minneapolis, MN: Augsburg, 1965.

"Linen [Rev 15:6]." In Seventh-Day Adventist Bible Commentary, edited by F.D. Nichol, 7: sv Rev 15:6. Washingto, DC: Review and Herald, 1976-1980.

Liturgiam Authenticam: Fifth Instruction on Vernacular Translation of the Roman Liturgy. Edited by Congregation for Divine Worship and the Discipline of the Sacraments. Washington, DC: United States Conference of Catholic Bishops, 2001.

Lonergan, Bernard. Method in Theology. New York: Crossroad, 1979. 
Long, Thomas G. Beyond the Worship Wars: Building Vital and Faithful Worship. Bethesda, MD: Alban Institute, 2001.

. The Witness of Preaching. 2nd ed. Louisville, KY: Westminster John Knox Press, 2005.

Luther, Martin. Luther's Works 55 Vols. American Ed., Edited by J. Pelikan, H. Lehmann and Hilton C. Oswald. St. Louis, MO: Fortress, 1955-1986.

Lyons, Patrick. "Liturgy and Ecumenism." In Handbook for Liturgical Studies: Introduction to the Liturgy, edited by Anscar J. Chupungco. Collegeville, MN: Liturgical Press, 1997.

Macleod, Donald. The Person of Christ, Edited by Gerald Bray. Downer's Grove, IL: InterVarsity Press, 1998.

Macpherson, Duncan. "Preaching in the Roman Ecclesial Context." In The Future of Preaching, edited by Geoffrey Stevenson. London: Student Christian Movement, 2010.

Macquarrie, John. Principles of Christian Theology. New York: Charles Scribner's Sons, 1966.

Maldonado, Luis. "The Church's Liturgy: Present and Future." In Toward Vatican III: The Work That Nees to Be Done, edited by David Tracy, Hans Küng and Johannes Baptist Metz. New York: Seabury Press, 1978.

Marias, Julian. History of Philosophy. Translated by Stanley Appelbaum and Clarence C. Strowbridge. New York: Dover Publications, 1967.

Markovic, John Jovan. "The Emerging Church: A Call to Action and Authenticity (Part 1 of 2)." Ministry Magazine March 2010, 18-21.

Marshall, Romey P., and Michael J. Taylor. Liturgy and Christian Unity. Englewood Cliffs, NJ: Prentice-Hall, 1965.

McCarthy, Timothy G. The Catholic Tradition: Before and after Vatican II 1878-1993. Chicago: Loyola University Press, 1994.

McClain, William B. "The Soul of Black Worship." AME Zion Quarterly Review 93 no 3 (October 1981): 11-29.

McDonnell, Kilian. Presence, Power, Praise: Documents on the Charismatic Renewal. 3 vols. Collegeville, MN: Liturgical Press, 1980. 
McGrath, Alister E. Christianity's Dangerous Idea: The Protestant Revolution - a History from the Sixteenth to the Twenty-First Century. New York: HarperOne, 2007.

McManus, Frederick R. Sacramental Liturgy. New York: Herder and Herder, 1967.

McNamara, Kevin. "Catholic Principles on Ecumenism." In Vatican II on Ecumenism, edited by Michael Adams. Chicago: Scepter Books, 1966.

Melton, James Van Horn. "Confessional Power and the Power of Confession: Concealing and Revealing the Faith in Alpine Salzburg, 1730-1734." In Cultures of Power in Europe During the Long Eighteenth Century, edited by Hamish Scott and Brendan Simms. New York: Cambridge University Press, 2007.

Merrill, Eugene H. "A Theology of Chronicles." In A Biblical Theology of the Old Testament, edited by Roy B. Zuck. Chicago: Moody Press, 1991.

Micks, Marianne. The Future Present: The Phenomenon of Christian Worship. New York: Seabury Press, 1970.

Milgrom, Jacob. Leviticus 17-22: A New Translation with Introduction and Commentary The Anchor Bible 3a. New York: Doubleday, 2000.

. Leviticus 23-27: A New Translation with Introduction and Commentary The Anchor Bible 3b. New York: Doubleday, 2001.

Miller, Donald E., and Tetsunao Yamamori. Global Pentecostalism: The New Face of Christian Social Engagement. Los Angeles: University of California Press, 2007.

Miller, Steve. The Contemporary Christian Music Debate: Worldly Compromise or Agent of Renewal? Wheaton, IL: Tyndale House Publishers, 1993.

Mitchell, Nathan D. "New Directions in Ritual Research." In Foundations in Ritual Studies: A Reader for Students of Christian Worship, edited by Paul Bradshaw and John Melloh. Grand Rapids, MI: Baker Academic, 2007.

Moffat, James. A Critical and Exegetical Commentary on the Epistle to the Hebrews International Critical Commentary. Edinburgh: T. \& T. Clark, 1952.

Morgan, Janine Paden. "Emerging Eucharist: Formative Ritualizing in British Emerging Churches." Ph.D. dissertation, Fuller Theological Seminary, 2008.

Morgenthaler, Sally. Worship Evangelism: Inviting Unbelievers into the Presence of God. Grand Rapids, MI: Zondervan, 1995.

Moring, Mark. "Pop Goes the Worship." Christianity Today March 2011, 22-25. 
Morton, Russell S. One Upon the Throne and the Lamb: A Tradition Historical/Theological Analysis of Revelation 4-5 Studies in Biblical Literature, Edited by Hemchand Gossai. New York: Peter Lang, 2007.

Moskala, Jiř́. "The Sabbath in the First Creation." Journal of the Adventist Theological Society 13/1 (Spring 2002): 55-66.

Motu Proprio of Pope St. Piux X on Sacred Music. November 22, 1903.

Mounce, Robert H. The Book of Revelation New International Commentary on the New Testament. Grand Rapids, MI: Eerdmans, 1977.

Mueller, Ekkehardt. "Christological Concepts in the Book of Revelation-Part 2: Christ's Divinity." Journal of the Adventist Theological Society 22, no. 1 (2011): 66-83.

Mulder, Martin J. 1 Kings Historical Commentary on the Old Testament. Leuven, Belgium: Peeters, 1998.

Murray, Paul D. "Roman Catholic Theology after Vatican II." In The Modern Theologians: An Introduction to Christian Theology since 1918, edited by David F. Ford and Rachel Muers. Malden, MA: Blackwell, 2005.

Najman, Hindy. "Angels at Sinai: Exegesis, Theology and Interpretive Authority." Dead Sea Discoveries 7, no. 3 (2000): 313-333.

Nemmers, Erwin Esser. Twenty Centuries of Catholic Church Music. Milwaukee, WI: The Bruce Publishing Company, 1949.

Nichols, Aidan. The Shape of Catholic Theology. Edinburgh: T \& T Clark, 1991.

Noakes, K.W. "From New Testament Times until St Cyprian." In The Study of Liturgy, edited by Cheslyn Jones, Geoffrey Wainwright, Edward Yarnold and Paul Bradshaw. New York: Oxford University Press, 1992.

. "From the Apostolic Fathers to Irenaeus." In The Study of Liturgy, edited by Cheslyn Jones, Geoffrey Wainwright, Edward Yarnold and Paul Bradshaw. New York: Oxford University Press, 1992.

Noel, Bradley Truman. Pentecostal and Postmodern Hermeneutics: Comparisons and Contemporary Impact. Eugene, OR: Wipf \& Stock, 2010.

Norén, Carol M. "The Word of God in Worship: Preaching in Relationship to Liturgy." In The Study of Liturgy, edited by Cheslyn Jones, Geoffrey Wainwright, Edward Yarnold and Paul Bradshaw. New York: Oxford University Press, 1992. 
Nygren, Anders. Meaning and Method: Prolegomena to a Scientific Philosophy of Religion and a Scientific Theology. Philadelphia: Fortress Press, 1972.

Oden, Thomas C. The Living God: Systematic Theology. San Francisco: Harper and Row, 1987.

Old, Hughes Oliphant. "Preaching by the Book: Using the Lectio Continua Approach in Sermon Planning." Reformed Worship 8 (Summer 1988): 24-25.

Olson, Roger E. The Story of Christian Theology: Twenty Centuries of Tradition and Reform. Downer's Grove, IL: Inter Varsity Press Academic, 1999.

Osborne, Grant R. Revelation Baker Exegetical Commentary on the New Testament. Grand Rapids, MI: Baker Academic, 2002.

Outler, Albert C., ed. Augustine: Confessions and Enchiridion, The Library of Christian Classics Vol VII. Philadelphia: The Westminster Press, 1955.

Palmer, Paul F. Sacraments and Worship: Liturgy and Doctrinal Development of Baptism, Confirmation, and the Eucharist. Westminster, MD: Newman Press, 1955.

Pannenberg, Wolfhart. Christian Spirituality. Philadelphia: Westminster Press, 1983. . Systematic Theology. Translated by Geoffrey W. Bromiley. 3 vols. Grand Rapids, MI: Eerdmans, 1991.

Paquier, Richard. Dynamics of Worship: Foundations and Uses of Liturgy. Philadelphia: Fortress Press, 1967.

Paulien, Jon. "The Seven Seals." In Symposium on Revelation--Book I, edited by Frank Holbrook. Silver Spring, MD: Biblical Research Institute, General Conference of Seventh-day Adventists, 1992.

Peckham, John C. "The Analogy of Scripture Revisited: A Final Form Canonical Approach to Systematic Theology." Mid-America Journal of Theology 22 (2011): 41-53.

. The Love of God: A Canonical Model. Downers' Grover, IL: InterVarsity Press, 2015.

. Canonical Theology: The Biblical Canon, Sola Scriptura, and Theological Method. Grand Rapids, MI: Eerdmans, 2016. 
. "An Investigation of Luther's View of the Bondage of the Will with Implications for Soteriology and Theodicy." Journal of the Adventist Theological Society 18/2 (Autumn 2007): 274-304.

Pecklers, Keith F. "History of the Roman Liturgy from the Sixteenth until the Twentieth Centuries." In Handbook for Liturgical Studies: Fundamental Liturgy, edited by Anscar J. Chupungco. Collegeville, MN: Liturgical Press, 1997.

. Dynamic Equivalence: The Living Language of Christian Worship. Collegeville, MN: Liturgical Press, 2003.

. Worship: A Primer in Christian Ritual. Collegeville, MN: Liturgical Press, 2003.

"Pentecost [Acts 2:1]." In Seventh-Day Adventist Bible Commentary, edited by F.D. Nichol, 6: s.v. Acts 2:1. Washington, DC: Review and Herald, 1976-1980.

Péter-Contesse, René, and John Ellington. A Handbook on Leviticus. New York: United Bible Societies, 1990.

Peters, Ted. "Worship Wars." Dialog 33 (Summer 1994): 166-195.

Peterson, David G. The Acts of the Apostles The Pillar New Testament Commentary. Grand Rapids, MI: Eerdmans, 2009.

Phifer, Kenneth G. A Protestant Case for Liturgical Renewal. Philadelphia: The Westminster Press, 1965.

Philipse, Herman. Heidegger's Philosophy of Being: A Critical Interpretation. Princeton, NJ: Princeton University Press, 1998.

Pike, Nelson. God and Timelessness. New York: Schocken Books, 1970.

Pilgrim, Gay. "Taming Anarchy: Quaker Alternate Ordering and 'Otherness'." In The Creation of Quaker Theory: Insider Perspectives, edited by Pink Dandelion. Burlington, VT: Ashgate Publishing, 2004.

Pinnock, Clark. Flame of Love: A Theology of the Holy Spirit. Downers Grove, IL: InterVarsity Press, 1996.

Pitre, Brant. "Jesus, the New Temple, and the New Priesthood." In Temple and Contemplation: God's Presence in the Cosmos, Church, and Human Heart, edited by Scott W. Hahn. Steubenville, OH: St. Paul Center for Biblical Theology, 2008.

Plato. Timaeus. Translated by Benjamin Jowett. New York: The Liberal Arts Press, 1949. 
Platvoet, Jan. "Ritual in Plural and Pluralist Societies." In Pluralism and Identity: Studies in Ritual Behaviour, edited by Jan Platvoet and Karel van der Toorn. Leiden: E.J. Brill, 1995.

Polhill, John B. Acts The New American Commentary 26. Nashville, TN: Broadman \& Holman, 1992.

Poloma, Margaret M. The Assemblies of God at the Crossroads: Charisma and Institutional Dilemmas. Knoxville, TN: University of Tennesse Press, 1989.

. "The "Toronto Blessing": Charism, Institutionalization, and Revival." Journal for the Scientific Study of Religion 36, no. 2 (1997): 257-271.

Portnoy, Julius. The Philosopher and Music: A Historical Outline. New York: The Humanities Press, 1954.

Power, Davd. N. Unsearchable Riches: The Symbolic Nature of Liturgy. New York: Pueblo, 1984.

Procopé, John. "Greek and Roman Political Theory." In The Cambridge History of Medieval Political Thought C. 350-1450, edited by J.H. Burns. New York: Cambridge University Press, 1988.

Propp, William H.C. Exodus 1-18: A New Translation with Introduction and Commentary The Anchor Bible 2. New York: Doubleday, 1999. . Exodus 19-40: A New Translation with Introduction and Commentary The Anchor Bible 2a. New York: Doubleday, 2006.

Provan, Iain W. 1 and 2 Kings New International Biblical Commentary 7. Peabody, MA: Hendrickson, 1995.

Puglisi, James F, ed. Liturgical Renewal as a Way to Christian Unity. Collegeville, MN: Liturgical Press, 2005.

Rad, Gerhard Von. Old Testament Theology Translated by D.M.G. Stalker. 1 of 2 vols. New York: Harper \& Row, 1962.

Rahner, Karl. The Trinity. Translated by Joseph Donceel. New York: Herder and Herder, 1970.

. Foundations of the Christian Faith: An Introduction to the Idea of Christianity. Translated by William Dych. New York: Seabury, 1978.

. Faith and Ministry. Vol. XIX Theological Investigations. New York: Crossroad, 1983. 
Ramsey, Ian T. Models and Mystery. London: Oxford University Press, 1964.

Ratzinger, Joseph. Theological Highlights of Vatican II. Mahwah, NJ: Paulist Press, 2009.

Rayburn, Robert F. Papal Legislation on Sacred Music. Collegeville, MN: Liturgical Press, 1979.

Reymond, Robert L. A New Systematic Theology of the Christian Faith. 2nd ed. Nashville, TN: Thomas Nelson, 1998.

Rhee, Victor (Sung-Yul). "Christoloy and the Concept of Faith in Hebrews 1:1-2:4." Bibliotheca Sacra 157 (2000): 174-189.

Rice, Charles Lynvel. The Embodied Word: Preaching as Art and Liturgy. Minneapolis, MN: Fortress Press, 1990.

Rice, Gene. 1 Kings: Nations under God International Theological Commentary. Grand Rapids, MI: Eerdmans, 1990.

Richard, Lucien, Daniel J. Harrington, and John W. O'Malley. Vatican II the Unfinished Agenda: A Look to the Future. New York: Paulist Press, 1987.

Roberts, Paul. Alternative Worship in the Church of England. Cambridge: Grove Books, 1999.

Robinson, Haddon W. "What Is Expository Preaching?" Bibliotheca Sacra 131 no 521 (Ja-Mr 1974): 55-60.

Robinson, J. The First Book of Kings Cambridge Bible Commentary. Cambridge: Cambridge University Press, 1972.

Roccasalvo, Joan Lucie. "The Eucharist as Beauty: A Study in the Thought of Hans Urs Von Balthasar." Ph.D. dissertation, Drew University, May 1998.

Rodríguez, Angel Manuel. "Sanctuary Theology in the Book of Exodus." Andrews University Seminary Studies 24, no. 2 (1986): 127-145.

Rollins, Peter. How (Not) to Speak of God. Brewster, MA: Paraclete Press, 2006.

Roloff, Jürgen. The Revelation of John Continental Commentaries. Minneapolis, MN: Fortress Press, 1993.

Ruff, Anthony. Sacred Music and Liturgical Reform: Treasures and Transformations. Chicago: HillenbrandBooks, 2007. 
Rush, Ormond. Still Interpreting Vatican II: Some Hermeneutical Principles. New York: Paulist Press, 2004.

Russell, Bertrand. A History of Western Philosophy. New York: Simon and Schuster, 1945.

Ruth, Lester. "A Rose by Any Other Name: Attempts at Classifying North American Protestant Worship." In The Conviction of Things Not Seen: Worship and Ministry in the 21st Century, edited by Todd E. Johnson. Grand Rapids, MI: Brazos Press, 2002.

Sachs, Curt. The History of Musical Instruments. New York: W.W. Norton \& Company, 1940.

Saliers, Don E. Worship as Theology: Foretaste of Glory Divine. Nashville, TN: Abingdon Press, 1994.

Schaff, Philip. The Evangelical Protestant Creeds with Translations. Vol. 3 of. 4th Revised and Enlarged ed. The Creeds of Christendom with a History and Critical Notes. New York: Harper and Brothers, 1877.

. History of the Christian Church. 8 vols. Grand Rapids, MI: W.B. Eerdman \& Sons, 1910.

Schillebeeckx, Eduard. The Real Achievement of Vatican II. Translated by H.J.J. Vaughan. New York: Herder and Herder, 1967.

Schouten, Ronald. "'Rituals of Renewal' the Toronto Blessing as a Ritual Change of Contemporary Christianity." Journal of Ritual Studies 17, no. 2 (2003): 25-34.

Scobie, Charles H.H. The Ways of Our God: An Approach to Biblical Theology. Grand Rapids, MI: Eerdmans, 2003.

Scruton, Roger. The Aesthetics of Music. Oxford: Oxford University Press, 1997.

Searle, Mark. "Ritual." In The Study of Liturgy, edited by Geoffrey Wainwright Cheslyn Jones, Edward Yarnold, Paul Bradshaw. New York: Oxford University Press, 1992.

Selman, Martin J. 2 Chronicles: A Commentary Tyndale Old Testament Commentaries. Downer's Grove, IL: InterVarsity Press, 1994.

Sendrey, Alfred. Music in Ancient Israel. New York: Philosophical Library, 1969.

Senn, Frank C. Christian Liturgy: Catholic and Evangelical. Minneapolis, MN: Fortress Press, 1997. 
She, King L. The Use of Exodus in Hebrews. New York: Peter Lang, 2011.

Shedd, William G.T. Dogmatic Theology. 3rd ed., Edited by Alan W. Gomes. Phillipsburg, NJ: P \& R Publishing, 2003.

Sinitiere, Phillip Luke. "Catholic Evangelicals and Ancient Christianity." In Vatican II Forty Years Later, edited by William Madges. Maryknoll, NY: Orbis Books, 2006.

Skelley, Michael J. The Liturgy of the World: Karl Rahner's Theology of Worship. Collegeville, MN: Liturgical Press, 1991.

Skudlarek, William. "Lay Preaching and the Liturgy." Worship 58 no 6 (November 1984): 500-506.

Smillie, Gene. "'The One Who Is Speaking" in Hebrews 12:25." Tyndale Bulletin 55, no. 2 (2004): 275-294.

Smith, Gordon T., ed. The Lord's Supper: Five Views. Downer's Grove, IL: IVP Academic, 2008.

Smith, James K.A. Desiring the Kingdom: Worship, Worldview, and Cultural Formation. Grand Rapids, MI: Baker Academic, 2009.

Sommer, Benjamin D. "Revelation at Sinai in the Hebrew Bible and in Jewish Theology." Journal of Religion 79 no 3 (July 1999): 422-451.

Sorke, Ingo Willy. "The Identity and Function of the Seven Spirits in the Book of Revelation." PhD dissertation, Southwestern Baptist Theological Seminary, 2009.

Spielmann, Richard M. History of Christian Worship. New York: Seabury Press, 1966.

Spiller, Roger. "Preaching and Liturgy: An Anglican Perspective." In The Future of Preaching, edited by Geoffrey Stevenson. London: Student Christian Movement, 2010.

Stefani, Wolfgang H.M. Music and Morality The Christian and Rock Music: A Study on Biblical Principles of Music, Edited by Samuele Bacchiocchi. Berrien Springs, MI: Biblical Perspectives, 2000.

Stefanovic, Ranko. "The Background and Meaning of the Sealed Book of Revelation 5." Ph.D. dissertation, Andrews University, 1995.

. Revelation of Jesus Christ: Commentary on the Book of Revelation. Berrien Springs, MI: Andrews University Press, 2002. 
Stephenson, Christopher A. Types of Pentecostal Theology. New York: Oxford University Press, 2013.

Stevenson, Geoffrey. "Introduction." In The Future of Preaching, edited by Geoffrey Stevenson. London: Student Christian Movement, 2010.

Stevick, Daniel B. Languague in Worship: Reflections on a Crisis. New York: Seabury Press, 1970.

Stott, John R.W., and David Lawrence Edwards. Essentials: A Liberal-Evangelical Dialogue. London: Hodder \& Stoughton, 1988.

Strand, Kenneth A. "The Sabbath and Sunday from the Second through Fifth Centuries." In The Sabbath in Scripture and History, edited by Kenneth A. Strand. Hagerstown, MD: Review and Herald, 1982.

. "Sabbath and Sunday in the Reformation Era." In The Sabbath in Scripture and History, edited by Kenneth A. Strand. Hagerstown, MD: Review and Herald, 1982.

. "'Victorious Introduction" Scenes." In Symposium on Revelation--Book I, edited by Frank Holbrook. Silver Spring, MD: Biblical Research Institute, General Conference of Seventh-day Adventists, 1992.

Stringer, Martin D. A Sociological History of Christian Worship. Cambridge: Cambridge University Press, 2005.

Strong, Augustus Hopkins. Systematic Theology. 3 vols. Chicago: The Judson Press, 1907.

Stumpf, Samuel Enoch. Socrates to Sartre: A History of Philosophy. New York: McGraw-Hill, 1966.

Sullivan, Francis A. From Apostles to Bishops: The Development of the Episcopacy in the Early Church. New York: The Newman Press, 2001.

Sullivan, Maureen. 101 Questions and Answers on Vatican II. New York: Paulist Press, 2002.

. The Road to Vatican II: Key Changes in Theology. New York: Paulist Press, 2007.

"The Synagogue." In Seventh-Day Adventist Bible Commentary, edited by F.D. Nichol, 5:56. Washington, DC: Review and Herald, 1976-1980. 
Taft, Robert F. Beyond East and West: Problems in Liturgical Understanding. Washington, DC: Pastoral Press, 1984.

"This Is My Name [Exod 3:15]." In Seventh-Day Adventist Bible Commentary, edited by F.D. Nichol, 1:511. Washington, DC: Review and Herald, 1976-1980.

Thurian, Max. "The Present Aims of the Liturgical Movement." Studia Liturgica Vol. 3 (1964): 107-114.

Tickle, Phyllis. The Great Emergence: How Christianity Is Changing and Why. Grand Rapids, MI: Baker Books, 2008.

. Emergence Christianity: What It Is, Where It Is Going, and Why It Matters? Grand Rapids, MI: Baker Books, 2012.

Toews, Thomas W. "Biblical Sources in the Development of the Concept of the Soul in the Writings of the Fathers of the Early Christian Church, 100-325 C.E. ." Ph.D. Dissertation, Andrews University, 2011.

Tongeren, Louis Van. "Liturgical Renewal Never Ends." In Vatican II and Its Legacy, edited by $\mathrm{M}$ and L. Kenis Lamberigts, eds. Leuven-Dudley, MA: Leuven University Press, 2002.

Tonstad, Sigve K. The Lost Meaning of the Seventh Day. Berrien Springs, MI: Andrews University Press, 2009.

Torgerson, Mark A. An Architecture of Immanence: Architecture for Worship and Ministry Today. Grand Rapids, MI: Eerdman's, 2007.

Towns, Elmer L. Putting an End to Worship Wars. Nashville, TN: Broadman \& Holman, 1997.

Tracy, David. Blessed Rage for Order: The New Pluralism in Theology. San Francisco: Harper and Row, 1988.

Treiyer, Alberto R. The Day of Atonement and the Heavenly Judgment from the Pentateuch to Revelation. Siloam Springs, AR: Creation Enterprises International, 1992.

. The Apocalyptic Expectations of the Sanctuary: Alberto Treiyer, 2008.

Truscott, Jeffrey A. "The Rite of Holy Baptism in the Lutheran Book of Worship." In Baptism Today: Understanding, Practice, Ecumenical Implications, edited by Thomas F. Best. Collegeville, MN: The Liturgical Press, 2008. 
Turner, Harold W. From Temple to Meeting House: The Phenomenology and Theology of Places of Worship. New York: Mouton Publishers, 1979.

Vagaggini, Cyprian. Theological Dimensions of the Liturgy: A General Treatise on the Theology of the Liturgy. 4th Italian ed. Collegeville, MN: Liturgical Press, 1976.

Vajta, Vilmos. Luther on Worship. Translated by U.S. Leopold. Philadelphia:

Muhlenberg Press, 1958.

. "Renewal of Worship: De Sacra Liturgia." In Dialogue on the Way, edited by George A. Lindbeck. Minneapolis, MN: Augsburg, 1965.

Wainwright, Geoffrey. "Recent Eucharistic Revision." In The Study of Liturgy, edited by Cheslyn Jones, Geoffrey Wainwright, Edward Yarnold and Paul Bradshaw. New York: Oxford University Press, 1992.

. Worship with One Accord: Where Liturgy and Ecumenism Embrace. New York: Oxford University Press, 1997.

Ware, Kalistos. "God Immanent yet Transcendent: The Divine Energies According to Saint Gregory Palamas." In In Whom We Live and Move and Have Our Being: Panentheistic Reflections on God's Presence in a Scientific World, edited by Philip Clayton and Arthur Peacocke. Grand Rapids, MI: Eerdman's, 2004.

Warrington, Keith. Pentecostal Theology: A Theology of Encounter. New York: T \& T Clark, 2008.

Webber, Robert E. Ancient-Future Faith: Rethinking Evangelicalism for a Postmodern World. Grand Rapids, MI: Baker Books, 1999.

. The Younger Evangelicals: Facing the Challenges of the New World. Grand Rapids, MI: Baker Books, 2002.

. Ancient-Future Time: Forming Spirituality through the Christian Year. Grand Rapids, MI: Baker Books, 2004.

. Ancient-Future Worship: Proclaiming and Enacting God's Narrative. Grand Rapids, MI: Baker Books, 2008.

. "Worship and Spirituality." Reformed Liturgy and Music 20, no. 2 (Spring 1986): 67-71.

, ed. The Biblical Foundations of Christian Worship, The Complete Library of Christian Worship. Nashville, TN: Star Song, 1993. 
, ed. Music and the Arts in Christian Worship, The Complete Library of Christian Worship. Nashville, TN: Star Song Pub., 1993.

, ed. The Renewal of Sunday Worship, The Complete Library of Christian Worship. Nashville, TN: Star Song Pub., 1993.

, ed. Twenty Centuries of Christian Worship, The Complete Library of Christian Worship. Nashville, TN: Star Song, 1994.

Weinfeld, Moshe. Deuteronomy 1-11: A New Translation with Introduction and Commentary The Anchor Bible 5. New York: Doubleday, 1991.

Welch, Claude, ed. God and Incarnation in Mid-Nineteenth Century German Theology. New York: Oxford University Press, 1965.

Westermeyer, Paul. "Instruments in Christian Worship." Reformed Liturgy and Music 25 no.3 (Summer 1991): 111-114.

White, James F. Protestant Worship and Church Architecture: Theological and Historical Considerations. New York: Oxford University Press, 1964. . Protestant Worship: Traditions in Transition. Louisville, KY: John Knox Press, 1989. . A Brief History of Christian Worship. Nashville, TN: Abingdon Press, 1993. . Introduction to Christian Worship. Third Revised and Expanded ed. Nashville, TN: Abingdon Press, 2000.

. Roman Catholic Worship: Trent to Today. 2nd ed. Collegeville, MN: Liturgical Press, 2003.

White, Susan J. "Christian Worship since the Reformation." In The Making of Jewish and Christian Worship, edited by Paul F. Bradshaw and Lawrence A. Hoffman. South Bend, IN: University of Notre Dame Press, 1991.

Wilkins, Ronald J. The Emerging Church: The Story of the Roman Catholic Church from Its Beginnings to the Present. Dubuque, IA: Wm. C. Brown Company Publishers, 1975.

Willimon, William H. Word, Water, Wine and Bread. Valley Forge, PA: Judson Press, 1980.

Wilson, Ian. Out of the Midst of the Fire: Divine Presence in Deuteronomy Society of Biblical Literature Dissertation Series 151. Atlanta, GA: Scholar's Press, 1995. 
Wilson-Dickson, Andrew. The Story of Christian Music: From Gregorian Chant to Black Gospel an Illustrated Guide to All the Major Traditions of Music in Worship. Minneapolis, MN: Fortress, 1996.

Wiseman, Donald J. 1 and 2 Kings: An Introduction and Commentary Tyndale Old Testament Commentaries. Downer's Grove, IL: InterVarsity Press, 1993.

Witherup, Ronald D. Scripture: Dei Verbum Rediscovering Vatican II, Edited by Christopher M. Bellitto. New York: Paulist Press, 2006.

Witvliet, John D. "Beyond Style: Rethinking the Role of Music in Worship." In The Conviction of Things Not Seen: Worship and Ministry in the 21st Centurgy, edited by Todd E. Johnston. Grand Rapids, MI: Brazos Press, 2002.

. "The Virtue of Liturgical Discernment." In Music in Christian Worship: At the Service of the Liturgy, edited by Charlotte Kroeker. Collegeville, MN: Liturgical Press, 2005.

. "For Our Own Purposes: The Appropriation of the Social Sciences in Liturgical Studies." In Foundations in Ritual Studies: A Reader for Students of Christian Worship, edited by Paul Bradshaw and John Melloh. Grand Rapids, MI: Baker Publishing, 2007.

. "At Play in the Lord's House: Why Worship Matters." Books and Culture 4, no. 6 (November/December 1998): 22-25.

Wright, David F., ed. Baptism: Three Views. Downer's Grove, IL: InterVarsity Press, 2009.

Yannaras, Christos. On the Absence and Unknowability of God: Heidegger and the Areopagite. Translated by Haralambos Ventis, Edited by Andrew Louth. New York: T \& T Clark, 2005.

Yarnold, E.J. "The Fourth and Fifth Centuries." In The Study of Liturgy, edited by Cheslyn Jones, Geoffrey Wainwright, Edward Yarnold and Paul Bradshaw. New York: Oxford University Press, 1992.

Ylvisaker, John. What Song Shall We Sing? Healing the Worship Wars with Fusion. Minneapolis, MN: Augsburg Fortress, 2005.

York, Terry W. America's Worship Wars. Peabody, MA: Hendrickson, 2003.

Young, Norman H. "'The Use of Sunday for Meetings of Believers in the New Testament" a Response." Novum Testamentum 45 (2003): 111-122. 
Zikmund, Barbara Brown. "Women as Preachers: Adding New Dimensions to Worship." Journal of Women and Religion 3 no 2 (Summer 1984): 12-16.

Zuesse, Evan M. "Ritual." In The Encyclopedia of Religion, edited by Mircea Eliade, 16:405-422. New York: Macmillan, 1987. 


\section{Curriculum Vitae}

\section{Karl Tsatalbasidis}

\section{Educational Achievements}

2019

Andrews University, Berrien Springs, Michigan

Ph.D. in Systematic Theology. Thesis - Toward a Biblical

Theology of God's Presence in Christian Theology: A Study of

How Different Interpretations of the Divine Presence affect

Liturgy

1997

Andrews University, Berrien Springs, Michigan

Master of Divinity

1993

Andrews University, Berrien Springs, Michigan

Bachelor of Arts, Religion Major and History Minor

\section{Experience}

July 2011-

Bible/Theology Teacher at Ouachita Hills College.

present

Courses taught: History of Christianity I \& II, Ethics, Daniel, Revelation, Intro to OT \& NT, Doctrines of the

SDA Church, Intro to Communication, Pauline

Theology, Music in the Church, Acts \& General

Epistles, Issues in Contemporary Theology,

Hermeneutics, and the Sanctuary

1993-June 2011 Pastor, Michigan Conference of Seventh-day

Adventists. Ordination took place in June, 1999 at the

Michigan Conference Camp Meeting

\section{Professional Activities}

\section{Service Activities}

2014-present Scriptwriter for It Is Written Canada

2013-present A regular visitor of the Adventist Sola Scriptura

Research Group under the Biblical Research Institute and the Adventist Theological Seminary that meets twice a

year 


\section{Research/Scholarship}

\section{Books}

Phillips, Keith, and Karl Tsatalbasidis. I Pledge Allegiance: The Role of Seventh-Day Adventists in the Military. Vicksburg, MI: Keith Phillips, 2007. 176 pp.

Tsatalbasidis, Karl. Drums, Rock and Worship: Modern Music in Today's Church. Roseville, CA: Amazing Facts, 2003. 71 pp.

\section{Periodical Articles}

Tsatalbasidis, Karl. "What Is Sin?" Adventists Affirm Vol. 23 no.2 (2009): 41-56.

. "If the Foundations Are Destroyed, What Can the Righteous Do?" Adventists Affirm Vol. 22 no.3 (Fall 2008): 50-60.

. "The Emerging Church: More Than Just a Face Lift." Adventists Affirm Vol. 22 no.2 (Summer 2008): 19-28.

. "Shall We Dance?" Adventists Affirm Vol. 17 no. 3 (Fall 2003): 15-20.

\section{Materials}

"The Great Worship \& Music Controversy: Are the Foundations Crumbling? These are 6 presentations on DVD which include 49 pgs of notes, 2010.

\section{Website and Ministry Information}

I am currently working on a ministry that I have named "Biblical Sanctuary Productions." There are 10 Newsletters on the website. Website info: www.biblicalsanctuaryproductions.com

\section{Speaking Appointments}

Hayden Lake SDA Church in Idaho. Nov 16-20, 2018.

Sandpoint SDA Church in Idaho. Nov 9-14, 2018.

Light Bearers Mission SDA Church Baltimore, MD. Oct 3, 2018.

Warburg Convocation in Alberta, Canada. Sept 28-29, 2018.

Scarborough Filipino Seventh-day Adventist Church, Ontario, Canada. July 13-14, 2018.

South Bay Church, Chattanooga, TN. Worship and Music Seminar, Nov 10-11, 2017. 
Advent Hope at Loma Linda University, lectures on the Emerging Church and the Biblical Pillars of Adventism, Oct 21-22, 2016

Michigan Conference Camp meeting lectures on the Emerging Church, June 15-16, 2016.

Ardmore Seventh-day Adventist Church, lectures on worship and music, May 21, 2016.

Fort Worth, Texas. Seminar on the Emerging Church, April 16, 2016.

Country Life Seventh-day Adventist Church, Cleburne, Texas, seminar on the Emerging Church, Feb 20, 2016.

ARK-LA-TEX Camp Meeting on the Emerging Church in Jefferson, Texas, July, 2015.

I did not take many appointments between 2012 to 2015 to work on teaching and on my dissertation.

Generation of Youth for Christ, lectures on worship and music, December, 2011.

Worship and Music Seminar in Quito, Ecuador. Nov 2-6, 2011.

Connecticut Valley Seventh-day Adventist Church, Seminar on Worship and Music, June $11,2011$.

Ukraine Camp Meeting. Lectures on Worship and Music, April 29-May 7, 2011.

Australian Youth Conference (AYC). Lectures on worship and music, Feb 17-20, 2011. I was invited, but I could not go because of comprehensive exams.

Avon Park Seventh-day Adventist Church, Avon Park FL. Lectures on Worship and Music, Sept 10-11, 2010.

Florida Youth Initiative. Lectures on Worship and Music, June 9-11, 2010.

Tulsa, OK. Lectures on Worship and Music, April 17, 2010

Edinburgh Seventh-day Adventist Church, Edinburgh, TX. Lectures on Worship and Music, March 27, 2010

STRIDE, Student Training \& Resource Institute for Discipleship Evangelism-Preparing secular campuses for the imminent return of Jesus Christ, located in Cambridge, MA, Lectures on Worship and Music, Feb 12-14, 2010.

Philippine Youth Conference at the Adventist University of the Philippines located in Silang Cavite, Philippines. Lectures on Worship and Music, Dec 4-12, 2009. 
Seventh-day Adventist Theological Seminary, presentation on the role of Seventh-day Adventists in the Military to the Faculty, Oct 2009 in Berrien Springs, Michigan.

Ghanaian Seventh-day Adventist Youth Camp Meeting, lectures on Worship and Music, July 2009 in Meadville, Pennsylvania.

Michigan Conference Camp Meeting, lectures on Worship and Music, June 2009.

Oxford Street Seventh-day Adventist Church in Wolverhampton, UK, lectures on Worship and Music, March 2009.

Mount Zion Filipino SDA Church in Ontario, CA. Lectures on Worship and Music. Generation of Youth for Christ, lectures on Worship and Music, Dec 2008 in San Jose, CA.

Bramalea SDA Church in Ontario, CA. Lectures on Worship and Music, 2008.

Kingsway College in Ontario, CA, presentation on the role of Seventh-day Adventists in the Military, Nov 2008.

Adventist Theological Society, presentation on the role of Seventh-day Adventists in the Military, April 2008 in Grand Rapids, Michigan.

I've also conducted about 8 evangelistic meetings during my pastoral experience.

\section{Honors \& Awards}

The Honor Society of Phi Kappa Phi, June 2011.

National Deans List, 1995.

\section{Family}

Wife: Lily May Fabriga Tsatalbasidis - BFA in Piano Performance, 1993 at Andrews University; BS in Nursing at Grand Canyon University, 2017. She has currently been working as a Registered Nurse. Marriage, September 15, 1991

Daughter: Sofia Tsatalbasidis - Graduated in May, 2018 from Southwestern Adventist University with a degree in Biochemistry. She would like to become a nurse. Born Dec 6,1995

Son: Dino Tsatalbasidis - Currently a junior at Southwestern Adventist University studying theology in order to become a pastor. Born Feb 5, 1998 


\section{References}

1. Dr. Fernando Canale - Retired Professor of Christian Philosophy and Theology at the Seminary, Andrews University.

a. Email: canale@andrews.edu

b. Home Phone: 269.471.4394

2. Chris Holland - Former Speaker/Director of It Is Written Canada and Currently at Adventist World Radio

a. HollandC@gc.adventist.org

b. 630.310 .4076

3. Magda Rodriguez - My Current Employer at Ouachita Hills College

a. Email:magdaohe@gmail.com

b. Work: 870.342 .6210

\section{Contact Information}

Karl Tsatalbasidis

1100 Snowberry St.

Cleburne, TX 76031

Cell (517) 243-0733

Email: ktsatalbasidis@gmail.com 